\author{
UNIVERSIDADE DE SÃO PAULO \\ INSTITUTO DE RELAÇÕES INTERNACIONAIS
}

RENAN HONÓRIO QUINALHA

Contra a moral e os bons costumes:

A política sexual da ditadura brasileira (1964-1988) 


\section{RENAN HONÓRIO QUINALHA}

Contra a moral e os bons costumes:

A política sexual da ditadura brasileira (1964-1988)

Tese apresentada ao Programa de Pós-Graduação em Relações Internacionais do Instituto de Relações Internacionais da Universidade de São Paulo, para a obtenção do título de Doutor em Ciências.

Orientadora: Profa. Dra. Rossana Rocha Reis

São Paulo 


\title{
Contra a moral e os bons costumes: a política sexual da ditadura brasileira (1964-1988)
}

\author{
Renan Honório Quinalha \\ Orientadora: Professora Doutora Rossana Rocha Reis
}

Tese apresentada ao Programa de Pós-Graduação em Relações Internacionais do Instituto de Relações Internacionais da Universidade de São Paulo, para a obtenção do título de Doutor em Ciências.

Examinada por:

Presidente: Profa. Dra. Rossana Rocha Reis - IRI/USP

Prof. Dr. James N. Green - Brown University

Profa. Dra. Felipe Loureiro - IRI/USP

Prof. Dr. José Reinaldo de Lima Lopes - FD/USP

Profa. Dra. Janaína Teles - Fundação Santo André 
Para aquelas e aqueles que desafiaram a moral e os bons costumes 


\section{AGRADECIMENTOS}

A James N. Green, por saber construir pontes como ninguém e ainda ter a generosidade de ajudar a atravessá-las. Sua parceria, na academia e no ativismo, é uma inspiração sem tamanho.

Para os amigos e amigas de São Francisco, de Rua Tucuna e de Saia de Chita, que seguem pela vida: Alvinho, Alê, Rafa, Kalil, Veri, Ricardo, Lupion, Muniz, Leila, Sertão, Ju Bueno Marina, Pablo, Silas, Gui, Leu, Cotô, Dani, Naná, Mari M., Regina, Ester, Chico, Fernando, Luizão, Vini, Flávia, Flavinho e Aline. A Paulo e Nina, pela maravilhosa acolhida parisiense nas férias da tese.

A Lucas, por ter vivido comigo várias fases deste processo e ter continuado perto mesmo depois do fim.

Para os dedos no **, grupo ativo de WhatsApp e de mundo real: Isa, Ganza, Flora, Mari C., Edu, Mari V., Brunão, Renata, Lucas F., Ane, Danilo, Zeca e Mila.

A Samuel, pela irmandade antiga que só faz crescer. A Edilene, por seu olhar atento e suas palavras certeiras. A Rachelle Balbinot, por compartilhar cada vez mais e mais. A Bianca Tavolari, pelo companheirismo da yoga ao fervo. A Laura Carvalho, pelas horas de biblioteca e samba acumuladas nos últimos meses de tese. Ao Amadeus, por trazer verdades para a Vila Buarque. A Jana Teles, pela insistência em brigar pelo certo. A Débora Arakaki, por estar sempre por perto. Ao Pedro Campana pelo carinho e cuidado. Ao Paulo Iotti, o defensor das causas necessárias e difíceis.

A Deisy Ventura, por ter me escolhido lá no início. A Rossana Reis, pela participação na qualificação e por ter me acolhido mais recentemente. Ao Edson Teles, pela amizade e pelos valiosos diálogos na banca de qualificação e também fora dela.

$\mathrm{Na}$ Brown University, a Edilza Sotero pelas escapadas para praia e corridas de fim de tarde com sorvete que me fizeram sentir mais perto do Brasil. Ao casal Danilo e Virgínia pela adoção calorosa, com cervejas em mãos, assim que cheguei em terras estranhas e frias. A Ben, Ramón, Flora, Pedro, Chloé, Paula, Leo, Sílvia, Seyda, Tedd e Joana Pedro, pessoas incríveis que tornaram essa estadia do "sanduíche" no exterior uma experiência inesquecível. Para Luíza, Jana e Ricardo pelas recepções animadas em Nova Iorque.

Aos queridos companheiros de Comissão da Verdade, em São Paulo, pelo tanto que fizemos e pelo que ainda faremos juntos: Adriano Diogo, Chaia, Amelinha Teles, Vivian, Pádua, Tati, Thaís, Ivan e Koba.

A Musse, Cilaine, Mirmila, Koba, Waltinho, Artur e Darci, por resistirmos, juntos e, 
sempre que possível, em festa.

E, mais importante, agradeço a quem, desde muito antes disso tudo começar, esteve incondicionalmente ao meu lado: minha família. Em especial, a minha mãe, por me oferecer sempre seu melhor e por me estimular em todos meus passos. A meu pai, pelo exemplo de integridade e de homem que um dia, com sorte, espero me tornar. Ao meu irmão mais velho, por me ensinar que a vida é leve e nos devolve o que fazemos pelos outros. A minha avó, por transbordar seu amor e nos fazer cada vez mais unidos.

Por fim, dedico este trabalho à memória de Cesar Teles, um revolucionário que lutou contra a ditadura, mas que nunca deixou de dançar. 
Pela lei do frei Quem administra A moral e os bons costumes Está desmoralizado E mal acostumado Pela lei do frei O que é gostoso $\dot{E}$ imoral

O que é imoral É ilegal

E o que é ilegal É o crime que o próprio frei perpetra

Trancado no banheiro Com o silêncio do cúmplice E o espelho Por testemunha

- Glauco Mattoso

Era tão irracional gemer de prazer nas vésperas de nossos crimes contra a segurança nacional era duro rimar orgasmo com guerrilha e esperar um tiro na próxima esquina.

- Alex Polari de Alverga 


\section{RESUMO}

O presente trabalho tem por objetivo investigar os contornos da política sexual concebida e implementada pela ditadura civil-militar (1964-1988). Marcado centralmente pelo lema da defesa da "moral e dos bons costumes", o regime autoritário brasileiro estruturou um complexo aparato repressivo orientado não apenas para eliminar dissidentes políticos, mas também para regular e normalizar os corpos marcados por orientação sexual e/ou identidade de gênero dissidentes. Para isso, foi preciso fazer convergir a atuação de diversas agências estatais que integravam as comunidades de informações, segurança e de censura em torno de uma agenda moral comum, apesar das disputas e tensões entre elas. Segundo essa perspectiva, erotismo, pornografia, homossexualidades e transgeneridades eram classificados como temas e práticas ameaçadores não apenas contra a estabilidade política e a segurança nacional, mas também contra a ordem sexual, a família tradicional e os valores éticos que, supostamente, coesionavam a sociedade brasileira. Cerceamento da produção cultural, repressão policial nas ruas, vigilância do nascente movimento homossexual e perseguição a seus veículos de expressão e comunicação foram algumas medidas de violência implementadas por diferentes órgãos repressivos e que são examinadas detalhadamente. A partir de uma minuciosa pesquisa nos acervos documentais produzidos pelos próprios órgãos encarregados da repressão, bem como de uma revisão bibliográfica da literatura existente, esta pesquisa pretende demonstrar como as questões comportamentais e sexuais foram centrais para o projeto da "utopia autoritária", ressaltando uma dimensão muitas vezes negligenciada tanto nas reflexões acadêmicas quanto no trabalho de memória sobre este período.

Palavras-chave: Ditadura; censura; moral e bons costumes; política sexual; homossexualidades. 


\begin{abstract}
The present thesis aims to investigate the contours of the sexual politics conceived and implemented by the civilian-military dictatorship (1964-1988). Centrally marked by the motto of the defense of "morality and good behavior", the Brazilian authoritarian regime structured a complex repressive apparatus oriented not only to eliminate political dissidents, but also to regulate and normalize bodies marked by sexual orientation and / or gender identity dissidents. In order to do so, it was necessary to bring together the activities of several state agencies that integrated the information, security and censorship communities around a common moral agenda, despite the disputes and tensions among them. According to this perspective, eroticism, pornography, homosexuality, and transgenderism were classified as threatening themes and practices not only against political stability and national security, but also against the sexual order, the traditional family, and the ethical values that supposedly integrated Brazilian society. The curbing of cultural production, police repression on the streets, surveillance of the nascent homosexual movement, and persecution of its vehicles of expression and communication were some violent measures implemented by different repressive organs and examined in detail. Based on a thorough research in the documentary collections produced by the agencies responsible for repression, as well as a bibliographical review of the existing literature, this research seeks to demonstrate how behavioral and sexual issues were central to the project of "authoritarian utopia," emphasizing a dimension often neglected in both academic reflections and the work about the memory of this period.
\end{abstract}

Keywords: Dictatorship; censorship; Moral and good behavior; Sexual politics; Homosexuality. 


\section{SUMÁRIO}

INTRODUÇÃO ............................................................................................................................15

Verdade e homossexualidades...........................................................................................................15

Regimes autoritários e regulação das sexualidades dissidentes ....................................................... 19

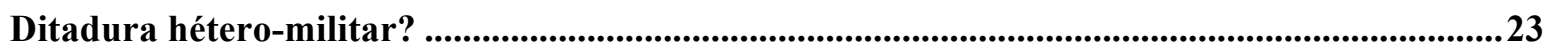

“Os ideais superiores da Revolução" .................................................................................................25

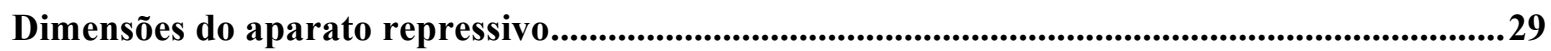

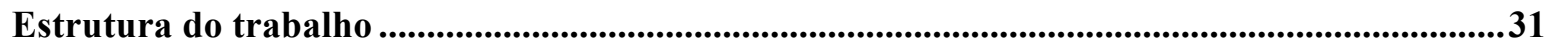

\section{CAPÍTULO 1: A CENSURA EM NOME DA MORAL E DOS BONS COSTUMES ....35}

"Os fatores adversos ao desenvolvimento dos valores espirituais e morais da nacionalidade" 35

Uma ou duas censuras durante a ditadura? ................................................................................................37

Duas censuras distintas: a moral e a política ..........................................................................................39

A moral também é política .............................................................................................................................41

Anticomunismo e moralidade pública ..........................................................................................

Evolução legislativa da censura na ditadura militar...............................................................45

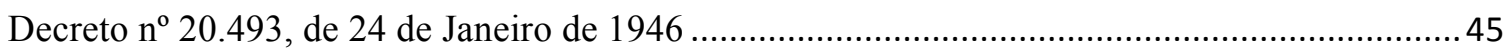





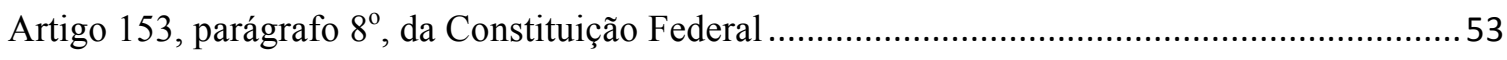

Decreto-Lei n. 1.077, de 26 de janeiro de 1970 ......................................................................... 57

Um emaranhado legal: hipernomia autoritária ........................................................................................61

CAPÍTULO 2: A CENSURA NA PRÁTICA: CONTROLE MORAL NAS ARTES, COMUNICAÇÕES E DIVERSÕES.........................................................................63

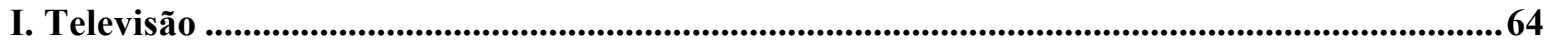

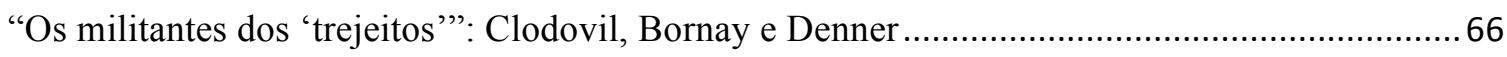

"Erradicar as insinuações de homossexualismo dos programas da televisão brasileira" ...............69

"Reiteradas reclamações acerca da presença de travestis" ............................................................... 70

"O relacionamento homossexual é uma aberração" ..................................................................... 72

"O orgasmo do censor sempre foi a proibição" ........................................................................ 73

“Tribuna de aliciamento, indução e apologia do homossexualismo"................................................ 75

"Essa livre expressão da imoralidade depõe também contra as autoridades da nossa Justiça" .....76



"Propaganda adversa nos meios de comunicação": a comunidade de informações em cena.........80 
“Toda censura é imoral”: Plínio Marcos na mira dos militares..................................................... 84

"A androgenia não quer dizer 'homossexualidade”": The Rocky Horror Show ............................86

"Vetando esse tipo de peça, estaria o DPF fazendo sua promoção: "Engrenagem do Meio" de

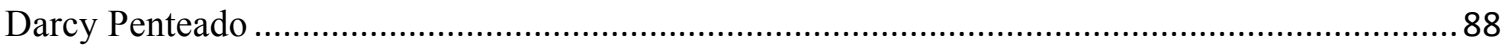

"Figueiredo e o Homossexualismo": "Leite Integral" de Carlos Leite ..........................................91

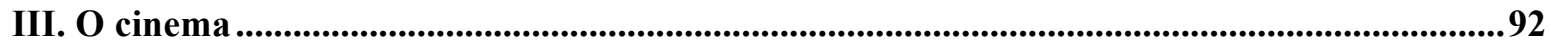

"Stanley Kubrick manda-lhe recomendações" ............................................................................. 93

"O erotismo é ultrapassado em direção a pornografia": "Garganta Profunda" ..............................95

"Cenas de sexo normal, anormal, homossexual, nus feminino e masculino" ...............................97

"Além de inconveniente, é altamente atentatório ao pudor e ao decoro público": "Viagem ao Céu

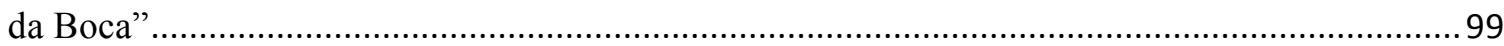

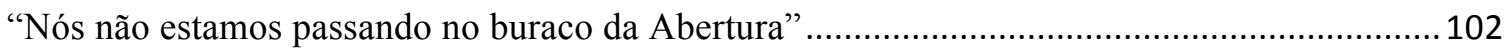

"Basta punir um para exemplo de todos": cidadão clamando por mais censura ........................... 104

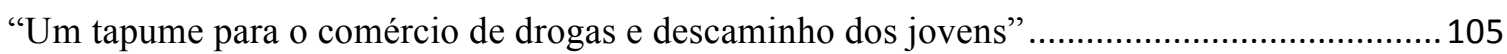

"Inocentes úteis dos vermelhos e dos imorais": a cruzada da extrema direita .............................. 107

"Abertura pornográfica do governo": salas de exibição cinematográfica restrita ......................... 108

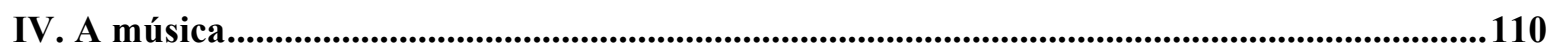

"A divulgação do homossexualismo é proibida pela lei censória".............................................. 110

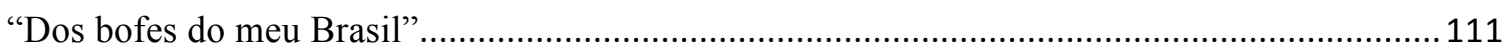

"Não vá se misturar com esses meninos cabeludos" .................................................................. 112

"Sou um frequentador da esquina do pecado" ........................................................................... 113

"Pensou que era mulher, mas era mesmo um homem" ........................................................... 115



"Não acho que o homossexualismo seja correto" .......................................................................... 117



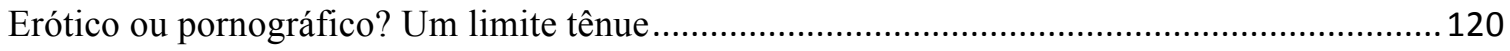

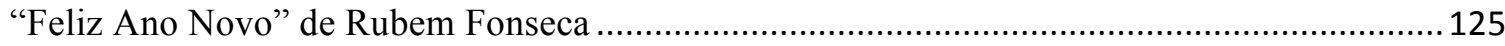

"O caos e a degeneração na célula básica da nação - a família”..................................................127

Index da ditadura: lista dos 205 livros proibidos e incineração ................................................. 129

"Não chegam a aguçar ou favorecer desejos sexuais": "Os tambores silenciosos" .....................130

"Um filão rentável na descrição ousada das relações homossexuais": o caso de Cassandra Rios

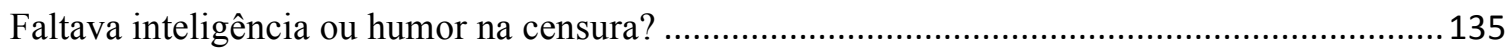

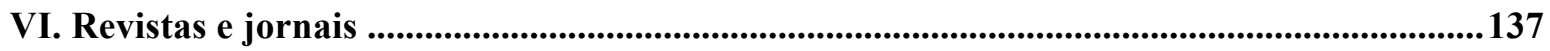

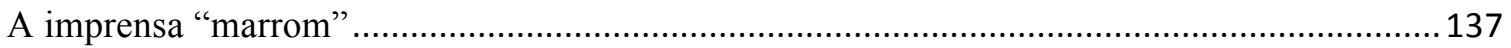


"Exploração grosseira de temas relativos a taras e inversões sexuais" .........................................139

"Difusão, com grande intensidade, desses assuntos proibidos" ................................................. 140

"Abertura de tudo que estava castrado pela repressão"............................................................. 141

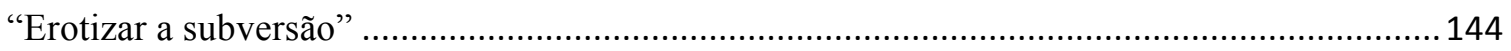

"Nádegas completamente nuas, seios totalmente à mostra, região púbica descoberta": imagens e fotografias obscenas

"Difícil afirmar que tais recursos ofendem à moral e aos bons costumes": maior tolerância ao erotismo publicitário 148

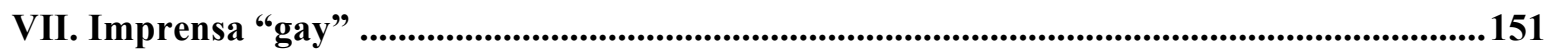

"Defendendo-se abertamente as uniões anormais entre seres do mesmo sexo" ........................... 152

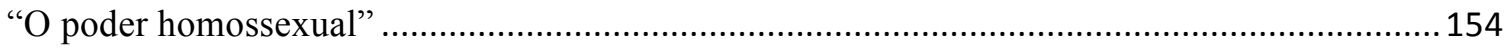

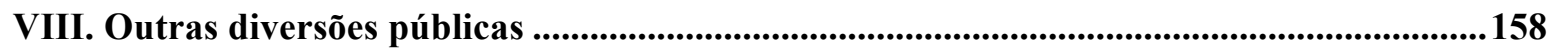

Conselho Nacional de Censura e começo do fim: os anos 1980 .................................................. 159

"Desajustes entre os critérios da DCDP (legal) e os do CSC (consensual)" .................................163

Liberalização da censura e novo manual da DCDP ...........................................................166

"Ninguém quer ficar com a imagem de censor" ....................................................................... 168

\section{CAPÍTULO 3: A VIOLÊNCIA NAS RUAS: CONTROLE MORAL E REPRESSÃO}

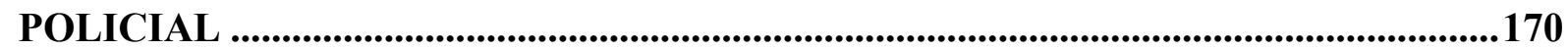

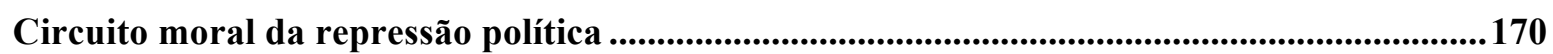

“Não sabe porque a gente se corta? É o único jeito de não ir presa" ......................................175

"Só ando com gilete. É a minha defesa contra a polícia" ...................................................................178

"Documento de bicha pobre é grade" ........................................................................................................180

"Gays quebram pau com delega machão" .............................................................................................181

“Afinal, quem define leis e direitos no País do Carnaval?" ...............................................................182

"Queremos condições para vender direito nosso corpo, sem perseguição da polícia": a

violência contra prostitutas ............................................................................................................184

"Nós estamos falando de uma violência institucionalizada" .....................................................185

Outros abusos: violência sexual e trabalho forçado..................................................................190

"Corre bicharada que a polícia chegou" "......................................................................................191

“Acontece - mas é ilegal”: a prisão cautelar...........................................................................................192

"O que a cidade, a Polícia e a Justiça têm a dizer sobre os Travestis?": Operação Limpeza 194

Richetti: “o comandante-em-chefe de uma guerra sem quartel” .................................................... 197

"Elas deram certo em um ponto: a cidade ficou limpa".....................................................................199

"Se não assinar, vai ficar no mofo por uns quinze dias" ..............................................................201

"Precisamos dar um basta à essa onda de violência. Todos ao Ato Público".............................207

"Deram certo e vão continuar": 0 apoio de comerciantes às rondas........................................209 
"Fora os marginais do centro": Richetti perante a Comissão de Direitos Humanos da ALESP



“Operação Sapatão": lésbicas como alvo da polícia .................................................................217

Violência policial fora do eixo Rio-São Paulo .........................................................................220

"Esquadrão mata-bicha": omissão ou cumplicidade do Estado? ..............................................2222

CAPÍTULO 4: MOVIMENTO HOMOSSEXUAL NA DITADURA ...........................227

"O ato de se organizar politicamente era uma empreitada de risco" .....................................227

“O pessoal não se une. Não há espírito de classe, nem de solidariedade”: a polícia acaba com o

I Congresso do Homossexual Brasileiro.

"Tivemos uma existência clandestina e muito conturbada": ser homossexual na ditadura ...234

“Uma maneira especificamente nossa [dos homossexuais] de fazer política": a criação do

Somos.....................................................................................................................................237

"Esse é o principal problema que tenho sentido: o medo de uma organização" ......................240

"Estão querendo convergir. Para onde?": a homofobia nas esquerdas.................................242

"A tal da felicidade também deve ser ampla e irrestrita": a Semana das Minorias da USP .. 245

"Descobrimos que não estávamos sozinhos": novos grupos homossexuais ..........................249

“Ninguém pensava tão cedo assistir a uma confraternização dessas": o I Encontro de Grupos



Primeiras mobilizações: o diálogo com outros movimentos sociais....................................254

“Embora sejam uma minoria insignificante no contexto social, representam, certamente,

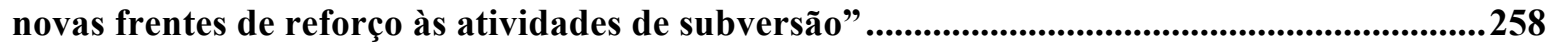

Entre a política "maior" e a "menor": o racha do grupo Somos/SP ........................................262

"Enquanto mulheres e homossexuais": as lésbicas do Somos para o GALF...........................269

O fracasso do II EGHO: fim do movimento homossexual? ..............................................2270

CAPÍTULO 5: LAMPIÃO DA ESQUINA ....................................................................277

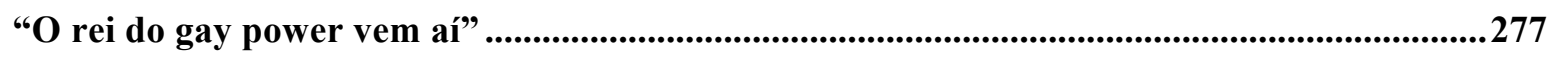

"Ocupando um lugar certo no mundo, inclusive politicamente"

"Mas um jornal homossexual, para quê?" "..................................................................280

Homossexuais e "nanicos": Lampião na imprensa alternativa ..............................................2283

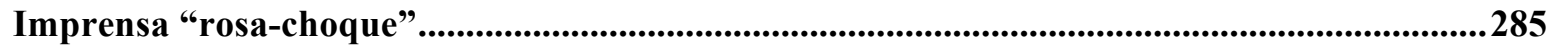

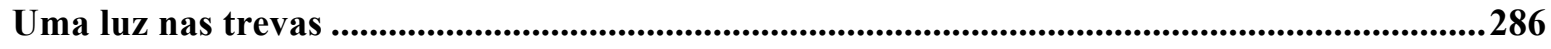

"Pelo orgasmo amplo, geral e irrestrito" ...............................................................................2290

Lampião sob vigilância: "Ga propaganda do homossexualismo" ..............................................294

"Ofensa à moral e ao pudor público": o inquérito 25/78......................................................296

“Quem nos financia?": a devassa nas contas do Lampião .....................................................301 


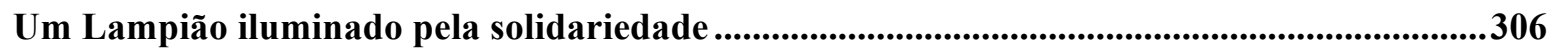

"Somos todos inocentes": o arquivamento do inquérito contra o Lampião ...............................307

"Eu atribuo o fim do jornal ao meu cansaço": "diário oficial do ativismo guei"? ...................309

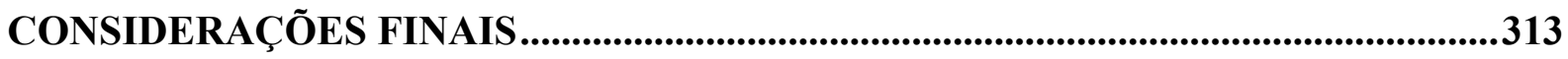

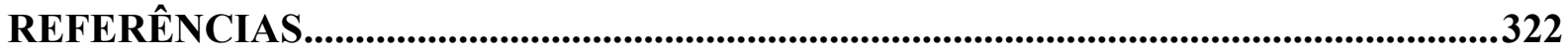




\section{INTRODUÇ̃̃̃O}

\section{Verdade e homossexualidades}

No dia 29 de março de 2014, no final de semana que marcaria o aniversário de 50 anos do golpe civil-militar que depôs o presidente João Goulart e instaurou um regime autoritário que se arrastaria por mais de 20 anos, realizou-se uma histórica audiência pública sobre um tema ainda pouco discutido no Brasil: os modos de existência das homossexualidades ${ }^{1}$ durante a ditadura.

Intitulada "Homossexualidades e a ditadura no Brasil", o referido encontro foi organizado pela Comissão Nacional da Verdade em conjunto com a Comissão da Verdade do Estado de São Paulo "Rubens Paiva", com o objetivo de "contribuir para uma análise interdisciplinar das relações entre a ditadura brasileira (1964-1985) e a homossexualidade. Em especial, pretende-se discutir de que maneiras a ditadura dificultou tanto os modos de vida de gays, lésbicas, travestis e transexuais, quanto a afirmação do movimento LGBT no Brasil durante os anos 1960, 1970 e 1980"2.

Foi bastante simbólico que o antigo prédio do DEOPS, onde funcionou um dos mais importantes órgãos repressivos da ditadura e que hoje sedia o Memorial da Resistência, tenha reservado a disputada data da efeméride do cinquentenário do golpe para pautar a discussão de um tema até então pouco prestigiado, tanto nas pesquisas acadêmicas, como nas políticas públicas de verdade, memória e justiça em relação aos crimes estatais do passado recente. Mais expressivo ainda é a constatação de que o tal prédio se localiza no coração da Boca do Lixo $^{3}$, região central paulistana com enorme frequência de pessoas LGBTs e prostitutas e que foi particularmente afetada pelas violências das forças de segurança à época.

\footnotetext{
1 "Homossexualidades" era o termo utilizado até começo dos anos 1990 para se referir ao conjunto de orientações sexuais e identidades de gênero consideradas não normativas ou dissidentes. Assim, naquele momento da ditadura em que se concentram as análises feitas no presente trabalho, as travestilidades e transgeneridades eram compreendidas nessa designação mais ampla de "homossexualidades", inclusive por travestis, daí o seu uso no plural para sinalizar essa abrangência. Ao longo do texto, quando for mais adequado e não soar anacrônico, no entanto, será usada a sigla LGBT, mais contemporânea e adequada por contemplar um avanço de formulação do próprio movimento.

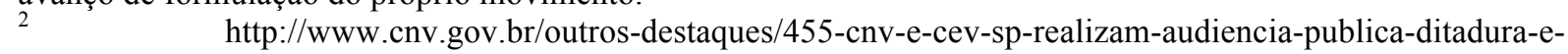
homossexualidade-no-brasil.html

${ }^{3}$ Também conhecida como "Quadrilátero do Pecado", a Boca do Lixo era o apelido para a área compreendida entre as ruas e avenidas Duque de Caxias, Timbiras, São João e Protestantes, no bairro da Luz. Ao contrário da Boca do Luxo, região que englobava os arredores da Praça da República e a Vila Buarque, a Boca do Lixo foi marcada como um território de "baixa prostituição", procurada por pessoas com menor poder aquisitivo e marcada pela sobreposição de diversas práticas tidas como imorais ou ilícitas. Ali, também, concentrou-se boa parte das produtoras e salas de exibição do cinema marginal das décadas de 1960 e 1970, tendo sido filmado ali o "O Bandido da Luz Vermelha", de Rogério Sganzerla, em 1968.
} 
No auditório totalmente cheio, com mais de 200 pessoas, encontravam-se diversos militantes, de diferentes gerações, do movimento LGBT brasileiro, demonstrando um interesse até então pouco evidente do ativismo por sua própria memória e história. As poucas pesquisas que abordavam aspectos específicos em torno da repressão a estes segmentos, bem como relatos da resistência empreendida por eles, foram expostas e debatidas naquela tarde ${ }^{4}$.

Tal iniciativa, que contava com representantes de duas das principais Comissões da Verdade do país, a Nacional e a estadual paulista, além de Secretários de Estado da Cultura e da Justiça, marcou simbolicamente um compromisso destes órgãos estatais perante a comunidade LGBT e a sociedade em geral. Selou-se, ali, naquele momento histórico e diante de uma plateia expressiva, como testemunha, uma espécie de acordo no sentido de que a história, até então oficialmente invisibilizada, viria à tona com o relatório final destas comissões.

Tudo isto foi fundamental para que, tempos depois, tal ajuste viesse a ser cumprido. A Comissão Nacional da Verdade, criada pela Lei n. 12.528 de 2011, incluiu em seu reporte um capítulo específico, localizado na seção de "Textos Temáticos" do livro II, denominado "Ditadura e homossexualidades", feito sob responsabilidade do comissionado Paulo Sérgio Pinheiro com “pesquisas, investigações e redação” por James N. Green e por mim 5 .

Por sua vez, a Comissão da Verdade do Estado de São Paulo "Rubens Paiva", presidida pelo Deputado Estadual Adriano Diogo, foi pioneira ao realizar sua $98^{\mathrm{a}}$ audiência pública em 26 de novembro de 2013, a primeira dedicada exclusivamente ao tema. Os convidados James N. Green e Marisa Fernandes, ambos ativistas importantes no começo do movimento homossexual e atualmente pesquisadores, conversaram sobre "Ditadura e homossexualidade: resistência do movimento LGBT", compartilhando tanto relatos pessoais do que eles próprios viveram nos anos 1970 e 1980, como análises daquele momento histórico ${ }^{6}$.

Outro órgão oficial que dedicou um capítulo particular à temática foi a Comissão da Verdade do Estado do Rio de Janeiro, intitulado "Homossexualidades, repressão e resistência

\footnotetext{
${ }^{4}$ Foram apresentados trabalhos desenvolvidos pelos seguintes pesquisadores: Benjamin Cowan (professor da George Mason University), James N. Green (professor de História da América Latina na Brown University), Jorge Caê Rodrigues (professor da Universidade do Grande Rio - Unigranrio), Marisa Fernandes (historiadora), Rafael Freitas (historiador), Renan Quinalha (advogado vinculado à Comissão Estadual da Verdade de São Paulo), Rita Colaço (historiadora).

5 Relatório Final da CNV, Livro $\quad$ II, $\quad$ pp. $\quad 300 \quad-\quad 311$. http://www.cnv.gov.br/images/pdf/relatorio/Volume\%202\%20-\%20Texto\%207.pdf

${ }^{6}$ As falas e discussões ocorridas nesse evento encontram-se resumidas no capítulo específico do relatório final da Comissão paulista em torno das "homossexualidades", disponível em http://comissaodaverdade.al.sp.gov.br/relatorio/tomo-i/parte-ii-cap7.html
} 
durante a ditadura", escrito pelos colaboradores James N. Green e por mim com o objetivo de iluminar questões específicas do território fluminense ${ }^{7}$.

Contudo, apesar dos significativos avanços representados por tal resultado, diversos fatores comprometeram a qualidade da abordagem da temática nas Comissões da Verdade. Primeiro, ao contrário da maior parte dos outros assuntos tratados pelas Comissões da Verdade, sobre os quais já havia uma quantidade razoável de material produzido pela academia e pelos próprios ex-perseguidos na reconstrução das memórias do período em relação às homossexualidades na ditadura, não se verificava, até então, um grande número de pesquisas feitas ou mesmo depoimentos em primeira pessoa que poderiam servir de ponto de partida $^{8}$. Depois, por ter-se constituído, durante muito tempo, como um tabu dentro e fora do mundo universitário, a homossexualidade não era vista como um tema sério de pesquisas e tampouco como um recorte pertinente para a reflexão acerca da ditadura e de seu legado.

O mesmo se passava no universo da militância pelos direitos humanos, que reproduzia a estigmatização social das sexualidades dissidentes ou mesmo a indiferença em relação ao tema. Inclusive porque os herdeiros mais credenciados na produção das memórias, os expresos políticos e os familiares de desaparecidos, não pautavam esta dimensão das políticas repressivas da ditadura, ainda que muitos deles a tenham apoiado com grande entusiasmo no período mais recente.

Nas Comissões, da mesma forma, a relevância da discussão não era algo pacífico, bastando mencionar, a título de exemplo, que na CNV houve uma discussão entre os membros, a ponto de um dos comissionados interrogar "por que esse tema de viados" (sic) deveria constar no relatório 9 . As resistências geradas, sobretudo pelo preconceito e pela falta de sensibilidade que alguns comissionados demonstraram para aceitar que tal tema frequentasse os trabalhos de investigação histórica, foram significativas.

Um terceiro fator que restringiu o alcance das investigações foi o prazo curto e a

\footnotetext{
${ }^{7}$ Relatório Final da Comissão da Verdade do Estado do Rio de Janeiro, pp. 149 - 159, disponível em http://www.cev-rio.org.br/site/arq/CEV-Rio-Relatorio-Final.pdf

${ }^{8}$ Alguns autores que escreveram sobre a história das homossexualidades e do movimento LGBT, ou mesmo sobre suas experiências pessoais, tangenciaram esse assunto específico. Ainda que tais trabalhos tenham aportado algumas contribuições relevantes para o relato de alguns casos particulares, o cruzamento entre ditadura e homossexualidades não era o foco principal dos mesmos. Ver, por exemplo, TREVISAN, Devassos no Paraíso; GREEN, James N. Além do Carnaval; GREEN, James N. Abaixo a repressão, mais amor e mais tesão; MACRAE, Edward. A construção da Igualdade; COLAÇO, Rita. De Daniele a Chrysóstomo - Quando travestis, bonecas e homossexuais entram em cena. Tese de Doutorado em História apresentada ao Instituto de Ciências Humanas e Filosofia da Universidade Federal Fluminense (UFF), 2012; SIMÕES, Júlio e FACCHINI, Regina. Nas Trilhas do Arco-Íris. O trabalho mais específico e sistemático sobre este tema, até o momento, é o de Benjamin Cowan: Securing Sex: Morality and Repression in the Making of Cold War Brazil. University of North Carolina Press, 2016.

${ }^{9}$ Essa colocação foi feita em uma reunião da CNV sobre o relatório e presenciada por um dos assessores que pediu para não ser identificado.
} 
deficiência de infraestrutura que, em geral, caracterizaram as Comissões da Verdade. Ademais, questões comportamentais e morais, tal qual a sexualidade e o gênero, não eram identificadas como prioritárias ou mesmo tão importantes dentre um conjunto enorme de outras agendas e reivindicações, ficando relegadas a segundo plano. Com efeito, considerando o atraso do Estado brasileiro para esclarecer os casos tidos como mais graves, como as mortes e desaparecimentos forçados, as Comissões da Verdade tiveram de concentrar seus recursos e energias escassos com essas demandas históricas do movimento por memória, verdade e justiça. Para que se tenha uma ideia das dificuldades encontradas, mesmo com todo o encaminhamento feito e com o trabalho pronto, até as vésperas da entrega do material para o relatório final, não se sabia ainda se o tema das homossexualidades mereceria um capítulo específico ou se acabaria restrito a algumas páginas de uma única seção junto com outros temas identitários, como raça e gênero. Esta questão só foi definida nos últimos dias, já na fase de preparação e edição do relatório final, que foi entregue à Presidenta Dilma Rousseff no dia 10 de dezembro de 2014.

Outro elemento que prejudicou a profundidade das contribuições das Comissões foi que estas não constituíram grupos de trabalho específicos para a temática, procedimento adotado para outros assuntos considerados prioritários. Ao contrário disso, elas apenas incumbiram, já na fase final de seus respectivos prazos de funcionamento, colaboradores externos para levantar material, realizar as pesquisas e redigir os referidos textos de abrangência nacional e regionais (SP e RJ), com pouco suporte efetivo das Comissões para levar a cabo tais tarefas. Neste sentido, um certo voluntarismo militante foi o determinante para abrir esta frente de trabalho em meio a outras tantas agendas e preocupações consideradas mais centrais na busca da verdade ${ }^{10}$.

Além disso, como o mandato legal destes órgãos era, basicamente, esclarecer as circunstâncias das "graves violações de direitos humanos", indicando, quando possível, a autoria das mesmas, o tipo de estrutura e linguagem, o parâmetro de tamanho e o objetivo impostos por este formato tão peculiar de relatório reduziam, significativamente, as potencialidades do texto enquanto uma escrita da história mais livre e minuciosa das diversas formas de repressão dos corpos marcados por sexualidade ou identidade de gênero

\footnotetext{
${ }^{10}$ Alguns militantes, contudo, posicionaram-se contrariamente à iniciativa. Por exemplo, o fundador do GGB Luiz Mott problematizou a afirmação da existência de uma política de Estado de feições homofóbicas na ditadura baseado em sua própria experiência pessoal e não em pesquisas fundamentadas. Em e-mail datado de 25 de agosto de 2015 em uma lista nacional de militância, ele afirmou que "não houve homofobia como política de estado durante a ditadura: a perseguição aos homossexuais e trans é anterior, durante e posterior ao golpe militar. Nunca foram assassinados tantos lgbt como no governo dilma, 316 em média por ano, 163 no governo lula, 127 durante FHC".
} 
dissidentes.

De qualquer modo, é necessário reconhecer que, sem dúvidas, este primeiro esforço mais sistemático de visibilização e de reconhecimento foi fundamental e contou com a valiosa colaboração de grupos do movimento LGBT, tanto na audiência pública da CNV, como por meio de ofícios pressionando pela inclusão de um capítulo específico dedicado exclusivamente ao assunto ${ }^{11}$. Isto, contudo, mostrou-se um esforço bastante limitado pelas diversas circunstâncias acima pontuadas, demonstrando-se mais como um ponto de partida, ainda bastante embrionário, isto é, com o objetivo de abrir um campo para novas investigações, do que um ponto final com revelações mais definitivas. De forma geral, prevaleceram, nos relatórios oficiais, análises de casos pontuais e particulares, que já eram mais conhecidos ou sobre os quais havia algum material previamente levantado.

A presente pesquisa investe-se neste esforço de reconstrução histórica mais ampla ao lançar luz sobre as tensões entre a ditadura e as homossexualidades. Este trabalho, de algum modo, decorre, das brechas abertas desde as Comissões da Verdade a fim de compreender as articulações entre regimes políticos e formas de regulação das sexualidades, com destaque para a ditadura brasileira. Buscando superar as deficiências e limites acima apontados para dar cabo a uma "versão oficial" deste capítulo de nossa história recente, nosso objetivo principal é construir uma narrativa mais aberta a partir das distintas dimensões e facetas da política sexual concebida e implementada pela ditadura por meio de suas agências de controle.

\section{Regimes autoritários e regulação das sexualidades dissidentes}

No Brasil, o momento privilegiado do trabalho de memória por conta das Comissões da Verdade parece ter catalisado e estimulado discussões sobre novas perspectivas em torno da repressão moral da ditadura. Mas, ao contrário da escassez de estudos específicos notada em nosso país, em outras nações que também viveram sob o fardo de regimes autoritários, é possível encontrar uma série de trabalhos acadêmicos ou jornalísticos abordando questões comportamentais e sexuais.

É evidente que todos os regimes políticos e formas de governo dispõem, em maior ou menor grau, de normas e instituições para regular dimensões da vida familiar de seus

\footnotetext{
${ }^{11}$ O GADvS - Grupo de Advogados pela Diversidade Sexual - e a ABGLT - Associação Brasileira de Lésbicas, Gays, Bissexuais, Travestis e Transexuais - enviaram ofício à Comissão Nacional da Verdade em 6 de outubro de 2014 para reivindicar esta inclusão. http://www.gadvs.com.br/?p=1920
} 
cidadãos. Essa invasão da esfera particular não é uma exclusividade de ditaduras. No entanto, quanto mais fechado e conservador é o regime político, mais há uma tendência em intensificar modos de controle nos espaços públicos e privados ${ }^{12}$. A partir desta perspectiva, pode-se afirmar que um indicador fundamental do grau de liberdade, inclusão e democracia de um determinado regime ou governo é a maneira como integra ou não uma agenda de diversidade sexual e de gênero nos discursos oficiais e nas políticas públicas ${ }^{13}$.

Diversos são os estudos que compartilham desta perspectiva e esforço para a reconstrução histórica da repressão às sexualidades dissidentes em distintos regimes de restrição a direitos civis e liberdades públicas. É bastante conhecido, por exemplo, o modo como, no nazismo alemão, a punição aos homossexuais estava consagrada no artigo 175 do Código Penal, chegando-se até mesmo a organizar um escritório central sob supervisão do comandante das SS, Heinrich Himmler, para combater a homossexualidade e o aborto, em 1936. Em torno de 50 mil pessoas foram condenadas por serem homossexuais, sendo que 15 mil delas, marcadas pelo triângulo rosa ${ }^{14}$, morreram em campos de concentração.

Por sua vez, na Itália fascista, em que não havia um crime tipificado no Código Penal e onde a repressão sexual assumiu um caráter peculiar de uma "revolução antropológica" para criar um novo tipo de homem devotado ao Estado, registros apontam que ao menos 300 pessoas foram acusadas de pederastia e condenadas ao exílio forçado, enquanto 88 presos foram considerados homossexuais ${ }^{15}$.

Dentre os estudos que buscaram compreender especificamente os modos de repressão às sexualidades sob contextos políticos autoritários, destacam-se ainda os trabalhos dedicados a regimes fascistas ou de inspiração fascista na Europa. Por exemplo ${ }^{16}$, Francisco Molina Artaloytia investigou, em uma perspectiva comparada, como psiquiatras e outros especialistas do campo da medicina contribuíram para a construção de um saber sobre as sexualidades desviantes na Espanha de Francisco Franco (1939 - 1977) e no Estado Novo português de

\footnotetext{
${ }^{12}$ Um estudo comparativo de fôlego das relações entre sexo e poder no século passado, a partir dos eixos do patriarcado, dos vínculos sexuais e da fecundidade, pode ser encontrado em THERBORN, Göran. Sexo e poder: a família no mundo (1900-2000). São Paulo: Contexto, 2015.

${ }^{13}$ Nesta mesma linha, para um panorama da evolução na legislação de reconhecimento de direitos e não discriminação, bem como de práticas exitosas relativas à expressão da diversidade de gênero e sexual, ver MINISTÉRIO DAS RELAÇÕES EXTERIORES. Mundo afora: políticas de combate à violência e à discriminação contra pessoas LGBT, n. 12. Brasília, 2015.

${ }^{14}$ BRAZDA, Rudolf e SCHWARTZ, Jean-Luc. Triângulo Rosa: um homossexual no campo de concentração nazista. São Paulo: Mescla, 2012.

${ }^{15}$ BENADUSI, Lorenzo. Homosexuality in Fascist Italy: the enemy of the new man. Wisconsin: The University of Wisconsin Press, 2012.

${ }^{16}$ ARTALOYTIA, Francisco Molina. Stigma, Diagnosis and Interaction: An Epistemological and Axiological Analysis of the Biomedical Discourses about Homosexuality in the Iberian Authoritarian Regimes of the 20th Century. Tese de Doutorado, Universidad Nacional de Educación a Distancia, 2015, 766 pp.
} 
António Salazar (1933-1974). Para compreender como a homossexualidade se tornou objeto da atenção científica e da repressão legal, ele investiga como o conceito de "Novo Homem" e os códigos jurídicos que criminalizam certos fenômenos "antissociais" serviram para estigmatizar os indivíduos que não se adaptavam a estes ideais na Península Ibérica. Também em relação à repressão em Portugal, sobretudo sob a vigência do salazarismo, há o trabalho jornalístico feito por São José Almeida, com um registro rico de episódios, personagens e "paneleiros"17.

Outro estudo comparado relevante é o de Huard sobre as diferenças e semelhanças da repressão à homossexualidade nas cidades de Paris e Barcelona nos 30 anos que sucedem a Segunda Grande Guerra. Para ele, enquanto a capital francesa estava mais preocupada em "dessexualizar" os espaços públicos e tornar as relações homossexuais privadas, a cidade espanhola, sob o franquismo, censurava discursos públicos que poderiam corromper a juventude e punia os homossexuais associando-os à delinquência a partir de um recorte de classe $^{18}$.

Ainda sobre o franquismo, há estudos como o de Javier Galeno, que se vale de fontes judiciais na cidade de Málaga para compreender como a perseguição legal contra os homossexuais foi praticada. Ele observa, a partir de casos concretos examinados, como "social hierarchies, local authorities' attitudes, and relations of patronage shaped the application of the law", além de concluir que "protecting public morality was one of the authorities' main concerns with respect to homosexuality, and that homosexuals did not relinquish their sexual and emotional lives in the face of state repression"19.

No que se refere à Argentina, há alguns trabalhos importantes dedicados ao tema da homossexualidade. Um panorama bastante geral, na forma de um ensaio crítico recheado de diversos depoimentos e memórias, aparece delineado no livro de Rapisardi e Modarelli sobre os gozos clandestinos que homossexuais argentinos encontravam nos banheiros públicos, nas estações ferroviárias, em festas particulares, no exílio e em outros refúgios diante da repressão e das patrulhas militares na mais recente ditadura que assolou o país (1976-1983) ${ }^{20}$. Outras pesquisas mais recentes, como a de Santiago Joaquín Insausti, com maior rigor metodológico e acesso a fontes documentais do período, por meio de uma genealogia da repressão policial

\footnotetext{
${ }^{17}$ ALMEIDA, São José. Homossexuais no Estado Novo. Porto: Sextante Editora, 2010.

${ }^{18}$ HUARD, Geoffroy. Los Antisociales: Historia de la homosexualidad en Barcelona y París (1945-1975). Madrid, Marcial Pons, 2014

${ }^{19}$ GALEANO, Javier Fernandez. Is He a "Social Danger"? The Franco Regime's Judicial Prosecution of Homosexuality in Malaga under the Ley de Vagos y Maleantes. In: Journal of the History of Sexuality, v. 25, n. 1, January, 2016, pp. 1-31

${ }^{20}$ RAPISARDI, Flávio, \& MODARELLI, Alejandro. Fiestas, baños y exilios: Los gays porteños en la última dictadura. Buenos Aires: Sudamericana, 2001.
} 
aos "maricas" e de uma problematização da produção das memórias pelos militantes, vêm questionando a existência de um plano sistemático de perseguição, tortura e desaparecimento de homossexuais na Argentina ${ }^{21}$.

Não obstante, não são apenas regimes de extrema direita que trataram com violência as pessoas LGBT. Determinados regimes de esquerda também institucionalizaram a violência contra estes segmentos. Na União Soviética, depois de um período de importantes avanços sociais e culturais após a Revolução de 1917, inclusive com liberalização dos costumes e maior diversidade de gênero e de sexualidade, a ascensão de Stálin marcou um retrocesso conservador em diversos sentidos. Já na primeira metade da década de 1930, uma nova lei de sodomia desconstruiu o legado da "revolução sexual" desencadeada a partir de outubro de $1917^{22}$, criminalizando novamente a homossexualidade e culminando na condenação de mais de 50 mil homossexuais até os primeiros anos da década de 1980, muitos deles mandados a campos de trabalho forçado - os gulag - sob as mais difíceis condições de sobrevivência.

Cuba é outro exemplo de um regime socialista, com significativas realizações de justiça social e igualdade material, mas que não conseguiu assimilar a diversidade sexual enquanto um valor fundamental democrático até recentemente, quando fez um balanço crítico e pediu oficialmente desculpas pelas perseguições. Poucos anos após a Revolução Cubana, Fidel Castro já revelava, em entrevista, sua concepção em relação à homossexualidade: “[...] não se deve permitir que os homossexuais ocupem cargos nos quais possam exercer influência sobre os jovens. Sob as condições em que vivemos, por conta dos problemas que o nosso país enfrenta, devemos inculcar nos jovens o espírito da disciplina, da luta e do trabalho"23. Isto sem mencionar os milhares de homossexuais enviados às Unidades Militares de Ajuda à Produção (UMAPs), em que o trabalho forçado e a "reeducação" eram impostos como uma maneira de criar o "novo homem"24.

\footnotetext{
${ }^{21}$ INSAUSTI, Santiago Joanquín. "Los cuatrocientos homosexuales desaparecidos: Memorias de la represión estatal a las sexualidades dissidentes en Argentina. In: D'ANTONIO, Debora (Org.). Deseo y represión: sexualidade, género y Estado en la historia argentina reciente. Buenos Aires: Ediciones Imago Mundi, 2015, pp. 62-82. Na Argentina, uma cifra bastante popularizada, ainda que não comprovada, é a de que teriam desaparecido 400 homossexuais pela ação da ditadura. Este dado, que serviria de base para afirmar a existência de uma política de desaparecimento contra homossexuais é questionado por Insausti. A origem do número está no livro de um dos mais importantes militantes gays argentinos que afirmou que um dos integrantes da CONADEP "afirma la existencia de, por lo menos, 400 homosexuales integrando la lista del horror (...). No los conocimos, no los conoceremos jamás. Son, solamente, cuatrocientos de los treinta mil gritos de justicia que laten en nuestro corazón". Cf.: JÁUREGUI, Carlos. La homosexualidad en la Argentina. Buenos Aires: Ediciones Tarso, 1987, p. 170.

${ }^{22}$ HEALEY, Dan. Homosexual Desire in Revolutionary Russia. Chicago: The University of Chiago Press, 2001, pp. 234 e ss.

${ }^{23}$ YOUNG, Alan. Los gays bajo la Revolución Cubana. Madrid: Playor, 1984.

${ }^{24}$ A repressão à homossexualidade por meio das UMAPs no período de 1965 a 1970 não teria sido, apenas, o resultado do machismo pré-revolucionário, mas uma maneira de enfrentar a crise econômica doutrinando a
} 
Tal panorama bastante geral de casos tão distintos entre si, referidos apenas pontualmente, não pretende, de forma alguma, colocar lado-a-lado regimes tão distintos, mas apenas evidenciar que se acumula um conjunto de trabalhos e reflexões sobre como regimes marcados pela centralização excessiva de poder político, ainda de diferentes matizes, reproduzem representações negativas e estigmatizantes de sexualidades dissidentes. No Brasil, contudo, ainda são poucos os trabalhos que adotam uma perspectiva semelhante de análise.

\section{Ditadura hétero-militar?}

Como já apontado, a repressão contra o comunismo e outras formas de subversão estritamente política, especialmente os grupos que pegaram em armas para resistir à ditadura, encontraram maior espaço já nas pesquisas acadêmicas, na literatura de testemunhos e nas políticas públicas oficiais de reparação das violências cometidas neste período. Com efeito, abundam trabalhos, sobretudo nos últimos anos, dedicados ao estudo dos pilares básicos do “projeto repressivo global”, quais sejam: espionagem, polícia política, censura da imprensa, censura de diversões públicas, propaganda política e julgamento sumário de supostos corruptos) $)^{25}$.

Contudo, em menor quantidade, são os escritos que não reduzem a história de 1964 a 1985 à história apenas do embate político entre ditadura e oposições, seja em sua dimensão parlamentar ou armada. De modo geral, temas comportamentais, discussões de gênero e questões sexuais, considerados assuntos de ordem moral, não receberam a devida atenção ou, quando muito, foram analisados como fenômenos sem estatuto próprio.

Assim, apesar dos fartos elementos que sugerem ser promissora a reflexão sobre o cruzamento entre regimes autoritários e regulação das sexualidades, a literatura sobre a ditadura brasileira concentrou-se em destacar aspectos mais traumáticos e clandestinos da repressão estatal contra dissidentes estritamente políticos. Tal postura pode ser compreendida considerando a gravidade das práticas de violência estatal durante o período, mas acabou, muitas vezes, reforçando uma representação do Estado como instituição fortemente

juventude para o trabalho manual e voluntário a partir de um recorte de gênero. Cf.: GUERRA, Lillian. Gender Policing, Homosexuality and the New Patriarchy of the Cuban Revolution, 1965-1970, Social History, v. 35, n. 3, August, 2010.

${ }^{25}$ FICO, Carlos. Espionagem, polícia política, censura e propaganda: os pilares básicos da repressão. In: FERREIRA, Jorge; DELGADO, Lucília de Almeida Neves (Orgs). $O$ tempo da ditadura: regime militar e movimentos sociais em fins do século XX. 2. ed. Rio de Janeiro: Civilização Brasileira, 2007, pp. 167-201. 
monolítica e centralizada. Por outro lado, contribuiu, ainda, para a construção de uma narrativa da convivência de uma repressão política dura e um controle moral brando, a emergência da contracultura ou do "desbunde", deixando uma impressão de que a ditadura teria sido tolerante ou condescendente com a evolução dos costumes e com a liberdade sexual que se impuseram naquele momento ${ }^{26}$.

No entanto, esse tipo de argumentação não se sustenta mais atualmente. Diante das fontes mais recentes e, sobretudo, dos novos olhares marcados pela preocupação com esse recorte da sexualidade, tem-se aberto a possibilidade de descortinar, com maior profundidade, dimensões específicas da repressão outrora ignoradas ou negligenciadas.

De qualquer modo, resta por ser escrita uma bibliografia mais específica que explore a dimensão sexo-gênero na elaboração das tecnologias repressivas e dos dispositivos disciplinares voltados aos setores considerados moralmente indesejáveis ${ }^{27}$. Ainda que o Estado não seja o único responsável por normatizar os discursos e práticas sexuais, sem dúvidas, durante a ditadura, ele se tornou um locus privilegiado de irradiação de regras proibitivas e licenças permissivas em relação às sexualidades, ajudando a definir as condutas classificadas como inaceitáveis.

É evidente que padrões de moralidade pública não invadiram o espaço da política somente com o início da ditadura brasileira. Não foi esta que inaugurou o peso da discriminação sobre as populações vulneráveis que, há tempos, já marcava a cultura brasileira. As tentativas de enquadramento e normalização das sexualidades dissidentes remontam a períodos muito anteriores à formação do Estado brasileiro. Discursos religiosos, médicos, legais, criminológicos e de diversas outras ordens se intercalavam e se combinavam de modo a produzir uma regulação específica das sexualidades em cada momento histórico ${ }^{28}$.

No entanto, constatar que sempre houve homofobia e transfobia entre nós é um truísmo que, em verdade, pouco explica, uma vez que não leva em conta as distintas formas

\footnotetext{
${ }^{26}$ Por exemplo, o filósofo Renato Janine Ribeiro chegou a afirmar que a repressão foi bastante leve - ou mesmo tolerante - no que dizia respeito ao sexo, a costumes, a sentimentos". Cf.: RIBEIRO, Renato Janine. A política dos costumes. In: Novaes, Adauto (Org.). Muito além do espetáculo. São Paulo: Senac, 2005, p. 138. No mesmo sentido, ver GOLDBERG, A. Feminismo e autoritarismo: a metamorfose de uma utopia de liberação em ideologia liberalizante. Dissertação (Mestrado em História), Universidade Federal do Rio de Janeiro, Rio de Janeiro, 1987.

${ }^{27}$ Exceções a esta constatação, que analisam, ainda que indiretamente, a questão da sexualidade no período da ditadura no Brasil, podem ser encontradas nas obras mencionadas na nota 8. Alguns trabalhos mais recentes têm explorado este novo campo, tais como GREEN, James N. e QUINALHA, Renan (orgs.). Ditadura e homossexualidades: repressão resistência e a busca da verdade. São Carlos; Editora da UFSCar, 2014 e LOPES, Fábio Henrique. Travestilidades e ditadura civil-militar brasileira: apontamentos de uma pesquisa. Revista Esboços, Florianópolis, v. 23, n. 35, p. 145-167, set. 2016, pp. 145-167.

${ }^{28}$ Ver, por exemplo, a história da homossexualidade masculina no Brasil escrita por James N. Green, Além do Carnaval.
} 
históricas de manifestação de um poder regulador de "desvios" sexuais e suas determinações particulares em cada conjuntura histórica. É fundamental, portanto, compreender não apenas as estruturas de continuidade e de permanência que marcam a cultura do preconceito, mas também o que há de específico, as mudanças e os deslocamentos relativos à violência empreendida em cada contexto histórico.

No Brasil, desde o Código Criminal do Império, de 1830, a prática homossexual não se encontra expressamente criminalizada para civis $^{29}$. Sem embargo, diversos outros dispositivos legais e contravencionais, tais como "ato obsceno em lugar público", "vadiagem" ou violação à "moral e aos bons costumes", foram intensamente mobilizados para perseguir as sexualidades desviantes.

Conforme apontou a Comissão Nacional da Verdade, durante a ditadura civil-militar, de forma mais intensa do que em outros períodos da nossa história, o autoritarismo de Estado também se valeu de uma ideologia da intolerância materializada na perseguição e tentativa de controle de grupos sociais tidos como uma ameaça ou perigo social. A criação da figura de um "inimigo interno" valeu-se de contornos não apenas políticos de acordo com a Doutrina da Segurança Nacional, mas também morais, ao associar a homossexualidade a uma forma de degeneração e de corrupção da juventude ${ }^{30}$.

Compreender esses traços específicos torna-se fundamental, portanto, para uma caracterização adequada do alcance e do sentido da repressão levada a cabo pela ditadura brasileira.

\section{"Os ideais superiores da Revolução"}

A retórica moralidade pública e dos bons costumes foi central na construção da estrutura ideológica que deu sustentação à ditadura de 1964. A defesa das tradições, a proteção da família, o cultivo dos valores religiosos cristãos foram todos, a um só tempo, motes que animaram uma verdadeira cruzada repressiva contra setores classificados como

\footnotetext{
${ }^{29}$ Para militares, contudo, a pederastia era criminalizada até recentemente. O art. 235 do Código Penal Militar previa o crime de pederastia ou ato de libidinagem nos seguintes termos: "Praticar, ou permitir o militar que com ele se pratique, ato libidinoso, homossexual ou não, em lugar sujeito à administração militar". Dentre as 29 recomendações da Comissão Nacional da Verdade, a de número 23 prescrevia justamente a "supressão, na legislação, de referências discriminatórias das homossexualidades", citando, como exemplo, o referido artigo do Código Penal Militar. Somente em 28 de outubro de 2015, ao julgar a Arguição de Descumprimento de Preceito Fundamental (ADPF) n. 291, o Supremo Tribunal Federal (STF) declarou como não recepcionados pela Constituição Federal os termos "pederastia ou outro" e "homossexual ou não", expressos no dispositivo do CPM.

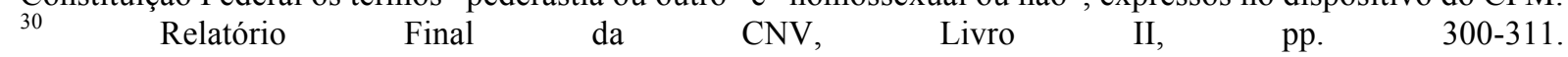
http://www.cnv.gov.br/images/pdf/relatorio/Volume\%202\%20-\%20Texto\%207.pdf
} 
indesejáveis e considerados ameaçadores à ordem moral e sexual então vigente ${ }^{31}$.

As diversas manifestações da Marcha da Família com Deus pela Liberdade, ocorridas entre março e junho de 1964, foram um prenúncio revelador do que estaria por vir $^{32}$. Católicos conservadores, grupos femininos de direita, moralistas de ocasião, grandes proprietários rurais e outros ramos do empresariado, bem como outras camadas das classes médias insufladas pelo discurso do combate à "corrupção" e à "ameaça comunista", ocuparam as ruas de diversas cidades brasileiras contra o governo João Goulart clamando por uma intervenção redentora das Forças Armadas e, a partir de abril, efetivamente em apoio ao golpe civilmilitar.

A agenda de valores conservadores destes setores que realizavam algumas das maiores manifestações públicas de nossa história política, de certo modo, mobilizava anseios antigos, mas também atualizava uma reação contra as mudanças atravessadas pela sociedade brasileira daquela época. Com efeito, para além das políticas progressistas e nacionalistas propostas pelo governo Goulart, tais como as Reformas de Base, desde a década de 1930 estavam em curso transformações culturais mais profundas decorrentes do processo de urbanização e modernização no Brasil que desestabilizavam as relações tradicionais em diferentes planos. Os costumes e as sexualidades não passavam incólumes aos agitados anos 1960.

Assim, as elites militares que capitanearam o golpe, com o apoio decisivo de setores civis, não demoraram a catalisar esse sentimento reacionário difuso em um discurso coeso capaz de justificar ideologicamente o novo regime em perfeita sintonia com as demandas por mais segurança, solidez das tradições e respeito à ordem que se estava perdendo ao longo do tortuoso caminho do desenvolvimento. O discurso marcadamente anticomunista, em prol da segurança nacional, apresentou-se em perfeita congruência histórica com a ânsia conservadora pela preservação da família e dos valores cristãos.

Os Atos Institucionais surgiram, assim, como instrumentos legais de enorme relevância na montagem da nova institucionalidade, materializando, desde o início, um

\footnotetext{
${ }^{31} \mathrm{O}$ clássico de Comblin sobre a segurança nacional já chamava atenção para a centralidade da agenda moral nas ditaduras latino-americanas: "Quanto mais ditatorial e violento for um Estado, mais ele tratará a nação como inimiga, e quanto mais proclamar pretensões de moralidade, mais edificante, moralista e espiritual será sua linguagem - a tal ponto que qualquer aula de moral vinda de um Chefe de Estado desperta imediatamente uma sensação de medo. Sob este ponto de vista, os discursos dos generais latino-americanos batem todos os recordes. A se acreditar neles, suas ditaduras não têm outra meta senão restaurar a moralidade da nação". COMBLIN, Joseph. A ideologia de Segurança Nacional. O poder militar na América Latina. Rio de Janeiro: Civilização Brasileira, 1978, pp. 222/223.

${ }^{32}$ Ver PRESOT, Aline. Celebrando a 'Revolução': as marchas da família com Deus pela liberdade e o Golpe de 1964. In: ROLLEMBERG, Denise; QUADRAT, Samantha Viz. (Org.). A construção social dos regimes autoritários: legitimidade, consenso e consentimento no Século XX - Brasil e América Latina. Rio de Janeiro: Civilização Brasileira, 2010. p. 71-96. SIMÕES, Solange de Deus. Deus, pátria e família: as mulheres no golpe de 1964. Petrópolis: Vozes, 1985.
} 
atrelamento estrutural entre moral e política constitutivo da ordem autoritária. O AI-1, de 9 de abril de 1964 - que veio à tona para "fixar o conceito do movimento civil e militar" que tomou o poder -, esclarecia, de partida, a tarefa de "reconstrução econômica, financeira, política e moral do Brasil", bem como "toma[va] as urgentes medidas destinadas a drenar o bolsão comunista, cuja purulência já se havia infiltrado não só na cúpula de governo como nas suas dependências administrativas". Já o AI-2, de 27 de outubro de 1965, reforçava o caráter "revolucionário" e originário do novo regime, destacando a aspiração de "erradicar uma situação e um Governo que afundavam o País na corrupção e subversão".

Esse dispositivo reforçava os já enunciados "propósitos de recuperação econômica, financeira, política e moral do Brasil", bem como o desafio de "preservar a honra nacional". Em seu artigo 12, o Ato Segundo modificava a redação do parágrafo $5^{\circ}$ do art. 141 da Constituição, passando a vigorar com a seguinte redação: "não será porém tolerada propaganda de guerra, de subversão, da ordem ou de preconceitos de raça ou de classe”. Já o AI-3, no seu preâmbulo, pontuava a necessidade de se "preservar a tranquilidade e a harmonia política e social do País": um lema constante para os "revolucionários" de 1964.

Por sua vez, o mais duro dos atos, o AI-5, outorgado em 13 de dezembro de 1968, em seus "considerados", já anunciava a necessidade de preservação de uma "autêntica ordem democrática, baseada na liberdade, no respeito à dignidade da pessoa humana, no combate à subversão e às ideologias contrárias às tradições do nosso povo, na luta contra a corrupção". Acrescentando, ainda, que o governo da ocasião, responsável "pela ordem e segurança internas, não só não pod[ia] permitir que pessoas ou grupos anti-revolucionários contra ele trabalh[assem], tram[assem], ou [agissem], sob pena de estar faltando a compromissos que assumiu com o povo brasileiro".

Mesmo com a nova Constituinte ensaiada com o AI-4, "atos nitidamente subversivos, oriundos dos mais distintos setores políticos e culturais, comprova[vam] que os instrumentos jurídicos, que a Revolução vitoriosa outorgou a Nação para sua defesa, desenvolvimento e bem-estar de seu povo, est[avam] servindo de meios para combatê-la e destruí-la". Concluindo, posteriormente, que "se torna[va] imperiosa a adoção de medidas que impe[dissem] [fossem] frustrados os ideais superiores da Revolução, preservando a ordem, a segurança, a tranquilidade, o desenvolvimento econômico e cultural e a harmonia política e social do País comprometidos por processos subversivos e de guerra revolucionária”. Afinal, "fatos perturbadores da ordem [eram] contrários aos ideais e à consolidação do Movimento de março de 1964".

A partir desta breve exegese legal, é possível notar, claramente, um discurso que 
consagra uma "ordem", inspirada pelos "ideais superiores da Revolução" e pela "honra nacional", que devia ser defendida contra qualquer ameaça de "subversão" e de "corrupção", seja ela "política", "cultural" ou "moral”. A "democracia" não era apenas ocidental e capitalista, mas também cristã, e precisaria estar permanentemente alerta contra os riscos criados e alimentados por conspiradores de fora e de dentro das fronteiras nacionais.

O uso recorrente de conceitos como "ordem" e seu oposto "subversão" no topo da pirâmide regulatória do novo regime é reflexo direto da Doutrina de Segurança Nacional, que traçava uma linha divisória entre os que estão integrados ao regime e aqueles que seriam desajustados e que, portanto, deveriam ser neutralizados em sua diferença, ou mesmo eliminados. A imposição de uma ordem estabilizada, segura e unitária, coerentemente homogênea, que repeliria qualquer tipo de perturbação, dissenso ou presença incômoda, foi uma marca característica da ditadura.

Tratou-se de uma verdadeira "utopia autoritária" "33, com pretensões de totalidade e de alcance absoluto de todas as dimensões da vida social. Um regime ditatorial, em verdade, não é apenas uma forma de organização de um governo orientado para a supressão de direitos e liberdades como um fim em si mesmo, mas se abate sobre os corpos social, político e individual como um verdadeiro laboratório de subjetividades para forjar uma sociedade à sua própria imagem. Quaisquer obstáculos a serem trilhados, neste sentido, para realizar a vocação de grandeza do Brasil, deveriam ser removidos, eliminados.

Contudo, para lograr êxito ao longo da empreitada pretensiosa de "utopia autoritária, era necessário estruturar um aparato complexo e funcional, que não se limitava apenas à difundida ideia de "porões da ditadura" isolados e afastados dos centros de poder para levar a cabo o trabalho "sujo" da repressão. Atualmente se sabe que as violações de direitos humanos foram concebidas enquanto políticas públicas oficializadas com envolvimento direto das altas autoridades em uma estrutura de comando institucionalizada ${ }^{34}$. Por isto é importante que qualquer discussão sobre o controle moral executado pela ditadura brasileira tome como ponto de partida um exame de sua estrutura repressiva.

\footnotetext{
${ }^{33}$ A expressão foi proposta originalmente por Maria Celina D'Araujo, Celso Castro e Gláucio Ary Dillon Soares. Cf.: D'ARAUJO, M. C. et al. (Org.) Visões do golpe: a memória militar sobre 1964. Rio de Janeiro: RelumeDumará, 1994, p. 9

34 Ver, por exemplo, o primeiro volume do relatório da Comissão Nacional da Verdade: http://www.cnv.gov.br/images/pdf/relatorio/volume_1_digital.pdf
} 


\section{Dimensões do aparato repressivo}

O controle da sociedade e, especialmente, dos elementos "subversivos" que se opunham à ditadura começa logo após o golpe de 1964 com a estruturação de um amplo e complexo aparato de repressão e perseguição a dissidentes. Mas, apesar do elevado grau de centralização de poder durante a ditadura, não houve um organismo único ou uma agência estatal responsável isoladamente pela política de "saneamento" da sociedade, de modo a expurgar os elementos tidos como indesejáveis. Pelo contrário, a estrutura do aparato repressivo foi sendo progressivamente construída a partir de diferentes vértices, conjugando organismos de controle moral preexistentes com outras agências criadas sob inspiração da "doutrina de segurança nacional" do regime. Além disso, o complexo aparato foi se modificando conforme as necessidades conjunturais de cada momento e, assim, assumindo distintas formas institucionais durante os anos da ditadura, a depender dos embates e negociações travados dentro do conjunto das elites civis e militares que capitanearam a edificação do regime autoritário.

Polícias políticas e judiciárias, comunidade de segurança, sistemas de espionagem e vigilância, órgãos de censura e de propaganda política, além do julgamento sumário dos supostos corruptos foram algumas das principais estruturas de que se valeu a burocracia estatal para conformar o já referido "projeto repressivo global". O fato de não haver um único órgão capaz de centralizar o controle dos dissensos acabou levando a uma multiplicidade de organismos e agências estatais dedicados a essas tarefas. Um grande desafio, para a continuidade do regime, passava necessariamente por articular esses órgãos repressivos de modo a diminuir as tensões entre eles e potencializar as ações conjuntas.

$\mathrm{Na}$ comunidade de informações e segurança, não raro houve casos de disputas entre os órgãos pelos créditos e reconhecimento das ações repressivas exitosas, com alguns deles, por exemplo, reivindicando a detenção de determinados prisioneiros para obtenção de informações sob tortura e até mesmo retendo as descobertas sem compartilhá-las com os demais organismos. No campo da censura comumente emergiam posicionamentos distintos entre os censores, o que configurava um casuísmo cuja racionalidade é de difícil compreensão.

A relativa autonomia destes órgãos, muitas vezes, desafiava a harmonia e a consistência que seriam esperadas na atuação de um Estado autoritário. Por mais centralizado que este tenha sido em determinados momentos da ditadura, especialmente após 1968, a multiplicidade de fontes de poder civil e militar minava a pretensão de uma instituição pública 
total e monolítica dotada de uma lógica repressiva inteiramente unitária e coerente. No caso da repressão às sexualidades dissidentes, esta característica central do aparato repressivo parece ser potencializada devido à relação intrínseca entre moral e política no regime.

Sendo assim, as diferentes camadas em que se desdobrava a repressão política e moral, em cada momento e contexto específico, assumiram contornos próprios em uma combinação sempre peculiar entre razões superiores de Estado, um sem número de atos legais esparsos e convicções pessoais dos agentes que implementavam as políticas públicas. Reconhecer tal sobreposição de fatores e motivações, de modo algum, significa diluir responsabilidades ou ignorar as forças centrípetas quase irresistíveis que asseguraram uma linha política identificável e com eficácia mínima. Antes, trata-se de dar conta da complexidade e profundidade das políticas que amalgamaram e mobilizaram diferentes dimensões do Estado para atingir os objetivos programados no âmbito da Doutrina de Segurança Nacional. Nessa linha, Gláucio Soares, ao analisar o aspecto específico da censura, afirma que

o estudo das proibições permite reiterar que a ditadura não foi integrada nem harmônica [...]. Os dados mostram que as proibições, originárias, em sua maioria, nos órgãos militares de inteligência, visavam à proteção do Estado autoritário; outras, originadas em numerosos minicentros de poder, obedeciam a interesses menores, locais e, até mesmo, pessoais das autoridades coatoras ${ }^{35}$.

Assim, é possível afirmar que a organização política, a partir de diversas instâncias, interesses, agências e setores, confere a relativa pluralidade que se materializa, muitas vezes, em embates institucionais dentro das próprias instituições públicas, manifestando o caráter heterogêneo do Estado com maior clareza.

Mas, a despeito destes atritos recorrentes e que servirão de guia para a análise que se seguirá no presente trabalho, emerge nitidamente um traço marcante da verdadeira órbita repressiva que organizou a experiência da ditadura brasileira: um fio condutor que, se não unificou, foi capaz de articular, de forma coesa, as diversas iniciativas repressivas. Um exemplo claro disto é que muitas das violências institucionais eram planejadas e executadas em conjunto, demonstrando uma unidade de ação capaz de dotar de coerência aquela difusa rede repressiva.

Carlos Fico considera que a centralização e coerência mínimas foram alcançadas graças à atuação da comunidade de informações como "porta-vozes especialistas" sob o influxo da comunidade de segurança. Segundo ele, a partir do final da década de 1960, a

\footnotetext{
${ }^{35} \mathrm{http}: / /$ www.anpocs.org.br/portal/publicacoes/rbcs_00_10/rbcs10_02.htm
} 
"'utopia autoritária', que inspirava, de maneiras diversas, os diferentes grupos militares, passou a ser interpretada segundo a chave dos setores mais extremados da linha dura, penetrando os diversos escalões governamentais e sendo aceita por concordância ou medo"36. Este teria sido o "cimento ideológico" que deu sustentação ao regime.

Neste sentido, as chamadas "comunidades de segurança e informações, instituídas de modo mais autônomo nos primeiros anos da ditadura, encontraram, a partir de 1968, uma centralização bastante marcada. O Sistema Nacional de Informações, criado em 1964, tinha propósitos mais modestos quando se converteu, a partir de 1967, no ponto de centralização e comando de uma ampla rede de espionagem. A vitória da chamada linha-dura, "representada pela decretação do AI-5, fez com que a espionagem passasse a atuar a serviço dos setores mais radicais, divulgando as avaliações que justificavam a escalada e a manutenção da repressão" ${ }^{37}$. Isso é bastante visível no caso das informações produzidas sobre atentados à moral e aos bons costumes, sempre acompanhadas do clamor por mais censura e por atuação mais rigorosa dos órgãos de segurança.

A ideologia e o aparato repressivos dão concretude, portanto, à preocupação marcada da ditadura brasileira com a pornografia, o erotismo, as homossexualidades e as transgeneridades, fenômenos classificados como temas e práticas ameaçadores não apenas contra a estabilidade política e a segurança nacional, mas também contra a ordem sexual, a família tradicional e os valores éticos que, supostamente, integravam a sociedade brasileira. Dessa forma, a análise aqui empreendida deve partir dessas esferas para demonstrar os traços da concepção oficial de política sexual da ditadura.

\section{Estrutura do trabalho}

Qualquer análise que pretenda explorar os contornos e contradições internas da política sexual implementada pela ditadura brasileira passa, assim, pelo reconhecimento da centralidade da moralidade conservadora na ordenação do regime e pelo exame da complexa e multifacetada estrutura repressiva.

Ainda que a manifestação do poder de caráter negativo e proibitivo seja a mais conhecida das formas de controle sexual, não nos ateremos apenas a esta dimensão. Desde os

\footnotetext{
${ }^{36}$ FICO, Carlos. Além do golpe: versões e controvérsias sobre 1964 e a Ditadura Militar. Rio de Janeiro: Record, 2004, p. 81.

${ }^{37}$ FICO, Carlos. Além do golpe: versões e controvérsias sobre 1964 e a Ditadura Militar. Rio de Janeiro: Record, 2004, p. 81..
} 
trabalhos de Foucault ${ }^{38}$, o poder, no campo da sexualidade, deixa de ser visto apenas como interdição para ser entendido também como algo positivo e produtivo. Em outras palavras, o poder não apenas reprime e silencia, mas estimula e até compele a profusão de determinados discursos sobre a sexualidade, pautando padrões de normalidade e, portanto, de exclusão, ainda mais quando o poder político é menos compartilhado democraticamente.

Neste sentido, nosso objetivo, aqui, é compreender os padrões morais que orientaram a atuação das principais agências encarregadas da vigilância, policiamento e censura durante o período que vai de 1964 até 1988. A escolha pelo marco final da Constituição Federal, ainda que não seja o mais aceito pela historiografia ou mesmo pelas políticas de reparação do Estado brasileiro, parece-nos mais adequado para os propósitos deste trabalho ${ }^{39}$. Trata-se de compreender não apenas as proibições e interdições, mas como a ditadura brasileira traçou uma linha de classificação das condutas sexuais consideradas legítimas e aceitáveis com discursos positivos.

A partir do levantamento minucioso e do exame detido das fontes documentais disponíveis ligadas ao aparato repressivo da ditadura, bem como fazendo uma revisão bibliográfica da literatura pertinente, buscaremos apurar como e em qual medida a ditadura implementou uma política sexual para o controle das sexualidades dissidentes e a repressão do movimento homossexual brasileiro e seus veículos de expressão. Assim, pretende-se demonstrar como as questões comportamentais e sexuais foram centrais para o projeto da "utopia autoritária", ressaltando uma dimensão muitas vezes negligenciada tanto nas reflexões acadêmicas quanto no trabalho de memória sobre esse período.

Sobre as diligências feitas junto aos acervos do Arquivo Nacional, ao Arquivo Público do Rio de Janeiro e ao de São Paulo ${ }^{40}$, foram utilizadas as seguintes palavras-chave que nos pareceram capazes de dar um quadro razoavelmente completo do que estamos designando por política sexual do regime: homossexual, homossexualidade, homossexualismo, invertido, pederastia, pederasta, sodomia, sodomita, pervertido, lésbica, viado, prostituta,

\footnotetext{
${ }^{38}$ FOUCAULT, Michel. História da Sexualidade: a vontade de saber. Rio de Janeiro: Graal, 1985. v. 1.

${ }^{39}$ Há algumas divergências na periodização da ditadura e, em especial, de qual o termo final mais adequado. A interpretação mais consagrada na historiografia do período considera o ano 1985, data da posse do primeiro presidente civil, ainda que eleito indiretamente; outros indicam 1989, quando foi eleito, por voto direto, um presidente civil. Para os fins deste trabalho, adotamos o ano de 1988 que marca o advento de uma ordem constitucional democrática e, sobretudo, porque foi quando a estrutura censória responsável pelo controle moral legada da ditadura foi extinta.

${ }^{40} \mathrm{O}$ recorte territorial efetuado justifica-se porque o Arquivo Nacional detém hoje a maior parte dos acervos dos órgãos repressivos, razão pela qual a pesquisa se concentrou nesses fundos documentais que se encontram já digitalizadas. Estendemos a busca para Rio de Janeiro e São Paulo por serem os dois maiores centros econômicos urbanos e com grande concentração de homossexuais, prostitutas e travestis em suas regiões centrais, mas encontramos relativamente pouco material nesses arquivos regionais.
} 
bicha, pornografia, pornográfico, degeneração, anal, erótico, erotismo, travesti, travestismo, permissividade, libertinagem.

É importante advertir que, tratando-se de pesquisa com o sistema de classificação feito pela própria ditadura e sobre uma questão moral tão delicada, os descritores utilizados refletem muito das concepções dos órgãos de repressão estudados. Para evitar o risco de reproduzir os critérios de exclusão e de estigmatização que essas agências implantaram, diversificamos ao máximo possível as categorias de busca para evitar uma cilada inscrita nos próprios rastros das fontes legadas pela própria ditadura ${ }^{41}$.

Mesmo com este risco à vista, fizemos esta escolha por priorizar as fontes documentais produzidas pela própria repressão porque nos parece ser esta a perspectiva mais privilegiada para compreender os contornos morais da política sexual do regime, mesmo com as limitações já apontadas. A abordagem que buscamos utilizar, mais do que apenas examinar a legislação e os discursos oficiais de autoridades ou mesmo revistas de escolas militares, é de uma compreensão do Estado "desde baixo", compreendendo o que os agentes públicos fazem e com que justificação o fazem. Focar em diversas instâncias e níveis de distintas agências nos permite ter um panorama mais fiel e representativo deste complexo universo. Além disso, o tipo de olhar dirigido aos órgãos estatais permite pensar o Estado não apenas como um ente monolítico, mas como arenas sobrepostas de negociação e conflito em torno da estruturação mesma das regras morais de política sexual ${ }^{42}$.

Tendo em vista tais preocupações e perspectivas para organizar a análise e a exposição do extenso material coletado, optamos por agrupar os documentos encontrados em quatro dimensões centrais, tanto de interdição como de profusão de discursos positivos sobre a política sexual: censura e cerceamento da produção cultural, violência policial nas ruas, vigilância do nascente movimento homossexual e perseguição a seus veículos de expressão e comunicação, especialmente o jornal Lampião da Esquina. A nosso ver, estes eixos são

\footnotetext{
${ }^{41}$ Cowan faz esta importante advertência em um artigo sobre o tema: "An investigation based around "homosexual" or "homosexuality" as such, then, actually threatens to elide queer subjects (men referred to by terms such as invert and especially queer women) and follows categories elaborated by police themselves, reiterating (as we shall see) these authorities' struggle to define homosex as a practice or, alternatively, as a determinant of identity". Cf.: COWAN, Benjamin. "A Passive Homosexual Element": Digitized Archives and the Policing of Homosex in Cold War Brazil". In: Radical History Review, n. 120, October, 2014, p. 184.

${ }^{42}$ Inspiramo-nos, aqui, no interessante trabalho de Canaday, que adota uma abordagem de "state building from the bottom up" ou "social history of the state". Para ela, "focusing on these kinds of spaces [low-level bureaucratic and judicial offices] provides an opportunity to think about the state as not only 'intervening' in, but as 'intervened' by sexuality as well. The state does not just direct policy at its subjects; various state arenas are themselves sites of contest over sex/gender norms, and therefore structured by those norms. This is, in large measure, what it means to say that we have a "straight state." Cf.: CANADAY, Margot. The Straight State: Sexuality and Citizenship in Twentieth-Century America. Princeton: Princeton University Press, 2009, pp. 5 e ss.
} 
capazes de mostrar os mecanismos de regulação e normalização dos corpos marcados por orientação sexual e/ou identidade de gênero dissidentes.

Assim, a estrutura do trabalho reflete esta divisão e se organiza em cinco capítulos: no primeiro, aborda-se o debate em torno da censura moral durante a ditadura brasileira, apresentando os debates sobre sua relação com a censura estritamente política a partir de um histórico das normas que compuseram o arcabouço legal que respaldou a atividade censória; já no segundo, analisa-se o monitoramento e a censura em defesa da moral e dos bons costumes na prática, examinando-se os documentos relativos à atuação de órgãos vinculados à comunidade de informações e do DCDP nos diferentes meios de expressão artística e de comunicação, quais sejam: televisão, teatro, cinema, jornais e revistas, imprensa gay e outros tipos de diversões públicas; por sua vez, o terceiro capítulo apresenta um panorama das violências policiais praticadas contra homossexuais, travestis e prostitutas em diversas capitais brasileiras, com especial destaque para o caso de São Paulo; o quarto capítulo trata dos desafios encontrados pelo então nascente movimento homossexual brasileiro para se organizar sob a conjuntura ambígua de uma liberalização política controlada e ainda marcada pela persistência das estruturas autoritárias e, por fim, o último capítulo é dedicado à análise da perseguição sofrida pelo Jornal Lampião da Esquina. 
- Capítulo 1 -

\section{A CENSURA EM NOME DA MORAL E DOS BONS COSTUMES}

\section{"Os fatores adversos ao desenvolvimento dos valores espirituais e morais da nacionalidade"}

Um documento classificado e carimbado, em diversos pontos, como "SECRETO", elaborado pela Divisão de Segurança e Informações do Ministério da Educação e Cultura, continha o Plano Setorial de Informações. Em sua capa, fora estampada a seguinte frase motivacional: "ganha a luta quem insiste mais cinco minutos" $"$. O referido plano havia sido aprovado pelo Decreto n. 66.732, de 16 de junho de 1970, como um dos elementos centrais da Doutrina Nacional de Informações para alimentar a comunidade de segurança com informações que pudessem orientar a ação repressiva do Estado nos campos da cultura e da educação. Seu objetivo era mapear e até antecipar as dificuldades e os problemas existentes ou estimados, antagonismos atuais ou potenciais, bem como grupos de pressões capazes de influir na manutenção das condições favoráveis ao desenvolvimento e à segurança da política governamental na área do MEC.

As Divisões de Segurança e Informações eram órgãos associados a ministérios civis e militares com a função de coordenar, sob comando dos respectivos ministros titulares da pasta, as comunidades setoriais em suas atividades de informações e contrainformações. Mas os referidos órgãos não tinham caráter decisório e não tinham a missão de apresentar soluções para os problemas-objeto de suas atividades, razão pela qual estavam sob supervisão direta do Sistema Nacional de Informações (SNI).

No âmbito do Plano Nacional de Informações ${ }^{44}$, o Plano Nacional de Buscas, no campo denominado "psicossocial", formula os seguintes questionamentos para orientar a busca de informações com o objetivo de desmantelar qualquer mecanismo de propaganda ostensiva ou clandestina adversa, interna ou externa, contra o governo:

\footnotetext{
${ }^{43}$ BR_DFANBSB_AT4_0020_0034_d

${ }^{44}$ Com base no "Conceito Estratégico Nacional", "o SNI aprovou, em junho de 1970, o 'Plano Nacional de Informações, durante a gestão do general Carlos Alberto da Fontoura (1969-1974), que definia todas as missões a serem cumpridas pelos órgãos que agora integram o Sistema Nacional de Informações (Sisni). O Plano seria constantemente atualizado com base nele, os diversos órgãos elaboravam seus planos setoriais". Cf.: FICO, Carlos. Espionagem, polícia política, censura e propaganda: os pilares básicos da repressão. In: FERREIRA, Jorge; DELGADO, Lucília (orgs.). O Brasil Republicano: O tempo da ditadura - regime militar e movimentos sociais em fins do século XX. Rio de Janeiro: Civilização Brasileira, 2009. pp. 176-177.
} 
Existem fatores adversos ao desenvolvimento dos valores espirituais e morais da nacionalidade?

Existe influência negativa dos meios de comunicação de massa, das organizações sociais (profissionais, religiosas, políticas, etc) e dos intelectuais na formação cívico-moral do homem brasileiro, em particular da juventude, que desvirtue os valores morais, cristãos e democráticos, e afrouxe os laços familiares?

Notam-se falhas na prevenção e repressão à inobservância dos preceitos morais, que contribuam para o descenso gradual dos princípios morais (deficiências da censura prévia no tocante a publicações e outras exteriorizações eróticas e pornográficas, e do combate aos tóxicos, em particular nas escolas)?

As medidas de censura prévia aplicadas nos estabelecimentos de ensino são adequadas para coibir as publicações e apresentações estudantis de caráter erótico ou pornográfico?

Quais os meios empregados para burlar essa censura?

Os órgãos encarregados da cultura (filme, teatro, artes, etc) conseguem prevenir e reprimir apresentações, representações, exposições, etc., atentatórios à moral?

Quais as falhas observadas? Os responsáveis? Medidas adotadas? ${ }^{45}$

Esse conjunto de questionamentos evidencia que as preocupações e orientações emanadas dos órgãos centrais da comunidade de informações estavam pautadas e agrupadas em torno de um eixo específico denominado "psicossocial". Tal chave de classificação, que aparecia em uma série de outros documentos, compreendia a dimensão moral, cívica e religiosa da repressão e da vigilância.

Despontava, assim, uma clara atenção dessas agências estatais para monitorar eventuais ameaças contra "valores morais e espirituais da nacionalidade", "formação cívicomoral do homem brasileiro, em particular da juventude", "laços familiares", "preceitos morais", dentre outras designações para a "guerra psicológica" que ameaçava desestruturar a hegemonia moral e sexual do regime.

É exatamente esta dimensão que será examinada minuciosamente neste capítulo, especialmente no que se refere à maneira como a censura da ditadura atuou contra produções culturais que contrariassem a fórmula "moral e bons costumes". Também será examinada detidamente a função que a comunidade de informações cumpria ao alimentar uma sensação permanente de indignação para provocar medidas cada vez mais rigorosas das estruturas censórias nas diferentes linguagens artísticas e meios de comunicação, quais sejam, televisão, teatro, cinema, música, livros, revistas e jornais, inclusive na chamada "imprensa gay". Depois de uma síntese das principais diretrizes legais relativas à censura, passaremos à análise

\footnotetext{
${ }^{45}$ BR_DFANBSB_AT4_0020_0034_d
} 
de cada uma dessas dimensões específicas com base em fontes documentais da própria ditadura e notícias da imprensa da época.

No entanto, antes, faz-se necessário abordar algumas questões mais gerais da censura e de seu enquadramento legal no regime autoritário iniciado em 1964.

\section{Uma ou duas censuras durante a ditadura?}

No Brasil, a história da censura não teve início com a ditadura. Deve-se ressaltar que o controle estatal sobre os meios de comunicação e as formas de expressão artísticas remontam a períodos bem anteriores da constituição de um Estado Nacional e de sua relação com a cultura.

A forte influência religiosa no período da colonização, por exemplo, foi um fator preponderante para o projeto de moldar uma sociedade tolerante na convivência com parâmetros restritivos de costumes. Obras literárias consideradas sediciosas eram proscritas e queimadas por ordem da Coroa portuguesa. A censura centrada em temas comportamentais também foi bastante marcante no teatro feito durante o séc. XIX, sem mencionar essa prática de interdição e controle durante os primórdios do período republicano, quando a presença do censor se tornou uma constante no mercado, em franca expansão dos divertimentos públicos $^{46}$. Já a censura estritamente política teve ampla utilização, ao lado de mecanismos de controle moral, durante regimes como o Estado Novo (1937-1945) e a ditadura civil-militar (1964-1985). Nota-se, assim, que mais de um tipo de censura tiveram lugar e conviveram entre si em distintos momentos históricos no Brasil.

Para dar conta das especificidades da repressão na ditadura, uma parcela relevante da literatura historiográfica demarca uma distinção entre dois tipos de censura: a políticoideológica e a moral. Na visão de Carlos Fico, um dos principais especialistas que sustenta essa perspectiva, não havia apenas uma, mas duas censuras na ditadura, sendo "possível distinguir a dimensão moral e a dimensão estritamente política seja na censura da imprensa, seja na censura de diversões públicas. Naturalmente, porém, prevalecia no caso da imprensa a censura de temas políticos, tanto quanto os temas mais censurados entre as diversões públicas eram de natureza comportamental ou moral" ${ }^{\prime 4}$. Acrescenta ele, em outro trabalho sobre o

\footnotetext{
${ }^{46}$ CARNEIRO, Maria Luiza Tucci. Minorias Silenciadas: História da Censura no Brasil. São Paulo: Edusp, Imprensa Oficial, Fapesp, 2002.

${ }^{47}$ FICO, Carlos. Além do golpe: versões e controvérsias sobre 1964 e a ditadura militar. Rio de Janeiro: Record, 2004, p. 91.
} 
tema, que "foi a politização da censura de diversões públicas que deu a impressão de unicidade às duas censuras, mas, na verdade, lógicas muito distintas presidiam as duas instâncias" $"$.

Corroborando com esta mesma visão, Glauco Soares pontua que, em se tratando da Divisão de Censura de Diversões Públicas (DCDP) ${ }^{49}$, “contrariamente ao mito, não era uma entidade política: os órgãos de segurança agiam através dela, mas ela não exercia atividades de censura política diretamente". Segundo ele, "esta separação entre a censura política e a censura moral, no âmbito 'dos costumes e diversões', era de se esperar, considerando a natureza tão diversa destas duas áreas de atividade humana" ${ }^{, 50}$.

Já Beatriz Kushnir, por outro lado, refuta esse tipo de distinção ao sustentar que a censura no pós-1968 está, de fato, “dividida em duas instâncias: uma se aplicava à diversão, outra à imprensa. Ambas com cunho político, contudo a primeira encoberta nas preocupações com a "moral e os bons costumes", acrescentando que a censura "era percebida sempre como um ato político" 51 .

Toda censura, sem dúvida, tem uma dimensão política inegável. Afinal, é da própria definição do processo censório impedir a produção de determinadas informações, restringir a liberdade de pensamento e de expressão, colocar obstáculos para que opiniões circulem no espaço público e acabar, com essa vocação autoritária, impondo uma visão única sobre assuntos complexos e que deveriam comportar uma pluralidade de perspectivas. Trata-se, portanto, de um ato essencialmente político. Além do mais, qualquer censura moral e dos costumes de uma sociedade também possui um aspecto intrinsecamente político de policiamento de condutas, de limitação das liberdades, de sujeição de corpos, de controle de sexualidades dissidentes, de domesticação dos desejos e mesmo de restrição às subjetividades de modo mais amplo.

Sob tal ótica, a diferenciação entre moral e política não faria sentido ou, ao menos, não

\footnotetext{
${ }^{48}$ FICO, Carlos. A pluralidade das censuras e das propagandas da ditadura. In. REIS, Daniel; RIDENTI, Marcelo; MOTTA, Rodrigo Patto Sá (Orgs.). O golpe e a ditadura militar: 40 anos depois (1964-2004). Bauru/SP: EDUSC, 2004. p. 271.

${ }^{49}$ Conforme se verá, detidamente, o Serviço de Censura de Diversões Públicas (SCDP) fazia a censura das "diversões públicas" (teatro, cinema, música, rádio, casas de espetáculo, entre outros) desde os anos 1940. Em 1972, sob gestão do Ministro da Justiça Alfredo Buzaid, o SCDP tornou-se Divisão de Censura de Diversões Públicas (DCDP) dentro da estrutura do Departamento de Polícia Federal com função de "direção, coordenação e controle", conforme previsão do Decreto n. 70.665, de 2 de junho de 1972. Por isso, ao longo deste texto, poderão ser encontradas as duas designações para a censura de diversões públicas que atuaram durante a ditadura militar.

50 SOARES, Glaucio Ary Dillon. Censura durante o regime autoritário. Disponível em: $<$ http://www.anpocs.org.br/portal/publicacoes/rbcs_00_10/rbcs10_02.htm>. Acesso em: 15 de janeiro de 2015.

${ }^{51}$ KUSHNIR, Beatriz. Cães de Guarda: jornalistas e censores do AI-5 à Constituição de 1988. São Paulo: Boitempo, 2004. p. 105.
} 
se mostraria muito funcional para a compreensão da censura durante a ditadura. Contudo, deve-se reconhecer que Fico, por exemplo, não chega a discordar da afirmação de que toda censura seja um ato político ${ }^{52}$. O que ele parece sustentar é a necessidade de um olhar que compreenda a singularidade de cada uma dessas frentes de atuação das agências de censura ${ }^{53}$. Vale apurar melhor sua posição.

\section{Duas censuras distintas: a moral e a política}

Os argumentos que sustentam a leitura de que havia duas censuras, basicamente, são que, em primeiro lugar, a censura moral já existia antes mesmo da ditadura. Aliás, é verdade que o Brasil contava já com uma tradição censória dos costumes bastante antiga e que se manifestou em diferentes períodos da história política e cultural do país, como mencionado. Em segundo lugar, o controle voltado aos espetáculos e diversões públicas era exercido a partir de um marco normativo claro que concentrava esses poderes nas mãos de um órgão bem definido na administração pública. Havia técnicos de censura, carreira estruturada, concursos públicos para seleção de profissionais, escritórios regionais vinculados a uma gestão central e uma série de leis e atos administrativos que respaldavam esta estrutura censória abertamente organizada e atuante, sobretudo durante a ditadura.

Um outro aspecto a acentuar a especificidade relativa desta modalidade de controle é o fato de que existia não apenas uma tolerância, mas um suporte efetivo da população que, com entusiasmo, defendia esses procedimentos, pedindo, muitas vezes, o endurecimento da censura moral. Foram numerosas as cartas e pedidos enviados às autoridades para que policiassem melhor e mais rigorosamente a programação da televisão, as revistas e jornais que estavam expostos nas bancas, os livros em circulação, os filmes exibidos nos cinemas e as peças de teatro em cartaz por todo o país ${ }^{54}$. Este clamor popular por mais censura tinha, como

\footnotetext{
${ }^{52}$ Esclareceu ele, em seminário realizado em 2012: “em certo momento, classifiquei a censura sobre a imprensa de política, e a censura das diversões públicas de moral. Logo as pessoas diziam: 'Mas então você acha que a censura do cinema, do teatro, da música etc, não é uma censura política?'. Não é isso. Claro que todo ato é sempre um ato político, mas é preciso distinguir as duas coisas [...]”. FICO, Carlos. Censura, ditadura e a 'utopia autoritária'. In: COSTA, Cristina (org.). Seminários sobre censura. São Paulo: Balão Editorial/Fapesp, 2012, p. 66.

${ }^{53}$ Afirma ele que "essa distinção chama a atenção para a necessidade de maiores pesquisas sobre fenômenos não explicitamente políticos (em sentido estrito), se quisermos entender globalmente o período que, muitas vezes, tem sido subsumido nesta esfera. De fato, a história do Brasil entre 1964 e 1985 não se restringe à história da ditadura militar". Cf.: FICO, Carlos. Versões e controvérsias sobre 1964 e a ditadura militar. Rev. Bras. Hist., São Paulo. v. 24. n. 47. pp. 37-38.

${ }^{54}$ Para um exame interessante das cartas enviadas para o Departamento de Censura e Diversões Públicas, ver FICO, Carlos. Prezada Censura: cartas ao regime militar. Topoi, Rio de Janeiro. v. 3. n. 5. pp. 251-
} 
contrapartida, um certo orgulho institucional por parte do governo e dos agentes públicos envolvidos na nobre tarefa de assegurar a integridade moral e as expectativas desses setores da sociedade. A repressão não era negada pelas autoridades e tampouco precisava ser clandestina ou escamoteada; antes, era franca e aberta. Muitas vezes, os atingidos questionavam a tesoura censória perante o Poder Judiciário, discutindo a interpretação adequada e a aplicação das regras ao caso concreto.

Por sua vez, segundo a visão que sustenta essa dicotomia, a chamada "censura política", que foi exercida prioritariamente contra a imprensa escrita, não esteve prevista de forma expressa, sequer na legislação autoritária do regime. Diferentemente de sua congênere moral, não houve um órgão estruturado oficial e abertamente, no âmbito da administração pública, encarregado desta tarefa. Muitas vezes, eram "bilhetinhos" que circulavam nas redações de jornais para orientar o que poderia ou não ser publicado. Fico aponta que "a censura moral era legalizada e a censura da imprensa era "revolucionária",55. Assim, vários expedientes foram utilizados neste último caso para sugerir que havia mais uma autocensura do que uma imposição estatal ${ }^{56}$.

Apesar das diversas previsões esparsas restringindo os direitos civis e as liberdades públicas perseguindo a "subversão política", os critérios não eram plenamente legalizados no ordenamento jurídico e oscilavam a depender do alvo a ser atingido. A justificativa era sempre de se tratar de uma intervenção "revolucionária" e impassível, portanto, de qualquer restrição legal ou questionamento judicial, já que os atos de exceção foram sempre colocados, propositadamente, à margem de qualquer controle externo.

Os dois critérios que embasam essa distinção, assim, são, por um lado, a diferenciação entre política e moral e, por outro, o grau de respaldo legal e aceitação social com que contava cada uma dessas práticas de censura.

De fato, política e moral não são redutíveis um ao outro. A despeito de intimamente implicados, trata-se de esferas da vida que guardam relativa autonomia entre si, estruturadas com códigos e funções próprios. Elas são marcadas, portanto, por peculiaridades que não podem ser desconsideradas ou subestimadas. Nem é necessária muita teorização para visualizar isto. Em termos bem concretos, por exemplo, a perseguição política a um jornalista

\footnotetext{
286, Dez, 2002.

55 FICO, Carlos. A pluralidade das censuras e das propagandas da ditadura. In. REIS, Daniel; RIDENTI, Marcelo; MOTTA, Rodrigo Patto Sá (Orgs.). O golpe e a ditadura militar: 40 anos depois (1964-2004). Bauru/SP: EDUSC, 2004, p. 271.

${ }^{56}$ Kushnir também registra este fato: "O órgão fiscalizador da imprensa tinha um caráter secreto, fora do organograma tanto da Polícia Federal quanto do Ministério da Justiça” KUSHNIR, Beatriz. Cães de Guarda: jornalistas e censores do AI-5 à Constituição de 1988. São Paulo: Boitempo, 2004, p. 105.
} 
considerado subversivo porque acusado de "comunista" era diferente, sob variados aspectos, das formas de repressão dirigidas a um outro jornalista acusado de violar "a moral e os bons costumes". Na primeira situação, pode-se mencionar o caso Vladimir Herzog, morto e desaparecido em 1975 sob a versão oficial de "suicídio". Pelas conexões da censura políticoideológica com os órgãos de segurança da repressão, não bastava calar sua voz, era necessário exterminá-lo fisicamente. Já no segundo caso ocorrido no mesmo período, em 1976, Celso Curi foi processado por violação à "moral e aos bons costumes" por conta da sua "Coluna do Meio", voltada para homossexuais, e acabou perdendo seu emprego no jornal "Última Hora", mesmo tendo sido, posteriormente, absolvido na Justiça. Os danos profissional e moral causados são inquestionáveis, mas sua integridade física foi preservada.

Estes dois casos, guardadas as devidas proporções, já que o primeiro termina extrapolando a dimensão estritamente censória, ilustram bem as possíveis diferenças de compreensão entre moral e política sob os olhos do regime autoritário.

\section{A moral também é política}

No entanto, é preciso problematizar visões que idealizem em uma divisão estanque e de contornos bem definidos entre as repressões política e moral durante a ditadura por diversas razões ${ }^{57}$.

Primeiro, porque os valores e comportamentos propagados por determinada moral são, sempre e necessariamente, de natureza política. A hegemonia de determinados padrões de conduta que define o que é aceitável é fruto de determinada distribuição social do poder. Deste modo, ainda que com outra linguagem, a moral é profundamente política e pode soar artificial o intento de separá-las sem as devidas ressalvas. Em segundo lugar, sob um regime autoritário com pretensão de controle total da vida social, é possível pensar que a moral é politizada a um nível ainda mais acentuado ${ }^{58}$, alçada a instrumento direto e sem mediações da

\footnotetext{
57 Essa advertência é também feita por Marcelino: "Sem dúvida, não se deve desconsiderar que a censura praticada pelo SCDP assumiu uma função política em vários momentos, particularmente no plano teatral e cinematográfico. Até porque, como já dissemos, uma diferenciação restritiva demais entre esse plano e aquele da moralidade corre grande risco de cair na superficialidade". MARCELINO, Douglas Attila. Subversivos e Pornográficos. Censura de livros e diversões públicas nos anos 1970. Rio de Janeiro: Arquivo Nacional, 2011, p. 32).

${ }^{58}$ Fico admite que "os militares e civis que estavam no poder durante a ditadura militar, quando se voltaram para a DCDP, procuraram modernizá-la, mantendo a mesma estrutura. E esta começou a sofrer também uma grande politização. As peças, as músicas, os filmes, os programas de televisão eram censurados conforme a tradicional clivagem, de perfil ético e moral - que inspira a censura brasileira desde sempre até hoje -, mas passou a servir aos interesses políticos do poderoso do momento" FICO, Carlos. Censura, ditadura e a 'utopia autoritária'. In:
} 
violência estatal.

Neste sentido, não seria demais afirmar, em se tratando da ditadura brasileira, que política e moral são duas faces complementares de um mesmo projeto global de repressão que pode ser designado como "utopia autoritária" moral o fato de o DCDP ter sido utilizado para censurar tanto temas moralmente inaceitáveis quanto artistas vistos como ideólogos da oposição à ditadura, atestando que o órgão assumia viés político-ideológico em sua atuação rotineira. Depois, o apoio social manifestado pelo "consentimento ativo" dos missivistas que enviavam suas cartas clamando por mais censura dos costumes não pode ser compreendido fora dos marcos de uma sofisticada estrutura de propaganda e irradiação de valores morais conservadores que partia tanto do Estado como de outras instituições da sociedade, como a própria Igreja. E ainda, o argumento de que haveria um amparo legal da censura moral, que a diferenciaria do caráter "revolucionário" e "anômico" da censura política é, sob diversos aspectos, bastante frágil.

Isto se deve ao fato de que a referida legislação era antiga e abusava de termos vagos e tipos poucos precisos em seus contornos morais. Assim, as instâncias da burocracia responsáveis por dotar estas normas do seu sentido prático, nos casos concretos, faziam isto com grande margem de arbitrariedade e, muitas vezes, com colaboração do sistema de justiça, em uma lógica bastante clara de excepcionalidade. Além disso, a diversidade regional e funcional na aplicação dos parâmetros legais, muitas vezes levava a visões diferentes sobre os critérios básicos de julgamento dos censores à revelia de regras universais e uniformes, resvalando para um casuísmo marcante. Em termos de procedimento, o fato de não haver uma obrigatoriedade estrita para a fundamentação dos despachos censórios levava a um desprezo das leis, pois os cortes eram apenas referenciados no número dos diplomas legais sem qualquer trabalho de subsunção do fato específico à norma geral. Esse tipo de modus operandi era recorrente e, a nosso ver, esvaziava normativamente a legislação censória, aproximando-a mais de uma legitimação do puro arbítrio do que de uma regulação efetiva do poder.

Em suma, ainda que faça sentido um esforço analítico com o objetivo de distinguir os

\footnotetext{
COSTA, Cristina (org.). Seminários sobre censura. São Paulo: Balão Editorial/Fapesp, 2012, pp. 70-71).

${ }_{59}$ Maria Celina D’Araujo, Celso Castro e Gláucio Ary Dillon Soares. Cf.: D’ARAUJO, M. C. et al. (Orgs.) Visões do golpe: a memória militar sobre 1964. Rio de Janeiro: Relume-Dumará, 1994, p. 9. Fico toma de empréstimo esta expressão para designar o "cimento ideológico" capaz de agregar todas as instâncias repressivas. Ele ainda menciona que, "para muitos analistas, esse papel teria sido desempenhado pela chamada "doutrina de segurança nacional” [...]. Talvez possamos dizer que a 'utopia autoritária' seja uma forma menos elaborada e intelectualmente diluída da doutrina. Mas é preciso não perder de vista que a antiga tradição brasileira de pensamento autoritário inspira ambas e que a propaganda anticomunista precede em muito a ditadura militar". Cf.: FICO, Carlos. Versões e controvérsias sobre 1964 e a ditadura militar. Rev. Bras. Hist., São Paulo. v. 24. n. 47. p. 38.
} 
padrões, mecanismos, objetivos, alvos próprios e especificidades das censuras moral e política, é preciso bastante cautela para não se assumir, acriticamente, uma divisão que, em última instância, foi construída pela própria ditadura com o efeito - mais ou menos intencional - de "despolitizar" a censura moral, apresentá-la como a-histórica e, assim, terminar sustentando sua legalidade e legitimidade naquele contexto. Esta foi uma estratégia de setores que sustentavam a censura moral nos estertores da ditadura, como se verá mais adiante.

Por tais razões e considerando o escopo do presente trabalho que não tem por foco exclusivo a censura, nossa intenção se limita a compreender justamente as conexões internas e fluidas entre esses dois palcos nos quais se desenrolou a ação repressiva contra a nudez, a pornografia, a sexualidade, as representações homoeróticas e as transgeneridades. O esforço a ser feito, portanto, não é no sentido de dissociar política e moral, mas, antes, analisar os modos de politização da moralidade e dos costumes, verificando como eles transitaram entre ambas as estruturas censórias no projeto global de controle imposto pelo regime autoritário.

Tal tarefa demanda um olhar clínico voltado tanto para a ideologia quanto para a prática concreta da ditadura, na prevenção e na repressão das condutas tidas por indesejáveis ou inaceitáveis. Assim, a análise não deve perder de vista como a estrutura censória esteve alinhada a um propósito mais geral de regular uma política da sexualidade, ainda que com suas importantes diferenças e tensões internas que minavam a pretensão totalizante de um Estado monolítico que nunca existiu.

\section{Anticomunismo e moralidade pública}

Assumir essa perspectiva que privilegia mais as aproximações do que os distanciamentos entre as duas censuras, em sua relativa autonomia e íntimo entrelaçamento interno, não significa, de modo algum, ceder à tentação de colocar a moral à serviço da política. Alguns estudos sobre a relação do Estado ditatorial com as esferas da sexualidade, gênero, corpo, drogas e costumes tendem a restringir estas diferentes dimensões da vida "privada" a uma chave exclusiva do anticomunismo e da doutrina da segurança nacional. Todas essas questões de ordem moral, sob essa perspectiva, não passariam de um apêndice da problemática mais ampla e central da política ideológica do regime.

É verdade que o sentimento anticomunista foi intensamente mobilizado para caracterizar a subversão moral como um artifício ardiloso do movimento comunista 
internacional para minar as instituições ocidentais ${ }^{60}$. De acordo com essa ótica, atentar contra a moral e os bons costumes seria menos um fim em si mesmo e mais uma tática insidiosa, no bojo de uma "guerra psicológica adversa" para promover uma revolução anticapitalista por meio do enfraquecimento dos pilares da nossa sociedade: a religião cristã e a família.

Exemplo típico dessa postura é a própria posição do ex-ministro da Justiça Alfredo Buzaid, que deixa claro que, a seu ver,

o Estado se viu na contingência de executar [a legislação repressiva], a fim de preservar a integridade da família brasileira e a sua moralidade tradicional, combatendo destarte o comunismo internacional, que insinua o amor livre para dilacerar as resistências morais da nossa sociedade ${ }^{61}$.

Ainda que tenha sido mesmo bastante convincente no contexto da Guerra Fria e atingido um grande alcance no Brasil, tal visão de mundo foi produzida e propagada, sobretudo, por alguns setores específicos da plêiade de grupos civis e militares que se uniram em torno dos “ideais da Revolução de 1964". Nomeadamente, foram sobretudo os ideólogos egressos da Escola Superior de Guerra (ESG) e os agentes públicos vinculados à comunidade de informações, muitos designados como pertencentes à "linha-dura", que travavam uma batalha incessante, no interior desse bloco de poder, para fazer triunfar essa perspectiva reducionista.

Não à toa, os relatórios de monitoramento dos meios de comunicação e das artes sempre destacavam, nas informações militares, a dimensão estritamente "psicossocial" da propaganda comunista, dentre outras frentes subversivas, como a trabalhista e a estudantil, como mostrado no início deste capítulo.

No entanto, não há evidências de que essa versão tenha sido a determinante, por exemplo, no interior da SCDP. Ali, assim como nas numerosas cartas enviadas por cidadãos comuns ao presidente ou aos órgãos censórios pedindo um endurecimento do controle moral, nota-se que a preocupação com a liberalização dos costumes não se subordinava à luta contra o comunismo. Antes, refletia mesmo uma postura reativa e algo defensiva em relação às profundas mudanças causadas pela revolução sexual em curso dentro e fora do país.

Mães preocupavam-se com seus filhos expostos a revistas pornográficas nas bancas de jornais, famílias se indignavam com as telenovelas com cenas eróticas invadindo seus lares,

\footnotetext{
${ }^{60} \mathrm{Um}$ excelente estudo que examina essa dimensão específica com fundamentação consistente e lastro empírico pode ser encontrado em COWAN, Benjamin A. Securing Sex: Morality and Repression in the Making of Cold War Brazil. University of North Carolina Press, 2016.

${ }^{61}$ BUZAID, Alfredo. Em defesa da moral e dos bons costumes. Brasília: Ministério da Justiça, 1970, p. 41.
} 
religiosos se revoltavam com setores cada vez mais amplos da juventude buscando prazer fácil e fugaz nas tentações mundanas. Mães, famílias, religiosos e outros cidadãos não agiam, necessariamente, por repulsa à ameaça comunista, mas antes por um sentimento quase atávico de autoproteção dos papeis sociais e dos valores tradicionais que cultivavam diante de mudanças culturais que estavam no horizonte ${ }^{62}$.

Desse modo, não é adequado reduzir todo o conservadorismo moral então em voga, animado por diferentes discursos e atores, com suas múltiplas causas e manifestações, a um mero desdobramento da paranoia anticomunista dos órgãos de informação e segurança. Este foi um dentre outros tantos vértices de produção de verdades no âmbito de um sistema repressivo complexo, ainda que fosse bastante influente no conjunto diante da militarização crescente da gestão política. Se é verdade que todos esses segmentos se unificavam em torno do pleito por uma censura moral mais rigorosa, coincidindo quanto a esse objetivo comum, ao mesmo tempo, cada um deles apresentava um diagnóstico e uma justificativa próprios para vocalizar suas demandas.

Esclarecidos esses aspectos mais gerais em torno da censura, vale compreender como tais princípios foram materializados na legislação autoritária e, em seguida, de que modo foram, na prática, aplicadas tais disposições legais que compuseram os pilares da estrutura censória.

\section{Evolução legislativa da censura na ditadura militar}

\section{Decreto $n^{0}$ 20.493, de 24 de Janeiro de 1946}

Apesar das estruturas de longo prazo que enraizaram culturalmente uma tradição censória de largo fôlego, o marco mais contemporâneo da censura de costumes e que deixou herança mais visível na mais recente ditadura brasileira foi, sem dúvida, a década de 1940 . Naquele momento é que foi instituído um padrão regulatório mais detalhado, materializado

\footnotetext{
${ }^{62}$ Nessa linha, concordamos com a posição bem formulada de Marcelino, que comenta: "é notória a conexão, feita por setores afinados com o anticomunismo, entre a adoção de 'novos' padrões comportamentais e supostos objetivos de subverter a ordem política. No âmbito do Serviço de Censura de Diversões Públicas, entretanto, essa era uma concepção muito menos difundida (apesar dos recorrentes esforços dos órgãos de informações). E, mesmo no que diz respeito aos grupos sociais que pediam mais censura a determinadas autoridades na década de 1970, ela também era, relativamente, pouco corriqueira. Na maioria dos casos, o que mais parecia incomodar esses segmentos era a chamada "revolução de costumes"'. MARCELINO, Douglas Attila. Subversivos e Pornográficos. Censura de livros e diversões públicas nos anos 1970. Rio de Janeiro: Arquivo Nacional, 2011, p. 32 ,
} 
sobretudo no Decreto $n^{\circ} 20.493$, de 24 de Janeiro de 1946. Este diploma legal foi editado logo após o governo autoritário de Vargas, que serviu de alicerce para a construção da política censória da ditadura no campo dos costumes ao regulamentar minuciosamente o funcionamento do organismo responsável pela censura e traçar certa diretrizes morais por muito tempo cultivadas entre nós.

Dentre as diversas agências governamentais e distintos parâmetros normativos do controle estatal sobre a cultura que se sucederam no século XX, estava o Serviço de Censura de Diversões Públicas (SCDP), criado em 1945, atrelado ao Departamento Federal de Segurança Pública (DFSP) que, por sua vez, fora criado em 1944, em substituição à Polícia Civil do Distrito Federal. O SCDP se tornaria, pouco mais tarde, o epicentro de um sistema mais complexo de controle moral implementado pelo regime autoritário, sobretudo após 1968.

De acordo com o Decreto que lhe deu origem, competia ao SCDP "censurar previamente e autorizar":

I - as projeções cinematográficas; II - as representações de peças teatrais; III - as representações de variedade de qualquer espécie; IV - as execuções de pantomimas e bailados; V - as execuções de peças declamatórias; VI - as execuções de discos cantados e falados, em qualquer casa de diversão pública, ou em local frequentado pelo público, gratuitamente ou mediante pagamento; VII - as exibições de espécimes teratológicos; VIII - as apresentações de préstimos, grupos, cordões, ranchos, etc. e estandartes carnavalescos; XIX - as propagandas e anúncios de qualquer natureza quando feitos em carros alegóricos ou de feição carnavalesca, ou, ainda, quando realizados por propagandistas em trajes característicos ou fora do comum; X - a publicação de anúncios na imprensa ou em programas e a exibição de cartazes e fotografias, quando se referirem tais anúncios, cartazes e fotografias aos assuntos consignados nos números anteriores dêste artigo; XI - as peças teatrais, novelas e congêneres emitidas por meio de rádio; XII - as exibições de televisão ${ }^{63}$.

Destarte, como já ressaltado, a censura no campo moral não foi uma invenção da ditadura militar e, mesmo sob o regime autoritário de 1964 , ela passou por distintas fases ${ }^{64}$. Do mesmo modo como ocorreu em relação a diversas outras instituições, normas legais, órgãos da administração pública e agências estatais preexistentes ao golpe de 1964, a ditadura ressignificou profundamente tais heranças, instrumentalizando-as e enquadrando-as a partir das finalidades "revolucionárias" do estado de exceção.

\footnotetext{
${ }^{63}$ Art. $4^{\circ}$ do Decreto n ${ }^{\circ} 20.493$, de 24 de Janeiro de 1946.

${ }^{64}$ Soares aponta que "a Censura não atuou de maneira uniforme durante os 21 anos da ditadura. Houve períodos de maior e de menor intensidade". Cf.: SOARES, Glaucio Ary Dillon. Censura durante o regime autoritário. Disponível em: <http://www.anpocs.org.br/portal/publicacoes/rbcs_00_10/rbcs10_02.htm>. Acesso em: 15 de janeiro de 2015 .
} 
Constatar, contudo, a precedência da censura moral à ditadura não implica, necessariamente, assumir uma perspectiva no sentido de subestimar as mudanças realizadas nas instituições e normas precedentes. Ao contrário, é impositivo observar como a censura moral se intensifica com o golpe, politizando-se ao extremo e passando a operar em outro patamar, já atrelada a um sistema de repressão mais coerente, ramificado e ostensivo durante a ditadura.

Dentre as medidas de "modernização" implementadas pela ditadura, destacaram-se a centralização da estrutura censória e sua aproximação à comunidade de informações, a maior profissionalização dos técnicos dessa agência governamental com treinamentos específicos para formação e exigência de diploma de nível superior, bem como a contratação de novos quadros para garantir maior agilidade e eficiência a este serviço público. Tais medidas figuravam-se necessárias para adaptar a estrutura censória a uma indústria cultural que se afirmava e crescia significativamente desde a década de 1960.

No entanto, esta atualização das antigas estruturas aos novos tempos não foi imediata e tampouco sem tensionamentos. Muitos censores não desejavam a transferência da Guanabara para Brasília, sem falar na resistência por parte de diversos órgãos regionais encarregados das atividades censórias, em cada Estado, que perderiam suas atribuições.

A desorganização e a precariedade ainda eram, assim, marcas do SCDP no início. Somente com a federalização e centralização da censura, por força da Constituição de 1967 , com a consagração do órgão no aparato policial e com sua crescente valorização enquanto dimensão de controle social imprescindível no contexto da "guerra psicológica adversa", é que o órgão assumiria maior relevância e teria melhores condições de atuação, incorporando cada vez mais competências e ganhando cada vez mais prestígio.

De qualquer modo, o cuidado com a "moral e os bons costumes", se antes se limitava mais à proteção abstrata da juventude à exposição de conteúdos imorais nos meios de comunicação, passaria a assumir, mais clara e contundentemente, a faceta de um projeto de saneamento e limpeza com status de segurança nacional, durante a ditadura. Isto acabou implicando um empoderamento deste órgão, culminando em sua formatação organizacional de modo mais robusta, como se verá.

\section{Lei n. 5.250, de 9 de fevereiro de 1967}

Também conhecida como "Lei de Imprensa", este diploma normativo foi imposto pelo 
General Castelo Branco sob a égide da Constituição de 1967, em um momento de fechamento do Congresso Nacional, com o objetivo de institucionalizar as restrições à liberdade de expressão e de informação, consolidando o regime autoritário do ponto de vista do controle da imprensa e da opinião pública. Assim, eram previstas penalidades mais severas para os profissionais do jornalismo, acusados de atentar contra os valores consagrados pelo regime vigente.

Seguindo as mesmas trilhas da típica legalidade autoritária para escamotear o arbítrio, $\mathrm{o}$ art. $1^{\mathrm{o}}$ assegurava, como regra geral apenas aparente, a liberdade de pensamento e de informação, independentemente de censura, nos seguintes termos: “É livre a manifestação do pensamento e a procura, o recebimento e a difusão de informações ou idéias, por qualquer meio, e sem dependência de censura, respondendo cada um, nos têrmos da lei, pelos abusos que cometer".

Contudo, logo em seguida, o parágrafo primeiro do mesmo artigo já ressalvava a conhecida fórmula de que não era tolerada "propaganda de guerra, de processos de subversão da ordem política e social ou de preconceitos de raça ou classe”. Já o parágrafo segundo excetuava os espetáculos e diversões públicas "que ficarão sujeitos à censura, na forma da lei”. Ademais, também previa a suspensão da liberdade de expressão na vigência de estado de sítio, "quando o Govêrno poderá exercer a censura sôbre os jornais ou periódicos e emprêsas de radiodifusão e agências noticiosas nas matérias atinentes aos motivos que o determinaram, como também em relação aos executores daquela medida".

É curioso notar que o estado de sítio nunca foi oficialmente decretado, a despeito de a censura sobre jornais e periódicos ter sido rotina durante a ditadura. Ainda que o AI-5 tenha significado, em termos práticos, uma autêntica configuração de estado de sítio, a verdade é que o regime nunca quis se assumir abertamente como de exceção, buscando sempre legitimar-se pela regularidade da legalidade ordinária.

$\mathrm{O}$ art. $2^{\circ}$, da mesma lei, realizava o mesmo procedimento, declarando ser "livre a publicação e circulação, no território nacional, de livros e de jornais e outros periódicos" para, logo em seguida, ressalvar a proibição daqueles que fossem "clandestinos" ou que atentassem "contra a moral e os bons costumes.

O Capítulo III da Lei é inteiro dedicado ao tema dos "abusos no exercício da liberdade de manifestação do pensamento e informação", instituindo ou agravando penas para uma série de crimes relativos à imprensa.

Destacam-se, dentre as infrações nomeadas, o crime de "fazer propaganda de guerra, de processos para subversão da ordem política e social ou de preconceitos de raça ou classe", 
com pena de 1 a 4 anos de detenção (art. 14), bem como o crime de "ofender a moral pública e os bons costumes", com pena de detenção de 3 (três) meses a 1 (um) ano, e multa de 1 (um) a 20 (vinte) salários-mínimos da região (art. 17). Combinam-se, assim, em caso de afronta à moralidade pública, o castigo de privação de liberdade com o apenamento pecuniário, o que indica a gravidade de tal conduta aos olhos do regime.

Além do mais, os impressos que "contive[ssem] propaganda de guerra ou de preconceitos de raça ou de classe, bem como os que promove[ssem] incitamento à subversão da ordem política e social” ou, então, que "ofende[ssem] a moral pública e os bons costumes" poderiam ser apreendidos e destruídos por determinação judicial, que dependia de pedido do Ministério Público (art. 61, incisos I e II). O prazo para o acusado apresentar resposta era de 24 horas e o Juiz deveria também decidir em apenas 24 horas, o que demonstra a celeridade ímpar atribuída a este procedimento para incrementar o nível de controle e neutralizar eventual efeito negativo de publicação com conteúdo proibido.

A fim de reduzir a repercussão de impressos indesejados, o parágrafo sexto, do mesmo artigo, dispensa maiores formalidades e ritos processuais em caso de que se tratasse de publicações consideradas contrárias à moral e aos bons costumes, prevendo a sua apreensão imediata, sem sequer oportunidade para oferecimento de defesa. Assim está redigida esta restrição mais gravosa: "Nos casos de impressos que ofendam a moral e os bons costumes, poderão os Juízes de Menores, de ofício ou mediante provocação do Ministério Público, determinar a sua apreensão imediata para impedir sua circulação".

Aliás, em havendo reincidência, especificamente de violação à moralidade pública praticada "pelo mesmo jornal ou periódico, pela mesma empresa, ou por periódicos ou emprêsas diferentes, mas que [tivessem] o mesmo diretor responsável”, o juiz poderia determinar, além da apreensão já mencionada, "a suspensão da impressão, circulação ou distribuição do jornal ou periódico" ${ }^{65}$, o que resultaria na extinção dos registros da marca comercial e na denominação da empresa editora e do periódico em todos os foros e cartórios, sendo que a publicação passaria, também, a ser considerada clandestina, conforme preceituava o $\S 2^{\circ}$ do art. 62 .

Ou seja, a publicação de assunto considerado atentatório contra a moral e os bons costumes poderia ensejar não somente apreensão do exemplar específico que contivesse o material proibido, mas também, em caso de reincidência, a própria cassação da circulação da

\footnotetext{
65 "Art. 62, § $4^{\circ}$ - Transitada em julgado a sentença, serão observadas as seguintes normas: a) reconhecendo a sentença final a ocorrência dos fatos que justificam a suspensão, serão extintos os registros da marca comercial e de denominação da emprêsa editôra e do jornal ou periódico em questão, bem como os registros a que se refere o art. $9^{\circ}$ desta Lei, mediante mandado de cancelamento expedido pelo juiz da execução".
} 
publicação em si e a extinção da empresa.

É sintomático o fato de que a sanção aplicável no que se refere a temas morais seja mais gravosa e penosa do que em assuntos estritamente políticos, o que coloca em xeque a ideia bastante difundida de que a censura moral tenha sido mais branda e leve do que outras formas de controle da subversão política. Esta nuance punitiva é um indicativo bastante exemplar da preocupação central da ditadura com o controle moral no contexto do fechamento do regime no final da década de 1960.

Para que tal repressão fosse ainda mais facilitada e excluída de apreciação judicial, em 20 de março de 1969, foi editado o Decreto-Lei n. 510 prescrevendo que, "quando a situação reclamar urgência, a apreensão poderá ser determinada, independentemente de mandado judicial, pelo Ministro da Justiça e Negócios Interiores”. Assim, todos os ritos e processos judiciais previstos se tornavam inócuos frente à tal exceção que centralizava ainda mais poder nas mãos do Poder Executivo.

\section{Lei n. 5.536, de 21 de novembro de 1968}

Não era só na imprensa que se notava a escalada repressiva. No plano infraconstitucional, alterações legislativas já indicavam o endurecimento também da censura das diversões públicas. Poucos dias antes da outorga do AI-5, foi baixada a Lei n. 5.536, de 21 de novembro de 1968, que dispunha sobre a censura de obras teatrais e cinematográficas, prevendo também a criação do Conselho Superior de Censura, que demoraria mais de uma década para ser implementado efetivamente.

A referida lei reproduzia a mesma lógica da legalidade autoritária típica da ditadura brasileira: enunciava formalmente um direito para, em seguida, restringi-lo com exceções vagas e genéricas previstas na própria lei e que permitiam, assim, uma ampla margem discricionária por parte dos agentes públicos na aplicação das normas. A Lei n. 5.536 realizava exatamente este procedimento, na medida em que prescrevia, em seu art. $1^{\circ}$, que "a censura de peças teatrais ser[ia] classificatória”, ou seja, não previa censura em sentido estrito, mas apenas uma classificação indicativa conforme a idade do público admissível em cada espetáculo, considerando o gênero e a linguagem em cena. No entanto, logo no art. $2^{\circ}$ do mesmo diploma legal, estabelecia-se que não se aplicaria o previsto no art. $1^{\circ}$ às peças teatrais que pudessem "I - atentar contra a segurança nacional e o regime representativo e democrático; II - ofender à coletividades ou às religiões ou incentivar preconceitos de raça ou 
luta de classes; e III - prejudicar a cordialidade das relações com outros povos". No parágrafo único deste mesmo artigo, reiterava-se a vigência da legislação anterior, qual seja, o Decreto n. 20.943/40, para a reprovação total ou parcial da peça analisada.

As obras cinematográficas, por sua vez, estavam sujeitas à aprovação desde que não fossem "contrárias à segurança nacional e ao regime representativo e democrático, à ordem e ao decôro públicos, aos bons costumes, ou ofensivas às coletividades ou às religiões ou, ainda, capazes de incentivar preconceitos de raça ou de lutas de classes".

Nota-se, assim, que qualquer obra que caracterizasse ofensa a referências vagas e abstratas como "ordem e decoro públicos", "bons costumes", "segurança nacional", "regime representativo e democrático", "coletividades", "religiões", ou mesmo incentivasse "preconceitos de raça ou de luta de classes", poderia ser enquadrada nos tipos legais genéricos que respaldavam a censura.

No entanto, a própria lei impunha parâmetros para a análise censória que, a rigor, não eram observados na prática cotidiana. $\mathrm{O}$ art. $4^{\circ}$, por exemplo, prescrevia que as obras deviam ser analisadas em seu contexto geral, sendo vedado isolar trechos ou mesmo formular recomendações críticas ${ }^{66}$. Embora isto não fosse o que acontecia na maior parte das vezes, quando os censores não apenas se conclamavam como arautos da moral, mas também como profundos conhecedores das linguagens artísticas com as quais trabalhavam.

A censura de espetáculos e obras cinematográficas era mais complexa, dependendo não de um censor apenas, mas de uma comissão colegiada composta por três técnicos de censura que avaliavam, individualmente, o material, e exaravam os seus respectivos pareceres que eram, em seguida, levados em consideração para a decisão final de liberação ou veto.

Os antigos Censores Federais foram transformados, com esta lei, em Técnicos de Censura: uma nova carreira vinculada ao Quadro de Pessoal do Departamento de Polícia Federal. A partir de então, com o intuito de profissionalizar a atividade censória, passou a ser obrigatório o diploma de conclusão de curso superior de Ciências Sociais, Direito, Filosofia, Jornalismo, Pedagogia ou Psicologia (art. 14, $§ 1^{\circ}$ ), ressalvada a situação dos censores já atuantes que ainda não tivessem qualificação superior nestas áreas. Aqueles que já possuíssem o diploma tiveram preferência para assumir os cargos superiores naquele momento ${ }^{67}$.

\footnotetext{
${ }^{66}$ Art. $4^{\circ}$ Os órgãos de censura deverão apreciar a obra em seu contexto geral levando-lhe em conta o valor artístico, cultural e educativo, sem isolar cenas, trechos ou frases, ficando-lhe vedadas recomendações críticas sôbre as obras censuradas.

${ }^{67}$ Para os antigos, foi promovido um Curso Intensivo de Treinamento de Censor Federal, realizado na Academia Nacional de Polícia e com professores de universidades como a UnB e a UFMG. Dentre as disciplinas oferecidas, constavam Comunicação e Sociedade, Filosofia da Arte, História da Arte, História e Técnica de Teatro, Técnica de Cinema, Técnica de Televisão, Legislação Especializada e Segurança Nacional.
} 
Uma outra inovação importante trazida por esta Lei foi a instituição do Conselho Superior de Censura (CSC), órgão diretamente subordinado ao Ministério da Justiça (art. 15), que funcionaria como instância de recurso contra decisões proferidas pelo Diretor-Geral do Departamento de Polícia Federal, em casos de censura a espetáculos e diversões públicas.

O CSC seria composto por representantes de diversos órgãos estatais e da sociedade civil vinculados ao campo da indústria da cultura brasileira: Ministério da Justiça; Ministério da Relações Exteriores; Ministério das Comunicações; Conselho Federal de Cultura; Conselho Federal de Educação; Serviço Nacional do Teatro; Instituto Nacional do Cinema; Fundação Nacional do Bem-Estar do Menor; Academia Brasileira de Letras; Associação Brasileira de Imprensa; Autores Teatrais; Autores de Filmes; Produtores Cinematográficos; Artistas e Técnicos em espetáculos de Diversões Públicas; Autores de Radiodifusão (art. 16).

No entanto, tal medida para a instituição de um colegiado amplo e representativo do universo cultural, com uma ampliação dos membros externos ao governo a fim de fixar as diretrizes superiores da censura, apenas aparentemente afigurou-se como uma medida democrática. De fato, o Conselho já fora esvaziado politicamente ao longo de sua instituição devido ao art. 18 da mesma Lei, que previa que, caso houvesse uma decisão "não unânime do Conselho Superior de Censura caber[ia] recurso ao Ministro da Justiça”.

Isto significava, na prática, uma total submissão do CSC ao Poder Executivo, que seguia impondo, em última instância, os padrões morais de orientação da atividade censória diretamente desde o governo. É evidente que um Conselho grande, com 15 membros de origens tão diversas, nunca ou raramente chegaria a acordos unânimes, em se tratando de temas tão polêmicos, como a censura das artes.

No entanto, mesmo com a limitação congênita que condenaria de partida o CSC à falta de autonomia, o Conselho não foi montado no mesmo período de intensificação da repressão, ao final dos anos 1960. Naquele momento, qualquer abertura, por menor que fosse, era indesejada e vista com desdém pelo regime. Talvez este fato explique a demora para que o CSC fosse efetivamente estruturado. Mais de 10 anos se passaram desde sua instituição, por força de lei, e sua instalação, que só ocorreu em 13 de setembro de 1979, pelo último presidente da ditadura, o General João Figueiredo ${ }^{68}$.

\footnotetext{
${ }^{68}$ Com efeito, foi somente o Decreto n. 83.973/79 que corroborou os termos da Lei n. 5.536 de 1968 e detalhou melhor o processo decisório e o processo de funcionamento do CSC, acrescentando, a este, além da função original de órgão revisor, a função de "elaborar normas e critérios que orientem o exercício da cesura, submetendo-os à aprovação do Ministro da Justiça” (art. 5º, inciso II).
} 
Artigo 153, parágrafo $8^{\circ}$, da Constituição Federal

Ainda que já houvesse o Decreto de 1946, a Lei de Imprensa de 1967 e a Lei n. 5.536 de 1968, o principal marco de sustentação da legalidade autoritária, no campo específico dos costumes, foi o artigo 153, parágrafo $8^{\circ}$, da Constituição. Não seria exagero afirmar que este dispositivo se tornou o vértice normativo de reordenação de todo o emaranhado de leis, decretos, atos administrativos e regulamentos preexistentes, aos quais foram sendo agregados outras regras criadas depois.

Esta preocupação quase obsessiva da ditadura em justificar suas práticas em algum lastro de legalidade, ainda que bastante rarefeito, é o que explica a profusão de dispositivos normativos com o intuito de racionalizar o uso puro e simples da força bruta contra os opositores políticos.

O uso instrumental do direito enquanto forma de controle social e político por um poder autoritário certamente não foi uma invenção brasileira, mas teve destaque especial na ditadura brasileira, que prezou por formas de escamotear o arbítrio por trás da aparência de normalidade das instituições jurídicas. A manipulação das leis, materializada por uma combinação peculiar de repressão judicial e extrajudicial, constituiu a tônica do processo de endurecimento político operado pelo regime instaurado em $1964^{69}$.

Muitas vezes, o texto legal não passava de ficção inteiramente ilusória, sem qualquer correspondência com a realidade. Em outros momentos, a mudança jurídica teve por objetivo inaugurar um novo flanco dentro do qual a repressão podia operar imune a controles de outros poderes ou das críticas da opinião pública.

Assim, no que se refere ao controle moral, a constitucionalização da escalada repressiva, verificada no pós-1968, vem tanto formalizar os atos que já vinham sendo praticados sem amparo, quanto lançar as bases para potencializar uma restrição ainda maior das liberdades públicas. O ponto de partida de toda esta discussão remete ao texto constitucional, que prescrevia o seguinte:

Art. 153. A Constituição assegura aos brasileiros e aos estrangeiros residentes no País a inviolabilidade dos direitos concernentes à vida, à liberdade, à segurança e à propriedade, nos têrmos seguintes:

$\S 8^{\circ}$ É livre a manifestação de pensamento, de convicção política ou filosófica, bem como a prestação de informação independentemente de censura, salvo quanto a diversões e espetáculos públicos, respondendo cada

\footnotetext{
${ }^{69}$ TELES, Janaína. Ditadura e repressão: paralelos e distinções entre Brasil e Argentina. Taller (Segunda Época). Revista de Sociedad, Cultura y Política en América Latina, Vol. 3, Nº 4, 2014.
} 
um, nos têrmos da lei, pelos abusos que cometer. É assegurado o direito de resposta. A publicação de livros, jornais e periódicos não depende de licença da autoridade. Não serão, porém, toleradas a propaganda de guerra, de subversão da ordem ou de preconceitos de religião, de raça ou de classe, e as publicações e exteriorizações contrárias à moral e aos bons costumes" (grifo nosso).

Importante frisar que tal exceção sobre "publicações e exteriorizações contrárias à moral e aos bons costumes" ao final deste parágrafo não existia originalmente na Constituição de $1967^{70}$, tendo sido incorporada ao texto por meio da Emenda Constitucional n. 1, de 17 de outubro de 1969, que coroou, no topo do ordenamento jurídico, o processo de fechamento político da ditadura no final da década de 60.

Em 1970, Alfredo Buzaid, catedrático da Faculdade de Direito da USP, ex-reitor da mesma universidade e então Ministro da Justiça do governo Médici, escreveu uma das mais detalhadas e consistentes argumentações jurídicas e políticas para dar concretude à "defesa da moral e dos bons costumes" com base nesse dispositivo constitucional. Essa fórmula tão vaga e indefinida, talvez e por conta mesmo de sua indeterminação, tenha sido a mais perfeita síntese do programa conservador da ditadura no campo dos costumes, entretenimento, propaganda e censura.

Buzaid, como jurista conservador que era, sabia manejar bem as estruturas normativas para conferir, ao sabor da conveniência de cada conjuntura, o conteúdo concreto do operador ideológico do regime. Recorrendo ao direito comparado, inclusive situando algumas experiências internacionais sobre o tema, com citação de autores estrangeiros de regimes autoritários europeus, sem deixar de sublinhar a especificidade da ditadura brasileira, sua análise esmiúça todo o conjunto de normas constitucionais e infraconstitucionais que desenham a regulação moral e sexual então vigente.

Este pequeno livro, editado pelo próprio Ministério da Justiça, consistiu em verdadeiro texto de intervenção para justificar as crescentes restrições do regime impostas à liberdade de pensamento e de manifestação, conferindo racionalidade e sustentação jurídica às posições dos setores mais vinculados à "linha-dura".

O ponto de partida de sua exposição é o referido parágrafo $8^{\circ}$ do art. 153 , que

\footnotetext{
${ }^{70}$ Era a seguinte a redação do art. $150, \S 8^{\circ}$ da Constituição Federal de 1967: "É livre a manifestação de pensamento, de convicção política ou filosófica e a prestação de informação sem sujeição à censura, salvo quanto a espetáculos de diversões públicas, respondendo cada um, nos termos da lei, pelos abusos que cometer. É assegurado o direito de resposta. A publicação de livros, jornais e periódicos independe de licença da autoridade. Não será, porém, tolerada a propaganda de guerra, de subversão da ordem ou de preconceitos de raça ou de classe".
} 
prescrevia uma regra geral, ainda que ficcional e sem lastro senão aparente na realidade, no sentido de que estariam garantidas as liberdades de pensamento e informação, sendo que a publicação de livros, jornais e periódicos não dependia de licença da autoridade. Contudo, logo após a enunciação da regra, no mesmo, uma ressalva é feita: "não serão, porém, toleradas [...] as publicações e exteriorizações contrárias à moral e aos bons costumes”.

Assim, no mesmo dispositivo, constava, por um lado, a regra da liberdade de expressão do pensamento, e, por outro, uma exceção que restringia como "intolerável",71 a difusão de publicações e exteriorizações contrárias à moral e aos bons costumes, “considerando-as tão atentatórias à segurança nacional quanto a propaganda de guerra, da subversão da ordem e dos preconceitos de religião, raça ou classe", 72 .

Segundo Buzaid, duas são as causas de tal proibição: a primeira delas reside no fato de tais publicações representarem "um mal que deve ser combatido com rigor, eficácia e perseverança", afinal, "a medicina as condena[va] por seus efeitos deletérios sobre as pessoas e as nações", sendo que a Itália, por exemplo, havia dado "um passo fundamental na luta contra a imoralidade, porque admitiu não só a repressão dos atos, mas especialmente o uso de meios preventivos"; por sua vez, a segunda causa dizia respeito ao fato de que "os agentes do comunismo internacional se serv[ia]m da dissolução da família para impor o seu regime político; para tanto busca[vam] lançar no erotismo a juventude, que facilmente se desfibra e perde a dignidade”. Para Buzaid, que então se servia dos dizeres de um expoente do pensamento católico leigo e conservador daquele momento, Gustavo Corção, "o conselho vem de Lenin: 'desmoralizem a juventude de um país e a Revolução está ganha'”. Não se sabe bem de que obra foi tirada a referida citação, mas Buzaid avança em suas famigeradas conexões entre "pornografia", "dissolução da família" e "dominação da juventude" como "meios empregados pelos marxistas" 73 . Para tanto, ele encontra exemplos em documentos do Maio de 1968 francês que dissociam sexualidade de reprodução e que se levantam contra a repressão sexual.

Nesta perspectiva, a propaganda em favor da plena liberdade sexual carregaria, necessária e implicitamente, "um plano de ação revolucionária que correspond[eria] aos propósitos de agitação marxista-leninista". Para combater tamanha ameaça, o ordenamento

\footnotetext{
${ }^{71}$ Para Buzaid, lançando a defesa da censura prévia, "adotou a Constituição um novo conceito - o de intolerabilidade. A intolerabilidade é uma idéia ampla, que abrange tanto a função repressiva quanto a função preventiva, ou, melhor dizendo, visa muito mais a impedir a publicação do que simplesmente a punir os que transgridem o mandamento constitucional". Cf.: BUZAID, Alfredo. Em defesa da moral e dos bons costumes. Brasília: Ministério da Justiça, 1970, p. 28.

${ }^{72}$ Ibidem, p. 6.

${ }^{73}$ Ibidem, p. 10.
} 
jurídico se desvelava como um instrumento fundamental de repressão e prevenção. Para o jurista, a norma insculpida no texto constitucional "não [tinha] caráter programático, nem constitu[ía] mera recomendação ao legislador ordinário para que edit[asse] normas tendentes a reprimir crimes contra a moral e os bons costumes", já que estes estariam definidos na legislação infraconstitucional (Lei de Imprensa, Código Penal e Lei de Segurança). No entanto, como tais dispositivos legais não são suficientes "para impedir a divulgação de publicações imorais", o legislador constituinte de 1969 decidiu impor "uma proibição formal e categórica" 74 .

Além disso, no que se referia às demais proibições de propaganda da guerra, da subversão da ordem, do preconceito religioso, étnico e de classe, "estas proibições fôram enunciadas em um único parágrafo, uma após outra e todas de modo peremptório, categórico e absoluto". Assim sendo, a subversão política e o atentado à moral seriam equivalentes no perigo que representavam à ordem social, considerando-se, portanto, "tão deletéria a subversão da ordem como a publicação de obras pornográficas”. Por esta razão:

[A Constituição] Não fêz entre elas distinção de grau, importância ou gravidade. Tratou-as igualmente, havendo-as por contrárias à segurança nacional. Logo, o que a Constituição declarou intolerável, aplic[ou]-se de imediato, independentemente de regulamentação particular. A norma constitucional [foi], pois, auto-executável" 75 .

Sobre a objeção de que inexistisse uma conceituação exata de "matéria contrária à moral e aos bons costumes", o próprio Buzaid reconhecia que "nem a Constituição, nem o Decreto-lei, nem a Portaria a defin[ia]m". Contudo, ponderava ele que, "quando a lei não formula uma definição, compet[ia] à doutrina elaborá-la" 76 .

Diante da dificuldade de conceituação, ele transcreveu dois longos e confusos trechos de dois penalistas italianos, Vincenzo Manzini e Giuseppe Maggiores, que apontavam que a moralidade pública seria a consciência ética de um povo em um dado momento histórico e que os bons costumes seriam aquela parte da moralidade pública que se refere à relação sexual. Sem adaptar quaisquer das definições ao caso brasileiro, Buzaid concluiu que "não [havia] mister outras especulações científicas ou filosóficas para concluir-se que o obsceno [era] contrário à moral e aos bons costumes" 77 .

Apesar de citar autores vinculados à cultura penal fascista, ele tentava claramente

\footnotetext{
${ }^{74}$ Ibidem, p. 14.

${ }^{75}$ Ibidem, p. 15.

${ }^{76}$ Ibidem, p. 20.

${ }^{77}$ Ibidem, p. 23.
} 
afastar-se de eventuais acusações de complacência com o autoritarismo, frisando que ao contrário da "Rússia marxista", da "Alemanha hitlerista" e da "Itália fascista", países que haviam colocado a imprensa a serviço de seus regimes políticos, "no Brasil, o Estado interv[inha] no domínio da moral pública em nome dos princípios cristãos, reprovando o ultraje ao dêcoro, a dissolução da família e o desfibramento da juventude" ${ }^{78}$.

Assim, em nome dos princípios cristãos, do decoro público, da família e da salvaguarda da juventude, tudo parecia ser legal e permitido. Até mesmo uma modalidade de "repressão preventiva" como a censura prévia que viria em seguida.

\section{Decreto-Lei n. 1.077, de 26 de janeiro de 1970}

Ao lado do Decreto n. 20.943 de 1946 e da Lei n. 5.538 de 1968, o tripé regulatório da censura $^{79}$ foi completado pelo Decreto-Lei n. 1.077, de 26 de janeiro de 1970, assinado pelo Presidente Médici e por seu Ministro da Justiça Alfredo Buzaid, durante o recesso do Poder Legislativo, com o objetivo de regulamentar a execução do artigo $153, \S 8^{\circ}$, parte final, da Constituição da República, provendo as autoridades públicas de mais instrumentos para a efetivação da censura com respaldo legal. Ao lado do Decreto n. 20.943 de 1946, este se tornou a principal referência normativa para os órgãos censores durante a ditadura de 1964.

O preâmbulo deste diploma do início de 1970 é bastante ilustrativo das motivações morais conservadoras do endurecimento legislativo então em curso. Uma série de "considerandos" foi aposta logo de início, justificando a medida com os riscos implicados na divulgação de "publicações e exteriorizações contrárias à moral e aos bons costumes" para a "família", os "valores éticos", a "mocidade". Assim, em última instância, o ataque a estes pilares da sociedade brasileira seria fruto de um autêntico "plano subversivo, que [punha] em risco a segurança nacional".

Vale a pena transcrever esta sequência que representa bem a lógica que orientou o raciocínio da comunidade de informações e dos órgãos de censura quanto aos temas morais, vistos como duplamente ameaçadores, primeiramente, porque afrontavam o que se poderia considerar como uma dimensão ética do pacto social imposto pela ditadura e, depois, porque, ao mesmo tempo, representavam uma das artimanhas dos "subversivos" para atacar a

\footnotetext{
${ }^{78}$ Ibidem, pp. $28-29$.

${ }^{79}$ Kushnir sugere esta expressão que é interessante por agrupar a parte mais relevante do arcabouço legal ordinário, mas acaba por perder de vista o mencionado art. 153 , parágrafo $8^{\circ}$, da Constituição que nos parece o vértice principal de um sistema normativo. KUSHNIR, Beatriz. Cães de Guarda: jornalistas e censores do AI-5 à Constituição de 1988. São Paulo: Boitempo, 2004, p. 81.
} 
integridade do país e a segurança nacional:

CONSIDERANDO que a Constituição da República, no artigo 153, § $8^{\circ}$ dispõe que não serão toleradas as publicações e exteriorizações contrárias à moral e aos costumes;

CONSIDERANDO que essa norma visa a proteger a instituição da família, preserva-lhe os valôres éticos e assegurar a formação sadia e digna da mocidade;

CONSIDERANDO, todavia, que algumas revistas fazem publicações obscenas e canais de televisão executam programas contrários à moral e aos bons costumes;

CONSIDERANDO que se tem generalizado a divulgação de livros que ofendem frontalmente à moral comum;

CONSIDERANDO que tais publicações e exteriorizações estimulam a licença, insinuam o amor livre e ameaçam destruir os valores morais da sociedade Brasileira;

CONSIDERANDO que o emprêgo dêsses meios de comunicação obedece a um plano subversivo, que põe em risco a segurança nacional.

Tendo em vista este diagnóstico de constantes ameaças à pureza moral por todos os lados, era preciso dispor de ferramentas de controle incidentes sobre os diversos meios e suportes de comunicação que veiculavam as mensagens tidas como "subversivas", tais como revistas, televisão, livros, teatro, cinema etc.

Conforme esclarecia Buzaid, fazia-se necessário controlar não apenas as diversões públicas, mas também as publicações. Para ele,

a censura a diversões e espetáculos públicos [seria] assim completada pela proibição de publicações contrárias à moral e aos bons costumes. $\mathrm{O}$ legislador constituinte, ao regular as duas matérias, [fora] lógico e coerente, porque não teria sentido fiscalizar previamente diversões e espetáculos públicos e permitir que medrassem livremente publicações pornográficas. ${ }^{80}$

Neste sentido, logo em seu art. $1^{\circ}$, o Decreto-Lei 1.077 reforçava o disposto na parte final do $\S 8^{\circ}$ do art. 153 da Constituição Federal, ressaltando que "não ser[iam] toleradas as publicações e exteriorizações contrárias à moral e aos bons costumes quaisquer que [fossem] os meios de comunicação". Por sua vez, o art. $7^{\circ}$ preceitua expressamente que a proibição "aplica[va]-se às diversões e espetáculos públicos, bem como à programação das emissoras de rádio e televisão".

Estes excertos não deixam dúvidas, portanto, de que nenhuma das formas de expressão do pensamento ou meio de comunicação estariam, assim, imunes à interpelação da censura, incluindo-se também as publicações estrangeiras que deveriam ser fiscalizadas

\footnotetext{
${ }^{80}$ BUZAID, Alfredo. Em defesa da moral e dos bons costumes. Brasília: Ministério da Justiça, 1970, p. 33.
} 
quando da entrada em território nacional, como rezava o art. $4^{\circ}$.

Em sua justificativa, Buzaid se valia da estratégia de desqualificar as publicações eróticas e pornográficas, retirando-lhes qualquer aura de arte ou de literatura. Para ele, "as obras pornográficas, as revistas imorais e as criações obscenas [...] não [eram] literatura, não [eram] obra de arte, não [eram] esplendores da inteligência. Representa[vam], ao contrário, degradações do espírito, condenadas pela legislação penal" ${ }^{\prime 81}$.

Contudo, um dos pontos mais polêmicos e controversos da intervenção governamental na seara cultural foi instituído, justamente, por este Decreto-Lei. Tratava-se de uma modalidade de controle que ficou conhecida como "censura prévia" por levar em conta que publicações fossem proibidas mesmo antes de serem dadas a público. Assim, o artigo $2^{\circ}$ do Decreto-Lei garantia ao Ministro da Justiça, por meio do Departamento de Polícia Federal, a prerrogativa de "verificar, quando julgar necessário, antes da divulgação de livros e periódicos, a existência de matéria infringente" (grifo nosso) à moral e aos bons costumes. E em caso de que o Ministro atestasse a configuração de violação à moralidade pública por uma obra, mesmo que em sede de apreciação administrativa e sem qualquer garantia de defesa ou de contraditório, ele "proibir[ia] a divulgação da publicação e determinar[ia] a busca e a apreensão de todos os seus exemplares", conforme previa o art. $3^{\circ}$.

Em seu libelo em defesa da moral e dos bons costumes, inclusive com a repressão preventiva, Buzaid afirmou que "o objetivo do Govêrno não [era] de exercer o controle da inteligência brasileira, sufocar-lhe o espírito criador ou restaurar a mesa censória dos tempos coloniais", acrescentando que

a preocupação do Govêrno consisti[a] em banir do mercado as publicações obscenas, que avilta[ssem] e degrada[ssem] a juventude, bem como proibir terminantemente que os agentes do comunismo internacional se servissem do rádio e da televisão para exercer através de programas insidiosos influência subliminar no seio das famílias

Afinal, "[era] por meio dos periódicos, rádio e televisão que o comunismo internacional atua[va] sobre o povo, invandindo sub-repeticiamente os lares" ${ }^{82}$. Assim, o argumento central para uma medida draconiana era justificado não apenas pela necessidade de reprimir o "mal”, mas de evitá-lo, conforme escreveu, ainda, o jurista:

\footnotetext{
${ }^{81}$ Ibidem, p. 42.

${ }^{82}$ Ibidem, p. 19.
} 
da ameaça que o erotismo representa, tolerar as publicações contrárias à moral e aos bons costumes significa concorrer para o aviltamento da juventude e dissolução da família. A legislação não poderia contentar-se com reprimir o mal; tem necessidade, a bem da segurança, de evitá-lo. E foi o que fề ${ }^{83}$.

Não é preciso ressaltar os ônus e prejuízos que decorriam de tais penalidades de busca e apreensão para os autores e editores das publicações. Além de não poderem mais vender o material, os exemplares já impressos e distribuídos em pontos de venda eram retirados de circulação e incinerados às custas do próprio autor ou editor, que pagava, assim, a conta da destruição de seu próprio trabalho e investimento. Sem contar a multa em que incorria o responsável pela obra, que consistia em "valor igual ao do preço de venda da publicação" (art. $5^{\circ}$, inciso I).

Por esta razão, não foram poucos os periódicos e as editoras que faliram por conta do estrangulamento financeiro que tais penalidades, sempre arbitrariamente aplicadas, provocaram. A grande maioria das empresas deste ramo eram pequenas, com situação financeira já precária e com produção em escala modesta. O transtorno que a proibição de uma obra implicava, com todos os transtornos e custos decorrentes de tal condição, poderia significar a inviabilização da atividade empresarial a médio e longo prazo, como de fato ocorreu com diversas publicações.

Não bastasse o Decreto-lei 1.077, para dar concretude a este e diante das pesadas críticas à censura prévia vindas de diversos setores, o ministro da Justiça Alfredo Buzaid baixou a Portaria 11-B, em 6 de fevereiro de 1970 e a Instrução n. 1, de 24 de fevereiro de 1970, com o objetivo de deixar claro que estariam subordinadas à verificação prévia "tão somente as publicações e exteriorizações que cont[ivessem] matéria potencialmente ofensiva à moral e aos bons costumes". Assim, o art. $1^{\circ}$ da referida Instrução esclarecia que "est[avam] isentas de verificação prévia as publicações e exteriorizações de caráter estritamente filosófico, científico, técnico e didático, bem como as que não versa[ssem] temas referentes a sexo, moralidade pública e bons costumes".

Nota-se, assim, que o governo pretendeu aliviar a crítica recebida quanto ao controle prévio das publicações, sem, contudo, renunciar à possibilidade de efetuar tal controle caso entendesse necessário fazê-lo. Trata-se de uma tentativa de sinalizar um recuo, mas sem efetivamente cassar a prerrogativa do Ministro em apreender previamente obras consideradas potencialmente subversivas. Entretanto, de algum modo, o objetivo do governo foi atingido e

\footnotetext{
${ }^{83}$ Ibidem, p. 25.
} 
as críticas cessaram, porque escritores e editores viram que o objetivo do Decreto-lei 1.077 foi o de combater sem tréguas a pornografia, considerada instrumento de dissolução da família e de degradação da juventude. A ação do Govêrno se voltava contra as revistas e os programas de televisão que insinuavam o erotismo e outras deformações do sexo, diminuindo ou abatendo a resistência moral da família ${ }^{84}$.

É importante registrar que, nos termos do art. $6^{\circ}$ do Decreto-lei, para além do controle administrativo bastante contundente e ostensivo, poderia também haver, ainda, a intervenção do sistema de justiça (Ministério Público e Judiciário) em relação aos mesmos fatos atentatórios à moral e aos bons costumes, especialmente com fundamento na Lei de Imprensa já mencionada. Agências e instâncias distintas, desta forma, superpunham-se em uma complexa rede de contenção para neutralizar os efeitos deléterios que a livre sexualidade, a pornografia, o erotismo e outras manifestações, consideradas atentatórias à moral e aos bons costumes, provocavam.

\section{Um emaranhado legal: hipernomia autoritária}

A partir desta breve síntese dos principais diplomas normativos que estabeleceram os critérios para o controle político e moral das artes e das comunicações no país, é possível perceber que a ditadura não exerceu sua violência em um contexto de anomia, senão, de uma hipernomia. Isto é, não se tratava apenas de opor um estado de fato ao direito, ou de sobrepor a lei pela força, mas de manipular um emaranhado legislativo e administrativo de acordo com os interesses políticos do regime.

O descompasso entre as linhas regulatórias originárias da censura moral, traçadas na década de 1940, quando a televisão sequer era uma realidade, bem como o cenário emergente de produção cultural em escala industrial, impunha uma permanente dificuldade para efetivar o policiamento ético de uma sociedade em intensa transformação. E embora seja da própria essência do direito um certo atraso em seu encontro com a realidade que pretende normatizar, este descompasso era potencializado em se tratando de um intento de regulação moral de uma área tão dinâmica e em fluxo constante como a cultura.

Não obstante, é importante notar que a aparente inconveniência de uma legislação ultrapassada, repleta de ambiguidades normativas e outras tantas fórmulas genéricas com

\footnotetext{
${ }^{84}$ Ibidem, p. 19.
} 
pouca aderência concreta ${ }^{85}$ era, no entanto, uma vantagem para ampliar a margem discricionária das autoridades na aplicação do direito. Isto porque a atividade hermenêutica dos tipos legais reservara ao intérprete uma considerável autonomia em reconstruir a dimensão normativa do texto a ser aplicado, sobretudo quando bastante abstrato e vago como eram as restrições de ordem moral.

Assim, este contexto possibilitaria que a censura usasse e abusasse de um emaranhado com o propósito de legitimar suas ações. A roupagem legal tornou-se fundamental para assegurar a sobrevida a uma atividade tão nitidamente autoritária e antipática como a imposição de sanções à produção cultural, como se verá no próximo capítulo.

\footnotetext{
${ }^{85}$ Esse fato, como se verá, chegou a incomodar até mesmo censores. Diante da necessidade de atualização da legislação, em abril, de 1974, o Ministro Armando Falcão chegou a criar, por "portaria reservada", uma comissão encarregada desta tarefa. A referida comissão era integrada por um de seus assessores especiais, por um professor catedrático da Faculdade de Direito da Universidade Federal de Pernambuco e por Rogério Nunes, então diretor da DCDP. A composição se altera depois de três anos, permanecendo apenas este último incumbido de apresentar uma minuta de anteprojeto. Apesar da urgência requerida pelo ministro, somente em 1979, nas últimas semanas do governo Geisel, é que o trabalho foi apresentado em caráter sigiloso, mas não teve seguimento. Para uma análise detida deste anteprojeto e as possíveis causas de sua paralisação na estrutura administrativa, ver: MARCELINO, Douglas Attila. Subversivos e Pornográficos. Censura de livros e diversões públicas nos anos 1970. Rio de Janeiro: Arquivo Nacional, 2011 p. 34.
} 
- Capítulo $2-$

\section{A CENSURA NA PRÁTICA: CONTROLE MORAL NAS ARTES, COMUNICAÇÕES E DIVERSÕES}

Do ponto de vista da sua imagem perante a sociedade, a censura manterá sempre uma duplicidade constitutiva, oscilando permanentemente entre dois polos que se mostraram mais complementares do que opostos: um primeiro, aparentemente mais sublime, marcado pela natureza intelectual e algo sofisticada do controle da expressão artística; e um segundo, mais bruto e explícito, que era nitidamente policial ou policialesco. As distintas formas que circunscreveram os modos de atuação da censura com os sistemas de informação e de segurança refletiram, sobremaneira, esta ambiguidade inerente à ditadura, a fim de justificar a censura. Deste modo, garantir-se-ia, de um lado, uma "melhora" na qualidade da cultura entregue aos lares dos brasileiros; de outro, o uso da força do Estado coibiria o fluxo de erotismo e pornografia que ameaçaria a integridade moral da nação, além de perseguir a arte política e combativa do período ${ }^{86}$, supostamente de viés comunista.

As cifras sobre o alcance da censura nas diversas linguagens artísticas ainda é algo sem contornos precisos. Há trabalhos específicos em cada área, indicados nas seções abaixo, que procuram estimar numericamente as obras vetadas e cortadas pelas tesouras dos censores. De qualquer modo, para uma visão ampla de conjunto, segundo Zuenir Ventura, nos dez anos de vigência do AI-5, foram censurados "cerca de 500 filmes, 450 peças de teatro, 200 livros, dezenas de programas de rádio, 100 revistas, mais de 500 letras de música e uma dúzia de capítulos e sinopses de telenovelas" $" 87$.

Mesmo que subestimados, estes números refletem uma aproximação realista do cenário do alcance do controle moral das artes, das comunicações e das diversões públicas. Mas um olhar qualitativo por detrás dessas cifras pode revelar os detalhes do funcionamento da tesoura censória. Passemos então à análise pormenorizada das seguintes dimensões da censura: televisão, teatro, música, livros e demais publicações impressas como jornais e revistas, inclusive da chamada "imprensa gay".

\footnotetext{
${ }^{86}$ STEPHANOU, A. A.. Censura no regime militar e militarização das artes. Porto Alegre: PUC-RS, 2001.

${ }^{87}$ VENTURA, Zuenir. 1968: o ano que não terminou. Rio de Janeiro: Nova Fronteira, 1988, p. 285. Estes números, como mencionado, podem estar subestimados. Deonísio da Silva, por exemplo, apresenta cifras significativamente maiores, afirmando que apenas Armando Falcão, Ministro da Justiça de Geisel, "passou à história como o maior censor do Brasil em todos os tempos: mais de 500 livros proibidos, além de centenas - e às vezes milhares - de filmes, peças de teatro, músicas, cartazes, jingles e diversas outras produções, entendidas como artísticas e culturais, censuradas entre 1974 e 1978". SILVA, Deonísio da. Nos bastidores da censura: sexualidade, literatura e repressão pós-64. São Paulo: Estação Liberdade, 1989, p. 15.
} 


\section{Televisão}

Os programas televisivos, especialmente os de auditório e as novelas, receberam especial atenção da censura contra a exposição de comportamentos sexuais e de gênero não normativos. Isto se deu graças ao alcance significativamente maior que a televisão já vinha conquistando em relação aos demais meios de comunicação. Apesar de ser relativamente recente, assistiu-se, a partir dos anos 1970, com a popularização progressiva da tecnologia, a um crescimento bastante expressivo no número de televisores nas residências brasileiras e as novelas já ocupavam um lugar de protagonismo na formação dos costumes das camadas urbanas.

Segundo Rita Colaço, o projeto engendrado pelas emissoras de televisão para formação e consolidação do telespectador brasileiro voltava-se especialmente para as camadas mais pobres da população, tanto pela aposta na expansão do número de domicílio com televisores, como pela escassez de outras opções de entretenimento para esse público. Para lograr a massificação da audiência, a programação exibida apontava para o apelativo, apropriando-se de aspectos da cultura subalterna, mas explorando, sobretudo, atrações vistas como aberrações, deformações patéticas ou ridículas ${ }^{88}$. Homossexuais, assim, deviam vestir o figurino de pessoas debochadas, expansivas, espalhafatosas, histéricas, fúteis, com trejeitos exagerados e uma língua ferina.

A presença de gays ou mesmo de pessoas identificadas com o gênero oposto, ou seja, homens com trejeitos femininos e mulheres com comportamento masculino, enquadrava-se exatamente na categoria de diversão de "clowns" e foi algo perseguido desde os primórdios da programação televisiva. Prova disto é que, já em 24 de abril de 1969, o Ofício n. 231/69SCDP enviado pelo chefe da Censura Federal, Aloysio Muhletnaler de Souza, ao Juiz de Menores do Estado da Guanabara, Dr. Alyrio Cavallieri, registrava as providências tomadas, por exigência deste, para que os homossexuais não fossem exibidos na programação televisiva. Ao que o chefe da Censura respondeu, ao magistrado: “em atenção ao ofício n. $174 / \mathrm{G}$ de 31/3/69, em que nos solicita medidas cabíveis no sentido de serem retirados dos programas de TV da Guanabara, os quadros em que exploram a figura do homossexual, temos a grata satisfação de informar a V. Sa. de que tais providências foram tomadas" ${ }^{\text {" }}$.

O mesmo tipo de cobrança se verificou em diversos outros momentos da ditadura,

\footnotetext{
${ }^{88}$ COLAÇO, Rita. De Denner a Chrysóstomo, a repressão invisibilizada: as homossexualidades na ditadura. (1972 a 1983). In: GREEN, James N.; QUINALHA, Renan (Orgs.). Ditadura e homossexualidades: repressão, resistência e a busca da verdade. São Carlos: EDUFSCAR, 2014, p. 210.

${ }^{89}$ BR_DFANBSB_NS_AGR_COF_CSO_0014_d
} 
tendo havido sempre uma marcada preocupação em relação ao alcance da influência da televisão, que logo se tornou o meio de comunicação em massa por excelência no país.

Tal vigilância postulava, sobretudo, que qualquer exposição das homossexualidades teria o efeito de fazer "apologia" ou "propaganda" de um comportamento sexual tido por “anormal”. A orientação, então, era, em primeiro lugar, pela interdição do tema. No entanto, mais tarde, com o enfraquecimento dos mecanismos censórios, diante da impossibilidade de silenciar uma forma de amor e de afeto que teimava em dizer seu próprio nome, sobretudo no contexto da inevitável liberalização dos costumes, a ditadura se empenhou em dirigir a produção e a circulação de discursos em torno da moralidade sexual.

Neste sentido, o Ofício n. 221/79-DCDP, de 12 de junho de 1979, enviado por José Vieira Madeira, diretor da DCDP, para Mauro Broja Lopes, Diretor Executivo da Central Globo de Produções, estava menos orientado em vetar e mais alinhado com a diretriz de modular a exibição de acordo com a régua moral do regime. Após reexame da clássica peça de teatro "Um gosto de mel", de Shelagh Delanev, que seria apresentada como espetáculo da série "Aplauso", o censor autorizou que o programa fosse veiculado, entretanto,

desde que [fossem] observadas as seguintes recomendações: 1. Que se evit[asse] detalhes inconvenientes na gravação da relação sexual [...] e 2. Que a atuação dos personagens que representarão a prostituta e o homossexual [fosse] a mais discreta quanto possível de modo a não colidir com o horário $(22.00 \mathrm{hs})$ e com o tipo de veículo (televisão). ${ }^{90}$

Assim, buscava-se atenuar, de um lado, a exibição de conteúdos demasiado explícitos e, por outro, impunha-se que os "desvios sexuais" fossem disfarçados ou, ao menos, apresentados de modo discreto para não causar impacto negativo na audiência naquele horário, ainda que noturno.

Estas diretrizes, nem sempre formalizadas, colaboraram enormemente para formatar, ou mesmo reforçar, uma mentalidade pautada na discriminação. Uma pesquisa sobre questões sexuais foi exibida no programa Fantástico, da TV Globo, em um domingo de junho de 1978. Dentre as diversas questões respondidas pelos entrevistados que participaram do levantamento, uma das mais polêmicas foi a relacionada ao homossexualismo. Na ocasião, perguntava-se "o que o brasileiro pensa[va] sobre o homossexualismo, tanto do homem como da mulher?". As respostas foram: 25\% consideram uma doença, 19\% culpa da falta de orientação dos pais, $18 \%$ um produto do desajuste do mundo de hoje e $11 \%$ uma falta de

\footnotetext{
${ }^{90}$ BR_DFANBSB_NS_AGR_COF_CSO_0158_d
} 
vergonha. Além de que, mais da metade dos entrevistados considerou o homossexualismo muito chocante, especialmente o masculino.

João Antônio Mascarenhas atribuiu, à censura, este resultado nada favorável aos homossexuais, uma vez que ela impediu uma discussão mais franca e serena sobre assuntos tidos como tabus. Ele afirmou, em texto publicado no Lampião, que devia-se lamentar a inexistência de debates dos problemas expostos, embora "não [pudéssemos] responsabilizar a emissora pela ocorrência; a culpa cab[ia] à rigorosíssima censura que pesa[va] sobre a rádio e a televisão" $"$.

Passemos, então, à uma análise de como a censura conseguiu pautar e dirigir o conteúdo dos programas televisivos, sobretudo no que concerne à sexualidade e, em especial, aos homossexuais.

\section{"Os militantes dos 'trejeitos"': Clodovil, Bornay e Denner}

Os programas de auditório foram uma modalidade de entretenimento que, desde a primeira hora, lograram um grande sucesso de público na televisão brasileira. No dia do descanso em família, aos domingos, diversas emissoras concorriam com atrações neste formato, com show de calouros, dançarinas, quadros engraçados e interação com a plateia. Mas uma marca bem característica destes programas eram os famosos júris que dividiam o palco com os apresentadores em permanente diálogo e troca de opiniões. Neles, sempre havia algumas personagens carimbadas e com lugar cativo independentemente da emissora: o homem com perfil mau, o pretenso erudito, a senhora bondosa e, em especial, o homossexual efeminado e com trejeitos.

Três homossexuais tornaram-se figuras recorrentes na programação dos principais canais de televisão, trabalhando junto aos apresentadores Chacrinha, Sílvio Santos e Flávio Cavalcanti e ajudando-os a angariar elevados níveis de audiência e anunciantes, eram eles: Clodovil Hernandez, costureiro famoso das mulheres das classes mais abastadas; Clóvis Bornay, famoso por suas participações performáticas em concursos de fantasias carnavalescas; e Denner Pamplona de Abreu, também costureiro e estilista. Um menos famoso, mas que também apareceu nos programas do Chacrinha e Sílvio Santos, foi o cabeleireiro Antonio Carlos.

Entretanto, a presença deles não duraria muito nos lares das famílias brasileiras. Uma

\footnotetext{
${ }^{91}$ Lampião da Esquina, edição 2, junho/julho de 1978, p. 9.
} 
comoção foi despertada em diversos setores mais conservadores da sociedade. No Legislativo, por exemplo, medidas foram propostas para lidar com a questão. Em 1972, o deputado paulista Januário Mantelli Neto chegou a apresentar projeto de lei na ALESP "proibindo a apresentação de homossexuais em programas de TV em todo território nacional" ${ }^{, 92}$. Ele teria recebido, conforme noticiou a Folha de São Paulo a 28 de abril daquele mesmo ano, comunicação oficial do governo federal registrando que "ser[ia] proibida a partir [daquela data] a apresentação de homossexuais em programas de televisão no Brasil”, razão pela qual vangloriava-se por ter "iniciado essa luta". Segundo ele, "as autoridades federais souberam compreender a necessidade de defender a família brasileira" ${ }^{\text {93. }}$.

Ainda que não houvesse uma norma relativa a este conteúdo, em especial, conforme anunciado pelo deputado, a reivindicação de defenestrar aquelas personagens estava caminhando aceleradamente. Reverberando a mobilização contra os efeminados, a revista Veja noticiou, em abril de 1972, que os "trejeitos" tinham seus dias contados na televisão brasileira: "A guerra está declarada e já fez a primeira vítima: Clóvis Bornay”. O famoso carnavalesco foi afastado do programa Sílvio Santos e por um "fulminante bilhetinho" da Rede Globo, por "sugestão" da censura. A ordem era apenas para "desarmá-lo" de seus trejeitos, mas sem estes, ele “já não tinha função no júri”. E a revista acrescentava que "um cerrado bombardeio moralista visa[va] a desalojar dos programas de auditório (onde [haviam se tornado] figuras obrigatórios ultimamente) todos os militantes dos "trejeitos""94.

A Veja também abordou o caso do programa "Dener É um Luxo", da TV Itacolomy, de Belo Horizonte, que enfrentava a pressão da Liga das Senhoras Católicas. Segundo Anael Pacheco ${ }^{95}$, comissário de menores que pediu ao Conselho de Censura do Juizado de Menores a proibição da apresentação do costureiro na TV, "seus maneirismos, sua falta de masculinidade [eram] prejudiciais à formação moral da infância e da juventude". Apesar de Dener tentar "controlar seus gestos", para ele e seus "colegas de estilo", o "comedimento é o suicídio, que lhes custa o interesse, a audiência e o emprego"96. Ou seja, ruim com os trejeitos, mas pior sem eles.

\footnotetext{
92 MOTT, Luiz. A tribo dos rapazes de peito. Folha de São Paulo, 16/6/1996. http://www1.folha.uol.com.br/fsp/1996/6/16/mais!/3.html

93 "Deputado confirme proibição". Folha de São Paulo, 28 de abril de 1972, p. 12.

94 "Veto ao trejeito". Revista Veja, n. 190, 26 de abril de 1972, p. 80.

${ }^{95}$ Depois de sua vitória contra Dener, Anael, que se autointitula "defensor inconstitucional [sic] da família, da moral, da disciplina e dos costumes", foi acompanhado pela Revista Veja pagando sua promessa em uma peregrinação de mais de 4 horas a pé: "se o santo acabasse com o Dener e os outros tipos iguais a ele na TV, eu vinha a pé a Rocas Grandes agradecer e rezar pelo nosso presidente da República". "As normas da boa conduta". Revista Veja, n. 193, 17 de maio de 1972, p. 86.

96 "Veto ao trejeito". Revista Veja, n. 190, 26 de abril de 1972, p. 80.
} 
Um mês depois, o Ministro das Comunicações, Hygino Corsetti, efetivamente anunciou que se reuniria com seus pares da Justiça, Alfredo Buzaid, e Educação, Jarbas Passarinho, para aprovar um pacote de "normas de conduta" da TV, com o objetivo de elevar a qualidade da programação, em especial dos programas de auditório. Além de sugerir a autocensura na televisão, ele adiantou que sua proposta consistia em buscar um "alto nível de moralidade", proibindo "situações que exalt[assem], direta ou indiretamente, o erostimo, o alcoolismo e as inversões sexuais" $"$.

A revista ainda registrava que "como aparentemente até [aquele momento] as emissoras nano mostraram o discernimento desejado pelo ministro", houve uma "solicitação de Brasília para retirar do ar dois exemplos que é mau”, rerferindo-se ao Clodovil, que participava do júri da "Hora da Buzina", e de Denner, que já havia sido demitido do programa de Flávio Cavalcanti e, em seguida, também da emissora mineira Itacolomy ${ }^{98}$.

O desgaste imposto a estas figuras era inevitável e contava com os órgãos repressivos. Um episódio bastante sintomático disso foi a escolha de Denner para paraninfo de formatura de uma turma do curso de Jornalismo da Universidade Católica de Permambuco, que motivou revoltas em diferentes instâncias. Um professor da universidade, José Rafael de Menezes, renunciou a seu cargo ao receber a notícia. Logo, ele foi prontamente aplaudido em sua conduta pelo deputado Severino Cavalcanti (Arena-PE), que criticou o fato de os estudantes homenagearem o "famigerado" costureiro que "jornalistas do País luta[ram] para expulsar da televisão, onde ocupa[va] o lugar de um profissional competente, que trabalha[sse] com

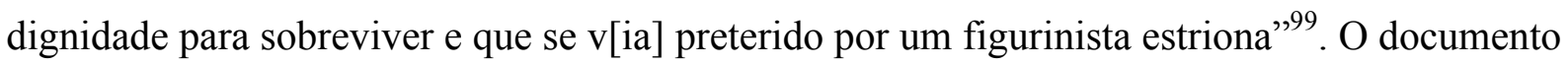
da repressão, a pretexto de analisar a homenagem a Denner, vai além e aponta que

[vinha causando] estranheza a liberalidade da Censura Federal com o assunto e não se compreend[ia] que a competição por pontos do IBOPE justifi[casse] a invasão dos lares por essa 'estranha fauna', uma vez que, na programação nobre de Domingo, o telespectador fica[va] com as alternativas de CLOVIS BORNAY, no 'Programa SILVIO SANTOS', DENNER, no 'Programa FLAVIO CAVALCANTI', ou o costureiro CLODOVIL, na 'Buzina do CHACRINHA'. Além da masculinidade em dúvida dos citados personagens, confirmada pelos trejeitos femininos, expressões faciais duvidosas e voz em falsete, procura[va]-se apresentá-los como 'entendidos', 'sumidades' etc, criando em tôrno dos mesmos uma imagem socialmente aceita a respeitável.

\footnotetext{
97 “As normas da boa conduta". Revista Veja, n. 193, 17 de maio de 1972, p. 85.

98 "As normas da boa conduta". Revista Veja, n. 193, 17 de maio de 1972, p. 85.

99 COLAÇO, Rita. De Denner a Chrysóstomo, a repressão invisibilizada: as homossexualidades na ditadura. (1972 a 1983). In: GREEN, James N.; QUINALHA, Renan (Orgs.). Ditadura e homossexualidades: repressão, resistência e a busca da verdade. São Carlos: EDUFSCAR, 2014, p. 214.
} 
Para arrematar, cobrava-se uma postura mais dura da censura contra aquela "estranha fauna".

Contudo, não só os homossexuais foram afetados pela homofobia na televisão. Depois de 20 anos à frente da "Buzina do Chacrinha", uma das maiores audiências da televisão brasileira, o apresentador Abelardo Barbosa teve seu contrato com a TV Globo rompido no dia 6 de dezembro de 1972. A direção da emissora alegou que a ruptura se deveu ao fato de que foi exibido, no programa, um "efeminado". Em comunicado, a emissora argumentou:

a Globo manterá o seu compromisso com o Governo de se manter dentro do Código de Ética. Não permitiremos que personalismos rompam o acordo assinado por todas as emissoras. Se outros animadores não obedecem, nós obedeceremos. Manteremos nossa programação dentro de regras morais, dentro da ética e dentro dos bons costumes. ${ }^{100}$

O apresentador chegou a ser pessoalmente advertido pelo diretor José Bonifácio de Oliveira Sobrinho, mais conhecido como Boni. Segundo a versão de Chacrinha, contudo, a motivação da rescisão contratual deveu-se à mudança do horário de seu programa por cinco vezes consecutivas ${ }^{101}$.

\section{"Erradicar as insinuações de homossexualismo dos programas da televisão brasileira"}

Tornara-se bastante comum, com o aguçamento da guerra cultural e de costumes no final da ditadura, o envio de cartas por cidadãos indignados por verem suas casas "invadidas" por uma programação televisiva com as quais eles não concordavam ou que conflitassem com os valores pessoais das suas famílias. Por exemplo, em 27 de maio de 1985, o policial militar reformado Geraldo Francisco Neves escreveu, desde Contagem (MG), uma carta para o Superintendente da Polícia Federal em Brasília reclamando da telenovela "Um sonho a mais", exibida pela Rede Globo. Segundo ele, na novela, "prostitutas e homossexuais num festival de pornochanchadas, violência, tóxico, falta de educação, violam nossas famílias". Em uma mensagem que transbordava misoginia e homofobia, afirmava o missivista que "nossas mulheres dotadas, mentalmente, igual à criança, absorvem todas essas imundícies, que são

\footnotetext{
100 “Agildo anima 'Discoteca' e confirma rompimento do Chacrinha com TV Globo". Jornal do Brasil, 7/12/1972, p. 16.

101 “Agildo anima 'Discoteca' e confirma rompimento do Chacrinha com TV Globo". Jornal do Brasil, 7/12/1972, p. 16.
} 
transmitidas aos maridos e aos filhos, causando-os distúrbios psicológicos. Os pais não conseguem impedir essas invasões aos lares. Quando a mulher quer, não adianta". E arrematava dizendo que "não devemos permitir que a SANHA de algumas autoridades, que não tem família, imoral e talvez, homossexual, venha desrespeitar-nos e deformar o caráter de nossas crianças" ${ }^{\prime 102}$.

A revolta deste cidadão devia-se, principalmente, ao fato de que o ator Ney Latorraca, travestido de mulher, fazia o papel da executiva Anabella Freire, tendo até mesmo dado um beijo em outro homem no ar e se casado com ele.

Não é de se estranhar esse tipo de correspondência histriônica e conservadora, expressando uma perspectiva sempre presente em alguns setores, mais ou menos expressivos, da nossa sociedade. A singularidade, durante o período ditatorial, repousava mais no fato de que tal tipo de discurso encontrava não apenas eco nas agências estatais, mas chegavam mesmo a servir de orientação para as políticas públicas, amplificando o alcance e a força da discriminação institucionalizada.

Nesta linha, em sua carta-resposta ao cidadão, a autoridade censória não apenas ratificou a crítica, mas também alimentou ainda mais a visão preconceituosa contra a homossexualidade. Escreveu o diretor da SCDP, que assumiu o órgão no mês de março, daquele ano, “já discordávamos do tratamento cênico e oral dispensado a determinados quadros da telenovela em questão, razão pela qual interferimos, solicitando ao autor da obra e aos responsáveis pela programação da emissora comedimento nas situações que insinuavam homossexualismo".

Ainda assim, isso não bastava, e o próprio censor informou: "determinamos que fosse colocado termo à abordagem, no que fomos atendidos, conforme poderá ser observado nos próximos capítulos". Por fim, frisou a firme intenção de extirpar a homossexualidade da televisão brasileira:

solidários na análise do problema e visando, em primeiro plano, preservar o menor de influências negativas à sua sadia formação, informamos oportunamente que providências estão sendo tomadas de forma a erradicar as insinuações de homossexualismo dos programas da televisão brasileira ${ }^{103}$.

\section{"Reiteradas reclamações acerca da presença de travestis"}

\footnotetext{
102 BR_AN_BSB_NS_AGR_COF_MSC 272

103 BR_AN_BSB_NS_AGR_COF_MSC_272
} 
Pouco tempo depois, em 9 de julho de 1985, inconformado com a exibição de "pervertidos" nos horários "familiares" da programação televisiva brasileira, Coriolano Fagundes editou uma norma específica para impedir a veiculação de personagens homossexuais "ostensivamente efeminados ou masculinizados", para evitar a "apologia" desses desvios.

O Diretor do DCDP, alegando nos "considerando" haver "reiteradas reclamações acerca da presença de travestis nas programações de televisão”, baixou a Instrução Normativa n. 03/85, com base no Decreto 20.943 de 1946, extrapolando seus poderes regulamentares por criar obrigações e exigências não previstas na legislação vigente. Com apenas dois artigos, o ato administrativo, apesar de apenas classificatório, anunciava a nova tendência de uma censura em vias de extinção e traçava uma linha tênue e vaga entre representações homossexuais discretas e toleráveis, de um lado, e figuras com excesso de trejeitos do gênero “oposto" que deveriam ser policiadas. Assim estava redigida a Instrução Normativa:

1 - A apresentação de travestidos, de homem ou de mulher aparentemente homossexual, respectivamente em atitude ostensivamente efeminada ou masculinizada, quer em telenovela como em programa de auditório, terá a veiculação televisava autorizada para após as 21 (vinte e uma) horas.

1.1 - O tratamento cênico dado, assim por animador como por narrador, travestido ou homossexual aparente não poderá ser ofensivo à dignidade humana do apresentado, nem apologética do transsexualismo ou do homossexualismo. ${ }^{104}$

A motivação principal da norma foi a veiculação da telenovela mencionada acima, "Um sonho a mais". Na troca de correspondências entre o diretor do SCDP, que praticamente endereçou a norma à rede Globo, e o vice-presidente da empresa, José Bonifácio de Oliveira Sobrinho, este manifestou sua preocupação com "decisões casuísticas e preconceituosas" que surgiam da instrução, reiterando que "trata[va] todos os telespectadores com respeito humano e não faz[ia] apologia do transexualismo, do homossexualismo ou de qualquer outra preferência sexual" ${ }^{105}$.

Em sua réplica, Coriolano elogiou a obediência da Rede Globo, afirmando que a norma não seria necessária "se todas as emissoras de televisão se conduzissem com a lisura com a qual se tem havido" a emissora. Aproveitou, ainda, para fazer um inventário dos programas ofensivos à moral familiar e pública veiculados pelas concorrentes no seguinte trecho:

\footnotetext{
${ }^{104}$ BR AN BSB NS AGR COF MSC 279

${ }^{105}$ BR_AN_BSB_NS_AGR_COF_MSC_279
} 
a apresentação de travestidos aos domingos à tarde, apresentados como se o transsexualismo fosse uma habilidade a mais para assegurar o sucesso artístico; as entrevistas de homossexuais aparentes em programas de auditório, com ofensa à dignidade humana do entrevistado; a veiculação de números eróticos de espetáculos de homossexuais, como se se tratasse de reportagem telejornalística; a entrevista com mulher declaradamente lésbica, em horário livre, na qual a entrevistada convida mulheres a terem uma experiência homossexual por considerá-la altamente gratificante - tudo isto levado ao ar por congêneres.

Tudo isso constituía, para Coriolano, um abuso da liberdade de expressão que justificara a edição da instrução normativa ${ }^{106}$.

\section{"O relacionamento homossexual é uma aberração"}

"Vale Tudo", exibida no horário das 20h, foi também atingida pelos cortes da censura. Ao mesmo tempo em que a novela das $19 \mathrm{~h}$ mostrava uma garota de 18 anos, que engravidou em uma festa-orgia sem saber quem seria o pai de sua criança, casou com um ladrão contumaz e deu à luz um menino minutos depois de assaltar um banco, a cena de duas mulheres adultas conversando sobre sua relação amorosa foi proibida. O motivo foi reduzido a uma única palavra: "aberração". De acordo com Raimundo Mesquita, diretor da Censura Federal,

esse assunto, quando não tratado entre quatro paredes, deve[ria] ter um enfoque científico ou didático. O lesbianismo, se colocado de forma jocosa ou simpática, pode[ria] parecer ao jovem uma prática sadia e induzir o préadolescente a aceitá-lo como solução. O relacionamento homossexual é uma aberração ${ }^{107}$.

Ele afirmou que o critério adotado pela censura era o da "sutileza", mencionando que uma personagem mulher que incorporasse o estereótipo da lésbica masculinizada poderia ser exibida, como a Mendonça da novela "Bebê a bordo", desde que não houvesse relacionamento homossexual: "Mendonça é, apenas, masculina. Quem pode afirmar que ela é lésbica, se não houve até agora insinuação de relacionamentos com outras personagens femininas?" 108 .

\footnotetext{
${ }^{106}$ BR_AN_BSB_NS_AGR_COF_MSC 279

107 "Tesoura em 'Vale Tudo": censura não deixa ir ao ar a cena da novela sobre homossexualismo". Jornal do Brasil, 19 de julho de 1988, p. 6.

108 "Tesoura em 'Vale Tudo': censura não deixa ir ao ar a cena da novela sobre homossexualismo". Jornal do Brasil, 19 de julho de 1988, p. 6 .
} 
É importante notar a legitimação que as medidas censórias dessa natureza encontravam em setores da sociedade brasileira que já demonstravam nostalgia dos períodos mais duros da ditadura. Uma correspondência enviada por um advogado de Carangola (MG), chamado Sérgio Nassar Guimarães, ao diretor da censura, logo após as declarações citadas acima, revela o apelo popular do veto da cena que continha demonstração de amor entre mulheres: "comungo com este censor o mesmo pensamento e irrestrito apoio à vossa atitude, pois, a homossexualidade é uma aberração advinda dos desvios de personalidade, e como tal, deve ser abordado não publicamente"109.

\section{"O orgasmo do censor sempre foi a proibição"}

Em 30 de abril de 1985, o Jornal do Brasil publicou declarações do chefe da Censura Federal, Coriolano Fagundes, em que este anunciava que o prazer que determinados censores sentiam em vetar obras artísticas havia chegado ao fim. "O orgasmo do censor sempre foi a proibição; agora, o censor não terá mais esse orgasmo", afirmou ele.

Isso porque estava em curso uma reorientação que tentava adequar a censura aos tempos da Nova República, mas certamente menos com o objetivo de extingui-la e mais com o propósito de dar-lhe sobrevida na conjuntura adversa - sob a ótica da continuidade da repressão - trazida pelo processo de redemocratização. O diretor da SCDP informava que, dos 150 censores do órgão, mais da metade optaria por continuar a carreira policial e os que optassem por seguir no posto de censor teriam de fazer "cursos de reciclagem" para entender que "não mais poderão banir qualquer manifestação do pensamento brasileiro" 110 .

Mas, como toda regra em momentos de exceção, o ímpeto liberalizante parecia ter limites. Os ares democráticos não alcançariam todo tipo de comportamentos, especialmente àqueles relativos à homossexualidade. Coriolano declarou que tudo que fosse "obsceno" deveria ser combatido com rigor e, segundo sua visão, "obsceno é tudo aquilo que sai da normalidade. Por exemplo, o ato sexual entre dois homens ou duas mulheres não é uma coisa normal, embora não vá nisso uma crítica ao homossexualismo" "111. Com esta breve declaração, o censor dava mais um sinal bastante claro de que os homossexuais ficariam de fora da agenda política da transição.

\footnotetext{
${ }^{109}$ BR_AN_BSB_NS_AGR_COF_MSC_349

110 “Manifestação artística não terá mais censura por motivos políticos”. Jornal do Brasil, 30 de abril de 1985, p. 16.

111 “Manifestação artística não terá mais censura por motivos políticos”. Jornal do Brasil, 30 de abril de 1985, p. 16.
} 
No entanto, esse tipo de colocação já não passava mais em branco diante do surgimento de outros grupos organizados de homossexuais que passaram a adotar uma tática de dialogar publicamente, cobrando autoridades e combatendo manifestações de preconceitos institucionalizadas em diversos órgãos. Assim, o grupo Triângulo Rosa, representado por João Antônio Mascarenhas, enviou uma carta ao diretor do SCDP, qualificando-o de "preconceituoso" e contestando sua afirmação de que a homossexualidade fosse "obscena". Mascarenhas, no comunicado, destacava a orientação despatologizante recentemente emanada do Conselho Federal de Medicina e afirmava que "não [havia] nada de obsceno na homossexualidade, nem, tampouco, na heterossexualidade, quando a atividade sexual se desenvolve[sse] sem violência e entre pessoas conscientes" ${ }^{\text {112 }}$.

No início da década de 1980, já com a transição no horizonte, grupos como o GGB e o Triângulo Rosa não precisavam mais sustentar um discurso de oposição à ditadura, que antes era incontornável para todos os movimentos sociais, inclusive os identitários. O lento processo de descompressão política foi marcado pela tolerância seletiva e gradativa de setores da oposição, com o retorno de algumas garantias de organização e liberdades de expressão e manifestação.

Assim, a partir de meados de 1980, diferentemente dos pioneiros do movimento homossexual, os grupos então mais recentes já haviam sido forjados em outro ambiente político, caracterizados por uma relação nova com a legalidade e as instituições do regime. Os anos do crepúsculo da ditadura condensaram mudanças importantes em um curto espaço de tempo e traçaram os contornos da incipiente democracia que estava por vir.

Com o relativo abrandamento da censura e a ampliação de um campo menos clandestino de ação política, marcado pelo florescimento de oposições cada vez mais pujantes, os novos agrupamentos LGBTs passaram a reivindicar uma agenda de reconhecimento e de políticas públicas. Este deslocamento do foco exigia mais uma postura de diálogo e cobrança do que combate aberto e sem concessões do Estado. Deste modo, a tônica das demandas passou a ser a supressão de legislações discriminatórias, a inscrição da proteção legal no ordenamento jurídico, o abandono de um discurso médico-legal de estigmatização pelas entidades de classe da área da saúde, acolhimento para vítimas de violência e investigação dos responsáveis, além de uma disputa aberta na imprensa contra veiculação de notícias sensacionalistas e preconceituosas ${ }^{113}$. Apesar das limitações, novos tempos pareciam efetivamente estar no horizonte.

\footnotetext{
112 BR_AN_BSB_NS_AGR_COF_MSC_270

${ }^{113}$ Ver capítulo 5 do presente trabalho.
} 


\section{"Tribuna de aliciamento, indução e apologia do homossexualismo"}

Um outro exemplo de atuação dessa natureza de grande repercussão foi a participação da ativista lésbica Rosely Roth no programa de televisão apresentado por Hebe Camargo na Rede Bandeirantes. Hebe convidara o escritor Ignácio de Loyola Brandão, a atriz Maria Lúcia Dahl, Marília Gabriela, a ex-diretora da Censura Federal Solange Hernandez e a já mencionada antropóloga Rosely Roth. O tema debatido em um dos programas de maior audiência em horário nobre era o "lesbianismo".

Contudo, dias após a exibição, a direção da emissora recebeu um ofício proveniente do escritório paulista da Censura Federal, com a assinatura do chefe da repartição Dráusio Dornelles Coelho, acusando Hebe de ter transformado seu programa em uma "tribuna de aliciamento, indução e apologia do homossexualismo". O documento cobrava "enérgicas providências" sob pena de proibir a transmissão ao vivo, impondo que o programa fosse primeiro gravado para análise da censura antes da exibição ${ }^{114}$.

Indignada, a apresentadora afirmou que não via razão alguma para este reparo por parte da órgão censório, pois procurou discutir o tema do homossexualismo "dentro da maior dignidade, ouvindo sempre pessoas que [trouxessem] alguma contribuição aos temas" ${ }^{115}$.

Mais uma vez, esta desavença pública demonstrava o desgaste da censura. O Triângulo Rosa interveio em defesa de Hebe. Em carta endereçada a Dráusio Dornelles Coelho, o grupo se disse "horrorizado" com a acusação censória, afirmando que "carecia de qualquer fundamento", já que "não se pode fazer "propaganda da homossexualidade", o que seria "uma perda de tempo e esforço"116.

Mas a censura, ainda que em fase de agonia e exaustão flagrantes, recebia ainda alguns apoios pontuais. O advogado e pastor mórmon Ciro Ludgero, por exemplo, escreveu um texto de protesto no jornal "Correio de Notícias", indignado com "pessoas que se apresentam insinuando a homossexualidade (quando não a confessando e aliciando abertamente como foi o caso de um programa de uma apresentadora muito conhecida no BRASIL)". Ele se referia justamente à Hebe Camargo. Reclamava Ludgero, sobretudo, de sinais de travestilidades na televisão, com "homens com vozes e gestos femininos e mulheres com caracteres masculinos, [que alcançavam] horários de grande audiência, sendo muitas destas programações dirigidas à dona de casa. Revistas e filmes exaltando o fenômeno [eram] oferecidas ao público sem a

\footnotetext{
114 “Censura ameaça Hebe Carmargo". Folha de São Paulo, 29 de maio de 1985, p. 37.

115 “Censura ameaça Hebe Camargo”. Folha de São Paulo, 29 de maio de 1985, p. 37.

${ }^{116}$ BR_AN_BSB_NS_AGR_COF_MSC_270
} 
menor reserva" $" 117$.

Curioso que o artigo motivou a Informação n. 022/01/85-SI/SR/DPF/PR, de 4 de setembro de 1985, enviado do escritório regional do Paraná para o Centro de Informações do Departamento de Polícia Federal sustentando a urgência de endurecimento da censura já em estado de perecimento, como se houvesse uma enorme pressão social e tal posição fosse representativa do conjunto da sociedade brasileira: "esses tipos de protestos públicos demonstram o inconformismo de segmentos da sociedade com a exibição do homossexualismo pela televisão, que dia a dia se intensifica, desde os programas humorísticos, até as novelas"118.

Em meio à batalha decisiva de costumes, era fundamental criar uma aparência de grande suporte por parte de setores importantes da sociedade para desacelerar o ritmo da abertura e a intensidade da liberalização, sobretudo a moral. Superestimar a legitimidade social de suas reivindicações particulares era uma velha estratégia dos grupos mais alinhados à "linha-dura" na ditadura brasileira, pressionando sempre para que suas posições fossem as hegemônicas e unificassem as comunidades de informação, de segurança e a censura.

\section{"Essa livre expressão da imoralidade depõe também contra as autoridades da nossa Justiça"}

Mesmo no período compreendido entre a posse de Sarney como primeiro Presidente da República civil depois da ditadura e a promulgação da Constituição de 1988, a censura permaneceu ativa. Exemplo disso, na televisão, é o Ofício n. 1.238/86-SE/DCDP, de 13 de novembro de 1986, que continha laudo de reexame do "Bem-vindo ao lar, Bobby".

Tratava-se de um filme, feito em 1986, sobre um personagem que foi preso pelo uso de drogas, quando a polícia descobre que ele havia feito sexo com um homem mais velho. Por conta da homossexualidade, começou a ser hostilizado pelos colegas da universidade, que pedem sua expulsão, causando constrangimento também à família. Em linguagem simples e acessível, sem qualquer apelo sexual explícito, o filme conseguiu tratar da polêmica temática de forma humana.

A empresa Worldvision do Brasil, responsável pelo filme, não se conformou com o veto que o filme recebeu para a exibição na televisão, justamente por não conter material

\footnotetext{
${ }^{117}$ BR_DFANBSB_ZD_0_0_0046A_0019_d0001de0001

${ }^{118}$ BR_DFANBSB_ZD_0_0_0046A_0019_d0001de0001
} 
explicitamente erótico ou pornográfico. No entanto, na reanálise feita pelo chefe da SC/SCDP, logo após a ditadura, reiterou-se a proibição porque era abordado o "homossexualismo, com situações de simpatia para esta forma de perversão sexual", o que seria “incompatível para o veículo televisivo [...] constituindo material altamente deletéria, atentatória à moral e aos bons costumes"119.

Mas a extinção iminente da censura, nesse momento histórico, acentuou cada vez mais a tensão entre liberalização e reação de cidadãos indignados. Uma carta de cobrança de maior dureza da censura, já no seu último ano de existência, foi enviada por Aguinaldo Torres Lucio, membro da Comunidade Evangélica Betel em Belo Horizonte, em 28 de junho de 1988, para o Diretor da Divisão de Censura e Diversões Públicas em Brasília/DF. Na mensagem, constava uma preocupação: “queremos externar a nossa tristeza e preocupação com o estímulo à sensualidade e à pornografia que muitos canais de comunicação promovem com grande liberdade entre nós". E prosseguia, caracterizando a situação como "uma grave violação aos nossos mais elementares valores morais e um ataque vil à ingenuidade e pureza de nossos filhos". Mas a principal reclamação foi mesmo contra os órgãos de censura e de controle que, segundo o missivista, não estariam cumprindo suas funções adequadamente: “essa livre expressão da imoralidade depõe também contra as autoridades da nossa Justiça; pois não respondem à altura, com órgãos de censura, que deveriam servir para, ao menos, ocultar tais aberrações culturais" ${ }^{\prime 120}$. E, por fim, destacava, ainda, que tais problemas poderiam parecer menos graves do que outros desafios postos pela realidade, mas ressalvava, diante dessa possível objeção: “[os adolescentes] se perdem na promiscuidade, iludidos que são pela idéia perniciosa de 'emancipação sexual'. Com isto, a família - instituição divina e célula vital de uma comunidade - está cada vez mais instável."121

A resposta da DCDP, datada de 15 de agosto de 1988, tentou esclarecer os limites do trabalho deste órgão com uma instância recursal mais liberal, o Conselho Superior de Censura, em um momento de mudança da legislação, sobretudo com a nova Constituição com o iminente fim da censura. Afirmou o Diretor, ao missivista: "temos a esclarecer que nos empenhamos em evitar a difusão das 'aberrações culturais', sendo, por isto condenados continuamente". Acrescentou, ainda, que o Conselho Superior de Censura "muitas vezes, libera obras que não receberam nossa aprovação para veiculação nos meios de comunicação”. Posteriormente, encerrou a resposta sem justificar, mas conclamando as pessoas desejosas do

\footnotetext{
${ }^{119}$ BR_DFANBSB_NS_AGR_COF_CSO_0389_d

${ }^{120}$ BR_AN_BSB_NS_AGR_COF_M MSC_ 347

${ }^{121}$ BR_AN_BSB_NS_AGR_COF_MSC_347
} 
endurecimento da censura em um contexto de redemocratização: "com a propalada extinção da censura, prevista com a promulgação da Constituição, a sociedade tem que começar a exercitar seu direito, reclamando diretamente junto aos canais de comunicação" ${ }^{\text {"122 }}$.

No mesmo sentido, um bilhete manuscrito enviado para a Censura Federal por um cidadão de Manaus manifestava incômodo com a novela "Olho por Olho", da extinta TV Manchete, em 14 de agosto de 1988, pedindo mais rigor no controle moral. Afirmava o missivista "pedir e protestar" contra exibição de "um travisti [sic] (bicha) em gritante escândalo de homossexualismo, coisa que devemos evitar nos lares". Acrescentava, em seu clamor, que "isto não pod[ia] ser aceito passivamente, a censura precisa[va] ter coragem de deter tais aparições nas TVs, ser bicha não é arte e sim pouca vergonha”. Por fim, registrava que era impossível desligar a TV antes de saber o conteúdo que ser[ia] veiculado: “[...] quem quizer [sic] as coisas imorais, que fassam [sic] em ambiente próprio e não em TV, que muitas vezes quando vamos desligar já foi veiculado o desagradável para nós e filho, dentro do lar"123.

Em 30 de agosto do mesmo ano, Raymundo Eustáquio de Mesquisa, Diretor do DCDP em exercício, respondeu, por meio do ofício n. 523/88 - GAB/DCDP: "nos empenhamos em evitar a apresentação de situação envolvendo homossexualismo na televisão, como foi exaustivamente publicado quando cortamos momentos da telenovela 'VALE TUDO', da Rede Globo". A justificativa residia no fato de que determinados detalhes, como a presença de uma travesti, não era conhecido pelo público por exibição na tela, mas por matéria jornalística que apurou o fato, "visto que procuramos retirar da obra este entendimento [de uma travesti]. O mesmo aconteceu com o relacionamento homossexual de 'VALE TUDO', quando nada foi mostrado na telenovela que claramente a confirmasse". Por fim, lamentava o censor que a DCDP “encontra[va]-se, praticamente, no término de suas funções” por conta do texto da futura Constituição que viria a extinguir o departamento. Assim, aconselha[va] ao missivista: “enaltecendo a preocupação de V. Sa., por um maior moralismo na televisão, sugerimos encaminhar também suas reclamações aos dirigentes das próprias emissoras"124, pois são os telespectadores que deverão influir nas programações.

Deste modo, neste período final da censura, os funcionários aproveitavam, em suas respostas, não apenas para prestar contas do estado de permanente e incansável vigília e atenção do DCDP nos conteúdos imorais, mas também para incitar aos cidadãos que

\footnotetext{
${ }^{122}$ BR_AN_BSB_NS_AGR_COF_MSC 347

${ }^{123}$ BR_AN_BSB_NS_AGR_COF_MSC 351

${ }^{124}$ BR_AN_BSB_NS_AGR_COF_MSC_351
} 
compartilhavam da mesma preocupação a exercerem a censura eles próprios. Talvez este esforço de educar cidadãos como se fossem censores tenha sido um dos legados mais perversos da ditadura no campo da sexualidade e dos costumes.

\section{O teatro}

O teatro tinha sua produção acompanhada bastante de perto pelos órgãos de censura. Ainda que não fosse uma forma de expressão artística de amplo alcance de massas, como a televisão que se consagrava como o maior meio de comunicação naquele momento, o teatro era muito influente na opinião pública e estava presente nas principais cidades brasileiras, dialogando com uma parcela expressiva da classe artística e da intelectualidade. É desnecessário ressaltar que o teatro era, justamente, um campo privilegiado de experimentação de novas estéticas da sexualidade e, portanto, potencialmente uma afronta aos costumes tradicionais.

Com efeito, ainda que atingisse apenas um público mais restrito e selecionado, o efeito da linguagem cênica na vida social e na política não podia ser minimizado. Diversas formas teatrais circulavam e dinamizavam os cenários locais vinculados a universidades, centros de cultura e mesmo a camadas médias da população que consumiam esse tipo de arte com cada vez maior frequência.

A censura no teatro tinha dois momentos fundamentais e complementares entre si. O primeiro era mais burocrático e consistia na apreciação do texto escrito para verificar o teor das falas e dos diálogos; já o segundo era marcado pelo contato direto do censor com a execução mesma do espetáculo. Assim, na primeira fase, os textos dramatúrgicos deviam ser submetidos à avaliação e poderiam ser liberados integralmente, liberados com cortes ou vetados. Caso liberados, posteriormente, a montagem também era fiscalizada na segunda etapa por técnicos de censura que observavam se os cortes impostos haviam sido, de fato, respeitados, além de analisarem outros elementos do espetáculo cênico, como a música, as luzes, a cenografia, enfim, a peça em movimento. Tratava-se, portanto, de uma censura prévia.

Para assegurar a fidelidade dos textos aprovados, a fim de que os mesmos não fossem alterados nas exibições já após a certificação censória, a Lei 5.536 de 1968 prescrevia claramente a vedação das mudanças: “as peças teatrais, após aprovadas pela censura, não 
poderão ter o seus textos modificados ou acrescidos, inclusive na representação" ${ }^{\text {125 }}$. Em caso de descumprimento da norma, o espetáculo poderia ser suspenso por 3 a 20 dias, além de incidir a pena pecuniária de pagamento de multa. Conforme o art. 13 da mesma lei, em caso de espetáculos e obras cinematográficas, a censura deveria ser feita por comissões colegiadas constituídas por três técnicos de censura, que avaliavam individualmente o material e exaravam parecer para as considerações superiores.

Ao longo das pesquisas em acervos documentais, foi possível localizar alguns pareceres interessantes feitos por censores em relação a peças teatrais, demonstrando como a regulação moral prevista na legislação censória combinava-se com as convicções pessoais dos agentes públicos para vetar, total ou parcialmente, trabalhos cênicos neste momento histórico $^{126}$. O teatro era compreendido como uma modalidade particular das "diversões públicas”, razão pela qual era a SCDP quem fazia sua avaliação e controle.

\section{"Propaganda adversa nos meios de comunicação": a comunidade de informações em cena}

Uma primeira dimensão marcante do controle moral e sexual no teatro é o monitoramento atento e ostensivo feito pelos órgãos de vigilância e informações sobre os textos e peças teatrais que estavam em preparação ou exibição. Deve-se, neste caso, observar que a comunidade de informações alimentava regularmente o sistema censório com suas análises para provocar e até cobrar um endurecimento do controle contra as peças consideradas subversivas.

Sucessivos relatórios sobre "propaganda adversa nos meios de comunicação social", periodicamente feitos e enviados diretamente de agências de informação ao Poder Executivo, a fim de que ele pudesse orientar sua ação repressiva, evidenciavam a preocupação constante do governo com os temas comportamentais. Considerava-se que a mera exibição de condutas sexuais tidas como inapropriadas não apenas chocaria os espectadores, mas teria o efeito de convencimento e de "propaganda" para que outras pessoas se entregassem aos mesmos

\footnotetext{
${ }^{125}$ Art. 11 da Lei 5.536 de 1968.

${ }^{126}$ Esta percepção de que as convicções pessoais e outros atributos de personalidade dos censores era o fator determinante nos vetos e liberações era razoavelmente difundida à época. Um carta de 7 de novembro de 1972, escrita pelo curitibano Adyr Gabrilo Carli e encaminhada ao Presidente da República Emílio G. Médici, clama por mais censura e recomenda "que os membros da Censura [fossem] substituídos de tempos em tempos, visto que de tanto lidar com imoralidades, seus corações [iam] aos poucos se empedernindo, e o que para outra pessoa mais afastada seria imoral, para eles [era] coisa normal, face a lida diária" (BR_AN_BSB_NS_AGR_COF_MSC_029).
} 
prazeres proibidos.

$\mathrm{Na}$ realidade, este tipo de relatório periódico de acompanhamento das diferentes formas de expressão cultural e artística era bastante comum na relação da comunidade de informações com o governo autoritário. Era com base nestes informes regulares de atos e pessoas considerados "subversivos" que a política repressiva era pensada e executada seletivamente, tanto pelos organismos de segurança, quanto pelos censórios. Vale destacar que a homossexualidade, ou "homossexualismo", como eles preferiam, era uma das preocupações mais recorrentes em tais documentos.

Um dos relatórios, por exemplo, seguia anexado na Informação $n$. 356/03/DSI/MJ/275281, de 13 de outubro de 1981, originada da AC/SNI e difundida diretamente para o gabinete do Ministro da Justiça. Tal documento expunha os resultados do "acompanhamento e análise" da "grande imprensa, o cinema, o teatro, o rádio e a televisão" deste período.

No relatório sob exame, apontava-se que, no teatro, merecia especial atenção a peça "BLUE JEANS" que "apresenta[va] um executivo homossexual, que [tinha] relações em seu apartamento com quatro garotos de idades entre 16 e 18 anos, de origens diferentes: um travesti, um michê, um marginal e um menor abandonado. A peça apresenta[va] cenas de sexo entre os atores, masturbação, curra, etc, com os participantes atuando nus em boa parte da peça. A apresentação do homossexualismo e prostituição de menores, com a utilização do nu masculino, cenas explícitas de sexo e a linguagem específica, tend[iam] a chocar os assistentes" $^{\text {"127 }}$ (grifo nosso).

No que se refere ao cinema, destacava-se a obra "ORGIA DAS LIBERTINAS", filme que "desenvolve-se em um sítio onde homens e mulheres se entregam a todo tipo de orgias" e "apresenta, durante todo o desenrolar cenas explícitas de sexo grupal e de lesbianismo"128. O destaque conferido a imagens que remetiam ao "homossexualismo" e ao "lesbianismo", ao lado de outras práticas sexuais não convencionais, como "orgia" e "exibição de nu masculino”, eram causas para a indignação dos órgãos repressivos.

Já o relatório constante na Informação n. 361/03/81/DSI/MJ, datado de 16 de outubro de 1981, também da AC/SNI para o Ministro da Justiça, no período de 2 a 8 de outubro, destacava, no teatro, as peças "BRENT, VILLAGE, AS TIAS, VIVA SAPATA, AS CRIADAS, todas apresentando como tema básico [o] homossexualismo"129.

\footnotetext{
${ }^{127}$ BR_RJANRIO_TT_0_MCP_AVU_0310

${ }^{128}$ BR RJANRIO TT_0_MCP_AVU_0310

${ }^{129}$ BR_RJANRIO_TT_0_MCP_AVU_0310
} 
Por sua vez, a Informação n. 22/0990/G2/82, da AC/SNI, de 9 de setembro de 1982, sobre "propaganda adversa nos meios de comunicação", destacava, no teatro, a peça "NIGHT AND GAY" que estava sendo apresentada no Teatro Alaska, no Rio de Janeiro. Segundo o relatório, tal peça mesclava críticas moral e política ao regime, incluindo na encenação situações que não estavam previstas no texto original: "trata-se de um show de travestis, onde a pornografia constitu[ía] a tônica do espetáculo, acrescida de críticas jocosas ao Governo e, particularmente, às Forças Armadas, através de situações que não consta[vam] no script" ${ }^{130}$.

Nesta mesma linha, a Informação n. 22/0990/G2/82, da AC/SNI, de 19 de outubro de 1982, também sobre "propaganda adversa nos meios de comunicação", destacava, no teatro, a peça “TEM EMBRULHO NO PACOTE”, de Emanuel Rodrigues, com direção de Brigitte Blair, apresentada no Teatro Miguel Lemos no Rio de Janeiro. De acordo com a avaliação feita pelos agentes da repressão, recheada de adjetivos e considerações opinativas, "a encenação, extremamente vazia em arte e técnica, emoldurada por homossexualismo, mundanismo e excesso de palavrões, [tinha] por preocupação principal satirizar segmentos da sociedade e do Governo. Enfocando o "empreguismo" que era utilizado pelos candidatos a cargos eletivos nas próximas eleições; todos os partidos políticos eram criticados, sendo substituídas suas verdadeiras siglas por palavras jocosas e ofensivas; mostrava-se, também, o envolvimento ilegal da Polícia no controle ao lenocínio e a jogos de azar não permitidos. Atacava frontalmente o Governo quando um travesti, provocando silêncio inusitado, anunciava: "vou falar um palavrão: FIGUEIREDO"131. Este final sugeriria que a ofensa ao então Presidente era mais grave porque advinha da boca de uma travesti.

Ainda sobre "propaganda adversa - teatro", a Informação n. 24/84 da ASI da TELEBRÁS evidenciou o monitoramento de peças em cartaz por todo o país no período de setembro a dezembro de 1983. Ela apontava que, em São Paulo, poderia ser visto nos palcos o trabalho "Revolução", de Issac Chocron. Escrita em 1917, a peça, sob direção do "esquerdista" Antônio Abujamra, "apresenta[va] as relações entre um artista travesti e seu empresário, também homossexual, com sua alternância de dominador e dominado"132. Outro trabalho destacado foi "Fim de Caso", de Aziz Basur, montado pelo diretor Tom Santos. A peça trataria "do relacionamento homossexual entre mulheres" 133 .

A atenção ao teatro não se restringia ao eixo Rio-São Paulo, estendendo-se também a outras capitais. Por exemplo, em João Pessoa (PB), mereceu atenção “Os réus da sociedade”,

\footnotetext{
${ }^{130}$ BR_DFANBSB_TS_ASI_PJU_0018

${ }^{131}$ BR_DFANBSB_TS_ASI_PJU_0018

132063 ASI_TB

133063 ASI_TB
} 
de Antônio Martins, encenada pelo Grupo de Teatro dos Estudantes de Alagoa com apoio da Fundação Paraibana de Teatro. Segundo o relatório, a peça procurava "evidenciar os conflitos entre grupos sociais, que, tidos como marginais, [eram] excluídos do convívio da sociedade maior, como é o caso das prostitutas, dos homossexuais e de outros grupos" ${ }^{134}$. Em Salvador, era exibida nesta mesma época "Paradise", peça dirigida por Leonel Amorim que abordava "o homossexualismo visto pela sociedade brasileira" ${ }^{\text {135 }}$. Ainda no Nordeste, foi sublinhada a realização do II Festival de Artes das Mulheres Cearenses, em Fortaleza, com "vários debates sobre temas polêmicos como 'controle de natalidade', 'homossexualismo', 'bissexualismo' e outros" 136 .

Estes relatórios eram uma constante e, regularmente, apontavam os mesmos trabalhos que seguiam em cartaz durante um longo período de tempo para serem monitorados. Como eram difundidos e compartilhados por diversos órgãos de informação de distintas repartições, muitas vezes esses documentos circulavam com o mesmo conteúdo apesar de numerados de outra maneira de acordo com os parâmetros de cada remetente. Este mesmo relatório sobre o teatro, por exemplo, também compunha a Informação n. 22/0055/G-2/84, de 18 de janeiro de 1984, na DSI do Ministério do Interior, acrescentando uma outra peça relativa à sexualidade, “Amizade Colorida”, de Hilton Chave, em cartaz em São Paulo que "mostra[va] os problemas e dificuldades no dia-a-dia de um homossexual" ${ }^{, 137}$.

Entre todos estes casos, datados sobretudo do início dos anos 1980, sobressai nitidamente a preocupação da vigilância com destaque para o tema da homossexualidade, comunicando-se os organismos responsáveis pela censura para avaliação da pertinência de sua intervenção. Como regra, a comunidade de informações desempenhava justamente a função de alimentar a paranoia da polícia política e da censura para fechar cada vez mais o regime e aumentar o controle da sociedade.

Contudo, infelizmente, os processos geralmente não tinham continuidade - ao menos nos acervos consultados - para viabilizar análises do ciclo completo e acompanhar os encaminhamentos dados a cada uma dessas notificações regulares da comunidade de informações para o Poder Executivo orientar sua ação.

Pelos documentos consultados, algumas comunicações se convert[iam] em diligências e procedimentos determinados pelo Ministro da Justiça e por sua assessoria, especialmente no Departamento de Polícia Federal; outras, no entanto, acabavam sendo arquivadas após ciência

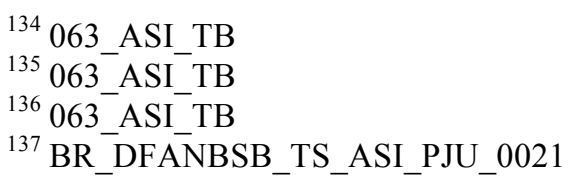


das autoridades competentes, que provavelmente se valiam dessas informações para traçar o plano de ação repressiva. Mas algumas peças específicas mereceram especial atenção da repressão, como se verá a seguir.

\section{“Toda censura é imoral”: Plínio Marcos na mira dos militares}

Considerado um dos maiores dramaturgos brasileiros, Plínio Marcos foi um alvo constante dos órgãos de controle moral durante a ditadura devido à sua postura combativa e refratária a fazer quaisquer concessões em seu trabalho, seja por pressão do mercado, seja por exigências do Estado.

Um relatório do Centro de Informações da Aeronáutica (CISA/RJ), de $1^{\circ}$ de setembro de $1975^{138}$, endereçado para dezenas de órgãos e repartições militares, apontava que um dos temas que vinha merecendo maior atenção na imprensa durante os últimos anos era o da censura sobre os órgãos de comunicação social, incluindo aquela imposta ao cinema, televisão e teatro. O documento anexava, ainda, uma matéria do Jornal de Brasília de 13 de junho de 1975, discutindo a proposta do então deputado Norton Macedo (Arena/PR) de criar um Conselho Federal de Análise e Classificação da Produção Cultural como um modo de abrandar a censura. Em relação à proposta, o jornal citava a opinião de Plínio Marcos, que afirmou que "toda censura é imoral". E, no debate, Paschoal Carlos Magno chegou a afirmar que "[era] uma perfídia, uma patifaria e uma safadeza o que est[avam] fazendo com este autor" $" 139$.

O escritor e embaixador Pascoal Carlos Magno, neste evento realizado na Comissão de Comunicação da Câmara dos Deputados, conforme registro da Folha de São Paulo, havia afirmado que "os homens, e principalmente os jovens, deveriam ter o direito de andar com suas pernas e pensar com as suas cabeças, e não serem perseguidos por uma censura subterrânea e tão violenta”. Ao lado dele, também na mesa de discussões, o teatrólogo Plínio Marcos, que vinha sendo vítima da censura, reclamava que "o homem que pensa nesse país, e diz o que pensa, é considerado por certas autoridades como comunista". Sobre a mudança do serviço de censura do Ministério da Justiça para o da Educação, ele afirmava que "não adiant[ava] mudar apenas o pouso do passarinho, pois o vôo é o mesmo, isto é, os dois

\footnotetext{
${ }^{138}$ BR_AN_BSB_VAZ_080_0077

${ }^{139}$ Jornal de Brasília de 13 de junho de 1975.
} 
ministérios fazem parte do mesmo sistema e seguem a mesma linha"140.

O documento mencionava, ainda, com certo tom de indignação, que manifestavam-se, sobre este assunto, "perseverança cotidiana", diversos profissionais, incluindo "pseudointelectuais" e "cripto-comunistas". Todos eles estariam "condenando a CENSURA, reverberando contra a CENSURA, acusando o Governo de querer amordaçar a cultura, taxando a CENSURA de instrumento coercitivo da DITADURA" ${ }^{141}$.

Ao referir-se a essas críticas, o documento registrava: "dir-se-ia, a julgar pelo que se lê nos jornais, que a extinção da CENSURA encontra respaldo popular". No entanto, o relatório anexava o texto de "Abajur Lilás", de autoria de Plínio Marcos. Na peça, que se passa em um “prostíbulo", a constante é a "desavença havida entre prostitutas e o pederasta dono da casa de tolerância" ${ }^{142}$. Para demonstrar a gravidade do tom deste texto, o relatório solicitava aos comandantes que reunissem seus oficiais, suboficiais e sargentos e determinassem "que [fosse] a 'peça' lida para os militares reunidos" ${ }^{143}$. A seguir, chegava-se a sugerir que, após a leitura, "[fossem] os ouvintes consultados se achariam razoável que suas famílias, ou a família de quem quer que [fosse], assistisse a esta peça, que a julgar pelo título "O ABAJOUR LILÁS”, nada teria de inconveniente". Sugeria-se, outrossim, que se recomendasse aos mesmos ouvintes que comentassem em casa e com seus amigos civis que esta peça é sumamente pornográfica, mas que mesmo assim seu autor não admite ser censurado, "porque toda a censura é imoral"144.

As palavras riscadas no texto da peça, tais como merda, puta, porra, michê, viado, desvelavam-se sintomáticas da visão moral restritiva da censura contra um diretor que produzia espetáculos reconhecidos por escancarar aspectos da dimensão humana, de modo que o público não era geralmente surpreendido com o que via ao escolher assistir a uma de suas peças.

A tentativa de recorrer ao Judiciário para barrar a censura, contudo, foi em vão. Conforme votação realizada pelo plenário do Tribunal Federal de Recursos em 30 de outubro de 1975, foi denegada a segurança pleiteada sob argumento de que "apenas nos casos extremos de evidente erro da censura poder[ia] ser feita a sua revisão pelo Judiciário", nos termos do voto do ministro relator Márcio Ribeiro. Acrescentou-se, ainda, a ampla margem de interpretação das autoridades censórias que, "na falta de conceito legal ou doutrinário preciso

\footnotetext{
${ }^{140}$ Folha de São Paulo, 13 de junho de 1975, p. 33.

${ }^{141}$ BR AN BSB VAZ 0800077

${ }^{142} \mathrm{BR}^{-} \mathrm{AN}{ }^{-} \mathrm{BSB}{ }^{-} \mathrm{VAZ}-080-0077$

${ }^{143}$ BR_AN_BSB_VAZ_080_0077

${ }^{144}$ BR_AN_BSB_VAZ_080_0077
} 
do que [era] pornográfico, obsceno ou contrário à moral e aos bons costumes, decorr[ia] ampla margem de discricionariedade às autoridades administrativas". Não considerou o ministro, assim, que o caso de Abajur Lilás fosse um "caso extremo" que justificasse a intervenção judicial no mérito da decisão atacada ${ }^{145}$.

Mas não foi só apenas no teatro que essa peça foi vigiada e perseguida. O livro publicado com este texto escrito sofreu ação da censura e não foi só proibido de circular, mas dezenas de exemplares encontrados à venda foram apreendidos e queimados, como comprova o auto de incineração do Serviço de Censura de Diversões Públicas, datado de 3 de janeiro de 1979, alguns anos mais tarde da censura teatral. Neste documento, revela-se que a peça já constava na lista de livros, filmes e materiais censurados. Naquela data, foram incinerados “42 (quarenta e dois) exemplares do livro "O Abajur Lilás", além de dezenas de outros livros considerados eróticos ou pornográficos" $" 146$.

Assim, não bastava impedir a apresentação de montagens baseadas no texto, era necessário mesmo retirar de circulação e incinerar os livro por serem considerados pornográficos e, portanto, atentatório à moral e aos bons costumes, ainda que não contivesse conteúdo subversivo em termos estritamente "políticos".

\section{"A androgenia não quer dizer 'homossexualidade"”: The Rocky Horror Show}

Um caso curioso em que se nota um grande esforço de erudição pode ser lido no parecer n. 146/75, assinado pela técnica de censura Marina de A. Brum Duarte, em 13 de fevereiro de 1975, analisando o texto e o ensaio do famoso espetáculo "The Rocky Horror Show", que estreou em Londres no ano de 1973, com composições e enredo de Richard O’Brien.

Por meio de uma mistura entre ficção científica e terror, o eixo da história se desenrola a partir de um casal recém-noivado que, diante de uma forte tempestade, busca refúgio na casa de um cientista apresentado como travesti. Ali, os noivos são recebidos por um mordomo corcunda e por duas servas andróginas. Ocorre que, justamente naquele momento, o cientista está dando vida à sua mais nova criação: um homem forte, musculoso, fisicamente perfeito, com cabelos loiros e pele bronzeada, chamado Rocky Horror. O espetáculo já havia feito sucesso na Inglaterra e nos EUA, tendo sido adaptado ao cinema, inclusive, neste mesmo ano

145 SILVA, Deonísio da. Nos bastidores da censura: sexualidade, literatura e repressão pós-64. São Paulo: Estação Liberdade, 1989, p. 136

${ }^{146}$ BR_AN_BSB_NS_AGR_CDO_006 
de 1975.

Segundo a censora, em parecer longo e minucioso, a inspiração do musical na clássica história "Frankenstein", de Mary Shelley, estava ligada à “onda Pop aderindo ou renovando o processo nostálgico procura[va] agredir, aliando o grotesco ao horror utilizando participação de personagens andróginos extra terrestres [...] O erotismo que entra[va] em sua composição, nada mais [era] do que uma mensagem de descompressão ao comportamento tradicional que inibe o homem a agir conforme sua natureza, natureza própria e intrínseca de sua constituição".

No entanto, em seu relatório censório, ela opina pela liberação dos cortes efetuados por considerar que "a peça não é pornográfica, nem usa pornografia" e "alguns personagens são andróginos e do outro planeta". A justificativa utilizada para sustentar uma distância entre androgenia e comportamentos ou identidades sexuais inaceitáveis é curiosa. Ainda que a técnica da censura ressalte "não nos cabe aqui, uma análise antropológica das razões que motivaram o autor a escrever a peça", ela discorre longamente sobre a androgenia como "a bissexualidade no mundo mítico (mitológico, como fórmula mítica da totalidade psíquica dos poderes feminino e masculino".

Assim, afirma ela que "a androgenia (da peça) não quer dizer 'homossexualidade"”, agregando a informação de que "FRANK FURST o vampiro bissexual não é um terráqueo travesti e sim um símbolo de uma entidade mítica (cosmogênica) que fugindo ao ritual do simbolismo usou fisicamente seus poderes (proibidos) e por isto foi condenado à morte, como as crianças gregas da antiguidade que possuíam tal sinal físico (hermafroditismo) próprio e inerente aos deuses".

A censora chega, inclusive, a justificar as cenas de carícia, alegando que o fato de o "senhor Frank haver submetido ou submeter a carícias sexuais tanto a jovem quanto o jovem Brad é uma prova (na peça) necessária à sua qualidade de andrógino hermafrodita (físico) sem o que perderia sentido sua morte e a volta ao planeta de origem". Aqui, revela-se uma confusão entre a bissexualidade, que não poderia ser aceita, com androgenia e hermafrodistismo, misturando-se questões de orientação sexual com identidade de gênero, sem falar na intersexualidade.

Assim, suas recomendações se restringem, enfim, à "abstenção de carícias corporais prolongadas, principalmente na projeção das silhuetas (sombras) do contato andrógino. Uso imoderado, apresentado, da destra nas partes sexuais, e carícias outras do mesmo gênero". Como androgenia de extraterrestres não se confunde com o comportamento homossexual, este sim repulsivo, opina a censora pela liberação da peça sem cortes para a faixa etária de 18 
anos, bem como o uso de slides de filmes de horror e máscaras de monstros.

\section{"Vetando esse tipo de peça, estaria o DPF fazendo sua promoção": "Engrenagem do Meio", de Darcy Penteado}

Outra situação foi a de "Engrenagem do Meio", salva da censura por um interessante raciocínio dos censores responsáveis. Segunda peça do então já consagrado artista plástico e homossexual assumido Darcy Penteado, que foi um dos membros de primeira hora e dos mais ativos colaboradores do jornal Lampião da Esquina, “Engrenagem' discute direta e objetivamente a homossexualidade", conforme anunciava o autor em artigo escrito para divulgar seu trabalho ${ }^{147}$.

Segundo ele, a proposta era romper com as formas tradicionais de representação dos homossexuais ou como o "clown" risonho e divertido ou como o enrustido que disfarça sua sexualidade em troca da aceitação. $O$ autor esclarecia que sua peça não mostrava a homossexualidade como "uma caricatura ou aberração", mesmo que isso signifique uma afronta à "mentalidade vigente" 148 .

Sem dúvida, Darcy conseguiu desafiar o conservadorismo dos órgãos de repressão. Ao escolher a travesti Tânia como personagem central, interpretada pela atriz e travesti Vera Abelha, além do fato de ser fruto da produção de um homossexual, "Engrenagem" gerou preocupação no serviço de vigilância e censura conforme registrado nos documentos oficiais. Afinal, tratava-se de texto de um homossexual sobre um casal homossexual e uma travesti representada, cenicamente, por uma travesti da vida real.

Conforme a Informação n. 463/78/DSI/MJ, da AC/SNI para o Ministro da Justiça, de 31 de maio de 1978, a peça que havia estreado semanas antes, em 9 de maio, era resumida como a "história de um triângulo amoroso, diferente do estilo clássico, pois envolv[ia] dois homens e um travesti na vida real" ${ }^{149}$. Neste sentido, destaca o informe, que "VERA ABELHA, por não precisar se travestir, preenche exatamente as exigências do autor para o papel que vem desempenhando na peça por se constituir o tipo de ator mais difícil de ser encontrado" 150 , evidenciando a dificuldade de pessoas trans se ocuparem de outras profissões que não o trabalho sexual. O fato de ela ser atriz é motivo de nota por ser inusitada tal

\footnotetext{
${ }^{147}$ PENTEADO, Darcy. "Nas rodas da engrenagem". Lampião da Esquina, n. 1, p. 11.

${ }^{148}$ PENTEADO, Darcy. "Nas rodas da engrenagem". Lampião da Esquina, n. 1, p. 11.

${ }^{149}$ BR AN RIO TT 0 MCP PRO 1334

${ }^{150}$ BR_AN_RIO_TT_0_MCP_PRO_1334
} 
ocupação.

Sobre o diretor, o relatório da vigilância afirma que Darcy “é tido como respeitado artista plástico, que já fez jus a vários prêmios. Em sua peça, procura dar aos homossexuais um tratamento normal, por considerá-los seres humanos saudáveis e não doentes mentais ou caricatura de gente como se tem feito até agora". E complementa: "o nominado faz parte do Conselho Editorial do jornal 'LAMPIÃO', que se propõe a ser o porta-voz do 'Movimento Gay". Além disso, o documento menciona outras obras feitas pela mesma companhia em outros teatros e que também "explora[vam] o homossexualismo: "BOY MEETS BOY" e "ZOO HISTORY"151.

José Carlos Silva de Meira Matos, assessor direto do Ministro Armando Falcão, assim resume o assunto ao chefe de gabinete: "trata essa informação das realizações da companhia teatral paulista - PROARTE. Segundo a informação, a nominada companhia vem montando diversos espetáculos focalizando o homossexualismo", dando ampla divulgação ao informe neste despacho de 20 de junho de 1978. Nota-se, assim, que a preocupação não era apenas com "Engrenagem", mas com uma série de peças teatrais que vinham representando a questão das homossexualidades de modo a não reproduzir as estigmatizações tão recorrentes.

Segundo Informação complementar n. 630/78/DSI/MJ, do CI/DPF, diretamente encaminhadas ao Ministro da Justiça, datada de 2 de agosto de 1978 e compartilhada com os órgãos AC/SNI, CIE, CISA e CENIMAR, a peça teatral em questão foi liberada pelo SCDP sem cortes e com impropriedade para menores de 18 anos.

Entretanto, considerando o fato de a peça ter gerado críticas e ressalvas tão contundentes, qual a explicação para que a mesma fosse liberada, ainda que com a classificação etária? A resposta é curiosa e consta expressamente na própria documentação. Conforme registrado no ofício,

o tema, em si, desperta muita preocupação, tendo em vista a mensagem preconizada pelo autor, que procura conscientizar a sociedade do problema dos homossexuais, que são seres humanos e precisam ser respeitados em sua integridade, apesar de suas preferências sexuais recaírem em pessoas do mesmo sexo ${ }^{152}$.

Nota-se, assim, certo incômodo com o fato de a peça tratar da homossexualidade de forma não patologizante. No item seguinte, o documento registrava a linha oficial do órgão que visava evitar a exposição do homossexualismo:

\footnotetext{
${ }^{151} \mathrm{BR}$ AN RIO TT 0 MCP PRO 1334

${ }^{152}$ BR_AN_RIO_TT_0_MCP_PRO_1334
} 
O Departamento de Polícia Federal (DPF) tem procurado coibir a 'apologia ao homossexualismo' feita através da imprensa alternativa, das revistas, livros, etc., inclusive determinando a seus órgãos Regionais que forneçam elementos ao Ministério Público, visando a aplicação da legislação vigente contra os responsáveis pelas divulgações caracterizadas como ofensivas à moral e aos bons costumes ${ }^{153}$.

Outro dado curioso é que a tentativa de aplicar certa racionalidade com uma ponderação entre o objetivo da censura e o ônus público decorrente de sua imposição em um contexto de abertura do regime, o ofício argumentava que o teatro normalmente teria, em comparação com os meios de "maior penetração ao público", audiência "reduzida e mais esclarecida". Por esta razão, concluía o relatório que "vetando esse tipo de peça, estaria o DPF fazendo sua promoção, ensejando portanto, sucesso de bilheteria e propagando aquilo que ele próprio coíbe" ${ }^{154}$. Isto porque a censura de determinados espetáculos ou músicas se convertia em verdadeira propaganda, despertando curiosidade do público, projetando o nome do artista e construindo uma aura de mistério quanto ao conteúdo subversivo, o que atraía mais do que afastava as pessoas interessadas.

O próprio assessor direto do Ministro da Justiça despachou, em 9 de agosto de 1978, considerando esta posição como uma linha oficial que "parece ser um esclarecimento da Divisão de Censura sobre as suas normas de liberação de peças de teatro que tenham como tema o homossexualismo. Após o conhecimento do Sr. Ministro, julgamos que pode ser arquivado" 155 .

Tal postura demonstra que a censura, ao menos em alguns momentos, negociava os limites de sua tolerância, conjugando-os com critérios como o alcance do meio de expressão ou comunicação utilizado, do tipo de público que consumiria o entretenimento, da gravidade do conteúdo sexual explícito e a maneira de retratar as perversões e anormalidades. Em outras palavras, esta postura poderia ser lida como um atestado, ao mesmo tempo, da fragilidade da censura e de sua astúcia para adaptar-se a outras realidades, reunindo um juízo de princípios com um de conveniência.

Ainda que não se possa afirmar que houvesse um conjunto claro, objetivo e previamente definido de critérios a orientar a ação dos censores, a estratégia de minimizar os impactos de publicidade da censura em alguns casos era algo explícito na atividade censória, conforme demonstra a situação concreta ora examinada. Isto não significa que todos agissem

\footnotetext{
${ }^{153}$ BR_AN_RIO_TT_0_MCP_PRO_1334

${ }^{154}$ BR_AN_RIO_TT_0_MCP_PRO_1334

${ }^{155}$ BR_AN_RIO_TT_0_MCP_PRO_1334
} 
do mesmo modo. Alguns censores não tinham esta visão mais astuta e sofisticada dos efeitos colaterais da censura, proibindo tudo de plano, apenas pelo conteúdo, e deixando prevalecer suas impressões pessoais sobre qualquer racionalidade mais estratégica.

De qualquer modo, o aperfeiçoamento desta "inteligência” parece ser algo que só emergiu com mais clareza já nos anos de abertura, quando o relaxamento da censura foi um imperativo por pressão da sociedade civil e da opinião pública, sendo insustentável manter um controle excessivamente restritivo sobre a produção cultural em um contexto de ampliação das liberdades públicas e dos direitos individuais no processo de transição.

\section{“Figueiredo e o Homossexualismo": "Leite Integral", de Carlos Leite}

Não apenas os textos dramáticos provocaram a ação censória. A peça humorística "Leite Integral" ou "Humor de Carlos Leite", do diretor Carlos Leite, também foi alvo do controle moral e, por dispor de amplo acervo de documentos contendo as sucessivas apreciações dos técnicos de censura, este caso permite uma análise privilegiada para compreender os mecanismos repressivos operando em suas diferentes fases no campo teatral.

O primeiro parecer censório do SCDP, n. 1723/83, datado de 21 de outubro de 1983, registrava que o show tinha "linguajar chulo, abusando de palavreado grosseiro", além de pontuar que "prevalec[ia] uma comicidade apelativa, grosseira e maliciosa". Como o espetáculo tinha como alvo o público adulto, apesar das referidas "impropriedades", o censor “opin[ou] pela liberação, com impropriedade para menores de 18 anos, em razão de abordagem negativa de temas como homossexualismo e sexo" ${ }^{156}$. O termo "negativa" aqui, parece-nos, referia-se muito mais à mera presença de temas "negativos", como homossexualidade e sexo, do que ao modo como eles eram retratados.

Já o parecer n. 313/84, datado de 24 de outubro de 1983, destacava a presença de "piadas picantes, versando sobre homossexualismo, crise social e econômica, crítica ao teatro, etc". Novamente, por conta do linguajar chulo e pornográfico, a censora opinou "pela liberação com impropriedade para menores de 18 anos" ${ }^{157}$.

O terceiro parecer, n. 312/84, foi lavrado quando da fiscalização da montagem no ensaio geral da peça, datado de $1^{\circ}$ de março de 1984. Registrou-se, no documento, que a peça seguia "fielmente o texto já liberado por este SCDP/RJ". Após pontuar as características de

\footnotetext{
${ }^{156}$ BR AN RIO TT 0 MCP PRO 1869

${ }^{157}$ BR_AN_RIO_TT_0_MCP_PRO_1869
} 
cenário, vestuário, marcação, linguagem, o censor opinou também "pela liberação, com impropriedade para menores de 18 anos, em razão de certas piadas e trejeitos obscenos" ${ }^{158}$.

Faz-se importante notar que a liberação para maiores de 18 anos, referido a todo momento como "público adulto", demonstra que a preocupação central era com a "degeneração" da juventude e a má influência que poderia ser exercida nas crianças. Além disso, a relativa tolerância a peças de teatro pelo alcance mais limitado mostra uma gradação algo estratégica do controle censório em relação aos diferentes meios e seus respectivos alcances de público.

No entanto, mudanças foram feitas no roteiro original da peça. Depois de ter sido aprovada com determinado texto, a peça foi alterada com a inclusão de algumas piadas, uma delas envolvendo o então presidente João Figueiredo, supostamente praticando um ato homossexual com alguns militares subordinados a ele.

Em ofício de Moacyr Coelho, diretor-geral do DOPS, endereçado ao Ministro de Justiça Ibrahim Abi-Ackel, datado de 14 de junho de 1984, noticiou-se a ocorrência, na peça, de "graves ofensas à honra do Excelentíssimo Sr. Presidente da República e sua esposa".

Com efeito, uma piada que insinuava uma cena de homoerotismo entre o presidente Figueiredo e três oficiais "puxa-sacos" em um banheiro foi acrescentada e gerou a indignação dos órgãos de segurança. Outra piada que despertou a ira da censura foi contra a esposa do presidente Figueiredo, razões pelas quais a peça foi imediatamente suspensa por 20 dias pela direção do DCDP devido à alteração do programa previamente aprovado, com pagamento de multa e instauração de procedimento para apuração de crime com o indiciamento de Carlos Leite. E ela só poderia voltar a cartaz depois deste prazo se as ofensas à honra do Presidente Figueiredo fossem suprimidas.

\section{O cinema}

O cinema também foi uma linguagem artística que apresentou vertiginoso crescimento durante o período da ditadura, inclusive com incentivos governamentais para a indústria cinematográfica, então compreendida como um projeto capaz de conferir um caráter de modernização que contribuiria para a construção da imagem de um Brasil grandioso - algo realmente caro para a ditadura.

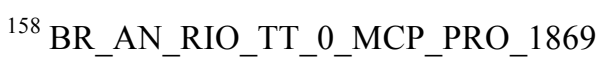


Neste particular, torna-se clara a distinção entre a seletividade da censura às artes, por um lado, e o estímulo a determinados ramos da indústria cultural, por outro. Não foi, assim, o cinema que fora censurado, mas determinados produtos fílmicos que desafiavam a política conservadora dos costumes implementada pelo regime. Era preciso incentivar e criar mercado de consumo de determinados produtos culturais, ao mesmo tempo em que se fazia necessário controlar firmemente o conteúdo dos discursos veiculados pela produção nacional ou estrangeira trazida ao país.

Sobre o mencionado crescimento do cinema, conforme levantamento de Ortiz,

na década de 1950, a média anual de filmes produzidos no Brasil girava em torno de 32 películas. Com a criação do Instituto Nacional do Cinema e, posteriormente, da Embrafilme, a produção cinematográfica toma outro fôlego. Em 1975 são produzidos 89 filmes, número que sobe para $103 \mathrm{em}$ $1980 .^{159}$

Assim, cresceram a produção nacional e a importação de filmes neste período. Ampliou-se o número de salas por todo o país e o cinema tornou-se uma forma de expressão artística cada vez mais relevante no cenário cultural, com a afirmação de grandes nomes de diretores e atores logo reconhecidos internacionalmente por seus trabalhos. Por outro lado, aumentou, também, a censura, com vetos à exibição ou mesmo cortes em diversos filmes, como demonstram os casos abordados a seguir.

\section{"Stanley Kubrick manda-lhe recomendações"}

A tesoura da censura aparecia com naturalidade na imprensa da época. Por exemplo, o jornal Folha de São Paulo, em 21 de março de 1972, noticiava a censura, por parte do DPF, do filme norte-americano "Sob o teto do diabo", de Metro Goldwin Meyer, por "ser contrário à moral e aos bons costumes", pois o filme apresentava cenas de homossexualismo e consumo de tóxicos ${ }^{160}$.

Pouco mais tarde, em 2 de janeiro de 1973, o jornal "The Tulsa Tribune", em Tulsa/Oklahoma, publicou a matéria intitulada "Brazil's Film Censorship Strictly Enforced: For Morality, National Security” (“Censura brasileira de filmes estritamente reforçada: pela

\footnotetext{
${ }^{159}$ ORTIZ, Renato. Revisitando o tempo dos militares. In: REIS, Daniel Aarão; RIDENTI, Marcelo \& MOTTA, Rodrigo P. Sá (orgs.). A ditadura que mudou o Brasil: 50 anos do golpe de 1964.1ed. Rio de Janeiro: Zahar, 2014, p. 119.

${ }^{160}$ Folha de São Paulo, 21 de março de 1972, p. 37.
} 
moralidade, segurança nacional"). O texto aborda a proibição, pela censura, do filme "Laranja Mecânica", a partir de uma anedota: um representante de diversos filmes no Brasil teria dito ao "principal censor do Brasil", General Nilo Canepa ${ }^{161}$, que "Stanley Kubrick [o diretor] manda[va]-lhe recomendações", ao que este teria respondido, ironicamente, "remeta-lhe meu abraço mecânico" $" 162$.

Segundo o texto, "a censura de filmes é uma das áreas mais rigorosamente policiadas do regime militar". Junto com "Laranja Mecânica", mais de uma dúzia de outros filmes acabaram parando na sala de cortes do maior mercado de cinema da América Latina, depois de serem "vistos por vários gabinetes de ministros, generais importantes e até por filhos do Presidente Emílio G. Médici, antes de serem rejeitados ou 'aprovados com cortes', por censores federais" que encontravam "duas razões para proibir filmes - 'atentados contra a moral e bons costumes', ou 'ofensa à segurança nacional", 163.

Não se sabe se a história do envolvimento pessoal de ministros, generais e até familiares de Médici apreciando os filmes antes da liberação é verdadeira. Contudo, por conta da publicação deste artigo, um leitor estadunidense chamado Bernis Duke, instrutor de tênis da Oral Roberts University escreveu, à mão, no próprio dia 3 de janeiro de 1973, uma carta ao General Canepa elogiando-lhe a atuação e remetendo-lhe um texto de Geraldo S. Pope publicado no Jornal Conservador Cristão cujo primeiro parágrafo inicia pela seguinte consideração: “[...] os temas enganosos que dominam as artes de hoje - sadismo, sodomismo, cultura da droga, sexo de paiol - e a apresentação crua dos mesmos, destilam veneno no organismo social". Logo em seguida, criticando as transformações por que passavam a indústria cinematográfica, o texto pontuava que "os temas sexuais no cinema não mais retrata[vam] a velha fórmula 'rapaz-com-moça', mas o que eventualmente, na realidade, tem sido 'moça-com-moça', como em 'The Fox', ou 'rapaz-com-rapaz', como em 'Os Rapazes da Banda" $" 164$.

$\mathrm{Na}$ carta manuscrita, Bernis declara sua admiração pelo General Canepa: "Desejo dizer que estou orgulhoso de sua coragem como censor! Deveríamos usar um pouco mais dela aqui”. Além disso, como expressão de sua gratidão, Bernis chega a oferecer ao General Canepa até mesmo uma bolsa de treinamento de tênis em sua escola: "se o Sr. conhecer um bom jogador de tênis que queira frequentar esta escola, poderei conseguir uma bolsa de

\footnotetext{
${ }^{161}$ Segundo Kushnir, Canepa, que dirigiu o DPF no final do governo Médici enquanto Buzaid era Ministra da Justiça, demonstrou-se um "general truculento" no comando das questões censórias. KUSHNIR, p. 125.

${ }^{162}$ BR AN BSB NS AGR COF MSC 035

${ }^{163} \mathrm{BR}^{-} \mathrm{AN}^{-} \mathrm{BSB}^{-} \mathrm{NS}^{-} \mathrm{AGR}{ }^{-} \mathrm{COF}^{-} \mathrm{MSC}^{-} 035$

${ }^{164}$ Christian Crusade Weekly, 31 de dezembro de 1972 , pp. 3 e 4.
} 
estudos".

A tradução de todos os textos do inglês para o português foi feita por Coriolano de L. C. Fagundes, técnico de censura dos mais atuantes e preparados no período, tendo sido o autor, inclusive, de uma proposta de alteração na legislação censória, que será apresentada mais adiante.

\section{"O erotismo é ultrapassado em direção à pornografia": "Garganta Profunda"}

Pedido de D. Burlamaqui à Divisão Pública de Diversões Públicas, feito em 6 de abril de 1981, argumenta pela liberação do filme "Garganta Profunda" (original "Deep Throat"), dirigido por Jerry Gerard. Segundo o requerente, o gênero pornográfico deveria ser liberado porque consistia em uma "compensação para o dia-a-dia" para uma parcela da população menos favorecida, que encontrava aí um "equilíbrio e evita[va] descarga de energia que, de outra forma, toma[va] corpo como ato de violência e de libidinagem, esses sim, prejudiciais à família, à sociedade" 165 .

Assim, o peticionário insistia no requerimento de popularização deste gênero, tão polêmico aos olhos dos espectadores mais conservadores:

\footnotetext{
esses filmes são assistidos por parte da população mais carente de divertimento, aquela de poder aquisitivo mais limitado e que não dá vazão às suas fantasias eróticas mais elementares, excluídos que são, por causa do baixo poder aquisitivo, das casas de massagens, dos motéis e lugares mais luxuosos ou ainda dos clubes 'privées' nos quais é comum a exibição do espetáculo erótico. ${ }^{166}$
}

Deste modo, fica evidente que o pedido se baseava em um argumento essencialmente de classe ao associar os grupos de "baixo poder aquisitivo" à necessidade de uma "descarga psíquica" que não poderiam realizar sem um "submundo" que fosse dedicado para tais atividades.

O início dos anos 1980 é marcado, no Brasil, pelo "ciclo da pornochanchada". Com a diluição progressiva da censura, passou-se a permitir, cada vez mais, a entrada de filmes pornográficos hard-core, que se expandiam em cinemas de rua. Com o esvaziamento do "cinema marginal", vários diretores incorporaram este modelo estrangeiro e fizeram produções de sexo explícito em melodramas pornográficos, que faziam mesmo grande

\footnotetext{
${ }^{165}$ BR_DFANBSB_ZD_0_0_0029B_0096_d0005
}

${ }^{166}$ BR_DFANBSB_ZD_0_0_0029B_0096_d0005 
sucesso de público ${ }^{167}$.

Nesta linha, o filme em questão foi um dos mais conhecidos exemplares dessa onda de pornografia cinematográfica. $\mathrm{O}$ enredo se baseia na história da personagem principal que, frustrada porque não consegue atingir o orgasmo em suas relações sexuais, é aconselhada por uma amiga a procurar auxílio de um psiquiatra especialista em transtornos dos comportamentos sexuais. O médico logo revela à moça a causa principal de sua insatisfação: seu clitóris estava localizado, estranhamente, no fundo da garganta.

Diante deste pedido, o serviço de censura exarou 4 pareceres elaborados entre 10 e 13 de abril de 1981 e assinados por diferentes técnicos sobre o filme, todos unânimes ao opinar pela interdição total da obra.

O primeiro deles, n. 1.195, foi assinado pela técnica da censura Jeanete de Oliveira Farias, segundo a qual o filme

serv[ia] apenas para exibir, em toda sua extensão, de modo apelativo e gratuito, comportamentos permissivos, configurados em longas sequências de relações sexuais, que incluem felação, cunilíngua, coito anal, triolismo e masturbação, mostradas através de cenas simultâneas e/ou alternadas, explícita e detalhadamente reforçadas por angulações que lhe confer[iam] um teor eminentemente pornográfico ${ }^{168}$.

Além disso, relatava a censora o excesso de "realismo" marcado pelos "closes" e "primeiros planos", que acentuam o exibicionismo de cenas pornográficas e impossibilitavam quaisquer cortes a solucionar este problema.

Por sua vez, o segundo parecer, n. 1.196, assinado por Maria Angélica R. de Resende, sustentava que, na obra, "o erotismo [era] ultrapassado em direção a pornografia, uma vez que as cenas de sexo [eram] tratadas de maneira vulgar, numa exploração rasteira de aberrações sexuais". Seu parecer ressaltava que "as cenas de sexo referidas não [eram] simuladas, mas próprias de um filme essencialmente pornográfico e levadas de forma a transpor, por completo, os limites permitidos pela legislação censória" ${ }^{169}$. O recurso à diferença entre erotismo e pornografia sempre aparecia como um elemento central na avaliação da censura, embora jamais apresentasse uma definição clara dos limites entre um e outro.

O terceiro parecer, n. 1.197, de autoria da técnica Maria das Graças S. Pinhati, seguia o mesmo raciocínio das demais colegas, destacando o caráter pornográfico e imoral do filme.

\footnotetext{
${ }^{167}$ GERACE, Rodrigo. Cinema Explícito: Representações cinematográficas do sexo. São Paulo: Edições Sesc e Perspectiva, 2015, p. 145.

${ }^{168}$ BR DFANBSB ZD $000029 B \quad 0096$ d0005

${ }^{169}$ BR_DFANBSB_ZD_0_0_0029B_0096_d0005
} 
Para ela,

trata[va]-se de uma produção de cunho pornográfico, que explicita[va] em 'close' o ato sexual e suas deformações, destacando, em angulação diversa, com enfoques simultâneos e repetitivos, cenas de sexo grupal, do ato de masturbação, felação, cunilíngua, sodomia, ejaculação, etc. ${ }^{170}$

Já o quarto parecer, n. 1.198, feito por Terezinha de Jesus Braga, denunciava também o elevado grau de exposição das práticas sexuais: "detalhadamente, são mostradas cenas de sodomia, cunilíngua, triolismo, masturbação, depilação de pelos pubianos com frequentes ‘closes' sobre a vulva, o pênis e o esperma ejaculado durante o ato". E concluía, então, que "o filme não fornec[ia] elementos que atenu[assem] o extremo realismo de seu conteúdo cênico e, também, não oferec[ia] condições para a utilização do recurso de cortes" ${ }^{171}$.

O último dos pareceres registrados, n. 1.199, assinado por Sergio Roldan de Oliveira, considerava que, "a princípio o enredo é até aceitável" por enquadrar o drama de uma mulher “com vida regrada" que não atingia um "orgasmo pleno". No entanto, o desenlace da história comprometia tal possibilidade, por levar a personagem a "praticar um comportamento sórdido, altamente contrário à preservação da moral e dos bons costumes, denigrindo por completo a obra". Destacava, ainda, o censor, que "a prática anormal e até animalesca torna[va] a película abusiva e obscena". E finalizava clamando pela total interdição e alegando ser impossível efetuar cortes de tantos trechos que mereceriam ser retirados, "haja vista, a grande quantidade de cenas atentatórias ao pudor e ao decoro públicos existentes, o que sem dúvidas, reduziria a película a poucos metros de fita" ${ }^{172}$.

É importante notar como, na censura moral, as apreciações subjetivas dos censores acabam transparecendo com naturalidade e até mesmo funcionando como fundamento para as opiniões supostamente técnicas, ainda mais considerando a precariedade legislativa de textos normativos muito vagos e genéricos que acabavam ampliando a margem de arbítrio dos intérpretes.

\section{"Cenas de sexo normal, anormal, homossexual, nus feminino e masculino"}

Outro filme, "Eva - o princípio do sexo", com direção de José Carlos Barbosa, causou

\footnotetext{
${ }^{170}$ BR_DFANBSB_ZD_0_0_0029B_0096_d0005

${ }^{171}$ BR DFANBSB ZD ${ }^{-} 0-00029 B^{-} 0096$ d0005

172 BR_DFANBSB_ZD_0_0_0029B_0096_d0005
} 
grande celeuma quando lançado ao público. O filme narra a história de Eva, uma professora de sexologia que trata da timidez sexual de Robertinho, mas acaba se envolvendo com ele e com sua irmã, Naná, chocando a tradicional família mineira dos dois irmãos.

O parecer da censura federal n. 2813/81 afirmava haver "cenas de sexo normal, anormal, homossexual, nus feminino e masculino, detalhes e sequências bastante demoradas". Já o parecer n. 2814/81 destacava a existência de "cenas longas detidas em closes de movimentos eróticos e gratuitos de nus" ${ }^{173}$. Por sua vez, o parecer n. 2815/81 indicava haver “[...] situações contínuas de relacionamentos sexuais, mostrando com detalhes, inclusive movimentos $[\ldots] "{ }^{174}$. Diante de tais apreciações restritivas, o filme foi vetado.

No entanto, em recurso para o Conselho Superior de Censura, o Conselheiro Roberto Pompeu de Souza Brasil registrou que se tratava de um "produto típico do chamando cinema da Boca do Lixo paulista", salientando, ainda, que o "filmezinho ordinário [era] um desserviço à cinematografia nacional. Mal-concebido, mal-dialogado, mal-dirigido, malinterpretado" e que "não [tinha] um só atributo positivo". Mas concluía que, "apenas por uma questão de princípio - de que não cabe ao Estado emitir juízo de valor nesse campo e de que ao espectador de cinema maior de 18 anos não cabe tutela do Poder Público nesse terreno”, ele era "pela sua liberação com impropriedade para maiores de 18 anos" 175 .

A decisão do relator foi acolhida pela maioria. O CSC era um órgão de recurso das decisões tomadas pelos órgãos administrativos da censura. Mas, por não ter se tratado de decisão unânime, o presidente do CSC, Euclides Pereira de Mendonça, em 18 de novembro de 1981, recorreu ao Ministro da Justiça pelo fato de a obra apresentar "movimentos eróticos e gratuitos de nus, relação sexual, sodomia, felação e lesbianismo, culminando com a insinuação do envolvimento de um sacerdote" ${ }^{176}$.

Este tipo de recurso não era comum e atestava a falta de autonomia e independência do CSC frente ao Ministério da Justiça. Isto ficou evidente quando o Ministro Abi-Ackel não só recebeu o recurso, com fundamento no art. 18 da Lei n. 5.536/68, como também o declarou procedente para “manter a interdição do filme”, em 25 de novembro de 1981.

No entanto, uma semana após a decisão, em 3 de dezembro de 1981, diante de um mandado de segurança que deixou claro não haver competência para reformar a decisão do conselho unilateralmente, o Ministro teve de recuar e reformar o despacho proferido, "para o fim de considerar liberado, sem cortes, o filme 'Eva, princípio do Sexo”, acolhendo a decisão

\footnotetext{
${ }^{173}$ BR DFANBSB ZD $0000029 B$ B 0096 d0011

${ }^{174}$ BR_DFANBSB_ZD_0_0_0029B_0096_d0011

${ }^{175} \mathrm{BR}$ DFANBSB ZD 0 0 0029B 0096 d0011

${ }^{176}$ BR_DFANBSB_ZD_0_0_0029B_0096_d0011
} 
anterior de n. 217/81, do Conselho Superior de Censura" ${ }^{\text {177 }}$. Este tipo de situação já indicava as dificuldades por que passava a censura em um momento de enfraquecimento do regime.

Já em 23 de maio de 1983, o mesmo relator Roberto Pompeu, a pedido do CSC, viajou ao Rio de Janeiro para apurar uma denúncia de que a versão mostrada nos cinemas não era a mesma submetida à apreciação da censura, fato recorrente na tentativa de burlar os controles morais da ditadura. No Cinema Rex, ele constata que houve

acréscimo de algumas tomadas de imagens que não constavam da montagem aprovada pelo CSC. Assim, várias das cenas de coito (tanto vaginal como anal), felação e lesbianismo - que, na versão apresentada ao CSC, eram apenas sugeridas ou mostradas em planos gerais não detalhados - são complementadas, na versão exibida comumente, com pormenorizados primeiros-planos, em que os órgãos sexuais assumem a condição de protagonistas principais das mencionadas cenas. ${ }^{178}$

Nota-se, assim, com clareza, que os produtores e diretores cinematográficos aproveitavam-se dos limites de estrutura e de formação dos censores para burlar as regras e tentar manter cenas de erotismo, pornografia e mesmo homossexualidade nos filmes que realizavam.

"Além de inconveniente, é altamente atentatório ao pudor e ao decoro público": "Viagem ao Céu da Boca"

O filme "Viagem ao Céu da Boca", com direção de Roberto Mauro e produção de Jecé Valadão, é um dos mais conhecidos representantes do gênero cinematográfico da pornochanchada nacional.

Seu protagonista, Nilo Barrão, é um perigoso bandido que, ao fingir ser funcionário da empresa de telefonia, entra na casa de uma família abastada. Ao buscar bens para roubar, encontra uma senhora envolta em uma toalha e aí começa uma série de atos sexuais praticados pelo bandido: primeiro contra a senhora, depois contra uma travesti que estava na casa e, por fim, contra a sobrinha da proprietária da casa, uma jovem ainda menor de idade. As cenas de sadismo, torturas e pedofilia são exibidas durante todo o tempo do filme. Até que, ao final, tudo se revela o sonho de um bandido que está na prisão sendo vítima de sessões de torturas perpetradas pelo Esquadrão da Morte.

\footnotetext{
${ }^{177}$ BR_DFANBSB_ZD_0_0_0029B_0096_d0011

${ }^{178}$ BR_DFANBSB_ZD_0_0_0029B_0096_d0011
} 
O parecer n. 1206/81 da DCDP, datado de 14 de abril de 1981, consignou que o filme estaria "baseado em um argumento sem expressão e enfocando, ligeiramente, o problema da delinquência juvenil”. No entanto, o foco da análise do conteúdo do filme recaía sobre a "exploração gratuita do sexo, de forma explícita, deprimente e repugnante" "179.

Um parágrafo específico é dedicado à travesti, assim retratada:

caracterizado no sexo feminino, um pederasta - objeto de ódio do assaltante - é submetido a toda sorte de sevícias: ridicularização de seu aparelho genital; introdução do cano de um revólver em seu orifício anal; alfinete enfiado em suas nádegas; relacionamento sexual em ato de felação e sodomia com uma mulher; mordidas em seu pênis até sangrar e finalmente, seu assassinato. ${ }^{180}$

A partir dessa breve análise do filme, a censora concluiu seu parecer sustentando a não liberação da película com fundamento no art. 3 da Lei n. 5536/68, que, como já citado anteriormente, no primeiro capítulo deste trabalho, prescrevia que

para efeito de censura classificatória de idade, ou de aprovação, total ou parcial, de obras cinematográficas de qualquer natureza levar-se-á em conta não serem elas contrárias à segurança nacional, e ao regime representativo e democrático, à ordem e ao decoro públicos, aos bons costumes, ou ofensivas às coletividades ou as religiões ou, ainda, capazes de incentivar preconceitos de raça ou de lutas de classes ${ }^{181}$.

Este dispositivo legal positiva, no ordenamento jurídico, mais uma vez o tipo abstrato e vago de "ordem e decoro públicos" e "bons costumes", abrindo uma margem enorme para a atuação arbitrária e para uma grande dose de subjetividade dos agentes públicos na atividade censória.

Por sua vez, o segundo parecer censório, n. 1211/81 e assinado pelo técnico Sergio Roldan de Oliveira, registra opinião semelhante. Atribui à obra "inexpressivo conteúdo", especialmente devido à “exploração do sexo de forma descabida, grosseira e imoral”. A partir desta constatação, o censor apontava que o filme

revela[va]-se como um verdadeiro afronto à preservação da moral e dos bons costumes, principalmente, levando-se em consideração que o seu objetivo [era] atingir a uma audiência, que embora [fosse] adulta, merec[ia] ser poupada das aberrações cênicas mostradas em todo o transcurso do filme. ${ }^{182}$

\footnotetext{
${ }^{179}$ BR DFANBSB ZD 0000037 A 0016 d0008

${ }^{180} \mathrm{BR}$ - DFANBSB ZD $0-0-0037 \mathrm{~A}-0016$ d0008

${ }^{181}$ BR_DFANBSB_ZD_0_0_0037A_0016_d0008

182 BR_DFANBSB_ZD_0_0_0037A_0016_d0008
} 
Indo além, o parecer indicava que a perversão sexual retratada tão obscenamente e em detalhes era tão marcante que se tratava de uma "inovação dentro da cinematografia nacional, o que, diga-se de passagem, além de inconveniente, [era] altamente atentatório ao pudor e ao decoro público" ${ }^{183}$.

Curiosamente, o censor aproveitava a oportunidade para advertir a seus superiores de que as mais recentes produções nacionais, tal qual a analisada, eram, "em termos comparativos, tanto ou mais grosseira[s] e imora[is] que as conhecidas revistas pornográficas e filmes em 'Super-G', vendidos clandestinamente em nosso mercado". Terminava seu parecer, ainda, afirmando que se faz impossível usar o expediente de alguns cortes para adequação, já que a "grande quantidade de cenas implicatórias que deveriam ser suprimidas" terminariam por reduzir "seu fraco conteúdo a poucos metros de fita". Assim, opinava pela não liberação sem declinar nenhum fundamento legal específico, mas apenas apontando o fato de a obra "contrariar os dispositivos legais contidos na legislação vigente"184.

Já o parecer n. 1248/81, assinado por Maria das Graças Pinhati, seguia o que já fora estabelecido por seus pares. Registrava que haver uma "série de desregramentos sexuais", tal como "sodomia". Após descrever alguns dos atos sexuais que [tinham] lugar no filme, ela encerrava concluindo que seria "desnecessário e deprimente [...] tentar descrever mais algumas cenas, tal a variedade das promiscuidades enfocadas" ${ }^{\text {"185 }}$, razão pela qual sugeriu a não liberação com fundamento no art. 3 da Lei n. 5536, de 1968.

Como se pode ver ao longo de tantos pareceres trazidos à baila no percurso de nossa análise, este tipo de decisão não fundamentada e repleta de opiniões pessoais era típica de órgãos administrativos que não estavam sujeitos a controle judicial em sua atuação, pois uma autoridade que não precisava motivar, na legalidade, seus atos, podia agir em total arbítrio.

É interessante observar este juízo de conveniência feito entre a viabilidade de liberar com alguns cortes e coibir a circulação deste material. Tal decisão, em última instância, era tomada pelos próprios agentes públicos que compunham o corpo técnico da censura e que determinavam se e quando uma determinada obra era possível de ser aproveitada.

Mas se os filmes eróticos e pornográficos já eram perseguidos pelo simples fato de exporem cenas de nus e de sexo de modo mais ou menos explícito, pior ainda era a situação de obras que conjugavam a "imoralidade" com a "subversão política". Exemplo disto, consta da Informação n. 22/1660/81, de 28 de dezembro de 1981, sobre "propaganda adversa nos

\footnotetext{
${ }^{183}$ BR DFANBSB ZD 0000037 A 0016 d0008

${ }^{184} \mathrm{BR}{ }^{-}$DFANBSB ZD ${ }^{-} 0-0-0037 \mathrm{~A}^{-} 0016$ - $\mathrm{d} 0008$

${ }^{185}$ BR_DFANBSB_ZD_0_0_0037A_0016_d0008
} 
meios de comunicação", que destacava, dentre as obras cinematográficas, "A NOITE DAS DEPRAVADAS". Tal filme era caracterizado como um misto de erotismo e desmoralização do regime: "embora rotulado como erótico, trata-se, na realidade, de um filme político". A estória se inicia quando o personagem "LUCAS": resolve trocar sua monótona cidade do interior por SÃO PAULO. Lá conhece um malandro chamado "CORUJA", que vive de pequenos golpes, da sedução profissional de viúvas, solteironas e travestis. A princípio, "LUCAS" obtém êxito, porém, mais tarde, se vê envolvido numa série de crimes pelos quais acaba sendo preso pela Polícia. A partir deste instante, detecta-se a preocupação do roteiro da película em desmoralizar o regime e as autoridades constituídas. Ao ser submetido a interrogatório, "LUCAS" manifesta-se contrário ao sistema e expõe sua revolta contra o comportamento da "classe dominante" 186.

Neste mesmo ano, a Informação n. 401/03/81/DSI/MJ mencionava filmes "atentatórios à moral e aos bons costumes", tais como "Esquadrão do sexo", "Delícias do sexo", "Orgia das libertinas", "As nazistas taradas", "Emanuelle Dois", "Confissões proibidas de uma freira adolescente", dentre outros. Segundo este relatório de monitoramento, "a grande quantidade de fitas dessa natureza vem ao encontro da estratégia comunista, de enfraquecimento das democracias ocidentais" ${ }^{\prime 187}$. Vê-se, com clareza, a associação da pornografia com a subversão comunista.

\section{"Nós não estamos passando no buraco da Abertura"}

O diretor de teatro José Celso Martinez Corrêa, que teve a adaptação para cinema de seu clássico "O Rei da Vela” pautado em sessão do CSC de 16 de setembro de 1982 junto com o "Ao Sul de Seu Corpo", filme erótico-político (e vice-versa conforme definido pelo diretor) de Paulo Cesar Saraceni, protestou de modo inusitado contra a censura. Seu filme, que havia sido alvo de cortes por "uso desrespeitoso de símbolos nacionais" e por "louvação das qualidades da maconha", teria seu recurso julgado naquela sessão.

Junto com o co-diretor Nilton Nunes, chegaram como cineastas, com câmera na mão, registrando a ação da censura na prática. $O$ filme foi a filmagem da montagem da peça de Oswald de Andrade que Zé Celso realizara em 1971, mas as filmagens se arrastaram por anos pela dificuldade de orçamento e, em 1974, o Teatro Oficina foi invadido e vários integrantes

\footnotetext{
${ }^{186}$ BR_DFANBSB_TS_ASI_PJU_0016

${ }^{187}$ BR_RJANRIO_TT_0_MCP_AVU_0311
} 
foram presos. O filme acompanhou o diretor para o exílio e foi guardado por pessoas em São Paulo, Lisboa, Londres e Maputo.

Após a leitura da defesa, Zé Celso questionou o presidente do CSC, Euclides Mendonça, no seguinte tom: “Agora existe um clima de opressão nesta sala. Esta atitude é incompatível com os rumos da Abertura. De repente, se alega que quem esperou 11 anos pode esperar mais um mês. Gostaria que o senhor tivesse ideia do que significa um só dia fazendo cinema aqui". E acrescentou: "Olha só a cara de cada um de vocês. O ar aqui está podre"188. Seraceni, por sua vez, acusou a diretora da censura, Solange Hernandez, de ser "pau mandado do SNI", pois dois dos cinco censores já haviam liberado o filme com elogios, mas os pareceres foram recolhidos quando a referida diretora voltou das férias por discordância desta em relação à posição de seus subordinados ${ }^{189}$.

Já o filme de Seraceni despertou grande atenção da censura. Documento de 12 de agosto de 1982, enviado diretamente do chefe do SNI para o Ministro da Justiça Abi-Ackel, com um bilhete manuscrito "não liberar", após descrever a história "subversiva" e as cenas incômodas de sexo e nudez, registrava que

este órgão é de parecer que o referido filme, de cunho político fortemente contestatório aos interesses do Governo, se liberado sem cortes profundos e cuidadosos, se constituirá em importante veículo de propaganda adversa sobre o público interno e, se exportado, em fator altamente negativo para a imagem do BRASIL no exterior ${ }^{190}$.

A análise dos filmes, contudo, ficou para outra sessão do colegiado, atrapalhando os planos de lançamento já previstos ${ }^{191}$.

A crítica à diretora da Censura Federal, Solange Hernandez, já estava frequentando a imprensa da época com certa constância. Na seção "Radar" da revista Veja de 22 de setembro de 1982, foi noticiado, em tom crítico, que a diretora "parec[ia] decidida a tratar seus subordinados com o mesmo rigor que orienta[va] sua cruzada em defesa da moral e dos bons costumes". Prosseguia, a nota, apontando que, na mais recente investida, a diretora cortou, por dois dias, o ponto do técnico Vicente de Paula Monteiro e o transferiu para a Academia de Polícia simplesmente porque ele "faltara ao trabalho no dia do velório de seu filho, ao qual a própria diretora da Censura esteve presente" ${ }^{\text {192 }}$.

\footnotetext{
${ }^{188}$ BR_RJANRIO_TT_0_MCP_AVU_0677

${ }^{189}$ BR_RJANRIO_TT_0_MCP_AVU_0677

${ }^{190}$ Revista IstoÉ, 29 de setembro de $19 \overline{9} 82$.

${ }^{191}$ Revista IstoÉ, 29 de setembro de 1982.

${ }^{192}$ Revista Veja, 22 de setembro de 1982.
} 
A prática de retaliação de funcionários do órgão por Solange Hernandez já era recorrente. O jornal Estado de São Paulo, em 28 de setembro de 1982, denunciou o desaparecimento dos pareceres da censura do processo de revisão no CSC referentes ao filme "Pra Frente Brasil”, de Roberto Farias. Segundo a diretora, “os pareceres não deveriam constar do processo, pois foram dados informalmente pelos técnicos de censura a pedido da própria diretora". A consequência foi que "pelo menos um dos técnicos de censura que opinaram favoravelmente à liberação de 'Pra Frente Brasil' foi 'punido' com a transferência para a Academia Nacional de Polícia: o professor Coriolano de Loyola Cabral Fagundes”193.

\section{"Basta punir um para exemplo de todos": cidadão clamando por mais censura}

A maior circulação de obras eróticas e pornográficas, que aumentou significativamente no final da década de 1970 e sobretudo nos anos 1980, provocou reações de diversos setores. Em alguns casos, a iniciativa de cobrar posturas mais rigorosas da censura diante de exibição de cenas eróticas ou pornográficas partia de cidadãos indignados. Exemplo disto é uma carta, assinada por Napoleão Bonaparte da Silva e datada de 17 de janeiro de 1984, enviada à Superintendência do Rio de Janeiro do SCDP.

Na missiva, o cidadão indignado levava ao conhecimento do Serviço de Censura o lançamento do filme "Sexo de Primeiro Grau (As Pipas)", de José Vedovato, no cinema Vitória, em 16 de janeiro de 1984. Relatava ele:

foram 'enxertadas' cenas de sexo explícito, cenas estas que destoam flagrantemente com as cenas de cores desbotadas e riscadas que sobraram do filme 'enxertado', com novas 'atrizes' entre aspas, para não dizer outra coisa, entre elas a 'manjadíssima' Jussara Calmon, sem que o nome dessas 'atrizes' constem dos créditos do filme trabalho de autêntica picaretagem cinematográfica, do atual dono desta nova 'versão', o Sr. Raffaelli Eossi, useiro e vezeiro na prática desse tipo de expediente ${ }^{194}$.

Em seguida, Napoleão ainda denunciava suposto expediente de fraude semelhante no trailer de outro filme, chamado "Carnaval das Taras", que apresentava no mesmo cinema Vitória “um 'festival' de cenas de sexo explícito jamais vistas em tão pouco espaço de tempo (3 minutos)" 195 .

\footnotetext{
${ }^{193}$ Jornal Estado de São Paulo, 28 de setembro de 1982.

${ }^{194}$ BR AN BSB NS AGR COF_MSC 238

${ }^{195}$ BR_AN_BSB_NS_AGR_COF_MSC_238
} 
Napoleão terminava sua carta cobrando uma punição dura e exemplar para os diretores dos filmes em questão, alegando que as "autênticas picaretagens cinematográficas que cada vez mais compromet[iam] o Cinema Brasileiro honesto, e a cada dia menos acreditado e cujos autores dessas patifarias deveriam ser punidos severamente. Basta[ria] punir um para exemplo a todos" 196 , resumia.

Assim como Napoleão, há diversos outros registros de cidadãos incomodados com a invasão do erotismo e da pornografia nas salas de cinema das grandes cidades, o que se deve, em certa medida, à educação moral que a própria ditadura impôs a uma sociedade, na época, pouco esclarecida, muito religiosa e com um pequeno grau de instrução formal.

\section{"Um tapume para o comércio de drogas e descaminho dos jovens"}

Outro exemplo ilustrativo dos incentivos e apoios com que contava o serviço de censura na sua cruzada moralizante, mas neste caso de uma autoridade eleita, foi a carta enviada pelo Vereador José Gorski, segundo secretário da Câmara Municipal de Curitiba, para Solange Hernandez, diretora do SCDP.

Na carta, em papel timbrado do Poder Legislativo municipal e datada de 18 de janeiro de 1985, o vereador registrava sua "preocupação ante os rumos da sociedade brasileira, indefesa praticamente em face do impiedoso ataque dos agentes da corrupção que, burlando a vigilância das autoridades, promov[iam] o confronto da nossa juventude e da família de um modo geral, com os espetáculos deprimentes, repletos de pornografia, destituídos dos mais comezinhos princípios da moral [...]"197.

A seguir, o Vereador mudava o alvo, pontuando sua indignação em relação às pornochanchadas. Afirmava ele que era preciso combater a

criminosa ação que visa[va] a insolvência da família [que] é a avalanche de filmes chamados 'pornochanchadas', que se exib[iam] também livremente em todos os cinemas brasileiros, além dos espetáculos teatrais que explora[vam] o erótico e os festivais de música, como o malfadado 'rock in Rio', que não são outra coisa senão um tapume para o comércio de drogas e descaminho dos jovens, tudo com o fito de desestabilizar a sociedade brasileira, corroendo-lhe o moral. ${ }^{198}$

\footnotetext{
${ }^{196}$ BR_AN_BSB_NS_AGR_COF_MSC_238

${ }^{197}$ BR_AN_BSB_NS_AGR_COF_MSC_253

${ }^{198}$ BR_AN_BSB_NS_AGR_COF_MSC_253
} 
Prosseguia, ainda, demonstrando consciência de seu papel público e afirmando que "como vereador e como chefe de Família, devo levantar a minha voz contra tais aberrações, que se pronunciam como verdadeiros caminhos abertos à corrupção dos costumes". 199

Programas televisivos, como os teleteatros seriados, também foram objeto da revolta do Vereador, ao escrever que tais programas eram “exemplos de má conduta em família e na sociedade, de prostituição, de libertinagem, induzindo ao desmantelamento da família, no que tem de mais sagrado: o respeito interpares". Como se nota, a maior preocupação exposta era precisamente com a integridade do núcleo familiar e da moralidade, sobretudo religiosa, associada ao arranjo conjugal em seu formato heterossexual e patriarcal tradicional.

Por fim, concluía, em um misto de elogio da ação da censura e uma exortação ao endurecimento do controle moral, com a seguinte afirmação:

Rogo-lhe continuar o seu trabalho, com destemor e em favor dos bons costumes, e em favor da cultura nacional. Tenha Vossa Senhoria a certeza de que, como eu, milhões de brasileiros bem formados, aplaudem a corajosa gestão de Vossa Senhoria na Censura federal, rogando-lhe, entretanto, ação ainda mais rigorosa contra os atentados que se perpetram em nome da liberdade de pensamento, de expressão e de autoria, mas desastradamente contra o Brasil. ${ }^{200}$

Em sua resposta ao Vereador, por meio do ofício n. 235/85-SO/DCDP, de 11 de fevereiro de 1985, a Diretora do SCDP demonstrou seu acordo com a manifestação do parlamentar, agradecendo o apoio e ressaltando a afinidade dos valores que orientam a ação censória:

é um estímulo ao nosso desempenho funcional, na árdua tarefa de extirpar das diversões públicas tudo o que possa redundar em prejuízo à boa formação da juventude brasileira ou vise deturpar valores aceitos e defendidos por uma sociedade sadia e responsável. ${ }^{201}$

Mesmo já no momento da abertura, com a progressiva perda de controle do autoritarismo político sobre os mecanismos repressivos e de propaganda que preservavam a hegemonia da moralidade conservadora de então, setores se mobilizavam para refrear a onda liberalizante que alcançava os costumes e a sexualidade.

\footnotetext{
${ }^{199}$ BR_AN_BSB_NS_AGR_COF_MSC 253

${ }^{200}$ BR_AN_BSB_NS_AGR_COF_MSC_253

${ }^{201}$ BR_AN_BSB_NS_AGR_COF_MSC_253
} 


\section{"Inocentes úteis dos vermelhos e dos imorais": a cruzada da extrema direita}

Mas não eram só cidadãos anônimos e mandatários legislativos que tomavam a liberdade de intervir e sugerir medidas ao serviço da censura. Em tom mais ríspido e até ameaçador, grupos organizados de extrema direita, que suportavam a ditadura e cobravam sempre ações mais duras de repressão, também marcavam presença nos debates sobre o alcance da censura.

Exemplo disto é uma carta do Comando de Caça aos Comunistas da cidade de Santos/SP que ameaçava livreiros e distribuidores por estarem circulando "propaganda comunista e literatura erótico-pornográfica". O intuito da mensagem era claramente no sentido de intimidar não somente as pessoas que produziam os conteúdos e publicações, que, já estavam sujeitas à censura e, muitas vezes, em regime de controle prévio, mas também as pessoas que comercializavam esses materiais. Tanto é assim que o texto era iniciado já advertindo que o CCC "identificou o senhor e a sua empresa em nosso Index como INOCENTES ÚTEIS dos vermelhos e dos imorais"202.

Em tom de alerta e de imposição, lê-se no documento que houve "o aumento da propaganda comunista e da literatura erótico-pornográfica em nosso país, distribuindo ou vendendo à população desta cidade (que um dia ensinou à Pátria a LIBERDADE e a CARIDADE), revistas obscenas e jornais marxistas-leninistas". Conforme consta da carta, outras entidades "patrióticas" também estariam enviando alertas semelhantes "advertindo as pessoas para o clima de subversão política, e de afronta à ordem moral da Família Brasileira" 203. O pedido é concluído com uma clara ordem: "para o bem da nossa cidade, do nosso querido Brasil e do seu próprio, EXIGIMOS que a sua empresa pare imediatamente de distribuir e/ou vender as seguintes publicações", passando a indicar uma lista de jornais e revistas, dentre os quais alguns direcionados ao público homossexual, como o Lampião da

Esquina e o Jornal do Gay, além de outras publicações eróticas e/ou pornográficas ${ }^{204}$. Mais do que uma exigência, havia uma ameaça explícita de possíveis "atitutes mais drásticas", com uma mensagem final destacada em letras maiúsculas com o seguinte teor: "ESPERAMOS CONTAR COM A SUA PATRIÓTICA COLABORAÇÃO. NÃO ADVERTIREMOS MAIS! CASO CONTRÁRIO TOMAREMOS ATITUDES DRÁSTICAS" ${ }^{205}$.

\footnotetext{
${ }^{202}$ BR_AN_BSB_PA_001_010

${ }^{203} \mathrm{BR}^{-}$AN BSB PA 001010

${ }^{204}$ BR_AN_BSB_PA_001 010

${ }^{205}$ BR_AN_BSB_PA_001_010
} 


\section{“Abertura pornográfica do governo": salas de exibição cinematográfica restrita}

No campo do cinema, uma série pressões contrárias aos apelos dos censores e de cidadãos conservadores, somava-se ao interesse de mercado das empresas provocando muitos embates na virada dos anos 1980 para os 1990.

O anteprojeto do decreto de criação de salas especiais para exibição de filmes considerados eróticos ou pornográficos gerou grandes polêmicas. Patrocinado pela indústria cinematográfica e pelas associações de exibidores, houve resistência de diversos matizes. De um lado, artistas e demais trabalhadores da cultura criticavam que a medida significaria apenas uma institucionalização da censura sob a aparência de uma liberação controlada; de outro, conservadores apontavam que o excesso de liberdade na exibição de imagens de sexo e de violência levariam à corrupção da juventude.

Com efeito, já à época, questionava-se por que somente os filmes vetados pela "censura moral" estariam sendo liberados em salas especiais, enquanto obras controladas pela “censura política" permaneciam proibidas:

Em primeiro lugar, se considerarmos que há duas linhas básicas de filmes, constantemente encalhados na censura - os pornográficos e os políticos vamos notar que a liberação foi apenas para os primeiros. Por que não se liberou também, "Estado de Sítio", do Costa Gavras, ou a Batalha de Argel, cujos temas estão muito mais próximos das lutas contra a opressão política, em defesa da liberdade de expressão?

Reivindicava a matéria de Murilo Carvalho, intitulada "Império lucrativo das salas especiais", publicada no jornal "Movimento", n. 280, de 10 a 16 de novembro de 1980, considerada, pelo monitoramento de propaganda adversa, como infração a dispositivos censórios que permitiam o enquadramento legal ${ }^{206}$.

O texto legal proposto definia que as produções cinematográficas que explorassem a "temática sexual" ou que contivessem "cenas gratuitas e exacerbadas de violência" receberiam, da Divisão de Censura de Diversões Públicas ou do Conselho Superior de Censura, o certificado liberatório restrito. Assim, tais filmes poderiam ser exibidos nas "salas de exibição cinematográfica restrita", que só poderiam veicular este tipo de produção e deveriam estar localizadas em capitais de Estados ou em municípios com mais de 1 milhão de habitantes ${ }^{207}$.

\footnotetext{
${ }^{206}$ BR_RJANRIO_TT_0_MCP_AVU_0464

${ }^{207}$ BR_RJANRIO_TT_0_JUS_AVU_039_d0001de0001
} 
Outra versão do anteprojeto foi feita pelo técnico da censura Coriolano de Loiola Cabral Fagundes, que já procurava definir e distinguir o filme obsceno e o erótico, questão nebulosa que sempre incomodou os censores e, ainda mais, os censurados. Segundo a proposta, que pretendia suprir uma lacuna normativa bastante presente nas atividades censórias, entendia-se por filme obsceno aquele que contém "o ato sexual claramente exibido, como tal entendendo-se a descrição ostensiva, insistente e detalhada de prática sexual, com enfoques em planos próximos e movimentos de câmera de maneira a destacar órgão genital em atividade". Já o filme erótico consistia na apresentação de

ato sexual de forma velada, como tal entendendo-se a descrição atenuada ou simulada de conjunção carnal, ainda que retratada com recurso formal destinado a excitar o espectador, contanto que na cena de sexo filmada não se verifiquem planos próximos ou movimento de câmera focando órgão genital em atividade, nem tampouco descreva a prática de qualquer perversão sexual. ${ }^{208}$

Mas este projeto teve enormes dificuldades de avançar. Um pronunciamento do deputado federal Igo Losso (PDS-PR), na sessão legislativa de 7 de agosto de 1981, registra duras críticas ao projeto então em discussão de uma regulamentação da exibição de filmes pornográficos e eróticos em algumas salas específicas. Acusava o parlamentar: "sob o velado nome de 'salas restritas', o Conselho Superior de Censura, órgão do Ministério da Justiça, aprovou recentemente a introdução da violência e da pornografia cinematográfica em nosso País”. De acordo com este projeto de decreto-lei, todas as capitais e grandes cidades poderiam contar com essas salas restritas. Na visão do deputado, trata-se de iniciativa que permitiria o acesso a "cenas de sadismo, sadomasoquismo, morbidez, crueldade e desvios eróticos variados, a exemplo do que acontece nos chamados países “civilizados' do exterior”209.

$\mathrm{O}$ anteprojeto do decreto fora discutido no contexto da abertura política e de maior profissionalização da indústria cinematográfica, mas o parlamentar discordara que tal medida representasse um "avanço democrático": "Não cremos, no entanto, que violência e erotismo deturpado sejam provas de democracia. É voz corrente de que os excessos são sempre

\footnotetext{
${ }^{208}$ BR_RJANRIO_TT_0_JUS_AVU_039_d0001de0001

${ }^{209}$ BR_RJANRIO_TT_0_JUS_PRO_258_d0001de0001. Editorial do Jornal do Comércio, de Porto Alegre/RS, intitulado "A abertura pornográfica do governo", de 2 de abril de 1980, critica o excesso de liberdade e de abertura do ponto de vista moral. Afirma o jornal ser um absurdo a mudança então em curso, afinal, como "o que era contrário à moral e aos costumes alguns dias atrás, de repente, torna-se moral?" E termina, após discorrer sobre os verdadeiros interessados neste "mercado obsceno" que se vai gerar com a decisão de flexibilizar a censura: "democracia e moral andam juntas. São inseparáveis [...] A abertura promovida pelo governo é necessária e saudável. Lastimamos, todavia, quando em nome da desativação da censura ideológica passa-se a destruir a censura moral que é o alicerce sem o qual nada de sério ou de realmente democrático poderá ser realizado" BR_DFANBSB_ZD_0_0_0038A_0043_d0003.
} 
prejudiciais, e, nesse caso, muito mais do que seria considerado razoável”. Mas, para o deputado, o mais grave seriam os efeitos desta medida para a juventude ainda em formação, pois, segundo ele, os jovens necessitam de boa orientação e não de erotismo e violência". E, "Caso os anteprojetos [fossem] aprovados, desencadear[iam] em nosso País certamente um incentivo à imoralidade, ao crescimento da brutalidade e crueldade, particularmente diante dos nossos jovens, ainda em período de formação". ${ }^{210}$

\section{A música}

\section{"A divulgação do homossexualismo é proibida pela lei censória"}

Luiz Ayrão, cantor nascido no Rio de Janeiro, trabalhava como advogado até ter algumas de suas composições gravadas por figuras conhecidas da Jovem Guarda, como Roberto Carlos. Mas Ayrão só conseguiu projeção nacional quando lançou "Porta Aberta", um compacto em homenagem à Portela, em 1973. Pouco tempo antes, no entanto, ele havia submetido à avaliação da censura, por meio de sua gravadora RCA, uma canção intitulada "Homossexual". A música teria sido feita como uma homenagem ao costureiro Clodovil Hernandez. Sem qualquer conotação erótica ou pornográfica, a letra abordava, de modo sensível e respeitoso, o sofrimento dos homossexuais incompreendidos e alvos de chacota por um "amor que o mundo não quer".

A canção, após denunciar, de modo bastante singelo, as várias dimensões da opressão sofrida pelos homossexuais, aponta que "a sociedade precisa entender/ Que é possível se viver sem conviver/ Não aplaudir mas não crucificar/ Não reprimir". E termina alertando que "toda força reprimida em vão /Aumenta mais a força da explosão".

A música foi integralmente vetada no ano de 1972 sob o lacônico argumento de que "a divulgação do homossexualismo é proibida pela lei censória", sem qualquer indicação do fundamento legal para esta assertiva. A censora Eugênia anota à mão o seu curto parecer no canto da folha apresentada para aprovação. Abaixo, outros dois censores não identificados escrevem apenas "de acôrdo" e apõem suas respectivas assinaturas. Foi unânime, portanto, o entendimento do órgão censório em vetar a circulação da referida música.

Deste modo, a canção "Homossexual" de Ayrão acabou ficando de fora do disco já

${ }^{210}$ BR_RJANRIO_TT_0_JUS_PRO_258_d0001de0001 
planejado, permanecendo inédita até hoje e se constituindo em um exemplo bastante simbólico da homofobia que orientava a visão da censura e dos censores.

Mas não apenas o amor entre os homens era interditado pela sanha da censura, as mulheres também não podiam cantar seus desejos e afetos se vividos entre elas. Neste sentido, na mesma época, um dos compositores que mais sofreu com os cortes censórios por motivação política teve uma de suas letras atingidas pela insinuação de uma relação lésbica.

Chico Buarque, em parceria com Ruy Guerra, escreveu a canção "Bárbara” para a peça "Calabar". A frase "nós duas", referente às personagens Ana de Amsterdã e Bárbara, viúva de Calabar, foi cortada por determinação da censura por sugerir algo entre as duas mulheres $^{211}$. Tratava-se, assim, de um amor que não se podia dizer o nome e tampouco cantar.

\section{"Dos bofes do meu Brasil"}

No carnaval de 1974, foi bastante tocada a música "Deus e o Diabo", de Caetano Veloso. Quando submetida à apreciação da censura, o único verso destacado e circulado de toda a letra, que explora a libertinagem da festividade carnavalesca criada pelo Diabo e abençoada por Deus, é “dos bofes do meu Brasil”".

No entanto, apesar do destaque, a técnica de censura Maria Luiza Barroso Cavalcante, em 25 de outubro de 1973, sustenta que há "duas alusões que merecem considerações mais demoradas: os trocadilhos 'o carnaval é invenção do diabo / que Deus abençoou" e "Cidade maravilhosa / Dos bofes do meu Brasil". Quanto ao primeiro trecho, aponta a censora que "apesar da assertiva duvidosa", ela "não [achava] poder enquadrar-se como ofensiva às religiões, seria duvidosa tal consideração, quando tanto se misturam Deus com diabo, na macumba, por exemplo". Em relação à segunda, "houve obviamente um plágio ao 'Coração do Meu Brasil', que poderá se afigurar de mau gosto e infeliz para alguns, mas que, ao [seu] ver, não pod[ia] se classificar como ofensivo à dignidade nacional". Ela então conclui: "creio não haver apoio legal para a não liberação da referida obra”.

A obra foi liberada. Mas, em 7 de março de 1974, o Ministro Alfredo Buzaid recebeu uma carta assinada por Ernesto J. Bernhoeft, presidente do Conselho de Pastores Evangélicos do Distrito Federal, pedindo uma audiência para discutir providências em relação à referida

\footnotetext{
211 ARAÚJO, Paulo Cesar de. Eu não sou cachorro, não: música popular cafona e ditadura militar. Rio de Janeiro/São Paulo: Record, 2015, p. 140. Um livro que retoma essa expressão como mote para traçar as representações LGBTs na canção brasileira é GONÇALVES, Renato. Nós duas: as representações LGBTs na canção brasileira. São Paulo: Lápis Roxo, 2016.
} 
música. Segundo o pastor, “dev[ia] ter havido um cochilo da Censura e mesmo omissão das altas autoridades eclesiásticas, uma vez que o teor da letra transcrita acima, de modo algum se coaduna[va] com as mais sagradas tradições do povo brasileiro, mas fer[ia] e desrespeita[va], em flagrante, os sentimentos religiosos dos quais a Nação ainda se orgulha[va]", clamando "para que tal blasfêmia não mais [fosse] repetida pelas bocas das inocentes crianças brasileiras".

Diante de tal reclamo, um novo parecer de n. 13797 da DCDP reiterou a liberação da música. Segundo o técnico da censura, em opinião exarada em 21 de março de 1974,

transparec[ia] realmente a irreverência da letra, mas não parec[ia] que a mesma [ferisse] o sentimento religioso do povo brasileiro, porque o Deus a que se refere não é a entidade sobrenatural teológica, mas sua idéia diluída no misticismo afro-brasileiro, sob cujo sentimento quase supersticioso se desenrola[va] a grande massa do atual carnaval brasileiro.

\section{"Não vá se misturar com esses meninos cabeludos"}

Rita Lee também foi alvo do filtro moral da censura em uma música que não versava sobre homossexualidade, mas falava abertamente do amor livre de uma juventude inspirada pelos "cabeludos" do movimento hippie. Na letra de "Gente fina é outra coisa", o embate cultural entre filhos e pais no campo dos costumes é a tônica: "E eu sei que você está com medo de dar / E o que vão pensar / Não vá se misturar com esses meninos cabeludos / Que só pensam em tocar / E você escuta o papa dizendo".

Conforme consta no processo n. 520 da Divisão de Censura e Diversões Públicas, a composição, que apontava para o descompasso entre a juventude e a geração mais velha de seus pais com seus ideais burgueses de sexualidade e relacionamento amoroso ${ }^{212}$, foi considerada "negativista e inoportuna", porque "conclama o jovem à marginalidade social, induzindo-o à filiação em movimentos tipo 'hippie", conforme opinião do técnico Paulo Leite de Lacerda no parecer 7303/73, de 4 de setembro de $1973^{213}$.

José de Carmo Andrade, outro técnico de censura, registrou que tal música continha mensagem "negativa" que "induz[ia] aos maus costumes", além de pertencer ao gênero de "protesto com linguagem de cunho simbólico e tema social". Na conclusão do parecer n.

212 "No show do Cilibrinas do Éden, a canção "Gente fina é outra coisa" possui uma tônica na representação do sujeito que assume dilemas contraculturais, em que a figurativização vocal reforça uma narrativa que polariza os desejos do indivíduo frente à sociedade e aos grupos familiares ou tradicionais". $<$ http://repositorio.unb.br/bitstream/10482/17182/1/2014_JeffersonWilliamGohl.pdf $>$, p. 165.

${ }^{213}$ ARQUIVO NACIONAL. DCDP. SC: Censura Prévia - letras musicais, cx. 644, Processo no 520. 
7046/73, de 30 de agosto de 1973, ele afirmou que "na letra em exame uma jovem insurg[ia]se contra o pátrio-poder, ao tentar persuadir um amigo a desacreditar de seu pai, para juntar-se a grupo juvenil de comportamento duvidoso". Indo além, o censor fez uma ponderação sobre o alcance que este tipo de produção artística de gravação em disco poderia ter devido à "grande penetração entre as diversas camadas sociais" ${ }^{214}$, ressaltando em sua conclusão que a letra não poderia, portanto, ser liberada.

Por sua vez, no parecer 7284/73, a censora Maria Luiza Barroso Cavalcante considerou que a música

teria influência perniciosa na juventude por seu caráter por seu caráter complamativo. Os jovens que seguem os caminhos impostos pela sociedade tradicional, com comportamento semelhante ao do pai é contestado. Atitude negativa em relação a este comportamento, suponhe [sic] a sugestão do que seria positivo: engajamento no mundo marginalizado de jovens rebeldes ${ }^{215}$.

O questionamento ao pátrio poder colocava em risco o fundamento de autoridade sobre o qual se erigia a sociedade. Proteger, assim, a família e os valores cristãos era uma necessidade diante das tentações de corrupção moral e de subversão que assolavam a juventude. Segundo esta perspectiva, os costumes integravam, claramente, uma razão de Estado.

\section{"Sou um frequentador da esquina do pecado"}

Mas não apenas os maiores nomes da Música Popular Brasileira foram afetados, também os cantores considerados "bregas" ou "cafonas" foram duramente atingidos pela repressão moralista.

O LP “Galeria do Amor",216, lançado em 1975 por Agnaldo Timóteo, em homenagem ao mais conhecido ponto de sociabilidade entre homossexuais daquele momento no Rio de Janeiro, era uma ode ousada à vida marginal na Cidade Maravilhosa. O título original da canção, que também dava nome ao álbum, era expressamente "Galeria Alaska", "mas o departamento de marketing da gravadora o aconselhou a mudar [o título], pois temia a face conservadora do público, acostumado à imagem do artista machão"217.

\footnotetext{
${ }^{214}$ ARQUIVO NACIONAL. DCDP. SC: Censura Prévia - letras musicais, cx. 644, Processo no 520.

${ }^{215}$ ARQUIVO NACIONAL. DCDP. SC: Censura Prévia - letras musicais, cx. 644, Processo no 520.

${ }^{216}$ Ver página XX do presente trabalho.

${ }^{217}$ ARAÚJO, Paulo Cesar. Eu não sou cachorro, não, pp. 141/142.
} 
Essa foi uma das primeiras canções compostas pelo cantor, que até então vinha gravando versões de sucessos estrangeiros ou interpretando músicas de outros artistas. O sucesso foi tamanho que, no ano seguinte, ele lançou a composição "Perdido da Noite", no LP homônimo de 1976, em que ele cantava: "somos amantes do amor liberdade / somos amados por isso também / e se buscarmos uma cara metade / como metade nos buscam também”.

Outro lançamento em clara referência ao drama da homossexualidade na solidão da cidade grande e em meio à hegemonia conservadora de valores, é o tango "Eu, Pecador", gravado no LP de 1977, que recebeu o mesmo nome. Ali, ele cantava em forma de prece pedindo a Deus que o perdoasse pelo pecado praticado: "Senhor, eu sou um pecador / e venho confessar porque pequei / Senhor, foi tudo por amor / foi tudo uma loucura / mas eu gostei...”. E, ainda, falava abertamente da repressão de provar o amor proibido: "Senhor, não pude suportar / a estranha sensação de experimentar / um amor por vós não concebido / um amor proibido pela vossa lei [...]. E arrematava: "sou um frequentador / da esquina do pecado".

Esses três sucessos de Agnaldo Timóteo, gravados entre 1975 e 1977, formaram sua "trilogia da noite" ${ }^{218}$, que causaram grande repercussão e atingiram enorme sucesso apesar dos temas morais polêmicos abordados. Mas, deve-se notar, apesar das restrições e mudanças impostas pela própria gravadora que já antevia os problemas que poderiam ser criados pela ditadura, que as músicas circularam sem maiores problemas, mesmo que contrariando os rígidos parâmetros morais do regime. Em boa medida, esta relativa liberdade se deveu à certa sutileza na forma de abordar a homossexualidade nas canções, com boa dose de ambiguidade e abuso de duplo sentido em alguns trechos. Não fossem estes estratagemas, importantes na época para evitar a exposição escancarada da temática homossexual, seria bastante provável que a tesoura da censura incidiria sobre as obras.

Outro cantor considerado brega, mas de grande alcance de público nas camadas mais populares, não teve a mesma sorte. Odair José teve diversas de suas músicas censuradas pela ditadura. Em especial, vale citar os problemas enfrentados por ele por conta da balada "Desespero", composta em 1974, que aborda a desconfiança da namorada em relação à masculinidade de seu companheiro. Diante dessas especulações, este desabafa: "você diz a todo instante / que eu não sou, meu bem / aquilo que aparento ser / diz até que não sou homem bastante / pra conseguir do meu lado ter você".

A música foi censurada quando já estava pronta para entrar no novo álbum do cantor

\footnotetext{
${ }^{218}$ Cf.: ARAÚJO, Paulo Cesar. Eu não sou cachorro, não, p. 144. Na obra, o autor menciona outros cantores "cafonas" que desafiaram os padrões morais estreitos da época cantando a homossexualidade, tais como Nelson Ned com "meu jeito de amar", Paulo Adriano, com "Preconceito", e Odair José, com "Desespero".
} 
sob a justificativa de que "questiona a masculinidade de um indivíduo" e "desperta o público para a questão do homossexualismo". O advogado da gravadora Phonogram, Dr. João Carlos Muller Chaves, recorreu ao CSC, mas o veto foi mantido com base em parecer assinado pela censora Zuleika Santos Andrade, que afirmava que "torna[va]-se inconveniente pela razão óbvia, concludente e flagrante de uma anormalidade confessa e aceita, em difusão do homossexualismo, prática considerada anti-social”219.

\section{"Pensou que era mulher, mas era mesmo um homem"}

No ano de 1977, Gilberto Gil e Rita Lee gravaram “De Leve”, uma versão da música "Get Back", composta por John Lennon e Paul McCartney que já tinha se tornado um grande sucesso dos Beatles.

A letra original contava a história de dois personagens. O primeiro era Jo Jo, um homem que abandonara sua terra natal de Tucson, no Arizona, em busca de uma nova vida e, especialmente, da maconha da Califórnia. Já o segundo era Loretta Martin, que "pensou que era mulher, mas era mesmo um homem".

$\mathrm{Na}$ adaptação feita para a versão brasileira, Jo Jo vira o "Jojô", que "era um cara que pensava que era, mas sabia que era não. Saiu de Pelotas e foi atrás da hera trepadeira de verão". Por sua vez, a Loretta Martin foi transformada em "Sweet Loretta Martinica da cuica, muito garotão curtiu. Juram que viram Loretta de cueca, dizem minas lá no Rio". No refrão, o título é repetido diversas vezes: "de leve, de leve, de leve que é na contramão", sugerindo uma leve tolerância aos comportamentos sexuais e de gênero não-normativos descritos pela letra da música.

Diversos carimbos de "PROIBIDO" estampavam a folha submetida à avaliação da censura. Os pareceres dos técnicos, nas folhas seguintes, fundamentam a posição de não liberação da música. O primeiro, datado de 17 de outubro de 1977, e assinado por Luiz Carlos Horta Fernandes, registra que "a referida letra musical enfoca[va], de maneira maliciosa, vultar e deseducativa o tema 'Homosexualixmo' [sic], não se coadunando com o veículo de comunicação a que se destina[va]".

Já o segundo, de autoria de Maria Urania Leite Correia Lima, de 16 de novembro de 1977, aponta[va] que "a letra em questão enfoca[va] o homossexualismo e lesbianismo de maneira vulgar, maliciosa e inadequada", uma vez "que tal assunto não dev[eria] ser tratado,

\footnotetext{
${ }^{219}$ Ibidem, p. 141.
} 
muito menos decantado de tal maneira e sim através do ponto de vista médico-científico", de modo que opinavam "pela NÃO LIBERAÇÃO da composição supra”. Ambos censores fundamentaram suas opiniões convergentes no art. 41, alínea "a” do Decreto 20.493/46.

\section{“Joohny pirou no negão"}

Leo Jaime se inspirou na música "Johnny B. Goode", do mestre do blues Chuck Berry. A letra original narra a história do caipira do Sul de Lousiana, perto de Nova Orleans, que vivia em uma cabana bem simples de madeira. Sem saber ler ou escrever, tocava violão como ninguém e pessoas de todos os cantos vinham para ouvi-lo até o sol se pôr. A versão brasileira chamada "Joohny pirou", contudo, foi uma adaptação bastante livre e ficou um tanto mais "apimentada".

$\mathrm{Na}$ letra em português, Johnny se transformou em um executivo de uma multinacional que foi a um jogo do Flamengo contra o Fluminense em um domingo no Maracanã. Lá, pela “primeira vez sentiu a sensação de um gol”. Contudo, sua vida mudou na ocasião do gol "quando um negão sua cintura agarrou / e com uma voz muito grossa em seu ouvido gritou / Foi gol”. Então, a música prossegue em uma analogia nada sutil entre a bola entrando no gol e o sexo anal que Joohny experimenta com o negão: "De repente o ponta pelo beque passou / E com muito charme para a área lançou / O goleiro apaixonado nem sequer reparou / Quando entre suas pernas a bola entrou / E o negão animadão novamente / A Johnny agarrou e beijou”. E arremata, no refrão, o título da música: "Joohny pirou no negão".

Ney Matogrosso gravou esta versão ousada em 1982, mas a canção logo foi "proibida pela censura de execução nas rádios" ${ }^{220}$, afinal, o gol foi acompanhado por dois homens agarrados se beijando, algo intolerável para a mentalidade estreita que ainda prevalecia na censura da época, ainda mais pela postura provocativa do cantor.

Ney Matogrosso já era visado há tempos. As performances ousadas, exibindo partes do corpo definido e elástico, sua voz de timbre agudo e contundente, além de sua dança repleta de rebolados e outros trejeitos tidos como "femininos", desde os tempos de Secos \& Molhados, geravam apreensão e curiosidade no público.

Em 30 de outubro de 1978, o advogado Dr. Alcides Cunha reclamou ao Ministro da Justiça e ao Presidente da República, em carta, sobre a exibição de "um infeliz rapaz de maneiras afeminadas, cognominado "Ney Mato Grosso", cuja triste e deplorável coreografia

${ }^{220}$ TREVISAN, p. 291. 
enviada de deboches e sandices despudoradas, chocou a grande maioria do público", na televisão. Ao final, o causídico carioca pedia que o governo agisse para resgatar "uma atmosfera livre de tantas impurezas, profundamente degradantes" 221 .

Outra música que foi alvo de um controle moral, tanto erótico quanto racial, foi "Menina Mulher da Pele Preta", de Jorge Lima Menezes, gravada por Jorge Ben. A letra descreve o desejo de uma pessoa dirigido a uma "menina mulher da pele preta, dos olhos azuis e do sorriso branco", cuja simples presença já provoca o eu-lírico da canção. Então este olha "com malícia" a "pele preta", os "olhos azuis", o "sorriso branco", enfim, o "corpo todo" da mulher.

A técnica de censura Maria Lúcia, ao ouvir a gravação da música, implicou com o termo "com malícia”: “Após a escuta, constatamos mensagem erótico-sexual pela repetição reiterada da palavra malícia, assim como o refrão. Art. 77, Cap. V, Decreto Lei 20.493 de 7 de dezembro de 1973". E acrescentou: "Solicita-se a mudança da frase 'Pele preta, sorriso branco"”.

Percebe-se, assim, que, além da preocupação com o suposto erotismo, um veto à visibilização da raça da mulher, negra, com seu sorriso branco. A diferença e o contraste, assim, eram algo intolerável na visão da censura, sobretudo porque o discurso de integração nacional imposto pela ditadura era bastante tributário a variações da teoria da "democracia racial" 222 .

\section{"Não acho que o homossexualismo seja correto"}

Já depois do final da ditadura, mas ainda na vigência de sua estrutura censória legada à Nova República, o preconceito contra os homossexuais seguiu sendo cultivado e manifestado pelos órgãos oficiais. Exemplo disso foi a proibição da música "Rubens", do grupo paulistano "Premeditando o Breque (Premê)", criado em 1976 por estudantes da USP com uma proposta bastante experimental e inovadora em seus arranjos e letras.

A canção em questão foi censurada por abordar o caso de amor entre dois rapazes e as dificuldades enfrentadas para viver e assumir a sua relação diante do preconceito da família, da religião e deles próprios. Merece transcrição um trecho, ainda que mais longo, da letra:

\footnotetext{
${ }^{221}$ Cf.: $<$ http://www.documentosrevelados.com.br/wp-content/uploads/2015/06/image-261.jpg >

${ }^{222}$ Cf.: $<$ http://memoriasdaditadura.org.br/movimentosnegros/>
} 
[...] Quero te apertar

Quero te morder e já

Quero mas não posso, não, porque:

- Rubens, não dá

A gente é homem

O povo vai estranhar

Rubens, para de rir

Se a tua família descobre

Eles vão querer nos engolir

A sociedade não gosta

$\mathrm{O}$ pessoal acha estranho

Nós dois brincando de médico

Nós dois com esse tamanho

E com essa nova doença

O mundo todo na crença

Que tudo isso vai parar

E a gente continuando

Deixando o mundo pensar

Minha mãe teria um ataque

Teu pai, uma paralisia

Se por acaso soubessem

Que a gente transou um dia

Nossos amigos chorando,

A vizinhança falando,

$\mathrm{O}$ mundo todo em prece

Enquanto a gente passeia,

Enquanto a gente esquece

$[\ldots]$

Rubens, eu acho que dá pé

Esse negócio de homem com homem,

Mulher com mulher

Logo após a proibição, o jornal Folha de São Paulo publicou declaração de Coriolano Fagundes, então diretor da SCDP, sustentando a censura da música e afirmando que "não tenho dúvida que o homossexualismo é uma forma de perversão sexual. Não acho que o homossexualismo seja correto. É preciso ter uma postura de educação em relação ao sexo e não de permissividade" 223 .

O Grupo Gay da Bahia, que já vinha adotando, no contexto da redemocratização, uma linha de ação de cobrança das autoridades e de disputa da opinião pública, sobretudo escrevendo para a imprensa, enviou uma carta criticando a posição do diretor da SCDP. Nela, Luiz Mott informava que a ciência, especialmente a medicina, dentro e fora do Brasil, já estava despatologizando a homossexualidade e que propagar preconceitos dessa maneira era

\footnotetext{
${ }^{223}$ Menciona-se outra música proibida pela mesma razão, chamada "Império dos Sentidos", que conta a história de um homem traído pela mulher que acaba morando junto dela e do seu amante em um triângulo amoroso. E o jornalista da Folha critica que "o estilete da censura democrática não poupou nem machões nem delicados. Atinge cobras e veados". "Cobras e Viados". Folha de São Paulo, 14 de setembro de 1986, p. 62.
} 
apenas uma reprodução do "machismo" e da "ignorância pré-científica". 224

Em sua réplica, Coriolano externa, com transparência, sua visão moralista e homofóbica. Afirmou que a homossexualidade não se reduzia às dimensões "éticoprofissional" ou "médico-psiquiátrico", mas seria, "antes de tudo uma questão moral". E acrescentou que "sob o prisma [da moral], todo o mundo civilizado norteia seu comportamento sexual dentro de parâmetros ditados pela Bíblia Sagrada, portadora do código judaico-cristão". Ao final, citou excertos da Bíblia, especialmente dos Levíticos, recomendando ao ativista gay que meditasse sobre o assunto ${ }^{225}$.

A postura de um alto funcionário do serviço policial demonstra que a diretriz censória esteva carregada de uma visão religiosa, quando não patologizante, da homossexualidade enquanto desvio moral ou questão de saúde. Esta concepção, que se fortaleceu significativamente durante a ditadura, seguiu informando a política censória até a extinção desses organismos, com a Constituição de 1988.

Para que se tenha dimensão do nível de intolerância cultivada contra qualquer manifestação de afeto entre pessoas do mesmo sexo durante a ditadura, vale citar o episódio de um beijo na boca que Caetano e Gil trocaram no Programa "Chico e Caetano" da Rede Globo, exibido no dia 26 de dezembro de 1986, ainda durante o processo de redemocratização.

Um cidadão, Paulo Fernando Vieira de Melo, enviou uma carta ao Ministro da Justiça Paulo Brossard cobrando providências enérgicas diante deste fato que significava a “desagregação dos valores morais tão caros e necessários a uma sociedade que se quer forte, digna e justa",226.

Tal acontecimento ensejou uma cobrança, por parte do Ministro Brossard, em face do SCDP. Fato que o diretor apurou e esclareceu, no despacho n. 02/87-SO/DCDP/DPF, afirmando que "o beijo foi de cumprimento, não se caracterizando como demonstração de homossexualismo" 227 , insinuando que, caso houvesse um componente homossexual, aí sim estaria plenamente justificada a necessidade de intervenção da autoridade pública.

\section{Livros}

\footnotetext{
${ }^{224}$ BR AN BSB NS_AGR_COF_MSC_324

${ }^{225}$ BR_AN_BSB_NS_AGR_COF_MSC_324

${ }^{226} \mathrm{BR}^{-} \mathrm{AN}^{-} \mathrm{BSB}{ }^{-} \mathrm{NS}^{-} \mathrm{AGR}{ }^{-} \mathrm{COF}^{-} \mathrm{MSC}^{-} 331$

${ }^{227}$ BR_AN_BSB_NS_AGR_COF_MSC_331
} 
O mercado editorial não ficou para trás em relação às demais formas de produção e circulação de bens culturais durante a ditadura. Para que se tenha dimensão do crescimento alcançado neste campo durante os anos de chumbo em uma sociedade cada vez mais urbanizada e letrada, "a produção de livros entre 1966 e 1980 passou de 43,6 para 245,4 milhões de exemplares; o crescimento das revistas entre 1960 e 1985 foi de 104 milhões para 500 milhões de exemplares"228. Reimão destaca que "em 1972, o Brasil ultrapassou, pela primeira vez, a barreira de um livro por habitante ao ano", já que naquele ano foram produzidos 136 milhões de livros para uma população de 98 milhões de pessoas, ou seja, 1,3 livro por habitante ${ }^{229}$.

Assim, adquirindo esta dimensão de relevância, a censura a livros e revistas, parte expressiva da imprensa escrita, foi bastante incisiva. O monitoramento era constante e, frequentemente, resultava na proibição de circulação, na apreensão e até na incineração do material atingido pela repressão. Cifras oficiais subestimadas dão conta de que, em 1975, foram confiscados 52.962 exemplares, decrescendo para 16.842, e aumentando significativamente para 226.641 livros no ano de $1978^{230}$.

Vale ressaltar que, além dos livros considerados "subversivos", em termos políticoideológicos, havia também uma preocupação central das agências da ditadura com a profusão de publicações "erótico-pornográficas", cujo volume de consumo também crescia conforme a tendência geral do mercado naquele momento. Ademais, a preocupação com os livros foi aumentando ao longo de todo aquele período, conforme se pode ver a seguir.

\section{Erótico ou pornográfico? Um limite tênue}

Uma das questões centrais dos órgãos de informações e de censura passavam pela definição das fronteiras, talvez propositadamente, fluidas e incertas entre a arte erótica e a mera pornografia. Enquanto que a primeira era dotada de uma aura de beleza e até de certa sofisticação, o que a tornava mais aceitável ainda que não fosse exatamente desejável, a segunda era considerada, de partida, repulsiva e intolerável. Ambas provocavam a indignação moral dos segmentos mais conservadores, sobretudo quando expostas na televisão, porque

\footnotetext{
${ }^{228}$ ORTIZ, Renato. Revisitando o tempo dos militares. In: REIS, Daniel Aarão; RIDENTI, Marcelo \& MOTTA, Rodrigo P. Sá (orgs.). A ditadura que mudou o Brasil: 50 anos do golpe de 1964.1ed. Rio de Janeiro: Zahar, 2014, p. 119.

${ }^{229}$ REIMÃO, S. Repressão e resistência: censura a livros na ditadura militar. São Paulo: Edusp, 2011, p. 31.

${ }^{230}$ MARCELINO, Douglas Attila. Subversivos e Pornográficos. Censura de livros e diversões públicas nos anos 1970. Rio de Janeiro: Arquivo Nacional, 2011, p. 131.
} 
entravam "dentro dos lares", mas a pornografia seria muito mais grave, merecendo ser eliminada.

A Informação n. 834, produzida pelo DOPS do Estado da Guanabara, foi encaminhada, em 20 de agosto de 1969, ao Presidente da Comissão Geral de Inquérito Policial Militar (CGIPM), no âmbito de um procedimento investigatório dirigido contra uma séria de livros considerados "eróticos"231. Uma das principais preocupações, naquele momento de endurecimento de regime, era definir, no bojo da Doutrina da Segurança Nacional, os critérios morais que presidiriam o saneamento dos valores compartilhados como referência na sociedade.

A CGIPM havia sido criada e instituída pelo Decreto-Lei n. 459, de 10 de fevereiro de 1969, por sugestão do Secretário Geral do Conselho de Segurança Nacional, estando vinculada à Presidência da República. Ela durou até 30 de novembro de 1969, quando foi extinta por ordem do então recém-empossado Presidente Emílio Garrastazu Médici.

Formada por representantes das três Forças Armadas e presidida por um general-dedivisão, as atribuições da CGIPM consistiam, basicamente, em "cooperar para assegurar a tranquilidade do país no campo da Segurança Nacional". O “combate à subversão" travado por esta Comissão ia desde a fase preparatória, na busca de informações, até a conclusão da ação e acompanhamento na justiça, passando também pela fase propriamente repressiva que culminava com os inquéritos. A CGIPM detinha diversas prerrogativas, tais como:

solicitar aos órgãos de informações - Serviço Nacional de Informações (SNI); Centro de Informações do Exército (CIE); Centro de Informações da Marinha (CENIMAR); Núcleo do Serviço de Informações e Segurança da Aeronáutica (N-CISA); Divisões de Segurança e Informações; Departamentos de Ordem Política e Social; Polícia Federal; a investigação de atos subversivos e contrarrevolucionários. ${ }^{232}$

Além disso, podia, também, realizar, com seus próprios meios, as diligências policiais.

O presidente da CGIPM, diante da referida denúncia sobre livros eróticos, escreveu à mão seu parecer sobre a obra inclusa no processo, "Vida erótica de Isadora", de Herman Miller:

o livro anexado a êste processo é um verdadeiro atentado à moral e aos bons costumes. Nada contém de subversão política, salvo a citação de Che Guevara, na página 184. Sugiro que o assunto seja levado à consideração do

\footnotetext{
${ }^{231}$ BR_DFANBSB_AAJ_IPM_0527_d

${ }^{232}$ Para mais informações sobre a CGIPM, consultar: $<$ http://atom.ippdh.mercosur.int/index.php/comissao-geralde-inquerito-policial-militar-cgipm>. Acesso em 17 de outubro de 2016.
} 
Exmo. Sr. Ministro da Justiça, por não ser da competência desta Comissão. 1/9/1969.

Mais uma vez, a distinção entre subversões política e moral emergia com relativa autonomia, conferindo, a esta última, uma solene e singular gravidade.

Meses antes, o Ministro da Justiça Gama e Silva já tinha se valido de suas prerrogativas de censura prévia ao editar uma portaria determinando a apreensão de duas obras: "Minha vida, meus amores", de Henry Spencer Ashbee, e "Filosofia na alcova" ou "Escola de Libertinagem", de Marquês de Sade. Conforme consta em matéria publicada no Jornal do Brasil, em 30 de maio de 1969, considerou-se que estas publicações, "pelo seu conteúdo, atenta[vam], frontalmente, contra a moral pública e os bons costumes da família brasileira". Acrescentava-se, ainda, ao texto legal, que "os livros mencionados constitu[íam] manifesto e deliberado instrumento de incentivo à prática de perversão moral" ${ }^{233}$.

O documento da Divisão de Informações do DOPS arrola uma lista das "publicações julgadas de natureza atentatória à moral e aos bons costumes da família brasileira", comunicando a apreensão das referidas obras que constavam na Portaria do Ministério da Justiça. Além disso, o documento menciona outros "livros que, também, parecem atentar contra a moral e os bons costumes", como: "Coleção erótica", com vários títulos; "Os insaciáveis", "Os libertinos", "Nexus", "Sexus", todos traduzidos pelo dramaturgo Nelson Rodrigues; e "É preciso salvar a mulher casada", de Carlos Renato ${ }^{234}$.

No entanto, a falta de contornos claros na definição do que se poderia considerar "ofensivo à moral e aos bons costumes" deixava os próprios agentes da censura em dúvida sobre qual material poderia circular e quais livros deveriam ser apreendidos e retirados do acesso do público. A vagueza da dicção legal, que funcionou como instrumento de potencialização da ação arbitrária de quem definia o que estava dentro e fora da norma em uma zona cinzenta de indistinção, por outro lado, atrapalhava o trabalho dos censores. Exemplo ilustrativo desta dificuldade consta logo após a lista de livros que "parecem atentar contra a moral e os bons costumes" (grifo nosso), seguindo-se o seguinte parágrafo: "Este DOPS, todavia, não dispõe de elementos melhor qualificados na especialidade, nem tão pouco conhece os critérios que presidiram a decisão do Sr. Ministro da Justiça. Em consequência, análise mais profunda da matéria torna-se necessária". Por fim, encerrou-se o relatório informativo mencionando de novo o livro anexado, "Vida erótica de Isadora", "livro êste, que

\footnotetext{
${ }^{233}$ BR DFANBSB AAJ IPM $0527 \mathrm{~d}$

${ }^{234}$ BR_DFANBSB_AAJ_IPM_0527_d
} 
nos parece, também, altamente "erótico"” ${ }^{235}$. Resta saber o significado desta gradação de parecer "altamente erótico" para a censura.

O presidente da CGIPM solicita, em 6 de maio de 1969, por meio do ofício n. 69/69GP, ao DOPS do Estado da Guanabara, aprofundamento de investigação sobre esse tema.

O ofício começa com a seguinte consideração, algo alarmista, sobre a presença deste tipo de livros em pontos de venda: "Tem sido observado ultimamente, sensível aumento na circulação de livros e outras publicações de caráter licencioso, pornográfico e erótico, cuja difusão é feita indiscriminadamente, não só em livrarias - como também em bancas de jornais, Feiras de Livros etc". E, logo em seguida, pontua a gravidade e a urgência conferidas ao assunto por representar uma ameação à juventude e à família, funcionando como componente psicológico da guerra revolucionária contra o regime:

\begin{abstract}
A facilidade com que tais publicações são adquiridas, o interesse que tal tipo de leitura poderá despertar, particularmente na mocidade e, principalmente, o seu conteúdo, constituem importantes fatôres que vão subrepticiamente abalando a pedra angular da sociedade democrática que é a família, contribuindo também para a corrupção da moral dos costumes, sendo lícito identificar nos fatos apontados, uma componente psicológica da GUERRA REVOLUCIONÁRIA em curso no Brasil e no mundo.
\end{abstract}

O ofício seguiu com a assinatura do Gen. Div. Humberto de Souza Mello, presidente da CGIPM.

Os sucessivos encaminhamentos entre órgãos da burocracia repressiva, em três diferentes anotações à mão no expediente de acompanhamento do processo administrativo, pontuavam e grafavam, sempre em destaque, a palavra "urgência" para atender ao requerimento. A associação entre a "corrupção moral dos costumes" com um componente psicológico da guerra revolucionária parecia preocupar bastante as autoridades.

Basicamente, o pedido buscava mapear todo o circuito de produção e circulação destas mercadorias, com evidente intuito de desbaratar por inteiro o seu comércio. Requeria-se, por exemplo, "relação das Editoras, Tipografias, etc, onde os mesmos [eram] imprimidos discriminando endereços e responsáveis", "relação das Distribuidoras, discriminando endereços e responsáveis", "nomes e endereços de autores das publicações" e "nomes e endereços dos indivíduos relacionados com o Comércio das publicações”.

Renato Caravita de Araújo, detetive do DOPS encarregado da tarefa de buscar as informações solicitadas, introduziu sua resposta à chefia da Seção de Buscas Especiais, datada

${ }^{235}$ BR_DFANBSB_AAJ_IPM_0527_d 
de 31 de julho de 1969, reiterando a crítica moralista às publicações nos seguintes termos:

vários são autores destas obras, a maioria traduzidas de autores estrangeiros consagrados pela minoria de uma sociedade confusa, que busca no sexo a resposta de suas frustrações. Este ciclo teve início com a difusão das obras do escritor Norte Americano Henry Miller, sendo logo em seguida republicado as obras de Marques de Sade, Brigitte Bijou e outros.

No entanto, o detetive relata uma dificuldade incontornável no que se refere à censura de livros:

apesar dos esforços, torna-se difícil uma mais completa e minuciosa informação para um assunto tão complexo, pois para determinar-se quais os livros que estariam sendo instrumentos de perversão moral, seria preciso conhecer-se não apenas as ilustrações das capas, e sim o conteúdo dêsses livros através da leitura e análise de cada um dêles ${ }^{236}$.

Assim, termina o agente público, restringindo-se apenas ao Estado da Guanabara por não poder obter os dados de livros editados em outras localidades, o que evidencia as dificuldades que a censura enfrentava para conseguir mapear, em todo o território nacional, com seus quadros e estrutura limitados, as supostas ameaças presentes em publicações imorais.

A incerteza dos critérios de interpretação e aplicação dos tipos legais excessivamente vagos de "moral e bons costumes" sempre foi uma constante na relação entre autoridades de distintos órgãos e motivou, por exemplo, o ofício n. 201/69- GAB sobre "publicações imorais e eróticas", que foi enviado, em 11 de setembro de 1969, pelo general de divisão Humberto de Souza Mello, presidente da CGIPM, diretamente para o Ministro da Justiça Luiz Antônio da Gama e Silva.

O general pleiteava, em seu ofício, que fossem esclarecidas as diretrizes da censura sobre o tema, solicitando ao Ministro "sua valorosa interferência para determinar providências [...] e consoante nosso entendimento verbal esclarecer a esta Comissão a sua orientação sôbre o assunto que motivou o mesmo ofício" ${ }^{237}$. Além disso, o ofício seguiu acompanhado de alguns anexos para análise do Ministro, tais como um exemplar da revista "êle e ela" (de setembro de 1969), o recorte de uma sátira publicada no Jornal do Brasil e um exemplar do livro "O Mundo Erótico de Isabela Durgan”, de Herman Miller. Por fim, o general requereu também que o Ministro examinasse os excertos das notas publicadas nos jornais $\mathrm{O}$ Globo e

\footnotetext{
${ }^{236}$ BR_DFANBSB_AAJ_IPM_0527_d

${ }^{237}$ BR_DFANBSB_AAJ_IPM_0552_d
} 
Jornal do Brasil a respeito do concurso "Henry Miller e a Literatura Contemporânea" 238 .

O norte-americano Henry Valentine Miller, ainda que não fosse homossexual e nem produzisse uma literatura homoerótica, era caracterizado como um escritor pornográfico, tendo livros seus censurados durante a ditadura. Homenageado pelo prestigiado crítico literário Otto Maria Capeaux no prefácio que este fez à obra "O Mundo do Sexo", em 1975, Miller foi despertando cada vez mais interesse dentre leitores brasileiros.

No entanto, o escritor já despertava a atenção da repressão anos antes. Em 6 de setembro de 1969, o jornal O Globo publicou nota dos prêmios oferecidos pela Gráfica Record Editora, responsável pela publicação do referido autor no Brasil, a estudantes que fizessem o melhor ensaio crítico com o tema "Henry Miller e a Literatura Contemporânea".

O Jornal do Brasil de 7 de setembro de 1969, também noticiou "Henry Miller, um tema para estudantes". Ao lado do recorte das duas pequenas notas de imprensa, constava anotação, à mão, feita por agente do DOPS/GB ao general de divisão Humberto, com a seguinte mensagem de preocupação: "quando estive aí falamos sobre livros eróticos e imorais, inclusive que o M. Justiça havia retirado alguns de circulação. Que te parece a promoção da Semana Henry Miller? Não seria o caso de alertá-los disso?"239

Isto demonstra o nível de importância que o assunto ocupava na alta hierarquia da burocracia estatal. Não há continuidade nas comunicações para indicar os caminhos tomados por este expediente, mas a vigilância atenta dos órgãos de segurança sobre uma semana literária de um autor "imoral e erótico" atesta a rigidez de valores do regime e a tentativa de formatar uma sociedade a partir dos estreitos paradigmas culturais que dominavam a mentalidade da censura.

\section{"Feliz Ano Novo" de Rubem Fonseca}

Deonísio da Silva, tomando como ponto de partida a proibição imposta ao livro de contos "Feliz Ano Novo", lançado em 1975 pelo escritor Rubem Fonseca, analisa um discurso censório bastante fundado na sexualidade como "um tema inconveniente, sobretudo por mesclar-se em sexualidades tidas por ilegítimas, recobertas de erotismos patológicos e

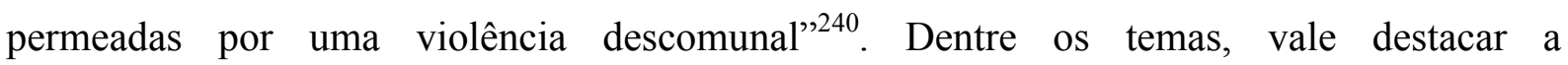

\footnotetext{
${ }^{238}$ BR_DFANBSB_AAJ_IPM_0552_d

${ }^{239}$ BR_DFANBSB_AAJ_IPM_0552_d

240 SILVA, Deonísio da. Nos bastidores da censura: sexualidade, literatura e repressão pós-64. São Paulo: Estação Liberdade, 1989, p. 12.
} 
homossexualidade que aparece, por exemplo, no conto "Dia dos Namorados", que descreve um "pederasta que finge ser uma jovem" ou, ainda, “74 degraus”, em que um casal de lésbicas comete um assassinato.

Em 15 de dezembro de 1975, depois de mais de 30 mil exemplares e há semanas na lista dos livros mais vendidos, o referido livro foi proibido e apreendido por ordem do Ministro da Justiça:

Nos termos do parágrafo $8^{\circ}$ do artigo 153 da Constituição Federal e artigo $3^{\circ}$ do Decreto-Lei n. 1.077, de 26 de janeiro de 1970, proíbo a publicação e circulação, em todo território nacional, do livro intitulado Feliz Ano Novo, de autoria de Rubem Fonseca, publicado pela Editora Artenova S.A., Rio de Janeiro, bem como determino a apreensão de todos os seus exemplares expostos à venda, por exteriorizarem matéria contrária à moral e aos bons costumes. Comunique-se à DPF.

O diferencial do caso de Fonseca e que o tornou um dos mais polêmicos é que, além de mexer com a intelectualidade que se levantou contra a proibição, ele provocou judicialmente "a própria censura, em razão de, pela primeira vez, obrigar os poderes censórios a declinarem os motivos da proibição de um livro"241. Isto porque, geralmente, as proibições de livro apareciam publicamente apenas fundamentadas em despachos sumários e sucintos do Ministro da Justiça com teor do tipo: “exteriorização de matéria contrária à moral e aos bons costumes".

No entanto, as tentativas de recorrer ao Poder Judiciário para rever atos de censura impostos, em geral, não foram exitosas. A intensa colaboração do sistema de justiça com as elites militares e civis, além do elevado grau de controle destas sobre aquele por conta da restrição de garantias da magistratura e cassação de juízes e outros membros de corporações jurídicas, prejudicou qualquer tentativa de controle judicial dos atos discricionários da administração pública no campo da censura ${ }^{242}$. Autores como Rubem Fonseca, Plínio Marcos, Chico Buarque de Holanda, Ruy Guerra e Robert Alley impetraram mandados de segurança nos anos 1970, todos julgados improcedentes. "Certamente, não será nenhuma surpresa lembrar que nos anos 1970, ao tempo em que se proibiam livros como os de Rubem Fonseca, negavam-se também as seguranças impetradas nos tribunais" 243 .

\footnotetext{
${ }^{241}$ Ibidem, p. 15.

${ }^{242} \mathrm{Um}$ estudo sobre essas relações, comparando Argentina, Brasil e Chile, pode ser encontrado em PEREIRA, Anthony. Ditadura e repressão: o autoritarismo e o Estado de Direito no Brasil, no Chile e na Argentina. São Paulo: Paz e Terra, 2010..

${ }^{243}$ SILVA, Deonísio da. Nos bastidores da censura: sexualidade, literatura e repressão pós-64. São Paulo: Estação Liberdade, 1989, p. 135.
} 
Mesmo com esta tendência dos Tribunais tolerantes à censura no caso dos livros, o Diretor-Geral do DPF em exercício, Raul Lopes Munhoz, enviou o Ofício n. 391/68-SCDP ao secretário do Conselho de Segurança Nacional, em 9 de outubro de 1968, queixando-se da excessiva liberalidade dos juízes permitindo que peças teatrais vetadas fossem exibidas:

Solicito a digna atenção de Vossa Excelência no sentido de que esse órgão possa interferir junto aos órgãos competentes a fim de que as decisões do Departamento de Polícia Federal, no tocante às proibições de espetáculos pornográficos e subversivos, não sejam sustadas com a concessão de liminares por parte daqueles magistrados. Tal solicitação prende-se ao fato de que dezenas de peças teatrais proibidas pelo Serviço de Censura de Diversões Públicas estão sendo liberadas, sumariamente, através de recursos impetrados à Justiça ${ }^{244}$.

\section{"O caos e a degeneração na célula básica da nação - a família"}

Nesse sentido, a posição do CIE é emblemática. O órgão emitiu um alerta que originou, em 5 de junho de 1975, a Informação n. 351/75/DSI/MJ sobre "proliferação de livros erótico-pornográficos" 245 , anexando um exemplar de "Os Degenerados", escrito por Oliver Ruston. O livro aborda, em linhas gerais, os depoimentos das experiências sexuais vividas por um jovem casal de irmãos com diversas outras pessoas, inclusive os pais, a um médico, que acaba tendo relações com a jovem sob tratamento.

A mensagem de preocupação com tal história ficcional no documento analisado é clara: "tem-se observado que está proliferando, em todo o país, a venda de livros eróticopornográficos, altamente atentatórios à moral e aos bons costumes" ${ }^{246}$. Mas o mais grave era que se tratava de publicações que seduziam, principalmente, aquilo que consideravam como uma juventude ainda frágil e despreparada:

o que de mais grave está a ocorrer, face a esta situação, é que seus leitores enquadram-se numa faixa etária jovem, justamente, na época em que a personalidade do indivíduo encontra-se em formação e que, por isso mesmo, necessita de orientação e cuidados especiais, quer familiares, quer governamentais. ${ }^{247}$

O principal ataque identificado nestas publicações estaria na intenção delas em atingir,

\footnotetext{
${ }^{244}$ Ibidem, p. 138.

${ }^{245}$ BR_DFANBSB_NS_AGR_COF_ISI_0088_d

${ }^{246}$ BR_DFANBSB_NS_AGR_COF_ISI_0088_d

${ }^{247}$ BR_DFANBSB_NS_AGR_COF_ISI_0088_d
} 
diretamente, a instituição tradicional da família, tida como a célula básica de toda a sociedade: “as aberrações e perversões sexuais e a pregação subliminar de dissolução da família, relações sexuais entre pais e filhos, ou entre estes, dão mesmo a impressão de que a 'idéia mãe', que norteia esse gênero de literatura, está em lançar o caos e a degeneração na célula básica da nação - a família" ${ }^{248}$.

Neste sentido, o relatório afirmava, categoricamente, que a tática comunista vinha se valendo de outras armas na luta de classes: "dentro da tática comunista de conquista de um povo, está a desagregação do mesmo, através do incentivo não só à corrupção e aos tóxicos, como, primordialmente, da deturpação das normas básicas sociais e morais, que regem a família, o que é conseguido pela exploração do sexo" ${ }^{249}$. Diante de tal diagnóstico crítico da realidade, as soluções propostas não poderiam deixar de ser rigorosas: "não basta, assim, somente a proibição de venda de tais livros e publicações congêneres. Urgem medidas de maior profundidade e severidade contra tal estado de coisas" ${ }^{250}$.

Os reclamos social e moral, bem como a segurança nacional, recomendariam então que "é de imperiosa necessidade, como justo reclamo social e moral e, até mesmo, de segurança nacional, a punição das editoras e seus responsáveis, além do recolhimento, no comércio especializado, dos livros em apreço" 251.

Diante da avaliação do CIE, que pretendia ser uma espécie de advertência das autoridades governamentais para um grave problema nacional, o Ministério da Justiça encaminhou o expediente para análise do DCDP. Dalmo Paixão, Técnico de Censura, exarou seu parecer de n. 5885/75, em 30 de junho de 1975, afirmando que o livro expunha "aspectos rotulados de degenerescências sexuais, em grau máximo, que [iam] desde a masturbação passando pela sodomia até - outras abomináveis práticas do coito" 252 .

Complementava sua análise julgando a legitimidade das práticas sexuais retratadas no livro, constatando que o "livro em exame [era] rico em descrições pormenorizadas de experiências ou vivências sexuais anômalas e com manifestações de relações sadomasoquistas entre as personagens, oferecendo níveis de 'apelação' condenados - pela moral social brasileira, com a agravante de ter a sua tradução realizada em bases medíocres”. Assim, diante de um "quadro de absoluta degradação moral", a obra "pode[ria] ser caracterizada, pelos seus excessos, como pornografia gratuita, sendo que seu alicerce pauta[va]-se numa

\footnotetext{
${ }^{248}$ BR_DFANBSB_NS_AGR_COF_ISI_0088_d

${ }^{249} \mathrm{BR}$ _DFANBSB_NS_AGR_COF_ISI_0088_d

${ }^{250} \mathrm{BR}^{-} \mathrm{DFANBSB}{ }^{-} \mathrm{NS}^{-} \mathrm{AGR}^{-} \mathrm{COF}^{-}{ }^{-} \mathrm{ISI}^{-} 0088^{-} \mathrm{d}$

${ }^{251} \mathrm{BR}^{-} \mathrm{DFANBSB}{ }^{-} \mathrm{NS}^{-} \mathrm{AGR}^{-} \mathrm{COF}^{-}{ }^{-} \mathrm{ISI}^{-} 0088^{-} \mathrm{d}$

${ }^{252}$ BR_DFANBSB_NS_AGR_COF_ISI_0088_d
} 
moral alienígena, contrapondo-se à formação da nossa sociedade" ${ }^{253}$. Opinou, portanto, pela proibição deste material.

O expediente foi encaminhado ao Ministro Armando Falcão, autuado como processo n. 59343/75. Conforme publicação do Diário Oficial em 10 de julho de 1975, o Ministro determinou não apenas a proibição de "publicação e circulação em todo território nacional, do livro "OS DEGENERADOS”, de autoria de Oliver Ruston”, como também determinou a “apreensão de todos os seus exemplares expostos à venda por exteriorizar matéria contrária à moral e aos bons costumes" 254

Foi aplicada ao livro, portanto, as penalidades máximas de proibição. Mas ele não foi o único. Ao lado dele, diversas outras publicações foram proscritas e inseridas no Index da ditadura.

\section{Index da ditadura: lista dos 205 livros proibidos e incineração}

Diversos livros foram proibidos durante a ditadura. Alguns sequer chegaram a ser publicados e comercializados. Outros foram impedidos de circular depois de já estarem impressos. Uns, ainda, já estavam editados e postos à venda, mas foram perseguidos e apreendidos, tudo para impedir que as ideias "subversivas" ou "imorais" chegassem ao público.

Um exemplo é o livro "O Louco", de autoria de Dr. G Pop, de 1975, que relata a história de um louco que descobre que seu meio-irmão é um "invertido sexual", descrevendo "pormenorizadamente, homossexualismo entre meninos, tentativa de estupro, relações sexuais, sexo grupal”. É curioso que, no parecer 05/79, a censora Teresa Cristina dos Reis aponte que o romance "diverge, em termos, de outros, puramente pornográficos, pois contém um enredo mais elaborado, não fugindo, porém, das passagens onde descreve desvios sexuais". Assim, nem a aparente maior sofisticação literária foi o suficiente para liberar o livro, pois é nítido o caminho pornográfico do romance em vista da importância dada, pelo autor, para tamanhas aberrações". Com base no Decreto-lei n. 1.077, ela sugere a proibição ${ }^{255}$.

Chegou-se, inclusive, a elaborar um documento, divulgado pelo Comando Aéreo Regional (COMAR), que tinha como anexo uma relação de livros proibidos pelo Ministério

\footnotetext{
${ }^{253}$ BR_DFANBSB_NS_AGR_COF_ISI_0088_d

${ }^{254}$ BR_DFANBSB_NS_AGR_COF_ISI_0088_d

${ }^{255}$ REIMÃO, Sandra. Repressão e resistência: censura a livros na ditadura militar. São Paulo: Edusp, 2011, p. 156.
} 
da Justiça "por sua natureza subversiva ou pornográfica". Datado de 13 de abril de 1976, esse relatório indicava 205 livros nacionais e estrangeiros proibidos, requisitando-se que, "sempre que [fosse] constatada a exposição à venda, em bancas de jornais, livrarias, supermercados, etc, de qualquer dos livros relacionados, dever[ia] ser providenciada comunicação a este Centro", e encerrava com o imperativo: "sugere-se ampla divulgação desta matéria à tropa" 256 .

Os livros apreendidos eram não apenas levados, mas tinham de ser destruídos por meio da incineração. O ofício n. 322/76-SCDP/SR/RJ encaminhado em 18 de maio de 1976 pelo chefe do SCDP para o diretor do mesmo órgão dava ciência a este da incineração de 12.246 volumes de publicações apreendidas "por terem sido proibidas por ato do Sr. Ministro da Justiça, em vista de seu conteúdo atentatório à moral e aos bons costumes" ${ }^{257}$. O chefe do SCDP destaca[va] que "a providência não ating[ia] os livros apreendidos por motivos políticos, mas apenas os que atenta[vam] contra a moral e os bons costumes". O que desvela a relativa autonomia da censura moral em relação à censura estritamente política.

Os livros já publicados que fossem proibidos e posteriormente apreendidos por mais de 120 dias deveriam ser incinerados, não admitindo-se nenhuma outra forma de inutilização de acordo com o art. 5\%, inciso II, do decreto 1077 de 1970. Por esta razão, constava, no âmbito do processo administrativo referido, um pedido para que o chefe de físcalização verificasse quais livros apreendidos encontravam-se ali armazenados por mais de 120 dias.

Tal lista foi preparada com "uma relação com títulos e números de exemplares" e mais de "2430 quilos de livros pornográficos" foram enviados para incineração na Companhia Municipal de Limpeza Urbana, vinculada à Prefeitura do Rio de Janeiro, que auxiliava a repressão na destruição das publicações apreendidas ${ }^{258}$.

\section{"Não chegam a aguçar ou favorecer desejos sexuais": "Os tambores silenciosos"}

O Ofício n. 29/SEC/GAB, de 17 de janeiro de 1977, de Moacyr Coelho, então DiretorGeral do DPF, ao Ministro da Justiça Armando Falcão, submetia à apreciação deste o livro "Os Tambores Silenciosos", do escritor Josué Guimarães, ex-funcionário do Tribunal de Contas do Estado do Rio Grande do Sul que foi desligado por abandono de função e passou a trabalhar como jornalista.

\footnotetext{
${ }^{256}$ BR_AN_BSB_VAZ_064A_0088

${ }^{257} \mathrm{BR}{ }^{-} \mathrm{DF} \overline{\mathrm{A}} \mathrm{NBSB} \mathrm{NS}^{-} \mathrm{AGR}{ }^{-} \mathrm{COF}$ ISI $0091 \mathrm{~d}$

${ }^{258}$ BR_DFANBSB_NS_AGR_COF_ISI_0091_d
} 
O livro fora denunciado ao DPF pelo comando do III Exército, por meio do Informe n. 0102 M 26 E2/77, por "vilipendiar" desembargadores do TCE/RS, acarretando o risco, segundo o informe do Exército, de "graves inconvenientes à administração pública e aos nomes de ilustres homens públicos do RIO GRANDE DO SUL" 259.

O Ministro da Justiça despachou determinando que o próprio Diretor-Geral do DPF procedesse à leitura dos originais e resolvesse conclusivamente o caso. No entanto, logo após, ele cancelou este despacho anotado no rosto dos autos do processo administrativo requerendo que seu chefe de gabinete então analisasse o livro e lhe desse um retorno. Tal mudança se devia, muito provavelmente, ao potencial risco de exposição pública de autoridades regionais que o Ministro estava tentando evitar. O chefe de gabinete, Pedro Henrique Antero, em 2 de fevereiro de 1977, também se esquivou de assumir a responsabilidade e sugeriu encaminhamento para que o próprio DPF decidisse em definitivo. No entanto, um bilhete manuscrito pelo Ministro Armando Falcão, em 9 de fevereiro de 1977, requereu que o expediente fosse encaminhado para o "Prof. Henrique Fonseca de Araújo, que leu os originais e conhec[ia] o fundo do problema" 260.

O então Procurador-Geral da República, Henrique Fonseca de Araújo, cumprindo a determinação acima, analisou toda a obra, destacando, em sublinhado, no seu parecer de 10 de fevereiro de 1977, que um dos desembargadores do TCE era retratado como "impotente e acabando por ser traído pela esposa, e, o que é muito mais grave, descrevendo minuciosamente os dois atos de adultério, ou seja, as relações sexuais praticadas, uma das quais consistente em ato de sodomia..." ${ }^{261}$. A gravidade da sodomia foi apontada com destaque no parecer.

Após ponderar as possíveis reações negativas da censura prévia, que segundo o Procurador não havia sido utilizada ainda em caso de livros, acabou-se sugerindo

a apreensão após a impressão do livro e antes de seu lançamento público, pode[ndo] ser sustentada e tida como feita 'a posterior', sem ser, assim, entendida como censura prévia, afastando a alegação de inconstitucionalidade, desde que a Censura [pudesse] justificar o conhecimento do texto. ${ }^{262}$

O processo foi, então, encaminhado pelo Diretor-Geral do DPF para análise de Rogério Nunes, diretor do DCDP, autoridade que examinou a controvérsia instaurada entre as

\footnotetext{
${ }^{259}$ BR_AN_RIO_TT_0_MCP_PRO_0719

${ }^{260}$ BR AN RIO TT_0_MCP_PRO_0719

${ }^{261}$ BR_AN_RIO_TT_0_MCP_PRO_0719

262 BR_AN_RIO_TT_0_MCP_PRO_0719
} 
apreciações precedentes. Sobre a censura prévia, ele afirmou que

a aplicabilidade, ou não, do sobredito decreto-lei [da censura prévia], ter[ia] de ser examinada em face da possibilidade do indicado livro colidir com o pudor público ou ofender à moral social. Cabe[ndo], portanto, distinguir entre descrições consideradas obscenas e manifestações realísticas de arte literária. $^{263}$

E prosseguiu:

a meu parecer, existem narrativas episódicas de relações sexuais desprovidas de baixo palavreado, sem atritarem abertamente com o sentimento médio de pudor ou com os bons costumes, mesmo porque não chegam a aguçar ou favorecer desejos sexuais, que caracterizariam o escrito pornográfico ou obsceno, reprimido pela legislação em vigor. ${ }^{264}$

O Diretor-Geral da DPF acabou endossando também este entendimento de que não restaria tão caracterizada a obscenidade e que o desgaste poderia ser muito maior em caso de censura prévia, cuja legalidade ainda era um tema que dividia opiniões. Então, afirmou ele que "resta[va] considerar, por fim, a inconveniência da repercussão desfavorável para o Governo, com a proibição do livro pelo Ministério da Justiça, já que não est[ava] bem caracterizada a existência de matéria contrária à moral e aos bons costumes". Talvez, ponderou, fosse o caso de determinar a apresentação do livro para verificação prévia "com maior rigor por uma equipe de técnicos de censura" 265 .

Nesta mesma linha, o Consultor Jurídico Ronaldo Poletti desaconselhou a medida de censura prévia e afirmou que "o livro não constitu[ía], obviamente, violação da lei de segurança nacional, nem seu conteúdo moral justificaria a aplicabilidade do Decreto-lei n. 1077/70", não se justificando "qualquer medida de proibição ou apreensão". Diante de tais argumentos, o Ministro Armando Falcão se convenceu, após envolver todo um conjunto de autoridades para opinar, evidenciando a preocupação gerada pelo livro e pelo tema, no sentido de arquivamento do processo.

Este caso ilustra bem a pluralidade de instâncias de avaliação e controle, com suas diversas camadas de subjetividades, arbítrios e interesses na apreciação do material para orientar a ação do Poder Executivo nestes temas. Mas fica claro que, na aparente desordem, havia uma racionalidade bem definida no sentido de verificar a caracterização de ofensa à

\footnotetext{
${ }^{263}$ BR_AN_RIO_TT_0_MCP_PRO_0719

${ }^{264}$ BR_AN_RIO_TT_0_MCP_PRO_0719

${ }^{265}$ BR_AN_RIO_TT_0_MCP_PRO_0719
} 
moralidade pública com um juízo de conveniência e oportunidade a fim de evitar desgastes desnecessários e elevados custos da censura. Assim, havia todo um feixe de posicionamentos distintos de segmentos judiciais e administrativos do Estado ditatorial brasileiro - as opiniões da consultoria jurídica, da procuradoria da república, de técnicos do DCDP, chefia do DPF que culminava na decisão de quem efetivamente mantinha o controle de um processo complexo e multifacetado, quer dizer: o Poder Executivo por meio do Ministério da Justiça.

\section{"Um filão rentável na descrição ousada das relações homossexuais": o caso de Cassandra Rios}

Exemplo de sucesso editorial, explorando intensamente o gênero erótico e o pornográfico, sobretudo a partir do olhar feminino, foi a escritora lésbica Cassandra Rios, um pseudônimo de Odette Rios. Com livros marcados por uma linguagem simples e popular, bastante acessível e com pouca sofisticação formal nas narrativas, a fortuna crítica da autora não recebeu, até hoje, um reconhecimento no mundo acadêmico e literário, embora ela tenha sido aclamada pelo público ${ }^{266}$.

Segundo uma matéria publicada na revista Realidade, já no final do ano de 1970, ela estava ocupando "uma posição jamais alcançada por uma escritora brasileira: ser[ia] a primeira mulher a atingir 1 milhão de exemplares vendidos", sendo a única mulher no Brasil a viver "exclusivamente de livros", ao lado de homens como Jorge Amado e José Mauro de Vasconcelos ${ }^{267}$.

Pode-se afirmar que ela foi a primeira escritora brasileira a vender mais livros no país, superando a marca de 1 milhão de exemplares em mais de 50 lançamentos, alguns deles ultrapassando a décima edição. Contudo, o êxito comercial não passaria desapercebido e ela acabaria sendo também a escritora mais censurada do país: teve ao menos 36 livros $\operatorname{proibidos}^{268}$. Ainda que uma parte desta censura tenha acontecido durante as décadas de 1940 e 1950, foi mesmo sob o controle moral da ditadura que se intensificou a perseguição a suas obras.

Os prejuízos decorrentes daí para sua vida pessoal e carreira profissional foram

\footnotetext{
${ }^{266}$ Uma análise literária da obra de Cassandra se encontra em: LIRA, Ramayana. Meta(na)morfoses lésbicas em Cassandra Rios. Estudos Feministas, Vol. 21, No. 1 (janeiro-abril - 2013), pp. 129-141.

${ }^{267}$ Realidade. "Cassandra Rios", n. 48, 1970, p. 116.

${ }^{268}$ FERNANDES, Marisa. Lésbicas e a ditadura militar: uma luta contra a opressão e por liberdade. In: GREEN, James N.; QUINALHA, Renan (Orgs.). Ditadura e homossexualidades: repressão, resistência e a busca da verdade. São Carlos: EDUFSCAR, 2014, p. 127.
} 
inestimáveis. Em entrevista ao Lampião, Cassandra afirmou:

estou desatualizadíssima, atualmente, porque só faço escrever, só me preocupo em repor Cassandra Rios nas livrarias. Porque me proibiram 36 livros, e então eu já escrevi outros nove. Eu tinha um padrão de vida correspondente àquilo que recebia desses 36 livros. Já imaginaram o choque? Eu não senti na hora, só vim sentir três anos depois". ${ }^{269}$

A homossexualidade feminina retratada em suas obras foi uma das grandes causas da repressão sofrida pela escritora. Em um dos pareceres sobre sua obra "Volúpia do Pecado", o censor demonstrou sua ira pessoal contra os desvios apresentados por Cassandra, ao dizer que:

a autora descobriu um filão rentável na descrição ousada das relações homossexuais, que se constituem em uma constante em suas criações subliterárias, onde prefere dar ênfase aos segredos 'caça-níqueis' do amor lésbico, sem se preocupar em levantar os sintomas e as causas dos desvios da conduta sexual ${ }^{270}$.

Outra de suas obras, "As traças", tem como enredo a relação de uma professora com uma de suas alunas, filha de uma ex-colega de magistério. A garota vive um extremo conflito pela descoberta de sua homossexualidade e acaba se refugiando nas drogas, a ponto de ter uma overdose e ser internada. Ao recobrar a consciência, ela escuta o diálogo entre a professora e a mãe, que sugeria ter havido entre elas - a mãe e a professora - o mesmo envolvimento sexual. A técnica de censura Ana Katia Vieira, ao analisar a obra, concluiu que o livro carregava "uma mensagem negativa sobre todos os aspectos", sobretudo "porque a autora afirma[va] que o lesbianismo é a verdadeira condição normal das mulheres. Contraria[ndo], assim, de maneira frontal, um padrão moral consagrado pela nossa sociedade" (grifo no original). Com base nesse parecer n. 1720, de 29 de outubro de 1975, o livro foi vetado (art. $1^{\circ}$ do Decreto-lei n. 1.077) ${ }^{271}$.

Também foi alvo da censura sua obra "A Paranóica", de 1976. Conforme o parecer n. 73/78, de autoria do censor Silas de Aquino Lira Gouvêa, feito em 27 de dezembro de 1978, o

\footnotetext{
269 “Cassandra Rios ainda resiste: com 36 livros proibidos, ela só pensa em escrever”. Lampião da Esquina, n. 5, outubro de 1978, p. 10.

${ }^{270} \mathrm{O}$ parecer é citado por Marcelino. O autor, em importante estudo sobre a censura de livros, aponta que, no caso de Cassandra, "havia não apenas o agravante do tom incisivo de suas narrativas, mas o fato de tratarem, sobretudo, do homossexualismo feminino, fartamente exaltado pela autora, exasperando os técnicos de censura encarregados da avaliação de suas obras". MARCELINO, Douglas Attila. Subversivos e Pornográficos. Censura de livros e diversões públicas nos anos 1970. Rio de Janeiro: Arquivo Nacional, 2011, pp. 152-153.

${ }^{271}$ REIMÃO, Sandra. Repressão e resistência: censura a livros na ditadura militar. São Paulo: Edusp, 2011, p. 150.
} 
livro narra a história de Ariella, com apenas 17 anos, que descobre ser filha adotiva e começa a usar de "todos os meios" para descobrir os mistérios que rondavam suas origens e chega a ter relações homossexuais com Mercedes, noiva de seu irmão. No parecer, o censor registra: "há homossexualismo, violência e o conteúdo do livro é deprimente", sugerindo, assim, a proibição, com fundamento no art. $1^{\mathrm{o}}$ do Decreto-lei $1.077 / 70^{272}$.

A vigilância cerrada fez com que Cassandra adotasse uma série de subterfúgios e estratégias para manter seus livros em circulação, bem como sua pequena livraria em São Paulo. No documentário biográfico dedicado a ela, a crítica literária Lucia Facco registra que Cassandra chegou a criar dois pseudônimos masculinos, sem mencionar os femininos, em livros contendo o mesmo grau de sexo explícito, mas com casais heterossexuais. Não houve censura, o que atestaria que "a pornografia era apenas uma justificativa para proibir o sexo entre mulheres"273.

Cassandra não foi a única escritora a sofrer duramente com a censura por alegar obscenidade. Adelaide Carraro, autora de dezenas de livros e outro sucesso de vendas à época, teve diversas de suas obras censuradas. Em uma delas, o áspero parecer proibitório do censor registrava não apenas o uso de "termos chulos e palavras de baixo calão", mas também o fato de a autora apresentar uma concepção que exaltaria o "homossexualismo de forma que chega[va] a dar nojo de ler tal porcaria" ${ }^{274}$. O grau de repulsa pessoal ao tema, manifestado nestas duras palavras, refletia como a censura moral era atravessada pelos preconceitos de cada censor.

\section{Faltava inteligência ou humor na censura?}

É recorrente e bastante popularizada uma crítica endereçada à censura, sempre em tom de gozação, que caracteriza o trabalho dos censores como desprovido de qualquer inteligência ou racionalidade, para não dizer burro mesmo. Esta fama dos órgãos responsáveis pelo controle político e moral das artes e das comunicações não nasceu recentemente, ela surgiu mesmo ao longo da ditadura e se consolidou no imaginário sobre o período. De algum modo, ridicularizar a censura tornou-se um meio mais fácil de criticá-la, isto é, mais fácil do que

\footnotetext{
${ }^{272}$ Ibidem, p. 152

${ }^{273}$ SACCO, Lucia. Cassandra Rios: a Safo de Perdizes (2013), realizado por Hanna Korich, 62 min.

${ }^{274}$ MARCELINO, Douglas Attila. Subversivos e Pornográficos. Censura de livros e diversões públicas nos anos 1970. Rio de Janeiro: Arquivo Nacional, 2011, p. 151.
} 
fazer uma análise de seu modus operandi, a fim de apontar as eventuais inconsistências ${ }^{275}$.

O jornal alemão Der Spiegel, de 3 de janeiro de 1977, trazia uma matéria chamada "Céu ou inferno deste mundo", sobre o contraditório "brilhante país do milagre econômico e o do sombrio cárcere" 276 .

Após abordar as dificuldades presentes na conjuntura política do país, a longa matéria sobre o Brasil dos generais pontuava que

discussões teóricas mesmo de natureza ideológica são para os detentores do poder um verdadeiro horror. Até discussões favoráveis ao sistema, de intelectuais e artistas, são tidas, por eles, com suspeita de esquerdismo tendencioso, com consequências fatais para a vida cultural. Alguns anos atrás, o ex-Ministro da Justiça Buzaid mandou confiscar as 'gravuras eróticas' de Pablo Picasso sob a suspeita de pornografia. O ridículo da situação não impediu que seu sucessor Falcão proibisse, no fim de março de 1975, uma representação na televisão pelo balé do Teatro Bolshói de 'Romeu e Julieta' de Prokófiev, com medo de propagação comunista.

Sem assumir esta visão que ridiculariza a censura, não deixa de ser curioso notar que, se faltou inteligência a alguns censores, também esteve ausente certo senso de humor. $\mathrm{O}$ Informe n. 1622/05/80 - CI/DPF, datado de 26 de fevereiro de 1980, oriundo do Centro de Informações do Departamento de Polícia Federal para todos os serviços de informações, comunica a apreensão do "Manual de Sexomobilismo", de Friedrich Skriepel ${ }^{277}$. O autor era apresentado como catedrático em "wagen-sex" da Universidade de Beidelberg. Tratava-se, o manual, de um pequeno livro, editado pelas "Edições Sapiens", que tinha por objetivo apresentar "um estudo posicional completo de sexo em automóvel, através de 43 fotos autorrealísticas com explicações científicas”.

No entanto, não havia registro de que o autor ou mesmo a universidade em questão existissem. Além disso, o teor do manual é flagrantemente cômico e fantasioso, tal qual se verifica pelo seguinte trecho da biografia do autor no início do livro:

Sempre interessado em sexo, fez graduação de Sexologia num curso por correspondência, conseguindo o grau de mestre em 'Sexo não Especializado' e finalmente doutorou-se na Universidade de Beidelberg em "Wagen-Sex" (sexo no automóvel), sendo atualmente o único especialista neste setor sobre

\footnotetext{
${ }^{275}$ Essa versão, no entanto, foi perdendo força por conta das pesquisas posteriores e mais profundas sobre as diferentes formas de atuação e racionalidades específicas do processo censório. Ainda que não se negue a existência de casos particulares de equívocos, enganos e despreparos de alguns censores, eles não se mostram em número suficiente a ponto de justificar a generalização do argumento.

${ }^{276}$ BR DFANBSB Z4 REX IBR 0049

${ }^{277}$ BR_DFANBSB_ZD_0_0_0037A__0004_d0001de0001
} 
a face da terra. Famigerado conferencista, já proferiu palestras nos maiores centros culturais do mundo, inclusive em Cangaíba e na Ilha Marajó.

Assim, mesmo diante de um manual que examina diferentes posições sexuais dentro de um automóvel com ilustrações feitas à mão ao lado de descrições em texto de maneira bastante irreverente, atestando tratar-se mais de uma peça humorística do que erótica, a censura não achou graça e vetou a circulação da referida publicação.

O relatório acusou a editora "como especialista em difundir, exteriorizar subliteratura (erótico-pornográfica), apresentando-a com características supostamente didáticas". O "Manual" foi descoberto porque os agentes públicos foram recolher outro material da mesma editora, o álbum "A iniciação de uma virgem".

Contudo, estes episódios curiosos e, em certa medida, cômicos, se, por um lado, revelam certa fragilidade do órgão repressivo, por outro revelam também que ele estava, sim, firme no propósito de identificar e perseguir o seu alvo no campo da produção cultural e da arte. Conforme adverte Deonísio da Silva,

se é certo que a censura confundiu muitos títulos, temas e autores, é certo também que a referida confusão guarda limites perfeitamente delineáveis. Nos dois momentos decisivos do exercício da censura, o que se viu foi que, primeiramente, a obra de Rubem Fonseca foi vetada pelas mesmas razões que resultaram na proibição dos livros de autores tão diversos quanto Xaviera Hollander, Cassandra Rios, Adelaide Carraro, Brigitte Bijou, Emanuelle Arsan etc., isto é, uma suposta pornografia, o uso do palavrão e outras obscenidades é que teriam amparado os vetos. A sexualidade dita e escrita é que constituía o alvo principal. ${ }^{278}$

Em outras palavras, era a expressão desabrida das sexualidades, sobretudo as dissidentes, que deveria ser coibida.

\section{Revistas e jornais}

\section{A imprensa "marrom"}

Os diversos órgãos integrantes da comunidade de informação acompanhavam o universo de publicações impressas periódicas, especialmente jornais e revistas, para verificar

\footnotetext{
${ }^{278}$ SILVA, Deonísio da. Nos bastidores da censura: sexualidade, literatura e repressão pós-64. São Paulo: Estação Liberdade, 1989, p. 43.
} 
se estavam em conformidade com os parâmetros morais e políticos fixados na Lei de Imprensa e no Decreto 1.077 de 1970.

A maior parte das publicações da imprensa "marrom", expressão usada para referir a veículos sensacionalistas, que publicava matérias ou reportagens sobre sexualidades dissidentes, de modo a reproduzir visões esteriotipadas e estigmatizantes. Geralmente, homossexuais e travestis eram associados à criminalidade e, com frequência, apareciam nas páginas policiais, seja como vítimas ou como suspeitos.

Mesmo quando esses veículos reverberavam representações negativas das pessoas LGBT, as agências de informação já criavam alertas específicos para pressionar a ação da censura ou de outros organismos do Estado. A mera exposição desses corpos e dessas existências, ainda que fosse apenas e tão somente no sentido de alimentar preconceitos e acentuar a marginalidade, já constituía, claramente, um incômodo na percepção dos órgãos responsáveis pela vigilância da subversão política e moral. Não bastava criar um discurso negativo, em muitos casos, era mesmo preciso silenciar essas dissidências.

Diversos documentos atestam uma preocupação constante com o tom "contrário à moral e aos bons costumes" de veículos da imprensa, sobretudo no período que vai de 1977 até 1982. Uma hipótese que pode explicar a concentração de informações oficiais sobre as publicações impressas na virada dos 1970 para os 1980 é que, nestes anos, circularam com maior intensidade jornais de diversos tipos e houve uma relativa liberalização política que ocasionou uma aumento significativo de bens culturais pornográficos ou eróticos no mercado brasileiro. Muitas das publicações misturavam a transgressão moral com a crítica social ou política ao regime chamando, portanto, ainda mais atenção.

Por exemplo, o Encaminhamento n. 423/77/DSI/MJ, datado de 27 de setembro de 1977, anexava exemplar do mensário "PINGENTE", publicano naquele mesmo mês e ano, denunciando que "sob o rótulo de jornal humorístico, na realidade, não se encontra[va] uma só página dessa publicação que não cont[ivesse] mensagens difamantes ao regime, à classe militar e a autoridades do governo. Como variante, [havia] cartuns pornográficos”. Diante da constatação, o relato foi concluído com pedido de providências, já que: “devido ao teor subversivo e difamatório do jornal "PINGENTE" torna[va]-se necessária uma atuação da Censura no sentido de proibir sua circulação ou, pelo menos, submetê-lo a um exame prévio" $^{279}$.

Outro exemplo é o documento com "análise de propaganda adversa" dedicada ao

${ }^{279}$ BR_AN_RIO_TT_0_MCP_PRO_0993 
jornal "Repórter", n. 23, de novembro de 1979. Após resenhar brevemente uma série de "matérias atentatórias à moral e aos bons costumes, bem como outras de cunho ideológico e ofensivas às instituições e à dignidade de autoridades", o documento concluía: “o jornal REPÓRTER, na sua linha de provocar sensacionalismo, continua publicando, sistematicamente, matérias relacionadas com o sexo e a miséria (prostituição de menores e homossexualismo), repressão policial”. O referido número do jornal foi apreendido por determinação de Portaria do Ministro da Justiça de 9 de novembro de 1979, pois antes estava sendo vendido em banca sem restrição etária ou preocupação com embalagem ${ }^{280}$.

\section{"Exploração grosseira de temas relativos a taras e inversões sexuais"}

Uma comunicação enviada pelo chefe do SNI, Octávio Aguiar de Medeiros, para o Ministro da Justiça Abi-Ackel denunciava, em 23 de janeiro de 1981, a "divulgação de matéria pornográfica no jornal 'Luta Democrática"”.

No relatório anexado, em que constam dados da editora responsável, registrava-se, ainda, que "a par do preço de Cr\$ 10,00 o exemplar e de veiculação de notícias sensacionalistas - bem ao agrado da massa menos esclarecida - servem-se, ainda, seus dirigentes da exploração grosseira de temas relativos a taras e inversões sexuais" ${ }^{281}$.

Nesta linha, exemplificando a afirmação acima, aponta-se que, na edição n. 8090, de 29 de novembro de 1980, que havia sido publicada a matéria intitulada "Xerife do xadrez errou na escola do 'Odalisco"”. Relatava-se, ali, um caso de homicídio doloso de um detento por seu colega de cela com a legenda "quis usar o bumbum $0 \mathrm{Km}$ e foi morto":

JOSÉ BATISTA RAMOS autor de seis homicídios foi morto na cela da 2a DP pelo colega de infortúnio PAULO CÉSAR JÚLIO DA SILVA, de 18 anos de quem a vítima estava cobiçando o bum-bum, segundo o dono, virgem. A morte foi por estrangulamento e houve até torcida no xadrez para que PAULO CÉSAR ganhasse a briga ${ }^{282}$.

Depois de relatar este e outros casos de pornografia sensacionalista, o relatório concluía que “assim agindo, os responsáveis pelo jornal 'LUTA DEMOCRÁTICA' vêm, com sua ação deletéria, contribuindo para a deterioração dos princípios éticos, morais, cívicos e

\footnotetext{
${ }^{280}$ BR AN RIO TT 0 MCP PRO 1738

${ }^{281}$ BR_RJANRIO_TT_ 0 -MCP AVU_ 0483

${ }^{282}$ BR_RJANRIO_TT_0_MCP_AVU_0483
} 
cristãos em que se fundamentam a sociedade brasileira"283.

Também neste sentido, o Chefe do SNI encaminhou ao Ministro da Justiça, em 13 de fevereiro de 1981, um ofício sobre "publicação pela imprensa de assuntos contrários à moral e aos bons costumes", caracterizados, segundo o documento, pelo "abuso no exercício da liberdade de manifestação do pensamento e informação, previsto no art. 17 da Lei 5.250, de 9 de fevereiro de 1967".

O relatório destacava matérias que tratavam de relações homossexuais, ainda que de forma sensacionalista, tais como "Bichas loucas sangram pelo amor do Pé de Mesa" (jornal Luta, de 6 de fevereiro de 1981, p. 1), "Bichas duelaram na rua pelo Pé de Mesa” (jornal Luta, de 6 de fevereiro de 1981, p. 4), “Gozo só por dinheiro: debate na zona”, com entrevista com prostitutas e travestis (jornal "Repórter", n. 38, fevereiro de 1981, p. 20), "Boca do Lixo é campeã de doenças venéreas" (jornal "Repórter", n. 38, fevereiro de 1981, p. 14).

\section{"Difusão, com grande intensidade, desses assuntos proibidos"}

A preocupação com a divulgação de conteúdos eróticos e pornográficos, ainda voltados para um público heterossexual, foi se tornando cada vez mais presente. Um documento de 12 de fevereiro de 1981 sobre uma "publicação pela imprensa de assuntos contrários à moral e aos bons costumes", reconstituía o enquadramento legal dessa matéria desde a Constituição até a legislação ordinária para indicar a necessidade de uma ação proibitiva e preventiva: "a publicação e exteriorização de assuntos contrários à moral e aos bons costumes é proibida no País", constituindo delitos como "abusos no exercício da liberdade de manifestação do pensamento e informação" e "ofen[ça] a moral pública e os bons costumes". Exemplos de publicações que continham matérias de difusão pública proibidas por lei, eram revistas como PLAYBOY, STATUS e ELE E ELA ${ }^{284}$.

O diagnóstico de que estaria havendo, na virada dos anos 1970 para os 1980, uma invasão dos mercados cultural e, especialmente, editorial brasileiros por produtos fortemente referenciados na sexualidade - alguns deles inclusive com uma aura científica de manuais de educação sexual - era cada vez mais presente ${ }^{285}$. Este argumento era mobilizado de forma recorrente pelos órgãos de informação para forçar uma reação à altura da repressão. Neste

\footnotetext{
${ }^{283}$ BR_RJANRIO_TT_0_MCP_AVU_0483

${ }^{284}$ BR_RJANRIO_TT_0_MCP_AVU_0485

${ }^{285}$ Sobre a censura moral a tais publicações eróticas, mesmo com estudos científicos para educação sexual, ver: MARCELINO, Douglas Attila. Subversivos e Pornográficos. Censura de livros e diversões públicas nos anos 1970. Rio de Janeiro: Arquivo Nacional, 2011, pp. 137 e ss.
} 
sentido, esse mesmo relatório acrescentava que "além das revistas acima citadas, exclusivamente pornográficas [sic], [vinha] se verificado, ultimamente, a difusão, com grande intensidade, desses assuntos proibidos, não só pelos veículos da imprensa, alternativa, como também por órgãos da chamada grande imprensa" ${ }^{286}$.

Os exemplos de assuntos proibidos que seguiam anexados ao documento eram: o jornal "Luta democrática", de 15 de janeiro de 1981, com matéria "Marido se amarrou no 'muy amigo': expulsou a mulher e sentou"; jornal "Luta democrática", de 27 de janeiro de 1981, com texto "Vela 7 dias no rabicó do derretido"; "Repórter" de janeiro de 1981, com o artigo “Operação-Sapatão: polícia ataca lésbicas”, dentre outros ${ }^{287}$.

\section{"Abertura de tudo que estava castrado pela repressão"}

A AC/SNI, em ofício de 20 de março de 1981, abordava, novamente, o tema “publicação pela imprensa de assuntos contrários à moral e aos bons costumes". O documento refletia o "acompanhamento de assuntos contrários à moral e aos bons costumes, veiculados por órgãos da imprensa, em textos ou manchetes, caracterizando abuso no exercício da liberdade de manifestação do pensamento e informação". No período de 20 a 26 de março de 1981, foram citados diversos jornais.

Um dos mais visados foi o jornal "Luta", sempre incorrendo nas mencionadas representações estigmatizadoras. Sua edição, de 14 de março de 1981, com uma nota de capa sobre o espetáculo "Gay Fantasy" dirigido por Bibi Ferreira e estrelado por Rogéria, veiculava a seguinte mensagem, com fotos de rosto de famosas como Rogéria, Jane, Cláudia Celeste, Marlene Casanova e Veruska: “Travesti é arte: para o produtor do 'Gay Fantasy', João Paulo Pinheiro, a abertura política proporcionou a abertura de tudo que estava castrado pela repressão. Daí, os travestis também quererem seu espaço social". ${ }^{288}$ Além disso, outra edição de "Luta", do dia 16 de março de 1981, retratava, em matéria intitulada "O Belo da Noite", a primeira eliminatória do concurso "Garoto Zona Sul", realizado na boate Belle de Nuit, em Copacabana. Fotos de homens sarados e definidos semi-nus e de travestis com poucas roupas acompanhavam o texto, que destacava "a presença de público variado, sem perder a maioria de homossexuais masculinos". 289

\footnotetext{
${ }^{286}$ BR_RJANRIO_TT_0_MCP_AVU_0485

${ }^{287}$ BR_RJANRIO_TT_0_MCP_AVU_0485

${ }^{288}$ BR_RJANRIO_TT_0_MCP_AVU_0499

${ }^{289}$ BR_RJANRIO_TT_0_MCP_AVU_0499
} 
O mesmo "Luta", em edição de 22 e 23 de março do mesmo ano, relatou como foi a segunda noite das eliminatórias pelo título "Garoto Zona Sul", que contou com mais de 500 pessoas e "muita sacanagem". Com fotos dos três rapazes escolhidos e de travestis que marcaram presença na festa, o jornal comentava que "o concurso Garoto Zona Sul 81 est[ava] se transformando numa noite de prazeres e libidinagem, onde a liberação [era] total, desprovida de preconceito, como as pessoas que frequentam normalmente a boate gay, Belle de Nuit”. ${ }^{290}$ Esta edição também foi classificada, em ofício de 3 de abril de 1980, como uma publicação de "assuntos contrários à moral e aos bons costumes" 291 , e endereçada ao chefe de gabinete do Ministério da Justiça,.

Um relatório de 23 de dezembro de 1981 sobre "publicação pela imprensa de assuntos contrários à moral e aos bons costumes", trazia diversos recortes do referido jornal em anexo, com manchetes do período de 6 a 17 de dezembro, que informavam o seguinte: "Destrincharam a bicha louca em 194 pedaços: retalhadinho, morto, nem conseguiu ser identificado pela arcada dentária. Foi festa de bichonas" (corpo impossível de identificar, presumiram ser homossexual por conta de um brinco na orelha apenas); "Corno mandou a mulher sapatão para o inferno: com o Diabo no corpo, o comerciante Juarez Vasile perseguiu a sapatão Ana Maria até fuzilá-la"; "Bichona macho aguentou três de uma só vez: era costureiro e estava em lua-de-mel. Levado para trás do carro teve que transar com os três, mas depois morreu"; "Sapatão não livrou nem a própria nora: o filho não sabia de nada, sua mãe, gostava de mulher. Nora não resistiu ao cerco e acabou agredida". ${ }^{292}$

Outro exemplo da "publicação pela imprensa de assuntos contrários à moral e aos bons costumes [...] caracterizando abuso na liberdade de manifestação do pensamento e informação", conforme registrava relatório de 12 de janeiro de 1982: "Flagrou o papai entubando uma 'jibóia' grande: cansou de ser homem, e queria fugir da rotina. Resolveu romper o ano sentado na 'boneca", ${ }^{, 293}$, em manchete do mesmo jornal "Luta", de 31 de dezembro de 1981.

Na matéria, a história de um idoso que manteve relações homossexuais com um jovem e que teria sido "descoberto em flagrante" por seu filho era relatada com ares de zombaria e de modo sensacionalista:

fã incondicional do cantor Ney Matogrosso e também cansado de ser homem

\footnotetext{
${ }^{290}$ BR_RJANRIO_TT_0_MCP_AVU_0499

${ }^{291}$ BR_RJANRIO_TT_0_MCP_AVU_0505

${ }^{292}$ BR_RJANRIO_TT_0_MCP_AVU_0584

${ }^{293}$ BR_RJANRIO_TT_0_MCP_AVU_0595
} 
durante tanto tempo, Almerindo da Silva, de apenas 49 anos, resolveu mudar a casaca ingressando no clube dos homossexuais onde foi recebido com muita festa e alegria menos pelo filho Carlos Alberto da Silva de 24 anos, que sofreu um ataque de histeria sendo socorrido as pressas no Pronto Socorro do Hospital Salgado Filho. ${ }^{294}$

A edição n. 437 do jornal "Luta: a voz do povo" foi apreendida por determinação do Ministro da Justiça, conforme atesta ofício da Coordenação Central Policial do DPF enviado ao gabinete do Ministério da Justiça, com data de 27 de dezembro de 1982. Dentre as diversas matérias consideradas "propaganda adversa", vale mencionar uma, em especial, por ser considerada "atentatória à moral e aos bons costumes". Tratava-se da coluna "Chêgay", de Anne Kleidy, colunista social que escrevia em tom de crônica bem-humorada sobre as personagens mais famosas do circuito homossexual do Rio de Janeiro, especialmente sobre as aventuras amorosas e crimes ocorridos neste circuito. Nesta edição, por exemplo, na seção propositadamente de duplo sentido "Curtas e grossas", lê-se:

Atenção, atenção. Na última reunião do SMRJ (Sindicato dos Michês do Rio de Janeiro) a assembléia foi unânime em votar para um reajuste nos preços das trepadas. A partir de $1^{\circ}$ de Janeiro, a taxa mínima na Cinelândia passa de Cr\$ 1.000 para Cr\$ 3.000. E tem mais. Querem um aumento semestral a partir de março de 1983. Vejam como a inflação está afetando a todas as classes. $^{295}$

Outra edição, de n. 437, datada de 14 de dezembro de 1982, também teve diversos exemplares apreendidos pela SR/DPF/RJ, nos termos do Ofício n. 431/82 - CCP/DPF de 21 de dezembro de 1982. Além das matérias mais estritamente políticas, a edição trazia a coluna "Chêgay", de Anne Kleidy, com as seções "Curtas e grossas", "Brilho Noturno", sobre a noite gay carioca, e "Vídeo Gay", com um breve conto sobre Shirley, travesti carioca que morava em Paris e que decidiu voltar ao Brasil para encontrar com seu bofe $\mathrm{e}^{296}$.

Esse era o tipo de matérias tradicionalmente publicado pela chamada "imprensa marrom" e que teve grande impacto na construção social dos preconceitos voltados contra as pessoas LGBT. Mas nem tudo era sensacionalismo e, em alguns momentos, circulavam matérias mais instrutivas e educativas sobre questões sexuais.

\footnotetext{
${ }^{294}$ BR_RJANRIO_TT_0_MCP_AVU_0595

${ }^{295}$ BR_RJANRIO_TT_0_MCP_AVU_0016_d001

${ }^{296}$ BR_RJANRIO_TT_0_MCP_AVU_0015_d001
} 


\section{"Erotizar a subversão"}

A Informação n. 081/03/DSI/MJ de 31 de março de 1981, originada na AC/SNI e destinada aos diversos órgãos da comunidade de informações, denunciava que o quinzenário "EM TEMPO", em sua edição n. 124, veiculava "matéria repleta de PROPAGANDA ADVERSA". Dentre outros assuntos incômodos para a censura, destacava-se a matéria feita por Wilma Monteiro, Júlio Dias Gaspar e Silvana Afram com o título: "CHANACOMCHANA, o primeiro jornal lésbico do Brasil, declara: por uma prática de erotizar a subversão".

O referido jornal havia sido lançado durante o III Congresso da Mulher Paulista, por iniciativa de ativistas lésbicas organizadas em grupos como o Ação Lésbica Feminista, oriundo do grupo SOMOS, e o Terra Maria-opção Lésbica, mas também por militantes independentes. Foi a primeira publicação impressa deste gênero no país, feito por e destinado para mulheres que desejavam outras mulheres. A matéria que incomodou o monitoramento feito pelos órgãos de controle moral da imprensa divulgava, de forma elogiosa, a novidade no mundo jornalístico da imprensa alternativa, registrando que a publicação surgia:

com uma concepção absolutamente nova e ousada, temos aí o Movimento Lésbico com propostas de quebrar estereótipos, contrariar todo e qualquer tipo de padrões estabelecidos, acreditar no feminismo como a ideologia de transformação radical da sociedade e com uma prática de erotizar a subversão. ${ }^{297}$

Por conta desta matéria e de outras consideradas contrárias ao regime, o relatório concluía que “da análise empreendida, verifica[va]-se que o jornal 'EM TEMPO', em seu exemplar n. 124, de 12 a 25 de Mar 81, volta[va] a infringir dispositivos que permit[iam] o seu enquadramento legal". 298

Na mesma época, um exemplar do jornal "Em Tempo", n. 129, de 28 de maio a 10 de junho de 1981, foi considerado preocupante pelo relatório de "Análise de propaganda adversa" em virtude de "indispor o Governo, o Exército e os Órgãos de Segurança com o povo responsabilizando-os pelos atos terroristas ocorridos no País" ${ }^{299}$. Com efeito, nesta edição, além da greve geral convocada pelo Sindicato dos Metalúrgicos do $\mathrm{ABC}$, com Lula à frente, outras matérias aponta[vam] a responsabilidade do governo por torturas e pelo

\footnotetext{
${ }^{297}$ BR_RJANRIO_TT_0_MCP_AVU_0303

${ }^{298}$ BR RJANRIO TT ${ }^{-}{ }^{-}{ }^{-} \mathrm{MCP}^{-}{ }^{-}$AVU ${ }^{-} 0303$

${ }^{299}$ BR_RJANRIO_TT_0_MCP_AVU_0527
} 
atentado do RioCentro.

Mas esta edição apresentava, ainda, diversas matérias sobre sexualidade que passaram batidas do relatório da repressão, diante de outras denúncias tão pesadas e contundentes sobre a violência da repressão. Por exemplo, foi publicada uma breve nota sobre a semana de eventos de maio, de 1981, realizada pelo grupo SOMOS, a fim de celebrar seus três anos de existência. Depois da exibição de filmes como "Lira do Delírio", "As filhas do Fogo" e "República dos Assassinos", houve um intenso debate sobre a representação dos homossexual no cinema. Conforme registrado na matéria, "um dos pontos mais discutidos foi o chavão de associar homosexualidade com violência e marginalidade" 300 . Outro assunto que marcou essa semana, com uma discussão realizada no dia 22 de maio na sede do grupo na Rua da Abolição com o antropólogo Peter Fry, foi a "situação do movimento homossexual, atualmente dividido em grande número de grupos"301. A centralidade da sexualidade dentre as demais agendas para o movimento também foi bastante discutida.

Na mesma edição, havia o relato de um grupo de mães da zona norte de São Paulo que iniciaram um movimento para acabar com a "pornografia na televisão". O alvo predileto do grupo era o quadro "Educação Sexual", veiculado no programa TV Mulher, transmitido pela Rede Globo, com apresentação da psicóloga Marta Suplicy. Mais de 100 mil assinaturas foram coletadas pelas senhoras que alegavam: "estamos presenciando em nossas televisões uma total inversão de valores, valoriza-se a infidelidade conjugal, o desamor familiar onde são mostradas cenas de estupro, masturbação, troca de casais". Segundo a matéria, o Ministro da Justiça Abi-Ackel, ao receber o abaixo-assinado, afirmou que estava tentando conter "a onda de licenciosidade na programação de vídeo" e que, na contramão da tão propalada flexibilização do controle moral, iria "propor a reformulação da legislação sobre a censura, de modo a permitir uma fiscalização mais eficaz nas emissoras de TV, e alterar a composição do Conselho Superior de Censura, para que dele [pudessem] fazer parte mães de família e representantes religiosos ${ }^{\text {302 }}$. Na época, o conselho já vinha assumindo uma posição mais liberal, reformando diversos vetos e cortes impostos pelo serviço de censura e gerando uma série de resistências na sociedade a na burocracia.

Tal diretriz ia na contramão do que advogava Edmar Morel, jornalista há mais de 50 anos, que havia sido vítima de diversos processos e alvo da censura, a partir de 1964. Em matéria do jornal "Repórter", n. 45, de 3 a 16 de junho de 1981, escrita por Dênis de Moraes e

\footnotetext{
${ }^{300}$ BR_RJANRIO_TT_0_MCP_AVU_0527

${ }^{301}$ BR RJANRIO TT 0 MCP AVU 0527

${ }^{302}$ BR_RJANRIO_TT_0_MCP_AVU_0527
} 
intitulada com uma afirmação de Edmar - "A imprensa tem que discutir sexo" -, ele falava sobre o maior espaço de temas sexuais na imprensa no contexto da abertura:

\begin{abstract}
se o aborto e o homossexualismo hoje estão sendo tratados com realismo e até com certa frieza, é porque o período ditatorial iniciado em março de 1964 quis esconder tudo. Censurou a imprensa, proibiu qualquer discussão sobre a vida das pessoas. Os fatos já existiam e agora cresceram em dimensões gigantescas. A mim, às vezes, choca ler uma matéria sobre homossexualismo, mas isso não quer dizer que a imprensa deva ocultar o que existe. ${ }^{303}$
\end{abstract}

\title{
"Nádegas completamente nuas, seios totalmente à mostra, região púbica descoberta": imagens e fotografias obscenas
}

Uma questão sempre presente nas publicações se referia aos limites impostos às imagens e fotografias publicadas nas matérias. Sem regras muito claras, muitas vezes a mera exibição de um seio descoberto, de uma nádega nua ou de qualquer outra parte íntima do corpo poderia motivar o veto censório.

Neste sentido, provocado por uma denúncia assinada pela Presidente do Movimento de Arregimentação Feminina, que lutava pela "preservação do lar e da família", o comandante do II Exército encaminhou ofício ao Ministro de Exército reclamando da "licenciosidade" das imagens veiculadas em algumas publicações; ele, por sua vez, entregou o expediente em mãos ao Ministro da Justiça Armando Falcão, solicitando-lhe providências. Este acionou o chefe da DP, Coronel Moacyr Coelho, para proceder à análise do caso.

Em 15 de setembro de 1977, Bloch Editores S.A., Editora Três LTDA, Editora Abril LTDA, GRAFIPAR, responsáveis pela edição de revistas como "Ele e Ela", "Status", "Lui", "Homem" e "Peteca", recebem ofício assinado por Rogério Nunes, diretor da DCDP, advertindo sobre os limites impostos pela censura em torno das imagens ou ilustrações que poderiam ser veiculadas nas publicações. Algumas das revistas citadas já haviam tido edições apreendidas e outras estavam sujeitas à verificação prévia de conteúdo por abordarem temas relativos à sexualidade, violando a moral e os bons costumes.

Assim, Nunes reiterou os termos de um expediente de 31 de janeiro, daquele mesmo ano, segundo o qual não estariam permitidas fotografias mostrando

${ }^{303}$ BR_RJANRIO_TT_0_MCP_AVU_0528 
púbica descoberta (sem sunga, tanga, biquini ou qualquer peça de vestuário), modelos em poses lascivas, relacionamento de homossexuais, indumentária transparente, permitindo visualizar partes íntimas do corpo. ${ }^{304}$

E consignou, de forma veemente, que qualquer imagem fora destes parâmetros estritos não passaria mais pelo crivo dos censores.

A guerra ao sexo nas revistas já havia sido oficializada com o Decreto 1.077 de 1970, que previa a regulação de imagens eróticas ou pornográficas. Em 17 de março de 1970, o diretor-geral do Departamento da Polícia Federal, Walter Pires de Carvalho e Albuquerque, editou a Portaria n. 219, que previa, ainda, que

publicações periódicas, ilustradas ou não, que cont[ivessem] matéria que exterioriz[asse] manifestação de temas eróticos de crimes de violência, aventura amorosa, horror, ou de humorismo picante, destinadas a se comunicar com um público adulto, só poder[iam] ser distribuídas aos postos de venda, ou encaminhadas aos seus assinantes, embaladas em material opaco, resistente e hermeticamente fechado.

A Portaria também impunha a inscrição "Proibida a Venda a Menores de 18 Anos de Idade" e salientava que não seriam "toleradas quaisquer publicações que cont[ivessem] matéria pornográfica, libidinosa, obscena, ou sadomasoquista".

Além do mais, quatro tópicos principais deveriam ser rigorosamente obedecidos nas revistas pornográficas: em primeiro lugar, só poderia ser exibido um seio apenas, estando o outro, se visível, ocultado por algum recurso técnico como tecido, espuma de sabão, flanco, corte, escurecimento etc.; a segunda exigência consistia na proibição de exposição das partes genitais, mesmo em sombra; a terceira restrição, que tratava sobre as nádegas, estabelecia que estas só poderiam ser exibidas se fizessem uso dos mesmos recursos impostos aos seios e, por fim, a última regra prescrevia que os "palavrões" deveriam ser eliminados ${ }^{305}$.

Em alguns casos, a DCDP, que se dedicava apenas à esfera específica da censura das diversões, era requisitada para opinar em assuntos morais em outras linguagens ou suportes. Conforme explicado em nota enviada, no ano de 1982, ao Juiz de Menores do Rio de Janeiro por Solange Hernandes, diretora da DCDP: "qualquer pronunciamento deste órgão, vinculado à moral e aos bons costumes fora do âmbito das diversões, VG, publicações (livros, revistas, jornais etc.) toma[ria] a característica de laudo técnico pericial" por não se tratar de esfera

\footnotetext{
${ }^{304}$ BR_AN_RIO_TT_0_MCP_PRO_1030

305 "Censura temia que erotismo derrubasse ditadura militar". Gazeta Mercantil, 3 de agosto de 2001. Disponível em: <http://www.terra.com.br/diversao/2001/08/03/016.htm>. A matéria registra, ainda, o caso da revista "Nova", número 3, de dezembro de 1973, que teve diversos artigos cortados integralmente pela censura, dentre eles o intitulado "Mulheres que vivem cercadas de homossexuais", que foi proibido de circular.
} 
habitual de atuação daquela repartição ${ }^{306}$.

Assim, a DCDP ganhava ainda mais centralidade e protagonismo na definição da linha censória, subsidiando, por meio de pareceres, inquéritos policiais por atentado à moral e aos bons costumes, mesmo que fora de suas atribuições originais. Isto conferia ao órgão uma espécie de legitimidade e autoridade de especialistas nos assuntos da censura

Um exemplo disto foi o Laudo Censório Pericial feito, sob requisição do Ministério Público, pelo técnico Coriolano Fagundes sobre a revista mensal FIESTA, ano VI, n. 70. Na opinião do censor,

a revista em exame cont[inha], a partir das contracapas, pornografia de homossexualismo feminino e masculino, da prática de cunilíngua, de inserção de dedos em vulvas e em ânus, relação sexual em público, insinuação de coito anal, desatinos e perversões outras que a transforma[vam] em publicação altamente deletéria e corruptora dos costumes.

E arrematou, apenas com breve fundamentação no Decreto-Lei 1.077 de 1970, que "[era] inegável a existência de matéria ofensiva à moral e aos bons costumes, na revista FIESTA objeto do presente Laudo"307.

\section{"Difícil afirmar que tais recursos ofendem à moral e aos bons costumes": maior tolerância ao erotismo publicitário}

Nem a publicidade ficava fora do radar do filtro moral dos órgãos de informação. Apesar de não ser controlada pelas mesmas agências de censura que cuidavam das publicações ou das diversões públicas, as propagandas, que usavam cada vez mais uma abordagem erótica ou sexualizada nessa fase de abertura, eram acompanhadas de perto e, aparentemente, com maior tolerância.

No dia 5 de janeiro de 1979, a título de exemplo, o jornal Tribuna do Paraná estampou em suas páginas uma peça de publicidade de um produto para automóveis capaz de promover uma economia do consumo de combustível. Ao fundo, via-se a imagem de uma mulher nua com os seguintes dizeres em destaque ao lado da foto do produto: "AUMENTE A POTÊNCIA".

Um ofício do DSI foi endereçado ao Ministro da Justiça, Armando Falcão, com a

\footnotetext{
${ }^{306}$ BR_DFANBSB_NS_AGR_COF_CSO_0233_d

${ }^{307}$ BR_DFANBSB_NS_AGR_COF_CSO_0233_d
} 
advertência de que fugiria às "atribuições da Divisão de Censura e Diversões Públicas (DCDP) qualquer atitude contra o tipo de publicidade ora divulgada". Acrescentava-se, no comunicado às instâncias superiores, que tal publicidade "contraria[va] as disposições da Lei de Imprensa (Lei n. 5.250/67), cabendo a competente ação penal por denúncia do Ministério Público, ou então, como atitude imediata, a apreensão dos impressos". 308

A "assessoria de assuntos sigilosos" do Ministério da Justiça opinou que este processo, autuado sob o n. MJ-100 371-S/79, deveria ser encaminhado para análise da Consultoria Jurídica da pasta. Curioso que o Dr. Ernani Magalhães Souto, em seu parecer datado de 18 de maio de 1979, estacou: "parece-nos que o apelo erótico na publicidade mais recente vem sendo bastante explorado pelas agências publicitárias. Parece-nos ainda difícil afirmar que tais recursos ofendem à moral e aos bons costumes, tal como nos afigura o caso presente" ${ }^{309}$. Nota-se, assim, que havia uma compreensão de que o uso publicitário do erotismo como estratégia de marketing parecia ser mais tolerável do que em outras circunstâncias.

Após ponderar sobre a legislação atinente ao caso e ressaltar a prerrogativa do Ministro de retirar de circulação a revista, mesmo sem necessidade de prévia determinação judicial, o consultor jurídico opinou que “a possível apreensão do periódico não mais nos parec[ia] aconselhável ou mesmo oportuna, tendo em vista o decurso [de] cinco meses desde sua publicação" ${ }^{310}$.

Este argumento expressava, mais uma vez, que deveria haver uma tolerância maior com o mercado publicitário em relação ao uso de imagens ou fotografias eróticas ou apelativas. Além disso, a burocracia impossibilitou uma avaliação de mérito do assunto, demorando 5 meses, após a sua publicação, para realizá-la, de modo que o objeto da discussão já estaria perdido, uma vez que a propaganda já havia circulado.

\section{"Somente dentro da legalidade deve a autoridade agir"}

As penalidades aplicadas poderiam ser excessivamente rigorosas em caso de descumprimento das regras. Um dos jornais de maior circulação que mais faziam sensacionalismo com as homossexualidades era "O Povo". Um caso ilustra bem a insensibilidade com a qual o periódico tratava o tema. Francinet mandara uma carta sincera,

\footnotetext{
${ }^{308}$ BR AN RIO TT 0 MCP PRO 1641

${ }^{309}$ BR_AN_RIO_TT_0_MCP_PRO_1641

${ }^{310}$ BR_AN_RIO_TT_0_MCP_PRO_1641
} 
em 14 de agosto de 1982, para a redação do jornal, pedindo ajuda para seu problema. Provavelmente uma travesti, ainda confusa sobre a expressão de sua identidade de gênero, ela pedia que o jornal divulgasse sua história para que a TV Globo pudesse promover uma campanha para financiar sua cirurgia de "mudança de sexo". Em sua carta, ela afirmava: "Meu problema é grande e tenho medo de não ser compreendida. Acontece que não sei se sou homem ou mulher. Sou bonita e minha alma é de mulher, mas o meu corpo continua de homem. Preciso de uma ajuda" 311 .

$\mathrm{Na}$ edição do dia 19 de agosto, o jornal publicou, na capa, um recorte da carta escrita à mão por Francinet, com a seguinte manchete: "TV Globo vai ter que dar a xoxota: homossexual procura recursos na Venus Platinada para trocar de sexo. Pretende viajar para submeter-se a uma delicada operação que vai realizar o sonho acalentado desde a infância”. Dentro do jornal, frases sensacionalistas tais como "Bicha quer virar mulher e pede ajuda" e "Homossexual tem um sonho na vida: transformar-se numa bela fêmea"312.

Esse tipo de publicação flagrantemente degradante enseja a Informação $n$. 290/04/DSI/MJ, de 17 de setembro de 1982, originado na AC/SNI e difundido para o gabinete do Ministro da Justiça, dedicada exclusivamente ao jornal “O POVO”, do Rio de Janeiro, que “[vinha] estampando, sistematicamente, nas suas páginas, grandes manchetes com expressões atentatórias à moral e aos bons costumes, abordando problemas policiais e sexuais". Lembra o informe que "a publicação e exteriorização de assuntos contrários à moral e aos bons costumes [era] proibida no País"313.

Este mesmo relatório da Agência Central do SNI seguiu acompanhado das Informações n. 306/04, de 14 de outubro de 1982, n. 317/19, de 9 de novembro de 1982, n. 317/04, de 12 de novembro de 1982, todas com o mesmo objeto, trazendo em anexo recortes do jornal com diversos exemplos que se enquadrariam na restrição legal: "Greluda troca marido legal por garotonas"; "Flagrou marido dando o brioco: mulher fez escândalo no motel ao ver seu homem de quatro sendo enrabado"; "Maricona morreu com o brioco para o alto"; "Lésbica louca de paixão trucidou o marido da amante".

Tais matérias, dentre outras, provocaram a apreensão de diversos exemplares do jornal, inclusive usando de violência na invasão da redação do periódico. Tanto que a $\mathrm{OAB} / \mathrm{RJ}$, por meio do ofício n. 726/GAB/83, endereçado ao Ministro da Justiça, repudiou o modo como vinham acontecendo as apreensões, mesmo após ter recebido o Ofício n. 2368, de

\footnotetext{
${ }^{311}$ BR AN RIO TT 0 MCP PRO 1839

${ }^{312}$ BR_AN_RIO_TT_0_MCP_PRO_1839

${ }^{313}$ BR_AN_RIO_TT_0_MCP_PRO_1839
} 
dezembro de 1982, no qual o Ministro da Justiça justificava as arbitrariedades, anexando recortes com as matérias sensacionalistas, de teor pornográfico.

No entanto, segundo a entidade da advocacia carioca, representada pelo Presidente Dr. Hélio Saboya, não se tratava de "defender a linha editorial do jornal em causa, nem tampouco atacá-la", mas sim de condenar "os métodos de que se valeu a autoridade para coibir o que foi entendido por esse Órgão como conduta infringente da Lei de Imprensa e da Constituição Federal". E terminou a carta "repelindo as invasões ao local onde era impresso aquele jornal, em consonância com a profunda convicção dos advogados de que somente dentro da legalidade deve a autoridade agir, quando entenda tenha sido ela violada por quem quer que seja"314.

\section{Imprensa "gay"}

Além do jornal "Lampião da Esquina", voltado para o público homossexual e tratado detalhadamente no capítulo 5, do presente trabalho, houve relativamente poucas matérias e publicações, ao longo do período da ditadura, abordando as homossexualidades de maneira mais séria e respeitosa, de modo a escapar das tentações dos estereótipos e preconceitos reproduzidos em larga escala pela imprensa marrom, conforme discorrido anteriormente.

Diversas razões elucidam esta escassez. A primeira e mais evidente explicação era a questão comercial: o sensacionalismo com suas manchetes chamativas tinham um grande apelo popular para venda de exemplares, enquanto que um tratamento jornalístico mais comedido e profundo provavelmente não contasse com o mesmo interesse do público; além disso, a permanente vigilância política dos veículos de imprensa, com ameaça de diversas ordens, provocava uma compreensível apreensão na abordagem de temas vistos, no mínimo, como controversos.

As diversas publicações caseiras e com distribuição concentrada em alguns pontos urbanos das maiores cidades, que estavam se expandindo desde os anos 1950 e 1960, acabaram prejudicadas com o advento da ditadura. Neste sentido, em entrevista para o Lampião, Anuar Farah e Agildo Guimarães explicavam como o golpe de 1964 fizera com que eles tivessem de parar com os jornais que editavam, especialmente "O Snob", por medo de represálias. Também a Associação Brasileira de Imprensa Gay - ABIG - foi afetada. Afirmou Farah, na entrevista: "nós fundamos a ABIG com todos os jornais gays editados no Brasil... A

\footnotetext{
${ }^{314}$ BR_AN_RIO_TT_0_MCP_PRO_1839
} 
ABIG durou de 62 a 64. Depois veio a Revolução e acabou"315.

O endurecimento político e o controle cultural que se seguiram ao AI-5, em 1968, conseguiram salgar o terreno para que não florescessem mais publicações voltadas a estes segmentos específicos ou para que, ao menos, não tratassem dos homossexuais como seres anormais, doentes ou criminosos. O primeiro esforço mais consistente, no sentido de romper com o tom hegemônico da mídia, que se esforçava para a homossexualidade em tabu, foi do jornalista Celso Curi, mas durou pouco devido à censura que sofrera.

\section{"Defendendo-se abertamente as uniões anormais entre seres do mesmo sexo"}

Celso Curi era então um jovem jornalista quando estreou, em 5 de fevereiro de 1976, sua "Coluna do Meio", no jornal paulista Última Hora ${ }^{316}$. Sempre com bom humor, ele inventava personagens para dialogar com o público, fazia uma coluna social, contava piadas e publicava cartas de homossexuais que buscavam amizade ou outras coisas mais com outros iguais na seção "Correio Elegante".

Eis um exemplo de anúncio publicado nas páginas do jornal pela remetente identificada como "Dondoca da Zona Sul":

sou loiro, olhos azuis, $1 \mathrm{~m} 70$ de altura, 65 quilos, 33 anos, inteligente, desinibido, rico, adoro festas e outros babados. Desejaria corresponder-me com adolescentes morenos, bronzeados, olhos verdes, bonitos, inteligentes (não precisam ser cultos), para simples amizade ou futuro compromisso. Fotos de corpo inteiro na primeira carta. ${ }^{317}$

Mas não era só um espaço de troca de correspondências para encontros entre homossexuais, ainda que só isso já significasse muito naquele momento. Curi também despejava algumas pílulas de sabedoria de personagens reais ou imaginárias, tais como "Quem dá aos pobres, empresta a Deus" (Baby Piolin); “Gracias a la vida que me ha dado tantos (Morrocha Martinez)”; “Antes mal acompanhada do que só (Dod Darling); "O homem

\footnotetext{
315 ““'Snob', 'La Femme'... Os bons tempos da imprensa guei”. Lampião da Esquina, n. 28, set., 1980, p. 7.

${ }^{316}$ Curi vivia na Alemanha e havia regressado ao Brasil apenas para resolver um problema com seu passaporte, quando foi convidado por Samuel Weiner, diretor do jornal que acabara de conhecer, para escrever na seção de Cultura. "Três anos depois tive a idéia de criar a coluna porque o Plínio Marcos escrevia uma coluna extremamente machista; havia outra, escrita por uma mulher sobre feminismo... Então fui falar com o Samuel, dizendo que eu queria escrever uma coluna falando de homossexualidade. O Samuel reagiu espantado: "Você vai me matar! Os Frias vão ficar loucos! Ninguém vai querer'”. A coluna só começou depois da saída do Samuel, em fevereiro de 1976. Cf.: DIAS, Lucy. Anos 70: enquanto corria a barca. São Paulo: Senac, 2004, p. 301.

${ }^{317}$ TREVISAN, João Silvério. Demissão, processo, perseguições. Mas qual é o crime de Celso Curi. Lampião da Esquina, n. 0, abril de 1978, p. 6.
} 
que diz dou, não dá. Porque quem dá mesmo, não diz" (Vinicius de Moraes) ${ }^{318}$.

A maneira inovadora e engraçada como Curi tratava desse tema, que lhe rendeu a glória de ser uma das colunas mais lidas de todo o jornal, logo gerou reação dos órgãos de repressão e do próprio sistema de justiça. "Celso Curi processado: mas qual é o crime deste rapaz" foi estampado na capa do número experimental "zero" do Lampião da Esquina. A chamada era para uma longa matéria de João Silvério Trevisan sobre o caso então paradigmático de perseguição a Curi.

Isto porque, provocado pelos órgãos de informação do DPF, que em outubro de 1976 acusara o jornalista de "promover a licença de costumes e o homossexualismo especificamente", o Ministério Público instaurou procedimento investigatório e apresentou denúncia alegando violação ao art. 17 da Lei de Imprensa (n. 5.250/1967) ${ }^{319}$. Segundo o promotor, em sua peça acusatória, o denunciado teria ofendido "a moral pública e os bons costumes" em sua Coluna do Meio, "cujo nome não deixa dúvidas quanto ao assunto tratado, o homossexualismo que é claramente exaltado, defendendo-se abertamente as uniões anormais entre seres do mesmo sexo, chegando inclusive a promovê-las através da seção Correio Elegante". 320

A denúncia fora aceita e tramitava regularmente quando, em novembro de 1977, Curi foi despedido do jornal por suposta redução de custos em um momento de crise financeira. Além disso, teve de assumir o ônus de sua própria defesa, pois quando procurou o advogado do Grupo Folha para lhe representar no caso, já que o grupo era proprietário do jornal, o profissional parece ter-se recusado: "Disse que não defendia 'esse tipo de gente",321.

Quase transcorrido o prazo de prescrição e o consequente arquivamento do processo, em 12 de março de 1979, o juiz da 14 a Vara Criminal de São Paulo, Dr. Regis de Castilho Barbosa, finalmente julgou o processo, absolvendo Celso Curi em uma sentença bem fundamentada. O magistrado alegou à Justiça "não [ter] como escopo abrigar exigências extraordinárias de um pudor hipertrófico" e que não via crime algum "em noticiar fatos sobre homossexualismo", pois a coluna "não cont[inha] o caráter de obscenidade que lhe quiseram

\footnotetext{
${ }^{318}$ TREVISAN, João Silvério. Demissão, processo, perseguições. Mas qual é o crime de Celso Curi. Lampião da Esquina, n. 0, abril de 1978, p. 6.

319 "Art. 17. Ofender a moral pública e os bons costumes: Pena: Detenção, de 3 (três) meses a 1 (um) ano, e multa de 1 (um) a 20 (vinte) salários-mínimos da região". Segundo depoimento de Curi no documentário sobre o Lampião da Esquina, o promotor considerou um atentado à moral e aos bons costumes até mesmo a expressão "Cidade Maravihoooooosa" que aparecia na coluna. LAMPIÃO da Esquina. Lívia Perez. São Paulo: Doctela, 2016. $82 \mathrm{~min}$, altura do $3 \mathrm{~min}$.

${ }^{320}$ TREVISAN, João Silvério. Demissão, processo, perseguições. Mas qual é o crime de Celso Curi. Lampião da Esquina, n. 0, abril de 1978, p. 6.

${ }^{321}$ COLAÇO, p. 223.
} 
atribuir" ${ }^{322}$.

Segundo Trevisan, na história da Justiça brasileira, "tratava-se do primeiro processo em que o homossexualismo esteve envolvido como objeto direto de denúncia. Assim, com a absolvição de Celso Curi, criou-se um importante precedente jurídico para a defesa dos direitos dos homossexuais no país" ${ }^{\text {323 }}$. Antes mesmo do desfecho feliz deste caso, contudo, outros veículos da imprensa identificaram o nicho de mercado que se abria com a presença cada vez mais notada dos homossexuais na cena pública brasileira.

\section{"O poder homossexual"}

A Isto É, de 28 de dezembro de 1977, publicou "Os gays saíram à luz". Escrita a diversas mãos, pelos jornalistas Alex Solnik, Fernando Sandoval, Maria Christina Pinheiro, Vera Dantas, Dulce Tupy, Tim Lopes, Lenora Bargas, José Aparecido Miguel e Nirlando Beirão. A matéria, de 8 páginas, em uma das principais revistas semanais, causou enorme impacto na época e vendeu uma grande quantidade de exemplares no período de final de ano.

Dividida em seções que abordavam perfis de diferentes personalidades vinculadas ao universo homossexual, tais como Vadinho, o inventor do cartão de crédito Gay Card com descontos especiais para gays, casado com uma mulher, mas assumidamente homossexual; o médico Manoel Messias Bacco, psiquiatra especialista em tratamento de homossexuais e que pretendia ser um candidato pelo MDB para defender esta categoria; o costureiro Dener, estilista da high society, que afirmava ter "inventado a frescura no Brasil"; o cantor Ney Matogrosso, que chocava a sociedade com suas performances e sua bissexualidade escancarada, além de um trecho sobre a cidade de Pelotas no Rio Grande do Sul e outro sobre a Coligay, torcida organizada do time Grêmio e formada apenas por homossexuais. Por fim, a última seção publicava, ainda, uma carta de Aguinaldo Silva, na qual ele anunciava as novidades sobre o jornal Lampião, ainda em gestação.

Logo de início, a matéria criticava a representação tradicional dos homossexuais como "anormais", "desajustados", "bichas" e outros nomes que dominavam a imprensa. Rompendo com esta visão estigmatizadora, os jornalistas esmiuçavam o drama da semiclandestinidade compulsória vivida pelos gays em uma sociedade que os discriminava - e discrimina - e que não os tolerava, destacando a repressão das forças policiais e das normas legais tão presentes

\footnotetext{
${ }^{322}$ TREVISAN, João Silvério. Justiça inocenta Celso Curi. Lampião da Esquina, n. 11, abril de 1979, p. 3.

323 TREVISAN, João Silvério. Devassos no paraíso: a homossexualidade no Brasil, da colônia à atualidade. São Paulo: Record, 2007, p. 347.
} 
durante a ditadura:

por força das circunstâncias, o homossexual é igual barata: só sai à noite. Em geral, mascarado, para não ser reconhecido pelo colega de repartição ou pelo chefe do escritório. As circunstâncias: o desprezo social e as represálias até policiais. Neste país, as leis ainda insistem em falar, repugnantemente, como no tempo de Oscar Wilde, em 'sodomia'. Aqui, 'atentado ao pudor' é noção suficientemente ampla para incluir até filmes de arte. ${ }^{324}$

O caso de Celso Curi foi referenciado de partida na matéria, demonstrando como ela foi inspirada provavelmente na atuação pioneira do jornalista na imprensa. Segundo a matéria, ele cometeu "o único pecado de publicar um 'Correio Elegante' dentro de sua coluna” e que, por isso, fora processado, acusado de violar "a moral e os bons costumes", sendo descrito como, possivelmente, o "primeiro mártir do movimento homossexual brasileiro". 325

Na já citada entrevista que saiu no número zero do jornal "Lampião da Esquina", Curi desenvolvia sua opinião de que não haveria um movimento homossexual no Brasil, mas somente uma movimentação:

quando me perguntam pelo movimento homossexual no Brasil, respondo que ele não existe. Existe é uma movimentação homossexual, da boate para o táxi, do táxi para a sauna. No Brasil nem movimento de manicure é possível. Imagine um centro acadêmico de manicure da Lapa! Coisa muito perigosa neste país. ${ }^{326}$

O coreógrafo e artista Lennie Dale, um dos Diz Croquettes, também afirmou, em entrevista ao mesmo jornal: “eu acho que no Brasil não vai ter movimento nesse momento. ${ }^{327}$

Entretanto, a matéria da Isto É respondia a tais colocações sustentando:

movimento ou movimentação? Jamais se chegará a uma unanimidade sobre isso. Mas é certo que, no último par de anos, nos últimos meses, vem ocorrendo um rosário de episódios, de fenômenos bem diferentes daqueles do tempo exclusivo dos travestis e das bichas-loucas. O Brasil gay se mexe mais do que isso, se articula". 328

Apesar do pessimismo realista de Curi devido aos contratempos vividos ainda em tempos de ditadura, havia diversos sinais que indicavam, naquele momento, a passagem de

\footnotetext{
324 “O poder homossexual”. Isto É, 28 de dezembro de 1977, p. 8.

325 "O poder homossexual". Isto É, 28 de dezembro de 1977, p. 8.

${ }^{326}$ TREVISAN, João Silvério. Demissão, processo, perseguições. Mas qual é o crime de Celso Cúri. Lampião da Esquina, n. 0, abril de 1978, p. 6.

${ }^{327}$ Lampião da Esquina, n. 2, de julho de 1978, p 5.

328 "O poder homossexual". Isto É, 28 de dezembro de 1977, p. 9.
} 
uma "movimentação" para um verdadeiro "movimento" de homossexuais. Em meio ao processo de distensão progressiva e de abertura controlada, os homossexuais desafiavam o ritmo lento da transição, ocupando cada vez mais a cena pública. Eram diversos os indicativos de aglutinação dos homossexuais, que começavam a politizar essa identidade tão marginalizada com um discurso cada vez mais claramente marcado pela tarefa da liberação sexual e com um movimento organizado contra as rígidas estruturas morais do regime. ${ }^{329}$

Essa fama do "Brasil gay" já começava a tomar o mundo. Stan Lehmann, gerente de notícias da United Press International, afirmou, à reportagem: “dizem que o Rio é, fora dos EUA, a capital gay do mundo". Sua agência de notícias preparava uma ampla reportagem sobre a temática, esperando-se que tal propaganda levaria a um aumento expressivo do fluxo de turistas gays em busca dos prazeres tropicais. Neste mesmo momento, rodavam também diversas publicações dirigidas e de circulação restrita a determinados circuitos homossexuais, que são destacadas na matéria da revista, tais como Entender, Gente Gay, Gay Press Magazine, Mundo Gay, todas sob olhar atento da vigilância dos órgãos de informação.

Mas nem todos celebravam a organização ainda incipiente dos homossexuais. $\mathrm{O}$ cantor Ney Matogrosso, por exemplo, afirmou à revista: “eu me interesso por mulher também, eu gosto muito de mulher, como gosto de homem também. Para mim, é tudo igual". Propondo-se a desorganizar as classificações e, assim, rompendo com o que considerava "rótulos", Ney confessou estar atento aos primeiros passos do movimento de homossexuais, mas, ao mesmo tempo, desdenhou desse mesmo movimento ao afirmar:

eu não acredito em movimento de conscientização do homossexual. Vejo que as pessoas estão se agrupando, mas eu não acredito. Eu jamais entraria, jamais me agregaria. Porque acho que não é preciso. Você pode viver a sua vida perfeitamente sem precisar estar agregado a movimento, a nada. Nem político, nem a coisa nenhuma. Acho que, se você se agregar, você já está se limitando.

A matéria foi fundamental por pautar, na grande imprensa, a temática da homossexualidade de modo não patologizante ou estigmatizante. É evidente que o interesse comercial da revista foi determinante na escolha da pauta e da abordagem, atestando certa sensibilidade para detectar o interesse social represado. Contudo, logo no ano seguinte, uma parcela da militância já colocaria em questão os limites deste tipo de discurso que comercializava a tolerância em relação aos homossexuais. Neste sentido, João Silvério Trevisan criticou a matéria da revista Isto É, afirmando:

\footnotetext{
${ }^{329}$ Ver, neste sentido, o capítulo 4, sobre o movimento homossexual, neste trabalho.
} 
faz algum tempo, a revista ISTO É apresenta o tema Poder Homossexual na capa, ilustrada pela foto de duas mãos masculinas entrelaçadas. Houve referências ao seu liberalismo, abertura, coragem até. Ora, esse número da revista conseguiu vender horrores em época de fim de ano, quando ninguém lê; tratava-se, antes de tudo, de um inteligente golpe de marketing. Quanto ao artigo propriamente dito, sua tônica eram pessoas desculpando-se de serem homossexuais - onde até Ney Matogrosso, que vende pacas às custas de sua imagem de bicha, afirmava ser apenas um artista descrente em movimento de conciliação do homossexual. Um fato é inegável: o homossexual está sendo digerido e transformado em produto de consumo. ${ }^{330}$

A afirmação da homossexualidade e a politização dessa identidade em um contexto de abertura democrática e de expansão do mercado, com uma ampliação das camadas médias urbanas, trouxeram, à ordem do dia, a tensão entre a assimilação dos homossexuais apenas pelo consumo e uma efetiva integração pela cidadania.

Não obstante, a ditadura estava de olho na emergência deste espaço conquistado pela "Imprensa Gay". O CIE, por meio da Informação n. 1676S/102-A11/CIE, difundida para AC/SNI, CISA, CENIMAR, DSI/MJ, em 29 de dezembro de 1977, apontava que a reportagem publicada pela revista Isto $E$ era "uma elegia [sic] à homossexualidade masculina", além de apresentar "aspectos chocantes para os moldes educacionais da sociedade brasileira". 331

Segundo o relatório oficial, que fazia um resumo do conteúdo da referida matéria, tratava-se de um encorajamento aos homossexuais que viviam às escondidas para assumirem sua condição, notando-se um "esquema de apoio à atividade dos homossexuais" coordenado a partir de "órgãos de imprensa sabidamente controlados por esquerdistas". Mas, e o que parecia mais grave, estava clara a "intenção dos homossexuais de se organizarem em movimentos e de ocuparem um lugar certo - inclusive politicamente", de onde se extrai o "alto interesse comunista no proselitismo em favor do tema". ${ }^{332}$

O órgão de informação ainda esclarecia, em tom de cobrança de providências, que "causa[va] estranheza [que uma] reportagem dessa natureza [fosse] publicada em revista de venda livre nas bancas", criticando a "maior liberdade [que] foi dada à imprensa dentro de uma diretriz política", que já se estaria convertendo em um "uso exagerado dessa liberdade", já que estavam em jogo “preceitos morais e éticos que são o sustentáculo da família brasileira,

\footnotetext{
${ }^{330}$ TREVISAN, João Silvério. "Um produto novo na praça”, Lampião da Esquina, n. 2, de julho de 1978 , p 5.

${ }^{331}$ BR_AN_RIO_TT_0_MCP_PRO_1219

332 BR_AN_RIO_TT_0_MCP_PRO_1219
} 
principal célula de resistência ao avanço de ideologias espúrias" 333 .

Por fim, em relação à declaração do estrangeiro Stan, da agência de notícias, o documento registra: "não bastasse a campanha de difamação que o BRASIL sofre no Exterior por ação do MCI", um estrangeiro ainda "[fez] declarações desairosas ao valor moral do país e ainda prev[iu] reportagens difamatórias sobre o assunto sem qualquer ônus de responsabilidade". 334

Por conta dessa matéria, em 1978, foi instaurado inquérito criminal contra os onze jornalistas envolvidos na escrita de "O poder homossexual” por "fazer[em] apologia malsã do homossexualismo". No mesmo ano, também pela mesma acusação, jornalistas da revista Interview também foram indiciados criminalmente ${ }^{335}$. Em 1979, era a vez do Lampião da Esquina e seus editores sofrerem o mesmo tipo de assédio, com até mais contundência ${ }^{336}$. Tais fatos demonstram a postura nitidamente homofóbica da ditadura na orientação de sua censura e serviços de informação e segurança.

\section{Outras diversões públicas}

Além das formas de entretenimento e expressão artística mais tradicionais, outros tipos de diversões públicas também foram alvo da repressão censória ou policial ao longo do período analisado, como os bailes e salões de carnaval, por exemplo. A Folha de São Paulo de 6 de março de 1973, em matéria intitulada "Decadência do Municipal", relatava o esvaziamento do tradicional baile de carnaval do Teatro Municipal do Rio de Janeiro, com as proibições morais que estavam descaracterizando a festa que se tornara uma marca da cidade:

Com as portarias proibindo as demonstrações ostensivas de homossexualismo, principalmente na televisão, os organizadores do baile resolveram proibir o desfile e o concurso de fantasias dos 'profissionais do carnaval', consentindo na apresentação sem interrupção da música de alguns destaques mais vistosos das escolas de samba. ${ }^{337}$

Outra matéria publicada no jornal O Globo, de 14 de janeiro de 1975, ostenta o título "biquini proibido nos salões". O chefe da Divisão de Censura e Diversões Públicas, o

\footnotetext{
${ }^{333}$ BR_AN_RIO_TT_0_MCP_PRO_1219

${ }^{334}$ BR_AN_RIO_TT_0_MCP_PRO_1219

${ }^{335}$ COLLAÇ, p. $\overline{2} 24$.

${ }^{336}$ Ver capítulo sobre o jornal no presente trabalho.

337 "Decadência do Municipal”. Folha de SP, 6 de março de 1973. BR_AN_RIO_TT_0_MCP_PRO_0690
} 
delegado Edgar Façanha, afirmara, na ocasião, que "os critérios de censura e os padrões morais [haviam variariado] de acordo com os frequentadores de cada salão", ressaltando que "os biquinis continuam proibidos, mas [que] haver[ia] uma compreensão para as fantasias de fundo erótico", afinal, "a Polícia não [era] censora da comunidade", mas, sim, "sua protetora". De modo que "não precisa[ria] inventar padrão de moralidade, [porque] o povo sab[ia] como se comportar",338.

Este mesmo delegado, conforme aponta James N. Green, foi bem atuante no sentido de proibir, a partir de 1971, as travestis de participarem do carnaval. Segundo declaração do delegado, "os homossexuais não pod[iam] ser proibidos de entrar no baile público, desde que se comport[assem] convenientemente".339

$\mathrm{O}$ argumento de que havia diversas moralidades concorrentes, que variavam entre si conforme os ambientes, e que as pessoas deviam saber como se comportar de acordo com regras que são tacitamente compartilhadas, como se a moralidade fosse uma evidência clara e pressuposta, era constantemente mobilizado nas defesas mais sofisticadas da censura.

\section{Conselho Nacional de Censura e começo do fim: os anos 1980}

O debate em torno das regras da censura se intensificaram ao final do período da ditadura. O desgaste do filtro moral já estava escancarado e as críticas, em um contexto de maior liberdade de manifestação e de opinião, provinham de setores cada mais vez mais expressivos da sociedade brasileira. Um dos palcos mais importantes dos debates em torno das mudanças na censura foi no próprio CSC.

O "Correio Braziliense", de 28 de março de 1980, trazia em destaque a matéria “Censura: Estado não cometerá mais abusos, é o que se promete" ${ }^{340}$. Segundo a reportagem, os membros do Conselho Superior de Censura estavam até incomodados com a terminologia que batizava o órgão, preferindo um "apelido menos comprometido com o conservadorismo ainda vigente", tal como Conselho de Diversões Públicas.

Além disso, mencionava-se, ali, o projeto de lei n. 55 (PL 55/1979), de autoria do Deputado Alvaro Valle (PSD/RJ), que extinguia a censura ao livro e às obras teatrais, revogando o decreto-lei 1077, de 26 de janeiro de 1970, e alterando a lei 5536, de 21 de

\footnotetext{
338 "O Globo", de 14 de janeiro de 1975.

${ }^{339}$ GREEN, James Naylor. Além do Carnaval: a homossexualidade masculina no Brasil do século XX. São Paulo, Unesp, 2000, p. 369.

${ }^{340}$ BR_DFANBSB_ZD_0_0_0038A_0043_d0002
} 
novembro de 1968. Tal PL foi apresentado na $3^{\text {a }}$ Sessão Extraordinária do Conselho Superior De Censura, realizada em 27 de março de 1980, pelo próprio autor da proposta legislativa. Conforme consta da ata da referida reunião, “o Dr. Octaviano Nogueira deu a palavra ao Deputado Alvaro Valle, que agradeceu o convite para comparecer à reunião, lendo sua exposição a respeito da censura política e moral, explicando seu projeto de lei 55-A".341

A distinção entre censura política e moral, de que já se tratou aqui, constava da justificativa do referido PL do Deputado Valle. Segundo a matéria do jornal O Globo, "pela primeira, entend[ia-se] que [era] inadmissível que uma sociedade em ritmo de redemocratização possa adotar soluções tolhedoras da liberdade política e no campo artísticocultural". Segundo o deputado,

no campo das artes, a censura política [era] ainda mais odiosa porque traduz[ia] o esforço de um grupo eventualmente dominante para cercear a criação, impedindo que o homem exerc[esse] o mais elementar de seus direitos, o de extroverter o produto de sua inteligência, de sua sensibilidade, de suas angústias, ou de seus sonhos, de tudo aquilo afinal que o distingue dos irracionais. Por isso, a censura [era] essencialmente embrutecedora do homem e da sociedade. ${ }^{342}$

No que se refere à censura moral, o deputado se posicionava favoravelmente à mesma, "levando em conta as características ainda vigentes da sociedade brasileira como uma sociedade de valores cristãos". Um substitutivo, que transformava o Conselho Superior de Censura em Conselho Superior de Classificação, ou seja, com uma censura mais classificatória a partir de faixas etárias definidas, foi apresentado pelo deputado Marcelo Cerqueira e considerado mais "eficaz" entre os membros desse órgão ${ }^{343}$.

A distinção entre censura política e moral, assim, ainda que útil dentro de certos limites do ponto de vista analítico, acabou servindo de justificação, no calor dos acontecimentos, para a persistência de um controle moral mesmo com o relaxamento e a distensão dos mecanismos de controle e repressão da ditadura. Essa era uma intenção declarada do plano de reformulação que Abi-Ackel implementou no Ministério da Justiça.

Conforme esclarece uma matéria publicada em 31 de outubro de 1981, o Serviço de Censura e Diversões Públicas, bem como as repartições relativas aos estrangeiros no Brasil, deixariam de estar vinculadas à Polícia Federal para passar ao gabinete do próprio Ministro. A reportagem ainda mencionava que, ao ser apresentado como mero remanejamento de

\footnotetext{
${ }^{341}$ BR_DFANBSB_ZD_0_0_0038A_0043_d0002

${ }^{342} \mathrm{BR}$ DFANBSB ZD $0000038 \mathrm{~A}^{-} 0043$ d0002

${ }^{343}$ BR_DFANBSB_ZD_0_0_0038A_0043_d0002
} 
organograma, o plano "representa[va] pelo menos o desengajamento físico de um setor de alta sensibilidade política, como [era] a censura, dos órgãos de segurança”. Assim, o setor de censura passaria a estar afeto ao Conselho Superior de Censura e, neste contexto de abertura, “a censura dever[ia] despojar-se do caráter repressivo que assumi[ra] em seu passado policial, para se dedicar exclusivamente no combate aos excessos praticados contra a moral e os bons costumes". 344

Tal fato mostra que, enquanto a dimensão estritamente política do autoritarismo era abrandada pelo projeto de distensão e liberalização do próprio regime, a manutenção de uma hegemonia cultural e de valores, pautada por uma moral conservadora, prosseguia como preocupação até mesmo de políticos contrários a esta, mas favoráveis, ainda, ao mesmo endurecimento moral que se vira até ali.

Neste debate, é importante ressaltar que o Ministro da Justiça Ibrahim Abi-Ackel era posto em situação delicada, pois vinha sendo "alvo de manifestações 'conservadoras', principalmente da Tradicional Família Mineira, no sentido de conter a onda de liberação do Conselho". Cartas e mais cartas eram enviadas ao Ministro, que tentava se eximir de sua responsabilidade por decisões do Conselho nos casos em que não houvesse unanimidade interna, mesmo com o voto decisivo que tinha, como no caso do filme pornográfico "Emannuelle", que foi liberado depois de muita polêmica e falta de consenso no interior do órgão. A estreia do filme havia sido prevista, inicialmente, para a Semana Santa, ideia da qual foram demovidos os organizadores para evitar uma maior confrontação com o regime. ${ }^{345}$

Tal assunto foi adquirindo maior visibilidade no ocaso da ditadura e no projeto de distensão controlada durante a abertura negociada do próprio regime, que passava a avaliar mais criticamente o desgaste público causado pelos órgãos censores. No começo de 1980, uma decisão do Conselho Superior de Censura flexibilizou entendimento restritivo anterior que vetava o nu frontal e passou a admiti-la, em filmes e peças teatrais, com faixa etária previamente definida. Nove filmes, antes considerados ofensivos à moral e aos bons costumes, foram então liberados, dentre os quais estavam "Black Emannuelle" e "O Último Tango em Paris". Nestes casos, conforme noticiado à época pelo jornal "O Fluminense”, “as proibições só aumentaram a curiosidade e contribuíram para o sucesso de bilheteria". 346

Uma edição do Jornal do Brasil, de abril de 1980, estampava uma matéria de página inteira sob o título "Abertura vs. Censura", focando, especialmente, o cinema. Para o jornal,

\footnotetext{
${ }^{344}$ BR_RJANRIO_LC_0_TXT_002_d0001de0001

${ }^{345}$ BR_DFANBSB_ZD_0_0_0038A_0043_d0002

${ }^{346}$ BR_DFANBSB_ZD_0_0_0038A_0043_d0002
} 
as "produções agressivamente eróticas ou de tipo capaz de provocar traumas setoriais perigosos para a continuidade da política de abertura", indicavam a centralidade que o tema da censura assumira em um contexto de distensão política, podendo até mesmo colocar em xeque o processo em si. A solução para a oposição entre abertura e censura, assim, passava pela criação de "salas especiais" para filmes "excessivamente eróticos" que seriam exibidos sem cortes. Esta proposta já havia sido cogitada pelo antecessor no Ministério da Justiça, Petronio Portella, mas só caminhou na gestão de Abi-Ackel. ${ }^{347}$

Tal liberalização provocou reação de diversos setores indignados. Já em dezembro, de 1979, uma edição do jornal O Fluminense, de Niterói/RJ, trazia a posição do pároco da Igreja Abrigo Cristo Redentor, Padre Noé, sobre o levantamento da censura em relação à nudez. Segundo o religioso, esta seria mais "uma contribuição para a desagregação da família brasileira", complementando que "os veículos de comunicação (televisão, cinema e jornal) colaboram para despertar na mente do espectador a sua vontade instintiva pelo sexo violento e imoral”. E arrematava sua apreciação sobre a flexibilização da censura afirmando ser necessário manter a proibição da divulgação da nudez "em favor da preservação da 'célula mater' da sociedade que é a família”. Mas não foi só o padre que se revoltou com a decisão. Outros leitores ouvidos pelo jornal também compartilharam de uma posição crítica à liberalização, afirmando, por exemplo, que "não est[ava] certo homem nu no cinema", que "o abuso est[ava] demais", afinal, "veja como ficaremos se estivermos assistindo a um filme com amigo ou o noivo e aparecerem cenas impróprias. É muito chato", dizia Fátima, balconista, de $18 \operatorname{anos}^{348}$.

Mas diversos dos outros leitores ouvidos pela reportagem manifestaram posição contrária, apoiando a iniciativa de liberação da nudez. A repressão não tinha mais o grau de consenso que alcançou na década anterior. Silvio do Nascimento, estudante de apenas 22 anos, opinava que "se o filme ou a peça for impróprio para 18 anos, qual [seria] o problema? As pessoas adultas já sabem tudo da vida, não há problema de moral e creio que ninguém ficará chocado" 349 .

O jornal O Globo, em edição de 30 de janeiro de 1980, trouxe algumas notas sobre esta discussão, demonstrando a forte pressão social que o tema despertava nos atores políticos com acesso à grande imprensa. Sob o título impactante "Libertinagem e crime", o periódico afirmava que ambos andavam lado a lado, tendo por "causa mais profunda" o

\footnotetext{
${ }^{347}$ BR DFANBSB ZD 0000038 A 0043 d0002

${ }^{348} \mathrm{BR}{ }^{-}$DFANBSB ZD ${ }^{-} 0-0-0038 \mathrm{~A}^{-} 0043$ - $\mathrm{d} 0002$

${ }^{349}$ BR_DFANBSB_ZD_0_0_0038A_0043_d0002
} 
“enfraquecimento da família e dos hábitos antigos que lhe davam vigor", já que "a disciplina, a austeridade, o respeito recíproco; est[ava] também na perda da Fé, a tudo arrasando no mais opaco imediatismo, na procura de gozos materiais sempre efêmeros e insatisfatórios, umbrais do desespero" 350 .

Mas não era só. A preocupação com as origens deste processo indicava uma longa guerra cultural em curso, já que "nada surgiu da noite para o dia. A permissividade, os tóxicos, o abortismo, toda sorte de delinquência e violência [vinha]-se acentuando, mais e mais velozes...". E o jornal arrematava:

o que está em crise - e o 'topless' o denuncia quase como uma caricatura - é o sentimento de decência, de brio do indivíduo perante o seu grupo social. A competição exibicionista e a preocupação de tudo compreender para nada reprimir concorrem também para o agravamento da crise. ${ }^{351}$

Uma coluna de opinião de Ida Laura, crítica de cinema importante, narrava um episódio curioso sobre a dificuldade de definir os limites entre o erótico e o pornográfico em artigo intitulado "Ainda a censura". Lembrava ela, na ocasião, que "em reunião com o diretor de produção e equipe da TV Globo, [o então ministro da Justiça Ibrahim Abi-Ackel] sentiu-se também constrangido quando lhe pediram que definisse 'uma cena sensual', negando-se a responder "porque havia senhoras no auditório" 352 .

A sociedade, de fato, mostrava os sinais de uma mudança de mentalidade importante na crítica à censura, baseada em valores morais cada vez menos universalizáveis na realidade brasileira e que se complexificavam e se abriam para os ares liberalizantes dos costumes que vinham de fora, em momento de rápidas mudanças na indústria cultural.

\section{"Desajustes entre os critérios da DCDP (legal) e os do CSC (consensual)"}

A mobilização na sociedade contra a censura também se organizava com cada vez mais força. O debate "A situação atual da censura", realizado em 13 de julho de 1982, nas dependências do Teatro Ruth Escobar, aglutinou diversos setores e mais de 250 pessoas para a formação de um "Comitê Permanente contra Censura e pela Liberdade de Expressão", congregando "intelectuais, clero, associações de bairro, partidos políticos, movimentos de minorias", com o objetivo de denunciar as arbitrariedades cometidas pelos órgãos censores. A

\footnotetext{
${ }^{350}$ BR_DFANBSB_ZD_0_0_0038A_0043_d0002

${ }^{351} \mathrm{BR}{ }^{-}$DFANBSB ZD $0-0-0038 \mathrm{~A}^{-} 0043$ - $\mathrm{d} 0002$

${ }^{352}$ BR_DFANBSB_ZD_0_0_0038A_0043_d0002
} 
proposta era articular a iniciativa com a mobilização que já vinha ocorrendo no Rio de Janeiro, no mesmo sentido.

O encontro foi monitorado de perto pelo órgão de informações da Superintendência Regional do Departamento de Polícia Federal de São Paulo, conforme comprova o Informe n. 312/A-2/IV COMAR, que relata minuciosamente as discussões e falas dos presentes, entre os quais estavam representantes dos grupos Somos/SP e Ação Lésbica-Feminista. ${ }^{353}$

Além disso, a Informação n. 152/05/82, oriunda do CI/DPF e datada de 19 de outubro de 1982, tratava sobre o referido "Comitê de Mobilização Contra a Censura Federal", registrando a campanha então em curso contra a censura federal, que "sempre foi combatida, criticada pelos intelectuais, pelos artistas, pela imprensa, etc., através de um movimento crônico que obedec[ia] a aspectos cíclicos". 354

O relatório traçava um breve panorama das mudanças existentes nas sucessivas gestões do serviço de censura federal. De 1972 a 1979, Rogério Nunes esteve à frente do órgão, em um momento no qual "os trabalhos eram executados com maior vigilância, dado o momento histórico e a aplicação do Decreto-Lei n. 1.077/70, tido no meio artístico-cultural e jornalístico como filho do ATO INSTITUCIONAL N. 5". Nesta época, descrita com certa nostalgia no informe, "movimentos e críticas contra a CENSURA FEDERAL existiam, porém, de maneira não muito contundente e continuada. Época em que os problemas políticos [...] eram examinados com maior rigor". 355

Em abril de 1979, tomou posse na DCDP José Vieira Madeira, que permaneceu no cargo até novembro de 1981. Neste momento, a censura passou a ser mais combatida, muito em função da "atuação do Governo Federal, que tinha por meta a abertura política à democratização do País, ocasião em que o meio artístico-cultural cobrava que essa mesma atitude fosse a ela também reconhecida". Foi exatamente neste período que o Ministro Petrônio Portela, finalmente, regulamentou o art. 15 da Lei n. 5.536 de 1968, que já previra a criação do Conselho Superior de Censura (CSC), o que foi feito por meio do Decreto n. 83.973 de 1979. De caráter mais recursal do que normativo ou executivo, o órgão reuniu-se, pela primeira vez, em 25 de outubro de 1979, passando a deliberar sobre a manutenção ou não dos vetos e cortes impostos pela DCDP. Acusa o relatório, sob comento, que o CSC "passou a liberar a maioria das obras a ele submetidas", fazendo com que a DCDP passasse a ser "mais exigida e combatida pelos elementos ligados aos meios artístico-culturais e pela Imprensa,

\footnotetext{
${ }^{353}$ BR_AN_BSB_VAZ_046A_0062

${ }^{354}$ BR_DFANBSB_HE_0_IVT-0067

${ }^{355}$ BR_DFANBSB_HE_0_IVT_0067
} 
que dela (DCDP) cobravam atitude 'mais liberal e menos obscurantista"'.356

Mas a principal reserva desse estrato inferior do aparelho de censura que foi dirigida ao CSC se assemelha, de forma bastante curiosa, às críticas da classe artística à DCDP: o casuísmo e a falta de critérios objetivos e minimamente claros para orientar a análise de casos diferentes. A reclamação, quanto ao CSC, era precisamente a de que ele "não nort[eava] suas decisões pela legislação censória, mas sobre alegações, argumentos subjetivos apresentados pelos senhores Conselheiros ou pelos defensores e/ou advogados das partes interessadas", de modo que "este procedimento [tinha] gerado desencontros, desajustes entre os critérios da DCDP (legal) e os do CSC (consensual)". Revoltaram-se, assim, os censores contra a “abertura de precedentes [pelo CSC] (sem embasamento na legislação censória) para a liberação de obras que somente poderiam ser liberadas se julgadas à luz das normas expressas da DCDP”, o que acontecia sempre que o voto do relator, acolhido pelos demais, firmava jurisprudência. $^{357}$

Ora, a atuação dos técnicos da DCDP tinha muito menos previsibilidade e aderência à legislação do que eles próprios - autocomplacentes, como acreditavam. As crenças religiosas, valores morais, preferências políticas e demais variáveis individuais eram os critérios mais marcantes no ato arbitrário de interpretação dos tipos legais vagos e excessivamente abstratos por parte dos executores da censura.

O relatório ainda fazia a defesa da diretora Solange de Maria Teixeira Hernandez, que tomou posse em novembro de 1981, alegando que "os trabalhos censórios est[avam] sendo executados também de acordo com a legislação até então vigente". No entanto, Solange estaria sendo alvo do recrudescimento da "grita contra a CENSURA FEDERAL, mormente contra a sua pessoa". A mudança de composição do CSC - mais os vetos total e parcial opostos pela DCDP aos filmes "PRA FRENTE BRASIL", de ROBERTO FARIAS, e "DAS TRIPAS CORAÇÃO”, de ANA CAROLINA - havia levado os setores do meio artístico a "declarar guerra" contra a diretora do DCDP. Segundo o relatório, "como se atravessa de uma fase pré-leitoral (sic), em que as oposições se serv[iam] de tudo para denegrir e empanar as realizações do Governo, pode ser que a CENSURA FEDERAL, dentre outros, est[ivesse] sendo utilizada como bode expiatório, vez que ela [foi] colocada como 'parte e braço da repressão" 358 . Concluía-se, o relatório, apontando que "exist[ia] uma campanha orquestrada para acabar com a CENSURA FEDERAL, uma vez que ela 'veda[va] a livre expressão do

\footnotetext{
${ }^{356}$ BR_DFANBSB_HE_0_IVT_0067

${ }^{357}$ BR_DFANBSB_HE_0_IVT_0067

${ }^{358}$ BR_DFANBSB_HE_0_IVT_0067
} 
pensamento', bem como 'imped[ia] e priva[va]' o grande público de conhecer as criações exteriorizadas artísticas e culturalmente". 359

\section{Liberalização da censura e novo manual da DCDP}

Diante da pressão social e especialmente da classe artística pela liberalização, bem como na tentativa de conter qualquer mudança mais radical que tirasse do governo o controle censório, o Ministro da Justiça, Petrônio Portela, baixou novas regras para a censura federal, no começo da década de 1980, tornando-a "mais liberal" nos seus diversos segmentos de atuação: teatro, cinema, televisão, letras musicais, revistas destinadas ao público masculino, livros (de conteúdo político-ideológico, erótico e/ou pornográfico).

O documento intitulado "Resumo das instruções aprovadas pelo Sr. Ministro, sobre atuação da censura" sintetizava as principais diretrizes que passariam a orientar a ação dos órgãos ligados à DCDP.

Dividido de acordo com cada uma das formas de linguagem ou de expressão artísticas, o documento começava com as regras aplicáveis ao teatro. Primeiro, apontava-se as condutas que passavam a ser toleradas: "o palavrão", a depender da "adequação da linguagem ao tema explorado"; "o nu, desde que não [fosse] com preocupação lasciva"; "o texto político, desde que não [fosse] injurioso às Autoridades constituídas, nem represent[asse] mensagem de violência contra o regime" e uma orientação específica salientando que "não dever[ia] ser proibido texto quando já estiver para ser encenado", sendo que os "problemas dev[iam] ser solucionados quando o texto [fosse] apresentado para o exame inicial" (grifos no original). ${ }^{360}$

Mas ali não constavam só medidas de flexibilização da censura. Aproveitou-se a oportunidade para apontar as condutas inaceitáveis no teatro. Não eram permitidas, assim, "a prática de sexo no palco" e "na peça de caráter político a crítica ofensiva à moral e à dignidade das autoridades constituídas". Frisava-se, por fim, que o marco legal e "o exame censório dever[iam] ser feito[s] com base na Lei n. 5.536, de 1968", sinalizando politicamente, de partida, os limites que tais mudanças deveriam respeitar. ${ }^{361}$

Em relação ao cinema, o documento adotava a mesma "linha de conduta estabelecida para o teatro", acrescentando que "os filmes de reconhecido valor artístico, cultural e educativo poder[iam] ser liberados integralmente". Para as letras musicais, aplicava-se "a

\footnotetext{
${ }^{359}$ BR_DFANBSB_HE_0_IVT_0067

${ }^{360}$ BR DFANBSB_HE_0_IVT_0067

${ }^{361}$ BR_DFANBSB_HE_0_IVT_0067
} 
liberalização dos temas políticos, contidos dentro das permissões estendidas ao teatro, observando-se, todavia, os limites da moral e dos costumes para os demais casos". É interessante notar que, no caso da música, em um momento de franca expansão da industrial cultural que atingia públicos mais amplos da sociedade, havia o destaque para a moral e os costumes como limites impositivos para a análise censória. ${ }^{362}$

No que se referia à televisão, o meio de comunicação de massa por excelência, a preocupação moral desponta[va] ainda mais claramente. De acordo com as novas regras, os parâmetros especiais para as novelas passavam a ser: "moderação e limpeza de linguagem"; "observância de certos tipos de temas morais, que dev[iam] ter uma postura condizente com o veículo e seu horário"; "maior atenção para cenas íntimas, bem assim com situações matrimoniais especialmente em horários permitidos a menores" e "criação de três blocos de faixa etária: livre, até 21 horas 14 das 21 às 23 horas e 18 anos, das 23 horas em diante". 363

Por fim, em relação às chamadas revistas masculinas, tais como as citadas "Lui", "Playboy", "Status", "Ele e Ela" e "Nova", apontava-se a necessidade de realização de uma reunião dos editores para "estabelecer um acordo mantendo-se os atuais padrões de publicação e os limites recomendados pela moral e pelos costumes, passando-se, daí por diante, às Editoras a autocensura, advertindo-as de que os excessos poder[iam] resultar em apreensão das revistas. Reforçava-se, ainda, a linha de que "a venda continuar[ia] em envelopes, e as revistas deve[riam] trazer a advertência de que sua venda [era] proibida para menores de 18 anos", refletindo a preocupação constante com a juventude que poderia ser "corrompida" pelo acesso a materiais pornográficos. ${ }^{364}$

Tais recomendações refletem, por um lado, uma preocupação liberalizante ao menos no plano discursivo para atender parcialmente aos reclamos contrários à censura e impulsionar algumas mudanças de interpretação; embora, por outro lado, a política oficial ainda permanecesse baseada na mesma norma rigorosa, restringindo, de forma expressa e mais clara, alguns temas e abordagens que permaneciam interditados aos olhos do regime. Esta medida desvelava-se, assim, ambígua em relação à flexibilização política e ao endurecimento moral, caracterizando-se como um recuo ou uma demonstração de fraqueza, mas também reafirmando seu poder de controle e de força normativa.

No frigir dos ovos, entre a pressão pelo fim total da censura e a demanda pelo endurecimento das regras de controle político e moral, a opção intermediária do regime foi

\footnotetext{
${ }^{362}$ BR_DFANBSB_HE_0_IVT_0067

${ }^{363}$ BR_DFANBSB_HE_0_IVT_0067

${ }^{364}$ BR_DFANBSB_HE_0_IVT_0067
} 
flexibilizar para manter o controle, refletindo o programa mais geral da liberalização outorgada e, assim, conferindo sobrevida à censura diante das disputas instaladas naquele momento. Mas já parecia tarde demais para sustentar uma acomodação a contento.

\section{"Ninguém quer ficar com a imagem de censor"}

Neste momento, o desgaste do casuísmo da censura foi bastante grande, inclusive no Conselho Superior de Censura. Em pronunciamento durante a reunião do referido órgão, de 2 de agosto de 1982, o conselheiro Ricardo Cravo Albin denunciou a falta de uma "justiça de critérios, por não-casuísmos de pesos e medidas diferentes e desencontradas quase sempre". 365 A motivação de sua manifestação dura contra o modo de atuação arbitrário da censura estava no fato de que a Rede Globo havia submetido ao DCDP os roteiros de uma nova série, intitulada "Bandidos da Falange", com 20 episódios, a ser veiculada sempre às $22 \mathrm{~h} 00$.

Contudo, pouco antes da estreia, quando já haviam sido realizados 5 capítulos devidamente encaminhados à análise da DCDP, esta exigiu que a emissora apresentasse todos os 20 capítulos, "o que seria rigorosamente impossível, a nível industrial, logo depois, para pasmo ainda maior, a DCDP desfecharia um golpe mortal no seriado liberando-o para horário das 23:00hs, o que, como se sabe, torna inviável qualquer projeto de produção mais elevada em termos de custo" ${ }^{366}$. Tal exigência por parte da DCDP fez com que a série não pudesse estrear na data prevista. Além disso, o conselheiro ressaltou que tal postura incentivava os "enlatados" de um "projeto cultural estrangeiro", prejudicando investimentos, geração de empregos, uma perspectiva nacional sobre problemas brasileiros e mesmo nossas fronteiras culturais.

A crítica à "insensibilidade do aparelho censório" e, em especial, à "atual administração da DCDP” foi, assim, a marca do pronunciamento do conselheiro. Na mesma linha, radiodifusores, por meio da Carta de Brasília aprovada no XIII Congresso de Radiodifusão organizado pela Associação Brasileira de Empresários de Rádio e Televisão, manifestaram-se no seguinte sentido:

no momento em que o presidente João Figueiredo encontra-se em plena realização de seu projeto de abertura política, anistiando cidadãos e realizando eleições, os radiodifusores estranham e repudiam o papel da

\footnotetext{
${ }^{365}$ BR_DFANBSB_HE_0_IVT_0067

${ }^{366}$ BR_DFANBSB_HE_0_IVT_0067
} 
censura, que vem privando o público das mais legítimas obras do espírito popular e causando vultosos prejuízos às emissoras de televisão.

Uma matéria do Jornal de Brasília ${ }^{367}$, de 21 de setembro de 1982, relatava a mudança da presidência do CSC em momento de franca e crescente pressão por parte do governo e da classe artística. Euclides Mendonça, que acumulava a função de chefe de gabinete do Ministro da Justiça Abi-Ackel, deixou a presidência do órgão para que José Rosa de Abreu Vale pudesse assumir, desvinculando a censura da figura do ministro. Mas a reportagem afirmava que "o cargo representa um verdadeiro 'abacaxi", por conta das "pressões oriundas do próprio governo federal, [e] até telefonemas na madrugada de advogados de empresas produtoras de filmes que tenta[vam] influir em decisões do CSC. No governo, ninguém quer[ia] ficar com a imagem de censor..."

Apesar de toda essa crise, o estado agônico da censura moral ainda se arrastou até a promulgação da Constituição Federal de 1988, quando foram extintos esses órgãos e os modos de controle do Estado sobre a produção cultural e artísticas, sendo ressignificados e reformulados essencialmente a partir de critérios de classificação etária indicativa.

\footnotetext{
${ }^{367}$ Jornal de Brasília, 26 de setembro de 1982.

${ }^{368}$ BR_DFANBSB_HE_0_IVT_0067
} 
- Capítulo 3 -

\title{
A VIOLÊNCIA NAS RUAS: CONTROLE MORAL E REPRESSÃO POLICIAL
}

\author{
Depois da cruzada contra o Pecado e da cruzada contra a Subversão, chegou \\ a vez da cruzada contra o Erotismo. \\ - Paulo Sérgio Pinheiro ${ }^{369}$
}

\section{Circuito moral da repressão política}

A repressão policial nas ruas foi a face mais visível da constante e costumeira violência que se abateu contra homossexuais, travestis e prostitutas nos grandes centros urbanos. Pontos de sociabilidade e de diversão frequentados por homens que desejavam outros homens e mulheres que buscavam outras mulheres, sofreram não apenas monitoramento intensificado neste período, mas foram constantemente assediados por batidas policiais seguidas de prisões arbitrárias, pela prática das mais diversas formas de torturas física e psicológica, pela extorsão e outros métodos de violação de direitos humanos desta população já marginalizada. As polícias, que logo integraram o complexo de aparatos repressivos da ditadura militarizada contra os subversivos "políticos", passaram a regular também o direito à rua para os segmentos LGBT.

Certamente, tal imposição violenta de isolamento e confinamento de homossexuais em guetos ostensivamente vigiados e rotineiramente abordados por forças de segurança pública não foi algo inaugurado pela ditadura. Contudo, a acentuada centralização do poder, típica dos regimes autoritários, foi conjugada com a estruturação de um mosaico repressivo em que o policiamento cumpria uma função essencial em espaços públicos, como as ruas. Ao lado da espionagem, da censura e da propaganda, a polícia política se constituiu como um dos pilares da atuação estatal. Ela não apenas deixou de ser controlada por um órgão externo e pela opinião pública, cujos principais meios de informação encontravam-se sob domínio da censura, mas também foi investida de atribuições cada vez mais abrangentes e de caráter militarizado na proteção da vaga ideia de segurança nacional contra os "inimigos internos", cujos contornos eram definidos convenientemente em termos políticos e também morais.

369 "Labaredas antieróticas", Folha de São Paulo, 30 de setembro de 1980, p. 3. 
Assim, a integração das polícias neste complexo de segurança ordenado para a perseguição de dissidentes significou uma carta branca para que os abusos se intensificassem cada vez mais. A violência de Estado, que sempre fez parte do cotidiano das clientelas tradicionais do sistema penal nas periferias urbanas e das zonas rurais mais isoladas, institucionalizou-se como uma autêntica política pública e passou a atingir as camadas médias e intelectualizadas que se colocaram contra a ditadura.

Assim, a prática generalizada de desaparecimentos forçados, execuções sumárias, ocultação de restos mortais, versões falsas para assassinatos, torturas sistemáticas, prisões arbitrárias e inúmeras outras violações de direitos, constituiu um repertório extenso de abusos de um circuito que era traçado pelo "poder torturador"370 contra os subversivos "políticos".

Com efeito, os suspeitos de pertencerem a organizações clandestinas de oposição ao regime recebiam um tratamento bastante específico quando se encontravam sob custódia do Estado. Eles eram geralmente sequestrados por forças policiais à paisana, sem qualquer ordem de prisão que legalizasse o ato de privação da liberdade, e conduzidos para centros de detenção e de tortura mais ou menos clandestinos. Familiares e amigos não recebiam informações do paradeiro da pessoa, que ficava incomunicável e não podia sequer ter acesso a um advogado. Ali eram seviciados por dias e submetidos a condições degradantes, com o objetivo de extrair o máximo de informações no menor tempo possível para chegar a outros militantes e, assim, desbaratar as organizações de luta armada.

Fatores diversos, e algumas vezes imponderáveis, determinavam o destino de um preso político neste itinerário repressivo. Por exemplo, os dirigentes dos grupos da esquerda, como regra, eram assassinados e seus corpos deviam ser desaparecidos. Mas o caráter seletivo e cirúrgico das execuções, concentradas no alto da pirâmide da subversão, nem sempre funcionou tal como planejado. Afinal, regras muito rígidas nunca combinaram muito bem com as arbitrariedades de regimes que funcionavam com base na indistinção entre poder e normas, o que fazia com que, em muitos casos, prevalecesse o imprevisível. Os que tiveram mais sorte conseguiram sobreviver e, depois de um período que variava bastante nos órgãos

\footnotetext{
${ }^{370}$ Inspirando-se no conceito de Pilar Calveiro sobre o "poder desaparecedor" que caracterizou o padrão repressivo da ditadura argentina, Janaína Teles destaca que a tônica da violência do Estado brasileiro nesse período autoritário foi um "poder torturador". Afirma ela que o Brasil "teve uma ditadura empenhada em ações repressivas seletivas, que preservou uma aparente normalidade institucional, com focos de ação violenta, os quais foram diferentemente orientados conforme o alvo e o período em questão. No que tange à organização do Estado, não houve uma simples continuação ou repetição aumentada de práticas antes vigentes, mas uma reorganização do aparelho repressivo previamente instalado". TELES, Janaína. Ditadura e repressão: paralelos e distinções entre Brasil e Argentina. Taller (Segunda Época). Revista de Sociedad, Cultura y Política en América Latina, Vol. 3, $\mathrm{N}^{\circ} 4$ (2014), pp. 100 - 102. Essa série de violações de direitos humanos está documentada com razoável amplitude no relatório final da Comissão Nacional da Verdade, disponível em: http://www.cnv.gov.br/.
} 
de tortura, tinham sua prisão oficializada perante o Poder Judiciário, e até mesmo acesso a um advogado, ainda que o processo jurídico fosse manipulado pelas autoridades judiciais e militares, sem qualquer respeito às garantias de defesa dos acusados, servindo apenas para legitimar, com uma aura de legalidade, a violência que já havia sido imposta pela força bruta. Permaneciam, a depender das acusações e condenações com base em provas forjadas, por anos em penitenciárias com outros presos políticos. Assim, os objetivos de todo este aparato eram, basicamente, executar uma política de extermínio físico de opositores e produzir o medo para desmobilizar resistências.

É verdade que as repressões moral e sexual empreendidas pela ditadura, nas ruas, seguiu um outro padrão. É visível que homossexuais não receberam o mesmo tratamento que foi dirigido para membros da resistência armada. Mas o fato de não terem sido submetidos ao mesmo modelo de violências não significa que não tenham sofrido de outros modos com ações, omissões e conivências estatais.

Reconhecer e analisar estas diferenças, assim, é fundamental por duas razões centrais: primeiro, porque permite compreender as formas de atuação do poder repressivo sob a ditadura brasileira, com suas lógicas próprias e racionalidades distintas, a depender do público-alvo, rompendo com visões que postulam a existência de um Estado monolítico e homogêneo; segundo, porque traz à tona uma dimensão da violência estatal tradicionalmente invisibilizada, mesmo pelos grupos que lutaram pela memória e pela justiça em relação aos crimes do passado.

Deste modo, o circuito da perseguição contra homossexuais passava por outros trajetos, a despeito dos inevitáveis pontos de contato com a estrutura repressiva que atingiam a "subversão política". Nas ruas, de forma geral, homossexuais eram assediados por batidas policiais ostensivas, que mobilizavam um número expressivo de agentes. Estas investidas ocorriam nas regiões de maior concentração, especialmente nos guetos e outros espaços de confinamento, que acabavam propiciando algum acolhimento e proteção aos homossexuais. Geralmente, eram detidos sem qualquer acusação mais consistente e submetidos a constrangimentos públicos pela exposição de seus corpos ou de suas preferências sexuais, que muitas vezes eram enrustidas e escondidas devido ao preconceito vivido nos universos escolar, familiar e profissional.

Apesar da ausência de legislação expressa criminalizando orientações sexuais nãonormativas, diversos outros tipos penais foram abundantemente mobilizados para enquadrar os homossexuais e coibir a sua existência aberta. Vadiagem, atentado público ao pudor, corrupção de menores, violação da moral e dos bons costumes, furtos e roubos, uso de drogas, 
foram alguns dos dispositivos utilizados para instrumentalizar o direito e realizar um controle legal destes grupos, geralmente jogados em um submundo associado a diversos tipos de contravenções e crimes morais ou patrimoniais. A prática policial criminalizava, assim, as condutas que a legislação não definia como delitos penais.

Os homossexuais, depois de detidos, eram levados para os distritos policiais ou prisões comuns, onde permaneciam por horas ou dias. Ali, eram submetidos a diversas humilhações e torturas relacionadas, muitas vezes, à orientação sexual ou à identidade de gênero. Como muitos eram abordados em zonas de prostituição e se dedicavam a esta atividade profissional, as "bichas" e travestis eram também extorquidas para serem liberadas ou mesmo para terem um tratamento menos violento. Ficavam por dias incomunicáveis, em condições precárias, que sempre foram características típicas do sistema penitenciário comum brasileiro, recebendo até mesmo menos atenção por parte de familiares e imprensa do que os presos políticos na época da abertura. Em vez de detenções por longos períodos, era mais comum ocorrer frequentes prisões por curtos períodos de tempo. Homossexuais não eram, assim, eliminados fisicamente, como acontecia com os subversivos "políticos". Antes, o objetivo dos órgãos repressivos era, primordialmente, um saneamento moral e uma higienização social que implicavam em disciplinamento das sexualidades dissidentes, sua normalização a partir dos valores conservadores irradiados pelo regime autoritário e a expulsão dos homossexuais e prostitutas dos espaços públicos, ainda que fossem os guetos ocupados por essa população.

A orientação clara de dispersão das pessoas LGBT dos lugares onde se concentravam em busca de amores furtivos ou de novas amizades expressava uma política executada por diversos organismos estatais e ainda era reforçada por alguns agentes públicos que imprimiam suas concepções conservadoras com total liberdade contando, frequentemente, com o respaldo de seus superiores.

Diversos são os registros históricos de abusos cometidos pelo aparato de segurança contra a população homossexual, mas a maior parte das fontes disponíveis datam do final da década de 1970, quando estava em pleno curso o processo de abertura. Apesar de ser contraintuitiva tal constatação, já que seria mais factível compreender o endurecimento moral nos marcos de um enrijecimento político do regime, tais fatores parecem indicar que as profundas mudanças desencadeadas pela agonia da ditadura despertaram reações sérias dos setores mais conservadores na medida em que estes vislumbravam uma perda de controle de limites impostos à transição tutelada pelos militares. Isto é, esta constatação pode indicar não exatamente um aumento da repressão mas, antes, uma importante mudança na sua forma de expressão e de exercício da violência. 
A visibilidade crescente da alta concentração homossexual nas grandes cidades, com a maior presença das travestis a partir dos anos de 1973 e 1974, especialmente em São Paulo, trabalhando como prostitutas, foi um fenômeno significativo para o tratamento desses corpos marcados por sexualidade e gênero dissidentes.

Outra hipótese factível para essa maior quantidade de referências à violência policial contra gays, lésbicas, travestis e prostitutas é o fato incontestável de que, com a abertura política e a expansão do mercado de consumo para estes setores, essas pessoas começaram a tomar mais as ruas e a exporem-se publicamente, reivindicando, senão a aceitação, ao menos uma tolerância ${ }^{371}$. A visibilidade foi um fato importante que alimentou reações conservadoras. Isso é aventado por MacRae, quando afirma que, neste período, assistiu-se à "proliferação de estabelecimentos orientados para uma clientela gay" e a uma grande "descontração com a qual homens e mulheres passaram a andar pelas ruas abraçados com parceiros do mesmo sexo e em alguns casos até se beijando na boca". Ele também ressalta que se "proliferavam os travestis que, segundo se dizia, estavam tomando todos os tradicionais pontos de prostituição" ${ }^{, 372}$. No mesmo sentido, Green ressalta que o crescimento do número de travestis nas ruas era "reflexo da crescente comercialização e mercantilização do sexo na sociedade brasileira" em um momento de relativa prosperidade econômica para as camadas médias que podiam, então, pagar por sexo. Além disso, ele aponta a flexibilização dos códigos de gênero com a emergência de um estilo unissex e a maior liberdade de adotar trajes mais provocantes. Isso levou a um movimento, inclusive, de fluxo de travestis brasileiras para a Espanha, a França e, depois, para a Itália ${ }^{373}$.

Além disso, como as forças de segurança não formalizaram explicitamente um plano para combate dos homossexuais, apesar dos diversos documentos analisados neste trabalho contra as homossexualidades, a maior fonte de registros das ações policiais investidas contra

\footnotetext{
${ }^{371}$ Em um trabalho sociológico clássico sobre as bases do pensamento conservador de uma "nova direita", Pierucci destaca o medo expressado por esses grupos por reação diante de mudanças em curso no longo processo de redemocratização: "Seu tique mais evidente é sentirem-se ameaçados pelos outros. Pelos delinquentes e criminosos, pelas crianças abandonadas, pelos migrantes mais recentes, em especial os nordestinos (às vezes, dependendo do bairro, por certos imigrados asiáticos também recentes, como é o caso dos coreanos), pelas mulheres liberadas, pelos homossexuais (particularmente os travestis), pela droga, pela indústria da pornografia, mas também pela permissividade "geral", pelos jovens, cujo comportamento e estilo de pôr-se não estão suficientemente contidos nas convenções nem são conformes com o seu lugar na hierarquia das idades, pela legião de subproletários e mendigos que, tal como a revolução socialista no imaginário de tempos idos, enfrentase a eles em cada esquina da metrópole, e assim vai" (PIERUCCI, Antônio Flávio. As bases da nova direita. Novos Estudos, São Paulo, n. 19, dez. 1987, p. 26). Disponível em: http://novosestudos.org.br/v1/files/uploads/contents/53/20080623_as_bases_da_nova_espera.pdf

372 MACRAE, Edward. A construção da igualdade: identidade sexual e política no Brasil da "abertura". Campinas: Editora da Unicamp, 1990, p. 223.

${ }^{373}$ GREEN, James Naylor. Além do Carnaval: a homossexualidade masculina no Brasil do século XX. São Paulo, Unesp, 2000, pp. 403-404.
} 
esta população, segue, ainda, sendo os vestígios deixados nas notícias publicadas na imprensa. Contudo, uma das dificuldades encontradas é o fato de que os principais jornais pouco publicavam sobre homossexualidade e as demais publicações de grande circulação eram de cunho sensacionalista, representando as sexualidades dissidentes como um misto de pecado, doença e desvio de caráter, como se viu no capítulo anterior. Assim, foi sobretudo na imprensa alternativa que se intensificou, no final da ditadura, os registros mais confiáveis, tanto das ofensivas da repressão, como das resistências do movimento organizado.

Neste sentido, uma das mais importantes fontes foi o Lampião, por se tratar do principal jornal em circulação naquele momento dedicado aos interesses dos homossexuais. Logo no seu primeiro ano de existência, a publicação já começava a denunciar e a documentar violações de direitos dos homossexuais decorrentes de operações policiais nas ruas, sobretudo no eixo Rio-São Paulo, onde se concentravam os editorialistas e colaboradores. Passemos, então, à análise das fontes que nos revelam como a perseguição às pessoas LGBT se materializou nos territórios urbanos das grandes cidades.

\section{“Não sabe porque a gente se corta? É o único jeito de não ir presa"}

Logo na primeira edição do jornal, foi veiculada uma longa reportagem, de autoria de Antônio Chrysóstomo, sobre a vida noturna dos “caubóis" e de outras personagens cativas do "triângulo da badalação entendida ou da prostituição masculina", expressão que fazia referência à Cinelândia, Galeria Alaska e Avenida São João, com expressiva concentração de homossexuais. A matéria já apontava o medo e a violência a que estavam sujeitos os frequentadores desses locais, sobretudo, as travestis. De acordo com a gíria dos entendidos paulistas e cariocas que frequentavam esses lugares, os michês aí eram conhecidos como "midi-naite cauboi". Nestes locais,

há desde os mais reles meninos de programa, michezinhos de 40 a 50 cruzeiros por pernoite, até os profissionais competentes, fisicamente atraentes, capazes de extrair, principalmente de turistas daqui e de fora, quantias de 500 a 1.000 cruzeiros em cada uma de suas saídas. Bem observados, travestis e viados finos, michês baratos e prostitutos de alto bordo, são todos meninos - não importa a idade - jogados entre a bondade e a perversidade sem limites, pois no, assim chamemos, triângulo da pegação, bem e mal têm fronteiras extremamente fluídas. ${ }^{374}$

\footnotetext{
374 “Os caubois, seus clientes: todos querem ser felizes no triângulo da badalação". Lampião da Esquina, edição 1, maio/junho de 1978, p. 5
} 
Na cidade do Rio de Janeiro, um dos pontos de encontro entre pessoas LGBT mais badalados era a Galeria Alaska, no bairro de Copacabana. Ligando as avenidas Atlântica e Nossa Senhora de Copacabana, na altura do Posto 6, a galeria não chegava a 100 metros de extensão, mas a travessia estava repleta de bares e boates. O local era refúgio de adolescentes e jovens que buscavam, por meio da prostituição, arrumar um parceiro mais velho e endinheirado ou até mesmo um lar. A qualquer hora do dia, o movimento ali era intenso e, durante as noites, os homossexuais procuravam abertamente encontros com outros entendidos, conforme cantado sutilmente por Agnaldo Timóteo na música "Galeria do Amor", que ele fez em homenagem precisamente à Alaska:

Na galeria do amor é assim
Muita gente a procura de gente
A galeria do amor é assim
Um lugar de emoções diferentes
Onde gente que é gente se
Entende
Onde pode se amar livremente
Onde gente que é gente se
Entende
Onde pode se amar livremente

Mas nem tudo era erotismo e romantismo, sendo naturalizada a violência contra os frequentadores habituais do espaço. A mesma "Galeria do Amor" foi objeto de um artigo escrito por Aristides Nunes Coelho Neto sobre as noites agitadas que eram ali vividas pelos homossexuais. Em relação ao tema da repressão constante contra os homossexuais, ele afirmou que existia um distrito policial logo na frente e que "a convivência entre o pessoal do lado de lá e os policias nem sempre se [dava] em bom nível”. Conforme pontuado no texto, era comum que pessoas ali na galeria fossem "convidadas" "a atravessar a rua e, na delegacia, tudo pod[ia] acontecer. Desde a simples intimidação verbal até a agressão física. Muitas vezes, pessoas que não [tinham] documentos passa[vam] a noite inteira numa cela escura e fria". 376

Esse tipo de relato é confirmado por Marcos S., um carioca de apenas 17 anos que era

\footnotetext{
${ }^{375} \mathrm{O}$ cantor, que nunca assumiu abertamente sua sexualidade, explica, em declaração citada no livro de Paulo César Araújo, a história da música: "Eu fiz esta canção por causa de uma noite de paquera. Eu cheguei de viagem, joguei a mala de dinheiro numa gaveta do quarto, desci, peguei meu carro e fui paquerar. E chegando ali eu vi aquele ambiente, as pessoas se olhando, os coroas paquerando os menininhos... foi numa noite de paquera. Aquilo que eu retratei na letra foi real, absolutamente real”. In: ARAÚJO, Paulo Cesar de. Eu não sou cachorro, não: música popular cafona e ditadura militar. Rio de Janeiro/São Paulo: Record, 2015, p. 142.

376 “Estrelas mil na Galeria Alaska”. Lampião da Esquina, n. 10, março de 1979, p. 5.
} 
um dos "midnight kids", também chamados "taxi boys" ou, ainda, "caubóis da madrugada", como eram mais conhecidos estes adolescentes. Geralmente menores de idade, eles ganhavam a vida se prostituindo na Galeria Alaska, sobretudo atendendo os desejos de homens gays mais velhos que visitavam o espaço em busca de sexo ocasional e fortuito.

A referência desse estrangeirismo na designação dos michês era devida ao clássico filme "Midnight Cowboys", de 1969, traduzido no Brasil como "Perdidos na Noite", dirigido por John Schlesinger e com roteiro baseado em obra de James Leo Herlihy. O filme narra o drama do jovem texano inculto, mas de boa aparência, Joe Buck, que estava convencido de que poderia fazer fama e dinheiro se prostituindo com as mulheres solitárias de Nova Iorque. Assim, estimulado pela influência da televisão, do rádio e de revistas eróticas, ele abandona seu emprego de lavador de pratos e, vestido com os trajes de cowboy, segue rumo à ilusão do sucesso. Ao chegar na cidade grande, contudo, sem dinheiro e sem conhecer ninguém, termina perambulando pelas ruas e conhece Ratso, um marginal do Bronx com quem enfrentará o mundo hostil que descobriu nessa mudança frustrada de vida.

No caso dos jovens caubóis brasileiros, oriundos do interior do país ou de bairros pobres das grandes cidades e acometidos pela mesma ilusão do dinheiro fácil, o problema era que as constantes batidas policiais atrapalhavam os seus negócios por despertarem atenção pública e romperem com o ar de anonimato que o gueto garantia a seus frequentadores noturnos. Assim, Marcos S. relatava: "na Galeria Alaska o ruim é a polícia. Eles não dão sossego e isso espanta o freguês. Sabe como é: tem bicha conhecida, que se descobrirem quem ela é, dá bode". 377

Em uma outra entrevistada na matéria, quem relata a violência policial é uma travesti, designada como "Paulo, Paulete, Paulona, a Doida - me chama como quiser", conforme ela mesma se apresentava. Segundo Chrystóstomo, tratava-se de "um cara [sic] disposto a tudo, cansado de apanhar, de ir preso, de lavar latrina de distrito policial, sem saber que crime cometeu". Ao perceber seus braços cheios de cortes e cicatrizes nos pulsos, até a altura do cotovelo, o jornalista questionou o que teria produzido aquelas escoriações, ao que Paulete respondeu: "Ocê não tá com nada, heim cara? Não sabe porque a gente se corta? É o único jeito de não ir presa, quando a polícia baixa na Lapa e na Cinelândia”.

Pegas "em flagrante" no trottoir que faziam para ganhar a vida, travestis como Paulete andavam municiadas com giletes que enfiavam nos seus próprios braços como um esforço antes de serem arrastadas para os camburões policiais que as levariam para a detenção. Assim,

\footnotetext{
377 "Os caubois, seus clientes: todos querem ser felizes no triângulo da badalação". Lampião da Esquina, edição 1, maio/junho de 1978, p. 5
} 
elas se viam obrigadas a mutilarem seus corpos, mesmo que isso deixasse suas marcas gravadas, para tentar escapar da violência do Estado. Nesta mesma entrevista, Paulete afirmou que, ao se cortarem, não dava outra: "os homens tem de levar [...] pro hospital, senão morre de sangrar. E no hospital a gente não apanha, até tratam bem". 378

\section{"Só ando com gilete. É a minha defesa contra a polícia"}

O documento com a Informação n. 128/79/DSI/MJ, enviado por órgãos de espionagem em 17 de maio de 1979 ao Ministro da Justiça sobre o tabloide "Flagrante Livre", caracterizado como "órgão mensal da 'imprensa nanica', editado no Rio de Janeiro" e descrito como de "radical posição contestatória ao regime e ao Governo"379 . O incômodo com o jornal não foi apenas pelos temas políticos em sentido estrito, mas também pelas questões morais tocadas pela publicação. O relatório afirma que "sua edição de Nov 78, além da característica acima, destaca-se pela apresentação de duas reportagens, abordando de modo atentatório aos bons costumes os assuntos de prostituição e homossexualismo". 380

Em especial, duas matérias chamaram a atenção da referida edição: a primeira delas "Acaba o mangue, mas a zona continua", que retratava, sem preconceitos, como o processo de urbanização com as primeiras obras do metrô estava alterando a concentração de prostitutas na área do Mangue - foi criticada por abordar "o problema da prostituição [...] de maneira cínica e pornográfica, com publicação de palavras e fotografias obscenas"; já a segunda, por sua vez, intitulada "Travesti, sedução e violência na batalha da noite", "aborda de forma semelhante [à primeira] o problema do homossexualismo, enfatizando supostas conivência e corrupção da polícia, além de apresentar a prática do homossexualismo como uma constante na vida noturna da cidade".

Os jornalistas, nesta segunda matéria, conversaram com diversas travestis que trabalhavam como prostitutas na região do Largo da Lapa, retratando o modo de vida, a relação com os clientes, a história de vida pessoal de cada uma delas. A violência policial e as constantes extorsões também aparecem na reportagem. Os riscos constantes que as travestis enfrentavam cotidianamente exigiam uma postura de atenção total ao meio em que se encontravam: "elas [as travestis] não param. Enquanto falam, olham sempre em volta, vigiam

\footnotetext{
378 "Os caubois, seus clientes: todos querem ser felizes no triângulo da badalação". Lampião da Esquina, edição 1, maio/junho de 1978, p. 5

${ }^{379}$ BR_RJANRIO_TT_0_MCP_AVU_0295

${ }^{380}$ Flagrante Livre, Novembro de 1980, p. 17.
} 
todos os lados e, qualquer sinal ou cheiro de polícia no ar, [ficam] atentas para entrar em algum lugar, mistura[ndo]-se aos passageiros no ponto de ônibus, desaparece[ndo] do local até que o camburão (ou similar) deixe a área. Durante a pegação, o travesti caça freguês e foge dos assalariados da PM". 381

Mas não bastava fugir dos policiais, era também preciso, na maior parte das vezes, pagar-lhes subornos e propinas. Na matéria, os jornalistas afirmavam que acompanharam a noite inteira das travestis naquela região: "mais tarde [à noite], com o trânsito mais calmo, pouco público, os policiais começam a circular. Com exceção apenas do freguês, todos os demais estão 'a fim de um troco", ${ }^{, 382}$. Uma das travestis, chamada Tatiana, reclamou da reportagem demonstrando a desconfiança que sentia quanto aos órgãos da imprensa que sempre faziam uma cobertura negativa das travestis:

olha, pelo amor de Deus não vai arrasar com os travestis não. Já chega o que a gente tem de aguentar... os garotões sacaninhas e enrustidos que passam de carro só pra mexer com a gente... a polícia. Tem vez que tem que dar até 300 cruzeiros pros canas deixarem a gente em paz, um horror! Geralmente a imprensa faz muito sensacionalismo e todo mundo acha que travesti é viado de viração. ${ }^{383}$

Quando Monique, outra das travestis entrevistadas, foi perguntada sobre os cortes em seu braço, ela se negou a falar, mas, com a insistência do jornalista, ela acabou contanto a função da mutilação, confirmando os relatos de outras travestis: "cortamos nossos braços, quando a polícia está a fim de grana, a gente não dá e eles levam em cana, arrochando cada vez mais. A gente se revolta e se corta. Então eles são obrigados a soltar, mandar pro Pronto Socorro. Mas não ponha isso no jornal, não, menino, tá louco?” 384 A colega Patrícia, comentou em seguida: "Põe sim. Eu também já me cortei... Na delegacia, o delegado veio forte, me escrachando. Eu fiquei maluca mais ainda, tirei a gilete e me cortei. As amigas falaram mal de mim na época..." Ambas carregavam uma gilete partida ao meio entre a arcada dentária e a bochecha. Monique tirou para mostrar ao jornalista e afirmou: "eu não ando com navalha, faca, gargalo de garrafa na bolsa, revólver, nada disso. Só ando com gilete. É a minha defesa contra a polícia”. ${ }^{385}$

\footnotetext{
${ }^{381}$ Flagrante Livre, Novembro de 1980, p. 17.

382 Flagrante Livre, Novembro de 1980, p. 17.

${ }^{383}$ Flagrante Livre, Novembro de 1980, p. 17.

${ }^{384}$ Flagrante Livre, Novembro de 1980, p. 17.

${ }^{385}$ Flagrante Livre, Novembro de 1980, p. 17.
} 


\section{"Documento de bicha pobre é grade"}

Entretanto, quando a estratégia bastante violenta da automutilação preventiva com a gilete não dava certo para assegurar a liberdade, as travestis acabavam sendo levadas coercitivamente para a carceragem das delegacias ou penitenciárias. Ainda em 1978, o Lampião publicou mais uma longa reportagem, também de Chrysóstomo, intitulada "Mônica Valéria, uma vida em segredo", que abordava a rotina de detenções de travestis. Na matéria, o jornalista relatava a vida de Mônica, também designada pelas siglas do nome masculino, L. C. T. Da S. Ela havia se mudado de Carangola (MG) para o Rio de Janeiro com o objetivo de ganhar a vida como empregada doméstica durante o dia e, nos finais de semana, de noite, trabalhando nas ruas da Lapa como prostituta para juntar mais dinheiro.

Mônica narrou em detalhes como era constante o assédio policial na região onde ela trabalhava durante as noites, não importando se ela e suas colegas de pista estavam portando documentos para identificação pessoal ou não. Acusações eram forjadas e inventadas pela própria polícia, enquadrando as travestis na proibição da vadiagem, ainda que tivessem trabalho e comprovassem isso:

[...] a polícia sempre deu em cima. Prendem a gente à toa. Documento de bicha pobre é grade. Eles põem a gente no camburão e falam pro Comissário que a gente é vagabunda, mesmo com documento, carteira assinada na bolsa. Diz que a gente faz bagunça, diz que bicha só fala palavrão. Se não falou, inventam... ${ }^{386}$

Em seu depoimento, ela descreveu a descrição das extorsões que sofriam em conluio dos policiais com lanterninhas. Uma de suas estratégias era deixar de se maquiar antes de entrar nos cinemas para fazer os programas, para não "dar muita pinta":

alguns da PM prendem as bichas pra tomar o dinheiro delas. Outros do distrito entram no cinema Iris, pintam e bordam, não querem nem saber se tem documento, se tem lei. A gente só se pinta depois que entra, dentro do cinema, pra não afrontar as famílias do lado de fora. Se não fosse a polícia e os marginais agindo junto com os lanterninhas, inventando flagrante e roubos para arrochar as bichas, era pro ambiente do Iris ser até bem civilizado. ${ }^{387}$

Por fim, ela destacou a atuação particularmente abusiva de um agente policial, o “comissário Black", que atuava na região da Praça Tiradentes: "[ele] prende bicha, toma

\footnotetext{
386 "Mônica Valéria, uma vida em segredo". Lampião da Esquina, n. 7, dezembro de 1978, p. 10.
}

387 "Mônica Valéria, uma vida em segredo". Lampião da Esquina, n. 7, dezembro de 1978, p. 10. 
dinheiro, bate e manda embora. Se reclamar, somem com o viado. Tem uma, a Carminha, um travesti lindo, moreno, precisava de ver, que arranjou encrenca e sumiram com ela". 388

\section{"Gays quebram pau com delega machão"}

Era comum que prostitutas, travestis e homossexuais resistissem ou "arrumassem encrenca", para usar a expressão de Mônica Valéria, quando eram detidas, ou mesmo na prisão. Uma matéria intitulada "Gays quebram pau com delega machão", do Jornal O Povo, de 28 de outubro de 1982, retrata a reação àquilo que ficou conhecido como "Operação Bicha", desencadeada sob o pretexto de que muitos furtos que estariam acontecendo na região da Lapa e Cruz Vermelha estariam sendo levados a cabo por travestis que ali trabalhavam como prostitutas.

Assim começava o relato: "Doravante, só vai poder rodar bolsinha na área da 5a DP ... quem tiver carteirinha e for devidamente catalogado naquela especialidade. Até os estagiários de bicha ou prostituta estão obrigados a isso" ${ }^{\text {389 }}$. O delegado determinou a retirada de "circulação" de mais de "50 "figurinhas' que esvoaçavam pela dita área", mas a matéria sensacionalista mencionava que, mais difícil do que retirar as bichas e prostitutas, foi "a trabalheira que elas deram na $5^{\text {a }}$ DP com seus gritos e shows de histeria madrugada adentro". 390 Algumas das travestis entrevistadas concluíram que "agora, 'todas' estão apavoradas com a nova ordem do delegado: prostituta e bicha de catálogo é uma novidade". ${ }^{391}$ Nem era tão inédito um procedimento dessa natureza, pois o delegado Guido Fonseca, em São Paulo, já adotava medidas semelhantes em São Paulo, conforme será abordado mais adiante.

De qualquer modo, vale notar que este tipo de violência homofóbica e transfóbica não era algo novo no Rio de Janeiro que ressuscitou, na década de 1970, uma figura conhecida na Zona Sul e no Centro e que havia sido responsável, desde os anos 1950, por batidas policiais nas boates, bares e hotéis cariocas: o delegado Deraldo Padilha. Naquela época, ele ocupou a Divisão de Meretrício da Delegacia de Costumes e Diversões, perseguindo incansavelmente prostitutas, travestis e homossexuais. Sempre acompanhado pela imprensa, que

\footnotetext{
388 “Mônica Valéria, uma vida em segredo". Lampião da Esquina, n. 7, dezembro de 1978, p. 10.

389 Jornal O Povo, 28 de outubro de 1982. Até mesmo uma matéria sensacionalista como essa despertava atenção da espionagem política, conforme análise dessa notícia presente na Informação n. 317/19/AC/82, da AC/SNI para o DSI/MJ, sobre "acompanhamento de assuntos contrários à moral e aos bons costumes, veiculados por órgãos de imprensa, em textos ou manchetes, caracterizando abuso no exercício da liberdade de manifestação do pensamento e informação..." (BR_AN_RIO_TT_0_MCP_PRO_1839).

390 Jornal "O Povo", 28 de outubro de 1982 (BR_AN_RIO_TT_0_MCP_PRO_1839).

${ }^{391}$ Jornal "O Povo", 28 de outubro de 1982 (BR_AN_RIO_TT_0_MCP_PRO_1839).
} 
propagandeava suas ações, ele voltava à ativa depois de um afastamento no ano de 1968, acumulando a titularidade dos $12^{\circ}$ e $13^{\circ}$ Distritos Policiais de Copacabana. A truculência com que ele invadia os estabelecimentos comerciais era tanta, que a associação comercial e industrial da Zona Sul começou a criticar e até a processar Padilha, a fim de interromper suas arbitrariedades. Ele acabou sendo aposentado compulsoriamente por ato do presidente Médici, em 19 de janeiro de 1973, sem que tenha sido claramente declinada a motivação ${ }^{392}$.

Outros delegados procediam da mesma maneira, alinhados à orientação da própria Secretária de Segurança Pública, como o Delegado José Gomes de Andrade que, em certa ocasião, chegou a afirmar:

Desde que assumi a $5^{\mathrm{a}} \mathrm{DP}$, há dois meses, vimos fazendo várias investidas na Praça Tiradentes, apesar desta não ter um grande número de ocorrências, para ver se conseguimos afastar os marginais e os homossexuais da área. $\mathrm{O}$ novo Secretário de Segurança Pública tem imprimido um maior rigor e, com a continuidade deste trabalho, a coisa tende a acabar. A partir do momento em que tivermos uma atuação sistemática na região, os homossexuais não vão se sentir bem ali e irão procurar outro lugar. ${ }^{393}$

\section{“Afinal, quem define leis e direitos no País do Carnaval?"}

As travestis eram, sem dúvida, o alvo privilegiado da repressão moralizante levada a cabo pelas forças de policiamento que circulavam pelas ruas. Primeiro, porque elas, diferentemente de alguns homossexuais que escondiam a orientação sexual dentro do armário, não podiam ocultar sua identidade de gênero do mesmo modo como gays e lésbicas ${ }^{394}$. Segundo, porque geralmente elas estavam mais expostas em locais públicos por se dedicarem, profissionalmente, à prostituição, diante da falta de outras oportunidades no mercado de trabalho. Terceiro, porque já sofriam duramente a repulsa da sociedade por conta do estigma criado em torno delas e das prostitutas que habitam estes territórios marginais. Por fim, é importante notar o expressivo crescimento no número de travestis na liberalização dos padrões de gênero em curso no final dos anos 1970 e início da década de 1980.

\footnotetext{
${ }^{392}$ MOREIRA, Antônio Carlos. "Deraldo Padilha: perfil de um delegado exibicionista". Lampião da Esquina, n. 26, julho de 1980, p. 19.

${ }^{393}$ MOREIRA, Antônio Carlos. “Corre que lá vem os home!” Lampião da Esquina, n. 36, maio de 1981, p. 13.

${ }^{394}$ Perlongher cita uma colocação de Richetti que, perversamente, toma o discurso gay para reprimir as travestis: "o homossexual não cria problema. Ele é uma pessoa humilde, recatada, cordata e envergonhada. Ele não se expõe" (PERLONGHER, Nestor. O negócio do Michê - A prostituição viril em São Paulo. São Paulo: Fundação Perseu Abramo, 2008 p. 97). Além disso, o mesmo autor afirma que "as irrupções [de violência contra homossexuais em boates] não costumam ter a sistematicidade nem a violência despeitada dos ataques contra as travestis" (p. 103).
} 
J. S. Trevisan, no texto "E o direito de ir e vir?", criticou as prisões injustificadas e arbitrárias, cada vez mais comuns, de travestis. Para ele, era um paradoxo que "no País do Carnaval, os machões [pudessem] se desrecalcar vestindo-se de mulher em fevereiro", enquanto as travestilidades fossem consideradas um "crime durante o resto do ano, quando os machões se vest[iam] de machões. Que o digam os travestis, continuamente presos e humilhados sob as mais diversas alegações" 395.

Trevisan abordava, então, o caso de "Kioko (aliás, Pedro Teruo)", uma travesti que estava passeando em São Paulo quando foi presa por uma semana "sem que ao menos pudesse ser acusado de vadiagem (ele é costureiro por profissão)”. Diante deste abuso, Kioko procurou um advogado e entrou com um pedido de habeas corpus preventivo. O Tribunal de Justiça de São Paulo lhe reconheceu, por unanimidade, o direito de livre-trânsito, "considerando que o trotoar, seja masculino ou feminino, não merece punição desde que não perturbe a moral ou a ordem pública". Para Trevisan, "exibir um salvo-conduto nada mais [era] do que o amargo atestado de que nos falta[va] até mesmo o direito de andar. Afinal, quem defin[ia] leis e direitos no País do Carnaval? " 396

Entretanto, mesmo durante as festas de carnaval, famosas pela suposta liberdade e libertinagem sexual, com as mencionadas trocas de papeis de gênero e inversões de todas as ordens, intensificava-se a repressão moral com conivência das forças policiais.

O jornal Lampião de março de 1980, logo após os festejos momescos, publicou a carta de um folião que relatava o aumento da violência em uma região tradicionalmente tolerante aos homossexuais no Rio de Janeiro, apesar das investidas repressivas já nas décadas de 1950 e 1960: a Cinelândia. Na carta, o leitor Osvaldo Farias do Nascimento, escreveu: “é incrível as atrocidades que ocorreram neste carnaval; principalmente no gueto de maior concentração guei, que é a Cinelândia. Onde bichas e travestis eram atacadas, surradas e rasgadas, como foi o caso de um elegante travesti". Além disso, ele denunciava o descaso e até cumplicidade da polícia: "nossa polícia, o que fez? Nada. Dez policiais da PM se mostraram impassíveis ante esta cena. Fato que me revoltou a ponto de me fazer chorar”. Ao que Aguinaldo Silva, em sua resposta, corroborou a triste constatação: "neste primeiro carnaval da supostamente libertária década de 80, viu-se uma coisa que há muito tempo não acontecia na Cinelândia: bichas sendo linchadas"397.

\footnotetext{
395 “E o direito de ir e vir?”. Lampião da Esquina, n. 10, março de 1979, p. 9.

396 “E o direito de ir e vir?”. Lampião da Esquina, n. 10, março de 1979, p. 9.

397 “Tá legal, 'Geni'; mas e a mãe, tá boa?”. Lampião da Esquina, n. 22, março de 1980, p. 2.
} 


\section{"Queremos condições para vender direito nosso corpo, sem perseguição da polícia": a violência contra prostitutas}

Ao lado das travestis, as prostitutas foram um dos segmentos da sociedade mais perseguidos e reprimidos pela ditadura em sua ânsia de proteção da "família" e dos valores cristãos. Em muitos casos, as travestis eram prostitutas, o que acentuava ainda mais a violência a que estavam sujeitas. Os michês, ainda que também sofressem com as perseguições regularmente, não eram assediados do mesmo modo como as mulheres ${ }^{398}$.

O mesmo que se passava em relação à homossexualidade, do ponto de vista legal, ocorria com as prostitutas. Como o trabalho sexual nunca foi legalizado e protegido plenamente, apesar de também não ser expressamente proibido, sempre houve uma zona cinzenta de normatividade permitindo uma arbitrariedade muito grande no tratamento que as forças policiais dispensavam para essa população concentrada em algumas regiões centrais das grandes cidades. A situação se agravava com a estigmatização social e o preconceito cultural largamente difundido, que acabava conferindo legitimidade às violências que levavam a cabo os projetos de "limpeza" ou higienização" tão em voga naquele momento.

Em São Paulo, a repressão contra prostitutas atingiu níveis tão extremos que culminou, em $1^{\circ}$ de dezembro de 1979 , em uma passeata de três horas, da qual participaram mais de 100 prostitutas da chamada Boca do Lixo, região no centro paulistano conhecida pela presença de prostitutas que atendiam clientes de menor poder aquisitivo. $\mathrm{O}$ ato foi encerrado na frente da Seccional de Polícia, com palavras de ordem pelo fim das extorsões constantes a que estavam submetidas e também contra os maus-tratos que sofriam sob custódia policial ${ }^{399}$.

Depois deste ato, a repressão, ao invés de diminuir, foi intensificada como uma espécie de retaliação contra as prostitutas que ousaram se manifestar aberta e organizadamente, rompendo com as barreiras dos guetos.

Dias após o ocorrido, e diante da escalada crescente de agressões contra as prostitutas, tanto por policiais como por grupos por estes incentivados, realizou-se uma reunião no Teatro Ruth Escobar. Estavam lá homossexuais, feministas, deputados da oposição e estudantes para discutir formas de apoio às prostitutas, que se fizeram no final da reunião. Uma delas, segundo a cobertura do encontro que Trevisan escreveu para o Lampião, deu um relato bastante detalhado das dificuldades enfrentadas e de suas reivindicações mais do que justas:

\footnotetext{
398 “... operações específicas contra os michês são também rotineiras, embora mais tênues e discretas” (PERLONGHER, Nestor. O negócio do Michê - A prostituição viril em São Paulo. São Paulo: Fundação Perseu Abramo, 2008, p. 103).

399 “A vida é fácil?”. Lampião da Esquina, n. 21, fevereiro de 1980, p. 2.
} 
Queremos condições para vender direito nosso corpo, sem perseguição da polícia. Tem aqui uma que já foi presa quatro vezes nesta semana. A gente trata bem a freguesia, mas a polícia vem e estraga tudo. Depois que a gente se movimentou, a polícia não deixa nem encostar ali no nosso canto, com respeito. Ninguém dá valor pra prostituta. Homem passa, mexe e xinga. Todo mundo mexe. Queremos ganhar nosso dinheiro sossegada, sem polícia espancando e deixando a gente nua na rua. Não deviam ter esse direito de enfiar a gente no xadrez, em sala forte. Eles marcam a gente e ficam prendendo sem parar. Levam pra inspeção mas acabam deixando presa dez dias. Já vi muitas abortando na cadeia. Lá a gente não recebe nem um café, só água fria no corpo. Queremos ganhar nosso dinheiro, porque temos filhos pra criar, diária no hotel e restaurante pra pagar. Mas eles não querem nem saber. ${ }^{400}$

\section{"Nós estamos falando de uma violência institucionalizada"}

"Dois travestis, uma advogada: três depoimentos vivos sobre o sufoco" foi uma longa matéria que traçou o mais completo panorama encontrado na imprensa na época sobre as violências sofridas pelas travestis, por ação policial, no centro de São Paulo. Para fazer a entrevista, Darcy Penteado aproximou seu carro de duas travestis na Rua Rego Freitas e propôs a elas a realização da entrevista para que relatassem as situações de abusos que elas sofrias nas ruas da capital paulista.

Tatiana, com 28 anos, e Flávia, com 22, aceitaram colaborar, depois de alguma insistência, e entraram imediatamente no carro de Darcy, que as levou para sua casa. Ali, as estava esperando a Dra. Alice Soares, advogada criminalista e orientadora do Departamento Jurídico XI de Agosto, vinculado ao Centro Acadêmico da Faculdade de Direito da USP que oferecia assistência judiciária gratuita para a população de baixa renda em São Paulo desde 1919. Dra. Alice Soares, que foi uma das mais atuantes defensoras das bichas, lésbicas, travestis e prostitutas naquele período, razão pela qual recebeu a alcunha de "santa dos travestis e homossexuais paulistas em geral" ${ }^{\text {"401 }}$, também foi entrevistada. Completaram o time de entrevistadores os jornalistas João Silvério Trevisan, Jorge Schwartz e Glauco Mattoso.

Tatiana perguntou, logo de início, por que a Dra. Alice estaria se dedicando "aos problemas dos travestis". Esta respondeu:

porque eu, particularmente e em nome do Departamento Jurídico, nós estamos lá justamente para atender a estes grupos oprimidos; acho que vocês

\footnotetext{
400 “A vida é fácil?”. Lampião da Esquina, n. 21, fevereiro de 1980, p. 2.

${ }^{401}$ Lampião da Esquina, n 24, maio de 1980, p. 4.
} 
no momento estão sendo perseguidos, oprimidos. Como também atendemos ao movimento negro; somos uma espécie de ponta-de-lança contra as injustiças. $^{402}$

Ela ainda explicou como era o difícil trabalho de defesa: "fazemos questão de atender e acompanhar vocês, quando são presos. Se vão para o DEIC, nós vamos lá e fazemos tudo, entramos com habeas corpus, batemos um papo com o delegado ou o investigador, procurando um meio de libertar o prisioneiro o mais depressa possível” ${ }^{403}$. E esclareceu que, geralmente, são “os amigos” [outras travestis] das presas que iam até o Departamento Jurídico, em busca de assistência jurídica e atendimento.

Flávia, por sua vez, reclamou da permanente vigilância de que eram vítimas e desabafou dizendo: "quando a gente sai de casa em pleno dia, eu pego uma sacola para dar uma disfarçada, senão eles [policiais] levam. Finjo que vou fazer compras" ${ }^{, 404}$. Essa declaração devela a dificuldade que as travestis enfrentavam para ocupar o espaço público, exercendo seu direito mais elementar de circular pela cidade, mesmo na luz do dia, para realizar tarefas rotineiras.

Questionada se já havia sido presa, Flávia logo respondeu: “eu, já! Eles não querem nem saber: pegam a gente e mandam pro camburão. Jogam dentro do carro. São todos mal educados, pegam em vez de levar a gente. Eu tenho documento, de ator; mesmo assim eles levam. Mesmo tendo carteira de trabalho; eu tenho" ${ }^{405}$.

Nota-se, assim, que as travestis era detidas, conforme já pontuado, mesmo quando portavam documentos de identificação. A prática corrente de prisão de quem não tivesse devidamente identificado adquiria contornos diferenciados quando essa pessoa era uma travesti, caso em que pouco importava a posse ou não de documentação. A regra era a prisão sumária pela simples existência. Flávia relatou esse tratamento mais intolerante quando “...uma vez eu estava com INPS, tudo certinho, e mesmo assim fui [presa]”. E Tatiana acrescentou: "pois eu já conheci muito travesti que mesmo trabalhando, com carteira assinada e tudo, fica 15, 20 dias de molho na prisão. Perde o emprego e tudo".

Sobre o tempo de privação de liberdade, não havia um parâmetro rigorosamente fixado, pois o procedimento era bastante arbitrário e variava, em última instância, conforme a

\footnotetext{
402 "Dois travestis, uma advogada: três depoimentos vivos sobre o sufoco". Lampião, n. 19, dezembro de 1979, pp $5-7$.

403 "Dois travestis, uma advogada: três depoimentos vivos sobre o sufoco". Lampião, n. 19, dezembro de 1979, pp $5-7$.

404 "Dois travestis, uma advogada: três depoimentos vivos sobre o sufoco". Lampião, n. 19, dezembro de 1979, pp 5-7.

405 "Dois travestis, uma advogada: três depoimentos vivos sobre o sufoco". Lampião, n. 19, dezembro de 1979, pp 5-7.
} 
acusação atribuída, as provas existentes e mesmo a vontade particular das autoridades responsáveis pela prisão. Flávia afirmou que, geralmente, ficavam presas por mais ou menos 3 dias, dependendo da fase da repressão. Mas, segundo Dra. Alice esse prazo poderia aumentar bastante, pois "na pior das hipóteses fica-se 30 dias preso. Já vi isso acontecer com vários travestis" ${ }^{406}$.

Isso porque o procedimento mais corriqueiro era a prisão em flagrante por algum elemento forjado com provas implantadas. Então o esforço dos advogados de defesa iam no sentido de relaxar o flagrante e permitir que a travesti acusada respondesse em liberdade. No entanto, diversos juízes achavam que, se a pessoa fosse embora antes de assinar a condenação, posteriormente não se conseguiria localizar e fazer cumprir a pena, sobretudo em se tratando de sanções consideradas mais brandas, como pagamento de multa.

Apesar de nitidamente abusivo, o tratamento agressivo das forças de segurança contra esses segmentos vulnerabilizados socialmente encontrava respaldo e justificação por meio da manipulação feita no ordenamento jurídico brasileiro. É fato que a prostituição e a homossexualidade, sejam masculinas ou femininas, não estavam tipificadas como crime no Código Penal. No entanto, para contornar a falta de previsão legal expressa para a perseguição, as autoridades se aproveitavam da contravenção penal de "vadiagem" para enquadrar qualquer pessoa considerada "sem ocupação". Sobre este aspecto da atuação policial, a Dra. Alice esclareceu que

geralmente eles prendem as pessoas e incluem em vadiagem, instauram a sindicância quando é a primeira vez. E depois, se a pessoa é presa novamente, cai no artigo 59 da lei das contravenções penais: vadiagem. De modo que fazem o flagrante, levam para a Casa de Detenção até o julgamento, que leva um mês.

Em relação à intensidade repressiva e sua variação durante as diferentes gestões do governo paulista, Dra. Alice afirmou que foi na época em que Erasmo Dias era o Secretário de Segurança Pública, entre 1974 a 1978, que a repressão nas ruas atingiu seu auge. Em boa medida, isso se deve ao já referido aumento da visibilidade da presença desses segmentos em determinadas zonas ocupadas pela classe média. Flávia corrobora a caracterização desse período de maior rigor ao relatar um caso em que ele mobilizou homens, mulheres e até cachorros para atacar as travestis e prostitutas: "O pior tempo que teve para os travestis foi o do Erasmo", arrematou ela. Mal sabiam elas, contudo, que ainda estava por vir o famigerado

\footnotetext{
406 "Dois travestis, uma advogada: três depoimentos vivos sobre o sufoco". Lampião, n. 19, dezembro de 1979, pp 5-7.
} 
delegado José Wilson Richetti, que faria campanhas ainda mais agressivas contra esses grupos, conforme se verá adiante.

No que se refere às agressões físicas e outros tipos de torturas, para além das detenções arbitrárias, as travestis afirmaram que apenas as que adotavam uma postura de resistência frente aos desmandos da polícia sofriam tais sevícias. Tatiana, por exemplo, relatou que uma amiga delas "deu escândalo e jogaram uma bomba dentro da cela; arrebentou tudo, ela saiu até no jornal" ${ }^{407}$.

Essas travestis que reagiam às violências, seja "partindo pra cima" dos agentes públicos ou mesmo se automutilando com giletes para serem levadas da prisão para um hospital, ficaram conhecidas como "do babado", uma gíria tipicamente utilizada neste universo LGBT.

As do babado ficaram revoltadas. As do babado são as que cortam, dão escândalo, apanham, chegam na polícia e já viram a máquina do delegado, batem nele, o delegado leva eles pro xadrez. Naquele dia, tiraram toda a roupa e tocaram fogo. Foi fumacê na cela, todo o mundo gritando. E aí falaram: vamos se cortar todos juntos. Uma dava a gilete para a outra... Já fazia quatro dias que estavam lá; então, se cortavam pra ver se levavam eles pro hospital, porque lá o pessoal tem medo do escândalo e solta elas. ${ }^{408}$

Outra modalidade de violência bastante corriqueira, e uma das prediletas dos agentes públicos contra as travestis, era a extorsão. Eles pediam dinheiro, descaradamente e sem nenhum pudor, em troca de deixar em liberdade as travestis. Questionada se os policiais tiravam dinheiro delas, Flávia respondeu categoricamente: "lógico que tiram!” E Tatiana acrescenta: "tem travesti que dá carro para eles, que vende tudo pra se livrar deles; se entram num flagrante de maconha, de alguma droga, tem muito o que fazer, é lógico..." Mas nem sempre pagar livrava a cara das travestis; muitas vezes, policiais pegavam o dinheiro e ainda levavam as travestis presas em flagrante por suborno. Tatiana descreveu um episódio em que esse tipo de abuso fica evidente:

estava eu e uma amiga, demos 50 cada uma, e sabe onde a gente foi parar? $\mathrm{Na}$ Casa de Detenção. Fiquei passada! Só aí eu fiquei sabendo que existia uma coisa chamada 'suborno à autoridade'; porque normalmente a gente dá dinheiro, mas eles acham pouco, então vira flagrante. ${ }^{409}$

\footnotetext{
407 "Dois travestis, uma advogada: três depoimentos vivos sobre o sufoco". Lampião, n. 19, dezembro de 1979, pp 5-7.

408 "Dois travestis, uma advogada: três depoimentos vivos sobre o sufoco". Lampião, n. 19, dezembro de 1979, pp 5-7.

409 "Dois travestis, uma advogada: três depoimentos vivos sobre o sufoco". Lampião, n. 19, dezembro de 1979, pp 5-7.
} 
No jornal "Repórter", n. 38, de fevereiro de 1981, foi publicada a carta do leitor Luiz da Silva, que se disse perplexo com o preconceito ao ler notícia de O Globo de 18 de janeiro de 1981 com o título "Prostituta diz que soldados lhe tomaram Cr\$ 500,00". O leitor afirmou indignado:

ela [a prostituta] é achacada por dois soldados da PM e um motorista de táxi marginal, agredida e roubada em $\mathrm{Cr} \$ 500,00$, grita, chama atenção de polícias que levam todo mundo pra delegacia e o 'delegado' solta os caras dizendo que não pode dar crédito à palavra de uma prostituta. Onde estamos? Uma prostituta é animal? É um ser inferior? Não é gente? Será que uma moça dessas não pode dar queixa de agressão e furto do qual foi vítima? Que justiça é essa? ${ }^{410}$

Esse trecho reflete não apenas a discriminação institucionalizada nos órgãos de segurança, em conluios de corrupção, mas também a maneira como agentes públicos se apropriavam do preconceito como uma arma para naturalizar a extorsão dessas vítimas.

Em relação a essa acusação de extorsão das prostitutas e travestis para liberá-las da cadeia, Richetti respondeu ironicamente ao jornalista: "estariam extorquindo dinheiro se deixassem as prostitutas agirem livremente. Se estão prendendo é porque não estão ganhando nada. Como as prostitutas podem ganhar dinheiro na cadeia para dar aos policiais? " 411

As prisões, assim, eram a rotina das travestis, especialmente daquelas que faziam a "viração", ou seja, tentavam ganhar a vida por meio da prostituição nas ruas do centro de São Paulo. Eram tão recorrentes as detenções que algumas das travestis sequer sabiam precisar quantas vezes haviam sido presas. Tatiana, por exemplo, afirmou aos jornalistas: “eu fui presa poucas vezes: umas dez". Questionada se achava isso pouco, ela respondeu ao Trevisan: "em vista das outras, que vão todo dia... Tem bicha que já foi presa mais de cem vezes”. E Flávia, também achando que foi presa apenas umas poucas vezes, declarou perder as contas: "Ih, eu conheço o $4^{\circ}$ distrito, o $3^{\circ}$, o $27^{\circ}$, tantos...”. Sobre quantas pessoas ficavam juntas em cada cela, ela disse: “Ah, eles põem bastante, até cem juntas. É uma cela pequena”. Ela também contou ao Lampião ter ficado detida com outras travestis e um garoto menor de idade em uma mesma cela do Presídio do Hipódromo, que também era utilizado como centro de detenção feminina de presas políticas da ditadura.

Amelinha Teles, que ficou ali detida ainda durante a primeira metade da década de 1970, afirmou, em entrevista para esta tese, que, já naquela época era impressionante o

\footnotetext{
410 "Repórter", n. 38, fevereiro de 1981.

411 “As ‘rondas' vão continuar e delegado nega acusações”. Folha de São Paulo, 10 de junho de 1980, p. 13.
} 
número de travestis existentes nas carceragens do Hipódromo. Ali, as travestis eram conhecidas pelas presas políticas como "corrós", em referência à situação em que se encontravam de cumprimento de medidas correcionais por conta do enquadramento na contravenção penal de vadiagem.

Ainda que se possa e que seja até mesmo recomendável problematizar eventuais exageros presentes nos depoimentos, pois podem estar influenciados pela percepção pessoal e subjetiva, estas fontes são das poucas disponíveis para analisar as violações de direitos humanos e, em seu conjunto, permitem-nos traçar um panorama que, a despeito de distorções pontuais, consegue ser bastante fiel à realidade.

\section{Outros abusos: violência sexual e trabalho forçado}

Outra revelação feita durante a mesma entrevista para o Lampião estava relacionada aos abusos sexuais constantes a que foram submetidas travestis e prostitutas. Flávia afirmou que

às vezes o policial exige que a gente faça sexo pra soltar a gente. Com a polícia, com o carcereiro, com o... O carcereiro é quem solta, então eu tive que fazer muito programa pra ele me soltar. Aliás, não foi programa, foi assim um meio-programa, um meio termo de sexo. Muitas vezes, levam a gente pras quebradas, e depois soltam. Não só eu: várias amigas vão juntas. $\mathrm{E}$ tem quatro policiais, geralmente. Eles escolhem quatro travestis, soltam as outras, fazem festa e tchau.

Além das agressões físicas, extorsões, violências sexuais, muitas vezes as travestis eram obrigadas a realizar trabalhos forçados dentro das delegacias e penitenciárias, limpando banheiros, celas e fazendo outros serviços para os policiais em flagrante abuso de autoridade.

Um ponto que merece destaque de toda a conversa publicada em o Lampião, foi a reflexão trazida por Dra. Alice sobre o respaldo institucional da ditadura em relação a tais práticas violentas contra a população de travestis, atestando não se tratar de um mero acaso ou um simples incidente causado apenas por alguns agentes públicos motivados por suas próprias convicções morais de foro íntimo. Antes, tratava-se de uma coordenação repressiva que combinava diferentes esferas em um plano de ação deliberado e uma série de incentivos institucionais para que os agentes perseguissem esses setores já discriminados. Afirmou ela, na entrevista, que 
a Corregedoria de Polícia também é muito mole. Fica tudo em família, eles se sentem acobertados. E depois, essa arbitrariedade que nós tivemos aí de 15 anos, esses atos de violência, isso de certa maneira incentivou. Veja, quando havia um Fleury lá no DEIC, do Esquadrão da Morte, prestigiado pelas forças armadas, os policiais iam fazer o quê? Se o subalterno percebe que o chefe é adepto da violência, ele também se torna violento: 'se até o diretor do DEIC pertence ao Esquadrão da Morte, por que eu também não posso?

Em seguida, ela conclui sua colocação com uma síntese sobre o estado de coisas então vigente: "Nós estamos falando de uma violência institucionalizada".

\section{"Corre bicharada que a polícia chegou"}

Pelo menos desde 1977, com a gestão de Erasmo Dias à frente da Secretaria de Segurança Pública paulista, intensificou-se, sobremaneira, as ações policiais para coibir a expansão das zonas de sociabilidade homossexual e de prostituição. Ainda que não fossem novidade, as ofensivas do Estado se multiplicavam por todas as grandes cidades. Mas foi mesmo em São Paulo, onde se concentrava o maior contingente de bichas, lésbicas e travestis, que teve lugar a maior e mais sistemática operação repressiva levada a cabo contra essas populações.

Exemplo de uma medida restritiva de direitos que preparava o terreno para as operações mais ostensivas foi a Portaria 390, de 1976, editada pela Delegacia Seccional Centro, em São Paulo. A norma era dedicada especificamente às travestis, que deviam assinar um Termo de Declarações com diversas informações pessoais (e.g. gastos com hormônios e ganho mensal); os prontuários policiais deveriam "ser ilustrados com fotos dos pervertidos, para que os juízes [pudessem] avaliar seu grau de periculosidade" ${ }^{\text {412 }}$. Essa relevância atribuída à aparência dos "acusados" ou "suspeito" para definir seu caráter ou propensão ao cometimento de delitos remonta a escolas conservadoras do campo da criminologia. Neste sentido, o delegado Guido Fonseca, que foi autor de pesquisas sobre o tema, comandou, entre 1976 e 1977, um arquivo especial com estas informações que visava facilitar a perseguição às travestis $^{413}$.

\footnotetext{
412 OCANHA, Rafael Freitas. As rondas policiais de combate a homossexualidade na cidade de São Paulo (1976 - 1982). In: GREEN, James N.; QUINALHA, Renan (Orgs.). Ditadura e homossexualidades: repressão, resistência e a busca da verdade. São Carlos: EDUFSCAR, 2014, p. 157.

${ }^{413}$ Rafael Freitas constatou que "entre 14 de dezembro de 1976 e 21 de julho de 1977, 460 travestis foram sindicados para o estudo, sendo lavrados 62 flagrantes, contabilizando $13,5 \%$ do total. O resultado mostra que 398 travestis foram importunados com interrogatório, sem serem vadios, e obrigados a demonstrar comprovação
} 
"Uma praça chamada República” é quase uma etnografia de Eduardo Dantas sobre a Praça da República e a vida homossexual nessa região em São Paulo, ainda em 1979. Sobre a repressão, ele narra, em um dos excertos:

"Corre bicharada que a polícia chegou". O alarme soa e de repente começa a
correria para todos os lados. A repressão é diária na praça e aumenta no final
de semana. E quando o pessoal está a fim de mostrar serviço, leva qualquer
um, com ou sem carteira profissional assinada, preto ou branco, bem ou mal
vestido. E ninguém quer dar uma vacilada desse tipo: passar a noite no
xadrez, levar umas bordoadas possivelmente (vai depender de diversos
fatores, até da lua e de quanto o cidadão carregar consigo em valores). Além
disso, muitos ali já têm algum tipo de antecedentes e simplesmente não
podem dançar de novo. Nessas horas vale a lei do salve-se quem puder.
Geralmente o rapa é feito por volta da meia-noite e pouco tempo depois os
policiais se retiram. A praça volta a ser do povo, está pronta para receber
novos visitantes. Afinal a noite mal começou...

Este trecho evidencia a rotina que era a repressão policial nos lugares de concentração do público LGBT. Também fica bastante claro os momentos de pico de violência e a total arbitrariedade das forças de segurança no modo de encaminhar essas detenções, que dependem do fator irônico da fase da lua, mas também da variável bem concreta de quanto dinheiro a pessoa porta consigo para subornar as autoridades.

A iminente presença do Papa João Paulo II em São Paulo, prevista para acontecer no dia 29 de junho de 1980, era o pretexto perfeito para desencadear uma cruzada moral contra corpos incômodos, tidos como imorais, que ocupavam espaços centrais da cidade. O combate à prostituição e às pessoas LGBTs, que sempre existiu, foi intensificado, a pretexto da visita ilustre, embora tenha projetado seus efeitos muito além dela.

\section{“Acontece - mas é ilegal": a prisão cautelar}

Nessa onda de escalada repressiva na abertura, no final de 1979, voltava à cena o cíclico clamor popular pelo endurecimento no combate aos criminosos, materializado sempre

\footnotetext{
de trabalho com mais exigências que o restante da população, já que a Portaria 390/1976 da Delegacia Seccional Centro estabelecia que travestis deveriam apresentar RG e Carteira de Trabalho acompanhada de xerocópia, a qual era encaminhada pela autoridade policial à delegacia seccional para arquivo destinado somente aos travestis. Os travestis que não apresentavam os documentos eram encaminhados ao distrito, onde aguardavam a formulação de inquérito que, em seguida, tornaria processo por vadiagem. Quando liberado, deveria ir com a maior brevidade possível a uma gráfica providenciar outra xerocópia para apresentar a polícia, caso fosse parado em uma blitz. A imagem também fazia parte dos estudos de criminologia e do inquérito dos travestis" (Ibidem, p. 47).

${ }^{414}$ DANTAS, Eduardo. “Uma praça chamada República”. Lampião da Esquina, n. 12, maio de 1979, p. 6.
} 
em legislações penais de ocasião que retiravam direitos e garantias processuais em nome de uma suposta eficácia. O fundamento era sempre a alegação de que os índices de criminalidade estariam crescendo sensivelmente, ainda que não houvesse dados confiáveis para respaldar esta afirmativa.

Foi assim que a proposta de liberação da prisão cautelar ganhou força, depois de apresentada ao Ministro da Justiça em um encontro nacional dos Secretários de Segurança Pública, em Brasília. O projeto de lei, de autoria do deputado paulista Erasmo Dias, pertencente à Arena e ex-Secretário de Segurança de São Paulo, foi aprovado no último dia antes do recesso de final de ano, na Comissão de Justiça da Câmara.

A regra geral era a de que o acusado só poderia ser preso em flagrante delito ou por ordem judicial. A prisão cautelar seria então uma exceção. Em havendo suspeita, poderia o delegado determinar a prisão e, de imediato, comunicar a um juiz especial, que poderia revogar ou manter a detenção por um prazo máximo de até 10 dias. Este projeto, assim, significava um empoderamento dos agentes policias, especialmente os delegados. Isto reforçava a arbitrariedade e a dificuldade do controle judicial sobre a dinâmica do sistema carcerário que se acentuava naquele momento.

Curiosamente, este pedido ao Ministro da Justiça ocorreu dias após o assassinato do cidadão Aézio da Silva Fonseca, em um distrito policial no Rio de Janeiro. Ele havia sido preso irregularmente, ou seja, por simples suspeita. Sua morte desencadeou uma onda de protestos contra as forças de segurança e aos quais o governo respondeu aumentando o uso de prisões excepcionais e fora do controle de outras autoridades.

O Lampião deu grande destaque ao assunto, pontuando como esta medida teria consequências prejudiciais na vida das chamadas minorias, destacando, como já era rotina, a prisão arbitrária de tais segmentos, bem como o quanto aquela alteração poderia agravar ainda mais a situação. Segundo o jornal,

a prisão por 'suspeita' ating[ia] diretamente aos homossexuais e outras minorias, como os negros, por exemplo. Por avaliação subjetiva, poder[ia] ser preso não apenas qualquer viado, como qualquer negro, qualquer pobre ou qualquer indivíduo que não consig[uisse] provar vínculo empregatício. Ué, mas isso já não acontec[ia]? Acontec[ia] - mas [era] ilegal. E se [fosse] legalizado, perder[ia-se] então qualquer possibilidade de luta ${ }^{415}$.

Mais uma vez, o Lampião estava certo. E nem foi necessário alterar a legislação sobre a prisão cautelar para que a violência contra as "minorias" se alastrasse em ritmo cada vez

\footnotetext{
415 “Uma luta de todas as minorias (da maioria)”. Lampião da Esquina, n. 21, fevereiro de 1980, p. 8.
} 
mais rápido e sem qualquer tipo de restrição.

\section{“O que a cidade, a Polícia e a Justiça têm a dizer sobre os Travestis?": Operação Limpeza}

Em 25 de março de 1980, o Estado de São Paulo publicou um anúncio de página inteira, com grande destaque, e que circulou por três dias, sobre uma reportagem que seria publicada em breve abordando o perigo representado pelas travestis nas ruas da cidade:

Eles se vestem de mulher, tomam conta de vários pontos espalhados pela cidade, são violentos e chegam a matar. No começo seu estranho comportamento não chegou a causar muitos problemas. Hoje as notícias sobre assaltos, brigas, escândalos e assassinatos já deixam a cidade com medo. Há poucos dias um antiquário foi jogado de baixo de um carro na República do Líbano e morreu na frente da mulher e dos filhos. O que a cidade, a Polícia e a Justiça têm a dizer sobre os Travestis? O ESTADO mostra o problema, em matéria especial sexta e sábado. ${ }^{416}$

Esse crime de assassinato do antiquário Agnaldo Guimarães, supostamente cometido por travestis em 15 de março, em uma zona residencial de São Paulo, foi o quanto bastou para o jornal mais influente do país, naquele momento, veicular duas reportagens, nos dias 28 e 29 de março de 1980, alertando a população sobre o "perigo dos travestis". Sob o pretexto de prestar um "serviço público", o periódico, que por seu caráter conservador até então evitava publicar matérias relativas aos LGBTs ${ }^{417}$, denunciava a "invasão" dessas pessoas em certas regiões centrais. O jornal já vinha, regularmente, desde 1979, alimentando uma oposição entre as "famílias decentes" e as "prostitutas" na região central, publicando diversas matérias sobre o "Edifício Século XX”, outrora de alto padrão, que estava sendo, cada vez mais, ocupado por trabalhadoras do sexo. ${ }^{418}$

A proposta de solução apresentada era de confinar tais presenças indesejáveis em certas ruas da "Boca do Lixo", a fim de proteger as famílias das ameaças de assaltos ou chantagens, "além de evitar aquela visão desagradável dos invertidos oferecendo o corpo

\footnotetext{
${ }^{416}$ O Estado de São Paulo, 25 de março de 1980, p. 35.

${ }^{417}$ Segundo Penteado, o jornal "sempre evitou referências ao homossexualismo em suas páginas" (PENTEADO, Darcy. Um apelo da tradicional família Mesquita: prendam, matem e comam os travestis!. Lampião da Esquina, n. 24, maio de 1980, p. 2). Para MacRae, "a novidade foi uma série de artigos publicados pelo 'O Estado de $\mathrm{S}$. Paulo’ em que se fazia uma campanha pela erradicação dos travestis, especialmente aqueles que faziam ponto em áreas residenciais finas da cidade" (MACRAE, Edward. A construção da igualdade: identidade sexual e política no Brasil da "abertura". Campinas: Editora da Unicamp, 1990, p. 223).

418 OCANHA, Rafael Freitas. "Amor, feijão, abaixo camburão" - Imprensa, violência e trottoir em São Paulo (1979-1983). Dissertação (Mestrado em História), PUC/SP, 2014, p. 80-81.
} 
pelas ruas decentes da cidade". O modelo ideal apresentado era o do famigerado delegado Sérgio Paranhos Fleury, que esteve à frente do DOPS em um dos períodos mais violentos da ditadura contra seus opositores e foi acusado de comandar diversas ações do chamado "Esquadrão da Morte", grupo paramilitar de execuções de "bandidos" nas periferias de São Paulo. Segundo o Estadão, quando Fleury era chefe do DEIC, "os dois xadrezes destinados exclusivamente aos travestis estavam sempre cheios" e ele exigia "que o travesti arranjasse emprego; caso contrário obrigava-o a deixar a cidade e na reincidência da prisão; autuava-o em flagrante por vadiagem. Mesmo assim a cada noite eram presos em média 40 homossexuais" ${ }^{419}$.

O cenário para a ofensiva já estava montado diante deste clima de medo criado em torno de um grupo já muito estigmatizado, com carta branca para a violência diante da reabilitação de uma figura que representava as práticas mais autoritárias do regime. Dois dias após a série de reportagens especiais, em $1^{\circ}$ de abril de 1980, um artigo publicado no jornal anunciava, com destaque: "Polícia já tem plano conjunto contra travestis". Nota-se, assim, que a "cobrança" feita pelo Estadão, poucos dias antes, já havia gerado resultados concretos. Diante de tão pequeno intervalo de tempo, entre a enunciação do problema e a apresentação da resposta estatal, não seria demais suspeitar de que já houvesse algum tipo de conluio ajustado entre as autoridades e o órgão da imprensa. A esta, caberia alertar a população para a "ameaça" e, àquelas, apresentar uma resposta dura e à altura dos reclames. E isto foi feito. No texto, constava que o delegado seccional Sul de Polícia, Paulo Boncristiano, e o coronel da Polícia Militar, Sidney Gimenez Palácios, ficaram "Impressionados com as reportagens publicadas" e, por isso, teriam se "reunido no final de semana" com o objetivo de traçar "um esquema de prevenção que já est[ava] sendo aplicado em toda a Zona Sul e pretend[iam] que o secretário de Segurança Pública adot[assem] as sugestões"420.

Curiosamente, os comandos das duas polícias, na Zona Sul, planejaram unir suas forças contra o que seria um inimigo comum. A rivalidade e os embates constantes entre as polícias militar e civil sempre foram uma marca institucional característica da segurança pública paulista, mas as pessoas LGBT conseguiram essa façanha de provocar ambas para uma rara atuação conjunta.

Basicamente, assim poderiam ser resumidas as tais sugestões das polícias paulistas que salvariam a cidade do "perigo que representa[vam] os travestis nas ruas da cidade": "tirar os travestis das ruas de bairros estritamente residenciais; reforçar a Delegacia de Vadiagem do

\footnotetext{
${ }^{419}$ OESP, 28 março de 1980.

${ }^{420}$ O Estado de São Paulo, $1^{\circ}$ de abril de 1980, p. 20.
} 
Deic para aplicar o artigo 59 da Lei de Contravenções Penais; destinar um prédio para recolher somente homossexuais; e abrir uma parte da cidade para fixá-los"421.

A matéria registra que, naquele momento da cidade de São Paulo, havia mais de 8 mil travestis. O delegado Boncristiano afirmou, como principal causa do "problema", que "est[avam] dando excessiva liberdade a estes homossexuais que tomaram conta das ruas importantes da Capital e dos bairros estritamente residenciais".

A primeira etapa do plano que foi elaborado rapidamente seria, assim, "a retirada dos travestis das áreas estritamente residenciais com a utilização de todo o dispositivo possível de homens e viaturas dos distritos policiais e das seccionais". Os travestis seriam, então, "detidos para averiguação", e os que não apresentassem carteira de trabalho assinada seriam “enquadrados no crime de vadiagem". Ao mesmo tempo em que a atuação nas ruas seria intensificada, a Delegacia de Vadiagem também deveria ser reforçada com equipes maiores de escrivães, investigadores e viaturas. Para que se tenha dimensão do crescimento do contigente e das estratégias que levariam a cabo, Boncristiano afirmou ao jornal que, segundo sua proposta, "os cartórios, com 10 escrivães, funcionar[iam] para aplicar a Lei das Contravenções Penais; nas ruas 10 viaturas e 30 investigadores, recolhendo os travestis, auxiliados pelos distritos", inclusive sugerindo que "a Secretaria da Segurança providenci[asse] um prédio próprio para recolher os travestis, enquanto os delegados os enquadr[ariam] nos dispositivos legais”. O Presídio do Hipódromo, onde já se encontravam diversas travestis detidas, seria o local utilizado para "abrigar os homossexuais".

Apesar de não usar expressamente o termo "confinamento", esta era a essência da proposta formulada pelos dois policiais no sentido de reservar alguns quarteirões, depois de determinados horários, quando o comércio já se encontrasse fechado, para a livre circulação das travestis com inferninhos e bares. O local sugerido, as "Bocas do Luxo e do Lixo", no centro paulistano, já contava com presença ostensiva dessa população. Dessa maneira, nas palavras de Boncristiano, "os travestis e as prostitutas poder[iam] andar livremente sem perseguição da polícia, deixando o resto da cidade para as famílias".

Mais uma vez, a imprensa dava mais uma de suas valorosas contribuições para propagar a estigmatização das pessoas LGBT a partir de uma associação bastante recorrente entre a criminalidade e os "desvios" sexuais e de gênero. Nota-se, na matéria da grande imprensa, não haver diferenciação entre travestis e homossexuais, ainda que a maior carga repulsiva das declarações recaíssem sobre aquelas.

${ }^{421}$ O Estado de São Paulo, $1^{\circ}$ de abril de 1980, p. 20. 
Aventava-se, seriamente, naquele momento, até mesmo incluir de forma expressa o travestismos na tipificação criminal, pois os policiais civis reclamavam de certa conivência da justiça diante da insuficiência da legislação para punir essas condutas. A dificuldade advinha do fato de que muitas travestis que se prostituíam durante a noite mantinham outros empregos durante o dia e, assim, a rigor, não poderiam ser enquadradas na contravenção penal de vadiagem. Como eram consideradas pertencentes ao gênero masculino, a exibição de seus seios também não podia ser caracterizada como atentado violento ao pudor.

Sempre atento para fazer o contraponto a esse tipo de abordagem na mídia, o Lampião publicava uma denúncia escrita por Darcy Penteado, na qual apontava que o "plano de repressão, como se vê, configura[va]-se de muita gravidade porque, além de contrariar a nossa constituição, violenta[va] o direito humano de não segregação" pelo modo como propõe o isolamento dessas populações em uma área específica da cidade. Mas o sensacionalismo e a incitação à violência não parariam por aí. Para ele, "além de não proporem qualquer solução além da repressão policial aos travestis (perdão, aos homossexuais), as reportagens incita[vam] sutilmente a uma 'revanche' pelas violências praticadas por travestisprostitutos" ${ }^{\prime 22}$.

\section{Richetti: "o comandante-em-chefe de uma guerra sem quartel"}

Após tais cobranças por parte da grande imprensa e o anúncio desse plano pioneiro, não demorou muito tempo para que uma política ainda mais agressiva contra as travestis, enquanto uma das populações mais vulneráveis, fosse posta em prática. O pretexto ideal para a "limpeza" da cidade era a iminente visita do Papa. E, para levar a cabo a hercúlea tarefa, ninguém melhor do que o delegado que se vangloriava por ter, no começo da década de 1970, enquanto titular do $3^{\circ}$ Distrito Policial, expulsado as prostitutas de São Paulo, de modo a criar a zona de meretrício de $\operatorname{Santos}^{423}$.

Conhecido por sua atuação perfeitamente coerente com os discursos oficiais de valorização da família e da moral, bem como pela experiência prévia na repressão a essa população cativa da região central, o delegado José Wilson Richetti, que estava dirigindo a

\footnotetext{
${ }^{422}$ PENTEADO, Darcy. Um apelo da tradicional família Mesquita: prendam, matem e comam os travestis!. Lampião da Esquina, n. 24, maio de 1980, p. 2.

${ }^{423}$ Em declaração ao jornal Folha de São Paulo, afirmou ele, lembrando de seu passado: "Pode escrever aí: eu, José Wilson Richetti, fundei a zona de Santos, levei tudo para lá". E ainda acrescentou, sobre suas façanhas na Boca do Lixo: "eu reduzi o número de hotéis de 108 para 52. Dos prédios frequentados por prostitutas só sobraram dois". In: Folha de São Paulo, 27 de maio de 1980, p. 11.
} 
Seccional de Polícia de Guarulhos, foi transferido, em 21 de maio de 1980, para a chefia da Delegacia Seccional de Polícia da Zona Centro ${ }^{424}$. Mas ele, que era o chefe dessas operações, nunca atuou sozinho, sempre esteve respaldado pelo seu superior imediato, Rubens Liberatori, diretor do Degran, pelo secretário de Segurança Pública Otávio Gonzaga Jr., e até mesmo pelo comandante do Segundo Exército, o general Milton Tavares, em um momento em que as instituições de segurança funcionavam por meio de coordenações repressivas.

Já em 23 de maio, dois dias após sua transferência para São Paulo, os jornais anunciaram a "Operação Cidade", planejada e já posta em curso por Richetti para funcionar dia e noite, em turnos ininterruptos de 8 horas, com 120 policiais (20 delegados e 100 investigadores), além do reforço da polícia militar. O objetivo, declarado ao jornal Folha de São Paulo, seria "prender assaltantes, traficantes de drogas e outros bandidos que frequentam ou agem no centro e bairros próximos". Além disso, consta na matéria que a referida operação tinha, como foco inicial, “atacar, primeiro, as chamadas 'Boca do Lixo' ( $\left.3^{\circ} \mathrm{DP}\right)$ e 'Boca do Luxo' ( $\left.4^{\circ} \mathrm{DP}\right)$, estendendo-se, depois, aos outros bairros" ${ }^{\prime 425}$.

A própria reportagem, feita pelo jornalista Ricardo Kotscho, menciona que a prisão massiva não parecia ser tão eficiente quanto parecia pela estrondosa propaganda anunciada. Isso porque, entre os detidos, não houve "nenhum assaltante, traficante ou assassino", mas apenas "um gerente de banco, dois estudantes de engenharia, boêmios, jogadores de sinuca e desempregados em geral" 426 .

A ação logo muda de nome e passa a se chamar "Operação Limpeza" e, logo em seguida, torna-se "Operação Rondão" "427. Independentemente do nome, o alvo seguia sendo o mesmo e o modelo de repressão intensiva gerava, ao menos do ponto de vista dos prejuízos, resultados imediatos. Em poucas horas depois de desencadeada a estreia da operação, "um hotel estava completamente destruído" e "172 pessoas haviam sido presas".

Um dos proprietários do Hotel do Carlinhos, Deraldo José Grats, foi ouvido pela

\footnotetext{
${ }^{424}$ A Seccional da Zona Centro, com sede na esquina da Rua Aurora com a Avenida Rio Branco, era responsável por coordenar, à época, oito Distritos Policiais adjacentes: $1^{\circ} \mathrm{DP}$ (Centro), $2^{\circ}$ DP (Bom Retiro), $3^{\circ}$ DP (Campos Elíseos), $4^{\circ}$ DP (Consolação), $5^{\circ}$ DP (Liberdade), $6^{\circ}$ DP (Cambuci), $8^{\circ}$ DP (Brás) e $12^{\circ}$ DP (Pari).

425 "Aumenta policiamento no centro da cidade". Folha de SP, 23 de maio de 1980, p. 9.

426 "Delegado quer 'botar pra quebrar". Folha de SP, 27 de maio de 1980, p. 11.

${ }^{427}$ As mudanças de nome da operação têm relação com as duras críticas que as operações sofreram, logo de início, dentro da própria polícia. Segundo alguns agentes, ela mobilizava um aparato de homens e viaturas grande demais das delegacias centrais, mas prendia mal, pois das mais de mil pessoas presas na primeira semana, só doze permaneceram detidas (oito por vadiagem e quatro por suspeita de assalto). Segundo um policial mais experiente ouvido por um jornalista da Folha de São Paulo, "o problema maior são os assaltantes e os traficantes de drogas, que as rondas, tenham o nome que tiverem, não conseguem prender. Assaltantes e traficantes de drogas só vão para a cadeia através de investigações, muitas vezes, pacientes e demoradas. As rondas só servem para prender prostitutas, travestis e homossexuais, que são soltos horas depois". No entanto, conforme a matéria registra, a despeito dessas críticas, o diretor do DEGRAN, Rubens Liberatori, respaldava as ações. In: "Policiais criticam rondas de Richetti". Folha de SP, 28 de maio de 1980, p. 13.
} 
reportagem e reclamou bastante da invasão policial que deixou "banheiros totalmente destruídos, portas, camas e armários arrebentados, espelhos estilhaçados, janelas quebradas, paredes manchadas com espuma de extintor de incêndio", revelando a grande violência com que decorreu a ação. Outros hóspedes relataram como foram acordados pela polícia no meio da madrugada: com pontapés na porta, com tudo sendo quebrado, armas apontadas e todo mundo levado à detenção com muita agressividade.

\section{"Elas deram certo em um ponto: a cidade ficou limpa"}

Richetti negou a responsabilidade pelos danos, já sinalizando o grau de violência que resultaria das ações, alegando: "qualquer operação que a polícia fizer, daqui pra frente, sempre vão aparecer vidros quebrados, mulheres rasgadas e vão dizer que foi a gente. Isso é coisa do sindicato do crime, dessa máfia que explora o lenocínio em São Paulo”. Grats retrucou à acusação de que teria quebrado seu próprio hotel afirmando:

isso é um absurdo. Eu levei dois anos reformando este hotel, é um patrimônio nosso, você acha que eu vou destruir o que é meu? Se eles estavam procurando algum marginal, não precisariam fazer isso. Prenderam todo mundo, até quem estava passando na rua e só soltaram às 4 da manhã. Foi uma coisa chocante. ${ }^{428}$

As declarações de Richetti ao jornal foram fortemente carregadas por sua visão conservadora, em prol da moral e dos bons costumes. Ele declarara abertamente que "o lenocínio é um crime social, um crime contra os costumes" e que era preciso "tirar das ruas os pederastas, os maconheiros, as prostitutas" ${ }^{429}$. Sua truculência, neste caso, contra o patrimônio particular em nome da ordem pública rendeu, dias mais tarde, um editorial duro da Folha de São Paulo, que asseverou que a prostituição e o homossexualismo não eram causa de polícia, ainda que com base em um discurso bem patologizante destes fenômenos:

pretende o sr. Richetti, segundo afirma, expulsar as prostitutas, homossexuais e travestis do centro tradicional e diluí-los por toda a cidade ou, talvez, repelindo a discutível façanha que ele próprio se atribui, transferilos para a cidade de Santos, cuja zona de meretrício estranhamente se orgulha de ter criado. Emprega, para isso, métodos que, além de violentos e

\footnotetext{
428 "Delegado quer 'botar pra quebrar"”. Folha de SP, 27 de maio de 1980, p. 11.

429 "Delegado quer 'botar pra quebrar"'. Folha de SP, 27 de maio de 1980, p. 11.
} 
ilegais, são perfeitamente inúteis. Pois nunca se teve notícia de que a polícia pusesse fim à prostituição ou ao homossexualismo, sobretudo quando suas causas sociais permanecem. ${ }^{430}$

No sábado, dia 24, mais de 700 pessoas foram presas, entre as quais encontravam-se "homossexuais, travestis, prostitutas e um elemento com posse ilegal de arma"431. Já se mostrava, assim, quem seria o alvo privilegiado da coordenação repressiva dos distritos policiais centrais batizada de "Operação Rondão". Segundo admitido pelo próprio delegado, as rondas levavam "de 300 a 500 pessoas por dia para a cadeia", mas só uma pequena porcentagem de $0,8 \%$ dos detidos tinha passagem pela polícia ${ }^{432}$.

Apesar da questionável eficácia das medidas para redução da criminalidade, as rondas começaram a servir de inspiração para as demais Seccionais de Polícia, primeiro nas zonas Sul e Oeste $^{433}$ e depois nas zonas Norte e Leste. Até no ABC as rondas chegaram. Segundo Rubens Liberatori, diretor do Degran que respaldava a iniciativa institucionalmente, "elas deram certo em um ponto: a cidade ficou limpa. Os assaltantes e traficantes de drogas fugiram das rondas e, por isso, não foram presos" ${ }^{\prime 34}$.

No balanço feito após os primeiros dez dias de rondas, Richetti disse que era positivo o resultado com as adaptações que foram sendo feitas nas ações:

Começamos as rondas com 100 policiais, mas, agora, elas são feitas com apenas 30 homens, que se revezam em grupos de um delegado e nove investigadores. Houve muitas queixas e mal entendidos, mas o objetivo, que era limpar a cidade, afastando dela os marginais, foi atingido ${ }^{435}$.

Além do respaldo da chefia imediata, as operações eram ordenadas diretamente pelo Secretário de Segurança Pública, o desembargador Otávio Gonzaga Jr. Em nota à imprensa, ele classificou estas medidas como "uma autêntica guerra contra a criminalidade", acrescentando que "a ordem vigorante [era] a limpeza geral". Demonstrando o apreço pelo trabalho de Richetti, a nota qualificava este como

o comandante-em-chefe de uma guerra sem quartel em toda a área central da

\footnotetext{
430 "Violência inútil". Folha de SP, 28 de maio de 1980, p. 2.

431 "Delegado quer 'botar pra quebrar"”. Folha de SP, 27 de maio de 1980, p. 11.

432 “Sociólogo detido por 'ronda' de Richetti fica preso três dias”. Folha de São Paulo, 11 de jun. de 1980, p. 14.

${ }^{433} \mathrm{Na}$ estreia da ronda nas zonas Oeste e Sul, foram presas 340 pessoas em uma única madrugada. Os chefes dessas Seccionais, Marcelo Alencar Peixe e Paulo Boncristiano respectivamente, afirmaram que "as rondas vão continuar, pois se o Richetti espanta os marginais do Centro, eles, naturalmente mudam para a Zona Oeste ou a Zona Sul". "Liberatori remaneja mais nove titulares de distrito". Folha de São Paulo, 31 de maio de 1980, p. 11. 434 "Rondas policiais serão estendidas a toda a cidade". Folha de São Paulo, 29 de maio de 1980, p. 11.

435 “'Com rondas, assaltos diminuem', diz Richetti”. Folha de São Paulo, 30 de maio de 1980, p. 12.
} 
cidade, não esperando a queixa de que o cidadão possa apresentar, mas indo nos locais suspeitos ou sabidamente condenáveis para conduzir qualquer um dos oito Distritos Policiais que integram a Seccional Centro, o explorador de lenocínio, o rufião, o travesti, o traficante de tóxicos, o assaltante, o 'trombada' ou a prostituta que acintosamente realiza seu 'comércio' nas vias públicas. ${ }^{436}$

Não era segredo para ninguém que os "excessos" se tornaram regras e que abusos, de diversas ordens, eram rotineiramente praticados pela polícia de Richetti contra os "marginais". Pouco mais de uma semana das rondas, a grande imprensa já veiculava as denúncias de detenções ilegais, triagem aleatória, extorsões, chantagem, furto de objetos pessoais, desrespeito a habeas corpus, espancamentos e outras torturas físicas nas carceragens em condições precárias, ameaças de morte e até abortos.

\section{"Se não assinar, vai ficar no mofo por uns quinze dias"}

Os abusos estavam claros e a Frente da Mulher Feminista, sob a liderança da atriz Ruth Escobar, promoveu o encontro de algumas das mulheres vítimas da repressão com deputados estaduais paulistas da oposição para discutir a possibilidade de instaurar uma Comissão Parlamentar de Inquérito que investigasse as violências. Escobar, ao lado de Darcy Penteado, do Lampião, e da psicóloga Irede Cardoso, estiveram, no sábado, dia 7 de junho, na Praça Júlio Mesquita, coletando depoimentos das prostitutas. Uma delas, que não quis revelar seu nome temendo represálias, com 24 anos, foi detida no dia 30 de maio e chegou na delegacia já sendo torturada. Perdeu um dente por conta de uma pancada dada diretamente por Richetti e, em seguida, os policiais começaram a dar pontapés no abdômen e nas costas da moça, que estava grávida. Por conta de uma hemorragia, ela abortou e foi parar na Santa Casa de Misericórdia ${ }^{437}$.

Outro caso relatado à reportagem por essa comissão foi o de Idália Cristina Ferreira, conhecida como "Paraguaia", de apenas 22 anos. Ela encontrava-se internada, também na Santa Casa de Misericórdia, com "a bacia fraturada e com escoriações generalizadas". A causa declinada no boletim médico era "queda a esclarecer". Idália havia sido detida no dia 3 de junho, uma terça, e solta dois dias depois. Mas sua liberdade durou pouco. No mesmo dia em que voltou às ruas, foi novamente presa com outras 40 prostitutas. Richetti chegou a

\footnotetext{
436 "Segurança continuará operação". Folha de São Paulo, 31 de maio de 1980, p. 12.

437 "Denúncias contra Richetti: prostitutas acusam policiais de violências e chantagem". Folha de SP, 9 de junho de 1980, p. 9.
} 
admitir, sem qualquer constrangimento, que já teria prendido Idália mais de 30 vezes em menos de dois meses no cargo ${ }^{438}$. No $3^{\circ}$ Distrito Policial, por ser ela uma reincidente, os policiais lhe disseram que ela ficaria 15 dias detida "para parar de dar voltinhas pelo centro da

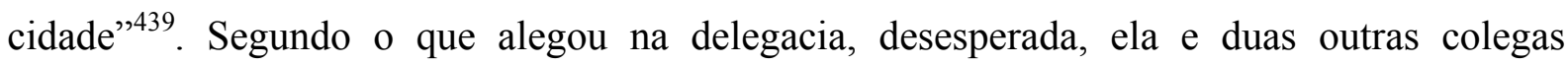
resolveram pular do $2^{\circ}$ andar para fugir, mas, na queda, ela acabou desmaiando. Entretanto, a versão dada logo se revelou mentirosa.

O jornal Folha de São Paulo apurou que as declarações das duas testemunhas que constavam do inquérito que registrou a "tentativa de suicídio" de Idália - que foi fichada com o nome social de Natália Silva Gama - foram falsificadas. Com efeito, Telma Laudicélia Quintino, que supostamente era uma das colegas que teria visto Idália se atirar da janela, negou que tivesse prestado qualquer depoimento aos policiais. Ela afirmou: "eles [os policiais] me apresentaram uma folha dobrada e disseram; assina aqui e você sai. Se não assinar, vai ficar no mofo por uns quinze dias". E complementou garantindo que não sabia bem o que estava assinando: "pensei que fosse um papel para minha soltura, não um testemunho sobre o caso da Natália" ${ }^{\text {440 }}$. Assim, além das violências físicas, as mulheres eram presas, mesmo se tivessem o habeas corpus preventivo, e eram impedidas de contato com advogados, sendo até mesmo manipuladas de forma perversa, como na situação descrita.

Esse caso, ao lado de outras denúncias, havia sido debatido em um encontro realizado no Teatro Ruth Escobar na tarde do dia 9 de junho, fazendo com que uma comissão de deputados, formada por Eduardo Suplicy, Irma Passoni, Fernando Morais e Audálio $\operatorname{Dantas}^{441}$, imediatamente se dirigisse para o $3^{\circ}$ Distrito Policial. Ali, esperavam encontrar cerca de 40 mulheres detidas em situação precária. No entanto, foram proibidos de fazerem a inspeção na carceragem, pois, na alegação de Richetti e de seu superior, a "visita provocaria alvoroço e manifestações dos presos". Testemunhas, contudo, viram que enquanto o delegado enrolava a comissão de deputados, mais de 30 mulheres foram sendo liberadas em fila por

\footnotetext{
438 "Richetti desmentiu que tivesse agredido um grupo de prostitutas nos xadrezes da seccional centro, o que teria provocado a tentativa de fuga de uma delas, Idália Cristina Ferreira, a Paraguaia, que caiu do $2^{\circ}$ andar e sofreu graves ferimentos. "Esta mulher já foi detida, desde que assumi a seccional, mais de 30 vezes e disse a duas amigas que não ficaria presa.” In: OESP, 10 de junho de 1980, p.10.

439 "Denúncias contra Richetti: prostitutas acusam policiais de violências e chantagem". Folha de São Paulo, 9 de junho de 1980, p. 9.

440 “'Testemunha' nega depoimento”. Folha de São Paulo, 11 de junho de 1980, p. 14.

${ }^{441}$ MacRae registrou que os parlamentares mais comprometidos com a campanha contra Richetti foram Eduardo Suplicy e João Batista Breda, já que Irma Passoni, Fernando Morais e Geraldo Siqueira participaram "atendo-se somente à problemática feminina ou à questão de direitos humanos", esquivando-se "de qualquer comprometimento maior com a questão da homossexualidade" (MACRAE, Edward. A construção da igualdade: identidade sexual e política no Brasil da "abertura". Campinas: Editora da Unicamp, 1990, p. 225), o que indica a dificuldade do avanço dessa pauta específica, mesmo dentro do campo da esquerda.
} 
outra saída ${ }^{442}$. Esse episódio ilustra bem a ousadia dos policiais, amparada no respaldo institucional com que contavam, a ponto de enfrentarem abertamente representantes do Poder Legislativo e até mesmo enganá-los. Mas os deputados também não deixariam barato e se articularam, em um pedido assinado por mais de 30 parlamentares, para que a Comissão de Direitos Humanos da Assembleia Legislativa convocasse o delegado Richetti para ele explicar "as violências que sua equipe estaria cometendo no centro da cidade",443.

É interessante notar como, em um contexto de abertura, a resistência às arbitrariedades passavam a tramitar em canais institucionais a despeito dos flagrantes limites que ainda apresentavam. Os deputados acionaram, ao mesmo tempo, instâncias diversas, como o delegado Liberatori, que era o superior de Richetti, a Corregedoria da Polícia Civil, o Ministério Público, a Ordem dos Advogados do Brasil em São Paulo (OAB/SP) e também o Conselho Parlamentar de Direitos da Pessoa Humana da ALESP. Ainda que não obtivessem uma solução favorável em nenhum desses órgãos isoladamente, por lhe faltarem autonomia ou disposição política para solucionar o problema, o conjunto de denúncias conferia maior publicidade ao caso e produziria cada vez mais pressão para colocar fím à violência injustificada.

A indignação da opinião pública crescia em ritmo bastante lento, apesar da enorme escala de violações de direitos humanos que marcava a atuação de Richetti. Apenas as feministas, os homossexuais e alguns deputados da oposição se sensibilizaram de início com as vítimas das operações. O verdadeiro turning point que fez com que diversos intelectuais, políticos e veículos de comunicação se posicionassem mais veementemente contra as rondas foi a prisão arbitrária, por três dias, do sociólogo do CEBRAP e ex-preso político Vinícius Caldeira Brant. Ele esperava um táxi na Avenida Nove de Julho, na noite do dia 7 de junho, quando foi abordado pelos policiais e, por ser profissional liberal, não conseguiu comprovar ser vinculado ao CEBRAP, pois não tinha sua carteira de trabalho assinada e ainda tinha precedente por condenação com base na Lei de Segurança Nacional, com pena já cumprida. Ele relatou as péssimas condições da carceragem e, sobretudo, das travestis e prostitutas: "fui levado ao $4^{\circ}$ Distrito e colocado numa cela de $3 \times 4$ metros, juntamente com 22 pessoas. $\mathrm{O}$ chão era de cimento e o cheiro, insuportável. As prostitutas e travestis, que estavam em duas celas próximas, foram tratadas como se estivessem em um campo de concentração",444.

\footnotetext{
442 "Richetti proíbe inspeção: comissão de deputados não pode ver carceragem". Folha de São Paulo, 10 de junho de 1980, p. 13.

443 "Richetti proíbe inspeção: comissão de deputados não pode ver carceragem". Folha de São Paulo, 10 de junho de 1980, p. 13.

444 “Em 3 horas, muitas acusações”. Folha de São Paulo, 13 de junho de 1980, p. 12.
} 
Além de prendê-lo, não permitiram que ele comunicasse sua família, que chegou a declará-lo desaparecido. Ele só foi liberado porque a família, junto com a Comissão de Justiça e Paz e o Comitê Brasileiro pela Anistia, conseguiram localizá-lo depois de buscas em hospitais, necrotérios e distritos policiais ${ }^{445}$. Richetti tentou se esquivar da responsabilidade por este equívoco, mas não conseguiu demonstrar que a tropa da Polícia Militar que executou a prisão não guardava relação com suas $\operatorname{rondas~}^{446}$. Este caso torna ainda mais evidente a arbitrariedade de Richetti e, por se tratar de um homem, pesquisador universitário, com uma rede de contatos influente, acabou tendo muito mais impacto na sociedade do que as denúncias feitas pela população de travestis e prostitutas. No dia seguinte à libertação, por exemplo, o deputado Eduardo Suplicy já fez um pronunciamento da tribuna da Assembleia Legislativa tratando do caso ${ }^{447}$.

A pressão dos deputados resultou em uma audiência com Rubens Liberatori, responsável pelo policiamento em São Paulo, na qual também estiveram cinco pessoas que sofreram abusos. Além dos depoimentos, foram exibidas diversas fotos das operações, como provas documentais, atestando a truculência da polícia. Liberatori, no entanto, não se mostrou muito sensível aos apelos da comissão, tendo se limitado a prometer "uma sindicância para apurar a veracidade dos fatos denunciados”. E acrescentou, para não deixar dúvidas de que lado estava: "mas delegado Richetti vai permanecer onde está, pois não posso substituí-lo por um outro que não tenha experiência de rua e fique todo bonitinho e com o cabelo bem arrumado enquanto a população vive sendo assaltada"448. Essa postura do diretor foi contestada até mesmo por órgãos da imprensa que, a princípio, foram entusiastas da "limpeza" social e moral da região central, como o jornal Folha de São Paulo, que em seu editorial afirmou que "as denúncias são tão claras e a documentação fotográfica fornecida pela imprensa tão irrefutável, que a atitude daquele diretor, cobrindo com sua autoridade os excessos atribuídos a seu subordinado, só pode ser entendida dentro da velha tese da violência necessária" $" 449$.

No mesmo dia em que se reuniram com Liberatori para relatar os abusos, veio a público o caso de Maria Marciana da Silva, conhecida como “Anona”, de 33 anos, uma vítima fatal da violência policial. Ela trabalhava durante o dia como pajem na creche Menino Jesus

\footnotetext{
445 "Sociólogo detido por 'ronda' de Richetti fica preso três dias". Folha de São Paulo, 11 de jun. de 1980, p. 14. 446 "Seccional fala sobre a prisão do sociólogo". Folha de São Paulo, 12 de junho de 1980, p. 17.

447 "Deputado protesta e denuncia". Folha de São Paulo, 11 de junho de 1980, p. 14.

448 "Detidos confirmam violência: pessoas que estiveram presas no $3^{\circ} \mathrm{DP}$ dizem que foram maltratadas por Richetti”. Folha de São Paulo, 13 de junho de 1980, p. 12.

449 "Caso de polícia”. Folha de São Paulo, 16 de junho de 1980, p. 2. O jornal lança, ao final deste editorial, uma incômoda pergunta que sinaliza a gradativa perda de apoio na opinião pública dessa repressão desenfreada: "A que interesses estará servindo tanto esbanjamento de tempo e dinheiro do serviço público?”.
} 
de Praga, vinculada à Igreja Nossa Senhora Aquiropita, e, à noite, complementava sua renda como prostituta. "Anona" havia sido abordada e levada para o $3^{\circ}$ DP na noite do dia 9 de junho por policiais que, segundo testemunhas, espancaram-na e golpearam-na na cabeça. Desde então, não havia sido mais vista. No dia seguinte, seu corpo foi encontrado "totalmente deformado" na estrada de Perus. A causa da morte foi traumatismo crânio-encefálico. Não fossem seus colegas de trabalho na creche para identificar o corpo, ela teria sido enterrada como indigente. É evidente que a responsabilidade por este homicídio não foi assumida pela polícia $^{450}$, mas havia indícios do envolvimento da equipe de Richetti com os espancamentos e tentativa de ocultar o cadáver mais de 50 quilômetros longe do centro da cidade ${ }^{451}$.

A repercussão crescente das denúncias despertou a reação de entidades representativas da sociedade civil que até então não haviam se envolvido com o problema. O Conselho da Ordem dos Advogados do Brasil - OAB -, em São Paulo, por exemplo, a pedido da advogada Zulaiê Cobra, aprovou, por maioria, a criação de uma comissão de criminalistas que foi incumbida de redigir um documento de repúdio às violências policiais comandadas por Richetti.

Mas a principal resistência às arbitrariedades veio mesmo dos próprios grupos vulnerabilizados. Na imprensa, a denúncia mais contundente das ostensivas rondas repressivas de Richetti foi escrita por Trevisan, em seu "São Paulo: a guerra Santa do Dr. Richetti”. Ele abria o texto já com a provocação contra a questionável proposta de limpeza:

como é que se limpa uma cidade de 10 milhões de habitantes, refúgio dos miseráveis de todo o Brasil, com taxa de desemprego atingindo $8 \%$ da população ativa? Fácil: dando serviço para a polícia que, nestes tempos de semi-anistia, é menos solicitada mas precisa mostrar serviço. E dá-lhe, desvairada Paulicéia! ${ }^{452}$

Com efeito, foi uma questão de tempo para que as tais violências de Estado despertassem revolta e impulsionassem a organização de bichas, travestis, prostitutas e negros nas ruas. Nas palavras de MacRae, "a violência desencadeada por um organismo estatal serviu de forma clássica como unificador de movimentos sociais. Através dos contatos que o movimento homossexual havia conseguido com sua política de alianças, foi armada uma campanha contra o delegado Richetti" ${ }^{\text {453 }}$. Assim, ainda que pareça frágil sustentar que a

\footnotetext{
450 A polícia deu uma outra versão, bastante rocambolesca, publicada em jornal dias após o ocorrido: "Esclarecida morte da mulher que sumiu após suposta prisão". Folha de São Paulo, 14 de junho de 1980, p. 10.

451 "Depois de detida, é encontrada morte". Folha de São Paulo, 13 de junho de 1980, p. 12.

452 "São Paulo: a guerra Santa do Dr. Richetti”. Lampião da Esquina, n. 26, julho de 1980, p. 18.

453 MACRAE, Edward. A construção da igualdade: identidade sexual e política no Brasil da "abertura".
} 
repressão ditatorial tenha constituído os movimentos negros, feminista e homossexual, certamente as operações de Richetti ajudaram na construção de pontes e intercruzamentos entre as agendas destes atores políticos.

Mas, deve-se notar que, como o movimento homossexual era predominantemente masculino, foi necessária certa pressão das travestis e prostitutas, que viviam mais profundamente as consequências da política repressiva de Richetti, para sensibilizar todos os segmentos. Darcy Penteado, em trecho que vale ser citado, discorreu sobre a importância da participação e da fala das poucas travestis no I EBHO para chamar atenção ao tema, mais seriamente:

Foi bastante importante a participação dos (poucos) travestis que tiveram a
coragem de comparecer ao I Encontro Brasileiro de Homossexuais. Seus
depoimentos pessoais sobre a repressão, maus tratos e extorsões que sofrem,
tiveram a força de um libelo, exigindo urgentes providências de nós, os
homossexuais, contra a máquina da repressão do sistema que ainda não foi
desativada, como se andou propalando. Tudo faz crer (tomara que não) que
esteja em fase de descanso para reparos. Não podendo mais ser usada para
fins políticos devido às modernas e anunciadas aberturas, usará sua força
para impor a moral de conveniência do sistema aos indesejáveis mais óbvios:
os homossexuais e particularmente os travestis - porque de qualquer forma,
além do mais, é preciso manter o empreguismo, conservador em ponto
neutro a desinformação ou, em última instância, satisfazer de alguma
maneira o sadismo das massas. Mesmo sem pão, abrem-se as portas do circo
- ou da arena. E o povão ingênuo, não percebendo a armadilha, aplaude e
pede bis.

Assim, no dia 6 de junho, uma manifestação pública foi programada para acontecer na Praça Júlio Mesquita para protestar contra as prisões de Richetti. A proposta era de que, depois que uma prostituta e uma travesti discursassem, os manifestantes queimariam um boneco de três metros de altura vestido como o delegado. $\mathrm{O}$ ato acabou adiado por conta das circunstâncias, mas demonstrava a incipiente organização contra a repressão e, assim que ficou sabendo do fato, Richetti afirmou, com seu habitual autoritarismo: "vou lá e prendo todo mundo". No entanto, depois de uma reunião com o seu superior, Rubens Liberatori, ele mudou seu discurso para uma maior tolerância: "vou fazer de conta que não é comigo. Bem, vou ficar na cidade. Vou considerar isso brincadeira. Estou limpando a cidade com as prisões de prostitutas e travestis e vou continuar fazendo isso. Que protestem e me queimem em praça

Campinas: Editora da Unicamp, 1990, p. 225.

454 PENTEADO, Darcy. "Um apelo da tradicional família Mesquita: prendam, matam e comam os travestis". Lampião da Esquina, n. 24, maio de 1980, p. 2. 
pública. Não vai adiantar nada"455. O tom da declaração revela como o delegado se sentia amparado pelas autoridades da polícia para continuar com suas operações repressivas.

A ideia de fazer um ato público pela destituição do Richetti só foi tomando mais força e um grupo de 13 entidades, sobretudo dos movimentos homossexual e negro, marcou, então, a sexta-feira, 13 de junho, como data para o protesto. A concentração foi programada para o final da tarde, nas escadarias do Teatro Municipal.

\section{"Precisamos dar um basta à essa onda de violência. Todos ao Ato Público"}

A carta de convocação para o ato, que funcionou como panfleto distribuído em diversos lugares dos guetos homossexuais, intitulada "Ato Público Contra a Repressão Policial", circulou na semana que antecedeu a manifestação. Ali, podia-se ler a avaliação compartilhada entre os grupos no sentido de que "uma nova onda de violência policial est[ava] se abatendo sobre São Paulo", comandada por Richetti e "prendendo indiscriminadamente todas as pessoas que, por ventura, estive[ssem] passando pelo local das 'batidas' (portando ou não documentos)". O documento registrava, ainda, que "o alvo preferido do delegado [eram] os homossexuais, os negros, travestis e prostitutas", logo conclamando "precisamos dar um basta à essa onda de violência. Todos ao Ato Público"456.

$\mathrm{Na}$ véspera do ato, o DOPS enviou uma resposta oficial à imprensa cujo teor debochado e claramente discriminatório contra os homossexuais revelava o respaldo institucional com que contava as investidas violentas de Richetti. Lê-se, no documento, que o delegado, preocupado com o ato público, “iria até a Catedral da Sé” para fazer suas orações e “ter certeza de estar vivendo em São Paulo, não em Sodoma e Gomorra, de tão tristes lembranças". Além disso, acrescentava ele que estava preocupado com o fato de o ato, marcado nas escadarias do Teatro Municipal, coincidir com uma apresentação do "Conjunto Nacional de Folclore da Hungria, num flagrante contraste entre a arte e a degradação humana (movimento de lésbicas, travestis, etc)", dizendo ainda acreditar que "as famílias que representam a grande maioria, em comparação com as 'minorias oprimidas', deixar[iam] de

\footnotetext{
455 “Manifestação contra o delegado Richetti”. Folha de São Paulo, 6 de junho de 1980, p. 8.

${ }^{456}$ Essa carta convocatória, junto com mais outros 13 documentos sobre o movimento homossexual produzidos entre 1979 e 1982 pelo DEOPS, encontram-se disponíveis na pasta 870 do Arquivo Público do Estado de São Paulo. A maioria, contudo, assim como em diversas outros conjuntos documentais de Ordem Política, são recortes de jornais de época com notícias relativas ao tema "homossexualismo", que dá nome à referida pasta. Trata-se da única contendo exclusivamente material sobre a temática.
} 
comparecer àquele teatro preocupadas com certeza de um escândalo público"457.

Escoltado por uma viatura do Deic e outra do Dops, sob garoa, cerca de 500 manifestantes, segundo a Folha de São Paulo, e 1000 pessoas, segundo o Lampião da Esquina $^{458}$, marcharam pela rua Conselheiro Crispiniano e caminharam pela Avenida São João, passando perto do $3^{\circ} \mathrm{DP}$, na rua Aurora, e pelo Largo do Arouche. $\mathrm{O}$ ato teve o condão de colocar lado a lado os grupos que há pouco tempo haviam cindido o movimento homossexual brasileiro. No entanto, nenhum dos deputados ou outras pessoas mais famosas apareceram, com exceção de Darcy Penteado, reforçando a tese de que a vinculação muito próxima com os homossexuais era algo indesejável e mesmo prejudicial para a imagem de algumas personalidades públicas.

No trajeto, algumas prostitutas na rua Aurora, que não desceram por medo de retaliações posteriores, apareceram nas janelas dos edifícios e gritaram junto com a passeata: "nosso mal é a repressão policial" e "o gay unido jamais será vencido"459. Outras palavras de ordem, mais ousadas e bem-humoradas atacando Richetti, foram destacadas na cobertura do ato pelo Lampião, tais como: "ada, ada, ada, Richetti é despeitada”; “a, b, x, libertem os travestis"; "Richetti enrustida deixa em paz a nossa vida"; "abaixo o subemprego, mais trabalho para o negro"; "amor, feijão, abaixo o camburão"; "Lutar, vencer, mais amor e mais prazer"; "amor, tesão, abaixo a repressão". Mas o refrão que mais ecoou entre os manifestantes foi "somos todas putas" entoado, inicialmente, pelas feministas presentes ${ }^{460}$. A dispersão do ato aconteceu próximo do cruzamento das ruas Major Sertório e Bento Freitas, no coração da "Boca do Luxo".

Foram distribuídas, aos transeuntes que estavam no caminho da passeata, uma carta elaborada conjuntamente pelos movimentos, denunciando as arbitrariedades de que estavam sendo vítimas e pedindo a destituição de Richetti. Mencionava-se, ainda, que as rondas eram ineficazes do ponto de vista da redução da criminalidade, pois apenas $0,8 \%$ dos detidos eram, efetivamente, indiciados, o que demonstrava como as prisões eram mais um modo de controle social e de eliminação, no espaço público, da presença incômoda das prostitutas, homossexuais e travestis do que um plano de combate aos bandidos. Citava-se, também, um fato bastante grave que não estava sendo noticiado na imprensa da época: a ocorrência de dois homicídios cometidos em decorrência das rondas. O operário Olivaldo de Oliveira e a já

\footnotetext{
${ }^{457}$ Pasta 870 , DEOPS.

${ }^{458}$ Trevisan afirmou, em seu relato, que, apesar da chuva intermitente, eram esperados, pelo menos, o dobro de pessoas que compareceram, mas muitos não foram porque "talvez os chamados setores democráticos não tenham achado a causa suficientemente nobre".

459 "Na av. São João, passeata pede o fim da violência”. Folha de São Paulo, 14 de junho de 1980, p. 10.

460 “São Paulo: a guerra Santa do Dr. Richetti”. Lampião da Esquina, n. 26, julho de 1980, p. 18.
} 
mencionada pajem Maria Marciana da Silva teriam sido capturados pelos policiais e depois apareceram mortos ${ }^{461}$.

Mesmo com a oposição cada vez mais organizada às operações, Richetti declarou à imprensa, no mesmo dia do ato, que iria intensificar sua atuação e reiterou a transfobia que informava sua visão sobre essa população: "quanto aos travestis, que invadiram a cidade de uns cinco anos para cá e que não prestam nenhum benefício à sociedade, ao contrário, só sabem assaltar, esses sim não permanecerão nas ruas, pois só causam transtornos às famílias que gostam de passear pelo Centro" ${ }^{, 462}$.

Uma modalidade de violência pouco visibilizada era, justamente, aquela empreendida especificamente contra a identidade de gênero das pessoas trans. Além das habituais agressões físicas e arbitrariedades decorrentes da prisão, havia relatos de travestis que foram desrespeitadas com o corte dos cabelos e o uso compulsório de hormônios masculinos para que "voltassem a ser homens". Nessa linha, a travesti Tatiana, com apenas 17 anos, relatou as dificuldades encontradas, por conta das rondas, desde que começou a trabalhar na região da Boca do Luxo:

eles querem reduzir as bichas a zero... A merda é que, com o Richetti, os melhores bofes sumiram. Eu também passei um tempo sumida. Como sou de menor, me levaram para a UT-3, da Febem, onde cortaram meu cabelo e me deram hormônios masculinos para eu virar homem e - imagina, eu hem? Nem morta! ${ }^{463}$

\section{"Deram certo e vão continuar": o apoio de comerciantes às rondas}

Alimentando uma cisão e até oposição da sociedade entre, de um lado, marginais associados à criminalidade e, de outro, "pessoas de bem" que estariam sendo molestadas, Richetti lograva maior suporte público para suas investidas e conseguia isolar ainda mais as populações já estigmatizadas. Ao contrapor o universo dos trabalhadores e das famílias ao do submundo das sexualidades dissidentes, ele chegou a afirmar: "somente irei acabar com isso quando os comerciantes ou famílias vierem até aqui para pedir que eu termine com essa

\footnotetext{
461 OCANHA, Rafael Freitas. "Amor, feijão, abaixo camburão" - Imprensa, violência e trottoir em São Paulo (1979-1983). Dissertação (Mestrado em História), PUC/SP, 2014, p. 119. Não encontramos outros registros que permitissem concluir pela responsabilidade da polícia na morte dessas duas pessoas, mas este é um tema que valeria um aprofundamento posterior para verificar se houve vítimas fatais decorrentes das operações.

462 "Richetti diz que continua na ação contra prostitutas". Folha de São Paulo, 14 de junho de 1980, p. 10.

463 "Na Pauliceia, com olhos de lince e pernas de avestruz". Lampião da Esquina, n. 32, janeiro de 1981, p. 5.
} 
ação" 464 . Isto, obviamente, não aconteceu, já que não eram essas pessoas as afetadas pela arbitrariedade policial cotidiana, ainda que o fossem pelo aumento da violência urbana.

A marginalização e a guetificação, provocadas por uma estigmatização social e uma 'criminalização branca' do ponto de vista legal, acabavam associando as práticas homossexuais, o trottoir das prostitutas e travestis, enfim, a vida noturna do submundo LGBT, a uma série de ilegalidades que se acumulavam nesses pontos de encontros furtivos. Constantes roubos e furtos, venda de drogas, agressões físicas e confusões, perturbação da ordem pública e atentado à moral e aos bons costumes eram a desculpa perfeita de que as forças de segurança precisavam para agir violentamente contra essas populações.

É evidente não ser justo reduzir todo esse submundo a uma ficha corrida na delegacia policial, como fazia crer a imprensa sensacionalista e a polícia, mas essa foi a astúcia das operações deflagradas pela ditadura para conter, isolar e estigmatizar estes segmentos já vulnerabilizados. O discurso médico-científico, mesmo quando não patologizava em si mesmas as "perversões" ou "desvios" sexuais, destacava aspectos da vida desses grupos que os identificavam, imediatamente, com doenças venéreas, por exemplo. Até mesmo o jornal "Repórter", geralmente mais progressista, embarcou nessa patologização indireta em matéria de autoria de Ulisses Tavares, sobre o alto índice de doenças venéreas na região conhecida como Boca do Lixo, na zona central de São Paulo.

A matéria afirmava a ocorrência de mais de 10 casos de gonorréia por dia, o que podia ser constatado "a olho nu", apesar da inexistência de estatísticas ${ }^{465}$. O jornalista constatava a precária situação da higiene pessoal das prostitutas e travestis, com a inexistência de água nos hotéis, e também entrevistava farmacêuticos naquela região, todos destacando a grande quantidade de gonorreias tratadas todos os dias. Na reportagem, as prostitutas mais velhas lembram com saudades dos tempos do ex-governador Adhemar de Barros: "a zona era mais organizada", afirma uma delas. Segundo a matéria, "elas acham que a situação piorou de 1964 pra cá: - Daqui pra frente, quem aparece por aqui é só a polícia" ${ }^{466}$. Isto não só reforçou os estereótipos para angariar suportes para a repressão, mas também afastou estes segmentos das políticas públicas de saúde durante um bom tempo.

É bastante possível, e até provável, que os índices de infecção por doenças venéreas naquelas regiões desprotegidas e desprovidas de assistência adequada atingissem, mesmo, esses patamares impressionantes relatados na matéria. O problema é que o tom moralista e o

\footnotetext{
464 "Richetti diz que continua ação contra". Folha de São Paulo, 14 de junho de 1980, p. 10.

${ }^{465}$ Repórter, n. 38, de fevereiro de 1981, p. 14. Essa matéria foi alvo do monitoramento da repressão. BR_RJANRIO_TT_0_MCP_AVU_0486

${ }_{466}$ Repórter, n. 38 , de fevereiro de 1981 , p. 14.
} 
ar sensacionalista da reportagem tinha por efeito um reforço à associação dessas populações à promiscuidade, às doenças e, em última instância, terminava por justificar as ações repressivas para conter as epidemias cultivadas nesse universo, visto não como caso de saúde pública, mas de controle policial.

A propaganda contrária à população LGBT e de prostitutas, por si só, não era suficiente para legitimar as ações. Por conta da resistência crescente e cada vez mais visível, Richetti passou também a mobilizar uma base de apoio na região para suas investidas. No dia 12 de junho, ele recebeu uma moção de apoio do Clube dos Diretores Lojistas do Arouche, elogiando sua atuação. Nessa oportunidade, ele declarou que a Operação Rondão continuaria e que "quanto aos homossexuais, somente numa ronda, meus homens detiveram 600 deles" ${ }^{, 467}$.

Nas regiões centrais, o número crescente de homossexuais, prostitutas e travestis, em um clima de entusiasmo com as promessas trazidas pelas mudanças políticas e culturais em curso, provocava certa apreensão e mesmo queixas dos moradores dos prédios dos arredores dessas zonas. As reações sociais dos habitantes e comerciantes com o "boom guei" "468 foram aproveitadas por Richetti e outros grupos para se capitalizarem dentro da corporação e até se promoverem profissionalmente.

Assim, a despeito das acusações frequentemente veiculadas nos jornais, nota-se que Richetti disputava a cobertura midiática sobre as rondas, em reportagens aparentemente encomendadas para divulgar o suporte que vinha recebendo, sobretudo de comerciantes da região: "O apoio é manifestado, diariamente, por cartas, telegramas, abaixo-assinados e, uma ou duas vezes por semana, uma comissão de comerciantes ou moradores leva pessoalmente o seu apoio ao delegado". Desde que iniciou as rondas, foram recebidos mais de 60 abaixoassinados totalizando cerca de duas mil assinaturas de comerciantes e moradores. Por sua vez, a Secretaria da Segurança Pública continuava prestigiando Richetti, depois de 20 dias de rondas, com um saldo de mais de 5 mil pessoas detidas e mais de mil inquéritos instaurados por vadiagem: "deram certo e vão continuar. O povo tem direito de morar e de andar pelo centro da cidade sem ser assaltado ou molestado. Esse direito lhe será assegurando custe o que custar" ${ }^{\text {469 }}$.

\footnotetext{
467 “Lojistas elogiam Richetti”. Folha de São Paulo, 12 de junho de 1980, p. 17.

${ }^{468}$ A expressão está em PERLONGHER, Nestor. O negócio do Michê - A prostituição viril em São Paulo. São Paulo: Fundação Perseu Abramo, 2008..

469 "Comerciantes apoiam rondas de Richetti”. Folha de São Paulo, 17 de junho de 1980, p. 11.
} 


\section{"Fora os marginais do centro": Richetti perante a Comissão de Direitos Humanos da ALESP}

Somente quase um mês depois de rondas ininterruptas e praticamente 24 horas por dia é que Richetti finalmente foi convocado pelos deputados para prestar esclarecimentos sobre sua "Operação Rondão", ao lado do secretário de Segurança Pública Otávio Gonzaga Jr. A iniciativa da convocação foi encabeçada pelo Deputado Eduardo Suplicy, que conseguiu mais de 30 assinaturas, entre seus pares, em uma carta de protesto em que afirmavam que

com a justificativa de terminar com os travestis, as prostitutas, os homossexuais e os traficantes de tóxicos, o delegado Richetti comanda[va] operações de quebra-quebra em hotéis e edifícios do centro de São Paulo, prendendo com o uso de violência indiscriminada pessoas que se encontram próximas daqueles locais. ${ }^{470}$

Um grupo de lojistas já se articulava, na véspera, para recepcionar ambas as autoridades às portas da Assembleia Legislativa, manifestando o seu apoio às rondas por meio de faixas que registravam os seguintes dizeres: "Rondão deve prosseguir"; "Fora os marginais do centro"; "Nosso repúdio aos advogados de causas perdidas". Um dos articuladores da iniciativa, o comerciante Caruso Martinez, declarou-se indignado com a convocação do delegado e do secretário "para dar conta do seu trabalho em prol da sociedade organizada, pelo simples fato de combater minorias de marginais, exploradores e conhecidos ativistas de esquerda que colocam em risco a segurança do cidadão comum e os bons costumes"471.

No dia seguinte, tal como programado, Richetti apresentou-se perante o Conselho Parlamentar de Defesa dos Direitos da Pessoa Humana, com uma plateia bastante polarizada entre aqueles que apoiavam o delegado e os que criticavam sua truculência. Meio nervoso no início, o delegado foi se soltando ao defender sua ação que "torna[va] as ruas limpas" de modo que "o povo pod[ia] transitar tranquilamente". Richetti abordou quatro casos específicos, alegando que não havia excesso, mas apenas legítima defesa por parte dos policiais que reagiam contra as perigosas travestis, e insinuou que a maior parte das acusações de violência não passavam de invenções, de um plano todo concebido pela atriz Ruth Escobar. $^{472}$

Um dos mais entusiastas defensores do delegado Richetti e das rondas na Comissão era o Deputado Estadual Manoel Sala, que havia sido eleito pelo PMDB e logo migrou para o

\footnotetext{
${ }^{470}$ Discurso de Fernando Moraes, pronunciado na $65^{\text {a }}$ Sessão Ordinária da ALESP, em 12 de junho de 1980.

${ }^{471}$ Folha de São Paulo, 29 de junho de 1980, p. 25.

${ }^{472}$ Richetti depõe para um Conselho esvaziado. Folha de São Paulo, $1^{\circ}$ de julho de 1980, p. 15.
} 
PDS, tendo uma boa relação com o Governador Paulo Maluf por conta disso. Na audiência, ele fez questão de ressaltar o apoio de Maluf para as rondas: "O Governador do Estado na manhã de hoje me dizia que o delegado Wilson Richetti vai contar com todo o seu apoio no sentido de se exterminar com a vadiagem no Estado de São Paulo - com a vadiagem e seus defensores. E o delegado Wilson Richetti não está só nessa campanha"473.

$\mathrm{O}$ artista plástico Darcy Penteado publicou artigo de opinião ${ }^{474}$ como resposta à postura do Deputado Manoel Sala. Conforme registra, após 4 horas de audiência pública, "as justificativas do delegado eram primárias e seus argumentos visivelmente distorcidos, mas, apesar das provas coletadas pelo deputado estadual Eduardo Suplicy (do PT) estarem acima de qualquer suspeita, a acusação foi tímida e insegura". Penteado, que fez um relato bem humorado e bastante ácido rebatendo os argumentos moralistas do deputado Sala, afirmava: “creio ser principio básico para uma comissão que discuta Direitos Humanos combater irrestritamente a violência. Porém nesta da Assembléia (espantem-se) existem deputados que as justificam ou as defendem". E acrescentava que Richetti estava sendo acusado de violências, com provas fotográficas e depoimentos, porém os deputados do governo aprovavam a violência, salientando que: "ainda mais revoltante é que uma pessoa tão preconceituosa como o deputado Manoel Sala seja integrante dessa comissão, pregando descaradamente a extinção da prostituição, para salvaguardar a honra da 'nobre família paulista"," 475

Opinião semelhante foi a da Folha de São Paulo que, em editorial, afirmou que "esquecem, talvez, os legisladores, que as denúncias não visavam à polícia, nem muito menos sua ação contra os criminosos, mas a violência e o abuso de poder dos acusados", acrescentando que acabou predominando um "tom de farsa", com "sarcasmo e acusações mútuas" sem que tenha sido votada qualquer resolução ${ }^{476}$.

Contudo, apesar da importante repercussão pública que a audiência conferiu às denúncias, amplificando, na institucionalidade, o que já vinha sendo sistematicamente escancarado por prostitutas e travestis, nenhuma deliberação mais concreta e efetiva foi tomada pelo órgão. E Richetti saiu ileso, bem cotado, inclusive, para promoção à classe especial da polícia civil paulista naquela mesma semana.

No entanto, os casos levados à Corregedoria foram aumentando. Uma situação bastante absurda ocorreu com Kátia Jacques Bueno Machado, que estava aguardando, no

\footnotetext{
${ }^{473}$ Diário Oficial do Estado de São Paulo, 9 de julho de 1980, p. 126.

474 "Homossexualismo não é uma doença e nem mesmo um crime". Movimento, 21 e 27 de julho de 1980, p. 20.

${ }^{475}$ BR_RJANRIO_TT_0_MCP_AVU_0413

476 “Assembleia omissa". Folha de São Paulo, 2 de julho de 1980, p. 2.
} 
carro, o retorno de seu marido, Mauro Machado, que havia estacionado em frente a um bar apenas para comprar cigarros. Neste intervalo curto de tempo, o carro foi cercado por policiais que logo mandaram-na sair e, mesmo tendo apresentado todos os seus documentos, ela foi levada para um camburão ao lado de prostitutas e travestis. O marido, quando saiu do estabelecimento, viu aquela cena insólita e tentou intervir, mas sem êxito. Sua esposa foi levada para o $4^{\circ} \mathrm{DP}$, onde ficou presa em uma cela com outras mulheres até o outro dia ${ }^{477}$.

Paulo Sérgio Pinheiro, cientista político e professor da Unicamp, publicou regularmente na Folha de São Paulo naquele período. Em alguns de seus "escritos indignados" em defesa dos direitos humanos, ele criticou duramente Richetti e suas operações. Pinheiro sustentou, em artigo de junho de 1980, que nas mãos da Delegacia Seccional Centro, "prostitutas, prostitutos, travestis e populares [eram] aterrorizados, maltratados e espancados sob testemunho da população, e da Imprensa, avisada previamente das "rondas" $" 478$. Além disso, Pinheiro coroava seu raciocínio contra as "cruzadas morais" afirmando que "tão grave quanto a ineficácia dessas 'rondas' [era] a sua flagrante ilegalidade", pois "o que est[ava] sendo implantado como política policial [era] o puro terror: um prolongamento dos métodos com que a polícia lida[va] com as classes populares, os operários, os negros, os menores" ${ }^{479}$.

Em outro artigo, de setembro do mesmo ano, intitulado "Labaredas antieróticas", Pinheiro critica novamente o plano da polícia de "limpar" o centro da cidade nos últimos dois meses, realizando uma "cruzada contra o pecado" com "milhares de prisões ilegais, aterrorizando prostitutas, homossexuais e travestis", ligando esta às cruzadas contra a subversão e contra o erotismo sob o mando de Juizados de Menores que agiam contra a circulação de revistas eróticas e pornográficas ${ }^{480}$.

Contudo, a despeito de casos mais escandalosos repercutirem negativamente na imprensa, nota-se que as operações estavam lastreadas, politicamente, nos níveis mais elevados da estrutura hierárquica da gestão pública paulista. Além disso, os órgãos de controle da violência policial, fosse ele interno (Corregedoria) ou externo (Ministério Público), pouco incidiam sobre a dinâmica cotidiana das operações. Assim, Richetti teve ampla margem de atuação nas ruas.

\footnotetext{
477 "Corregedoria apura caso de mulher presa por "rondão"”. Folha de São Paulo, 12 de julho de 1980, p. 12. Outra versão, que Richetti classificou como falsa, foi dada para a história posteriormente, mas tratava-se de outro caso mal explicado. In: "Casal enganou até a corregedoria com falsa denúncia”. Folha de São Paulo, 16 de julho de 1980 , p. 9.

${ }^{478}$ PINHEIRO, Paulo Sérgio. "Cruzadas inúteis”. Folha de São Paulo, 6 de junho de 1980, p. 3.

${ }^{479}$ PINHEIRO, Paulo Sérgio. "Cruzadas inúteis". Folha de São Paulo, 6 de junho de 1980, p. 3.

${ }^{480}$ PINHEIRO, Paulo Sérgio. "Labaredas antieróticas”. Folha de São Paulo, 30 de setembro de 1980, p. 3.
} 
Uma exceção à regra, entretanto, foi quando o juiz Joaquim Otávio Cardoso, da $24^{\mathrm{a}}$ Vara Criminal, aplicou multas de mil cruzeiros a alguns delegados de São Paulo, incluindo Richetti, por terem todos sonegado informações em habeas corpus impetrado em favor de oito prostitutas detidas durante a "Operação Rondão". O magistrado afirmou, em sua decisão condenatória, que "as prostitutas passa[vam] os maiores vexames por parte de investigadores e carcereiros" e que "esses fatos em geral [eram] públicos e notórios"481.

Mesmo com a mobilização popular dos movimentos sociais, o engajamento dos parlamentares solidários, as críticas de entidades de classe como a $\mathrm{OAB} / \mathrm{SP}$, as matérias negativas publicadas na imprensa e as diligências junto aos órgãos de controle da violência policial, como a Corregedoria e a Comissão de Direitos Humanos da ALESP, as rondas foram paralisadas apenas temporariamente, de modo que não houve uma mudança mais profunda em relação à atitude repressiva das forças policiais.

\section{"Tribunal autoriza caças aos travestis"}

Diante das dificuldades em emplacar vitórias com essas táticas, tentou-se buscar no Judiciário a proteção legal do direito de ir e vir para essas populações, impetrando-se habeas corpus preventivos ou mesmo após a prisão arbitrária. Mas o sistema de justiça ainda reproduzia muitos dos valores machistas, homofóbicos e transfóbicos presentes na sociedade brasileira e nos órgãos de segurança pública. Muitas vezes, em vez de frear os abusos e excessos, os juízes incentivavam e elogiavam a ação repressiva contra os grupos vulnerabilizados, ainda que houvesse importantes exceções a tal postura ${ }^{482}$.

“Em São Paulo, prostitutas e travestis vivem clima de terror”. Com esta afirmação, tem início a matéria "Tribunal autoriza caça aos travestis", de Rivaldo Chinem, publicada no “Repórter", n. 45, de 3 a 16 de junho de 1981, com referência à decisão recente do Supremo Tribunal Federal que passava a considerar o trottoir atentatório à moral e aos bons costumes "e fonte de constrangimento para transeuntes e residentes". A decisão foi tomada em recurso movido contra o acórdão do desembargador Ítalo Galli, da $1^{\circ}$ Câmara Criminal do Tribunal de Justiça de São Paulo, no qual o juiz afirmou: "O trottoir é imoral. Se assim não fosse, a

\footnotetext{
481 “Multas de Cr\$ 1 mil a delegados”, Folha de São Paulo, 4 de setembro de 1980, p. 12.

${ }^{482}$ Um juiz que se mostrou bastante antenado às lutas de defesa das "minorias", pela legalização da maconha e contra a prisão cautelar foi Álvaro Mayrink, da da $7^{\text {a }}$ Vara Criminal do Rio de Janeiro. Ele chegou a ser longamente entrevistado pelo Lampião e recebia, nas páginas do jornal, frequentemente, diversos elogios. Cf.: "Um juiz pelas minorias". Lampião da Esquina, n. 30, novembro de 1980, pp. 14-16. No entanto era evidente, e já se tinha a consciência, de que suas posições eram minoritárias no sistema de justiça.
} 
prostituta não se desnudaria na rua. E, se é imoral, a lei não pode proteger. Além disso, o trottoir é contravenção penal, é vadiagem. É um meio ilícito de sobrevivência" ${ }^{483}$

Por sua vez, a declaração do juiz corregedor dos Presídios e da Polícia, Renato Laércio Talli, foi em outro sentido, ao afirmar:

as prostitutas não são contraventoras. São infelizes que necessitam de compreensão acima de qualquer coisa. Claro, o trottoir acintoso tem que ser reprimido. Por exemplo, quando a mulher está despida na rua ou com o busto de fora, tem que ser recolhida mesmo. Agora, dentro da normalidade da conduta, a polícia não tem o direito de combater as prostitutas. Se agir assim, está cometendo uma arbitrariedade.

Mas a posição do juiz, ainda que com uma visão criminalizadora mais abrandada, era isolada no conjunto do sistema de justiça e acabou derrotada para dar lugar à posição mais duramente repressiva. Essa divisão, entre a compreensão do trottoir como direito de ir e vir ou como um atentado à ordem moral, se refletia no STF, que, no período de 1979 a 1982, julgou cinco casos de modos diversos, a depender dos juízes relatores e revisores designados ${ }^{484}$.

Segundo a matéria, um exército de mais de 100 mil pessoas viviam da prostituição naquela época na cidade de São Paulo. Uma das prostitutas ouvidas pelo jornalista, Kátia, trabalhava na avenida Rio Branco, na região central, e assim classificou a relação deste submundo com a polícia: "Os tiras fazem da gente gato e sapato. Já tentei ser empregada doméstica, mas não deu pé”. Outra delas, a travesti Milla, com apenas 21 anos de idade e há 3 fazendo trottoir, reclamava também da polícia: "Para não ser preso eu dou dinheiro aos policiais. Mas não adianta, há uns sádicos que batem na gente mesmo quando pagamos”.

Desde os corredores da Delegacia Seccional Centro, de onde partiam os rondões sob comando de José Wilson Richetti, um outro delegado dava uma outra versão ao jornalista: "No momento, a orientação é apenas para prender prostitutas e travestis que estejam utilizando o trottoir para o chamado 'abraço de tamanduá', isto é, envolver o transeunte com um abraço, mesmo que não seja um cliente, para lhe roubar a carteira”. E ainda afirmou que a polícia não se preocupava tanto com travestis e prostitutas, pois sabia dos outros envolvidos no negócio, como os "gigolôs e advogados de porta de xadrez, que dão habeas corpus

\footnotetext{
${ }^{483}$ Essa matéria consta de monitoramento dos órgãos de informação, conforme acervo do Arquivo Nacional: BR_RJANRIO_TT_0_MCP_AVU_0528

${ }_{484}$ Freitas analisa estes cinco casos e aponta uma preocupação em relação aos HC que fomentavam atentado ao pudor e abuso por parte das prostitutas no aliciamento de clientes na rua. Outro ponto, sempre destacado, é que, se fossem deferidas as ordens de liberdade, elas poderiam significar uma deslegitimação do poder da polícia sobre a vida urbana (OCANHA, Rafael Freitas. "Amor, feijão, abaixo camburão" - Imprensa, violência e trottoir em São Paulo (1979-1983). Dissertação (Mestrado em História), PUC/SP, 2014, pp. 156-158).
} 
preventivo, no valor de Cr\$ 15 mil, para prostitutas e travestis”. Não parecia, contudo, ser real a alegada tolerância das forças policiais à presença nas ruas das travestis e prostitutas.

caso de Richetti, sobre o qual abundam registros, denúncias e notícias, é importante porque ele foi exemplar ao demonstrar o modus operandi de controle da ordem moral e sexual, por parte da ditadura, que contou com a coordenação de diversos níveis de poder, atores estatais e instâncias de comando na cidade que contava já com o maior contingente de homossexuais do país. E atingiu diretamente também as mulheres.

\section{“Operação Sapatão": lésbicas como alvo da polícia}

Não era apenas os homossexuais masculinos, as travestis e as prostitutas que entravam no radar e no alvo do delegado Richetti. Ele também perseguiu as lésbicas com suas rondas. $\mathrm{O}$ Repórter, um dos jornais mais vendidos da imprensa alternativa, em edição de janeiro de 1981, publicou uma matéria de uma página intitulada “Operação Sapatão: polícia ataca lésbicas", tratando da repressão das forças de segurança contra mulheres que flertavam com outras mulheres nos bares da região central de São Paulo.

A Rua Martinho Prado era o epicentro do agito da vida noturna lésbica no período. Ali se localizava o Ferro's Bar, que foi o mais tradicional ponto de encontro homossexual entre mulheres desde a década de 1960. Este bar era o predileto das ativistas dos coletivos de lésbicas $^{485}$ e diversas moças, inclusive algumas que viviam fora da cidade de São Paulo, dirigiam-se até ali quando chegavam à cidade. No final da década de 1970, surgiram, na mesma região, outros bares do mesmo gênero, tais como o Cachação, o Canapé e o Último Tango, todos voltados à frequência de lésbicas com menor poder aquisitivo.

A matéria relata que, no dia 15 de novembro de 1980, todos esses lugares foram invadidos pela polícia e "quem fosse (ou tivesse cara de) lésbica, ia pro camburão. Não importava que tivesse documentos, carteira profissional assinada"486. O Lampião também noticiou a ofensiva, afirmando que Richetti e seus homens haviam encontrado um meio de comemorar a proclamação da República: caçando os homossexuais. Mas, “dessa vez, não

\footnotetext{
${ }^{485}$ Marisa Fernandes afirma que “O Ferro's Bar foi o local preferencial das lésbicas feministas do LF e do GALF para desenvolverem seu ativismo. Lá vendiam os boletins ChanacomChana que editavam e que falavam claramente da vida das lésbicas, sem vergonha ou medo. Ainda distribuíam filipetas chamando as frequentadoras para participarem de tudo o que o grupo realizava" (FERNANDES, Marisa. Lésbicas e a ditadura militar: uma luta contra a opressão e por liberdade. In: GREEN, James N.; QUINALHA, Renan (Orgs.). Ditadura e homossexualidades: repressão, resistência e a busca da verdade. São Carlos: EDUFSCAR, 2014, p. 145).

${ }^{486}$ BR_RJANRIO_TT_0_MCP_AVU_0485
} 
eram as bichas os alvos procurados, mas sim, as mulheres: os policiais invadiram os bares Cachação, Ferro's e Bexiguinha" e todas as mulheres encontradas foram “detidas debaixo do seguinte argumento: “é tudo sapatão",487.

Uma das vítimas foi uma lésbica de 22 anos, estudante da Universidade de São Paulo (USP), que estava no ponto de ônibus localizado na Rua Martinho Prado naquele fatídico dia. Ela preferiu não se identificar e relatou a ação repressiva então comandada pelo famigerado delegado Richetti: "Me levaram pra dentro do Cachação e fui logo mostrando meus documentos. Mas o polícia disse: não interessa documento, você é sapatão" ${ }^{488}$. Ela foi levada de camburão para o $4^{\circ}$ Distrito Policial, em uma travessa da Rua Augusta, junto com outras 200 mulheres que também foram detidas pelo simples fato de viverem seus desejos homoeróticos livremente. Sobre a chegada na delegacia, ela pôde observar a separação sob um viés de classe, que contava para o tratamento diferenciado entre as lésbicas: "primeiro me colocaram numa cela com mais 50 pessoas e mais tarde houve uma seleção. Quem tivesse boa aparência, estivesse bem vestido, era tirado pra outra cela. Junto ao policial que fazia essa escolha estava uma lésbica que conhecia a turma presa e ajudava na triagem". ${ }^{489}$

É curioso notar, neste depoimento, que o tratamento diferenciado que era conferido às lésbicas no encarceramento, a depender da aparência e dos trajes, sempre foram sinais exteriores usados pelas forças policiais para classificar status social e situação econômica das pessoas "suspeitas". Neste momento, ainda que já houvesse uma estratificação social incipiente dos espaços de sociabilidade homossexual - uma vez que a orientação sexual falava mais alto do que a distinção de classe e a escassez de pontos de pegação e interação - fazia-se, ali, uma distinção ainda maior entre pessoas devido às suas classes sociais. Além disso, a presença de uma lésbica - que conhecia as frequentadoras dos bares - colaborando direta e abertamente com a polícia sugere que as operações eram pensadas e planejadas com certa racionalidade, a partir de informações obtidas do próprio meio.

À certa altura da noite, a moça de 22 anos escutou outra das mulheres, uma assistente social que também havia sido detida, anunciar "eu pago 2 mil". Começou-se, então, a falar de dinheiro sem qualquer receio ou recato, demonstrando o quanto era normalizada e difundida a prática da extorsão das vítimas e de suborno das autoridades quando o assunto eram

\footnotetext{
487 "Richetti volta às ruas". Lampião da Esquina, n. 31, dezembro de 1980, p. 16.

488 BR_RJANRIO_TT_0_MCP_AVU_0485. Essa postura da polícia é confirmada pelo relato de Marisa Fernandes: "Mesmo portando todos os seus documentos, mulheres foram levadas indiscriminadamente sob o argumento "você é sapatão" (FERNANDES, Marisa. Lésbicas e a ditadura militar: uma luta contra a opressão e por liberdade. In: GREEN, James N.; QUINALHA, Renan (Orgs.). Ditadura e homossexualidades: repressão, resistência e a busca da verdade. São Carlos: EDUFSCAR, 2014, p. 136).

${ }^{489}$ BR_RJANRIO_TT_0_MCP_AVU_0485
} 
"infrações" que transitavam entre o questionável "ilícito" e o suposto "imoral". Ali era preciso, assim, literalmente pagar o preço de ser homossexual.

Diante deste cenário, ela ficou bastante preocupada, pois só tinha 100 cruzeiros no bolso e pensou "que não aceita[riam] tão pouco". Ela não soube precisar quem era o destinatário final dessas quotização em dinheiro - "talvez um funcionário subalterno", disse ela -, mas notou que quem dava mais dinheiro saía mais cedo. Ela ficou lá da meia-noite até três horas da manhã, tendo sido liberada apenas após ter dado dinheiro aos policiais. De acordo com a reportagem, "no fim, todo mundo teve que pagar. Quanto tivesse. A moça não viu ninguém sendo fichado, mas a polícia ficou com os nomes e os números de todas" 490

O episódio mais simbólico de repressão às lésbicas durante a ditadura ocorreria no dia 23 de julho de 1983. Naquele sábado, enquanto algumas mulheres do GALF vendiam o ChanacomChana dentro do Ferro's Bar, o proprietário e os funcionários do bar tentaram expulsá-las, inclusive usando a força física. Diante da resistência delas, a polícia foi chamada, mas rapidamente foi embora e nada fez de concreto para assegurar os seus direitos. Este assédio já tinha começado há algum tempo e o porteiro sempre tentava bloquear o acesso das lésbicas ao bar. Depois do episódio, as lésbicas decidiram marcar um protesto para a “retomada do Ferro's Bar”. Sob a liderança de Rosely Roth, foi combinado um ato para o dia 19 de agosto, articulando a imprensa, ativistas LGBTs, feministas e parlamentares progressistas. Neste dia, em torno das $21 \mathrm{~h} 30$, começou a concentração e, aos poucos, as pessoas adentraram anunciando o ato, quando boa parcela das pessoas já estavam dentro do recinto. Ali, a vereadora petista Irede Cardoso fez um discurso sobre a luta pelas liberdades democráticas.

Este acontecimento marcante, fruto da organização política autônoma das lésbicas, seria apelidado, mais tarde, como o "pequeno Stonewall brasileiro", em referencia à conhecida revolta considerada um marco no movimento LGBT internacional que foi iniciada no bar Stonewall Inn, na cidade de Nova Iorque, como uma reação à violência policial contra homossexuais e travestis.

Mesmo com a vitória, um mês depois das batidas que esvaziaram bares e boates, o cenário na Rua Martinho Prado era desolador. Até nas ruas eram vistas poucas pessoas circulando à noite. Nem mesmo na escuridão dos guetos esquadrinhados e confinados, em algumas áreas restritas das grandes cidades, pessoas LGBT podiam encontrar a liberdade de desejar e amar em tranquilidade.

${ }^{490}$ BR_RJANRIO_TT_0_MCP_AVU_0485 
Na entrevista, a estudante da Universidade de São Paulo confessou ao jornalista: "só nesses bares a gente encontra gente como nós, só lá somos aceitas, estamos em casa". 491 Assim, se era ruim no gueto, era pior fora dele. Ainda segundo a estudante,

até na Universidade de São Paulo, onde as pessoas se consideram avançadas, os homossexuais não são aceitos. Principalmente as lésbicas. No trabalho, quando descobrem, somos mandadas embora. Lá em casa minha mãe não consegue entender por que eu sou assim, por mais que eu tente mostrar a ela que estou bem assim, não tenho nada de anormal. ${ }^{492}$

Apesar de todo este cenário, Pelé, dona do Cachação, um dos bares mais frequentados pelas lésbicas na região, não demonstrou preocupação com Richetti e até mesmo elogiou sua atuação ao longo da reportagem: "conversei com ele, fui muito bem tratada e concordei com ele que a Operação Sapatão foi um mal necessário. Havia maus elementos que frequentavam aqui e agora sumiram"

A matéria destacava a atuação de oito grupos, em São Paulo, que haviam surgido para lutar contra as violências e discriminações: dois mistos, quatro de homens homossexuais e dois apenas com mulheres homossexuais. Ressaltava, ainda: "todos estão em formação, pois começaram mesmo nos primeiros meses de 1980, quando o delegado Richetti promoveu os famosos rondões que caçavam travestis. Para esses grupos organizados, as ações da polícia em novembro foram uma continuação daqueles rondões" ${ }^{\text {"494 }}$. Com efeito, com a exceção do Somos, os demais grupos se organizaram em 1979 e 1980 e teriam uma duração curta, conforme registrado no capítulo 4 deste trabalho.

\section{Violência policial fora do eixo Rio-São Paulo}

É válido dizer que, durante a ditadura, não foi somente no eixo das duas maiores cidades do país que a repressão contra os LGBT se intensificou nas ruas. Diversas outras capitais assistiram a processos muito semelhantes de combinação entre enrijecimento da estrutura repressiva, moralização das políticas de segurança e aumento do índice de violência policial, sem qualquer controle contra populações consideradas subversivas ou indesejáveis. O mais interessante, nestes casos, é notar como as diretrizes gerais de repressão se

\footnotetext{
${ }^{491}$ BR_RJANRIO_TT_0_MCP_AVU_0485

${ }^{492}$ BR_RJANRIO_TT_0_MCP_AVU_0485

${ }^{493}$ BR_RJANRIO_TT_0_MCP_AVU_0485

${ }^{494}$ BR_RJANRIO_TT_0_MCP_AVU_0485
} 
conjugavam com a cultura política e a moral locais.

A capital mineira, Belo Horizonte, povoada pela "tradicional família mineira" e por forças militares que contribuíram enormemente para o golpe de 1964, muitas vezes se esforçou em ser mais realista do que o rei na repressão aos costumes.

Logo em janeiro, de 1965, foi editada, ali, uma norma que só permitia as exibições de nu artístico, strip-tease e travestis "em teatro, sob severa fiscalização em que se resguard[asse] o decoro público e o respeito à sociedade". No mesmo ano, o delegado Francisco de Assis Gouveia apresentou um "plano de moralização da cidade", proibindo "invertidos" que usassem "calça justa", "batom" e "pó de arroz", alertando que seriam presos, em caso de descumprimento da ordem. Mas foi mesmo em 1969, logo após o endurecimento político e moral do regime, que a repressão se intensificou sob comando de Joaquim Ferreira Gonçalves, Secretário da Segurança Pública que desencadeou tremenda campanha contra o trotoar na cidade, também conhecida como "Operação Limpeza". Qualquer semelhança com as cruzadas de Richetti não eram mera coincidência.

Conforme nota Luiz Morando, em escrito repleto de episódios bem narrados sobre a situação de Belo Horizonte na década de 1960,

se ainda não ficava evidenciada uma relação direta entre a ideologia conservadora de vigilância e repressão aos costumes tal como era ventilado no discurso oficial, a Operação Limpeza desencadeada em janeiro de 1969 [deixa] bem transparente sua associação aos preceitos do AI-5. ${ }^{495}$

Recife também não ficou de fora. João Batista Acioly Sobrinho desencadeou uma onda repressiva contra o edifício Holliday, em Boa Viagem, no qual viviam mais de 200 homossexuais. Ele intensificou o policiamento arbitrário depois que um homossexual fora assassinado por um provável amante. Segundo a declaração homofóbica de José Édison Barbosa, delegado responsável por este caso na Delegacia de Homicídios, "entre homossexuais, os amantes são os primeiros suspeitos". Justificando suas operações repressivas, o delegado Acioly mostrou todo o seu zelo pela moral, na região desse edifício: “terão os responsáveis pelo edifício a obrigação de saber quais as pessoas que frequentam diariamente o imóvel, assim como controlar e evitar que atent[em] contra a moral" ${ }^{496}$

Este tipo de denúncia contra a homofobia das forças de segurança em Pernambuco já

\footnotetext{
${ }^{495}$ MORANDO, Luiz. Por baixo dos panos - repressão a gays e travestis em Belo Horizonte: In: GREEN, James N.; QUINALHA, Renan (Orgs.). Ditadura e homossexualidades: repressão, resistência e a busca da verdade. São Carlos: EDUFSCAR, 2014, p. 57.

${ }^{496}$ CARNEIRO, João. "Recife: mais uma bicha executada". Lampião da Esquina, n. 28, setembro de 1980, p. 3.
} 
vinham sendo feitas pelo primeiro candidato a assumir abertamente a defesa dos homossexuais. Baiardo de Andrade Lima concorreu a deputado nas eleições de 1978, ocasião em que declarou: "existem delegados que dão batidas em bares e restaurantes, simplesmente para caçar homossexuais, enquanto ladrões e assassinos atuam impunemente. A polícia pernambucana prende os homossexuais por puro sadismo, exibicionismo e falso moralismo" 497 .

Além das capitais mineira e pernambucana, Brasília também assistiu a demonstrações da força da polícia em batidas a lugares caros aos homossexuais. Em 21 de setembro de 1980, por exemplo, por volta da meia-noite, mais de 400 policiais deram uma batida generalizada com muita violência na região das boates Aquarius e Bataklan ${ }^{498}$.

Em Salvador, o mesmo se passava nos pontos tradicionais de sociabilidade homossexual e prostituição. O GGB lançou uma campanha de assistência médica e social a pessoas LGBT, denominada “Operação Pelourinho”. O médico responsável pelos atendimentos, sobretudo de pessoas trans, fez o seguinte relato, à época:

encontramos foi muita gente maltratada, com cortes profundos nos braços. Eles cortam os braços para que a polícia não os prenda, e vocês podem não acreditar, mas muitos não quiserem tratar dos cortes. Somente por serem homossexuais, estão sendo presos de roldão nessas batidas da polícia. ${ }^{499}$

Na mesma linha, um dos líderes do GGB, Luiz Mott, relatava que o tratamento médico das travestis era dificultado pelo fato de elas serem frequentemente presas, perdendo as datas agendadas de consultas e exames. Além disso, segundo ele, a prisão indiscriminada e arbitrária vinha sendo "um dos principais problemas relatados pelos travestis" que "pediramnos insistentemente que além do atendimento médico, providenciássemos assessoria jurídica, o que estamos tentando organizar". 500

Mas não era só por violência direta e por ação que a ditadura se fazia sentir nos corpos com gênero e sexualidade dissidentes por todo o país. Havia, como segue havendo, uma série de outras formas de cometer ou impedir a violência contra estas populações vulnerabilizadas.

\section{"Esquadrão mata-bicha": omissão ou cumplicidade do Estado?}

\footnotetext{
497 "Um candidato fala mais alto". Lampião da Esquina, n. 6, novembro de 1978, p. 4.

${ }^{498}$ RIBONDI, Alexandre. "Pega pra capar em Brasília". Lampião da Esquina, n. 29, outubro de 1980, p. 5.

${ }^{499}$ SILVA, Aguinaldo. "Bahia: os ativistas vão à luta". Lampião da Esquina, n. 34, março de 1981, p. 3.

${ }^{500}$ MOTT, Luiz. "Histórias de gente humilde". Lampião da Esquina, n. 34, março de 1981, p. 3.
} 
Uma outra dimensão da violência contra pessoas LGBT durante a ditadura não era cometida exatamente pelos agentes públicos, mas eram admitidas e até estimuladas por outras forças do Estado. A omissão e a conivência baseadas nos discursos LGBTfóbicos que emanavam dos órgãos oficiais da repressão foram fundamentais para alimentar culturalmente visões e práticas discriminatórias na sociedade brasileira. Além disso, a impunidade dos agressores de homossexuais, travestis e prostitutas era incentivada, quando não promovida, pelos próprios organismos estatais que deveriam proteger os direitos de cidadania de todos, sobretudo dessas "minorias" mais ameaçadas.

Assim como era feito em relação aos grupos de extrema-direita que colocavam bombas em bancas de jornais, nota-se ter havido certa tolerância, para não dizer cumplicidade, das agências de segurança com agrupamentos que atacavam fisicamente as pessoas LGBT e as prostitutas. Um exemplo de violência privada, respaldada pelo poder público, foi o que alguns chamaram de "esquadrão mata-bicha", que mereceu até um destaque de capa em uma das edições do Lampião, em janeiro de 1980.

O texto abordava a prática cada vez mais frequente de linchamentos contra homossexuais em curso no Rio de Janeiro. Conforme relata Aguinaldo Silva, estava havendo, na cidade, o "comportamento de alguns rapazes de classe média [...] que, organizados em bandos, [vinham] invadindo com uma frequência cada vez maior os locais frequentados por homossexuais para "castigá-los"”.

Não era raro que esses grupos fossem formados pelos próprios policiais, como um caso ocorrido no dia 21 de janeiro de 1980, na Gueifieira Palace, quando "um bando de soldados da Polícia Militar, armados de cassetetes de madeira, invadiu o banheiro de homens e surrou indiscriminadamente todos os que lá estavam, retirando-se depois, sem ser molestado" $" 501$.

Em São Paulo houve um fenômeno bem semelhante, tal como relata o jornal O Povo, de 31 de dezembro de 1982, em matéria intitulada “"Machistas' jogam pedras e ovos nas 'Genis' paulistas". De acordo com o jornal, um grupo de 20 "filhos de papai" estava "sentando o pau nos travestis e gays do bairro de Indianópolis" ${ }^{, 502}$. Acrescentando, ainda, que eles jogavam "pedras e ovos nas menininhas peludas, que fica[vam] achando tudo um horror". Marcelo Rodrigues Lins, uma das vítimas, com apenas 22 anos, levou socos e pontapés. Na delegacia, em seu depoimento, ele afirmou que os "machistas" apareciam sempre em um Corcel, placa KK 2853, ou com uma caminhonete F-100 branca, cuja placa era um mistério.

\footnotetext{
501 “Um esquadrão mata-bicha?”. Lampião da Esquina, n. 20, janeiro de 1980, p. 3.

${ }^{502}$ BR_RJANRIO_TT_0_MCP_AVU_0017_d001
} 
O jornal destacava que "os caretas garant[iam] que [iriam] fazer uma limpeza nas ruas de São Paulo" e completava que "[havia] muita preocupação, porque 'os machistas' promet[iam] chegar até o Centro da Cidade" ${ }^{503}$.

O caso estava sendo investigado pela $36^{\mathrm{a}}$ Delegacia de Polícia. Mas, segundo as travestis ouvidas pelo jornalista, "a polícia nunca [iria] tomar providência mais enérgica" devido à conivência manifesta com este tipo de violência. $\mathrm{O}$ jornal concluía que: "todos têm a mesma opinião que as ‘bichas frustradas', os machistas vão continuar a agir"”04.

Fora do eixo Rio-São Paulo, há registros deste tipo de atuação homofóbica e transfóbica. Um exemplo de veiculação de denúncias desta natureza pode ser encontrada no “Afinal”, um jornal "nanico" e abertamente de oposição à ditadura, fundado por diversos jornalistas prestigiados de Santa Catarina que vinham sendo perseguidos na imprensa tradicional, sobretudo por conta da cobertura que fizeram da Novembrada, o grande protesto ocorrido em 1980, em Florianópolis, contra o general João Batista Figueiredo.

Logo em sua primeira edição, de maio de 1980, o "Afinal” já declarava sua posição ousada de guerra ao governo:

\begin{abstract}
Afinal surge como uma alternativa de se furar esse bloqueio. Nosso compromisso é com o leitor, somente com ele. Por isso, a partir de agora, os desmandos, a corrupção, as arbitrariedades, o sofrimento do povo voltam a ser denunciadas em páginas de jornal. Nestas páginas. ${ }^{505}$
\end{abstract}

Não demorou para que o pequeno e corajoso periódico despertasse a preocupação e a indignação da repressão. Logo, ele passou a frequentar os monitoramentos da imprensa, feito pelos órgãos de informação.

Em especial, a edição n. 6, de outubro de 1980, foi objeto de um relatório que afirmava que "o mensário 'AFINAL', a exemplo do contido em Apreciações Anteriores, volta[va] a veicular matéria eivada de PROPAGANDA ADVERSA" ${ }^{\text {506 }}$. A principal acusação, assim, era a de "atentar contra a moral e os bons costumes, estimular o ódio racial e indispor o Governo com o povo", concluindo que o jornal "volta a infringir dispositivos que permit[iam] o seu enquadramento legal". 507

Isto porque, nesta edição, dentre outros assuntos, um dos destaques com a chamada de

\footnotetext{
${ }^{503}$ BR_RJANRIO_TT_0_MCP_AVU_0017_d001

${ }^{504}$ BR_RJANRIO_TT_0_MCP_AVU_0017_d001

${ }^{505} \mathrm{O}$ acervo digitalizado de todas as 13 edições (mensais ou bimestrais) do jornal "Afinal" pode ser encontrado no seguinte site: http://cangablogafinal.blogspot.com.br/

${ }^{506}$ BR_RJANRIO_TT_0_MCP_AVU_0451

${ }^{507}$ BR_RJANRIO_TT_0_MCP_AVU_0451
} 
capa era justamente a situação dos homossexuais submetidos à violência na cidade de Florianópolis. "Identificados os espancadores de homossexuais" era a chamada já estampada, de modo bem destacado, na capa. A matéria, por sua vez, escrita pelo jornalista Sérgio A. F. Rubim, intitulava-se "Recado das bichas à polícia e seus espancadores: "não é deste tipo de pau que a gente gosta"”. Apesar do título um tanto apelativo, que pode soar à primeira vista como reprodução das recorrentes abordagens jornalísticas superficiais e sensacionalistas sobre o tema, a reportagem era bastante crítica ao modo como os homossexuais vinham sendo tratados pela polícia e retratados pela imprensa.

Logo de início, era abordado, em tom de programa policial, o episódio que deu marco à onda de violências contra homossexuais e prostitutas:

\footnotetext{
segunda-feira, 16 de setembro de 1979. Aproximadamente 22 horas. O cabeleireiro Sidney caminha calmamente pela rua Almirante Alvim, em frente à Faculdade de Economia: é abordado por dois homens, que descem de um fusca vermelho e lhe pedem documentos. Assim começou, em Florianópolis, uma verdadeira campanha de violência desencadeada contra prostitutas e homossexuais, envolvendo desde policiais até grupos organizados. Durante as sessões de espancamento os tarados manifestam sua ideologia de preservação da "família, da moral e das tradições". 508
}

Diversos outros casos, como este, aconteceram, evidenciando tratar-se de um grupo organizado "com a certeza de que não ser[iam] punidos". Isto porque, "marginalizados e discriminados pela sociedade, os homossexuais não procura[vam] a polícia ou a imprensa para denunciar as agressões. Alega[ndo] não acreditar que as instituições lhes protej[essem] e também tem[iam] sofrer represálias". 509

Este outro aspecto, não apenas de uma indiferença, mas de um compromisso efetivo e declarado das instituições do Estado com a violência LGBTfóbica foi um dos mais perversos da ditadura, pois incentivava as agressões, naturalizava a discriminação, legitimava os perpetradores e garantia, enfim, a impunidade que reproduzia os mesmos crimes.

Além disso, este tipo de postura sonegava reconhecimento do sofrimento, fazendo com que as vítimas desistissem de recorrer às autoridades para buscar restauração, pois sabiam que nada aconteceria e ainda poderiam ser humilhadas nos próprios órgãos estatais. Assim, se a ditadura pode e deve ser analisada por suas ações positivas contra estes segmentos vulneráveis, ela também precisa ser avaliada por sua omissão e, sobretudo, conivência com apoio ativo aos agressores.

\footnotetext{
${ }^{508}$ Afinal, edição n. 6, de outubro de 1980, p. 14.

${ }^{509}$ Afinal, edição n. 6, de outubro de 1980, p. 14.
} 
Um exemplo deste comportamento policial foi o caso citado, na mesma matéria, de uma prostituta de 24 anos que foi agredida por "três PMs à paisana e um funcionário do Supermercado Central”. Conseguindo se desvencilhar dos agressores, a mulher dirigiu-se ao posto policial e, chorando muito, fez a denúncia. O cabo de plantão lhe respondeu "pode ir pra casa que eu vou encaminhar a denúncia à Delegacia”, mas sem anotar nada.

Com a aproximação do repórter, empenhado em obter maiores dados sobre o caso, os quatro tarados e o cabo da PM tentaram dissuadi-lo de publicar o fato: 'Deixa disso, rapaz. Estas putas e bichas tem mais é que apanharem pra aprenderem a ter vergonha na cara e não ficarem aí pelo centro da cidade. ${ }^{510}$

A análise de diversos episódios sobre o modo como se dava a violência estatal na interdição das sexualidades dissidente, atuando, sobretudo, na profusão de discursos normativos restritivos no campo dos costumes, indica contornos bastantes claros de uma política específica de regulação dos desejos, dos corpos e dos afetos por parte da ditadura brasileira. Esta política não era a mesma de extermínio de outros setores incômodos e opositores ao regime, mas teve uma coerência e uma sistematicidade que impressionam quando vistas conjuntamente. Sem sombra de dúvidas, o apagamento dessas violências deu uma contribuição inestimável para os altos índices de agressões e de letalidade das pessoas LGBT no Brasil de hoje.

\footnotetext{
${ }^{510}$ Afinal, edição n. 6, de outubro de 1980, p. 14.
} 
- Capítulo 4 -

\section{MOVIMENTO HOMOSSEXUAL ${ }^{511}$ NA DITADURA}

Uma metalúrgica que luta pelos seus direitos salariais no sindicato, mas aceita as imposições ditadas pela moral sexual dominante nas relações com seu companheiro, ou um bancário que se engaja no movimento de liberação dos homossexuais, mas ignora a luta pelos direitos sindicais, estão alheios, um quanto o outro, da luta mais ampla.

- Mariza, "Nossas gaiolas comuns”, Lampião da Esquina, n. 1, p. 2.

\section{"O ato de se organizar politicamente era uma empreitada de risco"}

Um dos grandes paradoxos da reflexão em torno dos cruzamentos entre a ditadura brasileira e as homossexualidades é o fato de que os primeiros passos do movimento homossexual tenham sido dados justamente sob a vigência de um regime autoritário que proibia a livre organização da sociedade civil e cultivava um preconceito institucionalizado contra os homossexuais.

O objetivo deste capítulo é, precisamente, refletir sobre os desafios enfrentados pelo movimento homossexual, em sua origem, sobretudo diante do fato de ter-se organizado sob uma conjuntura política hostil e em meio a um ambiente moral refratário às minorias sexuais. Esmiuçar a relação entre o Estado e o projeto coletivo de politização da homossexualidade nos parece fundamental para compreender algumas marcas congênitas ao movimento, que determinaram, de forma decisiva, algumas de suas potencialidades e também seus limites.

Para além das violências diretas na interdição e no silenciamento das sexualidades dissidentes, o Estado, junto à Igreja Católica, conseguia irradiar e fazer circular, com elevado grau de legitimidade, normas retrógradas de comportamentos de gênero e sexual. Mas, mesmo sob o fardo da marginalização e da estigmatização acentuadas pelo regime, os homossexuais começaram a se organizar no sentido de articular um discurso e uma prática de liberação não apenas deles próprios, mas também dos demais grupos vulneráveis que ficavam às margens do projeto de abertura política então em curso.

\footnotetext{
${ }^{511} \mathrm{Na}$ época, "movimento homossexual brasileiro (MHB)" era a expressão utilizada para designar o conjunto de militantes formado por homossexuais e pessoas trans. Somente durante os anos 1990 é que o movimento passou a ser também referenciado como LGBT para contemplar, expressamente, um arco mais amplo de identidades de gênero e de orientações sexuais. Um histórico das mudanças das denominações e siglas pode ser encontrado em SIMÕES \& FACCHINI, 2009, p. 14-15.
} 
Uma primeira e mais trivial explicação para este paradoxo poderia se basear na fórmula tentadora e bastante popularizada a partir da teoria política foucaultiana, segundo a qual "onde há poder, há resistência",512. Um exemplo de aproximação com este tipo de leitura, que atribui à ditadura "boa parte das condições para o boom movimentalista que ocorreu no decorrer dos nos anos 1970", é a colocação de Regina Facchini, segundo a qual é importante "notar o quanto a ditadura estimulou a formação de resistências em diversos setores sociais e como ela pode ter sido, inclusive, responsável pelo perfil fortemente antiautoritário que marcou a 'primeira onda' do movimento homossexual brasileiro" ${ }^{2513}$.

Este tipo de raciocínio postula, sem respaldo empírico adequado para mapear as causalidades de um fenômeno tão complexo, que demandas represadas e abafadas irromperam na cena pública com mais força justamente pela falta de canais adequados de participação política, transbordando os limites estreitos da ordem autoritária. Entretanto, ainda que tal resposta não deixe de ser factível, a nosso ver, ela é insuficiente, porque excessivamente intuitiva, abstrata e incapaz de dar conta das especificidades históricas e das determinações particulares que marcaram o controle dos costumes sexuais pela ditadura brasileira. Afinal, de algum modo, por trás dessa máxima, também repousa o risco de uma romantização da repressão, como se esta, por si só, estimulasse a criatividade organizativa, o despertar para a ação política, e fomentasse, em última instância, e necessariamente, a produção de resistências. Considera-se, aqui, que isto não é uma verdade no contexto de repressão do estado ditatorial brasileiro e atribui, a ela, uma virtude que não lhe cabe.

Com efeito, ainda que seja necessário compreender não apenas os efeitos negativos da ditadura na repressão ao movimento, também não se pode incorrer no outro extremo de atribuir a resistência à repressão. Tal como Roberto Schwarcz - que questionava a tese de que a contracultura surgida no final dos anos 1960 fosse fruto do endurecimento da censura, ressaltando antes que houve um longo período de gestação de novas formas culturais durante os anos 1950 e $1960^{514}$-, buscamos compreender as práticas e discursos em torno da homossexualidade. A relativa - e bastante relativa - liberdade dentro da qual se exerciam a sociabilidade e o prazer entre pessoas do mesmo sexo nos guetos existentes naquele período se explicam mais "apesar da" do que "por conta da" ditadura, como os diversos episódios de vigilância, censura e violências abordados neste trabalho demonstram.

\footnotetext{
${ }^{512}$ FOUCAULT, Michel. História da Sexualidade I: a vontade de saber. Rio de Janeiro: Graal, 1985. p. 91.

${ }^{513}$ FACCHINI, Regina. Sopa de letrinhas? Movimento homossexual e produção de identidades coletivas nos anos 1990. Rio de Janeiro: Garamond, 2005, p. 93.

${ }^{514}$ SCHWARCZ, Roberto. Cultura e Política. 1964-1969. In: O pai de família e outros estudos. Rio de Janeiro: Paz e Terra, 1978. pp. 61-92.
} 
É forçoso constatar que, mais do que política sexual repressiva, foram as transformações culturais e sociais por que passou a sociedade brasileira, desde a década de 1950, que cumpriram um papel fundamental para lançar as bases que viabilizariam a organização política dos homossexuais. Um longo caminho vai sendo trilhado no decorrer destes anos para que sejam tolerados, e abertamente vividos, determinados comportamentos não normativos de gênero e de sexualidade para além das festividades do Carnaval.

A concentração de populações de gays e lésbicas nos grandes centros urbanos em meados do séc. XX propiciou uma integração relativa desses grupos às cidades em expansão, ainda que inicialmente em guetos delimitados, isolados e estigmatizados. Além dos tradicionais pontos de pegação como parques, praças e banheiros públicos, onde era possível flertar e encontrar sexo casual entre homossexuais, outros circuitos menos clandestinos e marginais de sociabilidade, sobretudo com a exploração econômica de um mercado voltado a este segmento, foram sendo progressivamente desbravados, tais como bares, boates e festas privadas. Para Green, foi neste tipo de ambiente que se criou não apenas um senso de conectividade, "senão um tipo de comunidade em formação, em que as pessoas se identificaram, compartilharam códigos, comportamentos e costumes, ainda dentro de uma semiclandestinidade imposta graças à marginalização social da homossexualidade" ${ }^{\text {" }} 15$.

Assim, do ponto de vista dos costumes e da liberação sexual, o Brasil vinha passando por profundas mudanças que, com o golpe de 1964, foram postas em recesso e, a partir de 1968, foram definitivamente interrompidas, ou até mesmo parcialmente revertidas. Exemplo disso foram as ofensivas de repressão cada vez mais constantes em espaços fechados voltados para o entretenimento e a diversão entre homossexuais, que funcionavam como uma espécie de refúgio longe do alcance das investidas policiais, contra a concentração de gays e lésbicas em determinadas ruas e zonas abertas.

Neste sentido, é possível afirmar que "o Golpe de 1964 e o policiamento mais intensivo nos centros urbanos, especialmente a partir de 1969, dificultaram a sociabilidade pública nas ruas, nos parques e nas praças devido à crescente arbitrariedade das forças da ordem do Estado" 516 .

Tanto que foi somente no momento da distensão, ainda que controlada, que o

515 GREEN, James Naylor. O grupo Somos, a esquerda e a resistência à ditadura. In: GREEN, James N.; QUINALHA, Renan (Orgs.). Ditadura e homossexualidades: repressão, resistência e a busca da verdade. São Carlos: EDUFSCAR, 2014,, p. 184.

${ }^{516}$ Ibidem, p. 184. Perlongher, em sua etnografia na região central de São Paulo, parece confirmer essa tese ao afirmar que "o golpe military de 1964 demora em se fazer sentir no pedaço; 1966-1967 foi o auge da Galeria MEtrópole. A revolução [sic] de 1964 não surtiu efeito imediato entre as pessoas, só a partir do AI-5, em 1969”. PERLONGHER, Nestor. O negócio do Michê - A prostituição viril em São Paulo. São Paulo: Fundação Perseu Abramo, 2008. 
restabelecimento de algumas liberdades e garantias mínimas de expressão e de associação possibilitou a constituição de um movimento homossexual. Se nos EUA o ambiente social propício para a emergência do movimento homossexual veio da combinação da contracultura, das lutas pelos direitos civis e pelo pacifismo, no Brasil, foi o contexto de derrota da esquerda armada pela ditadura, agitado com a emergência também de novos sujeitos políticos, em um contexto de abertura tímida, que marcou a constituição do movimento. Dificilmente teríamos um movimento homossexual se este não tivesse sido encorajado pelas organizações de mulheres, negros, estudantes e trabalhadores na luta contra a ditadura militar ${ }^{517}$.

Nesta linha, parece bastante factível a hipótese aventada por Green no sentido de que a ditadura inviabilizou e acabou mesmo por atrasar a emergência de uma mobilização política dos homossexuais no Brasil, que só encontrou terreno fértil para florescer "tardiamente". A repressão do regime autoritário "fez do ato de se organizar politicamente uma empreitada de risco" e, assim, as organizações de gays e lésbicas "não tiveram espaço político para se desenvolver antes de 1977”. Ainda na opinião dele, isso teria prejudicado um acúmulo de experiências e ativistas mesmo em um cenário internacional de avanço do movimento, o que fez com que "quando as condições políticas se tornaram propícias à organização, eles [homossexuais brasileiros] tentaram ir de zero a cem numa única volta" ${ }^{\text {"518. }}$.

Para Rafael de Souza, em um interessante trabalho que adota uma perspectiva da sociologia política com destaque para a dimensão cultural, além da conjuntura da abertura, foi decisiva a emergência de uma imprensa alternativa e de um circuito de arte "marginal". Foram estes elementos que propiciaram aos grupos homossexuais sua própria interpretação da conjuntura nacional. Isto teria servido, ainda, de suporte para a crítica política dos costumes que marcaria a atuação do movimento homossexual desde sua mais remota origem, construindo, assim, uma retórica de "libertação sexual" que conferiu a singularidade desse ator político no processo de redemocratização ${ }^{519}$.

Ainda que a transição tivesse desencadeado um ciclo de protestos com pautas

\footnotetext{
517 GREEN, James Naylor. "The Emergence of the Brazilian Gay Liberation Movement, 1977-1981." Latin American Perspectives, vol. 21, no. 1, 1994,, pp. 40-43.

${ }_{518}$ GREEN, James Naylor. O grupo Somos, a esquerda e a resistência à ditadura. In: GREEN, James N.; QUINALHA, Renan (Orgs.). Ditadura e homossexualidades: repressão, resistência e a busca da verdade. São Carlos: EDUFSCAR, 2014, p. 184. Green relata ter tido clareza disto ainda na época da ditadura: "Em um encontro no Somos, defendi que se a violenta onda de repressão que se abateu a partir de 1968 não tivesse ocorrido, o movimento de liberação gay teria florescido como ocorreu na Europa, Estados Unidos, México, Argentina e Porto Rico. Gays e lésbicas simplesmente não tinham espaço para se organizar no clima político do Brasil". (GREEN, James. "Abaixo a repressão, mais amor e mais tesão": uma memória sobre a ditadura e o movimento de gays e lésbicas de São Paulo na época da abertura. Acervo, [S.1.], v. 27, n. 1, abr. 2014, p. 72)

519 SOUZA, Rafael de. Saindo do gueto: o Movimento Homossexual no Brasil da abertura, 1978-1982. (Dissertação de Mestrado). São Paulo, USP, 2013.
} 
diversificadas - como participação política, reforma agrária, direitos trabalhistas, saúde, educação, creches, saneamento básico -, houve uma especificidade da mobilização em torno das demandas por liberdade comportamental e por uma política da sexualidade mais permissiva. Este movimento conseguiu trabalhar com um estigma, considerado até então um tabu, convertendo-o em vetor de orgulho identitário e plataforma de ação coletiva. Mas este não foi um processo fácil, como se verá.

\section{"O pessoal não se une. Não há espírito de classe, nem de solidariedade": a polícia acaba com o I Congresso do Homossexual Brasileiro}

O Brasil assistiu, durante o século XX, a diversos esforços de associação entre homossexuais em momentos de nossa história em que sequer esta categoria era utilizada ou popularizada para referir-se àqueles que sustentam uma relação afetiva com pessoas do mesmo sexo. Eventos sociais, apresentações de travestis, folias carnavalescas, concursos de miss, desfiles de fantasias, boletins, e outras publicações mimeografadas, são alguns exemplos de iniciativas criativas e coletivas dos homossexuais que desafiavam as normas rígidas de gênero e sexualidade. Contudo, estas articulações e movimentações ainda eram circunscritas a alguns guetos territoriais e sociais, sendo muitas vezes qualificadas como "despolitizadas" pelos militantes que constituiriam o movimento a partir da década de 1970. Já na segunda metade desta década, foram ensaiadas as primeiras tentativas de organização política dos homossexuais de que se tem registro histórico, mas, por conta da conjuntura ainda incipiente da tão esperada "abertura", nenhuma dela logrou sucesso.

Em meados de 1976, começaram a circular bilhetes apócrifos com uma convocatória por toda a cidade do Rio de Janeiro. Sem identificar os organizadores da iniciativa, que assinavam apenas como "UHB" - União dos Homossexuais Brasileiros -, os convites não usavam de meias-palavras quanto ao objetivo do encontro a ser realizado nos jardins do Museu de Arte Moderna (MAM): realizar o I Congresso do Homossexual Brasileiro e instituir o Dia do Homossexual, em que seria comemorada a libertação desta comunidade. Constavam, ainda, no mesmo convite, os propósitos ousados do encontro até então inédito e marcado para o dia 4 de julho:

além de nos confraternizamos, teremos oportunidade de conhecer o perfil da luta em que nos empenhamos pelos direitos do homossexual brasileiro a uma vida digna e respeitada. Vá e leve o seu caso. Vá e leve os seus trabalhos. Se 
for simpatizante, leve o seu sorriso e o seu abraço para um amigo desacompanhado. Viva! Viva a União do Homossexual Brasileiro. Por melhores oportunidades e igualdade de condições. Viva o 4 de julho! Alegria. Amor. Respeito.

No tão esperado dia, em meio à grande expectativa, aglomeraram-se jornalistas do Rio de Janeiro e de São Paulo para cobrir o evento. No entanto, em vez de gays, lésbicas e pessoas trans, o que mais havia no local eram policiais. Uma matéria do jornal Última Hora, do dia seguinte ao encontro, relata a repressão contra a realização deste primeiro encontro dos homossexuais. Intitulada "Polícia acaba com o Dia do Homossexual", a reportagem noticiava:

Operação Salto-Alto da Polícia impediu ontem à tarde reunião nos jardins do Museu de Arte Moderna, para comemoração do Dia do Homossexual com a chegada de 20 carros e 70 homens do Departamento Geral de Investigações Especiais, da $3^{\mathrm{a}}$ DP da Delegacia de Vigilância-Centro, às $13 \mathrm{~h}$, poucos travestis se aproximaram do local, no Aterro do Flamengo. ${ }^{520}$

A breve nota comunicava que ninguém sabia quem organizou a festa, que consistiria em uma confraternização, mas também se propunha a tratar da União do Homossexual Brasileiro, com “Alegria, Amor e Respeito”. Um dos poucos presentes, José Jurandir Garrido, escapou ao bloqueio policial, mas "estava irritado" e "lamentou a ausência de outros adeptos à reunião". Esses números do aparato repressivo são confirmados pela publicação "Bagaço", que destacou a presença de 8 camburões entre os 20 carros de polícia rondando o local afastando, assim, os eventuais interessados que perambulavam pelo em torno.

O periódico ainda acrescenta sobre o receio dos presentes quanto à possibilidade de repressão do encontro:

dispersos pela vasta área do Aterro, a redor do MAM, os homossexuais que atenderam ao convite, em número reduzido, a interessados, não se sentiram à vontade com a demonstração ostensiva da máquina policial, montada para 'protegê-los', segundo palavras do Delegado Gilberto Guia aos participantes do "conclave".

Por sua vez, o jornal A Notícia, também de 5 de julho, apresentava uma declaração do delegado Gilberto Guia, que assegurava aos repórteres, na ocasião: “não há nada o que proibir aqui, desde que as manifestações não perturbem a ordem e a tranquilidade. Nós não viemos proibir, viemos apenas assegurar a ordem das manifestações”.

A própria reportagem, contudo, advertia que "o aparato policial assusta[va]". Às 14h,

\footnotetext{
${ }^{520}$ Jornal Última Hora, de 5 de julho de 1976.
} 
horário indicado para início do evento, não havia sinal de movimentação. Depois de meia hora é que algumas pessoas, timidamente, começaram a se aproximar e circular perto do local marcado para o encontro. Conforme registrou o jornal,

Eles vêm timidamente, quase a medo. Alguns sozinhos, outros em dupla. Passeiam pelos jardins, sentam nos bancos de pedra, fingem admirar a vista do Aterro do Flamengo, mas não se juntam, não há qualquer movimento de concentração. À chegada da reportagem, a maioria foge. Não parecem cidadãos vindos para se empenhar em luta ou reivindicar direitos.

Constatação semelhante foi feita pelo já mencionado José Jurandir Garrido, assim referenciado pela reportagem, mas provavelmente uma travesti com o nome social de Garrida. Vestindo botas de salto alto, calça justa de veludo azul e blusão, ela afirmava aos jornalistas:

vim para a realização da concentração, mas nem os promotores apareceram. Acho que ficaram com medo. Mas, não há nada a temer. Não há crime nenhum em ser homossexual. Temos que lutar por nossos direitos, mas desta forma não vamos conseguir nada. O pessoal não se une. Não há espírito de classe, nem de solidariedade. Como eu, muitos outros vieram, mas não houve a concentração.

Garrida estava, assim, frustrada com a ausência das pessoas nas mesmas condições que ela esperava encontrar ali, inclusive porque havia levado seus trabalhos de poesia para que recebessem apoio e fossem publicados em livro.

A declaração lúcida e corajosa de Garrida revela a dificuldade de mobilização das pessoas LGBT em período tão adverso, no qual imperava um clima de medo generalizado por conta da presença ostensiva das forças de segurança conservadoras, bem como uma dificuldade por parte dos homossexuais em assumir publicamente suas sexualidades dissidentes. O peso da repressão estatal e do preconceito internalizado é uma sombra constante sobre as iniciativas de organização política dos homossexuais.

Tal condição acabava impondo a única saída de uma dupla clandestinidade a estes segmentos: de um lado, era necessário fugir do contato direto com agentes do Estado, que reprimiam violentamente a vivência pública de condutas não-heterossexuais; por outro, era também preciso evitar a exposição da homossexualidade, repelida que era socialmente em virtude do preconceito arraigado.

De qualquer modo, apesar de todas as adversidades, a referida matéria do "Bagaço" sobre o ocorrido considera o evento, ainda que frustrado, um acontecimento histórico: 
é de se registrar um fato quase inédito na América Latina e no Brasil em particular. Trata-se da vontade manifestada pelos homossexuais de se reunirem para debater seus problemas. O momento que nosso País atravessa é dos mais significativos em sua história recente. Dificilmente se ouve falar que alguém ou algum grupo se reuniu para discutir ou questionar qualquer problema mais sério do que [...] futebol, por exemplo. E, na pauta do Congresso, fartamente distribuída, lia-se a palavra 'direitos'. Não por mera coincidência.

Tal registro demonstra como a organização dos homossexuais, ainda que difícil, já se anunciava como potencialmente subversiva e objetivamente desestruturadora para as estruturas morais do regime vigente, desafiando a normalidade e o ritmo da transição controlada que não parecia colocar em xeque as regras conservadoras que sustentaram ideologicamente o regime autoritário de 1964.

Não demoraria muito, depois deste episódio, para que o movimento homossexual, remando contra a corrente, iniciasse uma articulação política inédita e histórica dos setores sexualmente marginalizados pela sociedade profundamente heteronormativa de então.

\section{"Tivemos uma existência clandestina e muito conturbada": ser homossexual na ditadura}

Ainda no final de 1976, só que em São Paulo, um outro "grupo de entendidos" começou a se reunir para discutir seus problemas comuns, muito por iniciativa e teimosia de João S. Trevisan, logo que este retornara de seu auto-exílio em São Francisco (EUA) e no México, trazendo inspiração e diversas ideias do seu contato com o movimento gay internacional.

As dificuldades, no entanto, eram diversas em uma sociedade ainda dominada por preconceitos, com muita repressão introjetada entre os homossexuais e com o agravante de um regime político fortemente autoritário, mesmo com o discurso ainda duvidoso da "abertura". Basta lembrar que, nesse mesmo ano, o jornalista Celso Curi estava sendo processado por publicar, em sua "Coluna do Meio", assuntos considerados atentatórios à moral e aos bons costumes.

Nessas condições adversas, era pouco provável que a empreitada rendesse frutos imediatos. Para que se tenha uma ideia sobre o perfil dos participantes dessa tentativa bem embrionária, “70\% do grupo se julgava anormal, em função de sua homossexualidade. Como dizia um deles: 'Eu daria tudo pra ser um senhor casado e com filhos"”. Diante do cenário 
marcado por autoflagelação cristã, desejos enrustidos e permanente ameaça de criminalização de qualquer ação política, "o resultado foi desastroso, com tanta culpa, auto-desprezo e ausência de auto-imagem. Não deu em nada, depois de poucos meses",521.

Mas os anos de 1977 e 1978 começariam a alterar aquela realidade. Ainda que o projeto de distensão implementado progressivamente pelo governo seguisse bastante limitado e controlado, novos e antigos atores políticos entravam em cena disputando os rumos e o ritmo desse processo. A segunda metade da década de 70 foi caracterizada por manifestações massivas capitaneadas sobretudo por estudantes e trabalhadores, reivindicando as demandas reprimidas por mais de uma década e reabrindo arenas de ação política para diversos movimentos sociais, inclusive os de caráter identitário.

Foi então quase dois anos após essa primeira tentativa frustrada e um mês depois do lançamento da primeira edição do Lampião que ocorreu, em maio de 1978, por iniciativa de João Silvério Trevisan, a primeira reunião do "Núcleo de Ação pelos Direitos dos Homossexuais", que já carregava em seu nome uma orientação para a ação e uma gramática de reivindicação de direitos. Além de debater a condição homossexual e os temas abordados no Lampião, o grupo também chegou a redigir uma carta aberta à imprensa em protesto à forma estigmatizada como as homossexualidades eram retratadas na televisão.

Esse seria o embrião do Somos, o primeiro grupo organizado politicamente apenas com homossexuais, realizando reuniões periódicas e intervenções públicas com uma duração expressiva, tornando-se, reconhecidamente, o pioneiro do movimento homossexual brasileiro $^{522}$.

Em meio a uma intensa discussão, o grupo teve diversos nomes, "desde Clube da Bolachinha (nos reuníamos com chá e bolachas) até Núcleo de Ação pelos Direitos dos Homossexuais", sem contar apelidos como "grupo totó-fruta-conde". Mas o batismo definitivo foi escolhido em homenagem às "locas" argentinas, que fundaram o primeiro grupo do gênero na América Latina, a Frente de Liberación Homosexual (FLH), no ano de em 1971, e editaram alguns números de uma publicação intitulada, precisamente, Somos. Esse boletim

\footnotetext{
521 "Grupo SOMOS: uma experiência". Lampião da Esquina, n. 11, maio de 1979, p. 2.

${ }^{522}$ Green relata algumas mudanças políticas do país que lançaram as condições para a organização coletiva dos homossexuais: "A situação política brasileira tinha mudado drasticamente em 1976, quando Trevisan organizou os primeiros grupos voltados para ampliar o autoconhecimento entre gays e, um ano depois, quando o movimento decolou. Estudantes começaram a fazer passeatas nas ruas contra a ditadura. Grupos de direitos humanos corajosamente denunciavam os excessos do regime. Organizações de trabalhadores protestavam contra a política salarial do governo. Ativistas políticos de esquerda, incluindo o Partido Comunista Brasileiro, trotskistas e outros grupos recrutavam secretamente trabalhadores e estudantes para as suas fileiras. A sensação de que a mudança era iminente afetou também gays e lésbicas brasileiros". GREEN, James. "Abaixo a repressão, mais amor e mais tesão": uma memória sobre a ditadura e o movimento de gays e lésbicas de São Paulo na época da abertura. Acervo, [S.1.], v. 27, n. 1, abr. 2014, p. 64.
} 
circulou entre 1973 e 1976, quando um golpe militar instaurou uma ditadura também na Argentina. Além da homenagem, o nome também foi escolhido porque era "expressivo, afirmativo, palindrômico (procure no dicionário), rico em semiótica e sem contraindicações" $" 523$.

Sua primeira reunião ocorreu em maio de 1978, organizada em torno da ideia compartilhada por várias pessoas de constituir-se enquanto um espaço de encontro dedicado aos homossexuais "fora dos costumeiros ambientes de badalação e pegação (boates, bares, saunas, cinemas e calçadas)", algo considerado, desde o início como "inédito, urgente e fascinante" pelos participantes. Em torno de 15 pessoas, nem sempre as mesmas, frequentavam o grupo, inicialmente.

Nesta fase, a construção de uma identidade de grupo era a tarefa central e mais difícil para dar o pontapé na organização. A busca por pontos em comum, a partir de concepções e práticas de homossexualidade tão distintas e em um momento no qual não era possível falar abertamente sobre essas experiências, constituiu um desafio desde a primeira hora. Mas este aprendizado da diversidade como um valor a ser respeitado foi fundamental: "cedo percebemos que as experiências sexuais, as relações com o sexo oposto, o relacionamento familiar e profissional, a situação econômica e outros dados eram extremamente diversificados; não podíamos fazer generalizações a partir das vivências individuais" ${ }^{\text {" }}$.

"A coisa não foi fácil. Tivemos uma existência clandestina e muito conturbada",525, talvez seja um desabafo capaz de resumir bem a situação do grupo neste período. Tudo ainda era novo, não havia clareza quanto aos objetivos e à linha política que unificariam minimamente essa diversidade de expectativas e demandas, com o empecilho adicional de haver uma enorme rotatividade de pessoas que entravam e saíam porque não encontravam ali o que esperavam ou não conseguiam enfrentar seus medos e problemas de autoaceitação.

Além dessa dificuldade de recrutamento de pessoas dispostas a assumir abertamente a homossexualidade e enfrentar os riscos de se juntar a um coletivo considerado estigmatizado

\footnotetext{
523 "Grupo SOMOS: uma experiência". Lampião da Esquina, n. 11, maio de 1979, p. 2. Este artigo consiste em um interessante relato abordando as novidades implicadas na organização coletiva ainda em seu início, contando sua ainda breve história e convidando os leitores à maior participação política.

524 “Grupo SOMOS: uma experiência”. Lampião da Esquina, n. 11, maio de 1979, p. 2.

525 "Grupo SOMOS: uma experiência”. Lampião da Esquina, n. 11, maio de 1979, p. 2. James N. Green, um dos fundadores, também relatou a semiclandestinidade compulsória vivida ainda no grupo que antecedeu o Somos, confirmando as dificuldades postas por uma conjuntura ainda indefinida no que se referia à liberalização controlada em curso: "Ainda que o Brasil estivesse experimentando o início de uma liberalização política, ninguém estava completamente confiante de que não ocorreria mais repressão em algum momento. Alguns temiam que suas famílias descobrissem que eles estavam participando desses encontros, ou que fossem perder seus empregos caso o grupo se tornasse muito conhecido. Assim, abrimos o grupo de uma forma semiclandestina" ("Abaixo a repressão, mais amor e mais tesão": uma memória sobre a ditadura e o movimento de gays e lésbicas de São Paulo na época da abertura. Acervo, [S.1.], v. 27, n. 1, abr. 2014, p. 67-68).
} 
aos olhos da sociedade e subversivo aos do regime, havia mais um empecilho: a precariedade de recursos econômicos e culturais entre os homossexuais. Ainda que algumas lideranças que figuravam à frente da iniciativa tivessem contado com mais oportunidades, inclusive uma decisiva experiência internacional de educação e de ativismo em contato com a efervescência da contracultura ${ }^{526}$, a base do movimento era formada essencialmente por trabalhadores com empregos precários que precisavam ganhar a vida e com pouco tempo disponível para dedicar ao grupo. Green destaca estes obstáculos para uma profissionalização da militância, já que

os membros não possuíam muitos recursos financeiros extras para a sua vida social particular, e muito menos para sustentar a organização com facilidade. Além disso, também não existia, naquele momento, nenhuma possibilidade de apoio do estado ou de uma agência nacional ou internacional que pudesse ajudar a viabilidade financeira do grupo. ${ }^{527}$

Foi então, sob essas condições, e a partir dessas limitações, que o incipiente movimento homossexual brasileiro lançou suas bases. Mas não bastava apenas contornar estes obstáculos mais urgentes, era preciso também inaugurar uma forma de fazer política que estivesse à altura da novidade da iniciativa.

\section{"Uma maneira especificamente nossa de fazer política": a criação do Somos}

Somada aos entraves objetivamente antepostos a um projeto audacioso como este, a ousadia dos participantes tornou tudo ainda mais difícil de ser realizado em condições tão adversas. Não se tratava apenas de reproduzir as fórmulas organizativas consagradas no campo das esquerdas, muitas vezes classificadas de "autoritárias e patriarcais". Eles queriam encontrar "uma maneira especificamente nossa [dos homossexuais] de fazer política" e não apenas com um programa específico que contemplasse este segmento. Isto demandava uma "revisão dos métodos políticos geralmente machistas" que frequentavam os ambientes do movimento estudantil, já conhecidos por vários deles. Assim, pretendiam, com a própria

\footnotetext{
${ }^{526}$ Trevisan, por exemplo, viveu de 1973 a 1975 em Berkeley, Califórnia (EUA). Green, nascido nos EUA, já havia atuado junto ao movimento gay na Filadélfia e depois em São Francisco. Edward MacRae tinha travado contato com o movimento inglês, quando estudara em Londres.

527 Sobre a dificuldade em atrair pessoas oriundas das classes media e alta que poderiam auxiliar no financiamento do grupo, ele destaca três fatores: "o medo de participar em atividades políticas naquele clima autoritário do regime militar; o consumismo dentro do "gueto", que aliciava muitos gays e lésbicas e oferecia possibilidades de aventuras sexuais, parceiros, amizades e redes de apoio; e uma internalização dos conceitos sociais negativos sobre a homossexualidade" (GREEN, James Naylor. O grupo Somos, a esquerda e a resistência à ditadura. In: GREEN, James N.; QUINALHA, Renan (Orgs.). Ditadura e homossexualidades: repressão, resistência e a busca da verdade. São Carlos: EDUFSCAR, 2014, p. 187).
} 
organização, contestar o do poder por meio de uma práxis que se fundaria em um mix de "prazer e ternura" 528 .

Do ponto de vista da identidade homossexual, o grupo embarcava na opção pelo chamado "modelo igualitário-moderno" das relações sexuais e afetivas, sem as hierarquias tradicionalmente associadas à masculinidade e feminilidade ${ }^{529}$. Além disso, essa "primeira onda" 530 do movimento homossexual foi marcada por uma perspectiva fortemente antiautoritária, até pelo contexto ditatorial. Assim, repelia-se qualquer associação mais próxima com o Estado ou agrupamentos políticos, reforçando um discurso autonomista e cético em relação a quaisquer alianças que pudessem comprometer o foco do movimento.

Para que se tenha uma ideia do grau de desconfiança em relação a qualquer narrativa que fosse imposta desde fora dos espaços do grupo, até mesmo um dos membros, Edward MacRae, na condição dupla de militante e pesquisador, teve dificuldades para realizar o trabalho de campo de sua etnografia de doutorado sobre o Somos. Depois de violentas discussões e exigências postas à pesquisa ${ }^{531}$, a tese pôde ser realizada e se tornou um livro que apresenta uma das mais detalhadas descrições do funcionamento interno e das questões enfrentadas pelo Somos.

Para dar concretude a estes princípios norteadores da filosofia libertária do grupo, logo nos primeiros meses de atividade, o Somos passou a se dividir, do ponto de vista prático, em seis ou mais subgrupos, com funções distintas, de acordo com o interesse dos membros e conforme as circunstâncias que se apresentavam interna ou externamente.

Os principais e mais duradouros foram os subgrupos de trabalho seguintes: "identificação", orientado para o crescimento da consciência individual e reforço da identidade a partir da troca de vivências; "estudos", proporcionando a formação teórica e cultural sobre sexualidade com base em discussão de livros, filmes e peças; "atuação externa" com o objetivo de se apresentar mais publicamente e na relação com outras pessoas e

\footnotetext{
528 “Grupo SOMOS: uma experiência”. Lampião da Esquina, n. 11, maio de 1979, p. 2.

${ }^{529}$ FRY, Peter. Da hierarquia à igualdade: a construção histórica da homossexualidade no Brasil. In: Fry, Peter. (org.) Para inglês ver Identidade Política na Cultura Brasileira. Rio de Janeiro, Zahar, 1982,

530 A expressão é utilizada por Regina Facchini (Sopa de letrinhas? movimento homossexual e produção de identidades coletivas nos anos 1990. Rio de Janeiro: Garamond, 2005, p. 93).

531 Trevisan rememora esse fato como um elogio à postura do grupo na época: "Lembro de uma violenta discussão que eclodiu quando um dos membros do grupo, estudante de antropologia, começou a tomar notas exaustivas durante as reuniões, porque decidira fazer sua tese universitária sobre o Somos -- sem pedir licença aos demais participantes. Ele só pede continuar seu trabalho ali dentro depois de muitos debates, que culminaram numa série de exigências -- sobretudo a de que ele próprio, enquanto homossexual, seria apresentado como sujeito/objeto de sua pesquisa". TREVISAN, João Silvério. Devassos no paraíso: a homossexualidade no Brasil, da colônia à atualidade. São Paulo: Record, 2007, p. 348. Para outra versão deste conflito, veja GREEN, James. "Abaixo a repressão, mais amor e mais tesão": uma memória sobre a ditadura e o movimento de gays e lésbicas de São Paulo na época da abertura. Acervo, [S.1.], v. 27, n. 1, abr. 2014.
} 
entidades, sendo o setor mais nitidamente "ativista" para fora do grupo; "serviços", voltado para a execução de tarefas mais concretas; "atividades artísticas", dedicado a planejar intervenções culturais; e "expressão não-verbal", como o subgrupo que poderia trabalhar com outras formas de expressão, como o próprio corpo. Mais tarde surgiu, em virtude da autoorganização das mulheres, no ano de 1979, o grupo de "atuação lésbico-feminista" e também uma "Comissão de Defesa do Jornal Lampião" para manifestar a solidariedade contra a perseguição policial ao periódico.

No início, os grupos de identificação eram os mais numerosos e que mais congregavam pessoas, servindo como uma porta de entrada a novos interessados e, consequentemente, relegando os demais fóruns ao esvaziamento e a uma atuação apenas esporádica. Nesses subgrupos de identificação, havia uma ampla liberdade de trocas de experiências individuais e relatos pessoais, com o objetivo central de estimular a autoaceitação e permitir o "trabalho de autoidentidade" dos homossexuais por meio da quebra dos preconceitos e estigmas já internalizados. Os novos membros eram recebidos por um "grupo de recepção" e depois encaminhados para o processo de "identificação".

Conforme ressalta Green, esta porta de entrada do grupo mostrava-se especialmente importante para os homossexuais que não provinham de meios intelectualizados ou que não fossem dotados de melhores condições econômicas, pois funcionava como um espaço de trocas fundamental para ampliação dos horizontes e novas amizades e afetos. Afirma ele que "para a grande maioria dos membros do Somos, a sociabilidade alternativa que o grupo oferecia era muito importante, especialmente para as pessoas que não tinham recursos para acompanhar a vida noturna de gays e lésbicas, que efervescia na época". 532

$\mathrm{Na}$ mesma linha, MacRae apontou que a intensa convivência acabou se convertendo em um status de "casamento com o grupo", expressão usada com frequência que "refletia um sentimento de amizade e união entre os integrantes" e "tinha também um sentimento mais literal [de modo que] algumas pessoas até passaram a restringir sua atividade sexual aos integrantes do Somos" $" 533$.

Contudo, com as apresentações públicas cada vez mais regulares e as crescentes demandas postas com a consolidação da identidade do Somos, os demais subgrupos foram sendo, gradativamente, ocupados por mais membros, tornando a atuação dos mesmos mais

\footnotetext{
532 GREEN, James Naylor. O grupo Somos, a esquerda e a resistência à ditadura. In: GREEN, James N.; QUINALHA, Renan (Orgs.). Ditadura e homossexualidades: repressão, resistência e a busca da verdade. São Carlos: EDUFSCAR, 2014, p. 189.

533 MACRAE, Edward. A construção da igualdade: identidade sexual e política no Brasil da "abertura". Campinas: Editora da Unicamp, 1990, p. 122-123.
} 
dinâmica e diversificada.

O formato institucional encontrado para evitar a tentação de engessamento e acomodar o crescente número de pessoas interessadas foi fazer com que cada subgrupo se reunisse isoladamente e desenvolvesse regras próprias definidas por seus membros, marcando uma reunião mensal com todos os grupos em uma grande plenária para discutir as questões mais gerais e construir as deliberações do modo mais coletivo e horizontal possível. A regra geral era de tomada de decisões apenas por consenso para, supostamente, preservar a unidade do grupo, coibir a cristalização de lideranças e facções internas e fortalecer os princípios de autogestão. Na prática, contudo, era um tanto mais difícil fazer estes mecanismos funcionarem no dia-a-dia do grupo.

\section{"Esse é o principal problema que tenho sentido: o medo de uma organização"}

A preocupação em fundar o "novo" e não incorrer em burocratizações excessivas, que eram atribuídas aos agrupamentos das esquerdas opositoras à ditadura, foi-se tornando quase uma obsessão, materializada no discurso muitas vezes vago de defesa de uma "autonomia" abstrata e de um individualismo quase intocável pelas estruturas coletivas do grupo.

A inquietude gerada em relação a outros modos de organização e filiação a outros grupos, sobretudo a partidos políticos, se tornaria uma constante não apenas do Somos paulista, mas também de diversos outros grupos, como o seu par carioca, conforme revelado em entrevista de um de seus membros: "todos os membros do movimento nacional têm, obviamente, autonomia para uma militância política, sindical, etc., mas os grupos devem manter-se autônomos em relação aos partidos políticos" ${ }^{534}$.

Pode-se notar claramente que certas decisões sobre a dinâmica do grupo, suas instâncias e o processo decisório foram escolhas políticas conscientes. Outras, contudo, foram mais um produto das condições objetivamente vividas e enfrentadas naquele contexto.

Por exemplo, os encontros dos grupos eram feitos nas casas dos integrantes em sistema de rodízio, ainda que poucos tivessem apartamentos capazes de comportar grandes reuniões, sobretudo com os riscos representados com a presença ostensiva de homossexuais aos olhos dos vizinhos e mesmo da polícia. A falta de uma sede fixa era bastante sentida e sempre foi um desafio persistente, pois nunca havia condições econômicas suficientes para isso e tampouco fiadores. Alguns, como Trevisan, alegam que um espaço próprio poderia ter

\footnotetext{
${ }^{534}$ Radice, n. 14, de outubro de 1980, p. 28.
} 
burocratizado e centralizado demais a estrutura horizontalizada dos coletivos, além de exigir uma fonte de rendas regular para custeio e manutenção.

Contudo, as reuniões itinerantes também expressavam uma estratégia necessária à época para evitar a perseguição das forças policiais, mantendo um regime de certa clandestinidade:

\begin{abstract}
As reuniões se revezavam nas casas dos diversos participantes, já que não havia local parecido com sede - e nem se queria para evitar centralismos, burocratizações e também manter um clima de semiclandestinidade, ainda necessária naquele período da vida brasileira, inclusive porque tínhamos indícios de que a polícia acompanhava nosso trabalho. ${ }^{535}$
\end{abstract}

$\mathrm{Na}$ entrevista mais longa com o grupo, da qual se tem registro, que foi publicada nas páginas do Lampião em setembro de 1979, um membro do Somos, identificado como "Daniel", destacou o medo como uma das principais causas da desmobilização dos homossexuais no país. Esse receio era tanto de virar uma organização da esquerda tradicional, quanto de ser confundido com uma delas aos olhos da repressão. O medo era ainda mais acentuado considerando que poucas pessoas haviam tido alguma experiência prévia de militância com as esquerdas.

Com efeito, diante dessa obsessão pela autonomia e pela renovação, em um momento em que qualquer ação política transformadora poderia ser suspeita e perseguida, era compreensível o efeito paralisante que tal apreensão provocava: "Existe o medo. Medo é fogo. Esse é o principal problema que tenho sentido: o medo de uma organização. Que seja confundida com outras organizações, sei lá - sindicais, convergência socialista, mil coisas assim. Medo de que a política possa entrar. Isso também influi muito". ${ }^{536}$

Somente nos últimos meses de 1978 é que os participantes foram adquirindo um pouco mais de confiança uns nos outros e na abertura em curso, de modo a projetarem o grupo mais para fora do que para as atividades internas, que antes absorviam a maior parte da energia. Uma primeira reunião aberta, então, foi finalmente realizada no Teatro da Praça, para o qual eram esperadas mais de 50 pessoas, por ter sido bastante divulgada.

No entanto, apesar dos diversos convites mimeografados que foram distribuídos com uma convocatória ampla, o encontro contou apenas com umas 20 pessoas, e discussões aparentemente já superadas foram recolocadas pelos homossexuais que se apresentavam para

\footnotetext{
${ }^{535}$ TREVISAN, João Silvério. Devassos no paraíso: a homossexualidade no Brasil, da colônia à atualidade. São Paulo: Record, 2007, 345

536 “O pessoal do Somos (um debate). Lampião da Esquina, n. 16, setembro de 1979, p. 7.
} 
ingressar no grupo ${ }^{537}$. Este problema vinha sendo percebido por cada vez mais gente, que reclamava de certa paralisia no grupo por conta das pessoas novas que chegavam a cada temporada e que não tinham acesso às discussões já feitas.

A ausência de mecanismos internos para preservar o acúmulo das reflexões e deliberações feitas coletivamente era fruto da repulsa à institucionalização do grupo e de algumas regras elementares de seu funcionamento. Como a organização era tida, de partida, como sinônimo de burocratização e esta, por sua vez, parecia um vício incurável das esquerdas, já era possível antever uma difícil relação do grupo com outros setores oposicionistas da ditadura.

\section{“Estão querendo convergir. Para onde?": a homofobia nas esquerdas}

O trauma em relação à homofobia e ao machismo dentro das esquerdas, assim como em relação à reprodução de métodos autoritários por alguns desses agrupamentos, tinha razão de ser.

A influência do estalinismo espraiou, mundo afora, sua linha moralista oficial, por meio dos partidos vinculados à Terceira Internacional que hegemonizavam o campo progressista em boa parcela do Ocidente. O mesmo ocorria em relação às variações materializadas nos regimes comunistas chinês e cubano, que ganhavam cada vez mais espaço nos trópicos.

Essa "contribuição" do movimento comunista internacional para propagar a homofobia aportou no Brasil na forma de uma heterodoxa combinação com a ideologia católica secular conservadora quanto aos costumes sexuais e com um paradigma bem acentuado do então já velho machismo latino-americano. Além disso, nos agrupamentos revolucionários brasileiros, estava ainda presente o que Green designou, em um dos melhores textos em torno da relação das esquerdas com a sexualidade, como um "ethos de masculinidade revolucionária". 538

\footnotetext{
537 “Grupo SOMOS: uma experiência”. Lampião da Esquina, n. 11, maio de 1979, p. 2.

538 GREEN, James. Quem é o macho que quer me matar?: Homossexualidade masculina, masculinidade revolucionária e luta armada brasileira dos anos 1960 e 1970. Revista Anistia Política e Justiça de Transição, N. 8. Brasília : Ministério da Justiça , 2012, p. 86. Neste artigo, Green se propõe a investigar "as tensões entre os desejos sexuais não normativos de membros da esquerda revolucionária brasileira e as organizações das quais eles pertenciam". Com uma visão acurada e matizada, ele observa que se trata de "uma história complexa, na qual alguns membros de grupos revolucionários receberam o apoio de seus companheiros de luta quando discutiram discretamente seus desejos sexuais, enquanto outros meticulosamente esconderam suas orientações sexuais, por medo do ostracismo" (p. 61).
} 
Todos esses fatores conjugados colaboraram para decantar, mesmo nos setores de oposição à ditadura dos quais se poderia esperar um compromisso com a democracia e os direitos das minorias, uma representação das homossexualidades como "desvio pequenoburguês", manifestação da "decadência burguesa", comportamento sexual contrário à "moral revolucionária" ou ainda degeneração típica do "desbunde". 539

Herbert Daniel, guerrilheiro da luta armada e homossexual, em um dos mais instigantes livros de memórias sobre a experiência da resistência à ditadura, formulou, de modo bastante ácido, uma crítica a seus companheiros de militância. "O sexo não era uma preocupação política, achávamos. Militantes, tínhamos outros problemas a abordar”, afirmou ele sobre a compreensão do tema à época. Ainda com mais ironia, escreveu sobre a ilusão que a esquerda criava com sua idealização da classe operária: “onde vocês já ouviram falar de um operário bicha? Naquelas fantasias que inventamos, a Classe Operária não sofria 'desvios' sexuais. Porque não tinha sexualidade nenhuma. Era uma classe higiênica. Historicamente saudável”. E arrematava assim, falando sobre sua vivencia pessoal:

\begin{abstract}
meus problemas pequeno-burgueses me preocupavam, como tantos empecilhos que eu tivesse para poder me tornar um bom revolucionário. Entre eles a sexualidade, mais explicitamente, a homossexualidade. Desde que comecei a militar, senti que tinha uma opção a fazer: ou eu levaria uma vida sexual regular - e transtornada, secreta e absurda, isto é, puramente "pequeno-burguesa", para não dizer "reacionária", ou então faria a revolução. Eu queria fazer a revolução. Conclusão: deveria "esquecer a minha sexualidade". ${ }^{540}$
\end{abstract}

Curioso é notar como a paranoia anticomunista da ditadura desconsiderava totalmente as cristalinas posições do movimento comunista internacional no sentido de repelir e criticar as sexualidades dissidentes. Os órgãos de informação estavam tão sugestionados a analisar tudo na chave do anticomunismo, no contexto da Guerra Fria e sob influência da Doutrina de Segurança Nacional, que chegaram ao extremo de enquadrar a homossexualidade nos quadros de uma "subversão sexual" planejada pelos comunistas para destruir a família e os valores morais da sociedade brasileira com esses elementos "alienígenas". 541

\footnotetext{
539 "Desbunde" era o termo utilizado pela esquerda tradicional para designar os indivíduos e grupos que abandonaram uma perspectiva de ação política coletiva idealizando uma desconexão do mundo por uma via individualista e hedonista, geralmente associado ao tripé das drogas, do sexo e das artes.

${ }^{540}$ DANIEL, Herbert. Passagem para o próximo sonho: Um possível romance autobiográfico. Rio de Janeiro: Codecri, 1982, p. 96-97.

541 Cowan explora bem essa articulação do anticomunismo com o moralismo das forças conservadoras empoderadas com o golpe de 1964. Para ele, "the theory of sexualized subversion had, by the late 1960s, made inroads among the policemen and spies charged with securing the ideological and increasingly moral/cultural frontiers of dictatorial Brazil". E acrescenta que "Though paranoia about subversion led such warriors of
} 
Essas ideias foram absorvidas e reproduzidas por grupos influentes na resistência à ditadura, em suas diferentes fases, como o Partido Comunista Brasileiro (PCB), o Partido Comunista do Brasil (PCdoB) e os grupos guerrilheiros maoístas ou castristas. Neste cenário, era bastante compreensível que os primeiros passos do movimento homossexual se dessem com uma fundada desconfiança, e até certa repulsa por alguns coletivos homofóbicos, mesmo que progressistas do ponto de vista de seu discurso de justiça social e igualdade material.

Mas nem todos os grupos se comportaram da mesma forma e houve exceções dignas de nota. Uma delas era o caso da Convergência Socialista. A CS foi uma organização trotskista bastante atuante no conjunto das esquerdas brasileiras durante o período final da ditadura, fundada em 1978 a partir de um chamado feito pela Liga Operária, ela se engajou na construção do Partido dos Trabalhadores (PT), nele permanecendo até 1992, quando foram expulsos e vieram a se transformar no Partido Socialista dos Trabalhadores Unificados ${ }^{542}$.

Tratou-se da primeira organização da esquerda socialista brasileira a abrir espaço para a auto-organização dos homossexuais. Pouco depois de sua fundação, foi organizada, pela revista Versus, a Semana do Movimento de Convergência Socialista, de 24 a 30 de abril de 1978, com uma sessão específica voltada para a discussão da imprensa alternativa. Alguns homossexuais estiveram nos últimos dias de debates, reclamando da ausência de um representante do Lampião na mesa, já que o jornal havia sido lançado no mês anterior, e da dificuldade em tematizar abertamente as questões das homossexualidades.

Pouco tempo depois, Trevisan publicou um artigo bastante contundente no Lampião, intitulado "Estão querendo convergir. Para onde?" com uma crítica ao modo como foi pautada a discussão das "minorias" neste encontro aberto, no qual ele esteve presente. Segundo o jornalista,

a palavra homossexual foi pronunciada uma única vez: o presidente apenas sussurrou-a - quase engasgou, como se dissesse um palavrão. Acho que havia um espinho encravado em suas gargantas. Já nas reuniões preparatórias, a inclusão de um homossexual na mesa, ao lado de representantes das outras "minorias", provocou protestos, um determinado grupo, inclusive, ameaçou retirar-se caso isso se efetivasse. Resultado: os

national security to define subversion and subversives in the most wide-ranging of terms, there emerged a distinct tendency to interpret perceived moral and cultural deviance as 'cryptocommunism'." (COWAN, Benjamin. Securing Sex: Morality and Repression in the Making of Cold War Brazil. University of North Carolina Press, 2016, pp. 340-341).

${ }^{542}$ FARIA, Marcos Moutta de. Partido Socialista Ou Partido Dos Trabalhadores? Contribuição à História Do Trotskismo No Brasil. A Experiência Do Convergência Socialista. Diálogos: Revista do Departamento de História e do Programa de Pós-Graduação em História [on line], 2005. Disponível em: $<$ http://www.redalyc.org/articulo.oa?id=305526442015>. Acesso em: 26 de outubro de 2016. 
homossexuais acabaram não presentes à mesa. ${ }^{543}$

A moção bem curta e objetiva sobre o tema, apresentada por uma "bicha atrevida" que pediu a palavra, argumentava que no momento em que se discutiam as lutas democráticas do país, não era possível esquecer as lutas das minorias discriminadas. E, ao final, conclamava a Convergência Socialista a acolher essa demanda:

Os homossexuais, vítimas de um sistema discriminatório, reacionário e intolerante esperam da Convergência Socialista a acolhida de sua luta. Confiamos em que o socialismo que pretendemos seja um sistema equitativo, aberto e democrático que tenha o ser humano como peça fundamental independente de sua sexualidade, traga em seus fundamentos o necessário elemento democrático que permita a todos as mesmas possibilidades. ${ }^{544}$

Antes mesmo da fundação do primeiro grupo organizado, esse encontro começou a dar forma a diferenças que marcariam indelevelmente o movimento homossexual brasileiro, cindido entre um setor aliado aos demais movimentos que atuavam contra a ditadura e um outro grupo de pessoas que propugnavam uma concepção mais autonomista e anarquista da militância gay a fim de evitar que fossem instrumentalizados em nome de uma "luta maior".

\section{"A tal da felicidade também deve ser ampla e irrestrita": a Semana das Minorias da USP}

Foi mesmo com o debate na Semana das Minorias da USP, ocorrido em 8 de fevereiro, que o Somos se tornou mais conhecido e passou a receber mais pretendentes. Também novos grupos logo se formariam influenciados pelas discussões realizadas naquele encontro. Organizado pelo coletivo "Vento Novo", vinculado ao Centro Acadêmico do curso de Ciências Sociais, com o objetivo de debater os "novos movimentos sociais", o ciclo sobre as "minorias" durou toda uma semana e envolveu diferentes segmentos "identitários" que se articulavam no momento. Era a primeira exposição pública dos ativistas homossexuais e, apesar do receio pela situação inusitada de discussão aberta da sexualidade, acabou significando um tremendo avanço para o movimento.

O encontro específico que foi dedicado ao tema das homossexualidades durou mais de 3 horas e contou com uns 300 participantes, que lotaram a sala reservada para a atividade. $\mathrm{Na}$

543 “Estão querendo convergir. Para onde?”. Lampião da Esquina, n. 2, junho de 1978, p. 9

544 “Estão querendo convergir. Para onde?”. Lampião da Esquina, n. 2, junho de 1978, p. 9 
mesa, estavam integrantes do Conselho do Lampião (Trevisan e Darcy Penteado), três representantes do grupo SOMOS (Alfredo, Emanoel e Glauco Mattoso), o poeta Roberto Piva) e o pesquisador do CEBRAP, Cândido Procópio. O tema da semana era "O Caráter dos Movimentos de Emancipação", na qual, em cada uma das sessões, "os vários grupos discriminados apresentaram ali suas ansiedades, desejos, reivindicações, protestos". 545

Já se tinha consciência, mesmo no calor dos acontecimentos, que se tratava de um momento histórico: "afinal, não se tem lembrança de um debate tão livre e polêmico sobre um assunto que as autoridades policiais e grande parte da sociedade brasileira ainda consideram tabu"546. Trevisan, na cobertura jornalística que fez do encontro, concordou com essa avaliação, sustentando que "pela primeira vez no Brasil as lésbicas e as bichas tomaram seu espaço e vomitaram coisas há muito engasgadas" e complementou em um tom aparentemente conciliatório com as esquerdas:

acredito que nessa semana, e sobretudo em 8 de fevereiro, setores da esquerda tradicional podem ter sofrido um avanço considerável na compreensão da realidade brasileira. Ao mesmo tempo, os grupos discriminados avançaram politicamente: apossaram-se do seu espaço e provocaram uma rediscussão do fechado conceito de revolução, abrindo dúvidas sobre a condução desse processo. ${ }^{547}$

O centro do debate logo se deslocou da mesa expositora para a plateia, com intensa polarização entre os espectadores. O tema da homossexualidade revelou-se muito mais conhecido e difundido do que parecia à primeira vista, surpreendendo os ativistas homossexuais a participação tão intensa dos presentes. Um clima de tensão logo se instaurou no ar entre os setores mais tradicionais da esquerda e os homossexuais quando falaram sobre a maneira mais adequada de conjugar a "luta maior" com as lutas por emancipação dos grupos específicos.

Enquanto esse campo ainda hegemônico na esquerda acusava os movimentos identitários de "divisionismo" e "separatismo" diante da prioridade que seria o combate à ditadura, um rapaz tomou a palavra no plenário e polemizou em tom bastante duro:

Vocês querem saber se o movimento guei é de esquerda, de direita ou de centro, não é? Pois fiquem sabendo que os homossexuais estão conscientes de que para a direita constituem um atentado à moral e à estabilidade da

\footnotetext{
${ }^{545}$ TREVISAN, J. S. “Quem tem medo das “minorias'?” Lampião da Esquina, n. 10, março de 1979, p. 10.

${ }^{546}$ DANTAS, Eduardo. "Negros, mulheres, homossexuais e índios nos debates da USP: felicidade também deve ser ampla e irrestrita". Lampião da Esquina, n. 10, março de 1979, p. 9.

${ }^{547}$ TREVISAN, J. S. “Quem tem medo das 'minorias'?”. Lampião da Esquina, n. 10, março de 1979, p. 10.
} 
família, base da sociedade. Para os esquerdistas, somos um resultado da decadência burguesa. Na verdade, o objetivo do movimento guei é a busca da felicidade e por isso é claro que nós vamos lutar pelas liberdades democráticas. Mas isso sem um engajamento específico, um alinhamento automático com grupos da chamada vanguarda.

O mesmo rapaz foi responsável, pouco tempo depois, por uma das afirmações que melhor definiriam o espírito provocador desse encontro: "O problema de qualquer revolução é saber quem vai lavar a louça depois". 548

Segundo Trevisan, coerente com seu posicionamento crítico, "um dos maiores equívocos da plateia 'esquerdista' foi exatamente recusar o status de luta política tanto ao feminismo quanto aos demais grupos discriminados - falava-se em simples 'discussão existencial', num evidente tom de descaso" ${ }^{\$ 49}$, antecipando já críticas que ele levaria cada vez mais a sério contra grupos mais tradicionais da esquerda, inclusive dentro do Somos ${ }^{550}$. Segundo Green, que relatou ter tentado argumentar que "não existia contradição entre a luta contra a homofobia e opressão e a luta contra a ditadura" em meio àquela intensa divisão, "naquela noite, a discussão ficou polarizada numa caricatura do que seria o debate que, posteriormente, racharia o movimento" 551 . Essa dificuldade de diálogo, em suas palavras, parecia ser mesmo uma limitação de ordem quase cognitiva que impedia a comunicação parte a parte, pois "nem os ativistas gays e lésbicas, nem os defensores das esquerdas no debate tinham uma linguagem ou uma perspectiva mais universal para conversar sobre o tema" ${ }^{" 52}$.

Apesar desses duros embates, o grupo Somos conseguiu se destacar em sua estreia pública como uma alternativa para aquele número expressivo de homossexuais interessados em participar de alguma atividade entre seus pares. Foi uma primeira grande aparição, que rendeu bastante visibilidade ao grupo e, talvez até pelas calorosas polêmicas, convenceu uma série de pessoas a se engajar no ativismo homossexual.

Conforme registrado na matéria do Lampião sobre o encontro, em suma,

\footnotetext{
${ }^{548}$ DANTAS, Eduardo. "Negros, mulheres, homossexuais e índios nos debates da USP: felicidade também deve ser ampla e irrestrita". Lampião da Esquina, n. 10, março de 1979, p. 9.

549 TREVISAN, J. S. “Quem tem medo das “minorias'?”. Lampião da Esquina, n. 10, março de 1979, p. 10.

${ }^{550}$ Trevisan afirmaria, mais tarde, que os homossexuais lutaram em duas frentes para oferecer uma "contribuição particular para a transformação das estruturas" e exigir um "espaço próprio, para poder florescer, mesmo que isso nos tenha sido negado, tanto pelo governo da ditadura quanto por sua oposição institucionalizada" (TREVISAN, João Silvério. Devassos no paraíso: a homossexualidade no Brasil, da colônia à atualidade. São Paulo: Record, 2007, p. 348).

551 "Abaixo a repressão, mais amor e mais tesão": uma memória sobre a ditadura e o movimento de gays e lésbicas de São Paulo na época da abertura. Acervo, [S.1.], v. 27, n. 1, abr. 2014, p. 68.

552 GREEN, James Naylor. O grupo Somos, a esquerda e a resistência à ditadura. In: GREEN, James N.; QUINALHA, Renan (Orgs.). Ditadura e homossexualidades: repressão, resistência e a busca da verdade. São Carlos: EDUFSCAR, 2014, p. 191.
} 
apesar das contradições levantadas durante o debate - houve até gente dizendo que as bichas têm preconceito contra os esquerdistas, que também são uma maioria discriminada (sic) - a conclusão geral foi de que a marcha pela liberdade - social, racial, sexual - é uma só. Cada grupo minoritário deverá unir-se, organizar-se com seus integrantes, lutando por uma democracia de fato no Brasil. Só assim se conseguirá a tal felicidade, ampla e irrestrita, para todos. ${ }^{553}$

Aproveitando a onda crescente de interesse no tema, no dia 13 de fevereiro, foi realizado um encontro no teatro Tuquinha, da PUC/SP, no qual "um grande número de pessoas se ligou ao grupo" ${ }^{\text {} 554}$. Foi aí que também começou a haver um número maior de mulheres se juntando ao grupo, chegando ao ponto em que, em fevereiro de 1979, "as


Fernandes, por sua vez, aponta que foi a partir de março que "algumas lésbicas, aproximadamente umas 15, entraram no grupo", sendo que, já em outubro do mesmo ano, essas mulheres "assumiram a luta feminista e se organizaram com um subgrupo específico, o LF [Lésbico-Feminista]"

Para ilustrar a dimensão alcançada pelo grupo após o encontro da USP, mais especificamente em setembro de 1979, o SOMOS contava já com

uns oito ou nove pequenos grupos de identificação, com 12 participantes em cada um. Todos têm uma grande liberdade em termos de temário, a partir dos problemas surgidos internamente. Eles se reúnem com uma frequência de três vezes ao mês. Na quarta semana há uma reunião geral de todo o grupo Somos, à qual vai todo o mundo. ${ }^{557}$

Nessa linha, um texto escrito pelo grupo para a mesma edição do Lampião, aponta a crescente procura dos homossexuais pela organização, que já "conta com mais ou menos cem pessoas". Mas a oscilação de membros, constantemente se aproximando e se afastando, era bastante significativa, pois "desse total, 30\% aproximadamente tem uma participação flutuante". Além disso, informava-se, no artigo, um fluxo impressionante de chegada de novos membros, sendo que "a cada mês ingressam no grupo uma média de 20 a 30 pessoas ${ } 558$. A maior parte dos participantes concentrava-se na faixa etária de 20 a 30 anos,

\footnotetext{
${ }^{553}$ DANTAS, Eduardo. "Negros, mulheres, homossexuais e índios nos debates da USP: felicidade também deve ser ampla e irrestrita”. Lampião da Esquina, n. 10, março de 1979, p. 9.

554 “Grupo SOMOS: uma experiência". Lampião da Esquina, n. 11, maio de 1979, p. 2.

555 “Grupo SOMOS: uma experiência”. Lampião da Esquina, n. 11, maio de 1979, p. 3.

${ }^{556}$ FERNANDES, Marisa. Lésbicas e a ditadura militar, p. 129.

557 “O pessoal do Somos (um debate)". Lampião da Esquina, n. 16, setembro de 1979, p. 8.

558 “'Organização e métodos:”. Lampião da Esquina, n. 16, setembro de 1979, p. 9.
} 
vedando-se a participação de menores de dezoito anos ${ }^{559}$. No que se refere ao perfil socioeconômico, o grupo era majoritariamente de branco e de classe média e baixa, com pessoas provenientes de uma ampla gama de profissões, tais como massagistas, funcionários públicos, médicos, jornalistas, professores, estudantes, etc.

\section{"Descobrimos que não estávamos sozinhos": novos grupos homossexuais}

No entanto, não foi só o grupo Somos que surgiu nessa conjuntura. Valendo-se do centro de irradiação de ideias e de articulação de iniciativas em que se transformou o Lampião da Esquina, o grupo precursor do movimento começou a incentivar a formação de novos coletivos por todo o país, alguns inclusive com o mesmo nome do precursor, como o Somos/RJ e o Somos de Sorocaba/SP. Na edição do jornal de março de 1980, uma seção intitulada "Escolha aqui sua turma" (que em poucos meses viraria "Escolha seu grupo") apresentava os diferentes grupos, conclamando os leitores a se engajarem e a participarem desse primeiro encontro dos homossexuais organizados coletivamente.

Aprofundando essa primeira onda do movimento, diversos outros grupos homossexuais foram organizados em distintas localidades no final da década de 1970 e começo de 1980. Na matéria "Eles ousam dizer seu nome”, publicada no Lampião, abriu-se a discussão com o registro de que

\footnotetext{
de repente começaram a surgir em São Paulo vários grupos de homossexuais discutindo seus problemas, encontrando-se para estudar ou se divertir e conquistando seu espaço. Só na aparência trata-se de algo inesperado; na verdade, essa eclosão indica que as condições estavam maduras para a manifestação de desejos, sentimentos e intenções antigos. ${ }^{560}$
}

Um coletivo que se manifestou nas páginas dessa mesma edição do Lampião foi o então recém-fundado Grupo de Atuação e Afirmação Gay (GAAG), atuante na região de Duque de Caxias, no estado do Rio de Janeiro. Segundo a carta, o grupo "nasceu com um objetivo básico: participar da luta para a conscientização guei" ${ }^{, 561}$, razão pela qual oferecia sua solidariedade ao Lampião diante do inquérito então em curso.

Esta mesma edição, por exemplo, incluia um texto de apresentação do grupo Libertos,

\footnotetext{
559 “'Organização e métodos:”. Lampião da Esquina, n. 16, setembro de 1979, p. 9.

560 “Eles ousam dizer seu nome”. Lampião da Esquina, n. 16, setembro de 1979, p. 7.

561 "O pessoal do GAAG (uma carta)". Lampião da Esquina, n. 16, setembro de 1979, p. 9.
} 
organizado na cidade de Guarulhos depois da participação do Seminário sobre as Minorias do Centro Acadêmico de Ciências Sociais da USP, em fevereiro de 1979. Segundo o grupo,

naquela noite, descobrimos que não estávamos sozinhos, e que as (os) nossas (os) companheiras (os) estavam somente preocupados com as coisas superficiais, mas queriam também ver seus direitos de cidadãos brasileiros, maiores, trabalhadores de todas as categorias, que votaram nas últimas eleições, que estudam, pagadores de impostos e etc., respeitados. ${ }^{562}$

Dois meses após este encontro, houve a primeira reunião, com 23 pessoas discutindo por mais de três horas a criação do novo grupo.

No dia 15 de setembro do mesmo ano, ocorreu a primeira reunião do grupo Somos do Rio de Janeiro, com 48 pessoas, sendo 8 delas mulheres. Independente do seu homônimo paulista, o Somos carioca começou contando com presença de gente da Baixada Fluminense, da Cidade de Deus, de Copacabana, de Vila Isabel, dentre outros lugares. Tal composição "garant[ia], de saída, a heterogeneidade do grupo (isso é ótimo), o que vai enriquecer as discussões internas, fortalecendo-o para a luta contra a repressão sexual" ${ }^{163}$. Na sugestiva matéria intitulada "Somos, e daí?", os membros João Carneiro, Dolores, Antonio Carlos e Aristides relatavam as diversas ações do Somos/RJ em seu primeiro ano, formando frente com o grupo AUÊ, realizando o "Dia da Liberação Homossexual" no dia 28 de junho de 1980, e relatando: “partimos para trabalhar também com o Movimento Negro Unificado, o Coletivo de Mulheres e o Grupo Negro André Rebouças"564.

A virada da década de 70 para 80 , assim, marca um crescimento vertiginoso no número de grupos homossexuais organizados por todo o país. Para que se tenha uma ideia da dimensão do crescimento da organização dos homossexuais nesse período de efervescência política do movimento, considerando-se o Lampião da Esquina na contagem, "surgiram 22 grupos de militância homossexual entre abril de 1978 e fevereiro de 1981"565. Conforme registro da revista Radice, do final de 1980, existia, nessa época, 21 coletivos de pessoas LGBT organizados nos diversos estados do país.

A profusão de novos grupos homossexuais, capilarizando a mobilização em diversos segmentos e localidades, atrairia cada vez mais gente e culminaria na necessidade de organização conjunta ou, pelo menos, de diálogo entre as diversas iniciativas para

\footnotetext{
562 “O pessoal do Libertos (um balanço)”. Lampião da Esquina, n. 16, setembro de 1979, p. 9.

563 "No Rio, pessoa cria mais um grupo homo". Lampião da Esquina, n. 17, outubro de 1979, p. 2.

${ }^{564}$ Radice, n. 14, de outubro de 1980, p. 27.

565 ZANATTA, Eliane. Documento e identidade: o movimento homossexual no Brasil na década de 80 . Cadernos AEL, n. 5/6, 1996/1997, p. 198.
} 
potencializar a atuação.

\section{"Ninguém pensava tão cedo assistir a uma confraternização dessas": o I Encontro de Grupos Homossexuais Organizados}

Nesse sentido, a primeira iniciativa de um encontro nacional de grupos homossexuais surgidos nos últimos dois anos da década de 1970 aconteceu no dia 16 de dezembro de 1979 na sede da Associação Brasileira de Imprensa, no Rio de Janeiro. A proposta de realizar um encontro dessa natureza surgiu em uma reunião de pauta do Lampião, na qual os jornalistas e alguns membro do Somos/RJ "decidiram que tinha chegado a hora de se fazer uma tentativa de organizar e expor o conjunto de pontos de vista e de ideias que começa[va] a tomar corpo como resultado do nascimento de grupos de ativistas homossexuais por todo o Brasil"566.

Concebida para ser secreta, a reunião contou com a presença de mais de 60 ativistas homossexuais procedentes de cidades como São Paulo, Guarulhos, Sorocaba, Brasília, Belo Horizonte, Caxias e Rio de Janeiro. Estavam lá representados agrupamentos como Somos/SP e seu Grupo Lésbico-Feminista, Somos/RJ, Somos/Sorocaba, Beijo Livre de Brasília, Eros/SP, Libertos/Guarulhos, GAAG/Caxias, Auê/RJ, além de ativistas independentes de outras localidades que ainda estavam formando coletivos. Durante mais de 7 horas, com pequeno intervalo para alimentação, o eixo central que orientou as preocupações dos presentes, conduzidos pela impecável presidência de Teka, do Somos/SP, foi a apresentação de um "programa bem definido de reivindicações e atividade política". Mais especificamente, conforme a proposta trazida por escrito pelo Libertos de Guarulhos/SP, três pontos básicos guiaram os debates: realização de um congresso estadual em São Paulo, criação de um grupo de mobilização nacional permanente e trabalhos práticos imediatos com trocas de experiências $^{567}$. Dos encaminhamentos concretos, o mais importante destes foi a decisão de realizar, de 4 a 6 de abril de 1980, um segundo encontro mais abrangente em São Paulo, lugar onde os grupos já existentes encontravam-se melhor estabelecidos.

Leila Míccolis, responsável pela cobertura jornalística da dimensão mais descontraída e festiva desse encontro surpreendente, registrou bem a sensação de alegria e entusiasmo que tomou conta dos presentes: “emoção, sim. Tinha pessoas emocionadíssimas, juro eu vi com esses olhos que a terra há de comer. Era tanta a alegria pela reunião, que até gente doente, com febre e tudo, estava presente para prestigiar. Ninguém pensava tão cedo assistir a uma

\footnotetext{
566 "No Rio, o encontro nacional do povo guei”. Lampião da Esquina, n. 20, janeiro de 1980, p. 7.

${ }^{567} \mathrm{Um}$ relato mais minucioso da reunião e das falas de cada um dos presentes pode ser encontrado em "Seis horas de tensão, alegria e diálogo: é a nossa política". Lampião da Esquina, n. 20, janeiro de 1980, p. 8.
} 
confraternização dessas". 568

No dia 3 de fevereiro de 1980, realizou-se a segunda reunião organizativa do $1^{\circ}$ Encontro Brasileiro de Homossexuais, no Diretório Acadêmico da Fundação Getúlio Vargas. Com exceção do Beijo Livre e do GAAG, todos os demais grupos estiveram presentes ou se fizeram representar, com um total de 79 participantes, demonstrando a vitalidade e a pluralidade da reunião. Dentre as diversas discussões e definições, as mais relevantes tinham a ver com a deliberação de repartir o Encontro em duas partes, uma fechada e outra aberta. $\mathrm{Na}$ primeira, participariam apenas os grupos já organizados ou em constituição; já na segunda, poderiam estar jornalistas, representantes de outros grupos de minorias, tais como "presidiários, loucos, menores, prostitutas, velhos e defensores da ecologia", além dos "movimentos de negros, mulheres e índios",569.

Finalmente, no dia 4 de abril de 1980, teve início o I Encontro Brasileiro de Homossexuais em São Paulo, com a presença de Somos/SP, Ação Lésbico-Feminista/SP, Eros/SP, Libertos/Guarulhos. Auê/RJ, Somos/RJ, Somos/Sorocaba e Beija Livre/Brasília, além de representantes das cidades de Belo Horizonte, Vitória, Goiânia e Curitiba.

Nos dias 4 e 5, ocorreu o I Encontro de Grupos Homossexuais Organizados (EGHO), nas dependências do Centro Acadêmico da Faculdade de Medicina da USP, o CAOC. Apenas participantes credenciados pelos grupos podiam ter acesso às discussões, realizadas ou no formato de plenária, ou em subgrupos temáticos, que abordaram temas como: "A questão lésbica. O machismo entre homossexuais e papeis sexuais"; "Michês. O Travesti e a repressão que recebe"; "homossexualismo no presídio", etc. ${ }^{570}$ A sessão sobre a questão lésbica foi o "debate que atraiu o maior número de participantes, setenta pessoas", sendo que as mulheres assumiram tarefas fundamentais para a realização do encontro, desde impressão dos documentos, organização dos grupos de trabalho e registro visual ${ }^{571}$.

$\mathrm{Na}$ conjuntura de uma abertura tímida e ainda ambígua diante das violências cotidianas perpetradas contra as pessoas LGBT, exercitar o direito de reunião e de livre organização naquele momento era uma iniciativa não apenas insólita, mas ousada. Conscientes disso, os participantes fizeram do encontro histórico um momento de celebração fraterna e não desperdiçaram a oportunidade ímpar de articulação viabilizada pelo primeiro contato pessoal travado entre muitos ali.

\footnotetext{
568 "Na hora da festa, conosco ninguém pode". Lampião da Esquina, n. 20, janeiro de 1980, p. 9.

569 “Ai, que São Paulo gostoso”. Lampião da Esquina, n. 22, março de 1980, p. 3.

${ }^{570}$ MICCOLIS, Leila. "Mulheres compram a briga". Lampião da Esquina, n. 24, maio de 1980, pp. 6 - 7.

571 FERNANDES, Marisa. Lésbicas e a ditadura militar: uma luta contra a opressão e por liberdade. In: GREEN, James N.; QUINALHA, Renan (Orgs.). Ditadura e homossexualidades: repressão, resistência e a busca da verdade. São Carlos: EDUFSCAR, 2014, p. 132.
} 
Muitos conflitos emergiram dessa convivência intensa entre mais de 200 pessoas nos primeiros dois dias e mais de 1000 presentes no terceiro dia, em que foi realizado um grande ato público de encerramento no Teatro Ruth Escobar. Mas também houve avanços importantes do ponto de vista da articulação de propostas de atuação para o movimento no próximo período.

Dentre as deliberações tomadas, destacam-se as iniciativas de despatologização das homossexualidades junto a órgãos como a OMS e INPS, a discussão sobre a conveniência ou não de formalizar juridicamente a existência dos grupos organizados, estabelecer uma comissão para incluir na legislação o direito à livre opção sexual, especialmente na Constituição, dentre outros.

Mas um encontro com tal dimensão e representatividade não passaria em branco aos olhos atentos da vigilância política, por meio de policiais que lá estiveram observando tudo para depois relatar aos superiores. O documento elaborado pela Divisão da Ordem Política do DOPS/SP e endereçado para o diretor dessa unidade, Dr. Sylvio Pereira Machado, em 6 de abril de 1980, foi feito por um agente infiltrado e à paisana que esteve presente no último dia da reunião, no Teatro Ruth Escobar. Seu nome não é revelado no documento, ele é identificado apenas como um número no campo em que consta: "relatório feito por 2563". Isso comprova a intenção de preservar a identidade do espião, o que é corroborado pelo que consta no campo "assunto" do documento: "Observação velada. I Encontro Brasileiro de Homossexualismo".

Abre o documento o trecho "cumprindo determinação de V. Sas., estive presente ao Teatro Ruth Escobar", o que mostra que a ordem de monitoramento partiu do comando do órgão repressivo. O relato informa ainda que o encontro contou com a "presença de aproximadamente 500 pessoas (travestis, lésbicas e homossexuais)", metade do que os organizadores do evento contabilizaram. Sobre a mesa do ato final, informa o observador que nela estavam 8 "elementos de vários Estados", além do Movimento Negro Unificado, o Centro da Mulher Brasileira, Grupo Lésbicas Brasileiras e Sra. Alice Soares, advogada do C. A. XI de Agôsto. Apesar dos equívocos no registro dos nomes dos grupos, o próprio relato da repressão atesta o caráter amplo do encontro e a proximidade entre os movimentos homossexual, feminista e negro.

Foram destacados nos discursos que a discriminação "atinge todos os aspectos da nossa vida: como trabalho, religião, política, escola e família", ressaltando-se que a "vida política brasileira" considera os homossexuais "como MINORIA, juntamente com as mulheres, negros, índios”. No que se referia às finalidades do encontro, o relato ressalta que 
estas consistiam em "analisar nossas questões" e "formar uma plataforma para que nos una de norte a sul", sendo que essa plataforma deveria formar o "nosso tríplice direito: o livre uso do nosso corpo, a livre expressão de nossa afetividade e o direito ao prazer" ${ }^{\text {} 572}$. Ao final, constava um alerta de que "estão sendo formados em várias cidades e Estados vários grupos", sendo citados AUÊ/RJ, Beijo Livre/Brasília, Eros/SP, GAAG/RJ, Libertos/Guarulhos, Somos/Rio de Janeiro.

Além do mais, o relatório indica que havia, de fato, uma política deliberada de vigilância e monitoramento, mais ou menos clandestina, dos passos que estavam sendo dados pelo ainda incipiente movimento homossexual ${ }^{573}$.

\section{Primeiras mobilizações: o diálogo com outros movimentos sociais}

A abertura lenta, gradual e segura, se não significou uma efetiva democratização da estrutura do Estado e do sistema político, certamente coincidiu e favoreceu a organização autônoma de grupos vulnerabilizados, tratados genérica e imprecisamente como "minorias". Essa coincidência histórica de grupos que se organizavam ou se rearticulavam depois de uma longa quarentena dos direitos civis e políticos, produziu trocas e articulações decisivas para a redemocratização.

A primeira campanha mais concreta de mobilização articulada pelo Somos foi em defesa do Lampião da Esquina, que vinha sendo alvo de um inquérito sob acusação de violar a Lei de Imprensa e a moral e os bons costumes ${ }^{574}$. A solidariedade foi bastante importante para manter a circulação do jornal em condições tão adversas.

Pode-se dizer, assim, que a ascensão do movimento homossexual, neste período, foi caracterizada por um diálogo intenso com outros grupos. As manifestações convocadas pelo Movimento Negro Unificado nas escadarias do Teatro Municipal trouxeram novas perspectivas para o combate ao racismo. Os encontros e debates realizados pelo movimento de mulheres feministas, em apoio a suas próprias publicações e organizações, foram um avanço fundamental na luta contra o machismo. E os homossexuais não poderiam se fechar

\footnotetext{
572 Pasta n. 870 do APESP.

${ }^{573}$ Para Green, "na época, houve menos preocupação sobre possíveis infiltrados, mas as pesquisas realizadas nos arquivos da repressão nos últimos anos revelam que o Estado acompanhava o movimento homossexual, mandava pessoas para assistir às atividades públicas e escrevia relatórios sobre as atividades dos primeiros militantes do movimento" (GREEN, James Naylor. O grupo Somos, a esquerda e a resistência à ditadura. In: GREEN, James N.; QUINALHA, Renan (Orgs.). Ditadura e homossexualidades: repressão, resistência e a busca da verdade. São Carlos: EDUFSCAR, 2014, p. 189).

574 Ver capítulo 5 deste trabalho.
} 
para esta realidade.

Em certo sentido, essa condição existencial compartilhada por estes grupos, que eram alvos privilegiados do preconceito social e da repressão estatal naquela altura da ditadura, acabou favorecendo mais cruzamentos e intersecções entre esses movimentos. Nessa linha, o Movimento Negro Unificado realizou um ato público no centro de São Paulo para o dia 20 de novembro de 1979, na frente das escadarias do Teatro Municipal. A participação do Somos foi aprovada em assembleia e cerca de 20 membros do grupo estiveram presentes ao ato para demonstrar a solidariedade com a luta contra o racismo, distribuindo panfletos e destacando a intersecção dessa agenda com os debates sobre sexualidade. A presença dos homossexuais foi marcada com uma faixa que foi pintada na sede da CS com os seguintes dizeres: "Contra a discriminação racial, SOMOS: Grupo de Afirmação Homossexual”. Nas palavras de Green sobre esse dia, tratou-se da "primeira vez que gays e lésbicas protestaram nas ruas do Brasil". 575

A presença do grupo Somos/SP no ato de 20 de novembro de 1979, convocado pelo Movimento Negro Unificado com concentração na Praça Ramos de Azevedo, que chegou a contar, no seu auge, com mais de 1000 pessoas, foi destacada pela Informação n. 369/A-2/IV $\mathrm{COMAR}^{576}$. Tanto a faixa quanto a fala do representante do Somos foram destacadas no relatório, que também chamou atenção para o fato de que o "movimento homossexual" e o "movimento negro" que haviam organizado o ato, sendo estes os únicos atores políticos especificamente citados.

No entanto, a despeito de esforços conjuntos para aproximar as lutas "identitárias", outras tantas vezes as diferenças entre movimentos que estavam em busca de sua singularidade e agendas próprias acabavam falando mais alto. Assim, apesar do discurso sempre presente de diálogo, não eram raras as vezes, em que este discurso não se fazia valer na prática. Exemplo disso foi a declaração de um dos membros do Somos/RJ, que afirmou, com uma boa dose de machismo, estar clara a necessidade de "ocupar espaços e abrir alianças" fato que explicava o motivo do Somos/RJ estar "transando com o Movimento Negro Unificado e com o Coletivo de Mulheres, que [era] uma parte do Movimento Feminista, que em sua maioria tem uma tremenda hostilidade contra [eles]", algo que, segundo ele, Freud explicava $^{577}$.

Outro episódio de embate bastante emblemático se passou no II Congresso da Mulher

\footnotetext{
${ }^{575}$ GREEN, James. "Abaixo a repressão, mais amor e mais tesão”: uma memória sobre a ditadura e o movimento de gays e lésbicas de São Paulo na época da abertura. Acervo, [S.1.], v. 27, n. 1, abr. 2014, p. 70.

576 BR_AN_BSB_VAZ_024A_0138

${ }^{577}$ Radice, $\overline{\text { n. }} 14$, de outubro de 1980 , p. 27.
} 
Paulista realizado na PUC/SP em março de 1980. Ali, as mulheres lésbicas foram hostilizadas, tendo seu painel destruído por mulheres heterossexuais que não aceitavam a homossexualidade dentro do feminismo. Isto para não falar na postura de mulheres de grupos machistas da esquerda que também atacaram as feministas. Para uma das lésbicas presentes, esta participação "não foi bem-aceita, já que pela primeira vez se colocava a questão da sexualidade e do prazer sexual da mulher como uma possibilidade e um direito" ${ }^{\text {} 578 .}$.

O ponto mais sensível dentre os homossexuais, contudo, foi mesmo a intensificação das mobilizações operárias no ano de 1978 que, além de ter atingido em cheio a ditadura, também atravessou o movimento de forma irreversível. As greves massivas de trabalhadores, sobretudo aqueles vinculados ao setor automobilístico, despontaram como os acontecimentos mais impactantes na vida política brasileira, tornando-se fatores decisivos no desenlace do processo de abertura em curso.

A energia irradiada pelo movimento sindical, mesmo sob pressão e intervenção das autoridades públicas, era tão expressiva que, na abertura do I Encontro Nacional de Grupos Homossexuais Organizados, foi proposta, logo de partida, uma moção de solidariedade à greve dos metalúrgicos. Tal moção foi aprovada por unanimidade, "refletindo o sentimento generalizado de simpatia pelos trabalhadores" no meio homossexual, ao menos naquele momento ${ }^{579}$. Em virtude de sua origem social e de percepção de classe, muitos dos ativistas homossexuais conheciam de perto a realidade difícil dos trabalhadores brasileiros, sobretudo em um dos momentos de maior tensionamento dos sindicatos com o regime.

No entanto, já no segundo dia do Encontro, a proposta mais ousada não declarava apenas o apoio, mas a efetiva participação dos homossexuais nas mobilizações que marcariam o feriado do $1^{\circ}$ de maio daquele ano, convocadas pelas entidades sindicais do ABC. Tal proposta foi derrotada em votação apertada por 54 a $53 \operatorname{votos}^{580}$. Em contrapartida, as lésbicas, em conjunto, defenderam a resolução do movimento feminista, durante o II Congresso de Mulheres Paulistas, no sentido de participar das ações de apoio ao movimento

\footnotetext{
${ }^{578}$ FERNANDES, Marisa. Lésbicas e a ditadura militar: uma luta contra a opressão e por liberdade. In: GREEN, James N.; QUINALHA, Renan (Orgs.). Ditadura e homossexualidades: repressão, resistência e a busca da verdade. São Carlos: EDUFSCAR, 2014, p. 129. Um relato mais detalhado desse choque e dos conflitos ali existentes entre a esquerda e as feministas pode ser encontrado em TREVISAN, J. S. "Congresso das Genis: esquerda joga bosta nas feministas. Lampião da Esquina, n. 23, abril de 1980, pp. 6-7.

${ }^{579}$ GREEN, James. "Abaixo a repressão, mais amor e mais tesão": uma memória sobre a ditadura e o movimento de gays e lésbicas de São Paulo na época da abertura. Acervo, [S.1.], v. 27, n. 1, abr. 2014, p. 71.

${ }_{580}$ Conforme registra o livro elaborado por membros homossexuais da CS, na abertura da plenária, foi lida uma moção de apoio aos metalúrgicos do $\mathrm{ABC}$, em plena greve, [que foi] muito aplaudida. A discussão da relação do movimento homossexual com outros setores oprimidos e explorados ocupou grande parte dos dois dias anteriores, e acabaria por tumultuar a plenária diversas vezes. Uma proposta de participação no $1^{\circ}$ de Maio foi levada à votação, perdendo por um voto. Foi um divisor de águas dentro do movimento homossexual. In: OKITA, Hiro. Homossexualismo: da opressão à libertação. São Paulo: Proposta Editorial, 1981, p. 53.
} 
dos trabalhadores em luta contra a ditadura ${ }^{581}$. Os homens presentes, por sua vez, dividiram-se de acordo com a cisão que já vinha se desenhando há tempos.

Diante da derrota da proposta, o setor mais vinculado à esquerda organizada, que já representava a maioria dentro do Somos, decidiu formar o "Comissão de Homossexuais Pró $1^{\circ}$ de Maio" para organizar uma passeata gay na concentração dos operários no estádio da Vila Euclides, em São Bernardo do Campo. Duas foram as faixas levadas por esses ativistas homossexuais para expressar solidariedade à situação de pressão em que se encontravam os trabalhadores metalúrgicos: "Contra a intervenção no ABC" e "Contra a discriminação dos/as trabalhadores/as homossexuais", ambas assinadas "SOMOS: Grupos de Afirmação Homossexual”.

A atmosfera era de repressão nos entornos do estádio, com bloqueios policiais e helicópteros militares sobrevoando a região com o propósito de intimidar os manifestantes. De um lado, havia um grande receio de que a ditadura atentasse contra a vida e a integridade dos presentes, com todo o aparato armado mobilizado. Nas palavras de uma ativista que estava lá, "sentia-se muito medo, pois a qualquer momento a passeata poderia ser atacada pelas forças militares, de oito mil policiais armados com fuzis, em pé sobre as calçadas",582. Por outro, havia uma fundada desconfiança, por partes dos homossexuais, sobre como seriam recebidos no meio operário, bastante marcado, como todo o restante da sociedade, pelo machismo e pela homofobia. Mas a reação foi positiva e surpreendente:

havia uma certa apreensão, por parte dos ativistas, em relação à reação dos operários a essa atuação inédita na história do país, mas quando os 50 homossexuais (homens e mulheres) entraram no Estádio de Vila Euclides, a reação dos 100.000 operários ali reunidos foi das mais inesperadas. Aplaudiram vivamente o grupo. ${ }^{583}$

Assim, o contingente gay e lésbico de umas 50 pessoas, carregando as duas faixas, foi entusiasticamente aplaudido na sua chegada ${ }^{584}$. A emoção deste momento é bem descrita pelo

\footnotetext{
581 "Muitas das lésbicas organizadas não eram indiferentes à convocação do Primeiro de Maio com uma passeata rumo ao Estádio da Vila Euclides, sob as bandeiras da 'liberdade e autonomia sindical, direito de greve, garantia de emprego, salário mínimo nacional real e unificado, contra a carestia', pois o evento era uma clara manifestação contra a ditadura militar" (FERNANDES, Marisa. Lésbicas e a ditadura militar: uma luta contra a opressão e por liberdade. In: GREEN, James N.; QUINALHA, Renan (Orgs.). Ditadura e homossexualidades: repressão, resistência e a busca da verdade. São Carlos: EDUFSCAR, 2014, p. 140).

${ }^{582}$ Ibidem, p. 141.

583 OKITA, Hiro. Homossexualismo: da opressão à libertação. São Paulo, Proposta Editorial, 1981.

${ }^{584}$ Conforme o relato emocionante de Green, "Foi o primeiro grande passo para que o movimento gay saísse do armário no Brasil, e esse fato deixou fundações para uma aliança estratégica com o eleitorado de esquerda. Foi necessário um bocado de coragem para todos que marcharam, porque estávamos nos deparando com um novo desconhecido, ainda que muitos dos nossos temores talvez fossem infundados" (GREEN, James. "Abaixo a
} 
depoimento em primeira pessoa, escrito por Marisa Fernandes: "era um mar de gente, uma multidão, milhares e milhares de pessoas de todas as cores, de diferentes classes sociais, de rostos iluminados cantando, gritando palavras de ordem, clamando por liberdade. Eram muitas faixas coloridas, cada qual com desejos nelas expressos". 585

Esses aplausos, contudo, foram interpretados de outra maneira por Trevisan. Para ele, a recepção efusiva e calorosa representava, na prática, "o início da domesticação do nascimento movimento homossexual brasileiro", do qual ele dificilmente se recuperaria ${ }^{586}$.

Coerente com sua visão dessa contenda interna, Trevisan não apenas tinha se posicionado contra a "participação compulsória" das bichas no ato operário, mas se juntou às demais "bichas pejorativamente chamadas de anarquistas, surrealistas e reacionárias" para um ato de rebeldia com "autêntica desmunhecação: fazer um piquenique no Parque do Carmo. Ali, segundo ele relata, encontraram "milhares de operários a usufruir de sua folga". E arrematou: "No dia do Trabalho, operários e bichas comemorávamos nosso direito à preguiça e à desobediência". 587

A fratura já parecia, a esta altura, irreversível pela polarização das opiniões e a dureza das trocas de ofensas políticas e pessoais. A deterioração acelerada e sem fim das relações pessoas e políticas não podia mais ser contida. Mas a crescente interação do Somos com os demais movimentos sociais acabou dando maior visibilidade ao grupo e era interpretada, pela repressão, como comprovação das conexões do ativismo homossexual com o movimento comunista internacional, como se as homossexualidades fossem um mero instrumento para destruição dos valores familiares da civilização ocidental.

\section{"Embora sejam uma minoria insignificante no contexto social, representam, certamente, novas frentes de reforço às atividades de subversão"}

repressão, mais amor e mais tesão": uma memória sobre a ditadura e o movimento de gays e lésbicas de São Paulo na época da abertura. Acervo, [S.1.], v. 27, n. 1, abr. 2014, p. 73-74). Em outro texto, ele ressalta o caráter histórico do evento: "A participação destas 50 pessoas no Primeiro de Maio de 1980 marcou, pois, um dia histórico para o movimento LGBT brasileiro, revelando como pelo menos um setor do movimento esteve engajado nas mobilizações contra a ditadura" (GREEN, James Naylor. O grupo Somos, a esquerda e a resistência à ditadura. In: GREEN, James N.; QUINALHA, Renan (Orgs.). Ditadura e homossexualidades: repressão, resistência e a busca da verdade. São Carlos: EDUFSCAR, 2014, pp. 182/183).

${ }^{585}$ FERNANDES, Marisa. Lésbicas e a ditadura militar: uma luta contra a opressão e por liberdade. In: GREEN, James N.; QUINALHA, Renan (Orgs.). Ditadura e homossexualidades: repressão, resistência e a busca da verdade. São Carlos: EDUFSCAR, 2014, p. 141.

586 TREVISAN, João Silvério. Devassos no paraíso: a homossexualidade no Brasil, da colônia à atualidade. São Paulo: Record, 2007, p. 357.

${ }^{587}$ Ibidem, p. 357. 
Essa visão peculiar da repressão transparece no relatório periódico de informações confidenciais do Serviço de Informações da Superintendência Regional do Departamento da Polícia Federal, em São Paulo, RPI n. 024/09-80-SI/DPF/SP, de 8 de outubro de 1980, que descreve e analisa uma série de eventos considerados subversivos e ameaçadores à segurança nacional. O documento, difundido para o CI/DPF, SNI, II Exército, IV COMAR e para o serviço secreto da PM, dá notícias do monitoramento das atividades realizadas durante todo o mês de setembro de 1980, desde palestras, discussões acadêmicas, assembleias sindicais, atos de rua, discursos de políticos, dentre outras. Diversas informações estão ali registradas: participantes, organização, quantidade de pessoas presentes, conteúdo das falas e discursos, com destaque para os pontos considerados mais "subversivos", e encaminhamentos deliberados ${ }^{588}$.

Assim, o documento examinava a atuação das esquerdas, ressaltando as divisões e divergências quanto às "táticas de implantação de um 'governo popular"”. Destaque especial, contudo, foi conferido a pessoas e grupos integrantes dos recém-constituídos movimentos negro e homossexual, que já eram considerados vinculados à estratégia "subversiva".

O relato específico do dia 30 de setembro afirma categoricamente que

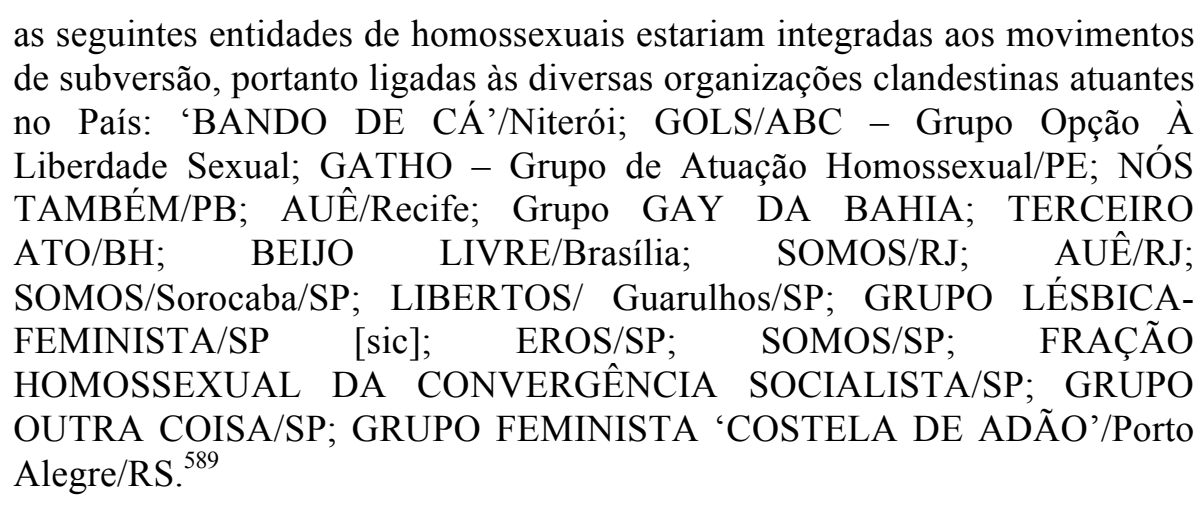

Nota-se que são citados os principais grupos organizados do emergente movimento homossexual brasileiro, concentrado sobretudo no eixo Rio-São Paulo, mas também já chegando a outras capitais, como: Brasília, Porto Alegre, Recife e Salvador. Pode-se afirmar que a maior parte desses coletivos e grupos, que atuavam de modos diferentes em seus contextos específicos, sequer tinham uma linha política clara de combate à ditadura e, muito menos, estavam vinculados a organizações clandestinas comunistas.

Segundo o mesmo relatório, para sustentar a tese questionável de associação dos

\footnotetext{
${ }^{588}$ BR_DFANBSB_ZD_0_0_0046A_0001_d0004

${ }^{589}$ BR_DFANBSB_ZD_0_0_0046A_0001_d0004
} 
grupos de homossexuais com as organizações trotskistas e anarquistas, "a propensão dessas entidades seria para a linha trotskista da CS e para o ANARQUISMO, visto que este último defende a participação dos homossexuais em sua pretensa sociedade libertária" ${ }^{590}$.

De acordo com esta perspectiva conspiratória típica dos discursos de preservação da segurança nacional, dois grupos, a Convergência Socialista (CS) e a Organização Socialista Internacionalista (OSI), eram os responsáveis pela organização de núcleos subversivos entre homossexuais e prostitutas, com o objetivo de enfraquecer o regime. Assim está redigido o trecho: "A CS, a OSI, e muito provavelmente adeptos do ANARQUISMO, vem formando seus NÚCLEOS DE BASE nos meios homossexualistas e entre as prostitutas, orientando-os a organizarem-se em associações como instrumentos de pressão e propaganda" ${ }^{591}$.

Além disso, o documento evidenciava como a vigilância acompanhava de perto as mobilizações dos movimentos de "minorias" e estava de olho na participação dos homossexuais nas outras mobilizações dos negros e mulheres: "várias dessas associações já constituídas participaram de reuniões e desfilaram em passeatas organizadas pelos trotskistas no mês passado. Embora sejam uma minoria insignificante no contexto social, representam, certamente, novas frentes de reforço às atividades de subversão" 592.

A CS, conforme já observado, era uma organização trotskista vinculada ao legado do argentino Nahuel Moreno. Por sua vez, a OSI foi produto do agrupamento de várias outras pequenas organizações trotskistas unidas ao Comitê Internacional pela Reconstrução da Quarta Internacional (CORQUI). O novo grupo foi fundado, em novembro de 1976, em um encontro clandestino realizado no litoral do Estado de São Paulo. Ela foi a precursora da Corrente O Trabalho, integrante do PT desde 1981 e também uma seção brasileira da Quarta Internacional, referenciada no legado do francês Pierre Lambert. No período final da ditadura, chegou a dirigir a oposição sindical de diversas categorias profissionais, além de ter tido presença significativa nos meios estudantis, por meio da Libelu (Liberdade e Luta). Ambos eram os grupos trotskistas com maior penetração e atuação na luta contra a ditadura naquele momento.

Outra participação importante para o reconhecimento do movimento homossexual, com especial destaque para a atuação da CS, ocorreu na $33^{\mathrm{a}}$ Reunião Anual da SBPC, uma entidade de caráter científico e acadêmico cujos encontros se tornaram, desde 1974, um polo de reflexão e articulação de setores oposicionistas à ditadura. Evidentemente que a

\footnotetext{
${ }^{590}$ BR_DFANBSB_ZD_0_0_0046A_0001_d0004

${ }^{591} \mathrm{BR}{ }^{-}$DFANBSB ZD $0{ }^{-} 0-0046 A^{-} 0001-\mathrm{d} 0004$

592 BR_DFANBSB_ZD_0_0_0046A_0001_d0004
} 
comunidade de informações estava bastante atenta e acompanhando essas reuniões que cresciam a cada ano, classificando as reuniões científicas de "grandes festivais das esquerdas".

De 8 a 15 de julho, em Salvador (BA), realizou-se a $33^{\mathrm{a}}$ Reunião Anual e, conforme consta da Informação n. 273/CH/CISA-BR/81, "houve significativo comparecimento de homossexuais, levados por orientação de grupos interessados na filiação dos 'gays' às organizações subversivas e a partidos de oposição". Mas a fissura instaurada no movimento homossexual já estava tão escancarada que o próprio relatório destacava as batalhas internas quanto ao relacionamento com a esquerda tradicional, pontuando que

os fomentadores dessa ideia [de se filiar a partidos da oposição] não obtiveram o sucesso desejado uma vez que os 'grupos gays' não conseguiram convencer-se das vantagens que lhes foram oferecidas, motivando, inclusive, uma reação contrária, tendo em vista exposição dos seus líderes, alertando-os da forma como são tratados nos regimes esquerdistas, onde sofrem humilhações, torturas e perseguições [sendo], finalmente, expulsos.

No entanto, houve uma discussão em torno desse tema, pois "um homossexual identificado como "Jimmy", militante da CONVERGÊNCIA SOCIALISTA/SP, recomendou a leitura do livro "HOMOSSEXUALISMO: DA OPRESSÃO À LIBERTAÇÃO", que desmistifica o raciocínio de que a esquerda persegue o homossexual"593.

É verdade que a CS foi a primeira organização da esquerda brasileira latino-americana a constituir um setorial específico de homossexuais ${ }^{594}$, priorizando o diálogo entre o programa do partido e as demandas particulares dos homossexuais. Esta prática era inovadora no contexto da época e polêmica dentro de setores do próprio movimento homossexual, que denunciavam o risco de "apropriação indevida" e "instrumentalização" das pautas dos homossexuais pelos grupos da esquerda tradicional, que nunca haviam dado muita atenção para essas demandas particulares, consideradas secundárias ou menores diante dos desafios da transformação social.

No entanto, ao contrário da crença generalizada pelos organismos de informação com o intuito de convencer os órgãos de segurança a endurecer a repressão, com a exceção da Facção Homossexual da CS, não houve outros partidos, de direita ou de esquerda, que se comprometessem publicamente com essa agenda ou que dessem espaço significativo dentro

\footnotetext{
${ }^{593}$ BR AN BSB VAZ 020080

${ }^{594}$ GREEN, James. "Abaixo a repressão, mais amor e mais tesão": uma memória sobre a ditadura e o movimento de gays e lésbicas de São Paulo na época da abertura. Acervo, [S.1.], v. 27, n. 1, p. 53-82, abr. 2014, p. 66.
} 
de suas organizações para fortalecer as lutas do movimento homossexual, que se desenvolvia prioritariamente em grupos autônomos e independentes.

\section{Entre a política "maior" e a "menor": o racha do grupo Somos/SP}

A despeito de alguns avanços na conscientização e no acúmulo destas questões, as disputas de poder para emplacar posições especificas em torno de questões polêmicas, tais como relação do movimento homossexual com a esquerda tradicional ou mesmo instituição de uma secretaria operativa ou coordenação nacional dos grupos homossexuais, foram a tônica de mais um encontro dos homossexuais feito até então, o I Encontro Brasileiro de Grupos Homossexuais Organizados ${ }^{595}$.

A presença de forças partidárias, tal como PT, PCdoB e Convergência Socialista, conferiram ao encontro uma perspectiva mais universal e interseccional do conjunto das lutas democráticas, mas, ao mesmo tempo, despertaram em determinados setores a apreensão com a possibilidade de o incipiente movimento homossexual ser instrumentalizado por outros atores políticos. A preocupação com a autonomia que tomava o grupo de São Paulo também afetava o seu par do Rio de Janeiro, conforme entrevista concedida por um de seus membros: “chegamos à conclusão, no $1^{\circ}$ Encontro Nacional de Homossexuais, que todos os membros do movimento nacional têm, obviamente, autonomia para uma militância política, sindical, etc., mas que os grupos devem manter-se autônomos em relação aos partidos políticos" ${ }^{596}$.

Como já foi apontado, tal tensão já vinha sendo amadurecida dentro do Somos paulista e de outros grupos fazia algum tempo. $\mathrm{Na}$ verdade, ela remontava aos primórdios do projeto de mobilização política dos homossexuais, quando a proposta de organização coletiva era mera virtualidade. Antes mesmo do Somos existir, uma entrevista com Leyland, publicada no número 2 do Lampião, expressava as posições divergentes que já frequentavam o movimento gay fora do Brasil e que aqui aportava junto com as novas ideias. Os entrevistadores foram $\mathrm{J}$. S. Trevisan e James Lavender, um pseudônimo utilizado por James N. Green para preservar certo anonimato - ambos, mais tarde, seriam os líderes das alas opostas que ocasionariam o cisma no Somos/SP.

$\mathrm{Na}$ entrevista, Leylando formulava uma crítica dura às organizações da "velha esquerda", como o trotskista Socialist Workers Party, e mesmo à "Nova Esquerda", expressão

\footnotetext{
${ }^{595}$ TREVISAN, J. S. "Encontros e brigas de vários graus”. Lampião da Esquina, n. 24, maio de 1980, p. 5.

${ }^{596}$ Radice, n. 14, de outubro de 1980, p. 28.
} 
usada para se referir aos movimentos populares e de luta pelos direitos civis surgidos na década de 1960, que demonstrariam uma visão mais "paternalista", "condescendente" e "oportunista" em relação aos homossexuais. Green manifestava sua discordância, demarcando sua visão que associava a luta dos homossexuais a um projeto socialista de transformação da sociedade, afirmando que "ainda exist[ia] muitos homossexuais esquerdistas que continua[vam] atuando dentro de grupos heterossexuais socialistas, na medida que esses grupos reconhec[iam] a existência de uma opressão específica contra os homossexuais", já que haveria uma "conexão entre a opressão ao homossexual e outros tipos de opressão social". Leyland rebateu esta colocação dizendo que "[seria] contraproducente e uma perda de tempo os homossexuais trabalharem politicamente dentro de grupos heterossexuais, enquanto indivíduos homossexuais", sustentando a prioridade da auto-organização em apartado dos homossexuais. Trevisan, que verbalizaria mais tarde a posição mais "autonomista" no Somos, já aderia à crítica às esquerdas, pontuando concordar "que a atuação política deve[ria] acompanhar-se de um desenvolvimento individual", afinal, havia "muita gente que se afunda na militância política porque isso os ajuda a se distanciarem de si mesmos. Trata[ndo]-se de uma alienação" 597.

O encontro, contudo, refletiu o estado de confusão generalizada do movimento e funcionou como o estopim que colocou às claras as diferenças que cindiam o grupo. A partir de então, tornava-se mais difícil conciliar a polarização, já tornada pública, em prol da mínima unidade necessária para evitar um racha.

Neste sentido, o Encontro constituiu-se em um marco histórico e um experiência coletiva incontornáveis para a trajetória do ativismo LGBT. Do ponto de vista externo, a surpreendente reunião de mais de 200 militantes de diversas partes do Brasil, coroada por um ato público com mil pessoas em plena ditadura, conferiu ao movimento homossexual uma notoriedade inquestionável. Essa projeção para a sociedade expôs algo que não se poderia mais esconder: a existência de homossexuais reivindicando seus lugares no mundo, inclusive politicamente. Já internamente, os desacordos intensos reconfigurariam de maneira irreversível o movimento, com divisões que já não podiam mais ser adiadas.

Diversas questões, de ordem política e também pessoal, compuseram o quadro dessa rivalidade dentro do agrupamento Somos que, por ser o mais antigo e estruturado, sintomatizou, de modo mais dramático, essas diferenças irreconciliáveis que atravessavam, em algum grau, todos os demais grupos. O pivô central da crise foi uma suposta e crescente

\footnotetext{
${ }^{597}$ Lampião da Esquina, n. 2, julho de 1978, p. 11.
} 
influência no movimento homossexual da Facção Gay da Convergência Socialista.

Organizada no final de 1979 no interior de uma das mais atuantes correntes da luta pela redemocratização do país, a Facção chegou a contar apenas com três militantes que também participaram do Somos e superou, em 1981, a marca de mais de duas dezenas de bancários, professores, artistas, estudantes universitários e secundaristas para discutir a opressão dos homossexuais sob uma perspectiva marxista. Como o primeiro coletivo homossexual de um partido da esquerda, chegou a promover debates internos, grupos de estudos e até publicações, destacando-se o pequeno documento "Teses para a Libertação Homossexual II", finalizado em outubro de 1979 e publicado, posteriormente, em livro, contendo as principais avaliações e estratégias do grupo ${ }^{598}$.

Este cruzamento perigoso entre comunismo e homossexualidade despertava preocupação especial nos órgãos de vigilância que geravam informações imprecisas, apreciações exageradas e até mesmo constatações equivocadas, aliás, como costumava acontecer. Um relatório de monitoramento que tinha por assunto "Convergência Socialista em BH e o homossexualismo", classificado como Informe n. 1083/300/ABH/80, de 21 de julho de 1980, resumia, detalhadamente, um artigo que James N. Green havia publicado no Lampião daquele mesmo mês.

No texto, Green, que era uma liderança da Facção, rebatia as críticas que vinha sofrendo por conta das polêmicas havidas no I Encontro Brasileiro de Grupos Homossexuais Organizados e reafirmava que o movimento era autônomo e independente, mas que não era justo vetar a participação de socialistas nos grupos homossexuais. Ainda que o resumo correspondesse ao conteúdo essencial do artigo, a repressão cometeu uma confusão entre o autor Jim Green e o intelectual e ex-preso político Fernando Gabeira, que há pouco tinha voltado do exílio e causava furor nas praias cariocas com sua tanga de crochê e as suas declarações a favor do movimento feminista e o movimento homossexual. Logo de início, dizia-se, no informe: "JIM GREEN, certamente pseudônimo do conhecido intelectual paulista Gabeira", o que demonstrava a falta de conhecimento do órgão de espionagem sobre o tema tratado. O documento ainda qualificava Green como "dirigente da Convergência Socialista do Estado do Rio, sendo um dos organizadores da força-homossexualista do País”, sendo que ele militava em São Paulo e era membro da "Facção Homossexual" da "força-homossexualista". Esta apresentação de Green era, na verdade, uma apresentação para evidenciar o risco da conduta do Sr. Paulo Haddad, do Instituto Estadual do Patrimônio Histórico e Artístico de

\footnotetext{
${ }^{598}$ OKITA, Hiro. Homossexualismo: da opressão à libertação. São Paulo, Proposta Editorial, 1981.
} 
Minas Gerais - IEPHA, que teria indicado dois elementos da Convergência Socialista local e homossexuais para o órgão, "onde o número de homossexuais cresc[ia] dia a dia". A organização subversiva que ali estaria se formando seria "composta de 10 homofilos acasalados", levando a uma crise com a imprensa, por exercitarem "o sistema homossexualista para fins esquerdistas" ${ }^{\circ 99}$.

A despeito dos flagrantes erros do informe, resta claro como a subversão política parecia ficar mais temerária, aos olhos da repressão, quando combinada com a homossexualidade e, sobretudo, ao envolver funcionários da máquina pública.

A atuação disciplinada de militantes trotskistas experientes, formados sob uma lógica bolchevique, acabou fazendo com que o grupo conquistasse cada vez mais espaço dentro do Somos $^{600}$. Era, no entanto, bastante clara a dificuldade de convencer pessoas a se integrarem, de forma orgânica, a um padrão de militância que exigia duros sacrifícios pessoais e profissionais em uma organização revolucionária, o que podia ser atestado pelo pequeno número de apenas três militantes da CS dentro do Somos. Mesmo com tal limitação para a construção da corrente no movimento homossexual, a influência política da CS era crescente, ao mesmo tempo em que gerava a desconfiança e o afastamento de outros participantes menos identificados com os setores da esquerda mais tradicional.

Era, assim, uma questão de tempo para que a tragédia anunciada se consumasse. A prevalência de uma posição autonomista radical dentro do grupo, que repelia qualquer “disputa de poder" e a "centralização de tarefas em lideranças", métodos que estariam associados à esquerda tradicional, acabou dificultando o encaminhamento das questões e as decisões sobre temas mais polêmicos em um grupo que contava já com mais de 100 membros. Nas palavras de Green,

tentar realizar uma discussão com cem pessoas em reuniões gerais sem um procedimento claro, uma cultura política de debate democrático ou pessoas responsáveis para coordenar as questões a serem consideradas sobre os rumos do grupo acabou provocando uma certa paralisia no processo de

\footnotetext{
${ }^{599}$ ABH_ACE_3116_81

${ }^{600}$ Para Green, tal influência parecia ser superestimada e funcionava como um modo de alimentar uma hostilidade à esquerda organizada dentro do movimento homossexual: "Creio que a maioria dos membros do movimento tinha uma atitude hesitante em relação a CS, e os ataques constantes feitos em Lampião da Esquina jogavam lenha nessa fogueira. Essa tensão criou, em um determinado setor, um clima de hostilidade em relação à esquerda. Além disso, entre 1978-1979, não estava claro ainda até que ponto o processo de liberalização da ditadura chegaria. Provavelmente, muitos gays e lésbicas sentiram que estariam assumindo riscos ao entrarem em uma organização homossexual. Alguns talvez não quisessem fazer parte de uma organização cujo comitê central tinha sido preso apenas um ano antes, e cujos membros haviam sido acusados de violar a Lei de Segurança Nacional" (GREEN, James. "Abaixo a repressão, mais amor e mais tesão": uma memória sobre a ditadura e o movimento de gays e lésbicas de São Paulo na época da abertura. Acervo, [S.1.], v. 27, n. 1, p. 5382 , abr. 2014, pp. 66-67).
} 
tomada de decisões. Quando surgiram perspectivas diferentes sobre o encaminhamento do grupo, a falta de fóruns de discussão e de experiência democrática da maioria dos novos membros criou muitas tensões dentro do Somos". ${ }^{601}$

Green relata ter debatido longamente com Trevisan a respeito do relacionamento entre a CS e o movimento homossexual. Mais tarde, ao fazer um balanço de sua atuação neste período, Green lançou um questionamento incômodo à posição de Trevisan. Afinal, por que "gastar tempo criticando a única organização de esquerda que tinha uma posição positiva em relação à homossexualidade, em vez de focar suas críticas nos grupos que não tinham posição ou que eram homofóbicos?"602.

Esse argumento parecia não ter apelo com a repulsa criada em relação às esquerdas. $\mathrm{O}$ grupo já estava, assim, irremediavelmente fraturado entre a posição mais libertária e autonomista, de um lado, e a concepção de que o movimento deveria aliar-se a outros movimentos sociais sem repudiar os setores da oposição organizada sensíveis às demandas dos homossexuais. Ainda que não assumisse um lado específico neste conflito, uma terceira postura que agravava o quadro de divisões internas era a das lésbicas, que na medida em que cresceram numericamente no grupo, e com cada vez mais contato com o movimento feminista, tendiam a uma auto-organização de maneira apartada.

Enfim, em 17 de maio de 1980, na $6^{\text {a }}$ Reunião Geral do grupo daquele ano, realizada nas dependências da boate "Mistura Fina", localizada na Rua Major Sertório, foi lida uma carta assinada por nove ativistas do Somos que declarava a ruptura imediata com a intenção de fundar um "novo grupo que se prop[unha] a afirmar a definição de grupo homossexual autônomo e interessado prioritariamente na questão homossexual ${ }^{603}$ ". A reunião, que contava com a significativa presença de 37 homens e 28 mulheres, foi bastante tensa após a retirada do grupo divergente e, ato contínuo, as mulheres aproveitaram para anunciar sua saída por outros motivos $^{604}$. Pouco tempo depois, com algumas reuniões realizadas, essas pessoas batizariam o novo agrupamento de "Outra Coisa - Ação Homossexualista" Somos/SP que manteve seu nome. Junto com Eros e o Libertos, o "Outra Coisa" ensaiaria a

\footnotetext{
601 GREEN, James Naylor. O grupo Somos, a esquerda e a resistência à ditadura. In: GREEN, James N.; QUINALHA, Renan (Orgs.). Ditadura e homossexualidades: repressão, resistência e a busca da verdade. São Carlos: EDUFSCAR, 2014, pp. 191/192.

${ }^{602}$ GREEN, James. "Abaixo a repressão, mais amor e mais tesão”: uma memória sobre a ditadura e o movimento de gays e lésbicas de São Paulo na época da abertura. Acervo, [S.1.], v. 27, n. 1, p. 53-82, abr. 2014, p. 66.

603 “O racha no SOMOS/SP - Documento 2". Lampião da Esquina, n. 25, junho de 1980, p. 8.

604 Uma descrição pormenorizada do episódio e das últimas reuniões bastante tensas do grupo pode ser encontrada em MACRAE, Edward. A construção da igualdade: identidade sexual e política no Brasil da "abertura". Campinas: Editora da Unicamp, 1990, pp. 208-217.

${ }^{605}$ Grupo Outra Coisa - Ação Homossexualista, Três anos (1980/1983), São Paulo, maio de 1983.
} 
formação de uma frente denominada "Movimento Homossexual Autônomo" (MHA).

Trevisan foi uma das figuras mais conhecidas da ala mais autonomista e anarquista do grupo. Em junho de 1980, ele publicou um manifesto claramente endereçado a seus colegas de militância contra a reprodução de práticas políticas partidárias, proclamando o movimento homossexual como um ator de relevo para contestar e não tomar o poder. Para concretizar essa "utopia", seria preciso contar

Com a afirmação de nossa 'anormalidade', ambiguidade, criatividade. Com nosso rechaço aos CENTROS decisórios onde se concentra o poder. É que nossa significação se encontra mesmo na margem. Por isso, nada é maior e prioritário para nós. Preferimos o menor, o individual, o infinitamente específico: só atingiremos o todo se partirmos da partícula menor, a mais individualizada [...]. Isso eu chamo de POLÍTICA MENOR. ${ }^{606}$

Os que permaneceram no grupo rechaçaram as acusações de terem desviado o foco de atuação do Somos para além da questão homossexual, "a não ser que se considere desvio a discussão fomentada pelos renunciantes quanto a possível influência externa. Ou sobre o trabalhador homossexual do ABC. Ou sobre o negro homossexual"607.

Os remanescentes também acusaram os que saíram de "radicalidade" porque "não discutiram a denúncia e nem a sua renúncia, dando como definitiva a retirada do grupo". No entanto, aqueles não fizeram concessões quanto à concepção do grupo que tinham, que era inevitavelmente política e em diálogo intenso com outros movimentos sociais, ainda que não tivesse vínculo partidário: “impossível, portanto, estabelecer, na realidade brasileira, hoje, um grupo discriminado por todas as políticas e que se defina como apolítico. Por isso a retirada afirmação de que o grupo Somos-SP não é um grupo de filiação partidária, mas é um grupo político" ${ }^{608}$.

Um dos dirigentes da Fração Gay da Convergência Socialista, James N. Green, escreveu um texto em resposta a todas as acusações contra seu agrupamento, que vinham sendo veiculadas recorrentemente pelo Lampião, cujo Conselho Editorial, ainda que não declaradamente, simpatizava com a posição mais autonomista e anarquista ${ }^{609}$.

\footnotetext{
606 "Por uma política menor: bichas e lésbicas inauguram a utopia”. Lampião da Esquina, n. 25, jun., 1980, p. 10.

607 “O racha no SOMOS/SP - Documento 3”. Lampião da Esquina, n. 25, junho de 1980, p. 8.

608 “O racha no SOMOS/SP - Documento 3". Lampião da Esquina, n. 25, junho de 1980, p. 8.

609 Além dos sucessivos textos de Trevisan, que aproveitava sua posição no Lampião para reverberar suas posições pessoais dentro do Somos/SP, como no texto "Boas de cama?" (cf.: Lampião da Esquina, n. 26, julho de 1980, p. 7) alegando haver uma "política de cama" por parte dos membros da CS, Aguinaldo Silva também chegou a manifestar sua posição no jornal. Ainda que se furtasse a assumir uma posição clara no texto, negando apoio aberto a qualquer dos lados da contenda, ele afirmava claramente: "não que eu discorde do ativismo homossexual; apenas acho que ou ele encontra o seu próprio caminho, ou acaba atropelado pelos ativismos
} 
No artigo intitulado "Autonomia ou não, eis a questão", Green defendia que o movimento homossexual deveria se organizar em uma frente única com "todos os grupos, organizações e indivíduos que estão lutando a favor da questão específica do homossexual" ${ }^{610}$. Segundo ele, explicando sua concepção de autonomia, a Fração concordava com a posição tirada no I Encontro de que o "MH como um todo não deve[ria] se afiliar a este ou aquele partido ou tendência política. Neste sentido, [era] 'autônomo', mas isto não pod[ia], nem $\operatorname{dev[ia]~excluir~qualquer~tendência~ou~organização~política~que~[quisesse]~participar~do~}$ movimento". Ele acrescentava, ainda, que era preciso compreender as relações existentes entre a opressão do homossexual, a repressão policial, a exploração no trabalho, a discriminação racial e o machismo "que a maioria da população brasileira sofre", com uma perspectiva marcadamente interseccional com os demais grupos vulneráveis. Por fim, o artigo saiu da postura defensiva e contra-atacou afirmando haver uma escolha no horizonte do movimento homossexual brasileiro: "ele pode crescer, incluir milhares de homossexuais e se aliar com outros setores explorados e oprimidos da sociedade ou ele pode ficar isolado. A opção é nossa para escolher",611.

Além disso, em relação às acusações de que estaria manipulando o movimento homossexual para submetê-lo a seus interesses exclusivamente partidários, Green afirmou, em artigo mais recente com um balanço reflexivo sobre sua experiência à época, que

embora seja uma homenagem às capacidades carismáticas e políticas de alguém dizer que as duas pessoas da CS que participaram do grupo foram capazes de manipular de 50 a 75 pessoas, as preocupações dos críticos que temiam a influência desses dois militantes eram mal direcionadas e um insulto aos membros do Somos que teriam sido supostamente manipulados. ${ }^{612}$

Green e Trevisan, de certa forma protagonistas desse cisma, conheceram-se ainda nos EUA e tiveram um envolvimento pessoal durante o início da militância conjunta. É curioso

maiores". Após muito tergiversar, revelava, ainda, abertamente: “eu abomino essa possibilidade [de arregimentação de homossexuais por organizações políticas], mas este é o meu ponto de vista pessoal. Trata-se de uma questão de competência: se o pessoal que optou pela autonomia quer evitar a invasão do movimento homossexual pelos partidos e organizações políticas, que trate de brigar por isso. E trate, principalmente, de evitar a paranoia que se abateu sobre todos, e que vem ressoar aqui em nossa pobre redação como um eco várias vezes ampliado". "Compromissos, queridinhas? Nem morta!”. Lampião da Esquina, n. 26, julho de 1980, p. 11. Em edições posteriores, as críticas à CS voltariam, tal como "Querem capar as lampiônicas", escrito por Celestino e publicado na edição 33, de fevereiro de 1981, do Lampião.

${ }^{610}$ GREEN, James N. "Autonomia ou não, eis a questão". Lampião da Esquina, n. 26, julho de 1980, p. 10.

${ }^{611}$ GREEN, James N. "Autonomia ou não, eis a questão”. Lampião da Esquina, n. 26, julho de 1980, p. 10.

612 GREEN, James Naylor. O grupo Somos, a esquerda e a resistência à ditadura. In: GREEN, James N.; QUINALHA, Renan (Orgs.). Ditadura e homossexualidades: repressão, resistência e a busca da verdade. São Carlos: EDUFSCAR, 2014, p. 196. 
que ambos entrevistaram Winston Leyland, quando ele visitou Brasil em 1978 e os dois chegaram a escrever, a quatro mãos, o artigo "A revolta de São Francisco", publicado no Lampião, em meados de 1979. No texto, que tratava da revolta da comunidade gay de São Francisco diante da inexpressiva pena de condenação de Dan White, assassino de Harvey Milk, os ativistas, que logo polarizariam o grupo Somos, apresentavam uma visão bastante afinada com as posições defendidas por Green dentro do Somos.

Na ocasião eles, então elogiosos ao ato dos homossexuais estadunidenses, escreveram:

é uma evidência de como faz sentido a aliança entre os vários grupos socialmente discriminados, inclusive a classe operária. Compreendida como parte de um contexto, a luta dos homossexuais torna-se comum aos vários grupos contestadores da desordem social. Assim também aumenta a participação de organizações homossexuais na luta das feministas, dos chicanos, dos movimentos antinucleares e ecológicos, dos boicotes contra governos ditatoriais, etc. Cresce a consciência de que a opressão que atinge a todos em níveis diferentes, tem origem nas mesmas fontes. Felizmente, as esquerdas americanas vêm compreendendo cada vez mais essa necessidade. Daí a presença de heterossexuais brigando lado a lado em uma revolta que só aparentemente se restringia aos homossexuais. ${ }^{613}$

Mas se, naquele momento, a aliança com os operários e demais grupos "socialmente discriminados" era uma questão pacífica entre ambos, não demorou muito para que essa oposição entre "antiautoritários", “comunitaristas", "socialistas" e "trotskistas", acabasse se convertendo no mote que justificou a divisão do grupo pioneiro do movimento homossexual brasileiro $^{614}$.

\section{"Enquanto mulheres e homossexuais": as lésbicas do Somos para o GALF}

Outra diferença latente que eclodiu logo após o encontro foi a capitaneada pelas mulheres auto-organizadas no Grupo de Atuação Lésbica-Feminista, "tudo no feminino" (antes era Grupo de Ação Lésbico-Feminista). Apesar de a divisão só ter ocorrido em abril de 1980, a entrada de diversas mulheres em um grupo até então quase que exclusivamente masculino, no início de 1979, já vinha expondo os problemas de machismo e sexismo dentre os homens gays do Somos. Assim, as lésbicas, cada vez mais próximas ao movimento

\footnotetext{
${ }^{613}$ GREEN; TREVISAN. "A revolta de São Francisco”. Lampião da Esquina, n. 13, maio de 1979, p. 3.

${ }^{614}$ Facchini registra importante ressalva no sentido de que havia, nesta "primeira onda" do movimento, outras propostas e trajetórias que não se enquadravam na dicotomia referida, ainda que não se negue a centralidade desta para o desenlace dos conflitos e da ruptura (FACCHINI, Regina. Sopa de letrinhas? Movimento homossexual e produção de identidades coletivas nos anos 1990. Rio de Janeiro: Garamond, 2005, p. 107).
} 
feminista que se rearticulava nesse mesmo momento, foram adotando uma auto-organização dentro do coletivo mais amplo. Após esse outro racha, apenas algumas poucas lésbicas permaneceram no Somos por acreditarem que o coletivo misto era um espaço mais adequado de militância para mulheres. Segundo elas, "dada a especificidade da discriminação que sofremos, enquanto mulheres e homossexuais, consideramos o processo de afirmação somente possível em reuniões separadas das dos homens", acrescentando que "a participação de lésbicas em grupos mistos tem impedido o desenvolvimento de uma consciência feminista, essencial, a nosso ver, para o próprio M.H. [Movimento Homossexual]"615.

No entanto, ao contrário do racha mencionado anteriormente, este das mulheres feministas não significava uma ruptura total. Na carta que elas publicaram no Lampião, elas deixaram em aberto a possibilidade de futuras alianças e trocas com os grupos mistos de homossexuais: "a nossa atuação externa, participações em congressos e manifestações, vem demonstrar não haver qualquer empecilho no sentido de uma ação conjunta, desde que sejam preservados nossos objetivos e autonomia"616.

Aliás, em texto de esclarecimento posteriormente publicado no Lampião, elas fizeram questão de ressaltar que "a autonomia do GALF em relação ao Somos/SP era anterior à divisão do grupo", tendo sido "mera coincidência histórica ela ter acontecido no mesmo dia em que algumas pessoas saíram para fundar outro grupo".

Com o espírito mais conciliatório do que sectário, elas afirmaram a firme intenção de não se "chocar com nenhum dos lados", pois consideravam "salutar a coexistência e

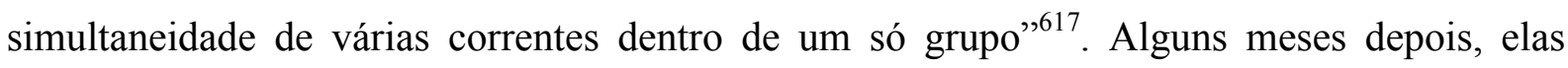
passariam a editar a publicação independente "CHANACOMCHANA", como um jornal de circulação pública e não apenas interna. Para elas, "a palavra Chana não pode ser definida como órgão sexual feminino. É algo tão mais amplo quanto os contrapontos de existir"618.

\section{O fracasso do II EGHO: fim do movimento homossexual?}

Foi neste contexto turbulento e de animosidades acirradas, com maior diversidade interna no movimento, que se tentaram realizar as reuniões preparatórias para o II Encontro de Grupos Homossexuais Organizados. O encontro era programado, nessa nova edição, para

\footnotetext{
615 “O racha no SOMOS/SP - Documento 1". Lampião da Esquina, n. 25, junho de 1980, p. 8. 616 “O racha no SOMOS/SP - Documento 1". Lampião da Esquina, n. 25, junho de 1980, p. 8.

617 “A posição do GALF”. Lampião da Esquina, n. 27, agosto de 1980, p. 5.

${ }^{618}$ RODRIGUES, Dolores. "Um jornal com muitas chanas". Lampião da Esquina, n. 34, março de 1981, p. 18.
} 
acontecer no Rio de Janeiro, motivo pelo qual a Comissão Organizadora era formada, principalmente, por membros dos grupos cariocas que, aliás, não se encontravam em clima de convivência muito pacífica, tal como seus congêneres paulistas. Sérios conflitos com o Lampião ${ }^{619}$ e entre os próprios grupos fizeram com que a reunião prévia realizada no dia 6 de dezembro tivesse duros embates e votações apertadas ${ }^{620}$.

Depois de horas de discussão sobre a possibilidade ou não dos representantes do Lampião participarem da reunião organizativa, o que foi aprovado por 23 votos a 11 , as seguintes diretrizes foram deliberadas para o II EGHO: ele não teria caráter deliberativo (por 20 a 17 votos), o tema de uma "Coordenação Nacional não seria mais discutido (por 17 a 12 votos) e o formato seria igual ao do primeiro Encontro. Além disso, o temário aprovado foi "estrutura e funcionamento dos Grupos, autonomia do movimento homossexual, sexualidade, movimento homossexual e repressão, a mulher homossexual, o negro homossexual e os conceitos de homossexualismo", revelando as principais preocupações que orientavam a militância homossexual naquele momento histórico.

Mas o Somos/RJ e o AUÊ decidiram abandonar a Comissão Organizadora do encontro por diferenças com o Lampião. Com o risco de não haver o encontro, o jornal se dispôs a assumir a organização do mesmo. Mas, em São Paulo, os grupos Somos, Ação LésbicaFeminista, Fração Homossexual da Convergência Socialista, Terra Maria e Alegria Alegria formaram uma Comissão Pró-II EGHO discordando que o Lampião assumisse a dianteira desse processo por já ter sido o pivô das discórdias com os grupos cariocas e propuseram, como alternativa, levar o encontro para São Paulo, que já detinha o know-how da versão anterior. Essa solução, contudo, foi logo contestada pelo Movimento Homossexual Autônomo ${ }^{621}$.

Para piorar a situação, em meados de 1981, o Lampião se apagou, deixando todos órfãos de uma publicação que cumpriu um papel essencial na mobilização do período

\footnotetext{
${ }^{619}$ O boicote ao Lampião estava tomando força entre alguns grupos, expondo uma fratura expressiva entre o movimento e o jornal. Cf.: NUNES, Aristides. "Jogaram bosta no II EGHO". Lampião da Esquina, n. 33, fevereiro de 1981, p. 18.

${ }^{620}$ Quando se apresentaram nessa reunião, os grupos mencionaram as dificuldades por que vinham passando e indicaram a quantidade de membros de cada um deles, o que permitia compreender a dimensão que alcançaram nesse momento de relativo esvaziamento: "GATHO-Recife (atualmente com 15 pessoas em média), Auê/Rio (com 17 membros), Eros/SP (com 15 pessoas fixas), Bando de Cá/Niterói (15 pessoas, mas apenas cinco trabalhando), GOLS/ABC (8 membros), Libertos/SP (15 membros), Somos/Rio (20 membros fixos e 15 flutuantes), Fração Gay da Convergência Socialista (13 pessoas, sendo que 5 mulheres e 8 homens), Grupo Gay da Bahia (17 pessoas fixas), Somos/SP (35 elementos), Terra Maria (10 pessoas), Alegria Alegria (10 membros), Grupo de Ação Lésbica-Feminista (8 mulheres fixas e 15 flutuantes)". Cf.: "Na reunião dos grupos, reflexos da crise". Lampião da Esquina, n. 32, janeiro de 1981, p. 13.

${ }^{621}$ Um resumo das divergências e embates em torno da realização do II EGHO encontra-se em MATTOSO; NUNES. “Novela: por que o II EGHO dançou?". Lampião da Esquina, n. 34, março de 1981, p. 4.
} 
anterior $^{622}$. Assim, sem um meio de comunicação para expressar as bandeiras consensuais e mesmo para debater as divergências internas mais amplamente, nada mais, além da subjetividade homossexual, parecia ser compartilhado entre os membros do movimento a fim de justificar uma atuação conjunta, ainda que em grupos separados. As carências comuns pareciam pulsar mais baixo do que as diferenças ideológicas e a falta de contato com os pares afetava a dinâmica de um movimento que se constituía essencialmente na base da pulverização e tensionamento mútuo entre os grupos, no afeto.

$\mathrm{O}$ rebuliço que inviabilizou o segundo encontro era a prova concreta de como o movimento mergulhava em uma crise cada vez mais profunda, sobretudo após a ressaca do efusivo primeiro Encontro. Aquela que seria a segunda reunião nacional acabou não acontecendo diante do clima de declínio, ainda que tenha havido, nos dias 14 e 15 de abril de 1981, o I Encontro Paulista de Grupos Homossexuais Organizados, uma semana depois do I Encontro dos Grupos Homossexuais Organizados do Nordeste, em Recife.

Tudo isto dava sinais de um esgotamento definitivo da primeira onda do movimento homossexual brasileiro, ao menos naquele formato que caracterizou os seus primeiros anos. $\mathrm{O}$ grau de acirramento interno e a incapacidade de organizar um evento conjunto, contemplando a diversidade de posições, selaram o desfecho da crise dos grupos ativistas ${ }^{623}$. Os persistentes problemas de financiamento e infraestrutura que afetavam, sobretudo, os grupos que tinham poucos membros, bem como a desmobilização de algumas importantes lideranças, a ilusão de que a democracia traria a igualdade naturalmente e sem esforços, a cobertura mais positiva das homossexualidades nas mídias e a integração acentuada pelo consumo, alteraram a percepção sobre a necessidade e o formato da organização política desses setores ${ }^{624}$.

$\mathrm{O}$ fato de terem emergido durante uma ditadura, que sem seu processo de distensão e perecimento progressivamente fortaleceu uma oposição bastante significativa e atuante, fez com que os grupos dos movimentos sociais agissem de modo mais acuado, marcados pela preocupação permanente de manterem-se equidistantes tanto da ingerência do Estado quanto das esquerdas. Isto deixou traços constitutivos e indeléveis no movimento muitas vezes

\footnotetext{
${ }^{622}$ Alexandre Ribondi, membro do grupo Beijo Livre e colaborador regular do Lampião, relatou essa dificuldade em entrevista ao Somos que "quando o Lampião deixa de existir, os grupos deixaram de existir e os que existiam, nós não tínhamos como saber deles”. Silva, 1998, p. 152.

623 "Três anos depois do início do Movimento os grupos ainda parecem estar num processo de perplexidade quanto aos rumos de atuação. Não chegaram a um acordo sobre o II Encontro Brasileiro de Grupos Homossexuais, que deveria se realizar no Rio, em abril de 81; mal conseguiram uma resposta à onda de repressão às lésbicas que ocorreu em São Paulo em novembro de 80. Essa inatividade é reflexo, principalmente, das diferenças ideológicas". OKITA, Hiro, Op. cit., p. 55

${ }^{624}$ GREEN, James. "More Love and More Desire": The Building of a Brazilian Movement. In.: Barry D. Adam, Jan Willem Duyvendak and André Krouwel (editors). The Global Emergence of Gay and Lesbian Politics: National Imprints of a Worldwide Movement Philadelphia: Temple University Press, 1999, p. 98.
} 
ensimesmado, fragmentado, projetado mais para fora, a fim de combater a ditadura e ou rechaçar as esquerdas, do que para dentro, de forma a lidar de maneira salutar com seus próprios problemas e divergências.

O Somos chegou a estabelecer, finalmente, uma sede em 1982, mas o contexto da redemocratização e da expansão de um mercado voltado aos homossexuais foi isolando cada vez mais o grupo. Chegaram a organizar cineclubes, debates, atividades, estudos e um jornal chamado "O Corpo", com meia dúzia de edições. Alguns foram para um grupo de vivencia chamado "Coletivo Alegria-Alegria", de curta duração. Mas, em 1983, o Somos se dispersou de vez. O "Outra Coisa", oriundo da fração mais autonomista que rompeu com o grupo, chegou ainda a pautar temas de sexualidade nas eleições de 1982 e começou a ser uma das primeiras organizações a divulgar informações sobre a Aids. Mas não tardou muito para encerrar as suas atividades, em 1984. O terceiro fragmento do Somos, o GALF, ainda atuou no movimento feminista e lésbico, mas passou também por diversas crises e rachas, embora tenha conseguido chegar aos anos 1990 como a Organização Não Governamental "Rede de Informação Um Outro Olhar",625.

Assim, sem reproduzir aqui as condenações um tanto fatalistas - em torno do "fim", da "acomodação" ou mesmo da "despolitização" do movimento homossexual -, fato é que a crise e o fim das organizações causou um impacto inegável - especialmente por terem ocorrido logo antes da eclosão da epidemia da AIDS -, alterando, de vez, as formas de ação política neste novo período.

A chamada "peste gay", logo associada aos homens que faziam sexo com homens, marcou de modo indelével não apenas o movimento, mas as próprias homossexualidades, os corpos e as subjetividades. Perlongher, já citado antropólogo e ativista argentino da FLH que chegou ao Brasil em 1982 realizando um trabalho etnográfico importante junto aos michês da zona central de São Paulo ${ }^{626}$, foi infectado pelo HIV e dedicou-se, em seus últimos textos, a uma crítica contundente de como o vírus comprometeria não apenas o movimento organizado, mas decretaria o fim mesmo da "festa da orgia homossexual" e da maior "revolução sexual que sacudiu o Ocidente": "um declínio tão manso que se a gente não olha bem não percebe: esse é o processo da homossexualidade contemporânea. Ela abandona a cena fazendo uma

\footnotetext{
${ }^{625}$ Mais informações sobre os desdobramentos e caminhos tomados por essa primeira geração, ver SIMÕES, Júlio; FACCHINI, Regina. Na trilha do arco-íris; do movimento homossexual ao LGBT. São Paulo: Editora Fundação Perseu Abrano, 2009, pp. 115-116.

${ }^{626}$ PERLONGHER, Nestor. O negócio do Michê - A prostituição viril em São Paulo. São Paulo: Fundação Perseu Abramo, 2008
} 
cena poética e desgarrada: a da sua morte"627. Esta visão apocalíptica revelou-se exagerada, pois, conforme destacou Santos, a AIDS não apenas estigmatizou as homossexualidades e desmobilizou a militância, mas também possibilitou uma "maior visibilidade da homossexualidade no cenário nacional", abrindo espaço para o "contato entre militantes e órgãos estatais", em um primeiro momento, e um fluxo de recursos do Ministério da Saúde, para prevenção e tratamento que possibilitou a "reestruturação do movimento homossexual em todo o país"

Neste sentido, compreender mais os deslocamentos do que simplesmente decretar o fim do movimento, ao final de seu importante trabalho de 1985, MacRae ressaltava um dos mais notáveis legados já visível naquele momento, afirmando:

embora o movimento homossexual brasileiro tenha entrado em declínio, restando pouquíssimos grupos em atividade, subsistiram redes de amizade e comunicação criados a partir deles. Poucos antigos militantes manifestaram disposição para qualquer volta à atuação nos moldes anteriores. Porém, em certos momentos críticos, os membros de diversos grupos extintos têm se reunido para discutir e tentar efetuar algum tipo de mobilização da população que se identifica como homossexual. ${ }^{629}$

Mas, além da herança das redes e laços criados ao longo destes quatro anos de intensa experiência coletiva, outras conquistas alcançadas nos anos 1980 foram tributárias, em boa medida, daquele movimento pioneiro. A criação jurídica e o reconhecimento oficial do Grupo Gay da Bahia, em fevereiro de 1980, e do Triângulo Rosa ${ }^{630}$, em 1985, no Rio de Janeiro, enquanto organizações declaradamente voltadas à defesa dos homossexuais, foram um marco importante. Inaugurando formas de atuação diferentes daquelas adotadas pela geração precedente, os novos grupos se voltaram mais à cobrança de reconhecimento legal e políticas públicas do que à oposição direta aos órgãos estatais.

O Grupo Gay da Bahia, por exemplo, encampou com afinco a luta pela despatologização das homossexualidades, uma reivindicação antiga do movimento, pedindo a revogação do parágrafo 302.0 do Código de Saúde do Instituto Nacional de Assistência Médica e Previdência Social (INAMPS). Tal vitória, uma das mais expressivas do movimento

627 PERLONGHER, Nestor. O desaparecimento da homossexualidade. In: LANCETTI, Antônio et al. SaúdeLoucura 3.São Paulo: Hucitec, 1993, p. 40.

${ }^{628}$ SANTOS, G. G. C. Mobilizações homossexuais e Estado no Brasil: São Paulo (1978 - 2004). RBCS. vol. 22. n. 63. Fevereiro de 2007, pp. 121-122.

${ }^{629}$ MACRAE, Edward. A construção da igualdade: identidade sexual e política no Brasil da "abertura". Campinas: Editora da Unicamp, 1990, p. 390.

${ }^{630}$ CÂMARA, C. Cidadania e orientação sexual: a trajetória do grupo Triângulo Rosa. Rio de Janeiro: Academia Avançada, 2002. 
homossexual até então, veio a se concretizar, depois de anos de campanhas, em 9 de fevereiro de $1985^{631}$.

Já o Triângulo Rosa esteve à frente de uma importante mobilização durante o processo constituinte de 1986 e 1987. Naquele momento, abriu-se uma oportunidade única para os movimentos sociais inscreverem, na ordem jurídica, o reconhecimento e a proteção de suas reivindicações históricas como direitos. Neste sentido, a tentativa era de incluir, no rol de discriminações proibidas pelo futuro art. $3^{\circ}$ da Carta Maior, aquela motivada por "orientação sexual" ${ }^{\prime 32}$. Apesar de não ter logrado êxito, este debate mobilizou diversos setores da sociedade e contou com o apoio de 47 constituintes, representando um avanço no debate público do tema no país.

Estes casos são apenas exemplos do quanto foi possível avançar na luta dos homossexuais no processo de redemocratização, em boa medida, graças ao acúmulo de conhecimento, contatos, redes de apoio, formulação teórica e experiência militante herdados do movimento que surgiu, ainda sob a ditadura, para lutar não apenas pela liberdade, mas também pelo reconhecimento das identidades e, sobretudo, pela igualdade. Foram os ecos dessa primeira geração que seguiram ecoando para movimentar os homossexuais nos anos 1980 e 1990.

Paradoxalmente, foi após o racha do grupo Somos que o movimento homossexual realizou sua mais organizada e contundente ação política de questionamento à violência policial durante a ditadura: o ato público contra as rondas do delegado Richetti, em São Paulo, como será visto a seguir.

\footnotetext{
${ }^{631}$ Assim foi redigida a nota comemorativa do GGB: "Com todas essas adesões e significativo apoio popular com mais de 16 mil assinaturas, finalmente aos 9 de fevereiro de 1985, o Conselho Federal de Medicina atendeu nossa reivindicação, deixando a homossexualidade de ser enquadrada no código 302.0 e passando para o código 2062.9, "outras circunstâncias psicossociais", ao lado do "desemprego, desajustamento social, tensões psicológicas". Como o "CID" inclui também códigos não relativos a doenças, os quais servem unicamente para codificar motivos de atendimento médico, a partir de então a homossexualidade deixou de ser considerada "desvio e transtorno sexual", para tornar-se apenas uma estatística do atendimento médico. Assim sendo, não há mais nenhuma lei, nem código no Brasil que se refira à homossexualidade como "patologia". Portanto é legal ser homossexual, é saudável ser homossexual. Nossos agradecimentos a todos que com sua assinatura e empenho colaboraram com o GGB nesta histórica vitória". BOLETIM DO GRUPO GAY DA BAHIA. Ano IV. № 11. Julho de 1985.

${ }^{632}$ Uma análise da dimensão jurídica e legislativa deste tema pode ser encontrada in: BAHIA, Alexandre; MORAES, Daniel. O longo caminho contra a discriminação por orientação sexual no Brasil no constitucionalismo pós-88: igualdade e liberdade religiosa. Revista Libertas, Ouro Preto, v. 1, n. 1, jan.jun., 2013. Disponível em: <http://www.libertas.ufop.br/Volume1/n1/volln1-2.pdf>.
} 
- Capítulo 5 -

\section{LAMPIÃO DA ESQUINA}

\section{"O rei do gay power vem aí"}

Em 30 de agosto de 1977, o jornal Folha de São Paulo, em uma seção de seu colunismo social, publicou uma nota chamando a atenção para a iminente chegada de Winston Leyland ao Brasil. Intitulada "O rei do gay power vem aí", a pequena matéria iniciava conclamando os homossexuais brasileiros com a seguinte mensagem:

Atenção poetas-namorados, correi, voai, saltitai: é chegada a hora de dar bandeira em São Francisco, o paraíso. Escrevam, escrevam muitos poemas, porque vem aí o diretor da revista Gay Sunshine, Winston Leyland, à procura de material bem fresquinho para uma antologia de textos latinoamericanos.

De fato, em outubro de 1977, conforme anunciado, Leyland, editor do mais importante jornal literário do movimento homossexual dos EUA, o "Gay Sunshine", fundado em São Francisco e contando então com mais de 30 mil leitores, visitou o Brasil por mais de um mês, percorrendo capitais como Rio de Janeiro, Belém, Natal, Salvador e São Paulo.

Nascido na Inglaterra em 1940, o editor mudou-se para os EUA quando tinha apenas 12 anos e chegou a ser ordenado padre em 1966, mas deixou a Igreja dois anos depois por conta da atitude desta em relação ao Vietnã e pela rigidez eclesiástica, de modo geral. Desde 1971, ele já dirigia esse jornal trimestral, que contava com a colaboração de escritores gays célebres, como Tennessee Williams, Gore Vidal, Allen Ginsberg e Jean Genet.

Hospedado inicialmente no Rio, pelo advogado João Antônio Mascarenhas, o "papa da homossexualidade", como alguns o chamariam, veio ao país para aprofundar sua pesquisa sobre literatura e arte na América Latina, com um enfoque na sexualidade. Segundo declaração do editor ao jornal Folha de São Paulo,

vim ao Brasil com o objetivo de coligir material para uma antologia 'gay' de poetas e prosadores latino-americanos, que deverá ser publicada em 1978. A editora da qual sou diretor, recebeu uma subvenção da "National Endowment for the Arts", um órgão financiado pelo Congresso dos Estados Unidos. 
Sobre o Brasil, que Leyland ainda estava conhecendo, sua impressão era no sentido de que

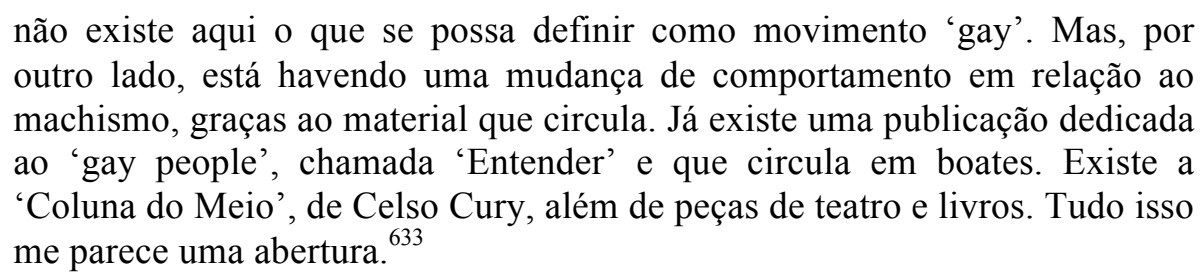

Mas mal sabia Leyland que sua visita ao Brasil teria o efeito de catalisar a vontade ainda incipiente e bastante dispersa de diversos intelectuais e ativistas no sentido de organizar uma publicação voltada especificamente para o público homossexual.

Com efeito, o grupo de jornalistas homossexuais assumidos que se articulou inicialmente em torno de João Antônio Mascarenhas, com o objetivo primeiro de entrevistar Leyland para uma matéria no Pasquim, acabou dando o pontapé inicial no projeto de uma publicação feita por homossexuais e voltada para os grupos minoritários.

\section{"Ocupando um lugar certo no mundo, inclusive politicamente"}

À frente da iniciativa, estavam figuras importantes da cena cultural carioca e paulista, além de intelectuais de prestígio, ainda que jovens, na universidade, no jornalismo e nas letras: os jornalistas Adão Costa, Aguinaldo Silva, Antônio Chrysóstomo, Clóvis Marques, Francisco Bittencourt, Gasparino Damata e João Antônio Mascarenhas; o artista plástico Darcy Penteado; o crítico de cinema Jean-Claude Bernardet; o escritor João Silvério Trevisan e o antropólogo Peter Fry. Alguns deles, como Aguinaldo, Bernadet e Trevisan, já haviam tido uma experiência de militância política nos grupos de oposição à ditadura.

Este grupo foi ampliado com a entrada de outros interessados e, para financiar o jornal, nove dos onze idealizadores cotizaram para criar uma editora. Além disso, fizeram uma campanha de arrecadação, mandando cartas para 12 mil amigos e amigos dos amigos homossexuais de todo o Brasil. Conforme relata MacRae, a recepção foi muito boa e o montante arrecadado financiou os dois primeiros números do jornal, que tinha formato de tabloide, com 20 páginas e uma tiragem mensal que oscilava entre 10 e 15 mil impressos ${ }^{634}$. A

\footnotetext{
${ }^{633}$ Folha de São Paulo, 3 de outubro de 1977, p. 21.

${ }^{634}$ MACRAE, Edward. A construção da igualdade: identidade sexual e política no Brasil da "abertura". Campinas: Editora da Unicamp, 1990, p. 72.
} 
entrevista com Leyland seria publicada justamente neste novo jornal, mas apenas em seu número 2, de julho de 1978, depois de recusas sucessivas por parte de outras publicações ${ }^{635}$.

Aguinaldo Silva, colaborador regular do jornal Opinião e membro do Conselho do Movimento, seria o futuro editor deste novo jornal e anunciara, na Revista Isto é, de 28 de dezembro de 1977, na matéria "Plataforma para o 'gay", mais detalhes sobre aquele periódico ainda em gestação. Segundo ele,

quanto ao jornal que estamos fazendo, queria dar algumas informações a respeito: ele vai ser nacional - tablóide, 32 páginas, 10 mil exemplares - e provavelmente vai comprar, no primeiro número, a briga do Celso Couri ('Coluna do Meio'), a briga da Leda Flora (aquela que denunciou ao Congresso a discriminação sexual) e a briga dos negros brasileiros que as multinacionais do disco-dance querem transformar em blackie brothers. ${ }^{636}$

Com uma crítica à estigmatização recorrente dos homossexuais na grande imprensa que se referia a eles como seres que viveriam apenas nas sombras, experimentando sua sexualidade como maldição e como desgraça, Aguinaldo pontuava que havia uma maioria “tentando viver exatamente como as outras pessoas - quer dizer, 'batalhando' pura e simplesmente pelo dia-a-dia". E acrescentava: "é esse lugar que a tal conscientização homossexual pretende ocupar - é esse território que a nossa tropa de choque pretende tomar do machismo" ${ }^{637}$. Frisando ainda a inspiração que o feminismo despertava nesse grupo pioneiro, "não se trata mais dessa coisa de assumir, de ter que 'ser aceito' - nada disso. O que a gente quer é acabar com essa história de que a nossa vida deve ter limites (e aqui a coisa se aproxima muito do movimento feminista)." 638

Esta entrevista, de 1977, evidenciava como, naquela altura, já estavam amadurecidos e bem delineados os contornos que caracterizariam o novo jornal. Aguinaldo, resumindo de maneira bastante objetiva os propósitos da iniciativa, afirmou que não se trataria de

\footnotetext{
${ }^{635}$ Os entrevistadores João Silvério Trevisan e James Lavender, que na verdade era James N. Green adotando um pseudônimo que não o colocasse em risco naquela conjuntura ainda arriscada, sobretudo para um estrangeiro, ofereceram a entrevista ao jornal Movimento, que recusou a matéria por "ser muito longa". Já a Revista Versus rejeitou porque a entrevista poderia "criar problemas com o Cardeal-Arcebispo de São Paulo, com o qual estamos colaborando politicamente; além do mais, somos moralmente contra a matéria em questão". Por fím, o jornal Beijo, que havia manifestado interesse, devolveu a matéria, após 3 meses, afirmando que ela "não era prioritária para o jornal". Cf. "Uma entrevista que ninguém ousou publicar: Leyland fala sobre atuação política". Lampião da Esquina, n. 2, julho de 1978, pp. 10-11. Todas as edições do Lampião encontram-se inteiramente disponíveis com acesso livre no seguinte link: <http://www.grupodignidade.org.br/projetos/lampiao-daesquina/>. James N. Green, em entrevista ao autor, discordou dessa versão de que o jornal Versus fosse "moralmente contra" o conteúdo da entrevista.

${ }^{636}$ Revista Isto É, 28 de dezembro de 1977, p. 14.

${ }^{637}$ Revista Isto É, 28 de dezembro de 1977, p. 14.

${ }^{638}$ Revista Isto É, 28 de dezembro de 1977, p. 14.
} 
um jornal que fal[aria] apenas sobre homossexualismo - menos ainda sobre travestis, que essa é outra repartição - e sim um jornal em que essas pessoas apresentem a sua visão do mundo em que vivem, e através do qual mostrem a sua intenção de ocupar um lugar certo - inclusive politicamente - dentro dele. ${ }^{639}$

Pretendia-se, assim, expor o modo de vida de homossexuais de forma a romper com a estigmatização e, ao mesmo tempo, conquistar o reconhecimento de um lugar no mundo, inclusive politicamente.

\section{"Mas um jornal homossexual, para quê?"}

Se a concepção mais geral já parecia definida, era ainda preciso escolher um nome à altura da ousadia desta empreitada. Aguinaldo, na mesma entrevista citada, já sondava batizar o jornal com a denominação que seria a definitiva:

há uma lista imensa, mas o que me agrada é Lampião: primeiro, porque subverte, de saída, a coisa machista (um jornal de bicha com nome de cangaceiro?); segundo, pela idéia de luz, caminho etc; e terceiro, pelo fato de ter sido Lampião um personagem até hoje não suficientemente explicado (olha aí outro que não saiu das sombras). ${ }^{640}$

Assim, "Lampião" combinava a referência ao cangaceiro nordestino "macho" e "valente", que era famoso e temido por sua virilidade, com o sentido de uma fonte de luz capaz de guiar os leitores em meio à escuridão de um regime castrador ou para fora do armário, onde muitos homossexuais ainda se escondiam.

Em abril de 1978, a edição experimental número zero foi lançada ao público, circulando mensal e ininterruptamente até junho de 1981, perfazendo um total de 37 edições em pouco mais de 3 anos de existência. No entanto, por haver um jornal gaúcho homônimo, que era editado desde 1976 por um grupo trotskista vinculado à corrente estudantil "Perspectiva" e a Raul Pont, o jornal passaria a se chamar "Lampião da Esquina", a partir de sua segunda edição. Além de se referir ao nome da empresa editorial ${ }^{641}$, a sugestiva imagem

\footnotetext{
${ }^{639}$ Revista Isto É, 28 de dezembro de 1977, p. 15.

${ }^{640}$ Revista Isto É, 28 de dezembro de 1977, p. 14.

${ }^{641}$ A empresa foi registrada como "Esquina Editora de Livros, Jornais e Revistas Ltda". Trevisan pontua que "o nome registrado do jornal era, na verdade Lampião da Esquina, artifício utilizado apenas para contomar o fato de que alguém anteriormente já patenteara o nome 'Lampião'. Como a empresa editorial se chamava Esquina, o sentido do nome continuava ambivalente" (TREVISAN, João Silvério. Devassos no paraíso: a homossexualidade no Brasil, da colônia à atualidade. São Paulo: Record, 2007, p. 342).
} 
da "esquina" que foi incorporada ao nome remetia a um território urbano tradicionalmente associado à vida noturna marginal das cidades e ocupado por muitos dos gays, lésbicas, travestis e outros grupos "minoritários" aos quais se dirigia a publicação.

O número zero do jornal estreia com um editorial convidativo e, ao mesmo tempo, provocador, revelando de partida uma proposta sofisticada. Com o título "Saindo do gueto", o texto começava com um diagnóstico de conjuntura elaborado, avaliando as potencialidades e limites da "abertura" então em curso no país. "Brasil, março de 1978. Ventos favoráveis sopram no rumo de uma certa liberalização do quadro nacional [...] Mas um jornal homossexual, para quê?" ${ }^{642}$, assim começa o texto de abertura do jornal.

Esta pergunta central seria uma presença constante na trajetória do "Lampião". O que era "ser homossexual" naquele momento? Qual o sentido de uma publicação voltada particularmente para um público marcado por esta identidade em construção? Estas eram questões que tinham a ver com a própria razão de ser de um jornal fundado por pessoas de perfis tão diferentes, ainda que todos fossem homossexuais ${ }^{643}$. É interessante notar como as próprias histórias de vida dos conselheiros, no que se refere à homossexualidade, cruzaram com os propósitos idealizados e realizados do jornal ${ }^{644}$.

A resposta dada coletivamente no ato fundador, contudo, era bastante clara e contundente. Contra a "resposta mais fácil" de "assumir" a cartilha já definida por uma "Grande Consciência Homossexual”, era antes preciso "dizer não ao gueto e, em consequência, sair dele", uma vez que "o que [lhes] interessa[va] [era] destruir a imagem padrão que se faz[ia] do homossexual, segundo a qual ele [era] um ser que viv[ia] nas sombras, que prefer[ia] a noite, que encara[va] a sua preferência sexual, como uma espécie de maldição" ${ }^{645}$.

Questionava-se, assim, a existência de uma única identidade homossexual confinada nos guetos e estigmatizada pela associação recorrente com o submundo da criminalidade, da corrupção moral e das drogas.

\footnotetext{
${ }^{642}$ "Saindo do gueto". Lampião da Esquina, n. 0, abril de 1978, p. 2

${ }^{643}$ Nessa primeira edição, o artigo "Senhores do Conselho" apresenta brevemente os onze criadores do jornal, que estariam encarregados de "traçar a linha editorial". "Senhores do Conselho". Lampião da Esquina, n. 0, abril de 1978, p. 2. Um fato ressaltado sobre a composição do Conselho era a ausência de mulheres. Segundo Trevisan, isto se deveu a uma recusa de diversas artistas e jornalistas contatadas: "é preciso registrar que mulheres (artistas e jornalistas) contatadas, no período, negaram-se terminantemente a colocar seus nomes no jornal. Daí porque era toda constituída de homens" (TREVISAN, João Silvério. Devassos no paraíso: a homossexualidade no Brasil, da colônia à atualidade. São Paulo: Record, 2007, p. 321).

${ }^{644} \mathrm{Um}$ trabalho interessante de registro e análise de história oral de vida para recuperar uma narrativa sobre o período do Lampião pode ser encontrado em: SILVA, Claudio Roberto da. Reinventando o sonho: história oral de vida política e homossexualidade no Brasil contemporâneo. (Dissertação de Mestrado). São Paulo, FFLCH/USP, 1998.

645 “Saindo do gueto". Lampião da Esquina, n. 0, abril de 1978, p. 2.
} 
Caracterizando os homossexuais como uma "minoria oprimida" que "precisa de voz", a proposta do jornal politizava esta condição e inovava ao postular:

Lampião reivindica em nome dessa minoria não apenas se assumir e ser aceito - o que nós queremos é resgatar essa condição que todas as sociedades construídas em bases machistas lhes negou: o fato de que os homossexuais são seres humanos e que, portanto, têm todo o direito de lutar por sua plena realização, enquanto tal. ${ }^{646}$

Afastando-se da tentação de abordar o tema da sexualidade de modo apenas negativo, como se os homossexuais fossem somente vítimas e não sujeitos da sua própria condição, ora por opção, ora por essência, o jornal se propunha a tratar não apenas "da discriminação, do medo, dos interditos ou do silêncio", como algumas das diversas facetas da violência homofóbica, mas também "soltar a fala da sexualidade no que ela tem de positivo e criador" ${ }^{647}$. A própria utilização da linguagem ferina e popular do meio homossexual, com o abuso de palavras outrora consideradas pejorativas como "bichas-loucas" e "bonecas", seria uma constante nos textos publicados.

Isto significava uma enorme ruptura com os modos já estabelecidos de tratamento das sexualidades dissidentes pelos veículos de comunicação. Na imprensa, por exemplo, a representação do homossexual era sempre feita de modo a estigmatizar e discriminar as sexualidades dissidentes. Esse público tinha lugar cativo e garantido nas seções policiais, sempre associados à criminalidade, ou nas abordagens satíricas, por meio de charges e ilustrações. Glauco Mattoso, em "Não me espreme que eu sangro!”, criticou o sensacionalismo de jornais deste período, como Notícias Populares e O Dia, que utilizavam a imagem de homossexuais para propagar o discurso de que "bicha quando não é apenas doente, é delinquente". Os homossexuais só eram retirados do gueto e visibilizados para a desqualificação de seu caráter ou integridade. Para Glauco, esta estratégia da imprensa fazia com que "os homossexuais acaba[ssem] visados em qualquer caso. Se [eram] eles as vítimas, [era] bem feito. Se [eram] eles os acusados, tanto pior”, consagrando-se, assim, uma ideologia que "enfatiza[va] a homossexualidade da vítima quando vítima e do acusado quando acusado", que "associa[va] homossexualidade com crimes" e "conclu[ía] que homossexual [era] sinônimo de criminoso" 648 .

Mesmo nos jornais menos sensacionalistas, quando as homossexualidades não eram

\footnotetext{
646 "Saindo do gueto". Lampião da Esquina, n. 0, abril de 1978, p. 2

647 "Saindo do gueto". Lampião da Esquina, n. 0, abril de 1978, p. 2

648 "Não me espreme que eu sangro!". Lampião da Esquina, n. 4, setembro de 1978, p. 5.
} 
retratadas de forma pejorativa, elas acabavam silenciadas ou interditadas. Quanto à Folha de São Paulo, por exemplo, Trevisan relatou que a palavra "lésbica" fora riscada de uma matéria $^{649}$. Daí também a revolta de Darcy Penteado quando escutou em um jantar, certa vez, uma amiga sua enunciar que os jornalistas do Lampião já ocupavam espaço em outros veículos da imprensa tradicional e, assim, teriam voz para expressar suas demandas. Ao que ele respondeu nas páginas do próprio jornal:

Você acha, por exemplo, que tudo isto que temos dito e continuaremos dizendo nas páginas de LAMPIÃO teria vez na imprensa hétero? A palavra 'homossexualismo' e suas decorrentes chegam a ser proibidas ainda em alguns jornais. A citação 'lésbica' foi cotada no artigo de um dos nossos colaboradores para um tabloide da imprensa alternativa. Vários desses mesmos tabloides que se apregoam contrários ao poder estabelecido, portanto, vanguardistas políticos, negam a vez e a participação aos assuntos sexuais 'por não serem prioritários'[...] Portanto, Darling, aqui estão algumas das muitas razões de LAMPIÃO ter sido aceso, no momento exato e necessário ${ }^{650}$.

Neste cenário, ser abertamente homossexual era necessário, mas não suficiente. Como proposta de emancipação, não se reivindicava, portanto, mera "adesão ao sistema" por parte dos homossexuais, mas, ambiciosamente, pretendia-se "ir mais longe, dando voz a todos os grupos injustamente discriminados - dos negros, índios, mulheres, às minorias étnicas do Curdistão: abaixo os guetos e o sistema (disfarçado) de párias" ${ }^{651}$. Mais do que libertar apenas os homossexuais, o programa anunciado consistia, assim, em uma declaração de compromisso com os demais setores oprimidos da sociedade, cujas demandas não encontravam eco, naquele momento, sequer nos grupos oposicionistas da ditadura.

\section{Homossexuais e "nanicos": Lampião na imprensa alternativa}

O contexto político no qual se deu o surgimento do jornal era bastante ambíguo. De um lado, o autoritarismo exausto da ditadura, depois de mais de uma década de contenção de resistências, tentava aproveitar o capital político que ainda lhe restava para impor uma agenda

\footnotetext{
649 "Eu próprio vi, riscado e corrigido por editores da Folha, certo artigo escrito por um jornalista amigo meu, no qual a palavra 'lésbica', então proibida de aparecer nas páginas do jomal, tinha sido mais de uma vez substituída pela palavra 'feminista'. Isso ocorreu no final da década de 1970" (TREVISAN, João Silvério. Devassos no paraíso: a homossexualidade no Brasil, da colônia à atualidade. São Paulo: Record, 2007, p. 362).

650 “Não seja tão boba, Darling!". Lampião da Esquina, n. 4, setembro de 1978, p. 2.

651 "Saindo do gueto". Lampião da Esquina, n. 0, abril de 1978, p. 2
} 
de liberalização e de abertura "lenta, gradual e segura" "652. Além disso, as denúncias das violações de direitos humanos e a rearticulação das oposições disputavam o ritmo e a intensidade da transição em curso. De outro, contudo, nada ainda indicava que a liberalização iria tão longe a ponto de logo alcançar o campo dos costumes, e tampouco parecia que os homossexuais seriam beneficiados diretamente por quaisquer mudanças. Isto porque a censura moral e as perseguições institucionalizadas às sexualidades não normativas seguiam firmes, a despeito das promessas de novos ares trazidos pelo incipiente processo de redemocratização.

Por isso, o movimento de articulação dos homossexuais que encontrou no Lampião um eco privilegiado propunha, em lugar da abertura "lenta, gradual e segura", o direito ao prazer e ao orgasmo "amplo, geral e irrestrito", parafraseando a principal bandeira da luta pela anistia que se desenrolou durante a década de 1970. Nas palavras provocadoras de Gabeira, que se tornaram uma espécie de lema emblemático desse movimento depois de uma entrevista concedida ao Lampião: "não se pode esperar 70 anos para ter um orgasmo quando a esquerda fizer uma revolução"653.

Tal postura significava, de imediato, uma afronta direta à ditadura, ao regime cujos esteios estavam fixados em uma moral conservadora que repelia o prazer e o desejo, sobretudo os homossexuais. No entanto, reivindicar a liberdade de orientação sexual e de identidade de gênero também representava um desafio bastante incômodo aos partidos e grupos vinculados aos setores mais tradicionais da esquerda, inclusive na imprensa, que não detinham ainda acúmulo e, muitas vezes, sequer abertura para esta agenda específica.

Neste sentido, o Lampião produziu certo estranhamento até mesmo no campo da chamada "imprensa alternativa". Esta alcunha era utilizada para designar a renovação em curso da imprensa escrita, com a proliferação de mais de 150 periódicos que surgiram em franca oposição à ditadura, embalados por jornalistas com perfil ativista.

Kucinski chegou a caracterizar este movimento como um "surto alternativo",654. Duas

\footnotetext{
${ }^{652}$ Em uma interessante conferência pronunciada no Congresso Nacional, em outubro de 1973, a convite do Instituto de Pesquisas e Estudos de Assessoria do Congresso (IPEAC), o cientista político Wanderley Guilherme dos Santos formulou um esquema analítico que pareceu antecipar a política oficial de abertura a partir de 1974 . Sustentava ele: "a política de descompressão deve ser uma política incrementalista, isto é, implementada por aproximações sucessivas, provocando modificações marginais no estado de coisas prevalecentes. Quer isto dizer que se trata de uma política de avanços moderados, introduzindo-se uma inovação de cada vez, enquanto se mantém sob controle o resto do sistema". Cf.: SANTOS, Wanderley Guilherme dos. Estratégias de descompressão política. In: Poder \& Política: crônica do autoritarismo brasileiro. Rio de Janeiro: Forense Universitária, 1978, p. 153.

653 "Fernando Gabeira fala, aqui e agora, diretamente dos anos 80". Lampião da Esquina, n. 18, novembro de 1979, p. 6.

${ }^{654}$ Ainda que alguns utilizem a expressão "imprensa nanica" para referenciar esse mesmo fenômeno, esta soa um tanto pejorativa e não capta os quatro sentidos essenciais que o adjetivo "alternativa" carrega: "o de algo que não está ligado a políticas dominantes; o de uma opção entre duas coisas reciprocamente excludentes; o de única
} 
foram as classes de jornais que circularam no período: os jornais "estritamente políticos", que tinham "raízes nos ideais de valorização do nacional e do popular dos anos de 1950 e no marxismo vulgarizado dos meios estudantis nos anos de 1960"; e aqueles mais voltados à crítica dos costumes e à ruptura cultural com o moralismo, inclusive das esquerdas da época, com "raízes justamente nos movimentos de contra-cultura norte-americanos e, através deles, no orientalismo, no anarquismo e no existencialismo"

O Lampião constituiu-se como um dos mais notáveis representantes deste segundo tipo de publicações, emergindo do cruzamento da emergência de uma comunidade homossexual com o fortalecimento da imprensa alternativa. Mas, mesmo dentro deste processo mais amplo de renovação da mídia, o Lampião se destacava por tematizar a sexualidade e os costumes de um modo muito mais ousado do que seus pares "nanicos", que ainda permaneciam um tanto vinculados a organizações mais tradicionais da oposição à ditadura, excetuando-se os jornais feministas que, sem depositar ilusões à direita, já rompiam com as amarras que determinados setores da esquerda representavam para o avanço das lutas das mulheres.

\section{Imprensa "rosa-choque"}

Ainda que pudesse ser lido como um capítulo específico da "imprensa alternativa", com muitas proximidades e afinidades com alguns jornais deste grupo, o Lampião também se vinculava a uma outra tradição mais longa de boletins e panfletos editados pelos homossexuais e voltados para eles.

Diversas publicações surgiram no decorrer dos anos 1960 para o público LGBT. O mais duradouro e influente, sem dúvida, foi o periódico caseiro $O S n o b$, editado a partir de 1963, no Rio de Janeiro, por iniciativa de Agildo Guimarães, com quase 100 números publicados. Entre 1964 e 1969, mais de 30 jornais do gênero, inspirados por $O$ Snob passaram a circular em diversas partes do país ${ }^{656}$.

Ao reconhecer que os primórdios da luta homossexual no Brasil se confundem com os esforços de fazer valer uma “imprensa guei”, Leila Miccolis publicou um artigo no Lampião

saída para uma situação difícil e, finalmente, o do desejo das gerações dos anos de 1960 e 1970, de protagonizar as transformações sociais que pregavam”. In: KUCINSKI, Bernardo. Jornalistas e revolucionários: nos tempos da imprensa alternativa. Edusp, 2001. p. 5.

${ }^{655}$ KUCINSKI, Bernardo. Jornalistas e revolucionários: nos tempos da imprensa alternativa. Edusp, 2001. p. 5

${ }^{656}$ GREEN, James Naylor. Além do Carnaval: a homossexualidade masculina no Brasil do século XX. São Paulo, Unesp, 2000, p. 298. 
que funcionava como uma espécie de inventário, ainda que parcial, das publicações especializadas ou das colunas voltadas exclusivamente à comunidade homossexual.

Segundo ela, ainda na década de 1960, foi criada a Associação Brasileira de Imprensa Gay (ABIG), presidida por Anuir Farah e o travesti Tabula Morgani, com reuniões na redação de O Estábulo, em Niterói, e com representantes da imprensa "entendida" ou "rosa choque", como gostavam de se rotular $O$ Snob (de Agildo Guimarães, Rio), La Femme, Subúrbio à Noite, Le Vic, Le Sophistique (de Campos), O Felino, Mito, Darling e os jornais de Salvador: La Saison Gay Society, Fotos e Fofocas - o primeiro jornal a cores segundo seu editor Waldeiton Di Paula -, Baby, Zéfiro, Little Darling (posteriormente Tiraninho) e Elo, todos mimeografados e distribuídos de mão em mão nos pontos de encontros homossexuais ${ }^{657}$.

Havia, também, seções dedicadas ao público homossexual em jornais mais convencionais, que veiculavam notas sociais e amenidades, tais como o Tudo Entendido (de Fernando Moreno, na Gazeta de Notícias, Rio), Guei (de Glorinha Pereira, no Correio de Copacabana, Rio) e Coluna do Meio (de Celso Curi, na Última Hora, São Paulo). Entre as pequenas e mais caseiras publicações, destacavam-se: Gente Gay e Gay Press (Rio, ambos xerocados, 100 exemplares), Aliança dos Ativistas Homossexuais (RJ), e, por fim, o já mais expressivo Entender, o primeiro jornal impresso guei, com tiragem inicial de 10 mil exemplares (distribuído mão a mão) e Jornal do Gay (depois Gay News), estes últimos vendidos em bancas de jornais (SP) ${ }^{658}$.

\section{Uma luz nas trevas}

Deste modo, ainda que não tenha sido o primeiro jornal voltado exclusivamente ao público gay e fosse tributário dessa tradição da imprensa "rosa-choque", o Lampião foi inovador sob diversos aspectos e por diferentes razões. Primeiramente, deve-se destacar que se tratou do primeiro dos jornais gays com circulação nacional, pois as publicações do gênero que circularam nos anos 1960 eram "distribuídas de maneira clandestina e quase sempre gratuitamente" ${ }^{\natural 59}$. Além disso, o fato de ter sido concebido e posto em funcionamento durante a ditadura, mais especificamente durante a liberalização do regime, estimulou uma maior politização do conteúdo do jornal.

Com efeito, o contexto peculiar da abertura fez com que a chama do Lampião se

\footnotetext{
${ }^{657}$ MICCOLIS, Leila. “28 de junho, um dia de luta”. Lampião da Esquina, n. 27, agosto de 1980, p. 4.

${ }^{658}$ MICCOLIS, Leila. “28 de junho, um dia de luta”. Lampião da Esquina, n. 27, agosto de 1980, p. 4.

${ }^{659}$ PÉRET, Flávio. Imprensa gay no Brasil. São Paulo: Publifolha, 2011, p. 51.
} 
acendesse, coincidindo, historicamente, com os primeiros passos ensaiados pelo movimento homossexual brasileiro, o que fez do jornal uma espécie de porta-voz desse sujeito coletivo e ainda amorfo que se organizava politicamente. Tornou-se, assim, um instrumento fundamental de conscientização e amplificação das ações do movimento e também de suas disputas. As relações do jornal com os grupos militantes eram intensas e próximas, sempre oferecendo um espaço aberto para a divulgação das atividades desses coletivos do movimento e reverberando as reivindicações mais urgentes em cada momento.

Tanto foi assim que membros do Somos, em uma entrevista publicada na edição de setembro, de 1979, destacaram essa admiração pelo jornal e o modo como a existência deste revertia a favor do grupo Somos. Nas palavras da militante identificada como Teka,

até o LAMPIÃO aparecer, não existia nada, mas nada mesmo, comparável nas bancas, nos jornais, no cinema, na tevê. Não existia nada que pudesse nos dar esperança, criar a possibilidade de um trabalho coletivo. A sobrevivência do Somos depende do LAMPIÃO como canal, e da própria atuação do grupo. Só o trabalho intenso do grupo, o trabalho de organização, é que está fazendo as pessoas pintarem no Somos. ${ }^{660}$

Esta característica fez com que o Lampião cumprisse um papel fundamental para decantar uma memória das lutas homossexuais dentro e fora do país, consagrando determinadas efemérides e bandeiras do movimento e fornecendo elementos para as construções identitárias de homossexuais - gays-machos, bichas-loucas, bonecas, veados, travestis e transexuais - que marcaram toda uma geração no Brasil.

Outra singularidade deste mensário em relação a seus antepassados foi que, pelo perfil intelectualizado e experiência profissional dos jornalistas que integravam o Conselho Editorial, o Lampião foi marcado por uma notável qualidade literária e política no tratamento de temas polêmicos e atuais para aquela época, extrapolando, ainda que não negando totalmente, as fofocas, as amenidades e o colunismo social.

Do ponto de vista do projeto gráfico, "de formato tabloide, o jornal não trouxe nenhuma novidade" ${ }^{, 661}$, afastando-se, conscientemente e, inclusive, com um discurso crítico que apareceu em algumas edições, das revistas gays norte-americanas da época que se caracterizavam por diagramações sofisticadas. Ainda que contasse com um artista plástico bastante conhecido dentre seus quadros editoriais, o Lampião era marcado por "manchas

\footnotetext{
660 “O pessoal do Somos (um debate). Lampião da Esquina, n. 16, setembro de 1979, p. 7.

${ }^{661}$ RODRIGUES, Jorge Caê. Um Lampião iluminando esquinas escuras da Ditadura. In: GREEN, James N.; QUINALHA, Renan (Orgs.). Ditadura e homossexualidades: repressão, resistência e a busca da verdade. São Carlos: EDUFSCAR, 2014, p. 96.
} 
gráficas pesadas, pouco claras, uma diagramação dura e de pouca inventividade", o que dava a entender que sua "preocupação maior" era mesmo com seu "discurso verbal". Rompendo com a recorrente associação da homossexualidade ao feminino e, portanto, ao refinamento estético e à delicadeza, a linguagem gráfica se valia de composições visuais padronizadas, com blocos horizontais ou verticais de texto, o que provocava no leitor uma tendência à monotonia e ao cansaço visual. Sintetizando esta crítica, Jorge Caê afirmou com precisão: “é como se a severidade da forma respaldasse a seriedade do conteúdo"662.

No entanto, a despeito da centralidade inegável da homossexualidade em toda a vida do jornal, diferentemente das publicações anteriores que eram dedicadas exclusivamente ao gueto gay, o periódico se propôs, logo de início, a não se restringir à defesa apenas dos gays. Antes, o Lampião efetivamente se comprometeu com a agenda de reivindicações dos diversos grupos oprimidos, propondo um programa interseccional que pautava um formato de ação política radicalmente democrático e plural. A repressão às homossexualidades, assim, passava a ser discutida de maneira mais séria, pois estas eram vistas como uma das muitas "minorias" oprimidas que deveriam se organizar para sua própria libertação ${ }^{663}$.

Exemplo disso é que, mesmo com o perfil exclusivamente masculino do Conselho, o que foi criticado por ativistas mulheres, o jornal foi progressivamente cada vez mais ocupado por elas. Diante das primeiras cobranças, Aguinaldo conclamou todas a aportarem suas contribuições:

que se reúna um grupo de mulheres e faça uma matéria sobre homossexualismo feminino para o Lampião. Que elas pautem a matéria, façam as entrevistas, escrevam, bolem tudo, e depois nos mandem. Nós publicaremos sem reescrever, sem cortar coisas, sem policiar. Tomem vergonha na cara e assumam esse compromisso, meninas; ponham o medo de lado e aceitem o fato de que o jornal é nosso, ou seja: também é de vocês. ${ }^{664}$

E não tardou para que isso acontecesse, pois dois meses depois sairia uma edição destacando na capa o tema "Amor entre mulheres: elas dizem como, quando, onde e

\footnotetext{
${ }^{662}$ RODRIGUES, Jorge Caê. Impressões de identidade: os caminhos da imprensa gay nacional. In: COSTA, Horacio et al. (Orgs.). Retratos do Brasil Homossexual: fronteiras, subjetividades e desejos. São Paulo: Edusp; Imprensa Oficial, 2010. pp. 406-407.

${ }^{663} \mathrm{O}$ foco, contudo, era na perspectiva dos homossexuais masculinos: "embora o Lampião inicialmente tenha se apresentado como um jornal que uniria mulheres, negros, ecologistas e homossexuais, permaneceu fortemente dirigido ao público homossexual masculino" (GREEN, James Naylor. Além do Carnaval: a homossexualidade masculina no Brasil do século XX. São Paulo, Unesp, 2000, p. 431).

${ }^{664}$ SILVA, Aguinaldo. “Lésbicas vendem mais jornal?” Lampião da Esquina, n. 10, março de 1979, p. 2.
} 
porquêe ${ }^{\prime 655}$. Isto sem falar nos diversos textos que abordavam a violência contra mulheres, o machismo e as mobilizações do movimento feminista e outros assuntos afins, conforme indicado mais adiante.

No que se refere à questão racial, Adão Acosta era o único negro dentre onze membros do Conselho do jornal. Mas esta representação diminuta, ainda que bastante sintomática da dificuldade de negros ocuparem posições de destaque em diferentes meios, não impediu que o racismo fosse frequentemente abordado e duramente combatido nas páginas do Lampião. Houve desde denúncias de casos de discriminação em estabelecimentos comerciais a textos criticando pensadores como Gilberto Freyre, sobretudo por sua tese da "democracia racial”, passando por longas entrevistas com militantes, intelectuais e artistas negros como Clóvis Moura, Abdias do Nascimento, Zezé Motta e Leci Brandão. Isto sem falar nos artigos que cobriam os atos do movimento negro e os elaborados ensaios do estudioso das questões afro-brasileiras, Rubem Confete, sobre arte e cultura negras ${ }^{666}$.

Um diferencial marcante do Lampião foi o fato de ele contar com a participação constante dos leitores, com publicação de suas longas mensagens na seção "Cartas na Mesa", que chegou a ocupar até três páginas inteiras do jornal ${ }^{667}$, bem como na seção "Ensaios Populares", composta apenas por artigos de leitores ou, ainda, a coluna "Escolha seu roteiro", em que gays davam dicas de atrações turísticas de suas cidades para eventuais visitantes "entendidos". Sem falar, ainda, da coluna "Troca-troca", em que homens e mulheres homossexuais mandavam mensagens contendo anúncios de si mesmos com o objetivo de encontrar possíveis pretendentes para encontros casuais, amizades ou mesmo relacionamentos amorosos mais sérios.

No entanto, os mesmos atributos que se afiguravam como qualidades, até certo ponto inéditas no conjunto do que se poderia designar como uma imprensa gay, também apresentavam alguns efeitos colaterais inconvenientes. Por exemplo, a íntima associação com o nascente movimento homossexual logo traria, para dentro do jornal, os cismas e embates

\footnotetext{
${ }^{665}$ Lampião da Esquina, n. 12, maio de 1979.

${ }^{666}$ Ver, por exemplo: "No Quilombo, o samba é pra valer" (n. 17, outubro de 1979); "Quanto vale o negro brasileiro?" ( n. 19, dezembro de 1979); “IBGE dá golpe nos negros" (n. 20, janeiro de 1980) e "Negros: vítimas da vadiagem" (n. 21, fevereiro de 1980).

${ }^{667}$ Uma interessante análise do processo de "assumir-se" e da criação de uma identidade homossexual na epistolografia do Lampião pode ser encontrada em: SOUTO MAIOR JR, Paulo Roberto. Escrever para inscrever-se: epistolografia homossexual nas páginas do Lampião da Esquina (1978-1981). Revista Tempo e Argumento, Florianópolis, v. 8, n. 19, pp. 254-282. set./dez. 2016. Há, ainda, outro trabalho que analisa uma amostra do total de 229 cartas recebidas pelo Lampião, discutindo as memórias discursivas e a criação de identidades que se deslocaram desde a afirmação de si, passando pelo homossexual político e chegando ao movimento homossexual organizado: SIMÕES JÚNIOR, Almerindo Cardoso. E havia um Lampião na esquina: memórias, identidades e discursos homossexuais no Brasil do fim da ditadura (1978 - 1980). (Dissertação de Mestrado). Rio de Janeiro: UNIRIO, 2006.
} 
entre os diferentes grupos em suas disputas cada vez mais intensas. Ou, ainda, o tom de erudição excessiva que marcava os textos mais longos, algumas vezes, descambou para um tipo de academicismo que mais afastava do que aproximava homossexuais e pessoas trans com menor nível de escolaridade formal em uma sociedade ainda carente de acesso à educação, ainda mais para populações historicamente marginalizadas.

Estes problemas pontuais, no entanto, não comprometeram o impacto do Lampião na chamada "imprensa nanica", que desafiou a ditadura, bem como sua influência em um momento fundacional do movimento homossexual. Diversas das questões que até hoje frequentam os encontros de militância de pessoas LGBT por todo o país foram abordadas e discutidas com argumentação consistente nas páginas do jornal, tais como: a autonomia dos homossexuais frente às outras lutas políticas e suas relações com outros movimentos sociais; os limites da integração dos gays apenas pela via do mercado de consumo; o machismo e a misoginia entre os homossexuais; a condição do gay negro; a diferenciação entre orientação sexual e identidade de gênero despertada pelas travestis e transexuais; polêmicas em torno da prostituição; modos de combater a violência policial, dentre outros.

A impressionante atualidade dos temas trabalhados revela a visão que este grupo pioneiro teve, em uma conjuntura desfavorável de tanta vigilância e controle, para organizar uma publicação antenada no que de mais recente e inspirador era produzido no movimento gay internacional, dialogando com veículos e conectado a outros grupos estrangeiros, além de mostrar-se permeável e aliado a diferentes movimentos sociais brasileiros, constituindo uma rica rede de colaboradores entre feministas, negros, ambientalistas e grupos pró-indígenas.

\section{"Pelo orgasmo amplo, geral e irrestrito"}

Como já foi mencionado, o jornal era editado no formato tabloide, com 20 páginas em média, dividido em diversas seções, compostas cada uma por um ou mais textos, geralmente assinados por um dos jornalistas do Conselho ou por colaboradores.

Ainda que tenha havido mudanças ao longo do tempo, as seções mais presentes nos jornais eram: "Opinião", com a linha editorial do jornal; "Reportagem”, sobre variados temas; "Entrevistas", com figuras públicas, artistas e ativistas ligados ao universo homossexual; "Esquina", com textos de diferentes formatos, desde mais ensaísticos até traduções de textos mais teóricos sobre o comportamento homossexual; "Ensaio", com contribuições mais livres em torno de temas mais abertos; "Tendências", que funcionava como uma coluna de dicas 
culturais, críticas e resenhas que se subdividia em "o livro", "o disco", "a peça", "a exposição", "o show", "Literatura"; "Ensaios Populares", que publicava artigos de leitores; "Cartas na Mesa", com inúmeras cartas enviadas com respostas bem-humoradas; "Badalo", que era composta sobretudo por notícias estrangeiras traduzidas sobre temas LGBT; "TrocaTroca", que era uma espécie de correio elegante com anúncios gratuitos para amizades "ou algo mais"; Ativismo, que trazia informações sobre a atuação dos grupos do movimento homossexual e estimulava adesões; "Festim", sobre badalação e atrações noturnas; "Bixórdia", produto da fusão das palavras "bicha" e "mixórdia", sob comando da personagem fictícia Rafaela Mambaba, uma “ignorante, beberrona e falaz" que comentava sempre ironicamente os últimos acontecimentos e fofocas; Dodô Darling, outra personagem misteriosa que editava a coluna "Pensamento do Mês", com pérolas de humor como "Não cuspa no prato que comeu"; "Bate/boca", que continha textos com posições opostas sobre temas considerados polêmicos à época, como o bissexualismo; "Bofarada" ou "Os meninos do Lampião" apresentavam ensaios sensuais com fotos de homens nus, dentre outras colunas mais eventuais.

Ainda que a publicidade no jornal nunca tenha sido muito expressiva, sempre havia alguns anúncios de galerias de arte, de profissionais como médicos e advogados, saunas, boates e depilação. Mas as maiores propagandas, que ocupavam quase páginas inteiras, eram de filmes e atrações teatrais ou mesmo de livros publicados por escritores gays. Na seção "Biblioteca Universal Guei”, assídua em quase todos os números e com um catálogo cada vez maior, eram divulgados e vendidos, por um serviço de remessa postal, inúmeros títulos de literatura de temática homossexual feita por homossexuais, que abrangiam tanto autores já consagrados, quanto os ainda jovens. Muitas das obras, de prosa ou de poesia, eram de autoria dos próprios jornalistas do Lampião.

Dentre as entrevistas com personalidades e artistas, geralmente longas, em clima bem informal e feitas por diversos jornalistas do Lampião junto com o convidado, merecem destaque as que foram realizadas com Lennie Dale (do Dzi Croquettes) e outra com Winston Leyland, do Gay Sunshine Press ${ }^{668}$, com a atriz Norma Bengell ${ }^{669}$, com o ativista negro Clóvis Moura e outra com Clodovil Hernandez ${ }^{670}$, com a cantora Leci Brandão ${ }^{671}$, com a travesti Mônica Valéria, que ganhava a vida nas ruas da Lapa ${ }^{672}$, com o cantor Ney Matogrosso ${ }^{673}$,

\footnotetext{
${ }^{668}$ Ambas no n. 2 de julho de 1978.

${ }^{669}$ n. 3, agosto, de 1978.

${ }^{670}$ Ambas no n. 4, setembro, de 1978.

${ }^{671}$ n. 6 , novembro, de 1978 .

${ }^{672}$ n. 7, dezembro, de 1978 .
} 
com o diretor de pornochanchadas Antônio Calmon ${ }^{674}$, com o líder sindical Luiz Inácio Lula da Silva ${ }^{675}$, com o intelectual negro Abdias Nascimento ${ }^{676}$, com a sexóloga Marta Suplicy ${ }^{677}$, com o ex-guerrilheiro Fernando Gabeira ${ }^{678}$, com a atriz negra Zezé Motta e com duas travestis das ruas de São Paulo ${ }^{679}$, com um jovem michê carioca ${ }^{680}$, com a lésbica Ninuccia Bianchi, acusada injustamente do assassinato de sua companheira ${ }^{681}$, com a escritora lésbica Cassandra $\operatorname{Rios}^{682}$, dentre outras. Esta relação demonstra que, tanto pessoas famosas, quanto anônimas, encontraram nas páginas do jornal um espaço para expressão de suas visões e demandas com total liberdade e respeito à diversidade de opiniões.

Em um total de 38 edições, em seus 3 anos de existência, sem contar as 3 publicações extras que circularam com as matérias que causaram maior repercussão, o Lampião abordou alguns temas considerados tabus na época, como uso da maconha ${ }^{683}$, masturbação ${ }^{684}$, educação sexual ${ }^{685}$, transexualidade e travestis $^{686}$, religiões afro-brasileiras ${ }^{687}$, doenças venéreas $^{688}$, sexualidade de pessoas com deficiência ${ }^{689}$, prostituição masculina e feminina ${ }^{690}$, violência psiquiátrica ${ }^{691}$, mulheres e feminismo ${ }^{692}$, racismo $^{693}$, ecologia ${ }^{694}$, sex shops ${ }^{695}$, pedofilia e exploração de menores ${ }^{696}$, dentre outros.

Além disso, a repressão e as agressões contra homossexuais eram um destaque permanente nas páginas do Lampião, que se tornou um instrumento importante de registro e de denúncia das violências sofridas por estes segmentos "minoritários". A perseguição nas

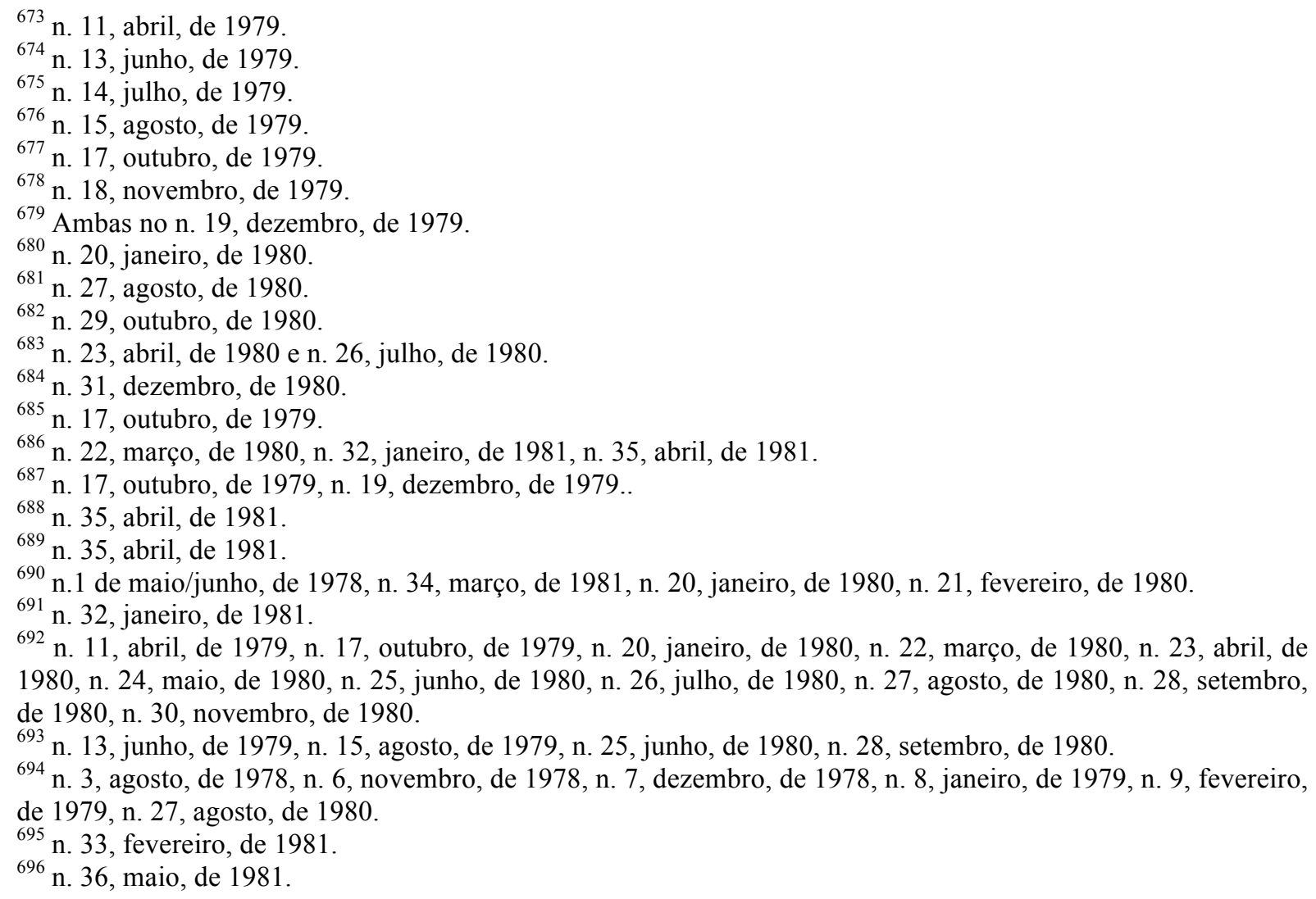


ruas pelas forças policiais, a censura em publicações e na televisão, a conivência do sistema de justiça com posturas preconceituosas e casos de discriminação de empregados no trabalho, também foram algumas das situações que contaram com a cobertura crítica do jornal.

Dentre os textos estrangeiros traduzidos, sempre relativos à situação dos homossexuais em cada um dos países e de suas ações políticas, destacam-se aqueles abordando o socialismo de Cuba, com uma imagem provocadora de Fidel travestido de Carmen Miranda na capa da edição ${ }^{697}$, a ditadura militar argentina, analisada em mais de uma ocasião ${ }^{698}$, o extermínio dos homossexuais nos campos de concentração da Alemanha nazista, além de discussões sobre coletivos e protestos de LGBTs então em curso no México ${ }^{699}$, EUA $^{700}$ e França ${ }^{701}$.

As seções de diversão, entretenimento, turismo e aquelas com certo apelo erótico, como as fotografias de jovens exibindo seus corpos nus, pareciam ocupar, gradativamente, cada vez mais espaço no jornal com o passar do tempo. Esta proposta, que curiosamente se fez mais presente no momento em que a crise do jornal já estava se aprofundando, destoava um tanto do propósito original, que era romper com as publicações anteriores que privilegiavam um colunismo social misturado com divulgação de atrações e com apelo sexual $^{702}$. De qualquer modo, nota-se que as fotografias tinham uma boa recepção conforme indicavam as cartas elogiosas de leitores. Além disso, até certo ponto esta onda também refletia o processo de relativa liberalização da censura à pornografia, apesar das constantes investidas contra esse tipo de publicação ainda neste período, conforme discutido no capítulo 2 do presente trabalho.

Vale notar que o Lampião conseguiu manter-se, apesar das naturais oscilações, por mais de 3 anos, estando sujeito aos diversos tipos de pressão, às disputas sobre os seus rumos e a um equilíbrio interessante entre assuntos sérios e abordagens divertidas - o que lhe permitiu alcançar um público bastante diversificado em todo o território nacional, em um

\footnotetext{
${ }^{697}$ n. 33, fevereiro, de 1981.

${ }^{698}$ n. 7, dezembro, de 1978, n. 21, fevereiro, de 1980, n. 22, março, de 1980, n. 25, junho, de 1980, n. 28 , setembro, de 1980, n. 33, fevereiro, de 1981.

${ }^{699}$ n. 7, dezembro, de 1978.

${ }^{700}$ n. 7, dezembro, de 1978, n. 9, fevereiro, de 1979, n. 10, março, de 1979, n. 19, dezembro, de 1979.

${ }^{701}$ n. 14, julho, de 1979, n. 15, agosto, de 1979, n. 18, novembro, de 1979, n. 22, março, de 1980.

${ }^{702}$ Para Jorge Caê, concordando com MacRae, "o jornal assume características dos jornais sensacionalistas", explorando mais o "corpo e o sexo" depois do fim do Conselho Editorial, que ocorreu a partir do número 32 (RODRIGUES, Jorge Caê. Um Lampião iluminando esquinas escuras da Ditadura. In: GREEN, James N.; QUINALHA, Renan (Orgs.). Ditadura e homossexualidades: repressão, resistência e a busca da verdade. São Carlos: EDUFSCAR, 2014, p. 115). Kucinski chega a afirmar que o Lampião começou "elegante e terminou pornográfico", pois "sua circulação coincidiu com a explosão pornográfica no país em decorrência da abertura e das pressões de uma demanda reprimida pela pornografia" Cf.: KUCINSKI, Bernardo. Jornalistas e revolucionários: nos tempos da imprensa alternativa. São Paulo: Edusp, 2001, p. 73. A colocação de Kucinski é nitidamente exagerada, pois os ensaios sensuais e eróticos nunca foram verdadeiramente pornográficos e nunca foram tão significativos na estrutura do jornal.
} 
momento chave para a constituição das identidades homossexuais ${ }^{703}$.

\section{Lampião sob vigilância: "a propaganda do homossexualismo"}

Apesar dos pesares, o jornal que marcou toda uma geração de gays que começavam a viver fora do armário, com todas as adversidades que isto implicava em um momento de conservadorismo acentuado, não passaria desapercebido aos olhos atentos da ditadura. Foram diversas as modalidades de violência e repressão que atingiram o Lampião e seus editores. A espionagem oficial esteve atenta para o risco que ele representava sobretudo à moral e aos costumes, desde a primeira hora de seus funcionamento.

O Documento da Divisão de Segurança Institucional do Ministério da Justiça, Informação n. 895/78, difundida para o gabinete e de caráter sigiloso, indicava uma preocupação bastante marcada com a possibilidade dos temas da "liberdade do homossexualismo" e da "legalização do aborto serem pautados nas eleições", que seriam realizadas naquele mesmo ano ${ }^{704}$.

Nota-se que, a despeito das poucas chances de vitória eleitoral, o sistema de informação do regime preocupou-se em levar o assunto até o gabinete do Ministro da Justiça, pois o Lampião havia destacado a ausência de candidatos claramente defensores dos direitos dos homossexuais, assim afirmando:

O periódico 'LAMPIÃO DE ESQUINA', publicado pela 'Esquina Editora de Livros, Jornais e Revistas Ltda', do RIO DE JANEIRO/RJ, órgão da imprensa 'nanica' que se dedica à promoção do homossexualismo, em sua edição n. 6, de Nov 78, publicou, na página 4, os artigos intitulados 'E NO DIA 15, A BONECA MORRE AFOGADA?', de DARCY PENTEADO, e 'UM CANDIDATO FALA MAIS ALTO', de AGUINALDO SILVA. ${ }^{705}$

Este último texto era, na verdade, de Baiardo de Andrade Lima, candidato a Deputado Federal pelo MDB de Pernambuco e único político que incluía expressamente a "liberdade do

\footnotetext{
${ }^{703}$ MacRae afirma que havia "grande diversidade de opiniões existentes não só na redação do jornal, mas também entre o seu público leitor", que era bastante heterogêneo em termos de classe, idade, ideologia, localização geográfica. E acrescentou que "apesar deste empenho em manter suas páginas abertas a outros grupos sociais, o Lampião nunca conseguiu ser plenamente aceito como um jornal das minorias", já que seu caráter homossexual terminava "afugentando os segmentos heterossexuais de seu público potencial" (MACRAE, 1990, p. 76).

${ }^{704}$ BR.AN.RIO.TT.0.MCP.PRO. 1567

${ }^{705}$ BR.AN.RIO.TT.O.MCP.PRO.1567
} 
homossexualismo" entre suas promessas de campanha nas eleições de $1978^{706}$.

Outros órgãos de informação expressaram a mesma preocupação em relação à postura do jornal. A Apreciação Especial n.001/19/AC/79, enviada da AC/SNI ao Ministro da Justiça, trazia em anexo um relatório com o assunto "atuação dos órgãos de comunicação social retrospecto do $2^{\circ}$ semestre de 1978 - perspectivas para 1979”. Um dos itens destacados neste balanço pontuava, especificamente, a "propaganda sobre o homossexualismo", que estaria sendo "divulgada, particularmente, através do periódico Lampião da Esquina ${ }^{707}$.

O Lampião tocava em temas delicados, merecendo uma preocupação constante por parte dos órgãos de informação que faziam o monitoramento da imprensa. Isto porque, como já mencionado ao longo deste trabalho, para além de criticar politicamente o regime, o jornal trazia uma proposta nova de integrar-se às lutas democráticas com uma agenda de minorias marginalizadas, até então, dentro do próprio campo oposicionista. O documento do Ministério da Aeronáutica, Informação n. 0854/CISA-RJ, difundido para os demais órgãos de informação, destacava a entrevista do intelectual e militante negro Abdias Nascimento para o jornal, na qual ele afirmava que "mulheres, negros, índios, homossexuais, dev[iam] lutar juntos contra a repressão" ${ }^{\text {,708 }}$, o que logo despertou a atenção da ditadura.

Outras formas de monitoramento e de sanção eram planejadas também pelos órgãos repressivos, como a recomendação dos órgãos de informação para o governo federal boicotar qualquer publicidade governamental no jornal, considerado parte da "imprensa contestatória". A Informação n. 051/19/AC/80, proveniente da AC/SNI, por exemplo,

não recomenda a difusão de anúncios de propaganda por entidades da Administração Pública Federal, em face da prevalência nesses veículos da divulgação de temas hostis ao Governo Federal, como também, em alguns casos, da abordagem de assuntos atentatórios à moral e aos bons costumes". Logo em seguida, constava o Lampião da Esquina, descrito como "periódico da imprensa "nanica" que "defende o homossexualismo e aborda assuntos atentatórios à moral e aos bons costumes. ${ }^{709}$

\footnotetext{
${ }^{706}$ Baiardo, formado em Direito pela Faculdade de Recife, foi o primeiro candidato de que se tem registro histórico a defender abertamente em seu material de campanha a "liberdade gay" e a "legalização do aborto", conforme consta em panfletos por ele distribuídos para essas eleições. No seu texto publicado no Lampião, ele propunha, em sua plataforma, com impressionante postura à frente dos políticos de seu tempo, uma "atitude racional para com pessoas sexualmente anormais, em especial para com os homossexuais, masculinos ou femininos", ressaltando que a palavra "anormal" deveria ser "eliminada, como estimuladora de discriminações e, principalmente, por força de conceitos modernos do que seja normalidade". Cf.: LIMA, Baiardo de Andrade. "Um candidato fala mais alto". Lampião da Esquina, n. 6, novembro de 1978, p. 4.

${ }^{707}$ Segundo o relatório, o segundo semestre de 1978 caracterizou-se pela "atuação adversa de expressiva parcela dos órgãos de comunicação", o que teria sido estimulado "pela ampla liberdade de manifestação do pensamento e da informação, que ensejou a prática de inúmeros abusos”. BR_AN_RIO_TT_0_MCP_PRO_1622

${ }^{708}$ BR_AN_BSB_VAZ_127A_0089

${ }^{709}$ BR_AN_BSB_AA7_001_001
} 
Em 1981, a diretriz foi reafirmada pela Informação n. 202/04/DSI/MJ/346778, de 26 de junho de 1981,na qual a Agência Central selecionou "os principais órgãos da imprensa (jornais e revistas) em que, considerando sua linha de atuação, não se recomenda[va] a difusão de publicidade, anúncios e atos oficiais", tendo sido o Lampião descrito como "mensário que defende o liberalismo [sic] sexual e faz propaganda do homossexualismo",710

Mas o pior não foi esse boicote econômico por parte das entidades da Administração Pública que pouco afetaria um jornal que já nascera independente, apesar das suas dificuldades econômicas permanentes. Diante da ineficácia destas medidas de boicote e da insistência dos órgãos de informação em chamar a atenção para o Lampião, a repressão passou a ocorrer de outras maneiras menos sutis.

\section{“Ofensa à moral e ao pudor público": o inquérito 25/78}

No artigo publicado no Lampião, com o título "Uma capa com muitas estrelas", que não foi assinado individualmente por nenhum dos membros do Conselho do jornal, muito provavelmente para evitar ainda mais exposição, os lampiônicos denunciaram a perseguição mais sistemática que começaram a sofrer no início de 1979, por iniciativa dos órgãos de segurança.

No ano anterior, Aguinaldo já havia sido convocado a prestar depoimento quando o jornal tinha recém-completado seis meses de vida. Conforme registra seu termo de declarações perante o DOPS/SR/DPF/RJ, datado de 24 de novembro de 1978, ele tentava já se esquivar da censura, destacando sua trajetória e outras experiências profissionais ao afirmar ser jornalista há mais de 17 anos, contando com trabalho fixo na Rede Globo e mais de 10 livros publicados de sua autoria. Aguinaldo asseverou que todos os textos eram aprovados pelos conselheiros, em suas reuniões mensais e "que todo o Conselho Editorial do jornal Lampião da Esquina é composto dessa minoria da sociedade, de homossexuais" "711. O grifo no original do documento indicava como a orientação sexual dos editores era uma informação considerada relevante para os investigadores.

O jornalista mostrou-se, ainda, bastante didático ao, aparentemente, tentar aliviar a repressão e despistar uma associação exclusiva do jornal com a homossexualidade, sustentando que "o objetivo fundamental da criação do Lampião da Esquina [era] dar

\footnotetext{
${ }^{710}$ BR_RJANRIO_TT_0_MCP_AVU_0306

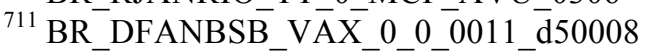


divulgação a matérias de modo geral, e também divulgar notícias sobre uma minoria, que [assim] é considerada perante a sociedade, ou seja os Homossexuais" e que "muito embora inicialmente est[ivesse] predominando sobre matérias referentes ao homossexualismo, dever[ia] modificar sua forma, para dar voz a uma outra minoria”. Ademais, "os artigos escritos pelo declarante não [vinham a] ferir a moral e os bons costumes" ${ }^{712}$.

Mas, apesar de não adotar uma postura de afronta, Aguinaldo não escondia que o jornal pretendia desvincular a homossexualidade da estigmatização que the era geralmente imputada pela imprensa, até porque isso já tinha ficado bastante claro nas primeiras seis edições:

até a fundação do jornal Lampião da Esquina, sempre houve dificuldade para uma publicação limpa sobre o homossexualismo, vez que outros jornais quando fazem referências ao homossexualismo, o fazem de maneira preconceituosa, ligando o homossexualismo a criminalidade. ${ }^{713}$

Não há registro de que o depoimento tenha avançado naquele momento, mas isto não tardaria a acontecer, como se nota em outros documentos disponíveis.

O parecer n. 3348, por exemplo, datado de 22 de dezembro de 1978 e assinado pela técnica de censura Marina de A. Brum Duarte, no âmbito do mesmo inquérito policial 25/78 DOPS, sentenciava que os artigos constantes dos dois primeiros números do jornal Lampião

enquadra[vam]-se na medicina psicológica e part[iam], sem dúvida, de personalidades com problemas comportamentais de natureza sexual, que se configura[vam] nas fronteiras psicológica e judicial e fer[iam] os preconceitos da moral e bons costumes de nossa sociedade heterossexual (Lei censória e seus artigos ) 20.493/46 em seu regulamento. ${ }^{714}$

A censora ainda acrescentava que "essas atitudes públicas [vinham] crescendo precisamente pela liberalidade licensiosa reinante (heterossexual) de revistas, bailes (enxutos), programas (novelas), etc. Que coloca[vam] concomitantemente o homossexualismo na pretensão de se afirmar e concorrer de igual para igual", isto é, "tudo isso ocorr[ia] pela amoralidade crescente da sociedade contraditória e violenta, cujos problemas se avoluma[vam] cada dia que passa"715. Assim, opinava pelo veto do periódico e de sua circulação, sendo que essa opinião consultiva bastante contundente de uma técnica

\footnotetext{
${ }^{712}$ BR_DFANBSB_VAX_0_0_0011_d50008

${ }^{713} \mathrm{BR}$ - DFANBSB VAX ${ }^{-}{ }^{-} 0-0011^{-} \mathrm{d} 50008$

${ }^{714} \mathrm{BR}$ BDFANBSB_VAX_0_0_0011_d50001de0001

${ }^{715}$ BR_DFANBSB_VAX_0_0_0011_d50001de0001
} 
“especializada" do aparato da censura foi determinante para a continuidade do inquérito.

Diante da convocação para a identificação datiloscópica, Agnaldo Ferreira da Silva, Francisco Badaró Bittencourt Filho, Adão José Acosta, Clóvis Marques e Roosevelt Antonio Chrysostomo de Oliveira, todos jornalistas do "Lampião", impetraram o Habeas Corpus n. 4.992 contra o Delegado Chefe da DOPS/SR/DPF/RJ, alegando coação indevida por parte dessa autoridade. O juiz federal Ariosto de Rezende Rocha, do Rio de Janeiro, em 25 de janeiro de 1979, oficiou referida autoridade para prestar esclarecimentos sobre a alegada coação até o dia 26 de janeiro às $14 \mathrm{~h}$.

Em sua resposta, o Delegado de Polícia Federal William Barth alegou que os impetrantes feriram a Lei de Imprensa por ofensa à moral e aos bons costumes, levando à instalação do Inquérito Policial n. 25/78. Depois de receber o parecer censório acima referido, argumentou a autoridade que era impositivo o indiciamento dos impetrantes. Apesar de terem comparecido no dia 23 na Delegacia para ratificar os depoimentos, os impetrantes "todavia, na hora da identificação datiloscópica, se furtaram a cumprir a formalidade legal, através da ingerência de seus advogados"716. Alegou, por fim, que esse tipo de identificação é uma formalidade padrão indispensável ao inquérito, não se constituindo em coação ilegal.

Apesar da tentativa de resistência, no dia 2 de abril de 1979 a investigação teve prosseguimento e cinco dos editores cariocas tiveram de comparecer à sede do Departamento de Polícia Federal, na Praça Mauá no Rio de Janeiro, para serem submetidos a procedimento de identificação criminal. Isto porque, dias antes, haviam sido já identificados os jornalistas Antônio Chrysóstomo, Francisco Bittencourt, Aguinaldo Silva, Clóvis Marques e Adão Acosta. Todos os cinco, membros do Conselho Editorial do Lampião e colaboradores regulares nas páginas do jornal, "foram fotografados de frente e de perfil (e não de costas, como se esperava) e tiveram suas impressões digitais tiradas dezenas de vezes" ${ }^{\circ 717}$, conforme registra ironicamente o periódico, que estampou em sua capa a referida fotografia de todos eles trajando a camiseta listrada de presidiário e com uma placa pendurada no peito com a inscrição "1077” e a data de 2 de abril de 1979.

O número "1077" era uma referência ao decreto editado em 1970 para atualizar as regras da censura, no qual estavam todos sendo enquadrados pela acusação de "ofensa à moral e ao pudor público" segundo matéria do Lampião, além da aplicação da Lei de Imprensa destacada nos documentos da repressão. Apesar de apreensivos, os jornalistas mostravam-se ainda altivos e bem-humorados no artigo de denúncia, reivindicando a imagem do pequeno

\footnotetext{
${ }^{716}$ BR_DFANBSB_VAX_0_0_0011_d50001de0001

717 "Uma capa com muitas estrelas". Lampião da Esquina, n. 11, maio de 1979, p. 3.
} 
Davi contra o Golias, gigante este que representaria a ditadura. Além disso, eles estavam confiantes e até otimistas, como transparecia na nota, pois as "absolvições recentes de Celso Cúri ${ }^{718}$ em São Paulo, e do poeta Nicolas Behr ${ }^{719}$ em Brasília, ambos enquadrados no mesmo item do decreto 1077 mostra qual é a posição da Justiça, a essa altura dos acontecimentos - e da vida nacional quanto a esse tipo de acusação" ${ }^{\text {"720 }}$.

$\mathrm{O}$ artigo até poderia estar correto em apostar, baseado nos casos de Curi e de Behr, que o caso deveria ser arquivado. Mas ainda era cedo demais para que tal afirmação se verificasse na prática, pois o inquérito já havia sido instaurado e se arrastaria por longos 12 meses, como um modo de intimidação e pressão sobre a publicação.

Dias após os depoimentos no Rio de Janeiro, tinha já chegado a vez dos membros do Conselho Editorial residentes em São Paulo - Darcy Penteado, João Silvério Trevisan, JeanClaude Bernadet e Peter Fry, que se livrou por estar em Fortaleza - prestarem depoimentos. Trevisan relatou a dificuldade que a polícia demonstrou, durante a oitiva de depoimentos, para compreender a existência de um jornal gay feito por "viados" que foram prestar depoimentos engravatados como homens e não travestidos de mulheres ou "desmunhecados":

Eu me lembro que, quando chegamos na delegacia, em Higienópolis, o delegado fez o interrogatório errado. Ele confundiu o processo, achando que se tratava de um caso de subversão. Ele nos perguntava: 'Mas quando é que vocês foram para Cuba? O que vocês foram fazer lá?', e foi o escrivão que percebeu o equívoco... ele [o delegado] não estava entendendo nada. ${ }^{721}$

Apesar dos equívocos e aparentes atropelos, o inquérito seguiu seu curso normal e foi definitivamente instaurado. Estranhamente, o inquérito se arrastou durante mais de oito meses sem qualquer ato oficial, dando respaldo à essa pouco habitual extensão de prazo. Mesmo à época, o inquérito já tinha sua duração delimitada para não submeter o investigado $a d$ aeternum ao ônus que advém da investigação criminal.

O relatório do Delegado de Polícia Federal e Chefe da DOPS/SR/DPF/RJ, Miguel de Lacerda Mendes, datado de 9 de agosto de 1978 e dirigido ao Coordenador Regional Policial Edyr Carvalho, apontou que o jornal

\footnotetext{
${ }^{718}$ Ver capítulo 2 deste trabalho.

719 Poeta que escreveu livros mimeografados como "Grande Circular", "Coroço de Goiaba", "Yogurte com Farinha", "Bagaço" e "Chá com Porrada", tendo sido processado, em agosto de 1978, acusado de "porte de material pornográfico". Foi preso com fundamento no art. 234 do Código Penal, que define o crime de comercialização de "objeto obsceno", mas a denúncia foi rejeitada pelo juiz que considerou não configurar crime a poesia, ainda que a tenha criticado na decisão. Ver SANTOS, Pilar Lago. Eu (também) engoli Brasília: poesia e utopia na obra de Nicolas Behr. Dissertação de Mestrado, PUC/SP, 2010, pp. 94 e ss.

720 "Uma capa com muitas estrelas". Lampião da Esquina, n. 11, maio de 1979, p. 3.

${ }^{721}$ PÉRET, p. 54.
} 
apresenta[va] matéria ofensiva à moral e aos bons costumes em suas notas e reportagens, vez que em suas mensagens [havia] um incentivo muito forte à prática do homossexualismo, sempre lastreado em nome de pessoas que conseguiram celebridade, fama e destaque junto à sociedade, devido suas atividades profissionais independentemente de suas preferências sexuais recaírem em parceiros do mesmo sexo, o que requer[ia] a aplicação das medidas em vigor para coibir tais abusos. ${ }^{722}$

A preocupação central continuava sendo, assim, com a "propaganda", o "exibicionismo" e a "apologia" à homossexualidade como uma ameaça à família e aos valores morais conservadores.

Registrava, ainda, o referido relatório, que o fato de "não haver clandestinidade na circulação do jornal", que estava devidamente registrado no Cartório do Registro Civil de Pessoas Jurídicas da capital fluminense, "não exim[ia], até pelo contrário, lhe imp[unha] o dever de respeitar e cumprir as regras de direitos que caracteriza[vam] a política do govêrno na área da moral e dos bons costumes, expressas com absoluta clareza no texto da Lei n. 5250 (Lei de Imprensa)" ${ }^{723}$.

Concluía-se o relatório examinando a linguagem utilizada pelo jornal que "somente pelo aspecto gramatical pod[ia] ser considerada normal, posto que sob o ponto de vista moral [era] acintosamente grosseira, de uma realidade grotesca e chocante"724. Anexo ao documento, encontravam-se as duas primeiras edições do jornal, consideradas "suficientes" como "prova do desrespeito às regras do artigo 17 da Lei 5250", sendo que algumas das gravuras "[eram] audaciosas e obscenas, sem desprezar a licenciosidade dos títulos". Encerrava-se o relatório com requerimento de "instauração do competente IPL".

A autoridade que recebeu este ofício logo despachou, em letras de mão, no próprio documento, o seu "de acordo. A DOPS para proceder na forma sugerida", despacho este de 15 de agosto de 1978. Seguindo esta determinação, consta Portaria sem numeração e datada de 21 de agosto de 1978, em que o Delegado de Polícia Federal e Chefe da DOPS/SR/DPF/RJ Miguel de Lacerda Mendes, com base na Portaria 359-B, do Ministério da Justiça, resolveu instaurar o inquérito policial. O objetivo era

a apuração do responsável ou responsáveis pela publicação, nos ns. 'ZERO' e 'UM' dos meses de 'Abril' e 'Maio', do Jornal 'LAMPIÃO DA ESQUINA', de matéria ofensiva à moral e aos bons costumes, vez que, em

\footnotetext{
722 BR_DFANBSB_VAX_0_0_0011_d50001de0001

${ }^{723}$ BR_DFANBSB_VAX_0_0_0011_d50001de0001

${ }^{724}$ BR_DFANBSB_VAX_0_0_0011_d50001de0001
} 
suas mensagens, [havia] um incentivo muito forte à prática do homossexualismo. $^{725}$

\section{"Quem nos financia?": a devassa nas contas do Lampião}

Diante da dificuldade em interromper a circulação do jornal pela censura direta, que geraria um desgaste elevado, os órgãos de segurança já haviam tentado atacar em outra frente, a contábil. No dia 10 de julho, ao chegar na sede do jornal, um dos lampiônicos deparou-se com um envelope timbrado do Serviço Público Federal. Na carta oficial, constava uma solicitação do delegado responsável pelo IPL 25/78-DOPS que tramitava contra o jornal. O requerimento dizia:

a fim de instruir inquérito policial que ora tramita nesta Regional, solicitamos a V. Sa. se digne determinar providências no sentido de fazer apresentar nesta DOPS ... no dia 13 de julho próximo, às 15 horas, 0 Tesoureiro ou pessoa encarregada da contabilidade relativa à movimentação do jornal Lampião da Esquina, munido das respectivas escriturações ou balancetes relativos aos meses de janeiro a maio de $1979 .{ }^{726}$

A ditadura, neste momento, lançava mão de uma devassa contábil baseada em uma ação administrativa e fiscal que, apesar de formalmente legal, era medida de perseguição política aos veículos considerados "subversivos". Uma perícia dessa natureza já havia sido feita com o jornal Versus em abril de 1979 e também havia culminado, em 1981, na penhora de bens do Tribunal da Imprensa, por conta de débitos previdenciários ${ }^{727}$.

A comunicação gerou grande apreensão, pois era imprevisível até que ponto a repressão poderia criar empecilhos para a continuidade do jornal, mas a solicitação não foi prontamente atendida. Consultado, Luís Celso Soares de Araújo, advogado da Associação Brasileira de Imprensa que assessorava o Lampião, ponderou que "a solicitação era ilegal e arbitrária, e deveria ser ignorada; mas, em nenhum momento deveríamos silenciar sobre isso: era preciso denunciar a arbitrariedade aos jornais" ${ }^{728}$. Conforme noticiou o Jornal de Hoje, que circulava na Baixada Fluminense, em sua edição n. 1472 de 13 de julho de 1979, “o conselho editorial do Jornal 'Lampião' decidiu não cumprir intimidação do delegado de

\footnotetext{
${ }^{725}$ BR_DFANBSB_VAX_0_0_0011_d50001de0001

${ }^{726}$ BR_DFANBSB_VAX_0_0_0011_d 50008

${ }^{727}$ KUCINSKI, Bernardo. Jornalistas e revolucionários: nos tempos da imprensa alternativa. São Paulo: Edusp, 2001. p. 96.

${ }^{728}$ SILVA, Aguinaldo. “De bicha, negro e louco, todos nós temos um pouco: pra que tanto medo?” Lampião, n. 15 , agosto de 1979 , p. 5.
} 
Polícia Federal, José da Silva Morra, para que o diretor responsável pela área financeira comparecesse hoje ao Dops" ${ }^{\text {,729. }}$.

Já em 11 de julho de 1979, dia seguinte à intimação, o Sindicato dos Jornalistas do Município do Rio de Janeiro enviou telegrama ao Ministro da Justiça solicitando providências quanto à devassa que era então realizada nas contas do "Lampião da Esquina". Afirmava a entidade sindical que estavam "animados com declaração de Sua Excelência, o Presidente, contra violência à sucursal mineira do Jornal Em Tempo" ${ }^{730}$, cuja sede havia sido atacada depois de ter sido o primeiro veículo do país a publicar uma lista com os nomes de 233 torturadores.

No entanto, cobrava o Sindicato, em defesa do mensário homossexual, "providências para apuração de responsabilidade e também definição do governo contra exigências na verificação contábil do jornal 'O Lampião' por parte da polícia federal"731. Assim, o requerimento apontava o descompasso existente entre um discurso mais liberalizante e uma prática ainda bastante autoritária do governo quanto à imprensa alternativa. Vale observar que o Sindicato dos Jornalistas, controlado por forças da esquerda organizada, manifestaram um apoio decisivo e contundente ao Lampião, o que, no mínimo, relativiza o argumento de que as esquerdas não se importavam com as lutas dos homossexuais como se se tratassem de algo menor e secundário.

Assim que o expediente chegou ao gabinete do Ministro da Justiça, ele foi analisado pelo assessor Jorge de Albuquerque e Melo, que propôs o encaminhamento ao DPF em 20 de agosto de 1979. Em 30 de agosto do mesmo ano, o chefe do DPF determinou à SR/RJ que informasse "quanto ao procedimento apuratório a propósito da publicação 'O Lampião",732. O expediente, após chegar ao órgão de destino, foi levado aos cuidados do Dr. Motta, em referência ao Delegado de Polícia Federal Bel. José da Silva Motta, então presidente do inquérito, em 10 de setembro de 1979.

Esta autoridade passou, então, a expor, em seu relatório, o andamento do procedimento e sua apreciação quanto ao tema. Segundo ele, o inquérito n. 25/78 foi instaurado

para apurar a responsabilidade criminal dos indivíduos que compõem o Conselho Editorial do jornal LAMPIÃO DE ESQUINA, autores de publicações de matéria ofensiva à moral e aos bons costumes, em flagrante

\footnotetext{
${ }^{729}$ BR_DFANBSB_VAX_0_0_0011_d50008

${ }^{730} \mathrm{BR}$ DFANBSB VAX ${ }^{-}{ }^{-}{ }^{-}{ }^{-} 001 \overline{1} \mathrm{~d} 50001 \mathrm{de} 0001$

${ }^{731} \mathrm{BR}$ _DFANBSB VAX_0_0_0011_d50001de0001

${ }^{732}$ BR_DFANBSB_VAX_0_0_0011_d50001de0001
} 
desrespeito às regras do artigo 17 da Lei 5.250, de 9 de fevereiro de 1967.

Sobre o pedido de vistas dos livros contábeis da editora do tabloide "Lampião", órgão que, conforme o apurado regularmente e com respaldo no Parecer Censório emitido pelo Serviço de Censura e Diversões Públicas/SR/RJ, se dedica exclusivamente à apologia do homosexualismo, queremos aqui esclarecer que a finalidade deste Inquérito é, não só enviar ao Estado-juiz a pretensão punitiva dos indiciados, como, por outro lado, considerando que [...] [a legislação] não tolera as publicações e exteriorizações contrárias à moral e aos bons costumes, solicitar enérgicas providências para a suspensão definitiva do jornal em questão. ${ }^{733}$

Deixa-se claro, assim, que o objetivo não era apenas punir os indiciados, mas cassar o funcionamento do jornal definitivamente, evidenciando uma estratégia mais ampla da ditadura de minimizar o fortalecimento das oposições no contexto da abertura mediante a cassação de seus órgãos de comunicação e de denúncia.

Prosseguia o relatório, seguido de assinatura do Dr. Motta e datado de 20 de setembro de 1979, afirmando que, após analisar a situação financeira bastante pobre do jornal, só poderia consistir em uma iniciativa de ataque ao regime e aos valores morais:

Para atender a tais providências solicitamos, através de ofício, a
apresentação da respectiva escrituração da firma, no que fomos atendidos,
com a qual pudemos provar ser uma empresa sem lucro de qualquer espécie,
com a ínfima tiragem mensal de cerca de 4.000 exemplares, inclusive não
contando com anúncios ou mensagens comerciais em suas páginas, fato este
que nos leva a pressupor, e neste caso a presunção é válida, de que o tablóide
LAMPIÃO DE ESQUINA [sic] tem como finalidade última uma velada
mensagem desagregadora, com vistas à destruição de nossa cultura,
interesses, sentimentos familiares, costumes e aspirações comuns. Ocorre-
nos pensar no emprego de técnicas sub-reptícias de aliciamento, no propósito
nefasto de enfraquecer os valores humanos, então presa fácil a desígnios
inconfessáveis, ou seja, à deterioração da autoridade e da disciplina que cria
condições pessoais que levam a juventude à aceitação de ideologias
estranhas às nossas concepções.

Mas estes documentos que revelavam, sem rodeios, as intenções ocultas, por parte do regime, de fechar o jornal, não eram plenamente conhecidos, pois o processo administrativo mencionado corria em caráter de confidencialidade. Mesmo assim, alguns sinais já indicavam que a medida arbitrária derivava de uma orientação do Centro de Informações do Exército para exterminar a Imprensa Nanica.

O documento que sustentava esta versão, publicado no jornal Estado de São Paulo, no dia 18 de abril de 1979, revelava um plano para a eliminação da imprensa nanica por meio de

\footnotetext{
${ }^{733}$ BR_DFANBSB_VAX_0_0_0011_d50001de0001

${ }^{734}$ BR_DFANBSB_VAX_0_0_0011_d50001de0001
} 
pressões econômicas, "sem atingir a liberdade de pensamento". Um dos itens do referido documento pontuava que "dentro da imprensa nanica [vinha] crescendo ultimamente a chamada 'imprensa gay', que se disp[unha] a defender as atitudes homossexuais como atos normais da vida humana" ${ }^{, 735}$. Percebe-se, assim, que se tratou de uma estratégia deliberada da repressão para conseguir coibir a circulação dos jornais menores sem, contudo, assumir o ônus que a censura aberta e declarada provocaria nos anos de abertura.

Aparentemente pego de surpresa, por se tratar de um inquérito legado por seu antecessor, o Ministro da Justiça Petrônio Portella determinou que, ainda no dia 11, o DPF lhe entregasse um relatório completo sobre o inquérito que corria contra o jornal.

A ordem foi cumprida e o Ministro divulgou, no fim da tarde desse mesmo dia, uma nota com a explicação do diretor do DPF, Moacir Coelho: com essa solicitação de livros contábeis e balancetes, pretendia a polícia provar que a editora "não tinha condições de sobreviver como empresa",736. Ao invés de abafar o caso, tal resposta gerou ainda mais indignação e solidariedade em prol da continuidade do Lampião, por confirmar os propósitos ocultos de fechar o jornal.

Na nota divulgada pelo jornal, encontra-se uma resposta contundente à alegação do coronel Moacir Coelho. O Lampião afirmou, na ocasião: “não cabe à Polícia Federal - e este é o ponto mais central da questão - verificar se uma empresa tem ou não condições de se manter". A nota criticava o fato de que devassas fiscais não eram feitas em empresas como as de José Wolney Atalla e Adolpho Lindenberg, cuja situação financeira, reconhecidamente péssima, implicavam uma crise de graves proporções para os trabalhadores. Além disso, pontua-se que, por não visar lucro, a editora do Lampião não apresenta problemas financeiros, sendo que o dinheiro arrecadado com a venda de um exemplar era consumido na edição do número seguinte. Por fim, os editores jogaram uma questão incômoda no colo do governo:

como um jornal de minorias, assumindo uma posição descomprometida em relação a todas as propostas ora em discussão no País, vem se tornando, nestes momentos de anunciada abertura, vítimas de constantes arbitrariedades desse tipo: seria a necessidade de eleger bodes expiatórios? Se o DPF acha que nós não temos condições de nos manter, que responda a essa pergunta: quem nos financia? O jornal está no n. 14, e nunca atrasou na sua chegada às bancas. ${ }^{737}$

Assim, em meio à tensão escancarada, somente após intimação pelo órgão competente

\footnotetext{
735 “Os que estão conosco". Lampião, n. 19, dezembro de 1979, p. 2.

${ }^{736}$ SILVA, Aguinaldo. "De bicha, negro e louco, todos nós temos um pouco: pra que tanto medo?” Lampião, n. 15 , agosto de 1979 , p. 5.

737 "Nossa pobreza é nosso maior charme", Lampião, n. 15, agosto de 1979, p. 5.
} 
é que, em 16 de agosto de 1979, a editora apresentou ao Delegado de Polícia Federal os balancetes extraídos dos livros contábeis da empresa responsável pelo Lampião. Conforme consta no documento protocolado pelo contador Josias Barbosa Santana, o balanço patrimonial do primeiro ano de funcionamento do jornal acumulou, até 31 dezembro de 1978, o prejuízo de 7.193,75 unidades monetárias da época. Já o balancete de verificação, assinado pelo mesmo contador em 16 de agosto de 1979, relativo ao primeiro semestre até 31 de julho de 1979, mostrava já um jornal em razoável saúde financeira, com um total acumulado de $648.323,25$, revertendo o prejuízo do ano anterior já no primeiro semestre de $1979^{738}$.

Além disso, um mês antes, provavelmente para conferência da veracidade das informações prestadas, o Delegado José da Silva Motta solicitou diligência registrada no Relatório de Missão n. 036/79-Cart/DOPS para verificar, junto à distribuidora de jornais e revistas, a quantidade do referido jornal distribuído ao público em 1979. Nesse informe, de 6 de julho, constam 4250 exemplares em janeiro, 4300 em fevereiro, 4400 em março e 4000 de março até julho ${ }^{739}$.

$\mathrm{Na}$ entrevista feita com Ney Matogrosso, publicada em dezembro de 1979, este inverteu a posição de entrevistado e perguntou aos jornalistas do Lampião a quantas andava o processo contra o tabloide. Aguinaldo Silva respondeu, ironicamente, que "o motivo [era] sempre o mesmo: 'ofensa à moral e aos bons costumes'. Ou seja: os 'bons costumes' dos Lutfalla, dos Abdalla e dos Grupos Lume da vida estão ameaçados porque há pessoas, como as do LAMPIÃO, que preferem fazer jornal, em vez de dar golpes na praça" ${ }^{\$ 40}$.

A despeito de todos os esforços para encontrar alguma irregularidade, nada foi encontrado de comprometedor do ponto de vista contábil, já que o jornal cativou um público expressivo e, se é verdade que não gerou muito lucro - o que sequer era seu objetivo -, ele conseguiu uma vendagem e anúncios suficientes para manutenção da circulação mensal por 3 anos ininterruptamente.

Isto atesta, cabalmente, que a exigência da ditadura não era uma preocupação com fundamento, mas mera tentativa de cercear a circulação do jornal por meio de algum expediente fiscal que não expusesse a repressão em estado bruto e gerasse ainda mais resistência e oposição ao regime.

\footnotetext{
${ }^{738}$ BR DFANBSB VAX 000011 d50010

${ }^{739}$ BR_DFANBSB_VAX_0_0_0011_d50010

740 "Ney Matogrosso sem bandeira". Lampião da Esquina, n. 11, abril de 1979, p. 7.
} 


\section{Um Lampião iluminado pela solidariedade}

Diante deste embate com risco de fechamento do Lampião, todos os grandes jornais da época noticiaram, com destaque, o fato, reproduzindo a nota do Lampião, tais como: O Globo, Tribunal da Imprensa, Última Hora, Estado de São Paulo, Folha de São Paulo, dentre outros.

Ao contrário do que aconteceu com Celso Curi, que foi vítima de um processo judicial com os mesmos fundamentos sem receber suporte expressivo para resistir às pressões que vinha sofrendo, a caça ao Lampião despertou solidariedade e apoio de diversos setores. Apesar do curto intervalo que separou os dois casos, os tempos já eram outros e, entre os inquéritos de Curi e Lampião, houve uma diferença fundamental: a emergência de uma novidade chamada movimento homossexual, que parecia ainda uma utopia irrealizável em 1976, conforme havia destacado o autor da "Coluna do Meio".

A Comissão Permanente de Luta pela Liberdade de Expressão, que congregava 25 entidades no Rio de Janeiro, divulgou nota com o seguinte teor: "No caso particular do Em Tempo e do LAMPIÃO, aguardamos do Poder Executivo a apuração da responsabilidade nas diferentes ações que vêm restringindo o trabalho e o exercício profissional dos que buscam, nestes jornais, dar a sua contribuição à construção de uma sociedade democrática",741.

Além disso, foi organizado um Comitê de Defesa do Jornal Lampião, composto por ativistas do Grupo Somos, jornalistas, intelectuais e leitores do periódico, com o objetivo de desencadear uma campanha de solidariedade na opinião pública. Nos termos anunciados no texto de lançamento do Comitê, o objetivo era colher "assinaturas de apoio a este jornal, e mobilizando entidades nacionais e internacionais para protestarem contra as arbitrariedades que vimos sofrendo" conforme divulgado nas páginas do próprio jornal ${ }^{742}$.

Um manifesto em defesa da imprensa alternativa foi também organizado, contando com a rápida adesão de amplo setor da intelligentsia brasileira, tais como Plínio Marcos, Ivan Lins, Antonio Candido, José Arthur Giannotti, Fernando Henrique Cardoso, Ruth Cardoso, Cândido Procópio, Nicete Bruno, José Celso Martinez Corrêa, Fernando Morais, Eduardo Suplicy, entre outros. Além disso, jornais tais como Versus, Convergência Socialista e Movimento, bem como entidades de trabalhadores como a APEOESP, Sindicato dos Jornalistas de SP e Sindicato dos Bancários de SP, também saíram em defesa do jornal. A coleta de novas assinaturas foi interrompida porque logo após o início da campanha, houve o

\footnotetext{
${ }^{741}$ SILVA, Aguinaldo. "De bicha, negro e louco, todos nós temos um pouco: pra que tanto medo?” Lampião, n. 15 , agosto de 1979 , p. 5.

${ }^{742}$ TREVISAN, João Silvério. Pintou a solidariedade. Lampião da Esquina, n. 15, agosto de 1979, p. 5.
} 
arquivamento do inquérito. De qualquer modo, este manifesto do campo democrático afirmava veementemente seu apoio ao Lampião:

\begin{abstract}
nós abaixo assinados, entendemos estes atos oficiais [do inquérito e do pedido de apresentação de livros contábeis] como uma tentativa de castrar o diálogo sobre os setores oprimidos 'minoritários' que se faz necessário e urgente dentro de nosso país, bem como repudiamos todas as atividades de coerção e repressão ao direito de existência e manifestação da imprensa alternativa. ${ }^{743}$
\end{abstract}

A repercussão do caso mobilizou, ainda, uma rede internacional de ativismo LGBT bastante surpreendente. O diálogo com entidades estrangeiras que o jornal mostrava nas traduções publicadas e os contatos de militantes de outros países cultivaram uma relação de cumplicidade significativa. Uma série de cartas e de abaixo-assinados, oriundas dos mais diferentes países e escritas em diversos idiomas, foi enviada ao Ministro da Justiça Armando Falcão e, posteriormente, ao Petrônio Portella, durante a tramitação do inquérito. Exemplos de entidades signatárias foram National Gay Federaion (Dublin), AHA (Berlim), Centre du Christ Liberateur (Paris), AG Lesben \& Schwule (Hamburgo), FUORI (Itália), Gay Activist Alliance (Inglaterra), National Gay Task Force (EUA), dentre outras dezenas de agrupamentos.

Todas elas, com uma redação mais ou menos igual e quase sempre em inglês, expressavam a "preocupação com a arbitrariedade e a severidade dessas medidas", requerendo ao Ministro que "exer[cesse] sua influência em nome dos direitos humanos e dos direitos civis no seu país" 744 .

Algumas das cartas eram ainda mais duras e afirmavam: "como ministro da Justiça, você certamente não gostaria de ser colocado ao lado de Adolf Hitler ou Anita Bryant, os quais, de uma maneira monstruosa, foram culpados pela difamação e assassinato de muitos homossexuais inocentes nesse século" ${ }^{745}$.

\title{
"Somos todos inocentes": o arquivamento do inquérito contra o Lampião
}

Diante da resistência implacável do Lampião e da expressiva rede de solidariedade articulada, passado mais de um ano de tramitação lenta e angustiante, o inquérito foi

\footnotetext{
743 “Os que estão conosco". Lampião, n. 19, dezembro de 1979, p. 2.

${ }^{744}$ BR_AN_BSB_NS_AGR_COF_MSC_159

${ }^{745}$ BR_AN_BSB_NS_AGR_COF_MSC_159
} 
arquivado por determinação judicial.

Mas até mesmo para obter esta vitória tão difícil e sofrida, foi necessário que a defesa aliviasse a homossexualidade dos editores e da linha política do jornal para não influenciar negativamente o procurador ou o juiz. Esta "timidez" imposta aos homossexuais, até mesmo na hora de sua defesa, é uma das perversidades que a homofobia institucionalizada da ditadura acentuou $^{746}$.

Em seu parecer, o Procurador da República Dr. Sérgio Ribeiro da Costa analisou o conceito de moral pública e bons costumes de que trata a lei de Imprensa. Segundo o procurador,

\begin{abstract}
filosoficamente moral e bons costumes se confundem, porque a moral é a parte da filosofia que trata dos costumes ou dos deveres do homem. Já a moral pública tem um conceito absoluto, vale dizer, é a conclusão moral que o público tira de uma determinada conduta. Simplificando, há fatos que pelo seu conteúdo ofendem a moral e alguns. A Lei visa, tão-somente, punir os fatos que ofedem a moral de todos - a moral absoluta - e não a moral de alguns - a moral relativa. No caso em exame, a publicação inquinada de ofensiva à moral pública pode ofender a moral de alguém, mas não de todos. Portanto, é relativo e não absoluto o conceito de moral daquele que condena essas publicações. Com efeito, as matérias publicadas no referido jornal referem-se a teses homossexuais, poesias ligadas a temas homossexuais, notícias ligadas ao mundo da homossexualidade, porém todas elas escritas num vocabulário que não atenta à moral pública. ${ }^{747}$
\end{abstract}

Acrescenta, ainda, o procurador, que inúmeros poemas da literatura universal estavam ligados a "problemas homossexuais", como de Miguel Ângelo e Shakespeare. Tal parecer foi acolhido pelo Juiz da $4^{\text {a }}$ Vara Federal do Rio de Janeiro, Dr. Ariosto de Rezende Rocha.

Em sua edição de novembro, o Lampião celebrou a tão esperada vitória em artigo assinado por Aguinaldo Silva e intitulado "Somos todos inocentes":

Foram doze meses de choro, ranger de dentes e defecções, desde aquele dia, no mês de agosto de 1978, em que chegou uma primeira intimação, em nome de Francisco Bittencourt; tratava-se, como se pode ver - agora que tudo terminou e nós, finalmente, temos acesso ao inquérito - de uma firme determinação do Departamento de Polícia Federal de não apenas fechar o LAMPIÃO como também punir os responsáveis por ele. ${ }^{748}$

\footnotetext{
${ }^{746}$ MacRae destacou este fato ao afirmar que "até durante os inquéritos policiais sobre o Lampião, a defesa achou prudente enfatizar ao máximo a categoria de 'jornal das minorias', tentando minimizar seu aspecto homossexual" (MACRAE, Edward. A construção da igualdade: identidade sexual e política no Brasil da "abertura". Campinas: Editora da Unicamp, 1990, p. 171).

747 "Somos todos inocentes". Lampião da Esquina, n. 18, novembro de 1979, p. 2.

748 "Somos todos inocentes". Lampião da Esquina, n. 18, novembro de 1979, p. 2.
} 


\section{"Eu atribuo o fim do jornal ao meu cansaço": "diário oficial do ativismo guei"?}

A despeito dos apoios e da vitória na batalha judicial, a crise do jornal vai se aprofundando, tanto pelos efeitos da perseguição institucionalizada da ditadura ${ }^{749}$ - que se arrefeceu oficialmente após o arquivamento do inquérito, como pela violência crua materializada nas bombas jogadas em bancas que comercializassem os jornais alternativos ${ }^{750}$. Alguns problemas enfrentados pelo Lampião eram, em certa medida, parte das dificuldades presentes em todos os demais veículos da imprensa alternativa. Além disso, havia também uma crise de identidade específica que começava a emergir depois de tanto tempo com uma série de atritos com o movimento homossexual, levando os editores a se questionarem se ainda e em que medida estavam conseguindo levar adiante o propósito original do jornal de inovar as formas de pensar as questões das minorias ${ }^{751}$.

Começaram a ganhar mais força, paralelamente às demais questões, as críticas dos grupos homossexuais que acusavam o jornal de um distanciamento das lutas concretas e do ativismo gay. Em novembro de 1980, os grupos Auê, Somos/Rio, Gols/ABC, Bando de Cá/Niterói, GGB/Bahia e GALF entregaram ao jornal um documento reclamando de seu distanciamento e das mudanças que estavam acontecendo ${ }^{752}$.

A cisão no interior do movimento homossexual também colocou em questão a neutralidade do Lampião na disputa de concepções de ativismo. O Jornal deixou de ser

\footnotetext{
${ }^{749}$ MacRae afirma que a perseguição ao Lampião era um capítulo da repressão mais ampla exercida contra os homossexuais: "este relato das perseguições sofridas pelo Lampião serve para ressaltar o quanto havia de fundamento para a percepção dos integrantes do Somos da opressão sofrida pelos homossexuais. Além da ridicularização e do ostracismo sofrido por eles a nível individual, razão para uma mobilização de natureza defensiva e de apoio mútuo, havia também uma série de entraves a uma discussão positiva e bem informada sobre esta manifestação de sexualidade. Como já foi mencionada, a perseguição policial não se restringia a um órgão da imprensa 'nanica' como o Lampião, mas até uma revista 'respeitável', como Isto É, e um jornalista escrevendo para a grande imprensa, como Celso Curi, chegaram a sofrer ataques por terem ousado levantar uma discussão mais informada sobre o assunto. O próprio documento do CIEx mencionava nominalmente o Lampião como um jornal a ser vigiado. A única forma oficialmente aceitável de abordar o assunto parecia ser aquela da imprensa sensacionalista do tipo Notícias Populares, ou deturpadora como a Manchete" (MACRAE, Edward. $A$ construção da igualdade: identidade sexual e política no Brasil da "abertura". Campinas: Editora da Unicamp, 1990, p. 170).

${ }^{750}$ Trevisan destacou que sequer havia investigações para apurar a responsabilidade sobre estes atentados convenientes para a repressão da ditadura: "No segundo semestre de 1979, começaram a explodir bombas em bancas de jornais de vários pontos do país, com panfletos anônimos exigindo que não mais fossem vendidos nem jornais alternativos (quase sempre de esquerda) nem revistas ou jornais considerados pornográficos (e numa das listas apareceu o nome do Lampião). As bombas foram vagamente atribuídas, pelo governo, a comandos paramilitares. Mas nunca se instaurou nenhum inquérito para apurar donde provinham e quem eram os integrantes de tais grupos autodenominados Falange Pátria Nova, Brigadas Moralistas e Comando de Caça aos Comunistas (TREVISAN, João Silvério. Devassos no paraíso: a homossexualidade no Brasil, da colônia à atualidade. São Paulo: Record, 2007, p. 346).

${ }^{751}$ Ver, por exemplo, o editorial da edição n. 28, de setembro de 1980, intitulado "Nós ainda estamos aqui".

${ }^{752}$ SILVA, Aguinaldo. "Lampiônicos: ativistas, astronautas?". Lampião da Esquina, n. 31, dezembro de 1980, p. 12 .
} 
unanimidade e passou a ser constantemente questionado em relação a suas escolhas editoriais e posições políticas ${ }^{753}$. O texto "Teses para a libertação homossexual II", da Fração Homossexual da Convergência Socialista, escrito em setembro de 1980, acusava o Lampião de arvorar-se na condição de "porta-voz do movimento homossexual" manter uma posição anárquica e anti-esquerda", bancando "um papel de frear o crescimento do $\mathrm{MH}$ e sua organização política", foi duramente respondido pelos membros do conselho editorial ${ }^{754}$.

Por exemplo, na edição de agosto de 1980, o Lampião reagiu à enxurrada de críticas e questionamentos. Aguinaldo Silva, que cada vez mais detinha o controle do jornal, publicou um texto intitulado "Uma cachoeira de grupos gueis", em que demarcava claramente uma distância com o movimento homossexual e afirmava que "não [era] possível, para nós, transformar o LAMPIÃO, uma espécie de 'diário oficial do ativismo guei"”, pois isso restringiria o alcance e as vendas do jornal ${ }^{755}$.

Espremido entre o que se consideravam ser os interesses inconciliáveis do mercado, de um lado, e os do ativismo gay, de outro, o jornal não conseguia contemplar, satisfatoriamente, nenhum dos dois públicos, pois o primeiro dispunha de outras revistas eróticas e pornográficas em circulação, enquanto os segundos já haviam se afastado. Dividido entre consumismo e ativismo, o jornal ficou sem espaço para continuar.

Ao lado de todas essas determinantes externas, agravaram-se determinados problemas internos quanto ao convívio que estava cada vez mais desgastado. O esgarçamento das relações provocados por um racha editorial também convergiu para provocar o fim do jornal. Duas das personagens mais influentes e ativas no Conselho, Aguinaldo Silva, no Rio, e Trevisan, em São Paulo, viram suas diferenças ficarem cada vez mais acentuadas diante da crise do Lampião.

Segundo Aguinaldo, "havia um grupo que achava que o jornal devia ser panfletário e não se preocupar em ter uma linguagem jornalística. E isso era um problema, porque um jornal que fosse só ativista acabava limitado. Nas reuniões de pauta, sempre havia discussões

\footnotetext{
${ }^{753}$ Trevisan, que foi militante ativo do Somos/SP e também participante de primeira hora do Lampião, afirmou que o jornal "acabou radicalizando infantilmente seu repúdio ao ativismo gay. Certos setores do jornal mergulharam num vago populismo, brandindo descabidamente o travesti em contrapartida ao guei-macho, o que acabou the dando um aspecto quase tão sensacionalista quanto os jornais da imprensa marrom", ocasionando a descaracterização das intenções do projeto original e uma diminuição nas vendas (TREVISAN, João Silvério. Devassos no paraíso: a homossexualidade no Brasil, da colônia à atualidade. São Paulo: Record, 2007, p. 361).

${ }^{754}$ BITTENCOURT, Francisco. "O que é bom para as bichas gringas é bom pras bichas do Brasil?" Lampião da Esquina, n. 31, dezembro de 1980, p. 13. E PENTEADO, Darcy. "Convergindo: da Mesopotâmia a Richetti". Lampião da Esquina, n. 31, dezembro de 1980, p. 14.

${ }^{755}$ SILVA, Aguinaldo. "Uma cachoeira de grupos gueis". Lampião da Esquina, n. 27, agosto de 1980, p. 4. Sobre os embates dentro dos grupos homossexuais, sobretudo no Somos/SP, ver o capítulo 4 do presente trabalho.
} 
árduas em torno dessa questão" "756. A politização da atuação do jornal não era uma questão nova, mas uma divergência constitutiva do próprio Lampião e sempre foi administrada dentro de limites que permitiram a continuidade do projeto com uma pluralidade de posições.

Por sua vez, Trevisan, que tinha um perfil mais assumidamente militante do movimento homossexual, acusava o grupo carioca de desvirtuar o projeto original do jornal, que "começou a tender para um certo sensacionalismo, com chamadas sensacionalistas, para chamar atenção de um público que não estava tão interessado assim" ${ }^{757}$. A ida constante ao Rio de Janeiro para as reuniões era desgastante e cara, além de que Trevisan não tinha apoio suficiente dos demais membros em São Paulo para assumir a condução do jornal. Assim, ele atribuiu a si mesmo a iniciativa de ter ido ao Rio exigir que o jornal acabasse, por ter cumprido sua função e ser hora "de passar para outra" 758 .

A versão de Aguinaldo foi no sentido de que ele próprio decidira pelo fim do jornal e, ao apresentar sua renúncia a seguir como editor, ninguém teria se voluntariado para substituílo nesta tarefa: "Eu atribuo o fim do jornal ao meu cansaço. Quando eu saí do jornal, eu disse: a partir de hoje eu não edito mais, vocês escolham outra pessoa... e ninguém se apresentou para editar, o jornal acabou por isso"759.

Além disso, as grandes diferenças de interesses e abordagens entre a imprensa "nanica" e a tradicional, também pejorativamente designada "marrom", foi diminuindo, com o passar do tempo, a afirmação dos movimentos identitários. Os veículos da imprensa alternativa provocaram mudanças importantes nos meios de comunicação hegemônicos, pautando temas que eram ignorados ou desprezados pela grande imprensa. Neste sentido, na opinião de Trevisan, questões de gênero, sexualidade e raça deixaram de ser exclusivas dos órgãos alternativos, o que contribuiu para o esvaziamento de alguns destes jornais: "De repente, a Folha começou a ter uma coluna feminista, começou a ter uma coluna sobre racismo, ecologia. Os temas típicos do Lampião foram cooptados pela grande imprensa" ${ }^{760}$.

Com efeito, o jornal, que havia surgido em um momento de efervescência da abertura, beneficiou-se de certo ineditismo da proposta e do retorno de exilados com ideias novas trazidas do estrangeiro. Essas novidades comportamentais e artísticas que eclodiram a partir do verão de 1980 foram atingidas em cheio pela crise econômica e inflacionária de 1981, levando à recessão de 1982. Com menos dinheiro e interesse cada vez menor, as vendas do

\footnotetext{
${ }^{756}$ PÉRET, Flávio. Imprensa gay no Brasil. São Paulo: Publifolha, 2011, p. 58.

${ }^{757}$ LAMPIÃO da Esquina. Livia Perez. São Paulo: Doctela, 2016. $82 \mathrm{~min}$, altura do $68 \mathrm{~min}$.

${ }^{758}$ LAMPIÃO da Esquina. Livia Perez. São Paulo: Doctela, 2016. $82 \mathrm{~min}$, altura do $72 \mathrm{~min}$.

${ }^{759}$ LAMPIÃO da Esquina. Livia Perez. São Paulo: Doctela, 2016. $82 \mathrm{~min}$, altura do $70 \mathrm{~min}$.

${ }^{760}$ LAMPIÃO da Esquina. Livia Perez. São Paulo: Doctela, 2016. $82 \mathrm{~min}$, altura do $71 \mathrm{~min}$.
} 
jornal caíram, o que acentuou a sensação de esgotamento do projeto.

Já para Glauco, colaborador assíduo do jornal, a transitoriedade era uma característica inescapável deste tipo de publicação inovadora e vanguardista, pois "não era um jornal para criar hábito, não era o caso do Lampião" ${ }^{761}$. Outro fator lembrado no documentário sobre o jornal foi a acusação de abuso de menor que pesava contra Antônio Chrysóstomo, preocupando alguns lampiônicos que houvesse uma associação entre pedofilia e homossexualidade ${ }^{762}$.

Em suma, não houve uma única causa capaz de explicar o apagamento do Lampião da Esquina. O contexto repressivo da ditadura que perseguia e ameaçava abertamente os jornalistas, os atentados paramilitares com bombas colocadas nas bancas em que o Lampião era vendido, as divergências internas quanto à identidade da publicação em uma conjuntura em franca transformação, o esfacelamento do movimento homossexual em aberto tensionamento com o jornal, a crise financeira e outros problemas pessoais dos conselheiros, foram fatores que concorreram para que a mais impactante experiência de imprensa gay chegasse a seu final, contribuindo também com o declínio do próprio movimento homossexual.

\footnotetext{
${ }^{761}$ LAMPIÃO da Esquina. Livia Perez. São Paulo: Doctela, 2016. $82 \mathrm{~min}$, altura do $70 \mathrm{~min}$.
}

${ }^{762}$ LAMPIÃO da Esquina. Livia Perez. São Paulo: Doctela, 2016. 82 min, altura do 77 min. 


\section{CONSIDERAÇÕES FINAIS}

Cid Furtado, relator do projeto de emenda constitucional que legalizava o divórcio, argumentou, em seu parecer contrário à proposta na Câmara Federal, que "desenvolvimento e segurança nacional não se estruturam apenas com tratores, laboratórios ou canhões. Por detrás de tudo isso está a família, una, solidária, compacta, santuário onde pai, mãe e filhos plasmam o caráter da nacionalidade" ${ }^{\$ 63}$. Esta frase do deputado arenista na discussão sobre o divórcio talvez seja uma das mais perfeitas sínteses da política sexual da ditadura. Sua indignação com o divórcio, na verdade, remetia a preocupações muito mais profundas com a revolução dos costumes, com a liberação sexual, com a maior presença da mulher no mundo do trabalho e no espaço público, com a entrada em cena de homossexuais e travestis, com cada vez menos pudores de assumir suas identidades sexuais ou de gênero.

A vida privada, a esfera íntima, o cotidiano, e o que se fazia entre quatro paredes foram também objeto da ânsia reguladora e do controle autoritário da ditadura brasileira. Pessoas eram vigiadas e, em seus dossiês produzidos pelos órgãos de informações, registravase, como uma mácula, a eventual suspeita, ou mesmo a certeza categórica de se tratar de um "pederasta passivo", como se isso diminuísse ou desqualificasse a integridade e o caráter da pessoa perseguida. Por ser homossexual, ela era menos humana e, portanto, considerada menos respeitável em sua dignidade. Publicações com material erótico ou pornográfico eram monitoradas e, muitas vezes, apreendidas e incineradas por violar o código ético da discrição hipócrita que grassava em uma sociedade que consumia vorazmente este tipo de conteúdo.

Músicas, filmes e peças de teatro foram vetadas e impedidas de circular por violarem, em suas letras, a moral e os bons costumes, sobretudo quando faziam "apologia ao homossexualismo". Na televisão, telenovelas e programas de auditório sofreram intervenção direta das giletes da censura, que cortavam quadros e cenas com a presença de personagens "efeminados" ou "com trejeitos" excessivos e que, portanto, com sua simples existência, afrontava o pudor e causava vergonha perante os espectadores.

Travestis, prostitutas e homossexuais presentes nos cada vez mais inchados guetos urbanos eram também uma presença incômoda para os que cultivavam os valores tradicionais da família brasileira. Por esta razão, passaram a ser perseguidos, presos arbitrariamente, extorquidos e torturados pelo fato de ostentarem, em seus corpos, os sinais de sexualidade ou de identidade de gênero dissidentes.

\footnotetext{
${ }^{763}$ Folha de São Paulo, 11 de abril de 1975.
} 
Editores e jornalistas que se dedicavam aos veículos da imprensa gay foram indicados, processados e tiveram suas vidas devastadas, muitas vezes com o apoio do sistema de justiça, porque tematizavam e mostravam as homossexualidades fora dos padrões de estigmatização e ridicularização que predominavam até então.

Todos estes são alguns exemplos que foram examinados mais a fundo neste trabalho para demonstrar como as questões comportamentais tornaram-se objeto da razão do Estado. A sexualidade passou a ser tema afeto à segurança nacional para os militares. Os desejos e afetos entre pessoas do mesmo sexo também foram alvo do peso de um regime autoritário com pretensão de sanear moralmente a sociedade e criar uma nova subjetividade.

Não que, conforme já apontamos, a ditadura tivesse inventado ou inaugurado o preconceito e a mentalidade conservadora que embalaram uma parcela significativa da população brasileira. O que ocorreu é que o golpe de 1964, ao estruturar um aparato de violência complexo e funcional para seus objetivos, proveu aos síndicos da moralidade alheia os meios de que precisavam para levar a cabo um projeto de purificação, desde as agências estatais. Isto fez com que estes padrões morais, outrora particulares e restritos a determinados grupos que, ainda que influentes, fossem então alçados ao status de políticas públicas e acabassem, por extensão, dotados da mesma legitimidade com que conta o Estado.

É neste sentido que se pode afirmar, com amparo em todas estas evidências empíricas encontradas em documentações produzidas pelos próprios órgãos repressivos, que houve uma política sexual oficializada e institucionalizada na ditadura para controlar manifestações tidas como "perversões" ou "desvios", tais como o erotismo, a pornografia, as homossexualidades e as transgeneridades.

Um olhar mais detido demonstra que não havia uma, mas diversas políticas oficiais da ditadura em relação aos temas morais. Mais complexa ainda se torna essa questão ao se constatar que diversas agências, com competências distintas, implementavam medidas variadas de normatização no campo da sexualidade, com enfoques específicos e a partir de suas órbitas de influência e esferas de atuação.

Algumas vezes, as motivações e discursos que justificavam a repressão levada a cabo por cada um desses órgãos eram muito parecidos e até coincidiam. Por exemplo, todos os órgãos examinados demonstravam preocupação com a corrupção das instituições familiares e da juventude considerada frágil e facilmente influenciável para as tentações mundanas. Mas isto nem sempre acontecia e não era raro que os órgãos divergissem entre si em torno da gravidade das condutas e comportamentos tidos como inaceitáveis. Tal modo de compreensão fica claro quando se nota que alguns censores encaravam a homossexualidade como algo 
repugnante e reprovável, mas preferiam liberar uma peça de teatro porque o eventual veto poderia resultar em maior projeção e divulgação, tendo o efeito contrário ao que se pretendia. Se o conteúdo avaliado fosse mesmo considerado nocivo e deletério, não faria sentido opinar pela liberação por uma conveniência e acabar negociando com o descumprimento das próprias regras morais e legais impositivas.

Percebe-se, ainda, que era recorrente, em diversos documentos, sobretudo naqueles produzidos pela comunidade de informação, que a pornografia, o erotismo e as homossexualidades representavam uma ameaça à segurança nacional e à ordem política, reduzindo-as a uma estratégia perversa e despudorada do movimento comunista internacional. Tal compreensão destituía os "desvios" sexuais de um estatuto próprio como modo de vida e território de organização dos desejos, tornando-os apenas um apêndice ou um acessório da luta política "maior", que buscava efetivar transformações mais amplas na sociedade ou no capitalismo. As "perversões" sexuais estariam, assim, meramente a serviço da política e da "guerra psicológica adversa" para minar as instituições ocidentais.

Outras vezes, contudo, a livre expressão da sexualidade era compreendida em um marco mais estritamente moral, ou seja, como uma afronta, em si mesma, aos valores tradicionais cultivados pelas famílias católicas brasileiras que, supostamente, representavam a média da consciência ética nacional que deveria ser resguardada pelo Estado. Os ataques contra a moral e os bons costumes até poderiam ser instrumentalizados e aproveitados, de forma oportunista, pelos opositores políticos que queriam derrubar o regime, mas isto não era o fundamental para compreender a dinâmica própria deste universo das sexualidades dissidentes. Pecado, falta de vergonha, anormalidade, degeneração, e até doença, eram as chaves mais tradicionais desta visão que prestigiava a situação específica do sexo em uma sociedade que passava por profundas mudanças nos costumes.

É importante ressaltar que estes dois polos não são tão puros e sequer opostos entre si. Se as breves descrições servem como tipos ideais capazes de ilustrar os traços específicos mais marcantes de cada um destes discursos, não se deve incorrer na tentação de separar de modo estanque, ou até mesmo opostos. Ambas, na prática, muitas vezes, se combinavam, e as políticas da ditadura oscilavam entre seus extremos, sempre mobilizando todo o arsenal de armas disponíveis para deslegitimar e desqualificar as experiências sexuais não normativas. Ordem política, de um lado, e ordem sexual, de outro, sobrepuseram-se na tutela moral que o regime autoritário tentou impor à sociedade.

Os meios variaram e passaram desde práticas aparentemente mais sutis de pedagogia das massas, com a censura e a veiculação de propagandas em defesa da família, até agressões 
físicas e outros tipos de violências diretamente praticadas contra travestis e homossexuais nas ruas. Interditar certas práticas, expulsar do espaço público certos corpos, impedir o fluxo de afetos e desejos, modular discursos de estigmatização, foram ações bem combinadas do aparelho repressivo, sobretudo nos campos da censura, das informações e das polícias. $O$ fato de o circuito de controle das sexualidades dissidentes não ter seguido o mesmo padrão e forma da repressão política em sentido estrito não significa que não houve uma política sexual específica e de caráter oficial, como alguns tentam sustentar.

Também se nota que o fluxo repressivo variou nos diferentes momentos da ditadura. De certa maneira, pode-se afirmar, com base no levantamento feito neste trabalho, que a repressão no campo moral refletiu tendências mais gerais do endurecimento do regime e da escalada de violências verificadas no final da década de 1960. No entanto, a relativa abertura do final da década de 1970, paradoxalmente, já não significou o abrandamento das violências e da censura contra estes segmentos. Ao contrário, a liberalização do sistema político com a permissão de uma oposição organizada conviveu com frequentes espasmos autoritários de fechamento da regulação no campo dos costumes. A popularização da televisão, enquanto meio de comunicação em massa e, sobretudo, a revolução sexual que se arrastou durante toda a década de 1970, serviram de pretexto para alimentar um pânico moral em diversos setores da sociedade que não conseguiam assimilar a velocidade com que tais mudanças ocorriam.

Assim, de um lado, é possível afirmar que a repressão moral oscilou conforme as inclinações mais gerais das políticas de fechamento e de abertura do regime, refletindo as variáveis mais globais. Por outro, percebe-se que havia determinantes e fatores específicos que influenciavam o comportamento particular da política sexual. Se é verdade que havia, como apontamos, um marco legal, ele era dotado de elevado grau de abstração e generalidade, o que fazia com que a universalidade destes padrões fosse comprometida pela aplicação seletiva e arbitrária das regras aos casos concretos.

Em última instância, acumulavam-se, assim, uma razão de Estado conservadora, consagrada em atos normativos e administrativos, com as concepções pessoais e de foro íntimo dos agentes públicos que eram responsáveis pela atividade censória ou de policiamento moral. Em diversos pareceres analisados, por exemplo, as opiniões particulares sobressaíam com tanta - ou até mais - importância do que a fundamentação legal da conclusão ali exposta.

É notória a dificuldade de encontrar documentação uniformemente distribuída durante todo o período que vai de 1964 a 1988, bem como outras fontes adequadas que permitam uma análise mais detalhada da movimentação do controle moral deste período. Em especial, são mais raros documentos relativos ao intervalo de 1970 a 1974, que permitiriam entender 
melhor como o endurecimento que se seguiu ao AI-5 teria se refletido nesta política sexual.

Além disso, no que se refere à perseguição nas ruas, há registros de ações repressivas logo após 1964, em 1968 e 1969 e, posteriormente, a partir de 1978, já na abertura. Isto indica que o golpe, ou o "golpe dentro do golpe", como alguns soem chamar o AI-5, aumentaram a arbitrariedade e ampliaram a margem de ação dos agentes públicos, inclusive políticas civis estaduais, que combatiam a presença de homossexuais, prostitutas e travestis nos pontos de prostituição e de sociabilidade LGBT.

No contexto de abertura, as ofensivas se intensificaram provavelmente porque, desde meados da década de 1970, aumentou o número de pessoas com poder aquisitivo e condições econômicas para pagar por sexo e, em paralelo, houve um crescimento expressivo no número de pessoas trans com as primeiras cirurgias e tratamentos de saúde disponíveis para esses segmentos. A visibilidade crescente desses segmentos a partir de meados da década de 1970 refletiu, por um lado, novos ares trazidos pela ainda incipiente abertura política, com promessas de maior tolerância moral e, por outro, os frutos da expansão econômica advinda do período de 1968 a 1973, conhecido como "Milagre Econômico".

Contudo, esta concentração nas regiões dos guetos parece ter provocado a reação indignada das camadas médias, que cresciam e assumiam uma importância política cada vez maior, passando a cobrar medidas mais enérgicas de limpeza moral das cidades. Este foi o combustível necessário para dar sobrevida a um aparato repressivo que se reinventava e experimentava uma mudança em suas funções habituais. Com a derrota imposta aos grupos de luta armada, já em meados da década de 1970, os aparatos da ditadura foram ficando cada vez mais ociosos e passaram a se concentrar no "cuidado" dos setores moralmente "indesejáveis", ajudando a concretizar o ideal de moralidade sexual propagado pelos segmentos mais conservadores e com cada vez mais eco dentro do Estado.

A noção de impunidade que imperava em relação aos graves crimes de Estado durante as décadas de 1960 e 1970 alimentou a violência que se intensificou, a partir dos primeiros passos da transição política, sobre as pessoas LGBT e outras "minorias". A Lei n. 6.673 de 1979, conhecida como Lei de Anistia, cumpriu também um papel importante para selar a garantia de impenitência destes setores. Aprovada com uma redação ambígua em seu texto, este diploma legal ainda hoje vem sendo interpretado pelo Poder Judiciário, de modo a beneficiar os violadores de direitos humanos, contribuindo desde aquela época para que agentes estatais pudessem praticar atos arbitrários de violência contra a população.

É sintomático que, ao menos em São Paulo, onde há mais fontes disponíveis, a ação do Estado tenha se abatido sobre uma região frequentada pelo público homossexual 
pertencente aos extratos mais carentes da população. As rondas de Richetti, por exemplo, funcionaram como um vetor de gentrificação e adotaram um flagrante recorte de classe, atingindo as "bichas" pobres que ficaram de fora da ilusão do crescimento econômico do período do chamado "Milagre". Assim, ao atender o reclamo de uma classe média decadente nas regiões do Arouche e da Vieira de Carvalho, a polícia parecia tentar dar uma resposta moral para a crise econômica vivida por estes grupos que não queriam conviver, no mesmo espaço, com as "minorias" estigmatizadas.

Foram os homossexuais e travestis pertencentes às classes populares que sentiram mais intensamente o peso da ação repressiva da ditadura em seus corpos e desejos. Enquanto que alguns homossexuais, geralmente enrustidos e com a vida dupla, integravam-se à cidadania pela via do mercado de consumo e pelo acesso a empregos formais no mercado de trabalho, LGBTs pobres que não tinham a mesma sorte eram enquadrados como "vadios", mesmo que portassem carteira de trabalho, sem qualquer direito de defesa.

Apesar dessas constatações, verifica-se também, no final dos anos 1960 e início da década de 1970, uma ambiguidade fundamental. Boates, bares, espaços de pegação e sociabilidade entre homossexuais cresciam e convivam proporcionalmente à repressão do Estado. Enquanto se mantivessem nas sombras do anonimato dos armários ou nos guetos em que se escondiam, os homossexuais podiam existir e fazer o que quisessem com seus corpos. O problema era quando vinham à luz e ocupavam o espaço público, reivindicando uma existência e um lugar político na sociedade.

Deste modo, o cerne da política sexual da ditadura não era exterminar fisicamente estes grupos vulneráveis do mesmo modo como se fez com a subversão política. Antes, o objetivo era reforçar o estigma contra os homossexuais, "dessexualizar" o espaço público expulsando estes segmentos e impelir, para o âmbito privado, as relações entre pessoas do mesmo sexo. A função da ditadura era atirar, para a invisibilidade, corpos e coletivos que insistiam em reivindicar o reconhecimento de seus direitos e liberdades. Sem sombra de dúvidas, a ditadura deixou um terreno fértil para que práticas de abusos e violências contra homossexuais fossem cometidas por agentes públicos, dado a falta de limites e até mesmo a presença de estímulos a tal.

Vale ressaltar que a estratégia repressiva malfadada, tramada pela ditadura contra as sexualidades dissidentes, não quer dizer que ela não tenha existido, como alguns parecem sugerir. É evidente que a "utopia autoritária" tinha pretensão totalizante, mas isto era impossível em se tratando de desejos e de afetos, que sempre se fazem valer em uma conjuntura de franca ascensão dos movimentos sociais identitários em contextos de abertura 
política de regimes opressores.

Analisar, assim, se a ditadura sustentou, de modo consistente, uma política oficial de perseguição às sexualidades dissidentes, não é apenas aferir a quantidade de documentos nos arquivos que atestem a violência estatal como uma repressão negativa. Antes, é preciso compreender como a moralidade sexual da ditadura impôs, a partir das agências de controle social e das comunicações, bem como dos aparatos de divulgação, uma profusão de discursos que normatizaram a sexualidade dentro do campo da tradição, da moral e dos bons costumes. Assentou-se, naquele período de formação da identidade homossexual, uma representação negativa graças à ação repressora do Estado. Mais do que interditar e silenciar as homossexualidades, a ditadura modulou uma série de discursos positivamente normativos que decantavam socialmente determinadas representações dos homens que amavam outros homens e das mulheres que amavam outras mulheres.

Ademais, para apurar esta questão, não se pode utilizar como fontes somente a versão consagrada nos documentos oficiais do Estado ditatorial, que registrou aspectos importantes, mas escondeu tantos outros que não queria assumir claramente. As denúncias feitas e reiteradas diversas vezes, sobretudo pelo nascente movimento homossexual e por seus veículos de comunicação, como o Lampião da Esquina, indicados nos últimos capítulos do trabalho, também indicam diversos elementos da perseguição então existente aos homossexuais, desde os órgãos estatais.

Nota-se, portanto, que o autoritarismo também valeu-se de uma ideologia da intolerância materializada na perseguição e tentativa de controle de grupos sociais tidos como desviantes, destacando-se as violências cometidas contra gays, lésbicas, bissexuais, travestis, transexuais e transgêneros (LGBT) por sua orientação sexual ou identidade de gênero diferentes dos padrões tidos como normais.

A criação da figura de um "inimigo interno", operador ideológico fundamental do modus operandi da ditadura brasileira, que precisava ser combatido a qualquer custo para salvaguardar a "segurança nacional", a "família tradicional" e os "valores" da sociedade brasileira, valeu-se de contornos não apenas políticos, mas também morais, por meio do apelo de que estes gozam em uma sociedade marcada por um conservadorismo no campo dos costumes e da sexualidade. Em um país que sempre se caracterizou por um elevado grau de violência estrutural contra segmentos excluídos e marginalizados, como os homossexuais, a intensificação de estruturas de exclusão agravou significativamente a situação desses segmentos.

Muitos afirmam que a existência de homossexuais deixou de ser legalmente 
criminalizada no país em 1830, quando o Código Criminal do Império português, que previa o tipo penal da sodomia, foi revogado expressamente por uma nova legislação mais liberal e menos restritiva.

O controle legal das homossexualidades, contudo, nunca deixou de ser feito pelas autoridades conforme a conveniência e os valores morais de ocasião. Mobilizando tipos penais flexíveis, como aqueles que vedavam as práticas sexuais com menores de idade, as regras que puniam atentado ao pudor ou ao decoro público, as normas sobre a preservação da moral e dos bons costumes e a legislação específica contra a vadiagem, sempre foram vigentes. Mas a escala e a intensidade, ainda que seja difícil de comprovar empiricamente pela ausência de registros confiáveis de uma série histórica mais longa, salta aos olhos durante a ditadura.

Este procedimento de legitimação via legalidade autoritária e aparente foi uma constante durante o regime autoritário: enunciava-se uma regra geral de consagração de um direito e garantia de uma liberdade fundamental; em seguida, ressalvava-se uma exceção bastante vaga e abstrata, que terminava por comprometer e minar a força normativa mesma da regra. Com esta fórmula, mantinha-se a vigência formal de regras que eram desconfirmadas e violadas sistematicamente na prática. Neste sentido, não é exagero afirmar, pelas dimensões alcançadas pelas violências, que a ditadura logrou uma criminalização branca das homossexualidades em nosso país.

Além disso, pela análise feita, é possível afirmar que a ditadura reforçou posições autonomistas radicais dentro dos grupos de homossexuais, por estes terem criado um rechaço a quaisquer formas de autoridade que eram identificadas ao autoritarismo. Isto dificultou qualquer organização interna mais sólida e consistente, pois qualquer passo neste sentido significaria burocratizar o grupo e, legalizá-lo, poderia provocar um controle ou intervenção direta do Estado sobre ele.

A visão da ditadura sobre essas "perversões" também se desloca a partir da afirmação da homossexualidade como uma identidade política e um suporte para a militância organizada contra o autoritarismo. Neste sentido, a homossexualidade mudou e influenciou a renovação da mirada repressiva da ditadura. Quando deixou de ser apenas uma prática sexual repulsiva e passa a ser um movimento social de contestação da ordem e de reivindicação de igualdade e direitos, colocou em questão as estruturas autoritárias e excludentes do regime.

Dentre os diversos legados da ditadura no campo dessa política sexual, pode-se destacar a deseducação política da sociedade, a moralização das sexualidades, a regulação ostensiva dos comportamentos e dos desejos, intervenção excessiva na vida privada, barreiras 
para a politização e a ação livre e coletiva dos homossexuais, incentivo a uma economia do consumo com acomodação dos setores mais favorecidos, reforço de uma clivagem de classe dentro da comunidade LGBT, censura a publicações e espetáculos envolvendo a temática da sexualidade, dentre outras tantas frustrações a projetos pessoais e coletivos que o autoritarismo ajudou a abortar.

Essa política sexual da ditadura, ao consagrar oficialmente a estigmatização cultural das sexualidades dissidentes, marcou profundamente o imaginário social em torno dos grupos "minoritários". A ditadura os rotulou como sócios menores do movimento comunista internacional. Outras vezes os classificou como agentes de ruptura da moralidade social. Outras tantas, ainda, carimbaram-nos com as marcas da classe social que portavam. Não à toa, como vimos, os movimentos identitários surgiram ou ressurgiram no final da ditadura, em uma rica experiência de alianças e trocas interseccionais entre raça, gênero, classe e sexualidade.

Esperamos que este trabalho possa contribuir, de algum modo, para despertar algumas inquietações quanto ao alcance da repressão moral da ditadura brasileira. Até o momento, a política sexual do regime autoritário não recebeu a atenção merecida nas análises, nas críticas e nem nas políticas de reparação voltadas à ditadura. Isto se deve, sobretudo, ao fato de que o olhar que dirigimos ao passado é forjado por uma democracia específica do presente, e esta nunca se mostrou efetivamente comprometida com a diversidade sexual e de gênero, ou mesmo com os direitos humanos. A proposta de conduzir e mudar o olhar para o passado diz respeito também ao desejo de olhar para o presente, a fim de buscar meios para que a moral e os bons costumes não voltem a ter o mesmo peso que tiveram há tão pouco tempo, entre nós. 


\section{REFERÊNCIAS}

ALMEIDA, São José. Homossexuais no Estado Novo. Porto: Sextante Editora, 2010.

AQUINO, Maria Aparecida de. Censura, imprensa e Estado autoritário (1968-1978): o exercício cotidiano da dominação e da resistência: o Estado de São Paulo e Movimento. Bauru: Edusc, 1999.

ARAÚJO, Paulo Cesar de. Eu não sou cachorro, não: música popular cafona e ditadura militar. Rio de Janeiro/São Paulo: Record, 2015.

BAHIA, Alexandre; MORAES, Daniel. O longo caminho contra a discriminação por orientação sexual no Brasil no constitucionalismo pós-88: igualdade e liberdade religiosa. In: Revista Libertas, Ouro Preto, v. 1, n. 1, jan./jun. 2013.

BENADUSI, Lorenzo. Homosexuality in Fascist Italy: the enemy of the new man. Wisconsin: The University of Wisconsin Press, 2012.

BRAZDA, Rudolf e SCHWARTZ, Jean-Luc. Triângulo Rosa: um homossexual no campo de concentração nazista. São Paulo: Mescla, 2012.

BUZAID, Alfredo. Em defesa da moral e dos bons costumes. Brasília: Ministério da Justiça, 1970 .

CÂMARA, Cristina. Cidadania e orientação sexual: a trajetória do grupo Triângulo Rosa. Rio de Janeiro: Academia Avançada, 2002.

CANADAY, Margot. The Straight State: Sexuality and Citizenship in Twentieth-Century America. Princeton: Princeton University Press, 2009.

CARNEIRO, Maria Luiza Tucci. Livros proibidos, idéias malditas: o Dops e as minorias silenciadas. São Paulo: Estação Liberdade; Arquivo do Estado, SEC, 1997.

CARNEIRO, Maria Luiza Tucci. Minorias Silenciadas: História da Censura no Brasil. São Paulo: Edusp; Imprensa Oficial; Fapesp. 2002.

COLAÇO, Rita. De Daniele a Chrysóstomo - Quando travestis, bonecas e homossexuais entram em cena. Tese (Doutorado em História). Instituto de Ciências Humanas e Filosofia da Universidade Federal Fluminense, 2012.

COLAÇO, Rita. De Denner a Chrysóstomo, a repressão invisibilizada: as homossexualidades 
na ditadura. (1972 a 1983). In: GREEN, James N.; QUINALHA, Renan (Orgs.). Ditadura e homossexualidades: repressão, resistência e a busca da verdade. São Carlos: EDUFSCAR, 2014.

COMISSÃO NACIONAL DA VERADE:

$<$ http://www.cnv.gov.br/index.php?option=com_content\&view=article\&id=571 $>$.

COSTA, Cristina. Censura em cena: teatro e censura no Brasil. São Paulo: Edusp, Fapesp, Imprensa Oficial, 2006.

COWAN, Benjamin. A Passive Homosexual Element: Digitized Archives and the Policing of Homosex in Cold War Brazil. In: Radical History Review, 120, October 2014.

COWAN, Benjamin. Securing Sex: Morality and Repression in the Making of Cold War Brazil. University of North Carolina Press, 2016.

DANIEL, Herbert. Passagem para o próximo sonho: um possível romance autobiográfico. Rio de Janeiro: Codecri, 1982.

D’ARAUJO, M. C. et al. (Org.) Visões do golpe: a memória militar sobre 1964. Rio de Janeiro: Relume-Dumará, 1994

FACCHINI, Regina. Sopa de letrinhas? Movimento homossexual e produção de identidades coletivas nos anos 1990. Rio de Janeiro: Garamond, 2005.

FAGUNDES, Coriolano de Loyola Cabral. Censura \& Liberdade de Expressão. São Paulo: Taika, 1974.

FERNANDES, Marisa. Lésbicas e a ditadura militar: uma luta contra a opressão e por liberdade. In: GREEN, James N.; QUINALHA, Renan (Orgs.). Ditadura e homossexualidades: repressão, resistência e a busca da verdade. São Carlos: EDUFSCAR, 2014.

FICO, Carlos. Prezada Censura: cartas ao regime militar. Topoi, Rio de Janeiro, v. 3, n. 5, dez. de 2002, pp. 251-286.

FICO, Carlos. Além do Golpe - Versões e controvérsias sobre 1964 e a Ditadura Militar. Rio de Janeiro: Record, 2004.

FICO, Carlos. A pluralidade das censuras e das propagandas da ditadura. In. REIS, Daniel; RIDENTI, Marcelo; MOTTA, Rodrigo Patto Sá (Orgs.). O golpe e a ditadura militar: 40 anos depois (1964 - 2004). Bauru: EDUSC, 2004. 
FICO, Carlos. Espionagem, polícia política, censura e propaganda: os pilares básicos da repressão. In: FERREIRA, Jorge; DELGADO, Lucília (Orgs.). O Brasil Republicano: o tempo da ditadura - regime militar e movimentos sociais em fins do século XX. Rio de Janeiro: Civilização Brasileira, 2009.

FICO, Carlos. Censura, ditadura e "utopia autoritária". In: COSTA, Cristina. Seminários sobre censura. São Paulo: Balão; Fapesp, 2012. pp. 65-76.

FICO, Carlos. Além do golpe: Versões e Controvérsias Sobre 1964 e a Ditadura Militar. Rio de Janeiro: Record, 2014.

FOUCAULT, Michel. História da Sexualidade I: a vontade de saber. Rio de Janeiro: Graal, 1985.

FRY, Peter. Da hierarquia à igualdade: a construção histórica da homossexualidade no Brasil. In: Fry, Peter. (Org.) Para inglês ver: Identidade Política na Cultura Brasileira. Rio de Janeiro: Zahar, 1982. pp. 87-115.

GALEANO, Javier Fernandez. Is He a "Social Danger"? The Franco Regime's Judicial Prosecution of Homosexuality. In: Malaga under the Ley de Vagos y Maleantes. Journal of the History of Sexuality, v. 25, n. 1, jan, 2016, pp. 1-31.

GARCIA, Miliandre. Ou vocês mudam ou acabam: teatro e censura na ditadura militar (1964-1988). Rio de Janeiro, 2008. Tese (Doutorado em História) - Instituto de Filosofia e Ciências Sociais, Universidade Federal do Rio de Janeiro.

GERACE, Rodrigo. Cinema Explícito: Representações cinematográficas do sexo. São Paulo: Edições Sesc e Perspectiva, 2015.

GOLDBERG, Anitta. Feminismo e autoritarismo: a metamorfose de uma utopia de liberação em ideologia liberalizante. Dissertação (Mestrado em História), Universidade Federal do Rio de Janeiro, Rio de Janeiro, 1987.

GONÇALVES, Renato. Nós duas: as representações LGBTs na canção brasileira. São Paulo: Lápis Roxo, 2016.

GREEN, James N. More Love and More Desire: The Building of the Brazilian Movement. In: The Global Emergence of Gay and Lesbian Politics.

GREEN, James N. Além do Carnaval: a homossexualidade masculina no Brasil do século XX. São Paulo: Unesp, 2000. 
GREEN, James N. The Emergence of the Brazilian Gay Liberation Movement, 1977-1981. In: Latin American Perspectives, v. 21, n. 1, 1994, pp. 38-55.

GREEN, James N. Quem é o macho que quer me matar? Homossexualidade masculina, masculinidade revolucionária e luta armada brasileira dos anos 1960 e 1970. Revista Anistia Política e Justiça de Transição, n. 8. Brasília: Ministério da Justiça, 2012.

GREEN, James N. "Abaixo a repressão, mais amor e mais tesão": uma memória sobre a ditadura e o movimento de gays e lésbicas de São Paulo na época da abertura. Acervo, [S.1.], v. 27, n. 1, p. 53-82, abr. 2014.

GREEN, James N. O grupo Somos, a esquerda e a resistência à ditadura. In: GREEN, James N.; QUINALHA, Renan (Orgs.). Ditadura e homossexualidades: repressão, resistência e a busca da verdade. São Carlos: EDUFSCAR, 2014.

GREEN, James N; TRINDADE, Ronaldo. Homossexualismo em São Paulo. São Paulo: Editora UNESP, 2005.

GREEN, James N; QUINALHA, Renan (Orgs.). Ditadura e homossexualidades: repressão resistência e a busca da verdade. São Carlos; Editora da UFSCar, 2014.

GUERRA, Lillian. Gender Policing, Homosexuality and the New Patriarchy of the Cuban Revolution, 1965-1970. In: Social History, v. 35, no. 3, Aug, 2010.

HEALEY, Dan. Homosexual Desire in Revolutionary Russia. Chicago: The University of Chicago Press, 2001.

HUARD, Geoffroy. Los Antisociales: Historia de la homosexualidad en Barcelona y París (1945-1975). Madrid: Marcial Pons, 2014.

INSAUSTI, Santiago Joaquín. Los cuatrocientos homosexuales desaparecidos: Memorias de la represión estatal a las sexualidades disidentes en Argentina. In: D’ANTONIO, Debora (Org.). Deseo y represión: sexualidad, género y Estado en la historia argentina reciente. Buenos Aires: Ediciones Imago Mundi, 2015, pp. $62-82$.

JÁUREGUI, Carlos. La homosexualidad en la Argentina. Buenos Aires: Ediciones Tarso, 1987.

KUCINSKI, Bernardo. Jornalistas e revolucionários: nos tempos da imprensa alternativa. São Paulo: Edusp, 2001.

KUSHNIR, Beatriz. Cães de Guarda: jornalistas e censores do AI-5 à Constituição de 1988. 
São Paulo: Boitempo, 2004.

LEITE, Gabriela Silva. Eu, mulher da vida. Rio de Janeiro: Rosa dos Tempos, 1992.

LIRA, Ramayana. Meta(na)morfoses lésbicas em Cassandra Rios. Estudos Feministas, v. 21, n. 1, jan-abril, 2013, pp. 129-141.

LOPES, Fábio Henrique. Travestilidades e ditadura civil-militar brasileira: apontamentos de uma pesquisa. Revista Esboços, Florianópolis, v. 23, n. 35, p. 145-167, set. 2016, pp. 145-167.

MACRAE, Edward. A construção da igualdade: identidade sexual e política no Brasil da “abertura”. Campinas: Editora da Unicamp, 1990.

MACRAE, Edward. Em defesa do gueto. In: GREEN, James; TRINDADE, Ronaldo (Orgs.). Homossexualismo em São Paulo e outros escritos. São Paulo: UNESP, 2005

MARCELINO, Douglas Attila. Subversivos e Pornográficos: Censura de livros e diversões públicas nos anos 1970. Rio de Janeiro: Arquivo Nacional, 2011.

MARCONI, Paolo. A censura política na imprensa brasileira (1968-1978). 2. ed. São Paulo: Global, 1980.

MARTINS, William de Souza Nunes. Produzindo no escuro: políticas para a indústria cinematográfica brasileira e o papel da censura (1964-1988). Tese (Doutorado em História) Instituto de Filosofia e Ciências Sociais, Universidade Federal do Rio de Janeiro.

MINISTÉRIO DAS RELAÇÕES EXTERIORES. Mundo afora: políticas de combate à violência e à discriminação contra pessoas LGBT, n. 12. Brasília, 2015.

MORANDO, Luiz. Por baixo dos panos - repressão a gays e travestis em Belo Horizonte: In: GREEN, James N.; QUINALHA, Renan (Orgs.). Ditadura e homossexualidades: repressão, resistência e a busca da verdade. São Carlos: EDUFSCAR, 2014.

MOUTTA DE FARIA, Marcos. Partido Socialista Ou Partido Dos Trabalhadores? Contribuição à História Do Trotskismo No Brasil. A Experiência Do Convergência Socialista. Diálogos: Revista do Departamento de História e do Programa de Pós-Graduação em História [on line], 2005.

OCANHA, Rafael Freitas. “Amor, feijão, abaixo camburão" - Imprensa, violência e trottoir em São Paulo (1979-1983). Dissertação (Mestrado em História), PUC-SP, 2014.

OCANHA, Rafael Freitas. As rondas policiais de combate a homossexualidade na cidade de São Paulo - (1976 - 1982). In: GREEN, James N.; QUINALHA, Renan (Orgs.). Ditadura e 
homossexualidades: repressão, resistência e a busca da verdade. São Carlos: EDUFSCAR, 2014.

OKITA, Hiro. Homossexualismo: da opressão à libertação. São Paulo, Proposta Editorial, 1981.

ORTIZ, Renato. Revisitando o tempo dos militares. In: REIS, Daniel Aarão; RIDENTI, Marcelo \& MOTTA, Rodrigo P. Sá (Orgs.). A ditadura que mudou o Brasil: 50 anos do golpe de 1964. Rio de Janeiro: Zahar, 2014, pp. 112-127.

PEREIRA, Anthony. Ditadura e repressão: o autoritarismo e o Estado de Direito no Brasil, no Chile e na Argentina. São Paulo: Paz e Terra, 2010.

PÉRET, Flávio. Imprensa gay no Brasil. São Paulo: Publifolha, 2011.

PERLONGHER, Nestor. O desaparecimento da homossexualidade. In: LANCETTI, Antônio et al. SaúdeLoucura 3. São Paulo: Hucitec, 1993, pp. 39 - 45.

PERLONGHER, Nestor. Territórios Marginais. In: GREEN, James; TRINDADE, Ronaldo. Homossexualismo em São Paulo. São Paulo: Editora UNESP, 2005.

PERLONGHER, Nestor. O negócio do Michê: A prostituição viril em São Paulo. São Paulo: Fundação Perseu Abramo, 2008.

PIERUCCI, Antônio Flávio. As bases da nova direita. In: Novos Estudos, São Paulo, n. 19, dez. 1987. pp. 26-45.

PRESOT, Aline. Celebrando a "Revolução": as marchas da família com Deus pela liberdade e o Golpe de 1964. In: ROLLEMBERG, Denise; QUADRAT, Samantha Viz. (Org.). A construção social dos regimes autoritários: legitimidade, consenso e consentimento no Século XX - Brasil e América Latina. Rio de Janeiro: Civilização Brasileira, 2010.

RAPISARDI, Flávio, \& MODARELLI, Alejandro. Fiestas, baños y exilios: Los gays porteños en la última dictadura. Buenos Aires: Sudamericana, 2001.

REIMÃO, Sandra. Repressão e resistência: censura a livros na ditadura militar. São Paulo: Edusp, 2011.

RIBEIRO, Renato Janine. A política dos costumes. In: NOVAES, Adauto (Org.). Muito além do espetáculo. São Paulo: Senac, 2005.

RODRIGUES, Jorge Caê. Impressões de identidade: os caminhos da imprensa gay nacional. In: COSTA, Horácio et al. (Orgs.). Retratos do Brasil Homossexual: fronteiras, 
subjetividades e desejos. São Paulo: Edusp; Imprensa Oficial, 2010

RODRIGUES, Jorge Caê. Um Lampião iluminando esquinas escuras da Ditadura. In: GREEN, James N.; QUINALHA, Renan (Orgs.). Ditadura e homossexualidades: repressão, resistência e a busca da verdade. São Carlos: EDUFSCAR, 2014.

SANTOS, Gustavo Gomes da Costa. Mobilizações homossexuais e estado no Brasil: São Paulo (1978-2004). Revista brasileira de Ciências Sociais, São Paulo, v. 22, n. 63, feb., 2007. pp. 121-135.

SANTOS, Pilar Lago. Eu (também) engoli Brasília: poesia e utopia na obra de Nicolas Behr. Dissertação (Mestrado). São Paulo, PUC-SP, 2010.

SANTOS, Wanderley Guilherme dos. Estratégias de descompressão política. In: Poder \& Política: crônica do autoritarismo brasileiro. Rio de Janeiro: Forense Universitária, 1978.

SCHWARCZ, Roberto. Cultura e Política. 1964 - 1969. In: O pai de família e outros estudos. Rio de Janeiro: Paz e Terra, 1978. p. 61-92.

SILVA, Claudio Roberto da. Reinventando o sonho: história oral de vida política e homossexualidade no Brasil contemporâneo. Dissertação (Mestrado). São Paulo, FFLCH/USP, 1998.

SILVA, Deonísio da. Nos bastidores da censura: sexualidade, literatura e repressão pós-64. São Paulo: Estação Liberdade, 1989.

SIMÕES, Inimá. Roteiro da intolerância: a censura cinematográfica no Brasil. São Paulo: Senac São Paulo, 1999.

SIMÕES, Júlio; FACCHINI, Regina. Na trilha do arco-íris: do movimento homossexual ao LGBT. São Paulo: Editora Fundação Perseu Abrano, 2009,

SIMÕES JÚNIOR, Almerindo Cardoso. E havia um lampião na esquina: memórias, identidades e discursos homossexuais. Dissertação (Mestrado em História Social), UNIRIO, Programa de Pós-Graduação em Memória Social, Rio de Janeiro, 2006.

SIMÕES, Solange de Deus. Deus, pátria e família: as mulheres no golpe de 1964. Petrópolis: Vozes, 1985.

SOARES, Glaucio Ary Dillon. Censura durante o regime autoritário. Disponível em: $<$ http://www.anpocs.org.br/portal/publicacoes/rbcs_00_10/rbcs10_02.htm>.

SOUTO MAIOR JR, Paulo Roberto. Escrever para inscrever-se: epistolografia homossexual 
nas páginas do Lampião da Esquina (1978-1981). Revista Tempo e Argumento, Florianópolis, v. 8, n. 19, set./dez., 2016, pp. 254-282.

SOUZA, Rafael de. Saindo do gueto: o Movimento Homossexual no Brasil da abertura, 19781982. Dissertação (Mestrado). São Paulo, USP, 2013.

STEPHANOU, Alexandre Ayub. Censura no regime militar e militarização das artes. Porto Alegre: Editora da PUC-RS, 2001.

TELES, Janaína. Ditadura e repressão: paralelos e distinções entre Brasil e Argentina. Taller (Segunda Época). Revista de Sociedad, Cultura y Política en América Latina, v. 3, n. 4, 2014.

TREVISAN, João Silvério. Devassos no paraíso: a homossexualidade no Brasil, da colônia à atualidade. São Paulo: Record, 2007.

VENTURA, Zuenir. 1968 O ANO QUE NÃO TERMINOU. Rio de Janeiro: Nova Fronteira, 1988.

VIEIRA, Nayara da Silva. Entre o imoral e o subversivo: a Divisão de Censura de Diversões Públicas (DCDP) no regime militar (1968-1979). Dissertação (Mestrado em História). Instituto de Ciências Humanas. Brasília: Universidade de Brasília.

YOUNG, Alan. Los gays bajo la Revolución Cubana. Madrid: Playor, 1984.

ZANATTA, Eliane. Documento e identidade: o movimento homossexual no Brasil na década de 80. Cadernos AEL, n. 5/6, 1996-1997. 